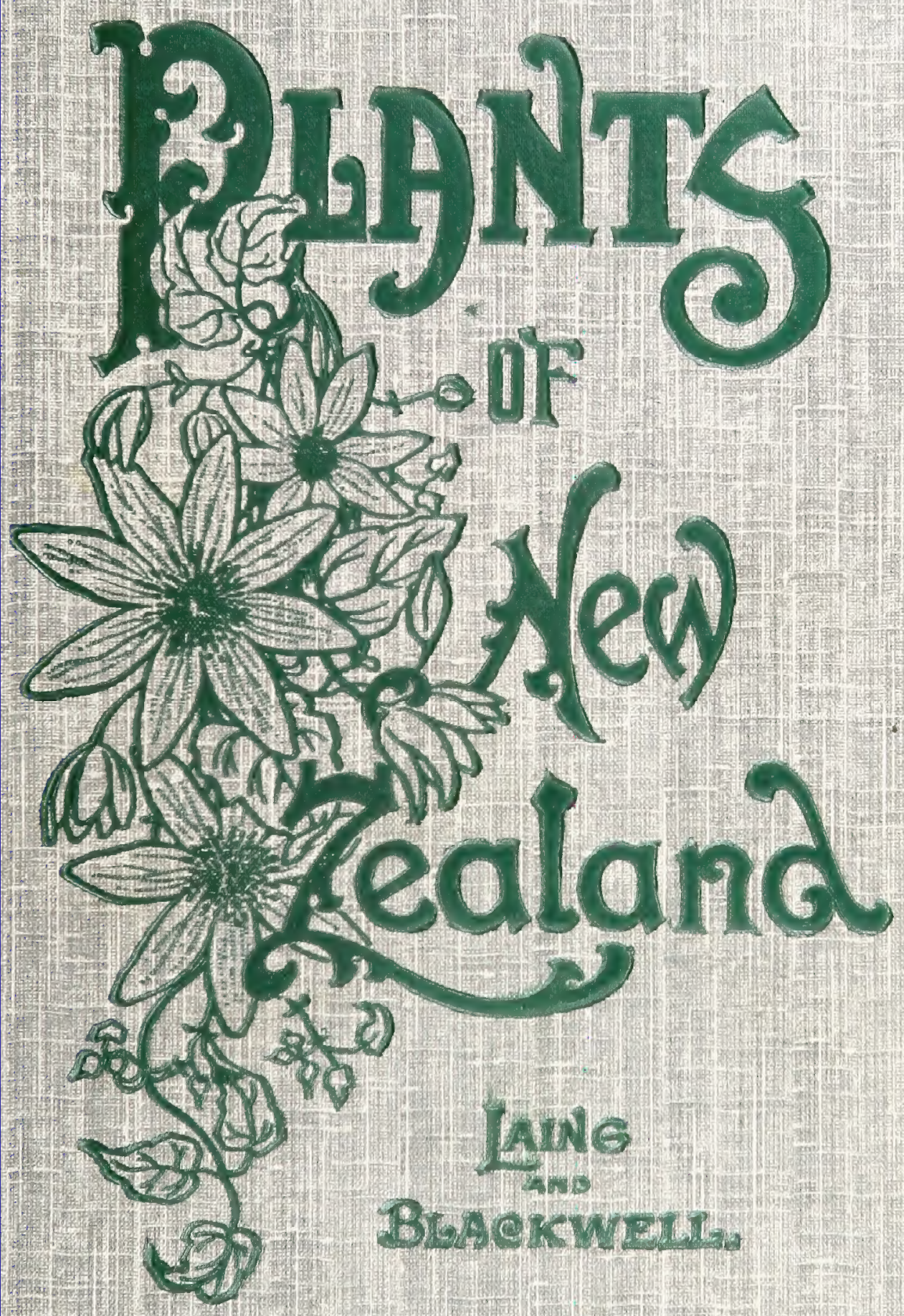




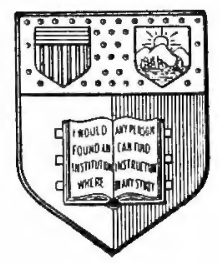

Bew 界ork

State College of Agriculture

At Cormell antibersity

Jtyaca, $\boldsymbol{\Omega}$. $\mathbf{B}$.

\section{II ibrary}

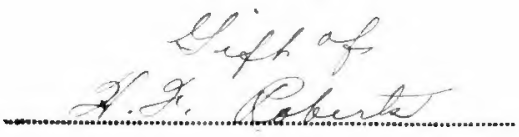


CORNELL UNIVERSITY LIBAARY

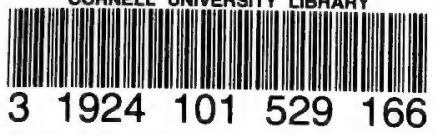




\section{Cornell University Library}

The original of this book is in the Cornell University Library.

There are no known copyright restrictions in the United States on the use of the text. 



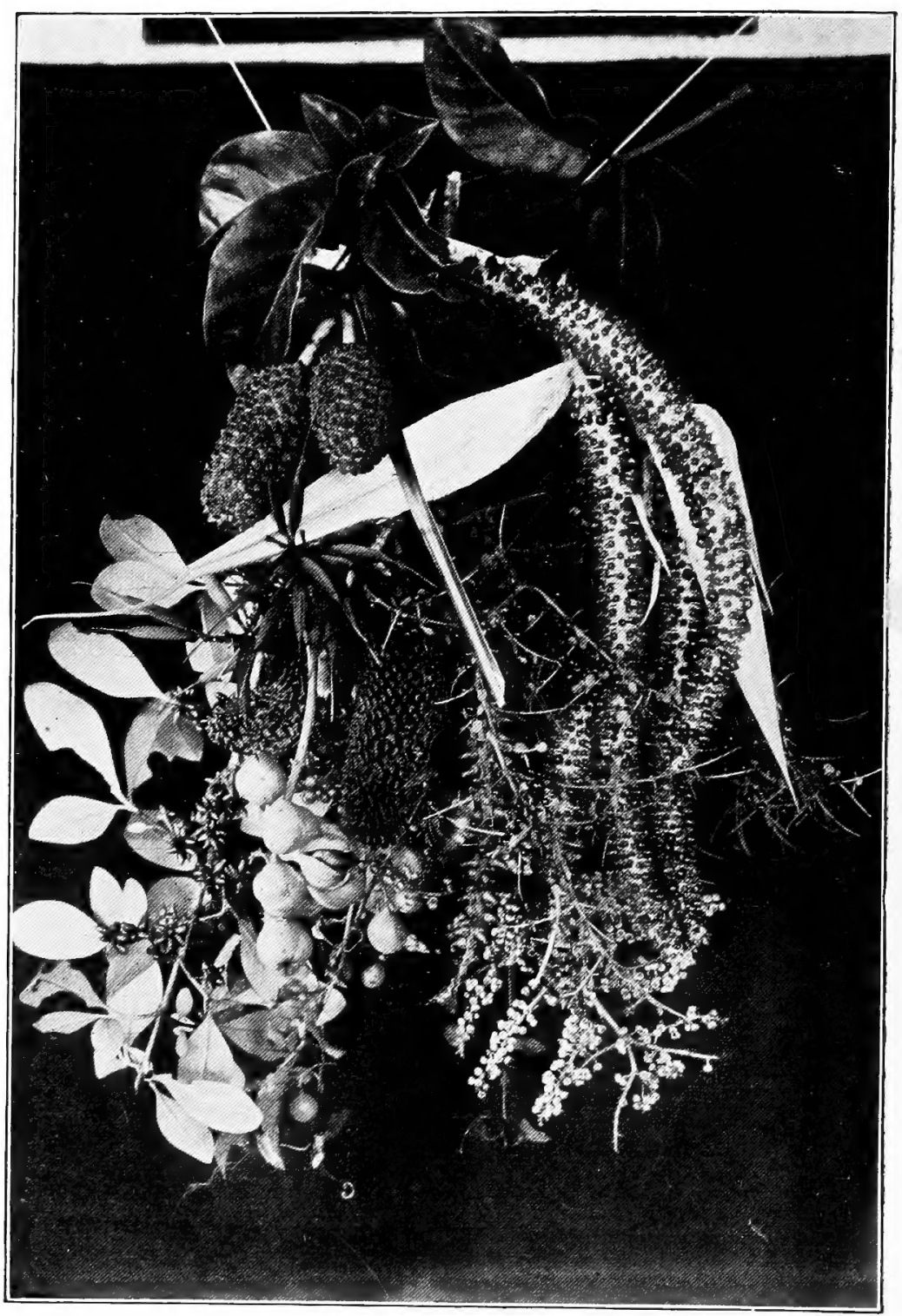

Sew Zetand Fruits.

Frejeinetiн Hanlinij.

Istelia r roningharuit

Coprosina, 3 4 .11

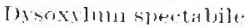




\section{Plants of New Zealand}

R. M. LAING, B.SC.

ANTS

E. W. BLACKWELL.

With 160 original Photographs by $E$. W. and $E$. B. Blactivell.

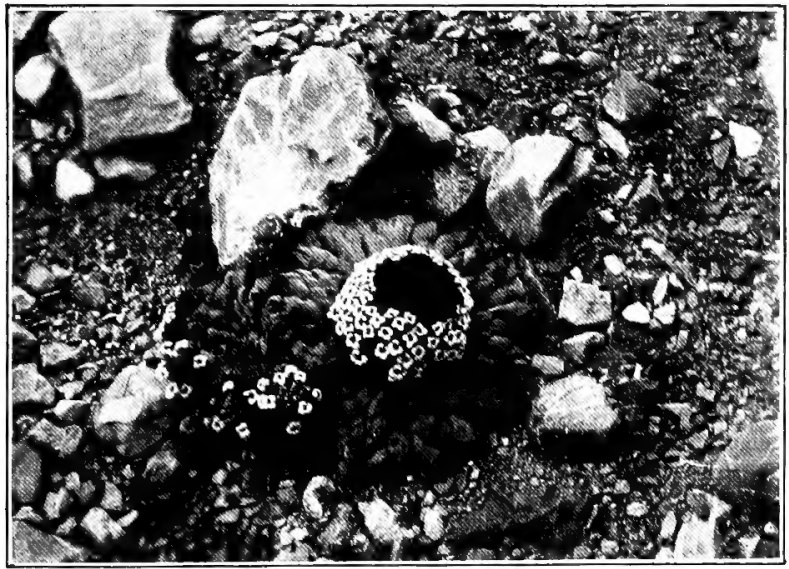

Notothlaspi rosulatum (f nat. size).

CHRLSTCHURCH, WELLINGTON, AND DLNEDIN, N.Z.; MELBOURNE AND LONDON :

WhITCOMBE AND TOMBS LIMITED. 1906 


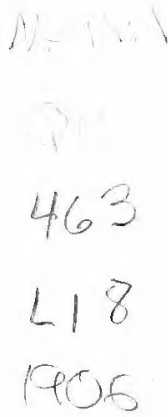

" Earth's crammed with Heav'n, And every common bush afire with God;

But only he who sees takes off his shoes."

-E. B. BRow NiNG. 


\section{PREFACE.}

The Flora of New Zealand is one of the most remarkable known. Indeed, it is so highly specialized, that these islands are generally considered to constitute a distinct Botanical Region. Drude divides the earth into fourteen such Regions, and New Zealand is the twelfth on his list. " This little colony is therefore botanically equal in importance to districts of much vaster area. In spite, however, of the fact that our Flora is one of the most interesting on the face of the earth, there are very few who have any real acquaintanceship, with it. This ignorance is doubtless due to the inaccessibility and technicality of the literature dealing with the subject. In this work an endeavour has been made to give an account of our native plants that will be intelligible to all. As few technical terms as possible have been employed herein, and those used have been explained either in the text or glossary. An attempt has also been made to give as many interesting particulars of the species as the limits of our space will allow.

It is hoped, therefore, that the volume will be of service to all who wish to know something more of a vegetation that is unique. To New Zealand teachers, but especially to those interested in nature study, it should be of considerable value; as well as to all colonists who have any love for the wild flowers of their neighbourhood. Tourists, also, will find here the means for readily identifying all the more conspicuous plants that they are likely to meet with, whilst en route through the colony. Though no new species are described here, many fresh facts have been embodied in the text, and a great quantity of botanical information has been culled from many sources for the book. Hitherto the student has only been able to obtain much of this material by wide and laborious reading in English and German publications and joumals. Hence the book will-we trust--be of some value to the botanist who wishes to procure, in small compass, a suggestive guide for further research.

\footnotetext{
* Handbuch der Ptlanzengeographie.
} 
The work is not a Floria, and therefore does not include all known species. It deals only with flowering plants, and, amongst these, omits the grasses, and certain less important orders. The grasses have been dealt with in special publications by $\mathrm{Mr}_{r}$. Buchanan. The other orders omitted are represented by species little likely to attract the attention of any but the trained botanist. All the more important and conspicuous flowering plants, and many of the rares ones, have been here described, except in the larger genera, such as Coprosma, Veronica, Ranunculus, Olearia, and Sonecio, where we have been reluctantly compelled to content ourselves with a selection of the chief types.

Such a book as this must be to a considerable extent a compilation; and we have therefore made free use of the labours of our predecessors in the field. Anongst these, especial mention may be made of Sir J. Hooker, Dr. Cockayne, Dr. Diels, and Messrs. T. Kirk, T. F. Cheeseman, G. M. Thomson, and D. Petrie. Indeed, all botanical papers in the Transactions of the New Zealand Institute* have been carefully consulted, and all literature obtainable, bearing on the subject, has been read. Unfortunately, the profound paper of Dr. Diels on the New Zealand Flora still remains untranslated, and so is unaccessible to most students. We have therefore made free use of it. We have to thank Dr. L. Cockayne for helping us over many slippery places, and for much generous assistance freely given. We are indebted to Mr. T. F. Cheeseman for the identification of many dried specimens, and for other kindnesses. Assistance has been received from Miss Irene Wilson in the preparation of the glossary, and from Mr. J. Christie in the proof l'eading. We are also under obligations to the following gentlemen for the gift of photographs for reproduction as illustrations: Mr. J. Deans, Mr. A. C. Gifford, Mr. A. Hamilton, Mr. H. Larkin, Mr. S. Page, Mr. J. Crosby-Smith, and Mr. R. Speight.

It should be mentioned that for the first time an endeavour has been made to bring the classification of the New Zealand flowering plants into accord with modern ideas. We have therefore arranged the families according to Engler's system, and not in accordance with that of Hooker and Bentham, hitherto in vogue. (Unfortunately we have been unable to find room for a synopsis of the families, but this may be obtained in any good modern text-book of botany.)

These are shortly referred to in the foot notes, as Trans. 
The book accordingly starts with the pines, - the lowest group of plants described,- and ends with the Composites, the most highly specialized family in the Vegetable Kinglom. This arrangement is much mole in harmony with evolutionary ideas than that usually adopted.

It is hoped that the book will be found up to date, and, though its authors are conscious of its many short-comings, they trust it will be of service to all who wish to learn something of the fascinating problems in the Plant World around them.

R.M.L.

E.W.B.

Mareh 30th, 1906. 



\section{'TABI,F OF CONTENTS.}

\section{INTRODUCTION}

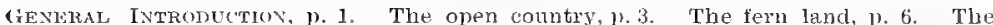
busti, $1 \% .8$. The natural pernianence of the bush, w. 10. The destruction of the forest, 1. 12. "The Passing of the Forest," p. 13. Tyles of forest, p. 15 . Linnes, p. 16. Fpiphytes, n. 20. The scrub, 1. 21 . Alpine vesetation, 1). 22.

The AGr AND AFfiximes of The Flora, p. 24. Oceanic and Continental islands, 13.26. The age of the Flora, 1). 27. The affinities of the Flora, 1. 30. The Australian element, p. 32. The Melanesian element, p. 35. South American element, p. 36. sub-Antarctic element, 1), 36.

Botavical Intronectiox, p. 38. Plant Life, p. 38. Root and stem, p. 39. The leaf, p. 39. The Hower, p. 43. The dispersal of seeds, 1).45, Classification, 1, 46 . Key to the New Zealand fanuilies of flowering plants, 1.49.

\section{THE GIMNOSPERIIS.}

The 1'sis: Fanily, p. 58. The Kauxi, p, 60. The Kawaka, p. 66. The Miro, p. 68. The Totara, 1, 69. The Black Pine, p. 69. The White Pine, 1). 70. The Red Pine, 1. 74. The (')lery-leaved Pine, 1). 76.

\section{THE ANGIUSPERIS.}

Thw, Moxocotrledoxs, p. 80. The Screw-pine Family, p. 80. The Palm Family, p. 80. The Lily Family, p. 88 . The Tris Family, p. 109. The Orchid Family, p. 109.

The Dicotrledons with Free Prtals, 1) 127. The Pepper Family, p. 127. The Beecla Fanily, p. 128. The Nettle Family, p. 136. The Mistletoe Fanily, p. 138. The Bottle-Brush Family, 1. 145. The Sandal-wood Fumily, p. 148. A Family of Root Parasites, 1. 149. The Buckwheat Family, D. 151. The Beet Family, p. 154. The Pink Family, 1), 156. The Marvel of Peru Family, 1). 159. The Mesembryanthemum Fanily, p. 159. The Buttexcup Fanily, p. 160, The Magnolia Fandily, p. 172. The pukatea, 12. 174. The Laurel Family, p. 175. The Wallfower Family, p. 177. The Sundew Family, 1", 180. The Currant-Tree Falnily, 1), 185. The "Matipo" Faunily, 1). 189. The Rose Family, p. 195. The Pea Family, 1, 203. The Geranium Family, 1). 215. The Flax Fanily, 1\%. 218. The Rue Family, p. 218. The Mahogany Tree Family, p, 222. The Smurce Family, 1, 22. The Maple Family, 1. 224. The Tutu Fannily, 1. 226. Pennantia, 1). 230. The Liaraka, 1. 233. The Buckthorn Family, D. 235. The Lime-tree Family, 13, 242. The Mrllow Family, p. 250. The Violet Family, p. 261. The Passion-flower Family, 12. 268. The Daphne Faunily, 1, 269. The MIjutle Faunily, 1, 270. The Fuchsia Family, p. 290. The Haloragis Fanily, 13. 295. The Dogwood Family, 1). 297. The Ivy Family, 1. 300. The Parsley Family, p. 313.

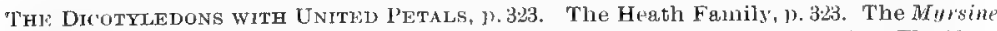
Family, 1, 331. The Prinnose Fannily, p. 333, The Olive Family, 1. 334. The NuxVomica Fanily, p. 334. The Gentian Family, 1).336. The Periwinkle Family, p.340. The Bindweed Family, p. 342. The Borage Family, 1. 346. The Verbena Family, p. 349. The Thyme Family, n. 3t4. The Ninhtshade Family, p. 365 . The Snap-dragon Family, p. 367. The Gloxinia Family, w. 366. The Butterwort Family, 1. 388. The Madder Faunily, p. 389. The Honessuckle Faunily, p. 399. The Cucumber Family, p. 399. The Canterbury Bell Fanily, p. 401. The Goodenin Frunily, p. 404. The Daisy Family, p. 405. 


\section{ITST OF ILLUSTRATIONS.}

Aciphylla Colensoi

, Nonroi

Agathis australis (bush)

, " (cones)

, . . (tree)

Aristotelia racemosa

Arthropodium cirrhatum

Astelia Banksii

, Cunninghannii

,. nerrosa

Avicennia officinalis (aerial roots)

Avicemula officinalis (flower) 115

$$
\text { . . (roots) } 117
$$$$
\text { " , (seed) } 118
$$

Beech Forest

(Photo by A. C. Gifform)

Beilschmiedia Tarairi

Fruchyglottis repanda

('abbage-tree bush

('arex secta i Phote bus. Jeernst

(ammehatelia australis (flower) fis , , ", (reed)

Carpodetus serratus

Cassinia Vauvilliersii

Celnivia coriacea

$$
\text { ", longifolia }
$$

(")ematis indiyisa

$$
\text { (st.zminate form) }
$$

('lematio indivisa

$$
\text { (pistillate form) }
$$

(lemation indivisa

$$
\text { (seed) }
$$

Clematis parvitlora

\begin{tabular}{|c|c|c|c|c|}
\hline Fit. & PAGE & & FIG. & PAGE: \\
\hline 103 & 318 & Cordyline australis (flower) & 23 & 95 \\
\hline 104 & 320 & Coriaria ruscifolia & 69 & 227 \\
\hline 6 & 61 & Corynocarpus levigata & 70 & 231 \\
\hline 7 & 65 & - & 71 & $2: 34$ \\
\hline 5 & 59 & (Photo by s. Pape) & & \\
\hline 75 & 245 & Corysanthes macrantha & 35 & 126 \\
\hline 27 & 109 & Criaspedia unitlora & 153 & 434 \\
\hline 26 & 101 & Cupressoid Types & 124 & 374 \\
\hline 24 & 97 & (Photo bif H. Larkin) & & \\
\hline 25 & 99 & Dacrydium cupressinum & 12 & 77 \\
\hline 116 & 355 & Dactylanthus Taylori & 42 & 150 \\
\hline & & Itendrobium Cuminghanii & 34 & 123 \\
\hline 115 & 353 & (Photo bu A.C. Grefford) & & \\
\hline 117 & 357 & Discaria tommatou & $7: 3$ & 240 \\
\hline 118 & $\$ 359$ & (Photo by Dr. L. Cockenume) & & \\
\hline 37 & 181 & Dracophyllum tuiflorum & 108 & 330 \\
\hline & & Drosera auriculata & 52 & 181 \\
\hline 51 & 176 & ,, spathulatid & 53 & 183 \\
\hline 154 & 485 & (Photo by J. Crosby Smith) & & \\
\hline 21 & 93 & Dysoxylum speetabile & 68 & 223 \\
\hline 2 & 5 & Earina suaveolens & 31 & 117 \\
\hline & & 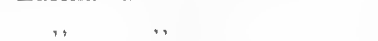 & $3: 3$ & 121 \\
\hline 62 & 207 & Eleocarpus dentatus & 76 & 247 \\
\hline 61 & 205 & ". Hookerianus & 77 & 249 \\
\hline 5.5 & 187 & Entelea arborescens & 74 & 243 \\
\hline 152 & $4: 31$ & Epacris pauciflora & 107 & 328 \\
\hline 144 & 419 & Flax, New Zealand & 28 & 105 \\
\hline 145 & 421 & Freycinctia Banksii (flower) & 13 & 79 \\
\hline 146 & 423 & ,, $\quad, \quad$ (fruit) & 14 & 81 \\
\hline 46 & 163 & Fruits, (Troup of & Prontic & piece \\
\hline & & Fuchsia excorticata & 94 & 291 \\
\hline 47 & 165 & Gayat Lyallii & 81 & 259 \\
\hline & & Gaultheria rupestris & 106 & 326 \\
\hline 45 & 161 & Geniostoma ligustrifolium & 111 & 336 \\
\hline & & Gentiana corymbifera & 112 & 339 \\
\hline 48 & 167 & Gnaphilium trinerve & 147 & 425 \\
\hline 63 & 209 & Griselinia littoralis & 95 & 299 \\
\hline 133 & 393 & (Plinto by J. Crosby Smeth) & & \\
\hline 132 & 391 & Hedycirya arborea & 50 & 173 \\
\hline 134 & $: 395$ & Helichrysum bellidioides. & 151 & 429 \\
\hline 21 & $9: 3$ & ," grandiceps & 150 & 428 \\
\hline
\end{tabular}

C'lianthus punicens

Coprosma arhorea

$$
+ \text { lucida }
$$

$$
\text { " tenuicaulis }
$$

Cordyline australis (bush) 


\begin{tabular}{|c|c|c|c|c|c|}
\hline & FIG. & $\mathrm{PA}(\mathbf{\mathrm { P }} \mathrm{E}$ & & ГIG. & PART: \\
\hline Helichrysum species & 124 & 874 & Myrtus bul]ata & 9.3 & $28 ?$ \\
\hline (Photo by H. Larkin) & & & Nertera dichondrufolia & 135 & 397 \\
\hline Herpolirion novae-Zelandiae & 29 & 108 & New Zealand Flax & 28 & 105 \\
\hline $\begin{array}{l}\text { (Photo by J. Crosby Smith) } \\
\text { Hoheria populnea }\end{array}$ & 79 & $25: 3$ & $\begin{array}{l}\text { Ngaio Tree } \\
\text { (Photo by S. P(r!fe) }\end{array}$ & 119 & $36 ; 2$ \\
\hline (var. angustifolia) & & & Nigger-heads & 2 & \\
\hline xerba brexioides" & 78 & 251 & (Photo by J. Decens) & & \\
\hline xerba brexioides & 54 & 186 & Nikau (bud in sheath) & 16 & 65 \\
\hline Kahikatea berries & 11 & 75 & ," (Hower) & 17 & \\
\hline Karaka grove & 71 & 234 & ,, (nat. size) & $1 R$ & 37 \\
\hline (Photo by S. Puge) & & & (Grove of) & 15 & \\
\hline Kauri bush & 6 & 61 & ", (abnomally branched) & 19 & \\
\hline ", cones & 7 & 65 & Nothofagus (trees) & 37 & \\
\hline, tree & 5 & 59 & (Photo bu A.C. Gifford) & & \\
\hline Kinightia excelsa & 41 & 147 & ,, Menziesii (flower) & 38 & $1: 35$ \\
\hline Kowhai (yellow) & 64 & 211 & Nothopanax Colensoi & 97 & $30: 3$ \\
\hline,$\quad$ (red) & 63 & 209 & Notothlaspi rosulatum & Title & Page \\
\hline Leptospermum ericoides & 87 & 277 & (Photo bu R. speight). & & \\
\hline , scoparium & 85 & 273 & Olea Cunninghamii & 110 & $3: 34$ \\
\hline (bush) & & & Olearia For & 142 & \\
\hline "' (Hower) & 86 & 275 & $\begin{array}{l}\text { H. Larkinl } \\
\text { lcea }\end{array}$ & 138 & 109 \\
\hline Leucopogon fasciculatus & 105 & 324 & , ilicifolia & 139 & +10 \\
\hline Lianes & 4 & 17 & 'Photo by J. Crosby Smith' & & \\
\hline $\begin{array}{r}\text { (Photo by S. Parge) } \\
\text { Cigusticum piliferum }\end{array}$ & & & $\begin{array}{l}\text { insignis } \\
\text { (Photo b" A. Hamilton) }\end{array}$ & 137 & \\
\hline $\begin{array}{l}\text { Ligusticum piliferum } \\
\text { Luzuriaga marginata }\end{array}$ & $\begin{array}{r}102 \\
22\end{array}$ & $\begin{array}{r}316 \\
94\end{array}$ & $\begin{array}{c}\text { (Photo but. Hamiton } \\
\text { nummularifolia }\end{array}$ & 140 & 411 \\
\hline (Photo by J. Crosby Smith) & & & ,, virgata & 141 & \\
\hline Macropiper excelsum & 36 & 129 & Orchids (group) & 30 & 113 \\
\hline Mangrove (flower) & 115 & 353 & Ourisia macrophylla & 130 & 385 \\
\hline$+\quad$ (aerial roots) & 116 & 855 & (Photobut A. Humilton) & & \\
\hline , (stilt roots) & 117 & 357 & Paratrophis microphyllus & 39 & 137 \\
\hline,$\quad$ (seed) & 118 & 859 & Parsonsia capsularis & 113 & 341 \\
\hline Melicope simplex & 66 & 219 & Passiflora tetrandra & 83 & 267 \\
\hline ," $\quad,, \quad$ (nat. size) & 67 & 221 & Phormium tenax & 28 & 10 \\
\hline Melicytus ramiflorus & 82 & 265 & Pimeleat virgata & 84 & 271 \\
\hline Meryta Sinclairii & 100 & 810 & Pittosporum cornifolinm & 57 & 19 \\
\hline Metrosideros hypericifolia & 89 & 279 & (Hower) & & \\
\hline ," robusta (flower) & 90 & 283 &,$\quad$ (seed) & 58 & $19: 3$ \\
\hline , (tree) & 88 & 278 & , tenuifolium & 56 & $1 !) 1$ \\
\hline ", scandens & 92 & 287 & Plagianthus divaricatus & 80 & 25.5 \\
\hline ," tomentosa & 91 & 285 & Pleurophyllum speciosum & 143 & 417 \\
\hline Microtis porrifolia & 30 & 113 & (Photo bu A. Humilton) & & \\
\hline $\begin{array}{l}\text { Miro berries } \\
\text { Mühlenbeckia axillaris }\end{array}$ & 8 & 67 & Podocarpus dacrydioides & 10 & \\
\hline $\begin{array}{l}\text { Mïhlenbeckia axillaris } \\
\text { complexa }\end{array}$ & 44 & 154 & ," ferruginea & 8 & \\
\hline $\begin{array}{c}\text { "' complexa } \\
\text { Myoporum lietum (flower) }\end{array}$ & 43 & 153 & ," totara & 9 & \\
\hline $\begin{array}{c}\text { Myoporum lietum (flower) } \\
,, \quad, \quad \text { (tree) }\end{array}$ & 120 & 363 & Pomaderris phylicefolia & 72 & 237 \\
\hline $\begin{array}{l}\text { "Photo by S.P(tre) } \\
\text { (Poe) }\end{array}$ & 119 & 362 & $\begin{array}{l}\text { Pseudopanax crussifolium } \\
\text { (flower) }\end{array}$ & 99 & 308 \\
\hline
\end{tabular}




\section{Pseudopanax crassifolium (tree) \\ (Photo by H. Luskin).}

Pterostylis Banksii

Ranunculus Lrallii

Rioulia australis

(Photo by H. Larkin)

$$
\begin{gathered}
\text {. mammillaris } \\
\text {, Photo by H. Lurkin) }
\end{gathered}
$$

Rlathdothammus Solandri

Rhipogonum scandens

Rhopalostylis sapida (grove of)

Rhopalostylis sapida (abmormally branched specimen)

Rhopalostylis sapida (bud in sheath)

Rhopalostylis sapida (inflorescence of)

Rlopalostylis sapida (Hower, nat. size)

Rimu (spray of)

Rubus australis

, Schmidelioides

Schefflera digitata

Selliera radicans

Senecio cassinioides

, Lyallii

$\begin{array}{rr}\text { FIG, } & \text { P4GF } \\ 98 & 306 \\ & \\ 32 & 119 \\ 49 & 169 \\ 148 & 426 \\ & \\ 149 & 427 \\ & \\ 131 & 387 \\ 20 & 91 \\ 15 & 83 \\ 19 & 89\end{array}$

Senecio saxifragoides

Solanum aviculare

Sophor: tetraptera (flower) (seed)

"Stilbocarpa polaris

'Photo by A. Hamilton,

Styplelia acerosa

Supple-jack

Tawhera

Thelynitra longifolia

Totara

(Photo by S. Pagp:

Tree-ferm

Tupeia antaretica

Tussock Country (Photo b!' J. Deans)

$16 \quad 85$

Veronica cataractae

, lycopodioides

, monticola

, salicifolia

, speciosa

, Traversii

Teronicas (whip-cord)

(Photo by H. Larkin)

ritex lucens

Whip-cord Veronicas 'Photo by H. Larkin'

White Pine

(Photo bus S. Pare)

$\begin{array}{rr}\text { FIG. } & \text { PAGE } \\ 157 & 439 \\ 121 & 365 \\ 64 & 211 \\ 65 & 213 \\ 96 & 301 \\ & \\ 109 & 33: 9 \\ 20 & 91 \\ 14 & 81 \\ 30 & 113 \\ 9 & 71 \\ & \\ 3 & 7 \\ 40 & 143 \\ 1 & 4 \\ & \\ 129 & 383 \\ 128 & 382 \\ 127 & 381 \\ 125 & 377 \\ 122 & 371 \\ 126 & 379 \\ 123 & 373 \\ 114 & 351 \\ 123 & 373 \\ & \\ 10 & 73\end{array}$

FIG. PAGE

1574339

$121 \quad 365$

211

213

301

$3: 3 \cdot 2$

381

371

379

373

351

136404

$155 \quad 437$

$156 \quad 43 \mathrm{~K}$ 


\title{
Plants of New Zealand.
}

\author{
GENERAL INTRODUCTION.
}

\footnotetext{
"Oh, when I am safe in my sylvan home, I treat on the pride of Greece and Rome, And when I am stretched beneatl the pines, Where the evening star so holy shines, I laugh at the lore and the pride of Man, At the sophist schools and learned clan. For what are they all, in their high conceit, When Man in the bush with God may meet? '
}

R. W. EMERSON.

New ZEALAND is almost in the centre of the greatest watersurface of the globe. It is indeed the Land's Fnd of the world; and as such affords to the geologist, biologist, and ethnologist, material of the highest interest. But not to the scientist alone is it full of fascination. Any lover of Nature will find here an inexhaustible store-house for his wonder and admiration. Life everywhere is infinite in its variety and unfailing in its resourcefulness. In New Zealand it has developed many plants and animals unknown in any other part of the world. Indeed, two-thirds of the indigenous species of flowering plants are not to be met with elsewhere. This is a much higher percentage of local forms than can be found in any other islands of approximately the same extent. This unparalleled proportion of endemic species is due, partly, perhaps, to the long isolation of the islands, partly to the great 
variety of conditions they offer, and partly, no doubt, to the nature of the floras from which their own has been derived; but also to unknown factors that have not, as yet, come within the ken of the investigator.

Not only does the flora contain a unique assemblage of local species, it also shows an unusually varied assortment of plant families and associations. Nor is this to be wondered at, if we consider the changes of climatic, geographical, and geological conditions to be met with every few miles. We would certainly expect to find many very different kinds of vegetation between the warm sub-tropical ravines of the volcanic Kermadecs, and the wind-swejt heights of the subAntaretic Auckland Islands; and we are not disappointed in our search. Hooker, and other early botanists, declared that the plant covering was constant over wide areas; but this generalisation was largely due to an imperfect acquaintance with the distribution of the species, and with the rarer forms of the flora. It has not been borne out by the work of more recent investigators. Many New Zealand plants are very restricted in their distribution.

The altitudinal changes of climate are as well marked as thuse of latitude. There is often not more than twenty or thirty miles distance between the line of sea-level and that of perpetual snow. Thus, within a comparatively small area, all types of plants may be found, from those of the sea-shore, to those of alpine heights. Great valiations in rainfall are also to be met with in places not far apart. This, of course, is larsely due to the presence of high mountain chains, such as the Southern Alps, the Kaikouras, and Ruahines. The smallest average rainfall yet recolded is that of Clyde, with 15 inches, and the highest, 228 inches, at Puysegur Point.: The former place is in Central, the latter in South-Western Otago; and the distance between then is only 150 miles. Indeed, there are few districts of equal extent that can show so many changes of climate, elevation, and surface in such a small 
space as New Zealand. It might be expected, therefore, that not many plants would cover large areas of the country to the exclusion of other species; and this is the case. Except for the beeches, the manuka, the tussock-grass, and the bracken fern, few species monopolise any large tract of country. The constant changes of surface, altitude, and climate nust of necessity be reflected in the plant-covering of the land. Even the most car'eless observer is struck by the great differences in the floras of the eastern and western sides of the dividing range-differences corresponding in a large measure, to increase or decrease of average rainfall. In some places, within a distance of a nuile or two, the beech forest of the drier regions changes into the mixed bush of the moister western area.

New Zealand, therefore, presents a field of unsurpassed interest to the botanist. Here he may find plants grouped together into as many different associations as on a continent. All classes of habitat, from the littoral to the alpine; from the arid plain to the lake, from the rock to the peat-bog, from moorland to salt meadow, are well represented. Plants are to be met with in an almost endless variety of situations. We shall, however, at present consider only the plants of the open plains, the forest (or, as it is locally termed, the "bush"), the scrub, and the mountains.

\section{The Open Countri.}

"I see again the upland wilds, Stern, rugged, bleak, and bare;

The strong winds sweep o'er the hill sides steep

And the tussocks toss in the icy air Silver and gold in the changing light, Gold and silver far up on the heights Of the mountain wild and bare."

DAYID MCKEE WRIGHT

Throughout New Zealand, from Southland to the North Cape, there are numerous open plains of greater or lesser extent. In England such spaces would be meadow lands, carpeted with 
a grassy sward, which would in spring and summer be spangled with flowers. In New Zealand, they are covered with a vegetation of a very different type. As far north as Lake Tampo, it consists chiefly of tussock grass, toi-toi, and cabbage tree (palm-lily). This plant formation is most highly developed in Canterbury, where wide open tussock-clad plains cover an area of two and a half million acres. The Englishuan, on his arrival here, is puzzled by the appearance of detached hillocks of grass, in place of the continuous turf of the green fields to which he is accustomed. He cannot understand that this dry
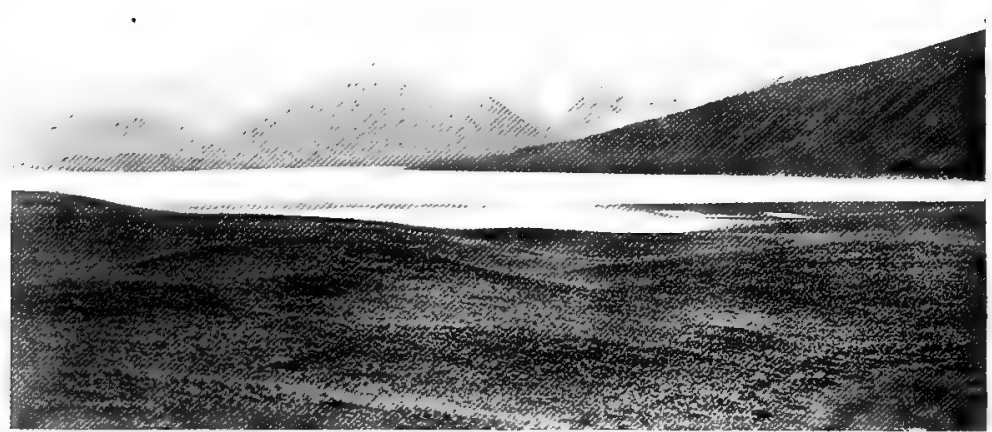

Fig. 1-Tussock Countri.

hart wiry straw can replace, to a large extent, the pasture lands of England. This plant association not only covers much of the flat country, but is found in many places throughout the South Island upon the hills, especially on the eastern slopes of the ranges. The chief species of grasses found in it are Pod caespitosa and Festuca duriuscula, but some Danthonias are also to be net with in such situations.

'The tussock comtry is dearly loved by every New Zcalander. It is full of associations for him. The stock-rider, the shepherd, the swagger, and even the sun-downer know every aspect of 
it. They have seen it in early morning, when every tawny thread had its string of clammy mist drops. They have seen it again at midday, a parched and thirsty land, that seemed to be covered with broken yellow wavelets, flying before the fierce squalls of the nor'-wester. They have stumbled through the entangled tufts at night, too tired to lift their feet. They have slept dmongst them, tying together adjacent bunches to form a tunnel in which they might be sheltered from the cutting night winds of the plain.

In many places, particularly near water courses or shingly river beds, the toi-toi (Arundo conspicua) largely replaces the tussock. It is the tallest and most conspicuous grass in the New Zealand Flora. It bears a considerable resemblance to

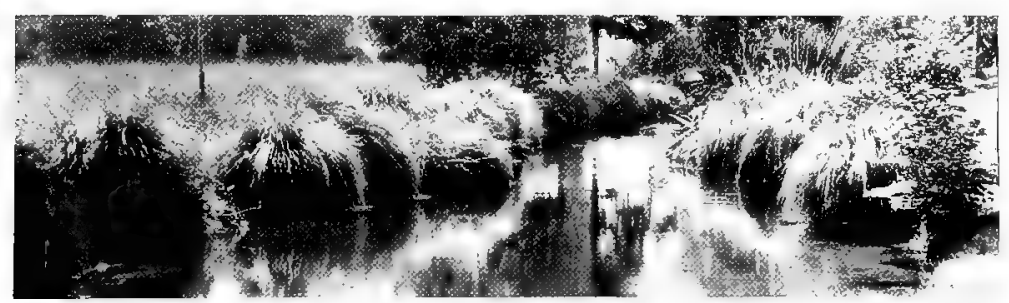

Fig. 2-Nigker-heads.

the magnificent Pampas Grass of the Argentine, now cultivated all over the world. It is not, however, so large or so beautiful as the American grass ; it flower's at a different season, and may readily be distinguished by the more graceful droop of the flowerstalk. The plumes of the pampas grass are taller, straighter, and stiffer than those of the toi-toi. The edges of streams on the tussock-clad plains are often fringed with flax and bulrush, whilst, in the water itself, stand numbers of blackened stumps about two feet high, bearing on their summits drooping brushes of long, coarse, green, or tawny threads. These are termed by the colonists, nigger-heads.

This plant, (Carex secta) carries out literally the advice of St. Augustine, and makes of its dead-self a stepping stone to 
higher things, for the lower portion of the stump consists of the dead roots of past seasons; and by growing on these the plant gradually raises itself out of the water of the bog in which it grows, into higher and drier levels.

The edge of the New Zealand swamp has been well described by Mr. A. H. Adams, in a poem called The Brave Days To Be-

\footnotetext{
"Out in the open, by the swampy pools,

The army of waving grasses went;

First in the van the hosts of ${ }^{1}$ raupo reared

Long lines of ruddy spears; close following

The green ranks of the "haralieke came,

Lifting aloft their sullen flashing blades,

And sturdy bronze-brown standards; and, behind,

The 'tois' white battalions flaunted far

Their dazaling banners aud soft silver plunes,

While gaunt and motionless upon the hill,

The naked "cabbage-trees stood sentinel."
}

\section{The Fern Land.}

North of Lake Taupo, the tussock country ends. In Auckland the open land is covered with heath or fern. Fern country is found throughout New Zealand, but becomes more plentiful towards the North. Here there are large areas covered with the bracken, (Pteris aquilina; var. esculenta). In many places it grows in great luxuriance, rising to the height of ten feet, and forming miniature forests that cover the land to the exclusion of all other vegetation.

The rhizone of this fern, as is well known, was used by the Maoris for food when none other could be obtained. It therefore held an important place in their dietary, though it can scarcely be described as a staple article of food. To prepare it for use it was soaked, washed, placed on a flat rock, and repeatedly beaten by a heary stone pestle or club (patu.) 
During the beating the fibres were picked out. The material left behind bore some resemblance to arrowroot, but only the pangs of hunger would induce the European to consider it palatable.

Though there are no other varieties which cover so wide an area, yet the ferns form such a prominent feature in the Flora, that New Zealand is often termed "The Land of Ferns," and a fern frond has been taken as its emblem.

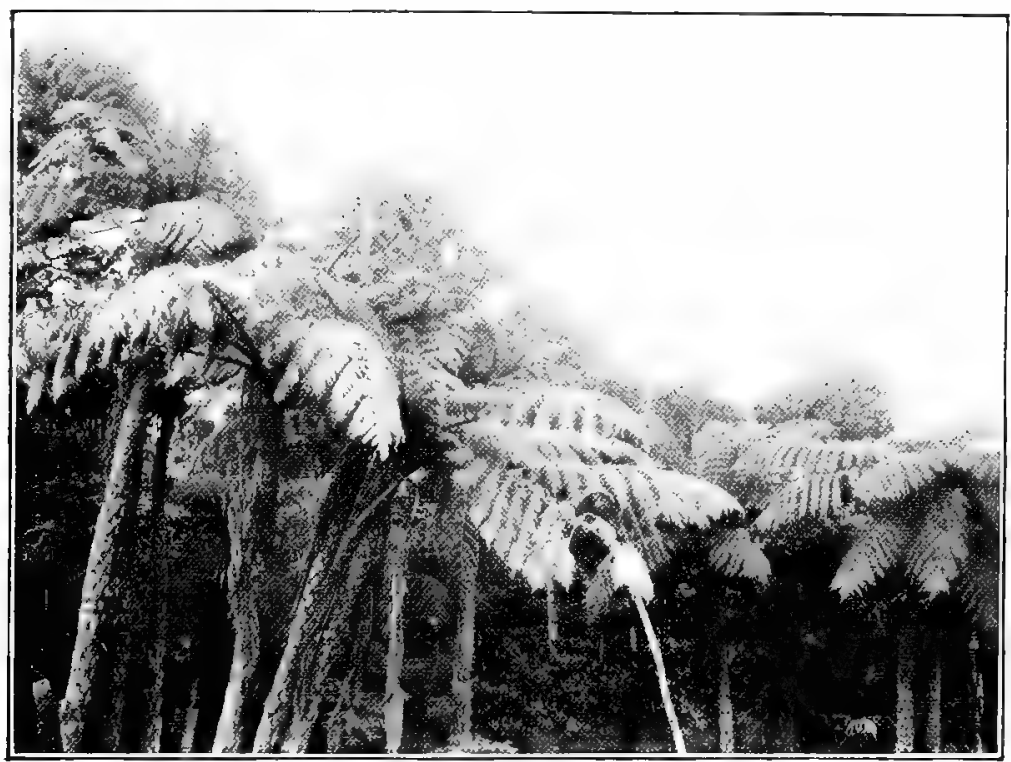

Fis 3-Tree-ferns.

Perhaps there is no country of equal size outside of the Tropics, which has such a large number of different kinds of ferns as New Zealand, and possibly none could show greater magnificence of fern-life. Prominent amongst the species are the tree-ferns. These help to give the forest that semi-tropical appearance, which will shortly be described. There are, in addition, a large number of species of Filmy-Ferns, (Hymenophyllum), Polypods, Aspleniums, and Lomarias. The 
New Zealand Club-Mosses (Lycopods) are also exceptionally well developed, and are the largest of the order known. The discovery of a number of the germinating spores of various species in New Zealand is likely, before long, to add considerably to our knowledge of the life-history and attinities of this interesting order of plants.

\section{The Bush.}

"I an Tante-the Tree-Grod! Mine are forestis not a fewForests, and I love them greatly, MIoss-encrusted, ancient, stately."

IDOMETT.

The New Zealand bush can scarcely be said to show any typical aspect. It reflects the prevailing lack of uniformity of the plant associations. Consequently, it is impossible to describe in a single epithet its chief characteristic. Indeed, so varied is it, that one can often find in a single forest, as many different kinds of trees as there would be in half of Europe ; and these, not belonging to a few orders as do the European trees, but to the most widely divergent families. Palm and pine, rata and mangrove, cabbage tree and fuchsia, beech and fern -the Malayan and South American plant grow here in apparent, if not real amity. At first sight, it would seem as if the ends of the earth had been laid under contribution for strange forms, which were afterwards assembled on these islands, but a closer examination shows that this has not been the case; for, though the bush has quite a patch-work appearance, most of cur trees, as will be shown subsequently, have come to us from Malaysia, or at any rate from Melanesia.

There is, however, one undeniable characteristic of the forests. They are gloomy, though it may be doubted whether they are more sombre than those of many other regions. The dark hue and leathery texture of the foliage, is no doubt due to 
the fact that the native trees are evergreen. Leaves that have to last through several seasons are rarely so soft in texture, or light in tint, as those that have only to withstand the storms of a few months. There are but few deciduous plants of any kind in New Zealand. Gaya Lyallii, Plagianthus betulinus, Olearia Colensoi, two species of Mïhlenbeckia, a North Island variety of Sophora, the Fuchsias, Discaria toumatou, are perhaps the only deciduous, or partially deciduous, plants to be found here. Hence the tender greens and browns, which in spring delight the eye in the English woods, and the more brilliant tints of artumn, are almost wanting in New Zealand. Some few of the evergreens, however, (e.g., Entelea, Aristotelia racemosa) in addition to the native deciduous species, have leaves of lighter green and softer texture than the ordinary bush tree. Indeed, if a forest is closely looked at from above, it will be found to show many different shades, though the prevailing type of foliage is mondoubtedly the dry, hard, glossy, dark-green, simple, more or less oblong leaf.

Nor is the characteristic gloom of the forest relieved by its blossorns, for the flowers of most of the New Zealand trees are quite inconspicuous. They are generally small, and oftentimes green, and completely hidden by the foliage. There are, of course, exceptions. Among these may be mentioned those of the whau, the hinau, pokaka, Gaya, Hoheria and the various species of Metrosideros (rata and pohutukawa). As none of these except the ratas ever form large forests, to the more or less complete exclusion of other trees, it is rare to find the bush showing any great profusion of bloom. Occasionally, however, the rata covers with its crimson flowers the flanks of some great mountain range, and the sight is then well worth going far to see.

Such brilliancy of colouring, however, is rare. Yet, particularly in the North Island, the beanty of the bush is much enhanced by the Nikan Palm, the fern-tree and the cabbagetree, which are frequently found growing together in great 
profusion. It would then almost seem as if the vegetation of a tropical island from the warm Southern Seas had been dropped in amongst our more sombre flord, for these three plants all bring with them suggestions of a warmer land than this. Indeed, some have said, basing their statements on this and similar facts, that the climate of New Zealand has been, in recent geological times, much warmer than at present. They endeavour to strengthen their argument by adducing in support of it, the evidence afforded by the profusion of climbers and twiners, which often render the bush an almost impenetrable jungle. However, conclusions as to past climate based only on present characteristics of mature plants are of little value. The true explanation of the resemblance between our forests and those of sub-tropical regions is to be found in the fact that nearly all our bush trees are of Melanesian origin. The beeches are the most important exceptions to this rule.

The Natural Permanence of the Bush.

Another erroneous opinion is that the bush is impermanent; that it actually flies before the advancing footsteps of civilization. It is said that whenever tracks are cut through it, decay sets in on both sides, the undergrowth dies, the ferns and mosses disappear, and even the trees themselves become gaunt and misshapen, and their leaves few and tattered. This statement can only be regarded as incorrect. Even in the drier districts where the trees are struggling against very adverse conditions, a forest that has been "cut out" will, in time, replace itself, if not subjected to the interference of man and other animals. Surveyor's' tracks through damp bush are soon overgrown when left undisturbed; and, as Dr. Cockayne has shown, a burnt area is soon re-forested, in the wetter districts at least, though not necessarily retaining the same predominant species. 
Yet, it must be admitted that the limits of conditions within which the varied life of the forest can maintain itself, are comparatively narrow. Many of the native trees are extremely susceptible to frost. Some of the bush-plants of Otago cannot endure the winters of the more Northern Canterbury Plains, but this is not because the forest is decadent. The climate of these plains is an extreme one. Plants that can flourish there must be able to withstand excess of drought, heat, cold, and insolation. Mr. T. W. Adams, of Greendale, has shown that there are but few foreign trees and shrubs which can adapt thenselves to these conditions. It is, therefore, scarcely a matter for surprise that this district and the somewhat similar one of Central Otago, should be treeless. Undoubtedly, they were both once partially bush-clad; but the destruction of their forests was probably not in any way due to an increasing severity of climate. It is susceptible of quite another explanation. In these districts the rainfall does not reach thirty inches a year. Now, the experience of many countries, but particularly of the United States, proves that forests cannot exist permanently in regions with a rainfall of less than thirty inches per ammm. If, owing to a cycle of wet weather, accompanied perhaps by other contributing causes, they manage to get a foothold in arid districts, they are always liable to be swept off by fire; and, being once so destroyed, it is difficult for them, without artificial assistance, to become reinstated.

The soil, unprotected by the shade of the foliage, dries up, and germination is soon made impossible. On hill slopes the spongy mosses no longer retain the moisture. After rain, the rivers and streams become more quickly flooded. Hundreds of acres of soil are thus frequently swept away, and a bare rocky surface replaces the once dense forest. This process is going on throughout New Zealand wherever the bush is being artificially cleared, but the devastation is greatest on the steep hill tops. In America it has been found 
necessary to take special steps at great expense, to reforest the upper mountain slopes. In New Zealand, the Forestry Department, with admirable foresight, has already secured a number of clinatic reserves on mountain summits. These will have to be fenced off to secure the exclusion of sheep and cattle, for such animals work irretrievable havoc in the forest undergrowth, and to them must be attributed much of the apparent decarlence of the natural forests. Wherever they have secured admission to the dense bush, seedlings and young trees are soon trodden under foot, broken down, and killed; light is let in, and the bush gradually decays and disappears.

\section{The Destirtction of the Forest.}

As we have already seen, much of the tussock country of the South was at one time forest-clad. The evidence of charred logs on or below the surface of the ground, proves that some of it, at any rate, was cleared by fire in recent times. This may have been started spontaneously, or may have been the work of pre-historic dwellers in the land. The Maoris in the South Island have a tradition that when the Te Rapuwai tribe slread over the country, Invercargill was submerged by water, the forests of Canterbury and Otago were destroyed by fire, and the Moa was exterminated. Canon Stack put this in lis list of uncertain traditions; but there is at lcast nothing inherently improbable in the destruction of these forests about this time. In Auckland, the presence of the kauri gum in vast areas now treeless, or occupied only by the manuka and other heath plants, is proof that at one time the kauri forests were of much greater extent than at present. The cause of their disappearance is unknown.

Whatever way have been the canses in the past, affecting the reduction or increase of forest areas, they fall into insignificance compared with the changes artificially wrought since 
the arrival of Europeans. It is impossible to give any but the roughest estimate of the area covered by forest, when the first white men reached New Zealand, but it was undoubtedly very great. In 1893 the area still bush-clad was estimated at twenty willions of acres. This acreage is being reduced annually by an amount of not less than 100,000 to 200,000 acres. Clearly, our forests will last only a comparatively short time if this rate is maintained. Of course, only a very small proportion of timber is removed and utilised. Most of it is burnt on the spot. Much of this destruction has been inevitable, but some of it, unfortunately, has been wanton. The remark of Sir Julius Vogel, "that a swagger would burn down a forest to light his pipe," is perhaps somewhat of an exaggeration, though it must be confessed that some of the finest kauri forests have been destroyed by such acts of carelessness. Happily, most of the bush is too damp to be in danger of accidental burning. The bigger trees must first of all be felled, and the forest afterwards set fire to in the drier season of the year. However necessary this clearing may be, it cannot fail to leave with the lover of nature a feeling of sadness. The Hon. W. P. Reeves (High Commissioner of New Zealand in London) has well expressed this sentiment in a noble poem. He has kindly given his consent to its publication here. The final stanza is, we believe, now for the first time printed.

"THE PASSING OF THE FOREST."

All cannot fade that glorifies the hills,

Their strength remains, their aspect of command,

Their flush of colour when calm evening stills

Day's clamour, and the sea-breeze cools the land.

With shout of thunder and with voice of rills,

Ancient of days in green old age they stand

In grandeur that can never know decay,

Though from their flanks men strip the woods away. 
But thin their vesture now -the restless grass,

Bending and dancing as the breeze goes by,

Citching quick gleams and clondy shades that pass,

As shallow seats reflect a wind-stirred sky.

Ah! nobler far their forest raiment was

From crown to feet that clothed them royally,

Shielding their mysteries from the glare of day,

Ere the dark woods were reft and torn away.

W'ell may these plundered and insulted kings,

Stripped of their robes, despoiled, unclonked, discrowned,

I) raw down the clouds with white enfolding wings,

And soft aërial fleece to wrap them round,

To hide the scar's that every season brings,

The fire's black smirch, the landslip's gaping wound;

Well may they shroud their heads in mantle grey,

Since from their brows the leaves were plucked away!

Gone is the forest world, its wealth of life,

Its jostling, crowding, thrusting, struggling race,

Creeper with creeper, bush with bush at strife,

Wirring and wrestling for a breathing space;

Below, a realm with tangled rankness rife,

Aloft, tree columms, shafts of stateliest grace.

Gone is the forest nation. None night stay ;

Giant and dwarf allke have passed away.

Gone are the forest birds, arboreal things,

Eaters of honey, honey-sweet of song,

The tui, and the bell-lird, - he who sings

That brief, rich music we would fain prolong.

Gone the wood-pigeon's sudden whirr of wings;

The daring robin, all unused to wrong.

Wild, harnless, hamadryad creatures, they

Lived with their trees, and died, and passed awar.

And with the birds the flowers, too, are gone

That bluomed aloft-ethereal, stars of light;

The clematis, the kowhai like ripe corn,

lusset, though all the hills in green wero dight:

The rata, draining from it tree forlorn

Rich life-bloor for its crimson blossoms bright,

Red glory of the gorges-well-a-day!

Flod is that splendonr, dearl and passed away. 
Gone are the forest tracks, where oft we rode Under the silver fern-fronds climbing slow,

In cool, green tunnels, though fierce noontide glowed

And glitered on the tree-tops far below.

There, mid the stillness of the mountain road,

We just could hear the valley river flow,

Whose voice through many a windless sumner day

Haunted the silent woods, now passed away.

Drinking fresh odours, spicy wafts that blew,

We watched the glassy, quivering air asleep,

Midway between tall cliffs that taller grew

Above the unseen torrent calling deep :

Till, like a sword, clearing the foliage through,

The waterfall flashed forming down the steep:

White, living water, cooling with its spray

Dense plumes of fragile fern, now scorched away.

Feen is the axe, the forest fire streams loright,

Clear, beautiful, and fierce, it speeds for man

The Master, set to change and stem to smite,

Bronzed pioneer of nations!-Ay, but sean

The ruined wonder wasted in a night,

The ravaged beauty God alone could plan,

And builds not twice! A bitter price to pay

Is this for progress, - benuty swept away!

\section{Types of Forest.}

Though the bush is generally of mixed type, yet, in certain districts, particular species predominate to the more or less complete exclusion of others. The Oxford and Alford Forests consist almost entirely of Nothofagus Solandri. Nothofagus Cliffortioides often forms the sole species in mountain districts. In the North of Auckland the kauri is found in groves, and sometimes even in forests. There are large areas in the eastcentral portion of the North Island, in which the totara is the prevailing tree. Throughout the lowland forests of the South Island the rimu is plentiful, but the sub-alpine forests of the 
western ranges consist almost entirely of the various species of Nothofagus. In wany districts of the North, particularly in the south of Auckland Province, the tawa is found in immense quantities. In swamps in both Islands large wasses of kahikatea (white pine) occur. In other places scattered through the islands the rata is the prevailing tree. The coastal forests usually produce a very great variety of trees. The beech, rata, and kauri forests will be described more fully when the trees themselves are dealt with.

\section{LIANES.}

"Exulting Nature so delights,

So riots in profusion, she

Twice orer does her work for glee!

A tangled intricacy first she wenves,

Under and upper growth of bush and tree

In rampant wrestle for iscendancy,

Then round it all a richer overflow

Of reckless regetation flings,

That here close-monleling on the shrubs below

A matted coat of delicate leaves,

Mantles the muffled life whereon it clings,

Into a solid mass of greenery.

There mounting to the tree-tops, down again

Comes wildy wantouing in a perfect rain

Of trailers -self-encircling living strings

Unravellable; see how all ahout

The hundred-stranded creeper cordage swings!"

DOMETT.

Plants which depend upon others for existence, and therefore cannot group themselves into associations, are said to form Guilds.* No description of the bush would be complete without some reference to the guilds it contains. The chief of these are the climbers or lianes, epiphytes, saprophytes and parasites. Of these, only the first two need be considered here. The climbing and creeping plants have had a special fascination

\footnotetext{
${ }^{+}$Ger., Genossenschuften.
} 


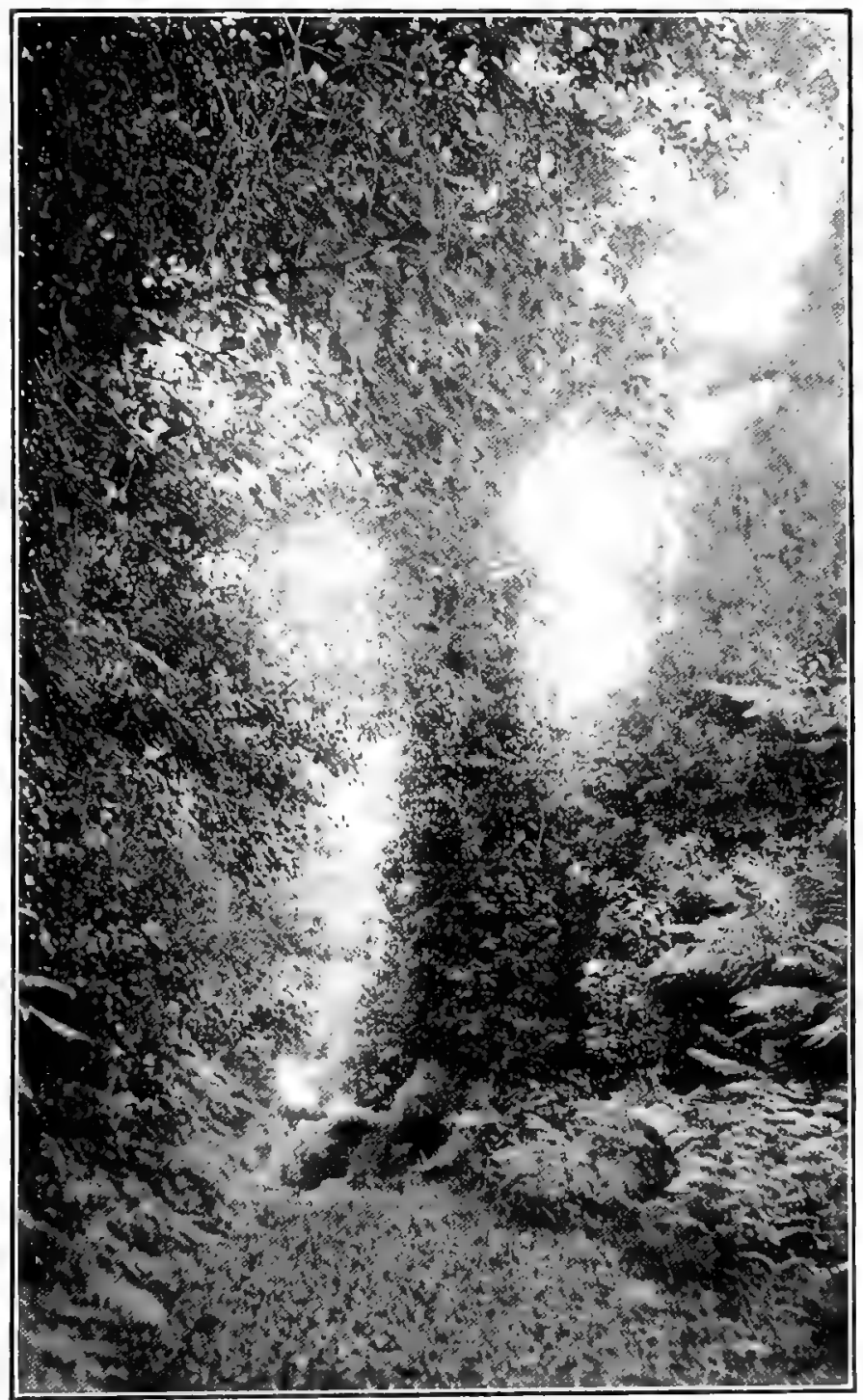

Fig. 4-Lianes. 
for many writers. The term liane, like the blessed word Mesopotania, seems alumost to have been sufficient to bring tear's to the eyes of Kerner. In a rapturous passage he alludes to it as the "beautiful word liane" the "sweet word liane."

It is difficult to see why the bush climbers should have arousen so much enthusiasm. Possibly, it is because they are comparatively rare in Europe, and have, therefore, been looked upon as symbolizing the luxuriance and strangeness of the tropical forest. In England there are no climbers that reach the tops of the trees except the ivy and honeysuckle. Lianes reach their highest development in the Tropics, but particularly in the WVest Indies and Brazil. In New Zealand, both they and the epiphytes are better represented than in any other extra-tropical country except Chili, whose forests show frequent resemblances to those of New Zealand.

The advantage of a climbing stem to the bush plant is obvious. Little direct sunlight can penetrate into the cavernous depths of the forest. The interior of the New Zealand bush is immersed in a cathedral-like gloom. Few plants, therefore, can grow upon its floor. Only when some giant of the forest falls, is there room for another to develop. Such seeds as germinate must quickly struggle up to the light overhead or die. There is no time for them to grow into trees. Many, therefore, have developed a climbing habit, in order to be able to ascend rapidly to the surface of the ocean of green boughs, that toss above in the wind under the 'sweet flooding sunshine.' They are careless of the means by which they climb. Their one cry seems to be, "more light, more light!".

Amongst our climbers many different methods are adopted for reaching the light. The kie-kie sprawls awkwardly over

It is easy to be stilty of the "pathetic fulluer," and to read into their upward strukifles our luunan emotions, as kingsles has done in a well-known passage in $4 t$ Last; lut sucl an interpretation will not holp us towards a real understanding of plant nature. At the same time, in unere description, it is often diffucult to avoid the use of words or phrases which may seem to iwly in the plant a luman motive. Where smch may halmen to occur in this book, they must be understood nurely in the dencriptive and not in tle telenlogical sense. 
the ground until it falls across a tree. Then it fixes its roots into the crevices of the bark, and pulls itself up. It often ends in smothering its living ladder with inmense masses of sword-like foliage, whose weight must be tremendous. Similarly, several of the rata vines ascend by ivy-like rootlets. The large rata-tree, however, strangles its support, putting out transverse finger-like roots that cannot fail to impress the ordinary observer with the apparent purposefulness of their grasp. The lawyer, on the other hand, cat-like, fixes its recurved claws into the bark of a tree, and thus drags itself up. The Clematis and Passiflora climb by tendrils. The Supplejact, Mïhlenbectias, Convolvuli, Parsonsias, Ipomea, and Senecio sciadophilus twine. None of these are strong enough to support themselves, though some of themparticularly the lawyers and Mïhlenbeckias-may occasionally be found in the open, where they form mounded heaps, often many feet in diameter, and several feet in height.

Wanderer's through the bush are often puzzled by observing cable-like stems that fall pendent from the roof of the forest to its floor, withont support. It seems impossible that these climbers, with their flexible stems, could have got into such a position without some external help. Often it will be found that these rope-like lianes belong to a species of Rubus, (the bush-lawyer). They have originally been endowed with hooks by which they have climbed up a tree. Their weight and upward growth have finally disengaged them from the trunk by which they have ascended, and in the course of years they may be removed by various processes to a considerable distance from it. If the liane is not a Rubus, then its position can only be explained by supposing that the tree up which it climbed has died, probably in an unavailing effort to push up to the light. Many young trees throughout the forest must perish in this way.

The structure of the stem in lianes is of considerable interest, but for a description of this some text book of botany must be consulted. 


\section{EPIPHYTES.}

$$
\text { "What a load }
$$

That sturdy giant lifts in air!

His mighty arms are strong and broad, But all with alien growths are furred, A shaggy hide of creepers rare; Their forks are all blocked up and blurred With tufts of clogging parasites That crowd till not a spot left bare Might offer footing for a bird!"

DOMETT.

The epiphytes constitute another important plant guild. These are plants which grow upon others, yet receive no nourishment from them. They must be carefully distinguished from parasites, with which they are often confused. The parasite obtains its nourishment more or less completely from the plant on which it grows. Some of the epiphytes, perhaps, owe their existence to the same cause as the lianes. They are plants which have assumed a habitat in the forks, or on the branches of trees, in order to obtain more light; but this explanation will scarcely account for the New Zealand species, as these, without exception, are occasionally found growing on rocks.

It is obvious that a plant which grows upon the bark of a tree must often suffer from scarcity of water. Hence most. of our epiphytes have contrivances to protect them from excessive transpiration. A plant, therefore, which can live epiphytically, is also adapted for living on such a dry situation as a rocky cliff. There, however, it may suffer from an excess. of sunshine. The physiological adaptations demanded by the one situation are not necessarily quite the same as those required for the other. Hence, though most epiphytes are inore or less commonly found growing on rocks, the converse is by no rueans true.

Epiphytes, like lianes, are generally supposed to be the mark of a tropical climate. In Great Britain epiphytical 
shrubs and trees are unknown, and the chief plants found on trunks and limbs of trees are accidental epiphytes, such as mosses and ferns. The light spores of these are blown. about by the wind, and thus are able to reach lofty situations on the face of a cliff, or in the forks of a tree. The seeds of some dicotyledonous epiphytes, such as those of the rata, may be carried about in the same way, but other's are deposited in position by birds. In New Zealand the number of epiphytes is very large, considering the latitude of the country. We must again, as in the case of the lianes, go to Chili to find forests in a similar latitude with an equal abundance of epiphytic growths. Diels suggests that this characteristic is due to large rainfall in the forest regions of both countries. The following list includes the unost important of the epiphytic species amongst the flowering plants:--Astelia Cuninghamii, A. Solandri, A. spicata, Earina mucronata, E. autumnalis, Dendrobium Cuminghamii, Bolbophyllum pygmaeum, Sarcochilus adversus, Peperomia Uvvilleana, Pittosporum comifolium, Metrosideros robusta, M. Colensoi, Griselinia lucida. Diels includes in his list Elatostema rugosum and Gaultheria epiphyta, but is surely in error in doing so. E. rugosum is found only on the sides of creeks and rivers, and in very moist places. It is plentiful, for example, on the rocky walls of the Wanganui River in some parts of its course. G. epiphyta is misnamed, and the error has apparently misled Diels.

\section{The Scrub.}

Perhaps some mention should be made here of the Scrub, as it is strange to the visitor from the Northern Hemisphere. The light underwood of the English copse or thicket is very different from the impenetrable shaggy scrub of New Zealand. In the wind-swept regions of the south, it is sometimes so 
dense that progress through it is impossible. It must be either avoided altogether or walked over. Anyone who essays the latter method of advance, does so with the risk of falling through the uneven floor of rigid branchlets which supports him. Should this accident happen, he may be much bruised or scratched, though he is not likely to be serionsly hurt. The scrub consists chiefly of Coprosmas, but also contains species of Cassinia, Olearia, Myrtus, etc. The leaves of the typical scrub plant are suall and sparse, the branches rigid, twiggy, and often pointed. The manuka is often termed a scrub plant, but its characteristics are rather those of the Heath, which will be described later.

\section{The Alpine Vegetation.}

In the South Island, the mixed lowland forest is generally replaced at altitudes of from 1,000 feet to 2,000 feet, by the beech forest. Beyond 3,000 or 4,000 feet this passes into the the region of sub-alpine shrubs, which are mostly Veronicas and Compositae. These, again, gradually give way to the alpine herbs of the mountain meadows, moors, and shingle-slips. With the line of perpetual snow all vegetation ends. In the North Island there are only three peaks which rise over 7,000 feet, the volcanic mountains, Ruapehu, Egmont, and Ngauruhoe. The first of the three is the highest, being just over 9,000 feet. In the South Island, the Southern Alps, which culminate in Mount Cook, 12,349 feet high, have hundreds of peaks which are over 7,000 feet. Hence the alpine vegetation flourishes best on that range. The perpetual snow-line ranges from about 7,000 feet in Otago, to 8,000 feet in Nelson. The Kaikoura range on the East Coast also has several peaks which are never free from snow. There, too, alpine herbage has been found, but this range has hitherto 
been explored very imperfectly by botanists. The vegetation of the Southern Alps, thanks to Buchanan, von Haast and Dr. Cockayne, is now comparatively well known, though there are doubtless a considerable number of mountain species yet to be discovered. It is to this range, then, that botanists must turn to find the best known New Zealand alpine plants. Nor need they be mountaineers, for many of the species that belong climatically to higher levels, come down to the lower passes, and sometimes descend the river beds almost to the plains. On the top of Arthur's Pass, on the Canterbury-Westland coach road, numerous alpine and sub-alpine species are to be found. Here, in January, the wild flowers blossom in the greatest profusion, forming a garden whose uncovenanted beauty wight easily put to shame the stately flower ranks and geometrical foliage beds of many a prized parterre. True, white is the prevailing colour, broken occasionally by gleams of yellow, but though there is no gorgeousness, there is at least no disharmony of tone. Ranunculus Lyallii with its large white cups, and Celmisias of various species, with their large daisy-like flowers, are conspicuous in such an alpine meadow, by the size, beauty, and profusion of their blooms. Even when these plants are not flowering, there is still to be seen that wonderful variety of leafage so dear to every mountain climber's heart. Ruskin has well described it, though writing of European forms. "The leaves of the herbage at our feet take all kinds of strange shapes, as if to invite us to examine them. Star-shaped, heart-shaped, spear-shaped, arrow-shaped, fretted, fringed, cleft, furrowed, serrated, sinuated, in whorls, in tufts, in spires, in wreaths endlessly expressive, deceptive, fantastic, never the same from footstalk to blossom; they seem perpetually to tempt our watchfulness, and take delight in outstripping our wonder."

The alpine plants and foliage must always have a fascination for those who delight in beauty and variety of leaf-form. 
Their flowers, too, are certainly the most attractive amongst those of the herbaceous plants of New Zealand. Town dwellers, in their untravelled and untrammelled ignorance, frequently say that New Zealand has no wild flowers. Certainly we have none in the neighbourhood of the cities, or on the plains, that can compare with those of the fields and hedgerows of England. One reason for this is obvious. Where not too dry, the land has, previous to the advent of the white man, been covered with forest. There have been no damp meadows or shady lanes to provide a home for annual or bulbous plants. But though we have no pale bearty of primurose or deep glow of violet, there is many a handsome plant and many a sweet-scented flower aunidst the great lonelinesses of the Alps, for the pleasure of those who care to leave the cities, and live for a time in the fresh air and glorious scenes of the mountain heights.

\section{The Origin of the New T/Aaland Flora.}

The discussion of the relationships of the farna and flora of Southern regions has given rise to some of the most fascinating speculations of modern science. It has provided us with quite unexpected glimpses into the past history of the earth's surface, and of the climatic conditions then prevailing. We have learnt from it stories of sunken continents, and of warm seas full of life, where now there are only barren ice-sheets. However pleasant it might be to follow the by-paths of Science in the investigation of such questions, the limitations of our space prevent us from giving them any adequate treatment here. A consideration of the chief factors involved in the present distribution of animal and vegetable life in the South Tempcrate Zone, would require references to stratigraphical geology, ocean soundings, and to general geological and astronomical theories quite outside the scope of this work. 
At present we are concerned solely with the origin of our Hora. It is clear, however, that such a question can only be very imperfectly treated, if confined to a discussion of the present distribution of plant life in southern lands. Any comclusions derived from the study of botanical relations alone, must be subjected to such modifications as may be demanded by evidence obtained from the study of the other sciences. For example, the plants of two widely separated districts often show closer relationships than the animals do. This apparent anomaly will be explained, if we remember that stretches of sea which may prove insuperable barriers to the passage of land animals, may be crossed by plants. We unust, therefore, in our treatment of the subject give conclusions that have been based on a wider discussion than is possible here.

Whilst doing this, we shall consider shortly the evidence of fossil botany, and of the present distribution of plant life throughout the Southern Hemisphere. The first problem that naturally arises in the discussion, is the connection existing between the New Zealand flora and the Australian. This is larger than can be accounted for by mere proximity. Another question of unusual interest, is the origin of the remarkable South American and Antarctic elements in our flora. Probably the most complete and ingenious theory, yet put forward to account for this connection, is that of the late "Capt. F. W. Hutton, F.R.S. Some of his views have been combated by Dr. A. R. Wallace and others; but undoubtedly the New Zealand biologist had a wuch wider knowledge of the present and past conditions of distribution prevailing in the Southern Hemisphere, than any of his critics. We shall, therefore, adopt his views here. In one point all are agreed, and that is as to the past great extension of the Antarctic Continent into sub-temperate seas. The demonstration of this has been recently termed "one of the greatest triumphs of

"In the recent death of this distinguished scientist, New Zealand has suffered a loss that can scarcely be too much deplored. 
modern science." We are proud to say that this magnificent generalisation is in considerable measure due to the work of New Zealand botanists. Before, however, considering the botanical evidence, we must treat shortly of the general characteristics of our fauna and flora.

\section{Oceanic and Continental Islands.}

For the purposes of the biologist, islands may be divided into two classes, continental and oceanic. A continental island is one which has at some period of its existence been united to an adjacent land-mass. Its fauna and flora contain few endemic species, and differ little, if at all, from that of the neighbouring continental area. Great Britain is an excellent example of a continental island. The British fauna and flora are simply parts of the European fauna and flora. In quite recent times the Straits of Dover have been dry land. An oceanic island, on the other hand, is one that has never been united to any continental area. Its fauna and flora are often very fragmentary, and frequently contain a high percentage of endemic species. Its plants and animals are generally provided with good powers of distribution; and have reached the island from across the sea. The Azores may be taken as an example of a group of Oceanic islands.

To which of these two classes shall we assign the islands of New Zealand? It has characteristics both of continental and oceanic islands, and it is, therefore, sometimes termed anomalous. However, there is much evidence to show that it was at one time attached to a land area probably much larger than that of Europe ; and that it is consequently entitled to rank, geographically speaking, as a continental island. Yet its fauna, unlike that of most large land areas, is very fraguentary. The flora, though wore complete than the fauna, has also many gaps in it, and both fauna and flora contain 
a larger proportion of endemic species than a typical continental island usually does. Nevertheless, there are many reasons for the belief that the ancestral stock from which New Zealand plant and animal life originated, was a continental one. Before attempting to answer more precisely the question: "Whence has our plant life come?" we must try to decide as far as possible how long the present flora has been in existence, and whether we must look for its ancestry here, $\mathrm{Or}^{*}$ in some foreign land.

\section{The Age of the Flora.}

There is a common but erroneous opinion, that the New Zealand flora shows marks of exceptional antiquity. There are perhaps several groups of facts which have led to this mistake. (1) Many of the New Zealand geological formations are of great age. New Zealand is an old land. (2) The almost complete absence of indigenous mammalia, and the presence of certain ancient forms of animal life, e.g. Peripatus Sphenodon, (the tuatara, etc.), prove the unusual age of the fauna. (3) The remarkable development of fern trees and of club-mosses, and the comparative absence of large and showy flowers seem almost to imply antiquity for the flora,

But none of these facts are sufficient to justify the belief. The high age of part of the rocks and of the fauna is not a necessary proof of the antiquity of the flora. Plants can transport themselves over barriers insurmountable to animals. Few wingless land animals can cross five hundred miles of sea, yet we have evidence that this has been done by the seeds of many plants. Hence, a comparatively young flora maysometimes be found living in company with a much more ancient fauna. We must, therefore, rely entirely on the evidence of the plants themselves for determining their antiquity or otherwise. Hooker, it is true, states that the New Zealand lycopods " are the largest of the order, and present nearer" 
affinities to the fossil Lycopodiaceae of the coal period, than any other existing plants" "; but this opinion cannot justify the extraordinary statement seen at times in the books of popular writers, that the New Zealand flora is more like that of the Carboniferous than is any other existing flora. As a matter of fact, our species of ferns and lycopods do not show affinities that tend to prove them older than the ferns and lycopods of other lands. Further, the evidence of the flowering plants does not suggest that those of New Zealand are of any high degree of antiquity. Many ancient forms, that once existed in New Zealand, and still exist in other lands, have been replaced here by plants of a more modern type. One of the oldest orders of the phanerogams is the Cycadeae. We have now no cycads in New Zealand, though fossils show that they fomerly existed here. Changes of climate may have driven them out. At one time they formed a considerable portion of the vegetation of the globe, and they are still found in large numbers in the tropical and sub-tropical regions of both hemispheres. Turning to the Monocotyledons, we obtain somewhat similar evidence. These plants are generally supposed to be older than the Dicotyledons, though the testimony of the rocks on this point is by no means indisputable. They are, however, assuredly extremely old, and if our flora were exceptionally ancient, we might expect them to be well developed in New Zealand. The contrary, however, is the case. Throughout the sonthern hemisphere the monocotyledons are more poorly represented than in the northern. Again, the facts of fossil botany seem to show that the palms are one of the oldest orders of monocotyledons. In New Zealand we have only one species of palm-tree. This paucity of forms way perhaps be due to climatic or similar conditions. In the tropies they are plentiful. On the other hand, it is to be admitted that we have an ancient monocotyledon in the cabbage-tree (Cordyline).

\footnotetext{
"Handhook of the New Zealand Flora." (1). 387).
} 
Amongst the dicotyledons, one of the oldest groups contains the willow, poplar, oak, hazel-nut, birch, beech, chestnut, and hornbeam. This group is highly characteristic of the Northern Hemisphere, but though once well developed in New Zealand, is now no longer represented here, except by the genus Nothofagus, in which are included the "birches" of the subalpine forests. The most highly developed family of plants, on the other hand, is the Compositae; and this, though almost wanting in the bush, is well represented in the open country and in the alpine and sub-alpine scrub by more than 230 species. There is, indeed, little if anything in the distribution of the dicotyledons, to suggest that the New Zealand Flora is older than the European.

Again, it may be suggested that the large number of green, inconspicuous flowers and the separation of the sexes in an unusual proportion of the species are marks of a primitive floral organization; yet it is doubtful whether they can be so interpreted. The former characteristic is obviously to a large extent dependent on local conditions; for the foreign representatives of New Zealand genera with small flowers have often large and showy blossoms. The New Zealand species of Viola, Passiflora, Myosotis, and of the various genera Orchidaceae have less conspicuous blooms than the corresponding species in other lands. This lack of brilliancy of the local forms, obviously cannot be due in all cases, to their greater antiquity, but is much more likely to be the result of the adjustment, or lack of adjustment, of the flowers to the insect life of the country. The unisexual condition of many of the flowers may be susceptible of a similar explanation. It is at any rate not a primitive but a secondary condition, for it can easily be shown that most of our dicecious plants were in quite recent times hermaphrodite. In a word, the long isolation of New Zealand has certainly resulted in the development therein of many unique forms, and also perhaps in the preservation of some antique types, yet it cannot be said there is a sufficient 
mass of facts to justify the statement that the flora as a whole is of an exceptionally ancient type.

One line of evidence that might help us largely is, unfoltunately, not available at present to any large extent. Of the fossil botany of these islands we know very little. The chief paper on the subject is by the famous palæo-botanist, Baron von Ettingshausen. A translation of this appears in volume xxiii. of the Transactions. If the data contained in it are reliable, it would seem (1) that the living flora has largely been derived from the tertiary flora; (2) that the tertiary flora was part of the original universal flora from which are descended all plants of the present day; and (3) that only one part of the tertiary flora has been changed into the living flora, the rest having become extinct. It would appear also that at one time there existed in New Zealand, trees similar to the great redwoods of California, the Norfolk Island pine, the she-oaks and gum-trees of Australia, the alders, oaks, elms, and maples of the Northern Hemisphere, and the fig. With the exception of the gum-trees, and perhaps the fig, these are all old types, now extinct here, though existing elsewhere. These identifications have in most cases been made from fossil leaves only, and in the absence of flowers and fruit; some of them, therefore, can only be regarded as tentative.

\section{The Affinities of the New Zealand Flora.}

The relationships of the New Zealand flora to those of other lands, have given rise to greater discussion than its affinities to those of the past. We have obviously much more material for the investigation of the present distribution of plant life, than for that of times long gone by. Still, many of the problens concerned are very difficult of solution. Amongst those who have dealt with these questions may be mentioned the late Captain Hutton, Dr. A. R. Wallace, Professor Engler, 
Mr. G. M. Thomson, and Mr. W. Botting Hemsley. It is inpossible to deal fully with the results of their work, but an attempt will be made to give an intelligible, though necessarily brief account of it.

Of the 1,400 flowering plants which New Zealand contains, some two-thirds are found nowhere else. A considerable proportion of the remainder is confined to New Zealand and Australia, or to New Zealand, Australia, and other southern districts. A section of the New Zealand flora shows a most striking South American aftinity. There are a few cosmopolitan plants, and there is also an element usually termed Scandinavian, which shows a relationship to a certain portion of the flora of the Northern Hemisphere. As, however, the endemic species constitute by far the greater portion of the flora, the foreign affinities are best shown in the genera. Of these, 80 per cent. are found in New Zealand, 10 per cent are endemic, and the remaining 10 per cent are variously distributed. It is clear, therefore, that the basis of the New Zealand flora has either been derived from Australia, or that the element common to both has come from the same source. As a matter of fact, the latter hypothesis is best supported by the evidence. Several lines of argunent, as has already been stated, show that at one time New Zealand was more extensive than it is now. It then stretched to the northward, through Lord Howe and Norfolk Island, to New Caledonia, and perhaps even as far as the Solomons. Another continental arm connected Queensland with New Caledonia. Through these northerm extensions there passed, though not necessarily at the same time, southward to New Zealand, and westward to Queensland, the ancestral forms of much of the vegetation common to the two countries. In this migration we have an explanation of the sub-tropical facies of the New Zealand forests, and also of the fact that nearly ninety per cent of our forest flora has Melanesian affinities. It is probable that this northern extension existed in Miocene 
times, but by the Eocene, much of it had disappeared. Thus far, the problem of the Australian relationships of our flora is comparatively simple, but on further examination we are soon confronted with the fact, that, although New Zealand plants show so many Australian affinities, yet most of the prevailing and characteristic Australian forms are entirely absent from ow shores. An attenut to explain this anomaly will require a somewhat fuller comparison of the two floras.

\section{The Floras of New Zealand and Australia.}

Isolation, varied environments, and doubtless other facts, have been at work for a long time to give New Zealand a unique flora. A visiting botanist would find here only unknown plants around hins. He would be puzzled, not only by the strange local species, but also by the large number of dissimilar plant associations to be met with in a small area. Perhaps there is no more difficult flora in temperate regions for the botanical tyro to classify. It seems to be a mixture of many incongruous elements. The visitor from Australia would be little better able to cope with its difficulties, than the traveller from England. In spite of the fact that so many of the New Zealand genera are also to be found on the neighbouring continent, no adjacent floras elsewhere are so unlike as those on either side of the Tasman Sea. Yet the distance between the two lands is little more than a thousand miles. This likeness with unlikeness constrained Sir Joseph Hooker to say: "Under whatever aspect I regard the flora of Australia and New Zealand, I find all attempts to theorize on the possible community of feature, frustrated by anomalies of distribution, such as I believe no two other similarly situated countries on the globe present."

The New Zealand forest is varied and mixed. The Australian often varies little over immense areas of country. 
The New Zealand bush is generally an impenetrable jungle, while throughout a great part of Australia

\footnotetext{
"The land lies desolate and stripped;

Across its waste has thinly strayed

A tattered host of encalypt,

From whose gaunt uniform is made,

A ragged penury of shade."
}

A mixed bush, somewhat similar to that of New Zealand, is however, found in the wetter regions of South-Eastern Australia. But the enigma which baffled the speculations of the earlier botanists, lies in the fact that the most important of the Australian genera are completely absent from New Zealand. Hence results the lack of superficial resemblance between the Horas of the two countries. The gum trees, wattles, she-oaks, bottle-brushes, hakeas, dc., which are so abundant in Eastern Australia, are without a single representative here. It might well have been expected that some of these would have found means of crossing the Tasman Sea.

It is little to be wondered at, then, that Sir Joseph Hooker should have found it difficult to theorize concerning the relationships of the two floras. Yet he seems scarcely to have realised sufficiently that the differences of climate, surface, and geological conditions existing between the two countries, are such, that similar plant associations could not be expected to occur in each. It unust, however, be admitted that these differences in themselves do not constitute a sufficient explanation of the absence from New Zealand of the characteristic Australian species and genera. The gum trees, wattles, hakeas, and sheoaks, flourish as well hele as in their native land; and some of these at least can and do maintain themselves without artificial aid in our islands. Of course they have been much assisted in gaining a foothold hele by the presence of clearings effected by civilized man. Yet, their complete absence from New Zealand, before the arrival of the European, can be explained only on the assumption that they never before obtained an opportunity of establishing themselves here. As 
we have no large deserts, we could scarcely expect to find in this country the mallee scrub, the myall, the salt-bush and the spinifex of the Australian "bad lands" ; but we might at least have anticipated that forms related to these should occur in New Zealand, modified only by the different conditions obtaining here, though their absence may perhaps be explained on the assumption that the specialized Australian forms did not reach the inter-continental bridge, which formerly connected New Zealand with the great northern land-area.

This answer to the problem may prove to be sutficient, but there is at present no consensus of opinion amongst biologists upon the subject. Dr. Wallace, looking rather to an Australian than to a Melanesian origin of our flora, has put forward a highly ingenious theory to account for the anomalies observed by Sir J. Hooker. This theory, at one time received tentatively, has more recently been subjected to considerable criticism at the hands of Mr. C. Hedley and others.* On account, however, of its general interest, it will probably be worth while to outline it here, without attempting to form an exact estimate of its value. In Cretaceous times, Australia existed as two islands, an eastern and a western. A wide belt of sea, broken by islets, stretched from the Gulf of Carpentaria to the mouth of the Murray river. The western island, according to Wallace's hypothesis, was the more ancient, and already possessed many of the ancestral forms of the peculiar and characteristic flora of to-day. In eastern Australia, however, the flora consisted chiefly of Melanesian and Antarctic species, with possibly a small proportion of the more typical Australian forms. About this time, or in the Eocene, the eastern island was united by way of a land-bridge to New Zealand, and by this connection the New Zealand flora obtained its Australian element. Subsequently the eastern and western islands became one, the connection with New Zealand was broken, and the Australian types overran the new 
continent. This theory seems to lay too much stress on the direct connection of Australia with New Zealand, whereas the facts of the case scarcely require any such connection. Indeed, we have in recent times received from Australia a few species of plants directly across the Tasman Sea. Species of Olearia, Senecio, Epacris, and of the Orchidaceae, have probably reached us in this way. All these plants, however, are provided with seeds that are either small, or furnished with a pappus, so that they may have readily been blown across the intervening ocean by a high wind. The fauna, however, shows that our connection has been with the islands to the north, rather than with Australia. There is evidence of a much more recent connection with New Guinea and Melanesia than with temperate Australia, which has perhaps not been united with New Zealand since the Triassic period.

\section{Other Foreign Elements.}

Other important elements in the New Zealand flora are the Antarctic and South American. It is difficult to measure their amounts statistically, as they depend not so much upon community of species, as upon the similarity of representative forms in many genera. The American section is that part of the flora which shows resemblances to plants living in temperate or tropical South America. The Antarctic element consists of plants which are related to others found in one or all of the following places: Patagonia, Southern Chili, Tierra del Fuego, the Falkland Islands, Tristan d'Acunha, The Crozets, Kerguelen Land and the mountains of Victoria and Tasmania. The term "Antarctic" as applied to these plants has been objected to, as all the districts referred to, lie outside of the Antarctic Circle. Dr. Cockayne has suggested the word "Fuegian," in place of it; but it is probable that the more correct term, "Sub-Antarctic," will be adopted. A few of the plants belonging to this section are also found in South Africa. 


\section{South American Element.}

The South American element is better developed in New Zealand than in Australia; this may be due to our being somewhat nearer to Peru and Chili, than Australia is. The genera Fuchsia and Calcolaria are confined to New Zealand, and temperate or sub-tropical South America. Myosums aristata, Sophora tetraptera. (The Yellow Kowhai), Haloragis alata, Hydrocotyle Americana, Teronica elliptica, and a few other species, are also confined to the same two districts. It may, however, be questioned whether the forms of these species, occurring on both sides of the Pacific, are exactly the same in every case. Further investigation is required on this point. Probably about a forrth of the New Zealand genera are also found in South America, though not confined to these two places. A connection of such a pronounced nature as this indicates that at some time the two stations must have been united by land, or at least by a chain of islands.

The evidence of animal life shows that the former alternative is the more probable one, and that there has been direct land commmnication with South America, perhaps in sub-tropical regions. From these and other reasons, Captain Hutton assumed that in the Cretaceous, or Early Eocene, a Pacific Continent connected New Zealand and New Guinea with Chili.*

\section{Sub-Antarctic Element.}

But a much more striking phenomenon is the existence between latitudes $55^{\circ} \mathrm{S}$, and $65^{\circ} \mathrm{S}$. of groups of islands separated sometimes by thousands of miles of sea, yet often possessing native plants of the same species. This community of species. shows that these islands must have been in comparatively close communication with each other in quite recent times. Some of the plauts referred to are found in New Zealand, more particularly in the Auckland Islands and Campbell Island. A

\footnotetext{
"Nature" "July 13th, 1905. (This letter is probalbly the last jmblished scientific writing of the great biolosist).
} 
few of them are also found in the Alps of South Eastern Australia. The following plants may be taken as examples of these sub-Antarctic types. Acaena sanguisorbae is known from the Kermadecs to the Macquaries, and is also found in Australia and Tristan d'Acunha, while $A$. adscendens occurs from Marlborough to the Macquaries, and also in Chili, Fuegia, and the Falkland Islands. Tillaea moschata is found throughout New Zealand and the Southern Islands, and also in South Chili, Fuegia, the Falkland Islands, Kexguelen's Land, and Marion Island. Oxatis magellanica has been collected in Victoria, Tasmania, Sonth Chili, and Fuegia as well as in New Zealand. Callitriche antarctica is found in the Snares, The Auckland Islands, Campbell Island, the Antipodes, Macquarie Islands, Kerguelen's Land, Falkland Islands, and Sonth Georgia. Other similar examples might readily be given, but these will probably suffice for our present purposes. This remarkable connection becomes even more striking, when we examine the floras of the sub-Antarctic islands thenselves. Thus Mr. Hemsley* states that of eighty-four gener'd found in the Falkland Islands, fifty-six are also represented in New Zealand. More recent research may have modified these numbers, but the proportion will probably not be largely altered. Though these sub-Antarctic islands show such marked resemblances in their plant life, there is no such similarity amongst them in the distribution of the higher types of land animals. Obviously, the connection, though a very recent one, has not been a close one. Hence Captain Hutton concluded that in Pliocene times "A number of islands existed in the Antarctic Ocean, which have since then disappeared." According to this theory, there has been no direct connection with the Antarctic continent since the Jurassic period. At that time, New Zealand, South America, and South Africa are believed to have been united by land. 
Such a hypothesis as this is at best only tentative, and its chief value lies in the stimulus it gives to research, and the aid it affords in placing subsequent hypotheses on a more solid foundation. There are numerous other problems of considerable interest in connection with both the internal and external distribution of our indigenous plants, but these will not be dealt with here.

\section{BOTANICAL INTRODUCTION.}

\section{Plant Life.}

At one time people spoke as if the life of the plant were different from that of the animal. There are few so ignorant now as to think that a distinction can be drawn between plant and animal life. The plant responds to stimuli, reproduces its kind, and grows, just as the animal does. Moreover, every plant has the power of spontaneous motion as a whole, or in some of its parts. Amongst the higher plants, movements are confined to parts of the plant - the tendils of the vine twine; the stamens of the barberry respond to a touch with a jumping motion; the leaves of many plants close at night; others alter their position with the direction of the light that falls upon them. In all, there are movements in response to gravitation, and to the action of light, and in connection with the processes of growth. In recent times sensation has been claimed for many plants. All apparently have the power of "sensing" gravitation, and some have been recently declared by Haberlandt to possess "ocelli" for perceiving light. However, the life of the plant is so remote from all that man knows of himsclf, that he can never hope to do more than realize its meaning very imperfectly, though it can scarcely be doubted that the more fully he can appreciate it, and the more fully he can enter into sympathy with it, the more fully will he understand himself. 


\section{Root and Stem.}

For our present purposes, a plant may be considered as consisting of root, stem, branches, leaves, flowers, and fruit. The root* is developed from the rootlet or radicle of the enbryo, and serves two purposes. It fixes the plant in the soil, and absorbs water and salts in solution by means of minute thin-walled hairs on the rootlets. The stem supports the leaves and branches. The crude sap ascends through it to the foliage at the tips of the highest twigs by a process or processes, even now not well understood. Here the water is evaporated, and any salts that it still contains are left behind in the leaves and shoots. The stem and branches therefore, as well as supporting the plant, enable the sap to ascend and descend, and thus provide communication between different parts of the tree.

\section{The Leaf.}

The leaf is the chief organ by which the plant nourishes itself. Air enters it by minute pores (stomata, singular stoma), and brings with it a small percentage of carbon dioxide. The leaf retains the carbon, giving up most of the oxygen. With the carbon, water, some oxygen and the salts obtained from the soil, the plant is built up by marvellous and little known chemical reactions. The leaf, like all other parts of the plant, consists of layers of very small cells. The first solid product to appear in certain highly specialized cells as a result of the absorption of carbon dioxide, is starch. This consists of the three elements, carbon, hydrogen and oxygen, and is produced only in the presence of the green colouring matter (chlorophyll) by the action of sunlight. The process by which starch is produced is termed assimilation.

A description of the structure of a typical dicotyledonous leaf, will enable us to understand this function better. 
The surface of the leaf is covered by a thin layer of waxy material, which is almost impervious to water. This is called the cuticle, and prevents the leaf from shrivelling up in drying winds. Immediately below the cuticle lies a layer of cells, which form the epidermis. In some cases they are specially modified for the purpose of providing storage for water, as a provision against drought. Below the epiclerumis of the upper surface of the leaf, lies a layer of elongated cylindrical cells, called the palisade cells. These are regularly arranged with their longitudinal axes at right angles to the surface of the leaf, and constitute the wonderful laboratories in which the process of assimilation is carried on. The sap from the roots reaches these cells by way of the nidrib and veins. From the outer air they obtain carbon clinxide. They are also provided with a large number of microscopic grains stained with chlorophyll-the chloroplasts. In the chloroplasts, under the action of sunlight-bright or diffused-starch is formed. This is afterwards converted into sugar, and conveyed by means of the conducting tissues or leaf veins, to the parts of the plant where it is required. Below the palisade tissue lie a number of loosely arranged cells of rather irregular shape, with air spaces between them. These constitute the spongy tissue, and though they doubtless manufacture some food, yet they cannot receive as much light as the cells above them. Consequently they do little work in the process of assimilation. The epidermis of the leaf is broken in numberless places by minute openings, the stomata, which have been already mentioned. These are often confined to the lower surface of the leaf. Fach stoma is surrounded by a pair of crescent-shaped guard cells, which by alterations in theix form can open or close it, and thus check or increase the amount of evaporation or transpiration from the leat.

Now, although there are thousands of plants in which the leaf structure conforms comparatively closely to that already 
described, there are many others in which the leaf is more or less modified to suit its special environment.

The anatomy and form of the leaf depend, to a very large extent, upon the reaction between the plant and its surroundings, as regards transpiration and assimilation. The object of the plant is to expose as large a leaf surface as possible to the action of the light; while at the same time a balance must be maintained between the loss of water and its supply. If more water leaves the plant than enters it, the leaves must inevitably wither, and this is a danger that the plant has to guard against at all hazards. Plants living in dry situations have adopted most ingenious devices to reduce transpiration to a minimum, whilst obtaining a maximum of assimilatoxy surface. Some of these devices will be considered in connection with the various species exhibiting them. Plants living in wet situations require a different structure from those that grow on bare rocky cliffs or shingle-slips. Hence, recent writers have found it convenient and helpful to group plants together, according to the modifications of stem and leaf structure that they exhibit, in response to their special environments. As the water supply is the chief factor in moulding the form of the plant, this classification has reference chiefly to it. Dry soils, such as those of desert regions, soils at times subject to a low temperature, or bogs abounding in humic and other acids, are generally inhabited by plants which have contrivances to check transpiration. Such plants are termed Xerophytes. In New Zealand this group is exceptionally well developed. Indeed, Dr. Diels, no mean authority upon the subject, speaking of the shrubs of the open plains, states "Their xerophytic structure is of striking intensity, and difficult to mderstand in comparison with other floras." Again, in discussing the plants of the sub-alpine pastures, he tells us their xerophytism is so extreme that their physiognomy can be compared only with that of the almost rainless Persian steppes. (For a fuller discussion of this anomaly, see Discaria, Plagianthus betulimus, etc.) 
Plants which have been evolved in soils containing more than a half per cent. of salts in solution, are termed halophytes. Such plants are found chiefly near the sea-shore, by river estuaries, or in salt marshes. They sometimes occur also in desert areas, particularly in the dried-up beds of salt lakes. They often bear resemblances to xerophytes. The water of salt-meadows is apparently not readily absorbed by plants, and consequently such situations may be physiologically dry. Probably the presence of salts in solution interferes with the passage of moisture by osmosis into the plant cells. A fuller consideration of the structure of halophytes will be found under the family Chenopodiaceae.

Hydrophytes are plants which have been produced amidst abundance of water of moderate temperature, and in the absence of an excessive amount of dissolved salts. They will be further considered under Myriophyllum. Mesophytes, on the other hand, are plants whose structure indicates that they have been developed in intermediate conditions, where there was neither saturation with moisture, nor was there drought. Mesophytes frequently lose their leaves at the end of the growing season, and often die back to the ground. Amongst them are a large number of annuals, bulbous, and tuberous plants. New Zealand has remarkably few mesophytes. Trees such as Entelea and Aristotelia racemosa are mesophytic, but dicotyledonous herbaceous mesophytes are almost completely absent from New Zealand. We have scarcely any annuals, and very few bulbous plants. It is due to lack of them that our lowland pastures and hedgerows do not display in spring and early summer such brightness of colour as is to be seen in many other lands. 


\section{The Flower.}

The function of the flower is to produce seed, and so to perpetuate the species. The essential parts are the stamens and pistil. The pistil is in the centre of the flower, and contains the female organs. At its base is the seed vessel, or ovary, containing the rufertilized seeds or ovules. At the tip is the stigma, which is the part of the flower specialized to receive the pollen or male element. The stigma is frequently supported by a stalk termed the style. In some flowers the pistil consists of a number of parts called carpels, each consisting of ovary, style, and stigma. These carpels may be separate from each other, or united to form a composite pistil. In some cases the union is so complete, that it is difficult to say of how many carpels the pistil is formed. Generally, however, the number of compartments or cells in the ovary, or the number of stigmas, affords a sufficient indication of the number of carpels present. Round the pistil the stamens are nsually arranged in one or more concentric circles. They consist of a stalk known as the filament, and an enlarged tip, usually yellow, the anther. Here the pollen is borne. It consists of very minute yellow grains which escape by the opening of the anther. Before seed can be developed, fertilisation, or union, must take place between the male and female elements. The pollen grain is conveyed to the stigma. It there grows, and puts out a long tube, which penetrates through the loose tissues of the style into the ovary. In the ovary, it enters the egg-cell contained in one of the ovules, and there fertilisation takes place. After fertilisation the ovule commences to develop into the seed.

The process by which pollen is conveyed to the stigma is called pollination or loosely, fertilisation. (Throughout the book we shall use the more correct term in place of the more popular one). Just as the formation and structure of the leaf depend to a large extent upon its adaptations to its environment, in respect of assimilation and transpiration, so the form 
and structure of the flower depend to a large extent on the method of pollination adopted by it.

These methods are very numerous, and often rery different, and a great deal of complexity of contrivance, and apparent purposefulness of action, is manifested by flower's in their endearours to secure effective pollination. If the pistil is pollinated from its own stamens, it is said to be self-pollinated. Darwin and other's have shown, that, as a rule, seed obtained from cross-pollinated thowers is healthier and more productive than that from self-pollinated Howers. The result of continued inbreeding is harmful to flowers as well as to animals; but there are probably more exceptions to this rule than was at first supposed; and in many plants there are special adaptations for self-pollination. Cross-pollination may be brought about by the action of wind or insects, or, more rarely, by birds or other aniuals.

The exact methods adopted will be discussed in connection with specific cases.

If stamens and pistil are found in one flower, it is said to be hemaphrodite. If they are found on different flowers but on the same plant, the species is then said to be monocious, but if on different plants, it is termed dixcious.

\section{The Floral Envelores.}

Surounding the stamens are usually two floral envelopes. The outer one is the calyx, and the inner is the corolla. The corolla is usually brightly coloured, and serves as an organ of attraction for insects and other animals. The individual leares of which it is composed are termed petals. They may be free or united, regular or irregular in form, and, indeed, manifest an infinite variety of shape, colour, texture and arramgement. These characteristics depend almost entirely mpon the adjustment of the flower to the function of pollination. 
The calyx is chiefly used as an organ of protection for the flower bud. Its individual parts are termed sepals. They are usually coloured green, but occasionally the calyx becomes brightly coloured, and usurps the functions of the corolla. Calyx and corolla together constitute the perianth. Sometimes there is only a single ring (whorl) of parts in the floral envelope, or both rings may be similar. In such cases the floral envelope is termed simply a perianth. Flowers without a perianth are said to be nated. If', however, it is clear that the perianth is either calyx or corolla, but not both, the more definite ter'm may be employed. The missing whorl is then described as suppressed or obsolete. Any leaf on a flower stalk not belonging to the perianth is termed a bract.

\section{The Dispersal of Seeds.}

After the seed is ripe, it has to be scattered. Many curious devices are used by plants to accomplish this end. The seeds may be so light or so small as to be blown about by the wind. They may be provided with down (e.g., as in the dandelion), to assist them in travelling before a breeze. Sometimes they are set in nucilage (as in Pittosporum). This may enable them to cling to passing animals, and so to be carried for longer or shorter distances; or, again, they may be provided with hooks for the same purpose, (as in the sedge Uncinia), or with a grapnel-head, (as in Acena). Again, the whole fruit may become sweet and succulent, and thus birds are attracted to it, and eat it. The seeds then pass through the digestive canals of the birds, and are distributed over the country by them. The elder, gooseberry, flowering-currant, etc., are thus being distributed by birds over New Zealand. Should the seed on the other hand fall to the ground immediately below the parent plant, it would very likely be choked in the struggle for existence, or might 
not obtain a sufficient amount of light to enable it to Hourish. Hence, it is to be expected that plants whose seeds are provided with good means for distribution, should be found widely spread over the country, and this is often, though by no means always, the case. The dandelion grows everywhere, but Senecio perdicioides, with similar means of distribution is confined to one locality. It is often difficult to say why one plant survives, and another becomes extinct, in the struggle for existence. However, new light is being thrown on plant mechanisms daily, and we are beginning to understand more fully the many adjustments of the plant to its environment. It is certain, too, that our outlook upon the regetable world is gradually altering, and that the centre of gravity of our ideas concerning the principles that guide plant evolution is also shifting to some extent.

\section{CIJASSIFICATION}

The vegetable world may readily be separated into two great divisions, plants without flowers, and plants with flowers. The former division includes the bacteria, sea-weeds, pondslimes, moulds, fungi, toadstools, lichens, liverworts, mosses, ferns, and club-mosses. They do not come within the scope of this work. The flowering plants may again be readily divided into two classes: (1) those in which the ovules are not enclosed in an ovary, Gymnosperms (pines, firs, etc.); (2) those with the ovules enclosed in an ovary (Angiosperms). There are probably about 100,000 distinct kinds or species of angiosperms at present living on the face of the earth. They include the vast majority of all flowering plants. In order that they may be properly studied they have to be classified in a complete and complicated fashion. One of the chief objects 
of this classification is to enable the investigator to identify with certainty the specimen under investigation. In some cases this can be done only after an elaborate study of the plant; but in the majority of instances, half-an-hour's work or less should be sufficient to enable the student to name it. To assist him in his work a key is here provided (v. p. 49).

The Angiosperms are first sub-divided into two sub-classes, the Dicotyledons and Monocotyledons. The dicotyledons, on germination, produce two seed-leaves or cotyledons, the monocotyledons only one. The seed-leaves of the dicotyledons are generally entire, simple, rather fleshy leaves, unlike those subsequently produced by the plant. The solitary seed-leaf of the monocotyledons is usually long, narrow and similar to those subsequently produced. There are many other external differences between the two classes. In the monocotyledons, the chief veins of the leaves run more or less parallel to the length of the blade; in the dicotyledons the chief veins are not parallel to each other, and are connected by a net-work of smaller veinlets. Leaves of the former kind are said to be parallel-veined. The latter are termed reticulate, or nettedveined leaves. The parts of the flowers in a monocotyledon are usually in three, or in some multiple of three. In the dicotyledons there are usually four or five, or some multiple of either of these numbers. The monocotyledon produces a root consisting of a number of fibres, which sprout from the base of the young plant. The seedling dicotyledon produces a single root (tap-root), which is continuous with the stem. These differences may be tabulated thus:-

Monocotyledons.

1. One seed-leaf.

2. Fibrous roots.

3. Parallel-venation.

4. Parts of flower in threes.

\section{Dicotiledons.}

Two seed-leaves.

Tap-root.

Netted-venation.

Parts of flower in fours or fives. 
For ordinary field purposes, the venation is the most readily available distinctive character, but the student will soon recognise the differences between a mono- and a dicotyledon. The leares of the monocotyledon are usually long and narrow, and often sword-shaped. They frequently have sheathing bases. The chief New Zealand monocotyledons are the grasses, rushes, cut-grasses, bulrushes, native flax (Phormium), cabbage-tree, supple-jack, and Nikau-palm. The dicotyledons constitute the great majority of flowering plants.

The classes are sub-divided into sub-classes. The subclasses are split up into order's, the orders into families, the families into genera, and the genera into species. The species form the units on which the whole classification is built up. It is impossible to define a species further, than by saying that all plants of one kind are included in it. All individuals within the species, are more like each other than they are like any plants outside of it. The species are built up into genera. The genus may contain any number of species. Thus, there is only one species of Entelea known, and it is confined to the Auckland province. On the other hand, there are some eighty species of Veronica in New Zealand, and many more in other parts of the world.

Every plant has two names: (1) the name of the genus to which it belongs; (2) the name of the species. Thus, there are two kinds of native flax, each with the same generic name (Phomium) but with different specific names, $P$. tenax and $P$. Cookianum. To the scientific name of the plant, should be attached the name of the author of the species. This has not been done hele, as the names given in Mr. Cheeseman's handbook have been adopted, except in one or two specially mentioned instances.

In endeavouring to identify a species, the student should remember that there is scarcely any rule in botany without exceptions. Many of our New Zealand plants do not completely exemplify the characters of the order, or genus, 
to which they belong. It must not be supposed that a plant cannot belong to a family, because in one or more points it does not completely agree with the characters of the family. On the other hand, it is also unsafe to suppose that becanse a plant has certain characters of a family or genus it must necessarily belong to that family or genus. The student cannot be too strongly warned against jumping at conclusions of this sort. It is better, moreover, in identifying a specimen to proceed by the method of "exhaustion" than by that of identification, that is to say, it is safer to exclude first all those families and genera to which the plant cannot belong: before deteruining that to which it does belong. An example will illustrate clearly the various classificatory divisions.

The native flax belongs to the-

SPECIES : tenax.

Gexus: Phormium.

Fanitit: Litiaceae.

Order: Litiiflorae.

Sub-Cuass: Monocotyledons.

Class: Angiosperms.

Key TO Classication.;

SUb-KINGDOM: Phanerogans or Flowering Plants.

1. Ovules not enclosed in an Ovary-Class 1. GrMnospermat, p. 46.

2. Ovules enclosed in an Ovary-Class $2 . \quad$ ANGIOSPERMAE, p. 46.

(i) Seed with one seer-leaf, leaves generally parallel-reined.

MIONOCOTYLEDONS, p. 47.

(ii) Seed with two seed-leaves, leaves generally netted-veined.

DicotyLEDONS, p. 47 .

ARTIFICTAL KEY TO THE ANGIOSPERMAE.

SUB-CLASS I. : Monocotyledons.

1. Perianth absent.

2.

Perianth present.

3.

2. Climbing, shrubby plant. Leaves long, prickly. Freycinetia, p. 80 .

Erect water or marsh plants. +Typha.

*N.B.-It is to be remembered that in many cases this key is true only for New Zealand forms.

† Not further described. 
3. Perianth superior, of 6 leaflets in 2 rows.

4.

Perianth inferior, segments petaloid or fleshy.

5.

4. Flowers very irregular. Anther 1, attached to the style.

Flowers regular, stamens 3.

5. Perianth petaloid. Fruit a 1-8-celled, 3 or more seeded berry or capsule.

Perianth fleshy. Fruit a 1-seeded drupe.

ORCHIDACEAE, p. 109.

Libertia, p. 109.

LILIACEAE, p. 88.

Rhopalostylis, p. 84 .

SUB-CLASs II. : Dicotyledons.

1. Flowers having both calyx and corolla.

2.

Flowers with a single perianth or 0 , the

calyx or corolla or both being absent.

80.

2. Petals free.

Petals more or less completely united.

50 .

3. Stamens more than 20.

Stamens less than 20.

4. Ovary inferior. Leaves usually opposite. Ovary superior.

4.

12.

5.

6.

5. Leaves with translucent dots. Shrubs or trees. Leaves fleshy. Creeping or trailing herbs.

6. Leaves stipulate.

Leaves exstipulate.

7. Anthers 2-celled.

Anthers 1-celled. Leaves simple.

8. Carpels free. Leaves compound.

Carpels combined. Leaves simple.

9. Stamens hypogynous.

Stamens perigynous, carpels free.

10. Carpels free.

Carpels united.

11. Leaves with transparent dots.

Leaves without dots.

12. Ovary inferior (or apparently so).

Ovary superior.

13. Flowers umbelled or in heads.

Flowers not in umbels or heads.

14. Herbs. Stamens 5. Fruit of 2 carpels separating when ripe.

Shrubs or trees (rarely herbs); fruit of two or more combined carpels.

15. Leaves stipulate.

Leaves exstipulate.

MYRTACEAE, p. 270.

AIZOACEAE, p. 159.

7.

9.

8.

MALVACEAE, p. 250 .

ROSACEAE, p. 195.

TILIACEAE, p. 242.

10.

ROSACEAE, p. 195.

RANUNCULACEAE, p. 160. 11.

$\dagger$ Hypericum.

TILIACEAE, p. 242.

13.

22.

14.

15.

UMBELLIFERAE, p. 312.

ARALIACEAE, p. 300.

RHAMINACEAE, p. 235.

16.

17.

20. 
17. Stamens pipetalous or alternate with the petals.

Stamens perigynous. Petals overlapping in the bud.

18. Stamens epipetalous.

Stamens alternate with the petals.

19. Cells of fruit 1-seeded.

Cells of fruit many seeded.

20. Cells of fruit 1 -seeded.

Cells of fruit many seeded.

21. Shrubs.

Herbs,

22. Leaves stipulate.

Leaves exstipulate.

23. Carpels solitary or free.

Carpels combined into a 1- or more-celled ovary.

24. Carpels solitary, 2 or more seeded. Flowers irregular.

18.

ONAGRACEAE, p. 290.

LORANTHACEAE, p. 138.

19.

CORNACEAE, p. 297.

SAXIFRAGACEAE, p. 185.

21.

SAXIFRAGACEAE, p. 185.

Griselinia, p. 298.

HALORAGIDACEAE, p. 295. 23.

33.

24.

25.

Leguminosae, p, 203.

Carpels several, free, 1-seeded. Flowers regular. ROSACEAE, p. 195.

25. Ovary 1-celled.

26.

Ovary 2 or more celled.

30.

27.

29.

Ovules fixed to the base of the ovary.

27. Climbing shrubs,

Herbs or shrubs not climbing.

PASSIFLORACEAE, p. 268.

28.

28. Viscid glandular herbs. Flowers regular.

Herbs or shrubs, not glandular. Flowers regular or irregular.

DROSERACEAE, p. 180 .

VIOLACEAE, p. 261.

29. Herbs. Stamens 3-5, attached to the petals.

30. Stamens hypogynous.

Stamens perigynous.

31. Leaves opposite. Water herbs.

Leaves alternate. Herbs.

CARYOPHYLLACEAE, p. 156.

31.

32.

tElatine.

GeraniaCEAE, p. 215.

32. Stamens opposite the petals. Ovules 1 in each cell. Shrubs.

RhamnaCEAE, p. 235.

Stamens 5, alternate, or 10 opposite and alternate with the petals. Ovules many.

33. Carpels several, free, or one.

Carpels combined into a 1 or more celled ovary.

34. Carpels several, free.

Carpels solitary, 1-celled.

35. Leaves opposite.

Leaves alternate.

SAXIFRAGACEAE, p. 185.

34.

35.

38.

37.

36.

RANUNCULACEAE, p. 160.

DRIMYS, p. 172.

Tree. Leaves simple, aromatic.

†Tillcea. 
Shrubs or herbs. Fruit enclosed by the fleshy carpels.

Coriaria, p. 226 .

40.

39.

Stamens perigmions.

39. Stamens 5. Ovule 1.

Stimens 10. Ovules 2 or more.

Corynocarpus, p. 233.

LEGUMINOSAE, p. 203.

40. St:mens 4-5, epipetalous.

MIYRSINAC'EAE, p. 331.

Stamens 5. Ovule 1, pendulous.

41. Ovary 1-celled, many oruled.

Oviry 2 or more celled.

42. Glandular herbs.

Herbs, not glandular.

43. Stamens bypogynous.

Stamens perigynous or inserted at the base of a tumnd disk. Trees or shrubs.

Pennantia, p. 230 .

42.

43.

Drosera, p. 180.

CARYOPHYLLACEAE, p. 156.

44.

47.

44. Herbs. Sepals 4. Stamens 6. Ovary 2-celled Stamens 5 or 10.

CRUCIFERAE, p. 177.

45. Shrubs or trees. Stamens free. Ovary 2-5 cellert.

Herbs. Ovary 5-celled.

Pittosporm, p. 189.

46.

46. Stamens 5.

Stimens 10, occasionally several sterile.

47. Leares with transparent dots.

Iseaves without dots.

Linum, p. 218.

GERANIACEAE, p. 215.

(including

OXALIDACEAE).

RUTACEAE, p. 218.

48.

48. Leaves pinnate.

Leaves inmple.

49. Sepals free. Petals lobed or cut.

Calyx 5-lobed.

50. Ovary inferior.

Ovary superior.

Dysorylum, p. 222.

49.

TILIACEAE, p. 242 .

Ixerba, p. 186.

51.

50.

51. Flowers minute, usually numerous, collected into involucrate healds.

Flowers not collected into involucrate heads.

52. Leaves opposite aud stipulate, or whorled.

Leaves alternate, exstipulate.

COMPOSITAE, p. 405.

52.

RUBAACFAE, p. 389.

5.3.

5.3. Stumens 2, filanents cohering with the style. HSTYLIDIACEAE.

Stamentis 5 .

54.

54. Stamens inserter on the corolla lobes.

55.

Stamens epigynous, or inserted at the base of the corollat.

CAMPANULACEAE, D. $401^{\circ}$

(including LOBELIACEAF and (TOODENIAC'E.tE)

55. Stamens iltermate with corolla lobes.

Alsenosmia, 1. 399.

Stamens olposite the corolla lobes.

5ti. Corolla regular.

Samolus, p. 383 .

Corolla irregular, 2-lipped.

57.

75.

Not further described. 
57. Ovary and fruit very deeply 2-4 lobed; lobes

1-celled, 1-seeded. Ovary not deeply lobed.

58. Leaves opposite. Uvary 4-lobed.

Leaves alternate.

59. Ovary 4-lobed. Ovary 2-lobed.

60. Leaves alternate or radical (0 in Cuscuta of Convolvulaceae).

Leaves opposite. Stamens epipetalous.

61. Stamens epipetalous.

Stamens 10, hypogynous.

62. Ovary 1-celled.

Ovary 2 or more celled.

63. Herbs. Sepals 2.

Herbs or shrubs. Sepals 4 or 5.

64. Shrubs, leaves with glandular dots.

Herbs, leaves not dotted.

58.

60.

LABIATAE, p. 364.

59.

BORAGINACEAE, p. 346.

Dichondra, p. 344.

61.

71.

62.

ERICAC'EAE, p. 323.

63.

65.

† PORTULACEAE.

64.

Myrsine, p. 331.

Śmolus, p. 333 .

65. Fertile stamens more than 6. Anthers 1-celled. Fertile stamens 6 or ferver.

66. Stamens 4, filaments long.

Stamens alternating with scales or antherless filaments.

Scales and sterile anthers absent.

67. Shrub or tree. Leaves alternate.

Leafless climbing herb.

68. Anthers 1-celled. Shrubs or trees. Ovary 5-10-celled.

Anthers 2-celled.

69. Climbing or trailing herbs.

Erect shrubs.

MALVACEAE, p. 250.

66.

+ Plantago.

67.

68.

+ Sapota.

Cuscuta, p. 344.

ERICACEAE, p. 32\%.

69.

CONVOLVULACEAE, p. 342. 70 .

70. Corolla-lobes overlapping in bud. Ovary 2-4celled.

VERBENACEAE, p. 349.

Corolla-lobes plaited in bud. Ovary 2-celled. SOLANACEAE, p. 365.

71. Stamens 2 or 4 .

Stamens 5 .

SCROPHULARIACEAE, p. 366.

72.

72. Climbing shrubs, anthers adhering to the stigma.

Herbs or shrubs, erect or prostrate.

73. Herbs, sepals 2.

Calyx 4 or 5 -cleft.

74. Herbs, very bitter.

Erect or prostrate shrubs.

75. Leaves opposite.

Leaves alternate or 0 .

76. Ovary 4-lobed to the base.

Ovary not deeply 4-lobed.

Parsonsia, p. $3 \pm 0$.

73.

†PORTUlaCEAE.

74.

Gentianaceae, p. 337.

LOGANIACEAE, p. 335.

76.

79.

77.

78.

+Not further described. 
77. Herbs.

Shrubs or trees.

78. Ovary 1-celled, nearly 2-celled from the 2 projecting placentae.

Ovary 2-celled.

79. Small trees. Stamens 4. Leaves with pellucid dots.

Herbs. Stamens 2. Leaves bair-like or 0.

80. Perianth single.

Perianth wholly wanting.

81. Orary inferior. +

Orary superior.

82. Trees or shrubs.

Herbs.
LABIATAE, p. 364 .

VERBENACFAE, p. 349.

Rhabdothammus, p. 388.

SCROPHULARIACEAE, p. 366

Myoporum, p. 362.

Utricularia, p. 388.

81.

118.

82.

92.

83.

87.

83. Parasitic shrubs. Leaves opposite, exstipulate. "LoRANTHACEAE, p. 138.

Trees or shrubs not obviously parasitic.

84. Flowers bisexual.

Flowers unisexual.

85. Shrubs or small trees, leaves alternate with deciduous stipules.

Leaves opposite or alternate, exstipulate.

86. Tree. Leaves alternate, with deciduous stipules.

Tree. Leaves alternate, exstipulate, very large.

87. Flowers bisexual.

Flowers unisexual.

88. Stamens more than 20.

Stamens less than 20.

89. Tuberous root parasite. Stems scaly.

Non-parasitical leafy plants.

90. A plant climbing by tendrils.

Not climbing by tendrils.

91. Aquatic plants. Leaves opposite or whorled. Scape bearing plants. Leaves radical.

92. Leaves stipulate.

Leaves exstipulate.

93. A spiny shrub or small tree, often leafless, stipules small.

Spineless herbs or shrubs.

94. Herbs and shrubs. Stipules membranous, sheathing the stem.

Herbs and shrubs, stipules free. Flowers unisexual.

95. Carpels many, free.

Carpels solitary or 1-celled, or ovary 2 - or 3-celled.
84.

85.

86.

Pomadervis, p. 236.

SANTALACEAE, p. 148.

Nothofagus, p. 128.

Meryta, p. 313.

Accena, p. 201. 88.

+Acena glabra.

89.

Dactylanthus, p. 150.

90.

*Sicyos, p. 400.

91.

HALORAGIDACEAE, p. 295.

*Gunnera, p. 297.

93.

95.

Discaria, p. 239.

91.

POLYGonaCeAe, p. 151.

URTYCACEAE, p. 136.

96.

97.

Those marked * have really a double perianth, but the calyx is so obscure, that they are likely to be sought for in this division.

tNot further described. 
96. Stamens hypogynous.

Stamens perigynous.

97. Carpels solitary or ovary 1-celled. Ovary 2-or 3-celled.

98. Leaves 0 .

Leaves opposite or alternate.

99. Twining, slender, parasitic plant.

Plants not parasitic or twining.

100. Fleshy, jointed, maritime herb.

Small shrub. Branches grooved. Fruit red.

101. Leaves opposite. Herbs.

Leaves alternate. Shrubs or trees.

RanunCulaceae, p. 160.

MLNIMIACEAE, p. 174.

98.

113.

99.

101.

Cassytha, p. 176.

100.

Salicomia, p. 156.

†Exocarpus.

102.

106.

102. Flowers unisexual, minute, green. Stamens 4. Parietaria, p. 138.

Flowers hermaphrodite.

103. Flowers minute, white.

Flowers minute, green.

104. Flowers in axillary fascicles.

Flowers in pairs. Stamen 1. Seed 1.

105. Flowers in axillary spikelets. Ovule 1.

Ovules many.

106. Stamens 6 or more.

Stamens less than 6.

107. Flowers unisexual. Stamens 6-8. Leaves piunate.

Flowers hermaphrodite, leaves simple.

103.

104.

105.

$\dagger$ Alternanthera.

†Scleranthus.

Chenopodiun, p. 155.

C'ARYOPHYLLACEAE, p. 156.

107.

109.

Alectryon, p. 225.

108.

108. Leaves large. Stamens 6-10, hypogynous. Pisonia, p. 159.

Stamens 6-15, perigynous, opening by valves.

109. Flowers minute, green. Stamens 1-5, perigynous.

Stamens 2-5, attached to the perianth lobes.

110. Stamens 2 or 4 , on top of the perianth tube. Stamens 4 or 5 . Leaves not imbricated.

111. Leaves with transparent dots. Stamens on the base of the perianth lohes.

Leaves without transparent dots.

LAURACEAE, p. 175.

CHENOPODLACEAE, p. 154. 110.

THYMELACEAE, p. 269.

111.

MIYRSINACEAE, p. 331.

112.

112. Stamens on base of deciduous perianth lobes. Stamens 4 on middle or top of decidnous perianth lobes.

113. Shrubs or trees.

Herbs.

114. *Herb, juice milky. Leaves alternate. Herb, sepals 4, stamens 6 .

115. Leaves opposite or 0 .

Leaves altemate.

Santalum, p. 148.

PRoteACEAE, p. 145.

115.

114.

Euphorbia, p. 224.

CRUCTFERAE, p. 177.

116.

117.

116. A spinous shrub. Leaves opposite or 0 . Stamens 4 or 5 , perigynous.

Discaria, p. 239.

"The apparent perianth is really a ring of bracts.

INot further described. 
Shrubs or trees. Stamens 2.

117. Tree. Flowers unisexual. Stamens on the perianth segments.

118. Leaves reduced to scales. Root parisite.

Leaves present.

119. Leaves opposite.

Leaves alternate.

120. Leaves serrate, stipulate.

Water-herb, leaves exstipulate. Stamen 1.

121. Herbs, leaves fleshy.

Shrub, leaves very aromatic.
Olea, p. 335 .

PROTEACEAE, P. 145.

Dactylanthus, p. 150.

119.

120.

121.

+Ascarina.

tCallitricle.

Peperomia, p. 127.

Macropiper, p. 128.

An example or two of the method of using this key will probably be of assistance to the novice. He has found,-let us suppose,-an unknown plant which from its venation and general appearance he recognizes as a dicotyledon. It will be useless in most cases to try and identify it without the flower, and frequently specimens also of more or less mature fruit will be required. The first thing to notice is whether both calyx or corolla are present. This being determined in the affirmative, the student is directed to No. 2 in the Key. On ascertaining that the petals are free he passes to No. 3. In this flower the stamens are less than 20, this brings him to No. 12. At this point he decides the ovary is inferior and so passes on to No. 13. As the flower's are not in umbels or heads, he proceeds to No. 15. His plant has exstipulate leaves, and this brings him to No. 16. The simple style and stigma lead to No. 17, and the stamens alternating with the petals to No. 18, thence to No. 19; and as the cells of the ovary in his specimen are many seeded, he concludes that it belongs to the family Saxifragaceae. On looking this up, he finds a key to the genera. This he follows out in a similar manner, and arrives at the Gemus Carpodetus. There is only one species, C. serratus, and in all probability he will find his speciunen coincide in detail with the description given of this. Let us take one more example. In this case the plant has the petals united. That leads us to No. 50, and as the ovary is superior, we come to No. 56. The corolla of our 
plant is regular, so we reach No. 57; and the ovary not being deeply lobed we proceed to No. 60. The leaves being alternate, we reach No. 61, and the stamens being attached to the petals we arrive at No. 62. The one-celled ovary brings us to No. 63 , and the fact that there are five sepals to No.64. Oux plant is a herb, so that it must evidently belong to the genus Samolus, and as there is only one species it must be S. littoralis. Of course, if there is a large number of species in the genus, it may be impossible to determine the specific name of the plant from the information in this volume. Recourse must then be had to one of the standard floras of New Zealand (e.g. Cheeseman's, Kirk's, or Hooker's). 


\section{Coniferae.}

\section{The Pine Family.}

Distribution.-The Coniferae form a widely distributed and ancient family, having been well represented in the Carboniferous Age. In the northern regions of the northeru hemisphere they outnumber the ordinary broad-leaved trees by about ten to one, and are of great importance and utility. The order includes a number of large and valuable timber-trees, whose juices are almost invariably resinous, and are used in the manufacture of turpentine, pitch, and Canada balsam. Some of the New Zealand genera, such as Agathis, Phyllocladus and Dacrydium differ much from the true pines, but all possess the same straight, strong timber and resinous secretions. Outside New Zealand the best known species are the Scotch Fir, the Norway Pine, the Californian Redwood, the English Larch, the Norfolk Island Pine, the Deodar of the Himalayas, and the Cedar of Lebanon. The last named is one of the most majestic and imposing of trees. Sequoia gigantea of California (the Wellingtonia of our gardens), is the largest known Conifer, the finest specimen seen having reached the height of 329 feet; while the tiny Dacrydium laxifolium, 2 inches in height, found in alpine districts in New Zealand, is the smallest.

\section{Chief Characters.}

The true Pine has a branching trunk and evergreen leaves, which are pointed and needle-like-sometimes set in little bundles of two, three, or five. The plants bear pistillate and staminate flowers upon the same stem. The staminate flower is composed of a floral axis, bearing a number of stamens, and the pistillate flowers form a catkin, each flower being composed of a scale-like bract: with ovules suspended on its inner surface. When the flowers ripen, these scales become hard and thickened at the top, thus forming the collective fruit called a cone.

The cone of the fir-tree differs from that of the pine, being furnished with thin scales, rounded at the apex. Its leaves also are more scattered. The leaves of the Larches spring from a bundle of scaly buds, and become scattered or solitary by the lengthening of the stem. The imbrications of the cone are very loose, and the leaves

\footnotetext{
"The hounologies of the various jarts are still in dispute.
} 


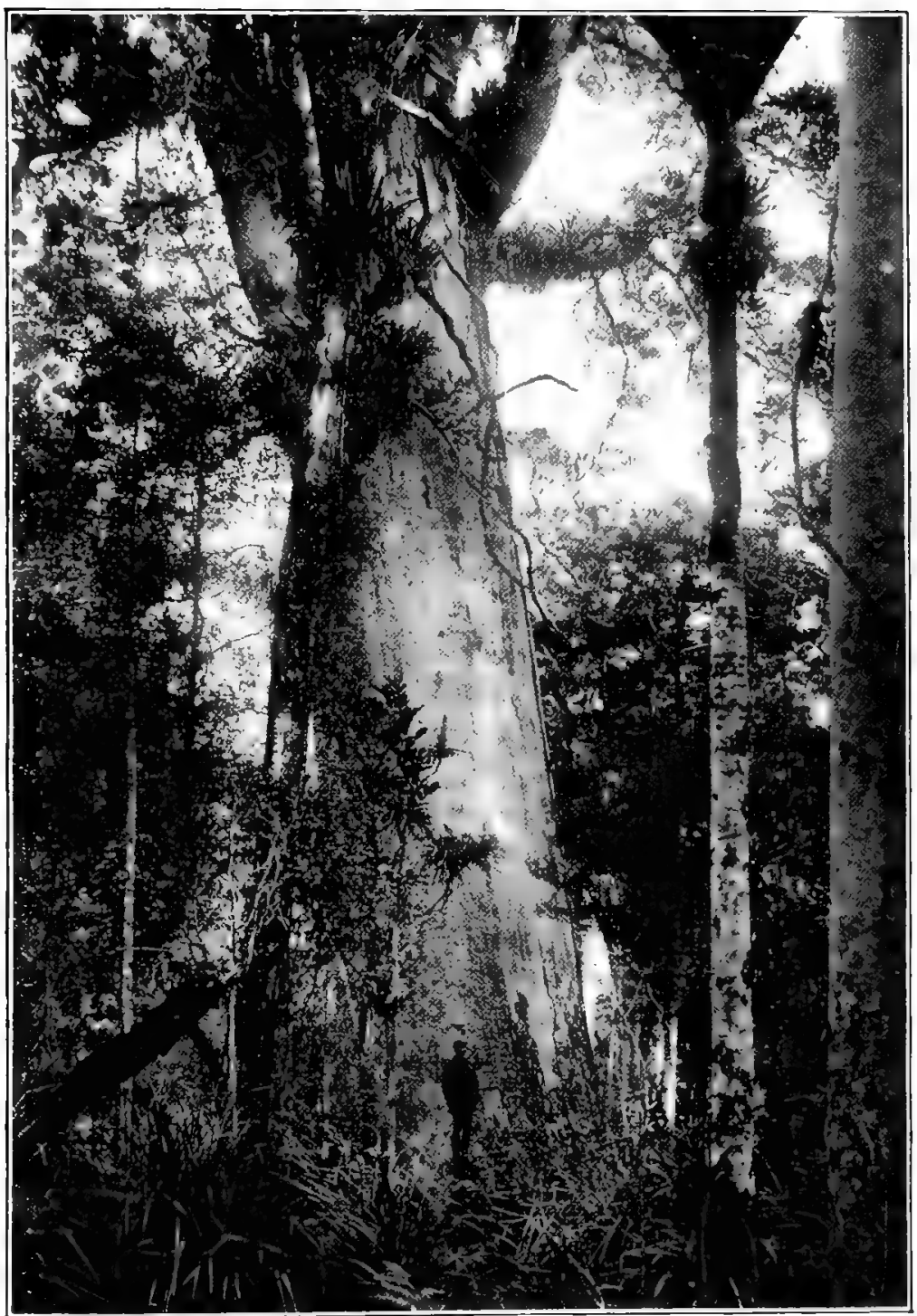

Fig. 5. A giant Kauri (Agathis). 
are deciduous. The Cedars, again, differ from the Larches in keeping their leaves for several years, and in bearing closely imbricated cones. The stamens of the Junipers and Cypresses bear spheroidal pollen, instead of oval, as do the Pines; and the Yew is easily distinguished by its coral-like drupes or berries. The leaves of this tree are poisonous to animals, but the berries appear to be imnocuous. The Yew attains to a great age, and has been reckoned to live for three or four hundred vear's.

The woody tissue of the Conifers is noted for the absence of ducts or vessels, and the presence at the same time of bordered pits. This structure can be readily perceived even in silicified wond. There is a similar structure in some of the Magnoliaceae, such as Drimys, etc., but the character of this wood differs considerably in other ways. The New Zealand Coniferae include the Kauri, the Kahikatea, the Totara, the Rimu, the Matai, the Tanekaha, the Miro, etc. The Tanekahd (Phyllocladus) possesses only scale-leaves, the functions of the leaves being performed by leaf-like flattened branchlets (phylloclades). The genus Agathis is an ancient one, related to the Awracarias (Monkey Puzzle, etc.)

\section{Key to the Genera.}

1. Exuit a cone. Fruit a nut or drupe.

2. Leaves oblong. C'one large, of many overlapping scales.

Leaves small. Cone of few, erect, woody seales.

3. Fruit a drupe, on flesley, scarlet peduncle.

Fruit a nut in a fleshy culp.

1. Stems flattened into fan-shajed phylloclades. Leaves linear or scale-like.

\section{2}

3

Agrathis, p. 60 .

Iibocedrus, p. 66.

Porlocaipus, 1). 68 . 4

Phyllocladus, y 76 . Dacrydium, p. 74.

\section{Genus Agathis.}

This genus is found only in Australia, New Zealand, the Malayan and Fiji Tslands, New Hebrides, and New Caledonia. Leaves flat, broad, parallel-veined; ovule solitiry. Seed winged. Agathis orientalis of the East Indies is remarkable for the quantity of valuable resin (Dammar) which it produces. (Nime from the (ireek meaning " ball of therd, in allusion to the nearly spherical cone). $1 \mathrm{sp} .{ }^{*}$

"The number of species from New Zealand and the ontying islands recorded in ¿heeseman's Handhonk. 


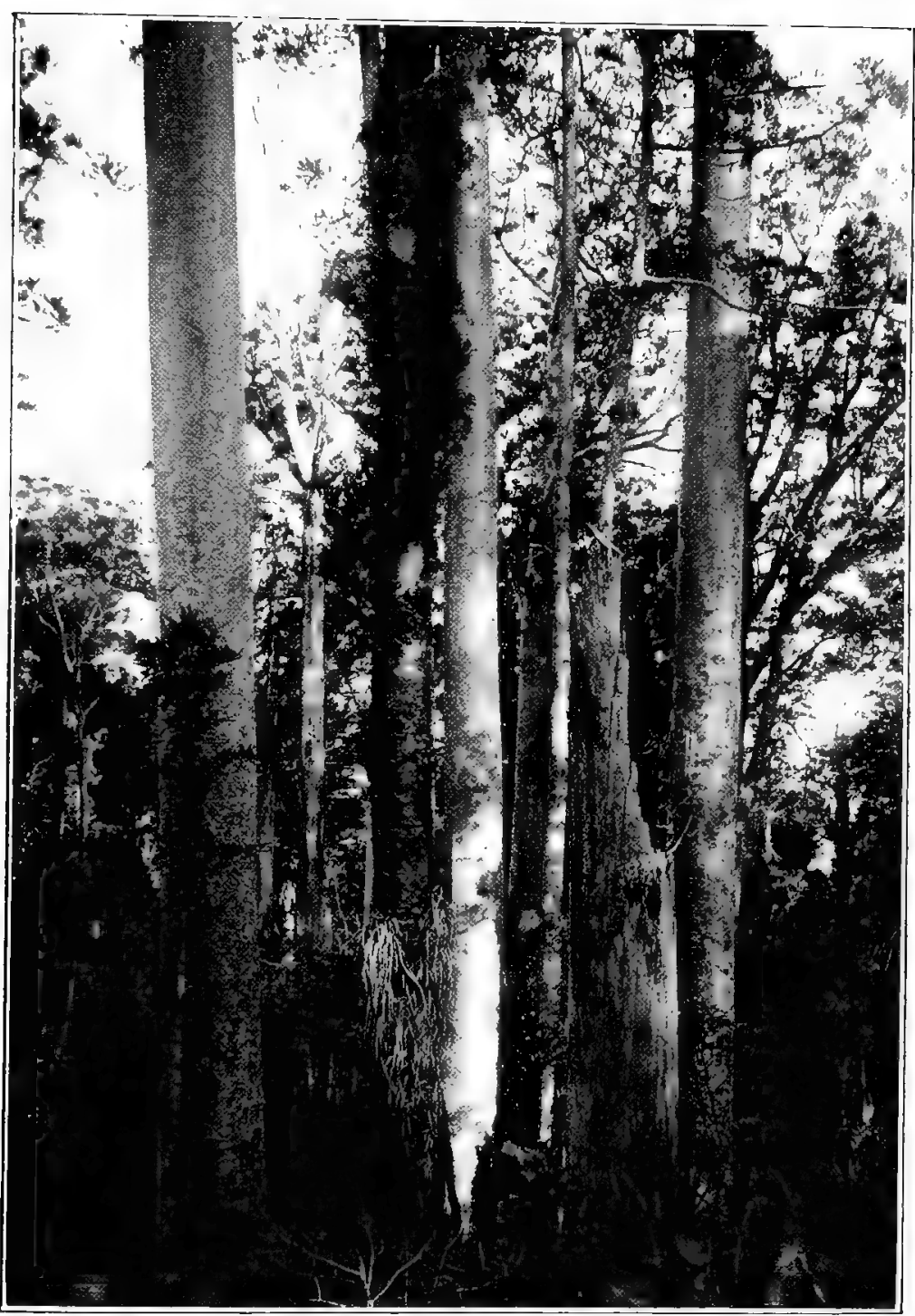

Fig. 6. Kauri Buslu 


\section{Agathis australis.}

The Kauri Pine is one of the most magnificent timber trees known, but it is unfortunately fast disappearing under the onslaughts of bush fires and needy colonists. Nor are new plantations formed, as is the case with many other trees, for the kauxi is of such slow growth, that no man thinks it worth his while to plant trees which take a thousand years to mature. A kauri forest is a wonderful sight, with the clean, erect stems rising like grey columns to a height of from 80 to 100 feet,- - sometimes 60 or 70 feet without throwing out a branch. The bark is thick and lead-coloured, and peels off in heavy flakes. "The ashy hue of the bark appears under certain atmospheric conditions to surround the trunks with an undefined haze." Though from 80 to 100 feet is the usual height of the forest kauri, trees have been found 150 feet high. There is a specimen at Mercury Bay, which is 80 feet to the lowest branch, and 24 feet in diameter. A tree five feet in diameter has been calculated to be three centuries old. The undergrowth is usually not so thick in a kauri forest as in ordinary mixed bush. A small tree-fern, Nikau palms, a variety of Astelia, the fragrant crimson Alsenosmia, and the climbing fern (Lygodium articulatum) are, however, often found growing under the stately pines.

The germinating kauri develops two seed leaves, narrow and flat, extremely unlike any of those produced by the pines of the Northern Hemisphere. The leaves in the young plants are often spotted, and are of a reddish brown colour. They have no foot-stalks. The older leaves are thick, leathery, and green. The branches are large and spreading,-leafy towards the top of the tree. The male and female flowers are produced in separate cones on the same tree; the male catkins being one inch long, and the cones almost 
round, two to three inches in diameter, and borne near the tips of the branches. Each scale of the cone bears a single ovule. The seeds are wedge-shaped and brown, bearing at the top on one side a thin, transparent wing, which enables the wind to carry them readily. The kauri is noted for its sound timber-hollow and defective trees being rarely found. The price of the timber is usually ten shillings for one hundred feet. The wood takes a fine polish, and is generally wavy in grain, but a mottled variety is found which is especially valuable in cabinet work. This mottled variety is most frequent in rocky situations, and is sometimes caused by the excessive development of small branchlets, but in many cases the bark cannot keep pace in speed of growth with the woody tissue. Flakes of bark thereupon become enclosed in the sapwood, and under the tremendous pressure form dark patches on a light ground. Occasionally thin films of clear resin are also enclosed, which add to the colour and beauty of the markings.

When the kauri trees are felled, it is a work of some difficulty to transport them, as the country north of Auckland, the special home of the kauri, is exceedingly rough and broken. If the trees are growing on the banks of some stream, they are felled, cut into suitable lengths by means of cross-cut saws, worked by two men, and the logs rolled into the water. Here they lie until a "fresh" drives them down to the creek or harbour" where the "boom" lies waiting. This boom is formed of a circle of logs fastened together with chains. There may be as many as fifty logs forming the chain, which sometimes encloses acres of water. The logs enter the boom,-are fastened together into a kind of raft, and towed to their destination. If, however, the felled trees are far from deep water, their carriage is much more difticult. A skidded road, six to eight feet wide, is formed of greased logs. Thus a sort of rough wooden tramway is made. The logs are hoisted on to this road by means of "jacks," or dragged by a team of 
bullocks, anyhow, over and through the bush, breaking down the thick undergrowth as they pass. The timber shrinks very little if cut at the dormant season. It is used for general building purposes,-for houses, bridges, wharves, and for boats, masts, deck-planking, etc.

The whole tree is extremely resinous. Even the leaves of fallen trees shew small white patches of gum when they begin to shrivel, while large masses often form in the forks of the branches. Climbing for gum is a difficult and dangerous task. The fact of the barrel of the tree being so huge, and rising so high without a branch, renders the usual kind of climbing impossible. A piece of weighted twine attached to a rope is flung over the lowest bough, and the rope is hauled up over the branch and down the other side. The climber then ascends the rope, gains a foot-hold, and cuts out the gum from the forks of the branches. A good tree-climber is said to make $\mathfrak{E} 3$ or 't't per week, but men sometimes come to their death in this dangerous work. The resin of the highest value, however, is that which has been fossilized, and which is dug up on lands where kauri bush once stood. This is the kauri gum of commerce. Clear, transparent pieces conmand a high price, and are used in place of amber in the making of small ormaments. The scrapings and dust are used in the manufacture of fire kindlers; the gum is used for varnish. Sometimes clear pieces of gum are found in which are embelder cones, leaves, small insects, etc. These specimens are much admired. The colour of the gum varies from a pale lemon-yellow to a reddish-brown, or even black. When the children of the settlers desire a little pocket money, they will often ask permission to go gum-digging in some newly ploughed paddock, and are usually rewarded within a few hours by a find of gum which will fetch several shillings at the store. The price of the resin varies from $\$ 60$ to $\$ 120$ per ton. Gum digrging is the great resource of those who cannot find work elsewhere, ws a merely nominal fee is charged for digging on 


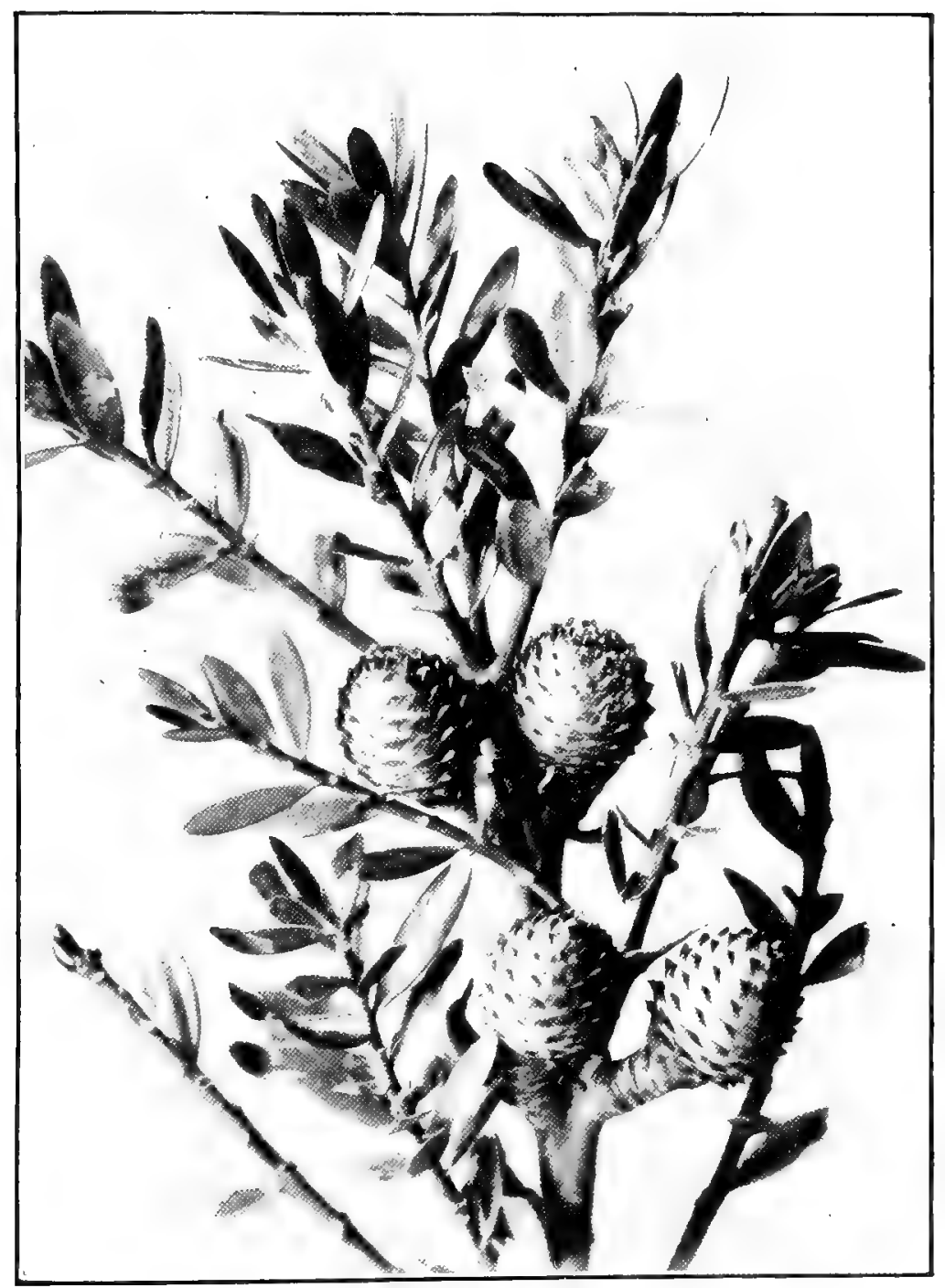

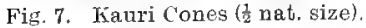


Crown lands, and the work requires only a light iron rod and a spade. Those who are old hands at the work are quick to discover the best places to dig. When a large tree falls, its roots tear up the earth, and form a mound with a hollow beyond it. By the position of these mounds and hollows, an expert will quickly decide on the direction in which the tree fell. By the size of the mound, he judges the probable height of the tree, and by the height of the tree he guesses the position of the first branch. Then, stepping out this distance, he puts in his spear to find the gum which lay in the forks of the branches when the tree was alive and standing. One of the finest collections of kauri gum has been gathered by a Mr. Rentoul in the Kaipara. These valuable and beautiful specimens are worthy of a fine museum. The Maoris often use pieces of gum to light their fires, or as torches on a dark night. Such torches burn with a bright flame, but give off a dark, heavy smoke, with a strong resinous odour.

\section{Genus Libocedrus.}

Shrubs or trees. Branches in young plants much flattened; four-sided when mature. The male flowers form small catkins of 6 or 7 stamens; the female, small cones of four woody scales. Ovules 2 ; seed winged. A genus of eight species, two in Chili, two in New Zealand, and one each in New Caledonia, Japan, China, and Califormia. (Name from the Greek, signifying the drooping cadar).

\section{Libocedrus doniana (The Kawaka).}

A lofty pine, 60-100 feet high, believed at first to be a Dacrydium. Its folixge in the young stage somewhat resembles a fern. The leaves are of two kinds, and are arranged in four rows. This four-sided arrangement is most plainly seen in the mature branches. The male and female flowers occur on the same tree, and are borne on the tips of the branchlets. The cone is $\frac{1}{2}$ in. long, small and woody, containing either two or four sceds. The timber is finely marked, and of a deep red colour, much valued for ornanental work by the cabinet-naker. North Island only. Bay of Islands, Hokianga. Native name Kawatia or Ngawaka, often termed New Zealand Arbor vite by the settlers.

\section{Libocedrus Bidwillii (Bidwill's Libocedrus).}

This is a smaller and more common tree. Its timber is durable and useful, but not so beautiful as that of the Fawaka. It is found in mountain districts in both islands. The tree is often known to the bushmen as the Kaikawaka, 


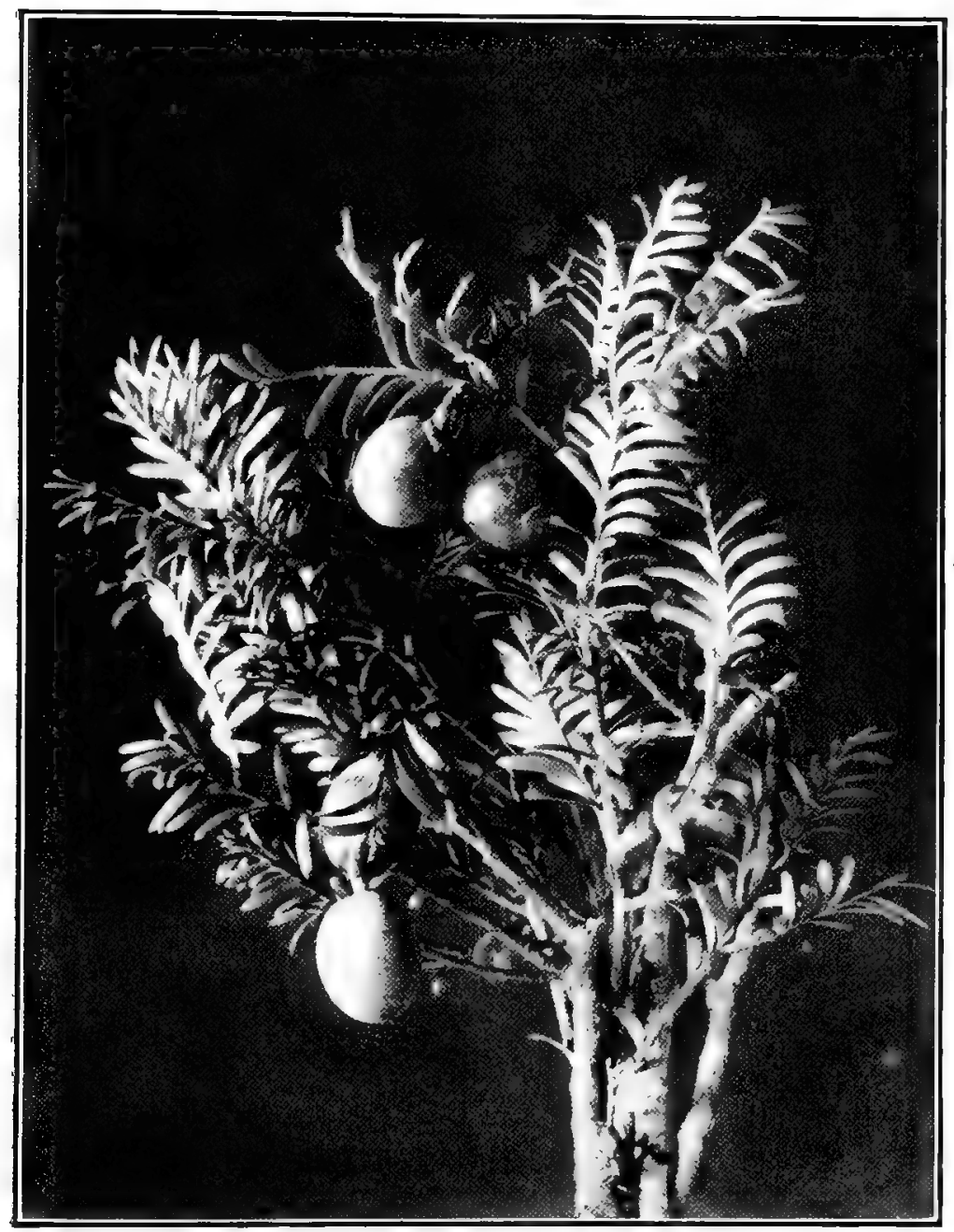

Fig. 8. Miro Berries (nat. size). 
though Colenso states that its correct name is Pahautea. The polysyllabic name "Totarahivitiotukutuku" has also been applied to it, but Colenso, with admirably unconscious humour, states that "no old MLari would have thought of such a thing." It and the previous species are sometimes also called the New Zealand Cedar, but must not be confused with Dysoxylum spectabile, to which this name is often applied.

\section{Genus Podocaipus.}

Shrubs or trees. Leaves very variable. Catkins variable. Fruit a drupe, often edible. A large genus found in tropical and sub-tropical countries. According to the theory of Celakowsky, the female flower consists of one carpel, and one ovule with two integuments. In most of the New Zealand species, as the ovule ripens, the integuments become crimson and flesby, thus attracting birds. (Name from the Greek signifying foot-fruited, in allusion to the fleshy peduncle). $7 \mathrm{sp}$.

Podocarpus ferruginea (The Rusty Podocarys or IIiro).

A large tree, covered with a grey or blackish bark, which peels off in large flakes. The leaves are narrow and pointed, and are set in two rows on the branches. Male and female flowers are on separate trees-both axillary. The fruit is of the size of a small plum. It is of a bright red colour, and is covered when first ripe with a waxy powder, which gives it a delicate bloom. Native pigeons are very fond of the miro berries, and become very fat and lazy when feeding on them. These fruits have the odour and the taste of turpentine. They ripen in July and August, and the flowers are prodnced in October and November. The timber is hard and tough. It is not easily worked, neither is it so durable as that of most of the other pines. The gum which oozes from this tree possesses healing properties. It is found in both islands. The specific name alludes to the rusty colour of the leaves.

\section{Podocarpus nivalis (The Mountain Totara).}

A much smaller tree than the preceding, often only a low shrub, densely branched. The branches grow ontwards rather than upwards, and send out roots from their lower surfices, thus forming a matted growth over the surface of the ground. These matted roots serve to hold together the loose soilsand shingle of the alpinc slopes, thus preventing landslips. The leaves are thick and leathery, with a stout midrib. The integuments of the ovule become very 
swollen and form an attractive fruit, pleasantly sweet to the taste. Podocarpus nivalis grows at an altitude of from 2,000 to 4,000 feet. The specific name has reference to its sub-alpine habitat.

\section{Podocarpus totara (The Totara).}

A lofty timber tree, one of the most valuable in the colony. The wood is of a reddish colour, and is equalled only by the kauri for lightness, toughness, and durability. It is used for telegraph posts, wharf piles, and sleeper's - in fact, for anything where durability is required. The Maoris hollowed out their war canoes, sometimes seventy feet in length, from single totara logs. Its timber was so highly prized by the natives that fine, healthy trees became heirlooms, and disputes for possession of these trees often led to bloodshed. Its chief defect is in its brittle nature, as, when loaded to its full strength, it may break suddenly without warning. It is very hard, and resists the boring of the teredo or ship-worm (a marine boring mollusc) more successfully than any other timber. This tree is peculiar to New Zealand, and attains its greatest height on low levels. The stiff, narrow leaves culminate in a sharp, needle-like point. The bark of the tree is often horizontally ringed near the base, and hangs in thin, papery strips. The foliage is of a brownish hue, especially in the young state.

Podocarpus spicata (The Spriked Podocarpus or Black Pine).

This pine, known to the natives as the Matai, is a lofty tree, but never of very great diameter. In its young state the branches are drooping, and bear scattered leaves of a deep coppery tint. When mature, however, the branches are upright and spiky like those of an ordinary pine. Both male and female flowers are born in spikes; hence the name spicata.

The young and the old trees are so extraordinarily different in appearance, that they were for some time believed to be separate species. Specimens have, however, been observed 
with the weeping, copluer-tinted branches below, and ordinary upright ones above. These are generally young trees of from ten to twenty years old.

At a certain time of the year the matai trumks present a brilliant appearance. Where the bark peels off, bright scarlet or crimson patches appear below, and a tree thus scaled is a beautiful object.

The wood of this tree is of great value, but is very slow in growth. It is often used for the floors of ballrooms, skating rinks, etc., as it takes an excellent polish, and can be made to reflect almost like a looking-glass. One curious fact in comnection with this timber is, that it will lie prostrate in the bush for year's without decaying. Mr. Buchanan tells of a prostrate matai over which three broadleaf trees (Griselinia littoralis) had grown, enfolding it with their roots. These trees were calculated to be over 300 years old, yet the matai was perfectly sound, and was split up for fencing posts. Another was discovered with a fuchsia stem nine inches in diameter growing across it.

One would not at first sight, imagine the matai to be one of the Coniferae, as its leaves are flat rather than needle-shaped, and its fruit is like a small black plum, containing only one seed. The cotyledons, also, are two in number, as in any broad-leaved tree. The shape of the mature tree is not conical like that of a pine, but spreading, after the fashion of an ordinary dicotyledon.

Podocarpus dacrydioides (The Din'ydinm-lite Podocalnes or White Pine.)

Native name, Kahikatea. The following, probably fanciful, derivation has been given of this name: tea, whitish, from the colour of the wood, and hathiti, an ancient chict.

The Nega-potiki Manris tell a pretty story concerning the origin of this stately tree. It is said that a chief named Ion-ranga-hua was once blown out to sea in his canoe and cast ashore upon a strange istand. The name of this istand 


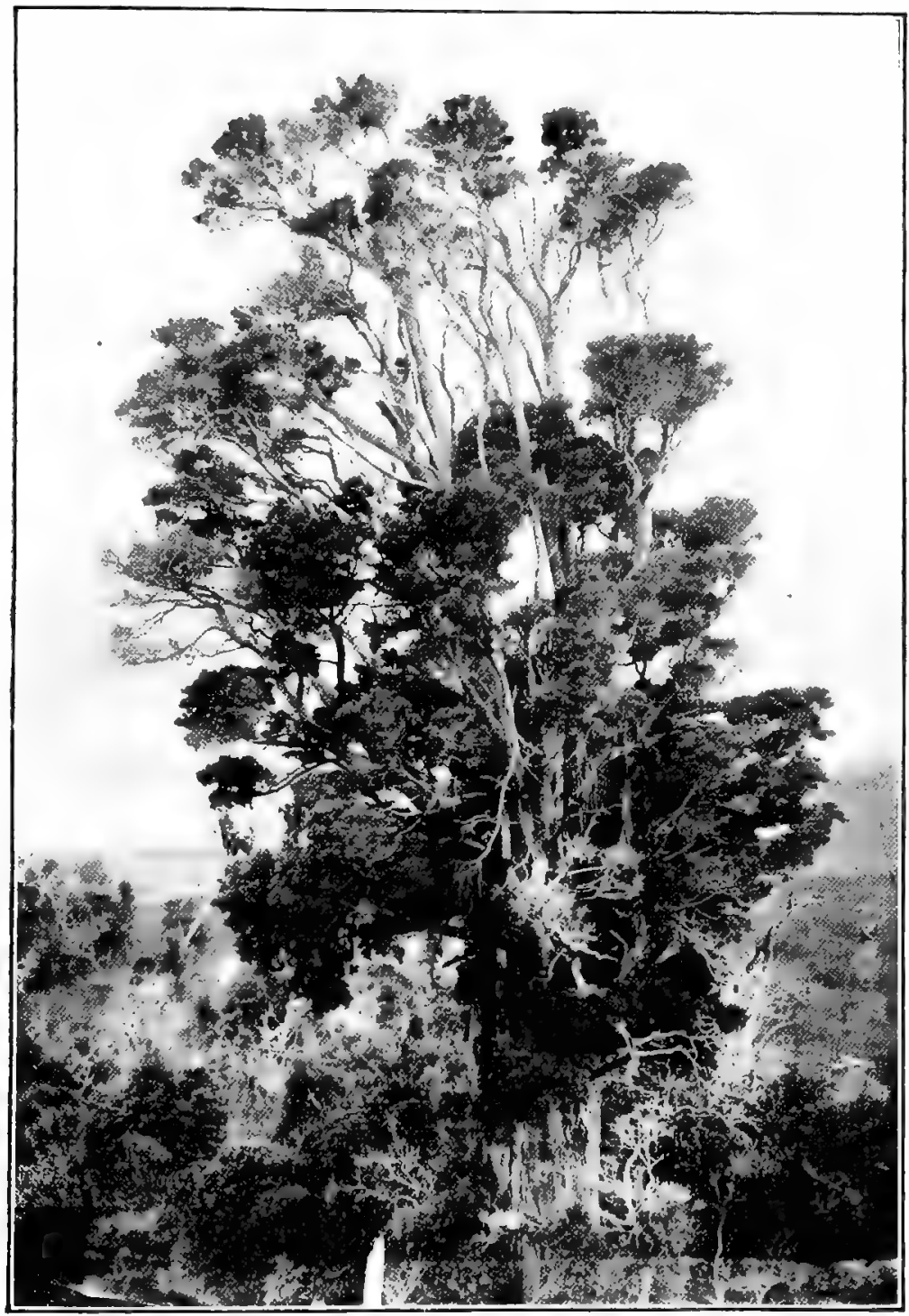

Fig. 9. The Totara (Podocarpus totara). 
was Hawaiki. Here Pou-ranga-hua abode for some time, and was kindly treated by the inhabitants, but longed to return to his home and his wife. His canoe, however, was destroyed, and he had no means of reaching the mainland. At last his yearnings for home could be stifled no longer, and he begrged a luuge bird, of the name of Tawhaitari, to fly with him to Aotea-roa (New Zealand). On approaching the mainland, Pou reached out his hand, and stretching under the wings of the great bird, pulled out some of its finest and downiest plumes, which he threw into the ocean. From these plumes arose a lofty tree, which still bears fruit in the midst of the waters. A branch of this was broken off by the wind and cast ashore, and from this branch came all the kahikatea forests of New Zealand. It is said that Pou carried with him upon his aerial journey two baskets of seed kumaras, which were unknown in New Zealand until that time.

The trunk of this tree is often branchless for seventy or eighty feet. The young leaves are flat and bronze-coloured, but those of the mature tree are green and scale-like. The catkins are very small, and are borne on the tips of the branchlets. The fruit is set upon a curious red berry, eaten by the Maroris. This berry or drupe is not the actual fruit, but is formed from the scales which bear the fruit. In their earliest stages these scales are white, and each one carries an ovule. As a rule, only one of these ovules comes to perfection. When this has occurred, the scales unite, become fleshy, and of a rich crimson colour, forming an oval receptacle with the shining blue-black nut embedded at its point. The undeveloped ovules are still seen as little white points at the base of the receptacle.

The timber of the kahikatea is light in colour, and the logs, having the same specific gravity as water, will not float until fully immersed. Some of these logs, however, will not float at all, and are known to the bushmen as "sinker's." 


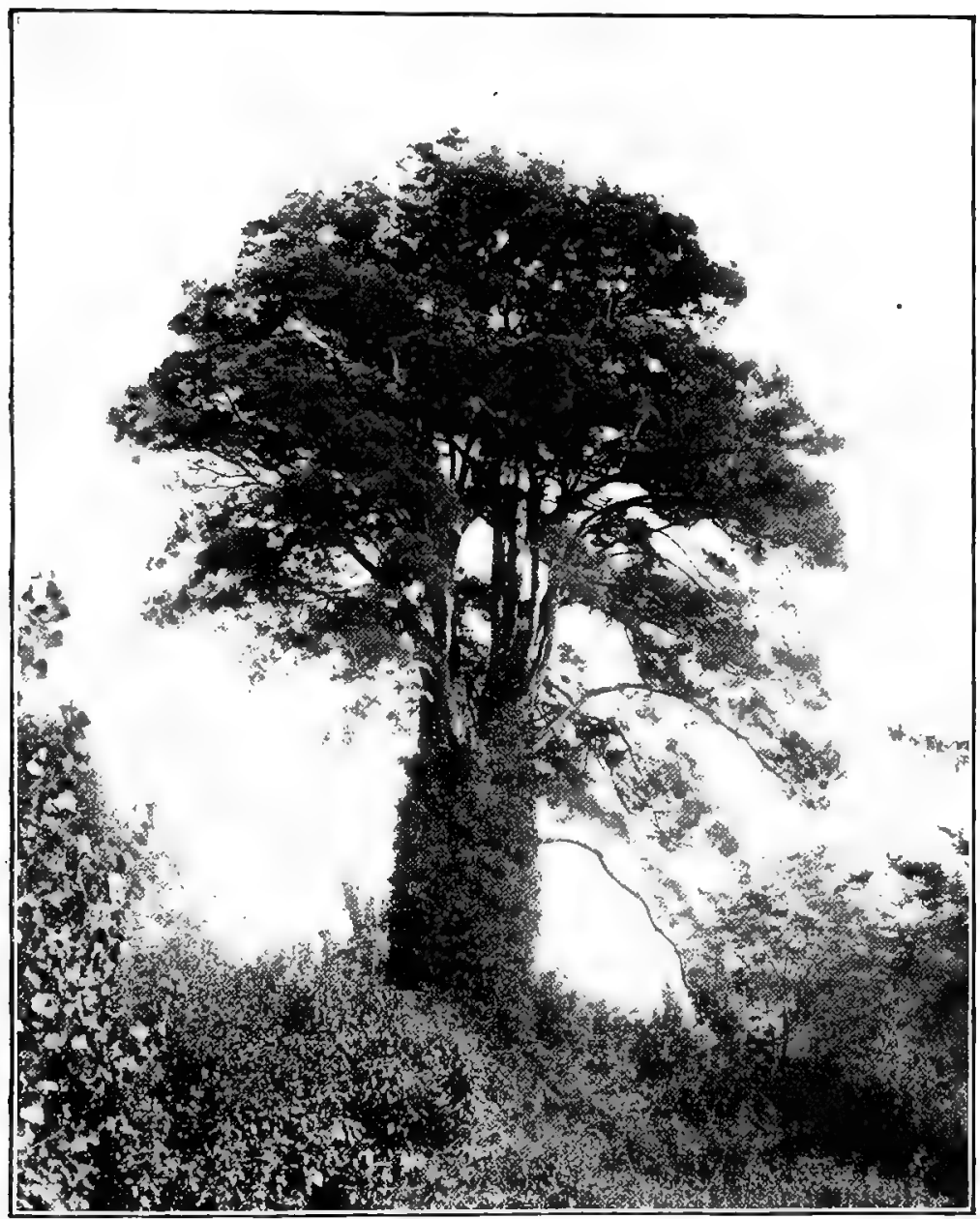

Fig. 10. The White Pine or Kahikatea. 
The wood is very suitable for the manufacture of paper and is now used for that purpose. The tree grows chiefly in swamly districts and in both islands.

\section{Gemus Dacryatim.}

Shrubs or trees, found only in New Zealand, Tasmania, the Malay Arcbipelago, and the jslands of the Pacific. Leaves nurrow and scale-like. Male and female flowers on separate trees. Fruit, a small nut enclosed in a fleshy cup. (Name from the Greek for ateal, in allusion to the weeping habit of some of the species). 7 sp.

\section{Dacrydium cupressinum (The Rimu or Red Pine.)}

This pine is one of the most beautiful objects in the New Zealand bush. Its pale-green, drooping branches differ from those of any other forest tree. "The leaves are only small prickles, running up a long stem, from which branch out other small stems whose united weight causes the main stem to hang like the branches of the weeping willow." The whole tree, when young, has the appearance of a lycopodium. Sprucebeer was made from the young branches by Captain Cook, and proved an excellent remedy for the scurvy. The seed is curious, consisting of a nut placed in a cup like that of an acorn. This fruit is tiny, but beautiful, the nut being of a blue-black and the cup red. The male flowers are produced in inconspicuous green catkins at the end of erect branchlets. The female are solitary, at the tip of curved branchlets, and the nut is about one-eighth of an inch long. Prickles such as those on the leaves run spirally round the trunk. The timber is of a red or yellow colnur, and beautifully marked. It is used to great advantage in dadoes, panels, and for ceilings. The Tarmaki rimu is especially straight in the grain and very resinous. It is much used for bridge-building in that district. The hent-wood is extremely resinous, and was made into torches by the natives. It was split into shreds and tied into bundles, and only needed the ashes to be occasionally knocked off to bum with a bright, steary blaze. The rimu 


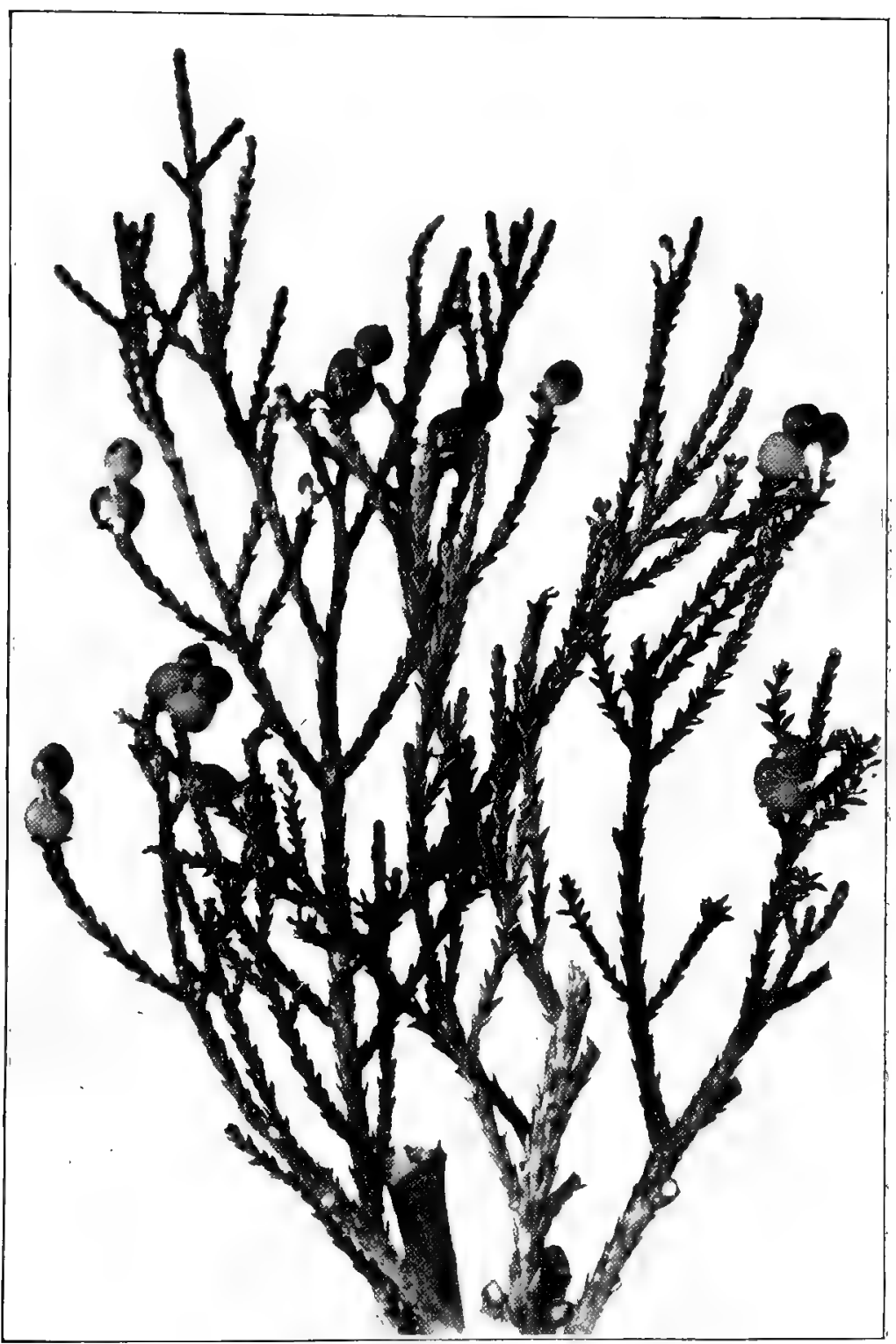

Fig. 1I, Fahikaten Ferries (nat. size). 
bark is said to be healing, but must be taken, so say the natives, from the side of the tree toward the sunrise.

\section{Dacrydium laxifolium (The Loose-leaved Ducrydium).}

This is the smillest conifer known. Trees of only two inches in height may sometimes be found in fruit. The largest specimens are from 2 to 3 feet high, but these have weak, straggling stems, and are compelled to support themselves by the bush amongst which they grow. The flowers and fruit are similar to those of the ordinary rimu.

\section{Genus Phyllocladus.}

A small genus, confined to New Zealand, Tasmania and Borneo. Leaves of two kinds, some linear, others small and scale-like. True leaves are found only upon young plants. As the tree grows these leaves disappear and their place is taken by fan-shaped phylloclades. Nale and female flowers upon the same tree. Fruit, a small nut. (Name from the Greek signifying twig-leaf, in reference to the fact that the leaves are replaced by shoots). $3 \mathrm{kp}$.

\section{Phyllocladus trichomanoides (The Celery-leaved Pine).}

The native name of this tree-Tanekaha-is said to signify virile, or strong in growth. It is chiefly remarkable for the beauty of its leaf stalks, which are so enlarged and flattened out as to present the appearance of true leaves. In shape they are fan-like, and closely resemble the fronds of a maidenhair fern. This emrious metamorphosis of the leaf-stalks usually takes place in those plants which inhabit hot and arid regions.

The female flower of this pine is borne upon the edges of the phylloclades, and the male flowers upon catkins at the tips of the branches. The seedling tanekaha bears long, narrow leaves, brownish-red above and green below, but these soon fall away, and the true leaves are seen only as small scales on the ends of the branches. The fruit is a small, inconspicuous nut. The tree will grow to a height of sixty or seventy feet, and the timber is much valued for its strength and durability. The bark contains a large quantity of tannin, and a red dye is obtained from it which is sometimes used in the preparation of kid for gloves. The tannic acid of the bark is a valuable 


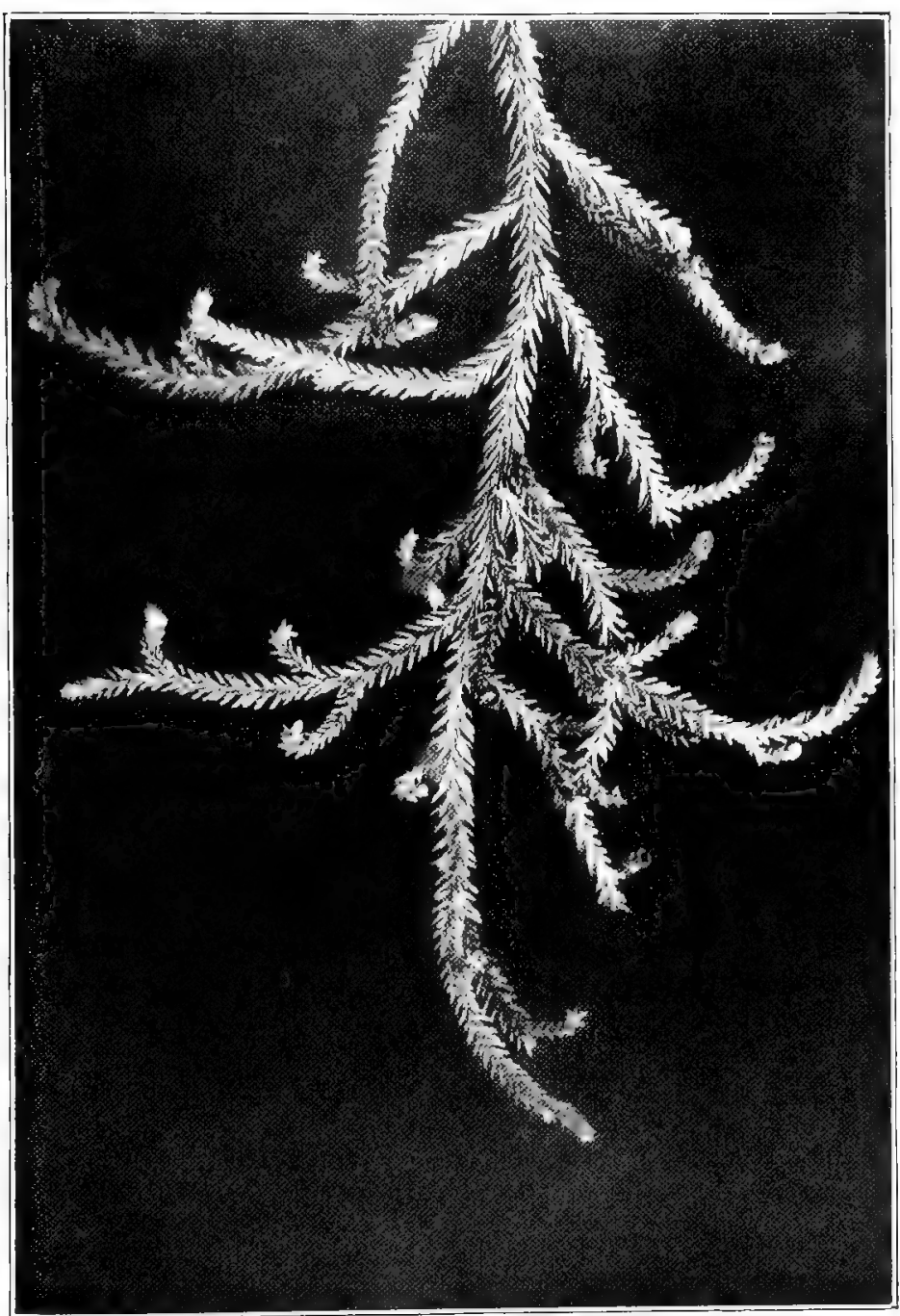

Fia. 12. A Spray of Rimu (nat. size) 
astringent. The young saplings make excellent walking sticks. If the stem, while growing, is bruised by some blunt instrument, at regular intervals, the red dye contained in the bark stains the white wood, giving to the stick a beautiful mottled appearance.

Phyllocladus alpinus (The ILountain Celery Pine or Toa-toa.)

This tree, like Phyllocladus trichomanoides, produces no true leaves, but only flattened twigs, which exercise all the functions of leaves. These, however, are very differently shaped from those of the lowland tanekaha. They are clustered heavily together at the ends of the branches, and are thick and fleshy, rather irregular in outline, and usually finelytoothed. The male catkins are found in clusters of from three to seven at the tips of the branches. The female are in cones, the ovules in fleshy cups of a bright crimson colour.

The growth of this tree is rather curious. The lower branches bend down in a sweeping curve, rooting where they touch the ground. The tips of these branches, however, rise again, and form the stem of a new tree. This, in its turn, when its own branches are sufficiently grown, will repeat the process and so form another new generation. An old tree will in this way form a series of rings, with the parent still growing in the centre. The tree thus performs for itself the process of layering carried out by nursery gardeners with many herbaceous plants. (There must be, one would think, some difficulty in the ripening or dispersion of its seeds, which has caused the tree to adopt a different method of reproduction.) 


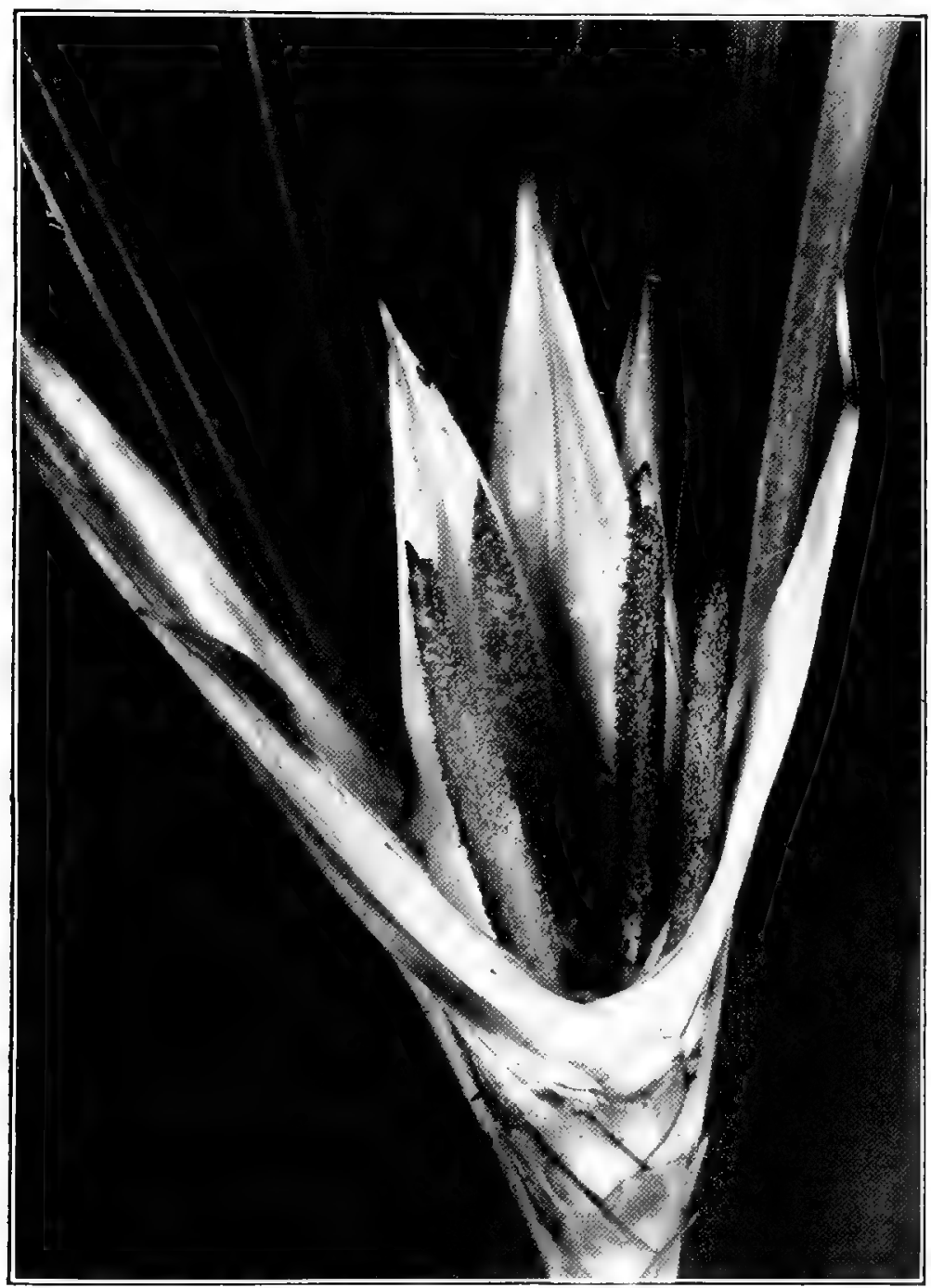

Fig. 13. Freycinetia Banksii (The Kie-kie) Flower (요 nat. size). 


\section{Pandanaceae.}

\section{The Screw-Pine Family.}

Distribution.-Chiefly a tropical family. Some of the species form large trees, but the majority are thick bushes. The name Screw-pine was given on account of the remarkible twisting of the stem in some species. The various species of Pandanus are noted for the large aerial roots, which, like flying buttresses, prop the stem. Their leaves contain a strong fibre, which is used in the making of sugar-saclis and fish-bags.

\section{Freycinetia Banksii (The Kie-kie).}

A lofty, climbing shrub. Leaves $2 \mathrm{ft}$. in length, finely-toothed, concave, sheathing at the base, with prickly margins. Flowers in teminal spikes, 3in.-4in. long, surrowuded by white, fleshy bracts. Male flowers consisting of bundles of stanens, female of several oviries, surrounded by infertile stamens. Fruit an oblong green spadix, with numerous, closely compressed carpels, each $\frac{3}{3}$ in. long; the lower part soft and hollow, filled with pendulous seeds; the upper part hard and solid. Seeds small, numerous, oblong. The fleshy white bracts and young spikes of fruit are eaten by the natives and by children. The long fibrous leaves are used in the manufacture of baskets. North Island: and west coast of the South Island to Milford Sound. Fl. Sept.-Oct. Maori name Kie-kie. The fruit is usually called Tawhara. 1 sp.

\section{Palmaceae.}

\section{The Palim Famili.}

Trees or shruls, rarcly climbers. Leaves large, divided, fan-like, with sheatlung petioles. Flowers on a branched axis, enclosed in a spathe. P'erianth of 6 segments; stanens 6. Fruit a berry or drupe.

Distribution.- This family of plants, which is said to be more valuable than any other, is represented on the manland of New Zealand by a single speciesthe Nikau Palm-Rhopakstylis sapida. This tree is closely related to the Betelmut of the East (Areca Catechu).

Palm-trees are chietly found in tropical regions, where they are often of wonderful utility, in bestowing upon the inhabitants of those lands shelter', food, light, heat, and clothing. The Coco-nut Palm, the Date Palm, the Sago Palm, 


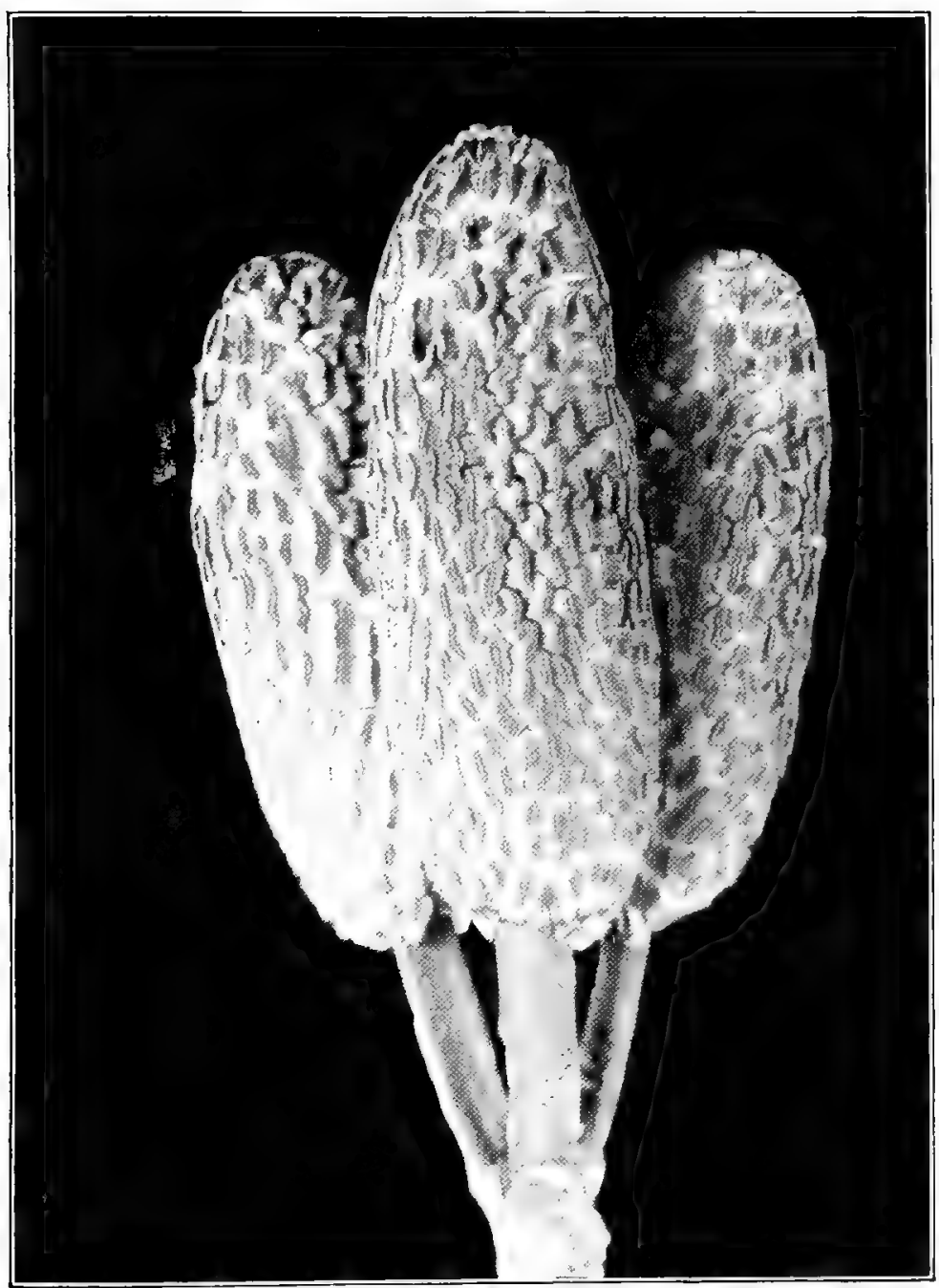

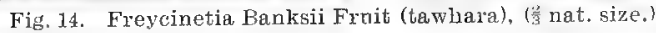


and the Oil Palm together furnish sugar, starch, oil, resin, cordage, writing materials, material for building and thatching, edible fruits, pleasant beverages, vinegar, sonp, etc. The palms reuch their southernmost linit in New Zealand.

The stem of the palm differs greatly in structure from that of other trees. The ordinary forest tree grows in thickness by depositing fresh layers of tissue between the wood and the bark. If a felled trunk be observed, it will be seen at once that there is or has been a central pith, and around this, concentric shells of wood have been deposited. In young plants, the pith occupies a considerable portion of the stem, in old trees it becomes obsolete. The stem of the mature tree is, in fact, made up of a series of hollow cylinders of woody tissue tapering to the top, and placed one inside the other. The growth of such a stem is due to the presence of a generating tissue immediately below the bark, which annually gives rise to a layer of wood. Each woody sheath is in reality wade up of a number of longitudinal strands or bundles (the fibro-vascular bundles). Between the bundles, lines may be seen radiating out from the centre to the outer edge of the wood. These are the medullary or pith rays. The bundles comprising such a trunk are said to be open, because the generative tissue does not become exhausted, but the stem continues to grow in thickness from year to year. Such a structure is typical of the stem of a pine or dicotyledon.

On the other hand, in a monocotyledonous tree, such as a palu, the pith always constitutes a considerable portion of the stem, and the woody bundles are scattered through it, not arranged in a circle round it as in the dicotyledons. Such bundles are no longer capable of growth in thickness, as the generating tissue is exhausted in their production. They are therefore said to be closed. The stem of a palm-tree therefore tapers but little, and cannot go on increasing in thickness. This is typical of a monocotyledon".

The stem of the cabbage-trea, corduline, in excentional. 


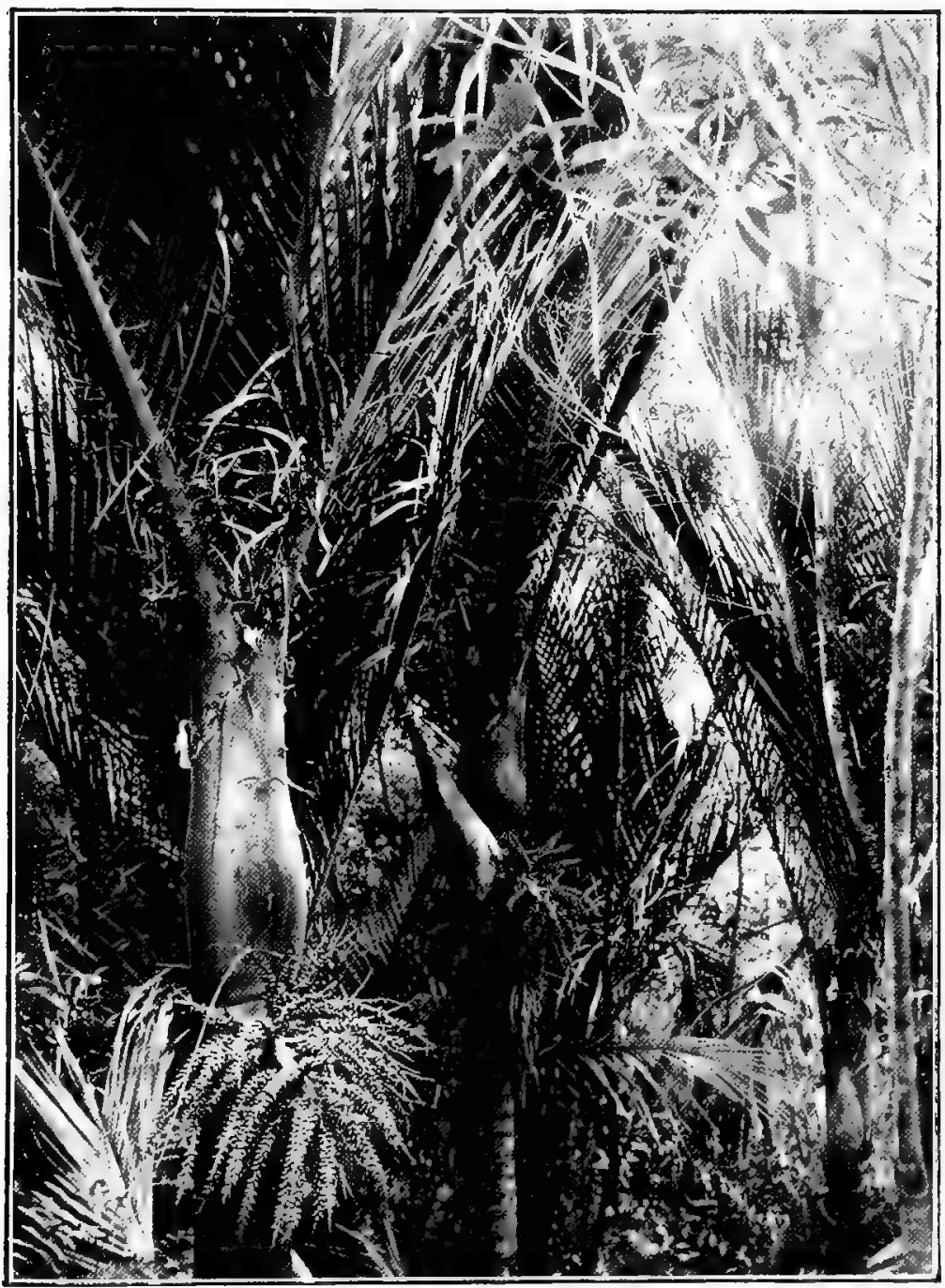

Fig. 15. A Nikau Grove (Rhopalostylis sapila). 
The fan-like appearance of the beautiful leaves is due to the splitting $u$, of the large, entire leaf, caused by the shrinkage of certain tissues. The flowers are sometimes borne on the axils of the leaves, but in other cases are terminal. They are, however, always enclosed while in bud, in a large spathe or sheath.

\section{Genus Rhopalostylis.}

Trees with pinnate leaves, and ringed trunks. Flowers in large axillary punicles. Flower-buds enclosed in a spathe. Stamens 6. Fruit a drupe. 2.sp.

\section{Rhopalostylis sapida (The Nikan P(tm).}

A tree, sometimes $30 \mathrm{ft}$, in height. Stem ringed, green. Leaves $4 \mathrm{ft}$. in length. Spathes 2 or 3, 12in. long. Flowering axis white; flowers white. Drupe $\frac{1}{2}$ in. long. Both islands: as far south as Akaroa on the east coast and Dusky Bay on the west.

This elegant and graceful palm is found usually in thick bush. Any specimen standing alone will have its leaves bruised or broken. The Maoris used the nikan leaves in the construction of their whares, or native huts. A frame-work was made of manuka sticks, and the roof and walls composed of palu leaves, which formed a covering as water-tight as if built of iron. These leaves keep out the wet in a marvellous manner, even though sitting underneath them, one can see the clouds and star's through the interstices. Every separate leaf division is a little channel, which conducts the rain-drops to the ground ontside. Nikau whares are extremely pretty and picturesque, but are now rarely scen, owing to the unfortunate cheapness of corrugated iron. Bushmen, however, still make them occasionally for temporary residences.

The top of the stem is fleshy and juicy, and is sometimes eaten. The nikau palm will stand fire almost as well as the cabbage-trce. After a big bush fire most of the trees are killed, except the nikaus, the cabbage-trees, and the ferntrees.

The flowers are sessile upon a thick, fleshy axis, the whole inflorescence being enclosed when young in a large spathe. 


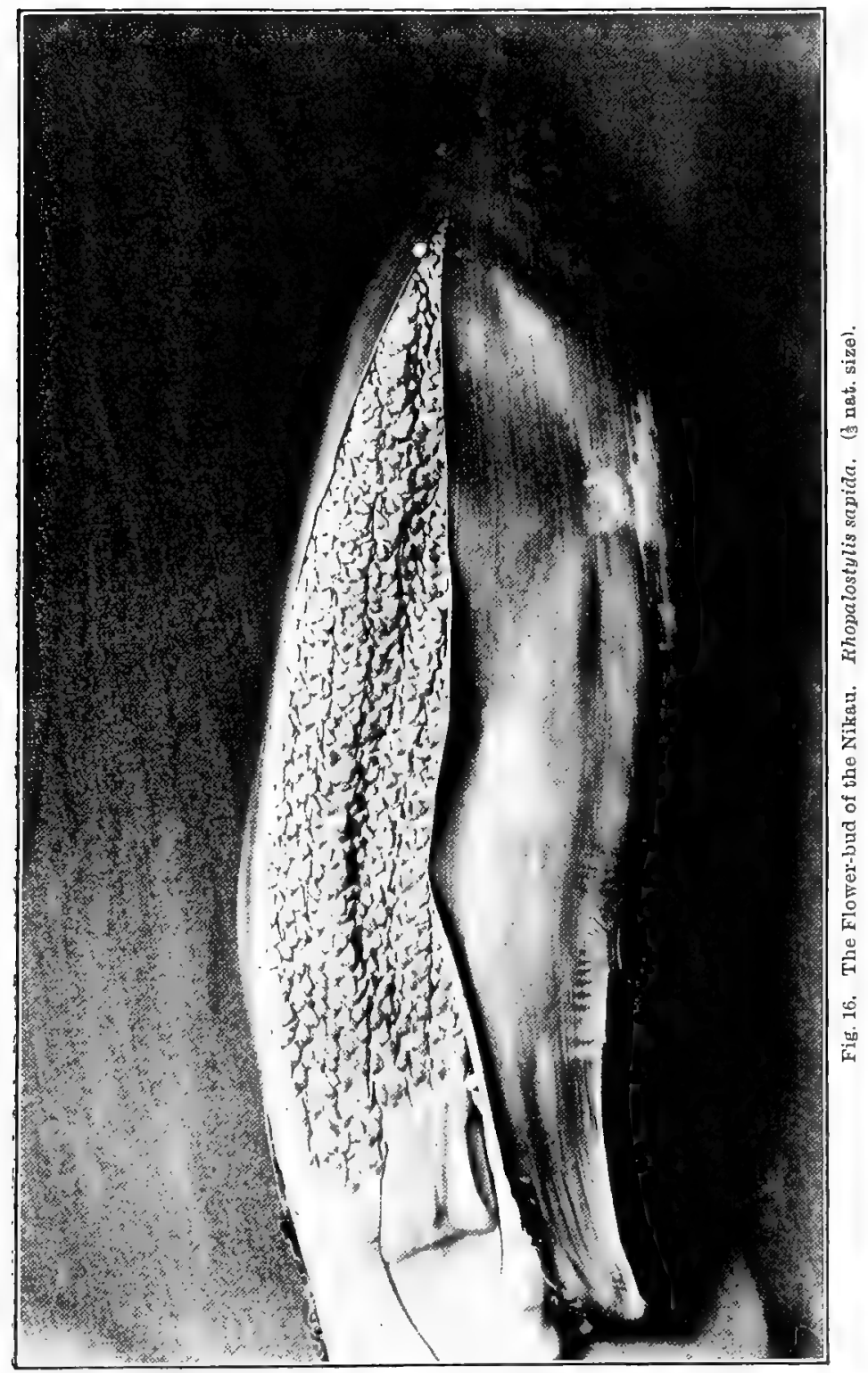


The fruit is of a vivid red when ripe, appearing like a huge bunch of coral. The berries are about the size of a large pea, and are extremely hard. They have been used by settlers for bird-shooting when ammunition was scarce. Though so hard, however, they are much relished by the kakas or wild parrots. These birds, unable to find foothold upon the smooth stem of the palm, hang upside down, with one claw fixed on the base of a leaf, and thus enjoy their meal.

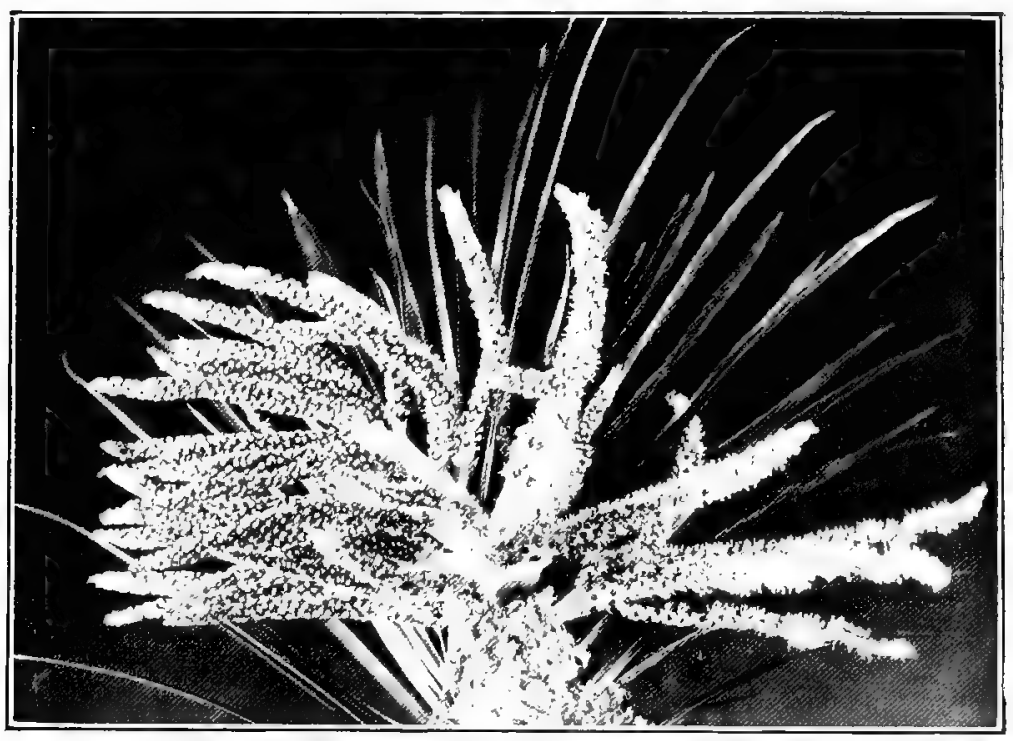

Fig. 17. Flower of the Nikau. Rhopalostylis sapiala. (1 nat. size),

The leaf-strips are much used by the Maoris for weaving into baskets and kits of every description.

The bark is ringed with cicatrices formed by the falling off of the dead leaves. The base of a fallen leaf, with the fan-like part torn off, makes an excellent basket for carrying flowers.

A curious six-headed specimen of the nikau, about forty feet high, was discovered not long ago in the Kaipara. (Fig. 19). 


$$
17
$$


A species of Polypodium is sometimes found climbing up the nikau stem, but as a rule the trunk is too smooth and polished to allow creepers to gain any hold upon it.

\section{Liliaceae.}

\section{The LiLy FAmiLY.}

Distribution.-An extensive family, occurring in all climates. The greater number of these beautiful plants are herbaceous, with bulbous roots, but in tropical countries they sometimes attain to the size of large trees. Two of the most notable plants of this family, found in New Zealand, are the Cabbage Tree (Cordyline australis) and the Flax (Phormizm tenax). The lilies, tulips, and hyacinths are well-known garden flowers, while the onion, leek, and asparagus are useful vegetables. The Butcher's broom is the only shrubby British species. The calyx of all liliaceous plants is petaloid, that is, the sepals have tho appearance of petals. The herbaceous species usually produce large and showy flowers.

Key to the Genera.

(a) Leaves net-veined. Fruit a berry. climbing shrubs. Creeling berls.

(b) Leaves parallel-veined. Frut a bery. Glabrous terrestrial herbs. Berries blue. Tufted silky herbs, usually epiphytic. Trees, or rarely herlus, Flowers white.

(c) Leaves yarallel-veiner. Fruit a capsule.

1. Flower's racemed, yellow, with spreading rerianth. Flowers panicled.

2. Flowers white, perianth slureading. Pedicels jointed. Flowers red and yellow, tubular. Flowers, solitary, in syathes (sheathing bracts), when in bud.

Rhipogonum, 1\%.90 Luzuriaga, 1). 92.

Dianella, 1). 98. Astelia, p. 98. Cordyline, p. 92 .

Bulbinella. 2

Artlrovodium p. 100. Phomilum, 1) 102.

Herpolixion, p. 108.

\section{Genus Rhipogonum.}

A genus of three species, one New Zoaland and two Australian. Ropo-like climbers with alternate leaves, and racenes of greenish flowers. Perimith of 6 leaflets. Stamens, 6; longer than the petals. Fruit, a berry, scarlet. (Name from the Greek, meaning jointed twig). 1. sp. 


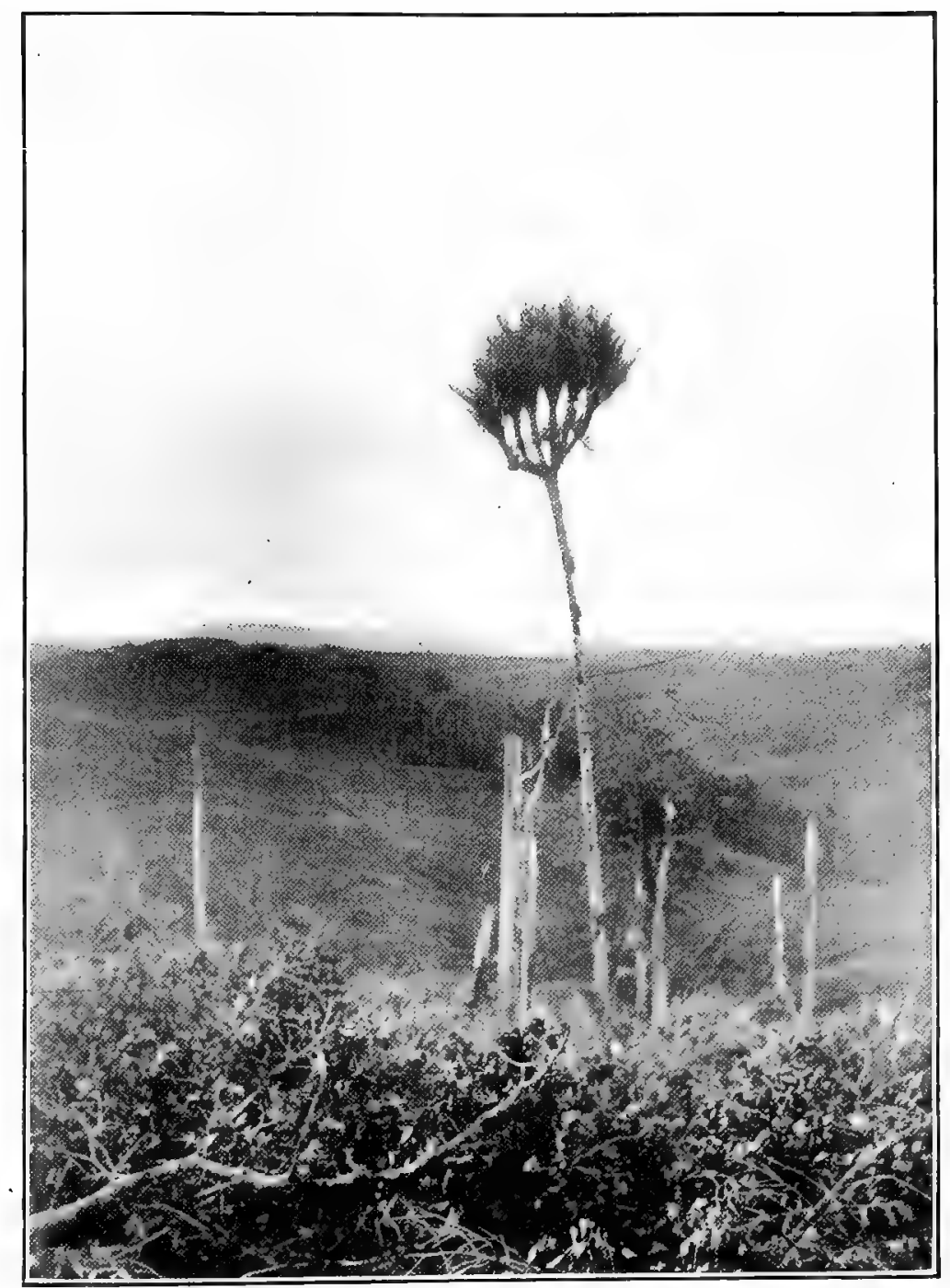

Fis. 19. Abnorwally brenched Nikau (Rhovalostylis sapida). 


\section{Rhipogonum scandens (The Climbing Rhipoyontm).}

This is one of the most curious plants of the order. No one who saw for the first time the black, snaky liane-like stems of the supple-jack, would dream of relegating this plant to the lily tribe. The flower is green and inconspicuous, and is borne in long spikes or racemes, at the end of the shoots. It is only by noting the number and arrangement of petals and stamens, that one can realize that the Rhipogonum is a lily. This strangling creeper forms one of the chief obstacles in getting thromgh the bush; and occasionally renders progress impossible. The brown and black ropes hang and twist everywhere, binding one tree to another, and forming loops and nooses above and below. The leaves, which are seen in any number only near the ends of the shoots, are opposite, oval, and entire, thick and leathery, with a metallic sheen upon them. The berries are oval, pointed at the end, and of a brilliant scarlet. The wiry stems are so strong, that they may be used as cords without fear of breaking. Rope-ladders have been made from them, for the purpose of climbing the steep cliffs which shut in the Wanganui River. They are used also in basket-work. In the Chatham Islands, we hear of native huts built of fern-posts, lashed together with supplejacks, and thatched with toi grass; also of rafts formed of the flower stalks of Phomium Tenax, spliced with supplejacks.

The roots of the Rhipogonum are used by bushmen as a medicine, and the pliut is sometimes called "Bush Sarsaparilla." The native name is Kare-ao, which is plausibly interpreted to mean a twisting rope. Fl. Dec.-Feb.

\section{Gemus Luzuriaga.}

Small, croeping, glabrous herbs, with stems knotted at the joints. Leaves with notted venation, altemate. Flowers regular. Perianth of 6 lenflets. Fruit a berry. A genus of two species, one in South America and one in New Veatand. 


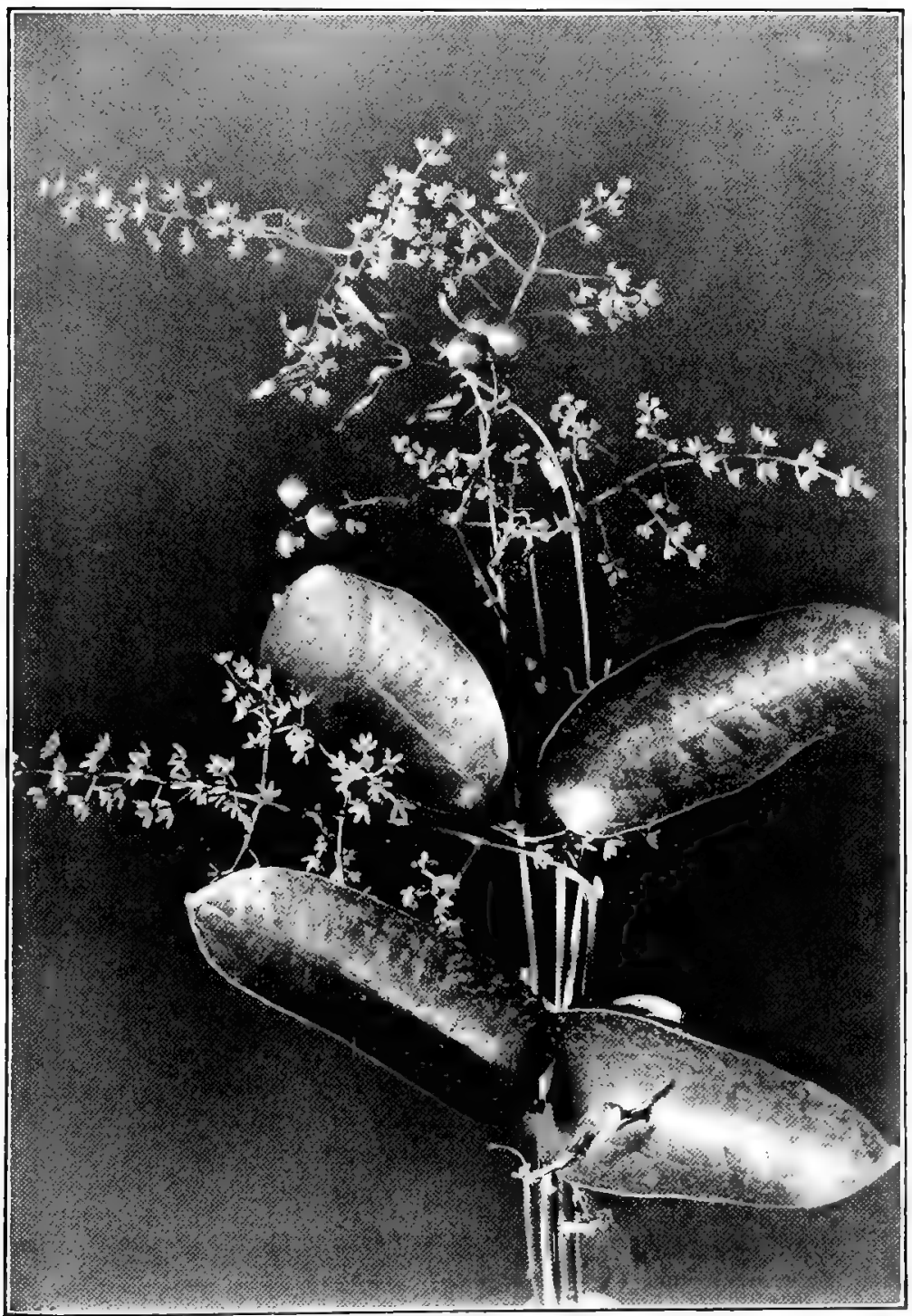

Fig. 20. Spray of Supple-jack ( $\frac{1}{2}$ nat. size) 


\section{Luzuriaga marginata*" (The Maryinate Luzuriaga).}

A pretty little plant, found chiefly in hilly districts. Lenves shining, 3 in. in length. Petioles twisted. Flower teminal, white, sin. long. Berry round. Both islands. Fl. Dec. and Jan. (The plant appears under the synonym Callixene parriflora in Hooker's Handbook and as Enargea marginata in Cheeseman).

\section{Genus Cordyline.}

A genus found in New Zealand, Australia, and the Pacific Islands. The five New Zealand species are all endemic. Herbs or trees. Leaves crowded, and sword-like. Flowers regular, bell-shaped, white. Stamens inserted on the petals. Berry whitish, containing angular, black seeds. (Name from the Greek signifying $a(c h b)$. 5. sp.

Cordyline belongs to the sub-family Dracenoideae, and is therefore related to the dragon-trees. Dragon's blood is the resin which exudes from the bark of Dracena Draco. A very famous specimen of this tree existed on the island of Teneriffe. It was supposed to be about 6000 years old, but was unfortunately blown down in 1868. It was then 70 feet high, and nearly 45 feet in girth.

A peculiar secondary thickening of the stem takes place in this sub-family. The primary arrangement of the bundles of the stem is the same as in one of the palun-trees ( $\mathrm{v}$. p. 82); but after all the woody cylinders have been originated and are in course of development, a generating tissue appears in certain regions of the stem round the bundles, and grows radially, thus giving rise to secondary wood. For a fuller description of the processes of division and extension of the growing tissue, some text book of anatomy should be consulted. The anatomy of the stem in the New Zealand species of Cordyline does not appear to be known at all fully, and would probably afford a profitable subject of investigation.

Diels makes a curious mistake with regard to $C$. anstralis. $\mathrm{He}$ is surprised to find that it has a xerophytic structure,

'This name is siven on the authority of Engler and Prantl's Pfrenzenfumilien. 
though it grows, according to him, in dense shade. As a matter of fact, the cabbage tree, though often found in swamps, is characteristic of open dry lands and bare grassy hill sides. (See fig. 21). It is, therefore, not a matter for wonder that the leaves should have devices protecting them against excessive transpiration. The stomata are placed in the grooves of the leaves, and are covered by cuticular projections, and thus the passage of gases from and into the leaf is checked.

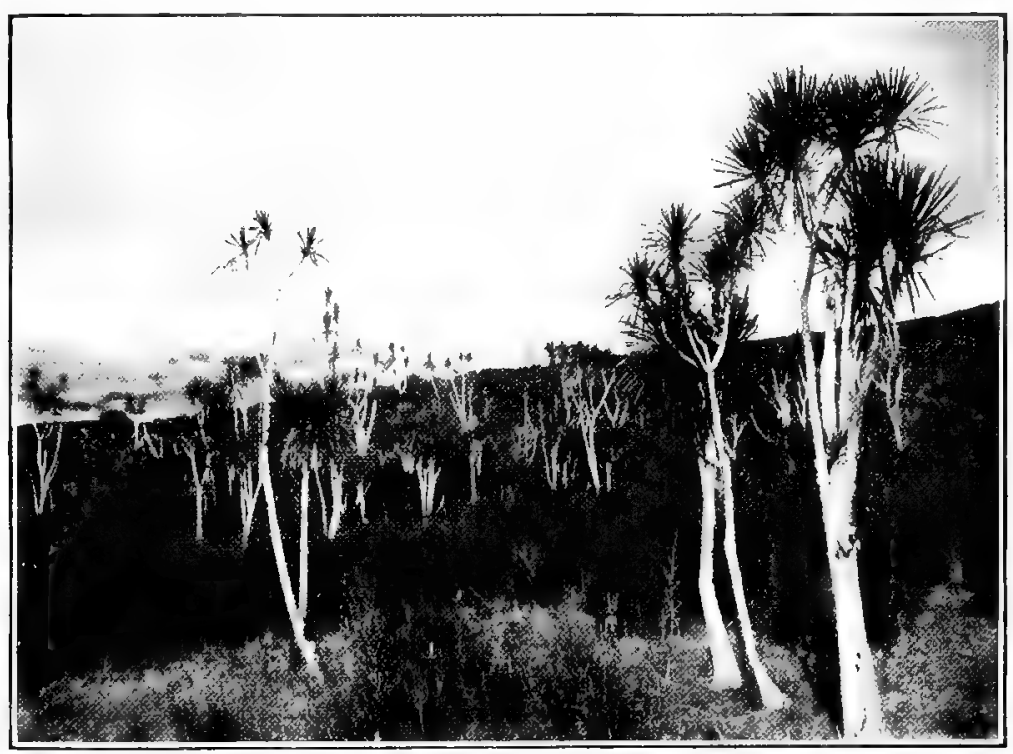

Fig. 21. Cabbage Tree Bush.

A similar arrangement is to be found in Dracophyllum latifolium.

\section{Cordyline australis.}

\section{(Ti-kouka. The Cabbage Tree, or Palm Lily).}

This is allied to the celebrated $\mathrm{Ti}$ (Cordyline terminatis) of the South Sea Islands, which formed an important part of the food of the Polynesians. The prepared roots were eaten, and 
from them an intoxicating drink was also obtained. The leaves are eaten br cattle. They are also used in thatching, and a rough kind of cloth is woven from the fibres. The genus is found over the greater part of the tropical old world, but chiefly in New Zealand, Australia, and the islands of the Pacific. There are several interesting species found in New Zealand-some tall and palm-like,-others stemless, sending

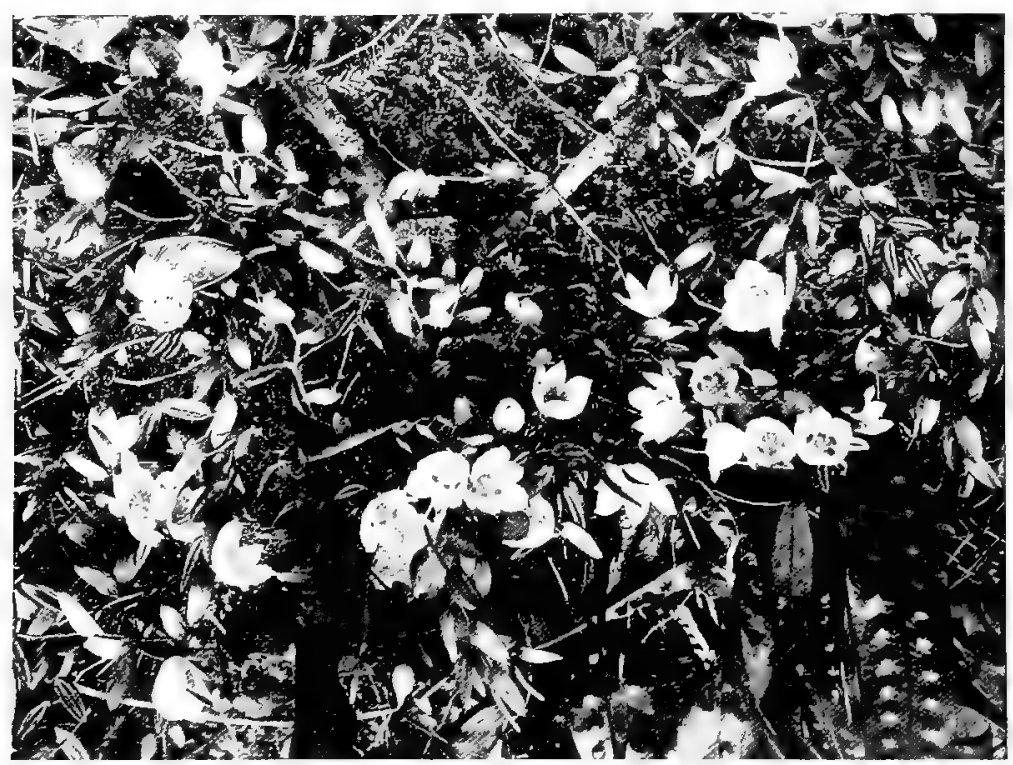

Figr. 22. Lnzuriaga marginata (2 nat. size).

up their long, narrow leaves straight from the crown of the plant just above the soil.

The cabbage-tree forms one of the most striking objects of the Now Zealand bush scenery. Its inappropriate name is said to have been given by the early settlers, who used the young and tender heads in place of cabbage. Palm Lily, however, is a better term. The long bare stems, with their bushy hads of grass-like leaves, cannot be confounded with those of any other tree, and give to the landscape a 
strangely tropical appearance. It is one of the largest of the liliaceous plants. Colenso states that he once saw a specimen,

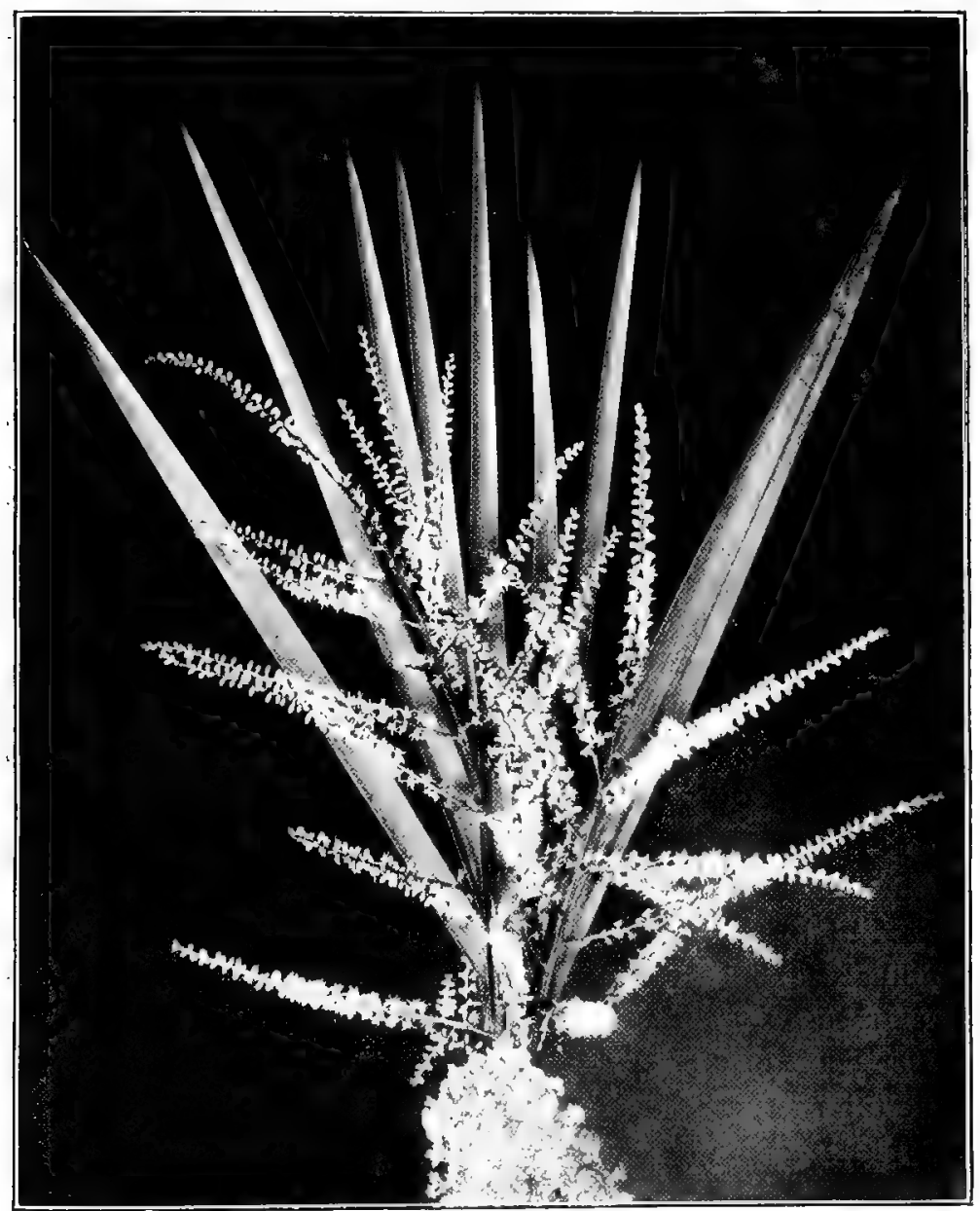

Fig. 23. Cordy line australis (flower and leaf) के nat. size.

the trunk of which was sufficiently large to be used as a storeroom. A Maori had fitted a door into the trunk, and kept his tools and baskets within it, though the tree was still living. 
These plauts appear to be wonderfully tenacious of life,-indeed it seems to be alnust impossible to kill them. A number of trees were once cut down and thrown ovel a fence on to the shingly beach of a creek. For eight months they lay there, one fortnight rolling up and down in the salt tide, the next baking high and dry in the sun. At last an exceptionally high tide lifted them back again over the fence into the paddock. As soon as they found theruselves upon soil once wore, they sent out rootlets, and shortly afterwards were seen to be budding vigorously.

A gum-digger in the north made his chimney of cabbagetree stems, digging a trench, and setting in the trunks side by side. These were then nailed together, and for some wonths a fire was kept alight continuously, - until the stems were burned through, and only parts of the outside bark left. The man then left the place, and within a short time, that which had been a blackened chimney, became a mass of living green, Even a dry chip, flying f'rom the axe, will, if it falls into a damp place, root and bud. The fibre of the leaves is perhaps stronger than that of the flax (Phomium), and is much used by the settlers in place of twine. The leaves are well adapted for the making of pajer.

The flowers of the various kinds are all white or creamcoloured, and give ont a strong, sweet scent. They are much visited by bees. The fruit is not capsular, as is usual among the liliaceae, but succulent, and contains a number of angular: black seeds.

The cabbage-tree differs from most of its tribe in bearing a huge tap-loot, instead of bulbs or rhizomes. This root, when the plant is dead, rots away in the ground, and leaves a narrow, round hole, sometimes eight feet in depth. Ferns and small plants grow over the hole, and an unwary rider may be easily thrown if the horse catch his foot in it.

The decaying leaves of the cabbage-tree are often phosphorescent at night. Pigeons feed upon the milky-white 


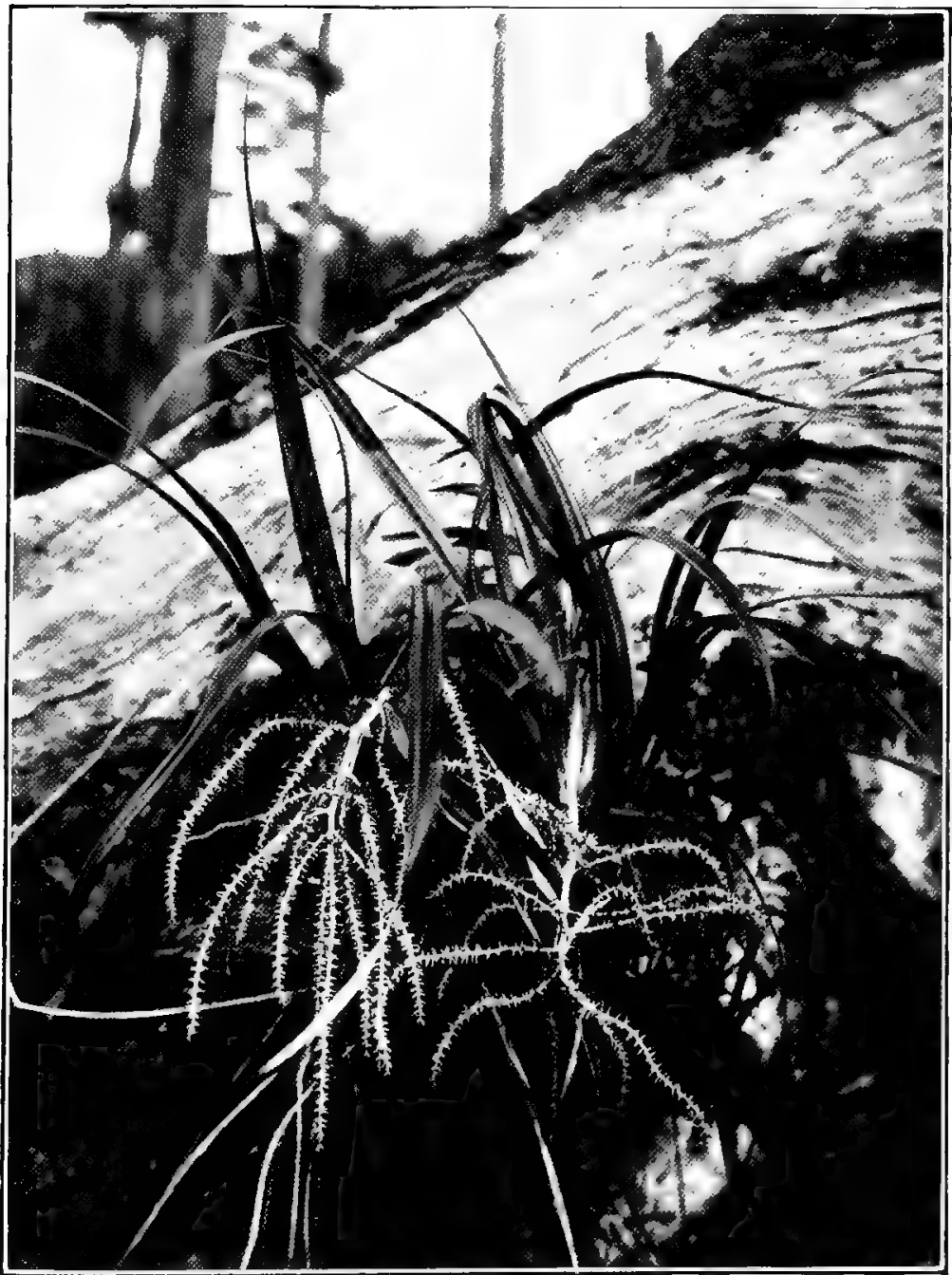

Fig. 24. Astelia Cunninghamii ( $\frac{\pi}{10}$ nat. size.) 
berries. It is found in both islands, and flowers in November and December.

Cordyline Banlesii is distinguished from Cordyline australis by its much longer leaves, $5 \mathrm{ft}$. to $6 \mathrm{ft}$. in length, and its drooping panicle of flowers.

Cordyline indivisa is a smaller tree, not often more than $10 \mathrm{ft}$. in height. Its leaves are very thick and leathery, with yellowish midribs. This plant has also a drooping flower-panicle. The fibre of its leaves was used by the Maoris in the making of garments, and is said to be stronger than the fibre of the Phormizm.

Cordyline pumilio is a small grass-like herb, with leaves not exceeding $2 \mathrm{ft}$. in length, and a loose spreading panicle of white flowers. It is found only in the northern parts of the North Island, and is easily distinguished from the other species.

\section{Genns Dianella.}

A small genus, chiefly Australian. Rigid, shining herbs, with large panicles of white or blue flowers. Leaves long, narrow. Perianth of 6 leaflets. Stamens 6 . Filaments incurved. Berry round or oblong. Seed, round. Root a rhizome. (Name from the Latin "Diana," the Goddess of the woods). I sp.

\section{Dianella intermedia (The Intermediate Dianella).}

This plant is found in woods or open fern lands. The leaves are from $1 \mathrm{ft}$. to $5 \mathrm{ft}$. in length, and the flower panicles $10 \mathrm{in}$. to $18 \mathrm{in.} \mathrm{long.} \mathrm{Flowers} \frac{\mathrm{t}}{2} \mathrm{in}$. across, white or pale blue. Berry $\frac{1}{2}$ in. long, blue. Both islands, also Norfolk Island. Fl. Nov,-Dec.

\section{Genus Astetia.}

Large herbs, with heads of sword-like leaves, usually epiphytic. (Name from the Greek, meaning wanting a stem or trunk). A very noticeable genus, forming immense tufts high up on the branches of the loftiest forest trees. The flowers are produced in large spreading panicles, like those of the Cabbage-tree (Cordyline). The male and female flowers are found upon separate plants, and owing to the height at which they grow, there has been some difficulty in matching the sexes. Now and again, in traversing the bush, one will find a mass which has been torn from its support by its own weight, and has fallen to the ground. In such a case it is possible to examine at leisure the long, silky, chaffy leaves, with their sharply defined nerves, and-if it happens to be the flowering or fruiting time-the great silky 
panicle of sweet, creamy or purplish blossoms, or close-set, transparent, wine-coloured berries. In the European forests, the trees invariably shed their leaves during winter, thus giving to the smaller plants which grow beneath them a possibility of obtaining air and sunshine, which is never available in the New Zealand bush. The dark-green gloon of the latter is never lightened, and few rays of sunshine can ever filter through its leafy roof. The smaller plants are thus

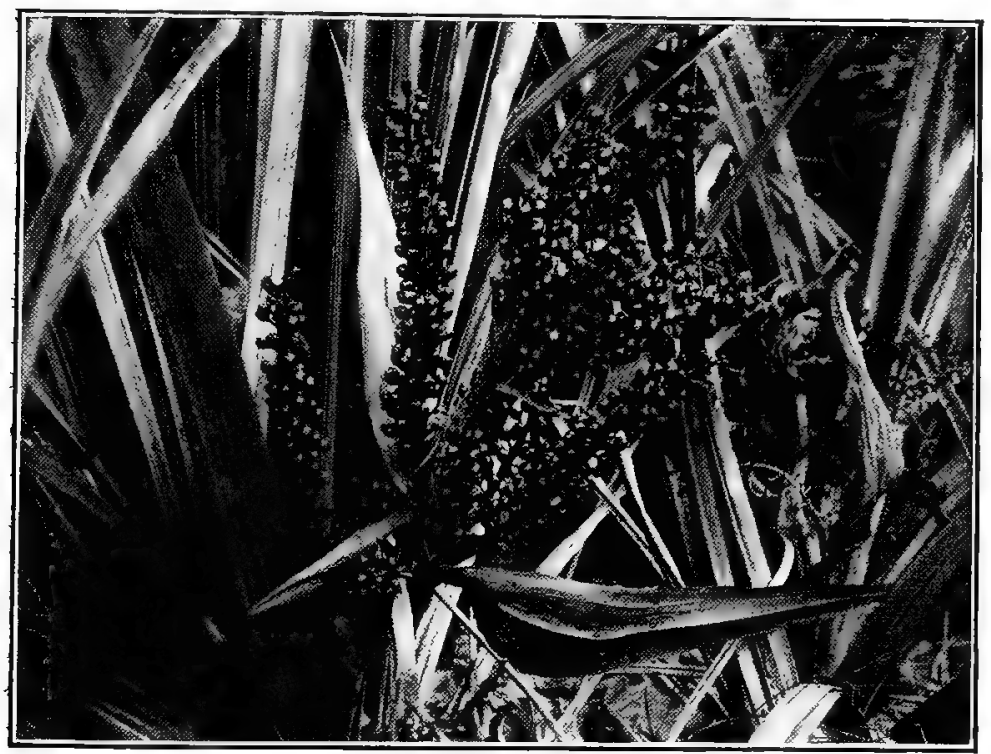

Fig. 25. Astelia nervosa ( $\frac{7}{4}$ nat. size)

threatened with death by suffocation, and their only chance of life is to raise themselves to the level of the forest trees, and so share with them the upper, sunnier air. Some, starting on the ground, wreathe themselves around a sturdy tree-trunk and climb steadily, leaving behind them leafless rope-like stems, until they reach a place where they may open out into leaves and flowers, with some surety of bringing them to perfection. Others, like the Astelias, rest securely in the 
forks of the highest branches, eighty or one hundred feet above the ground, appearing to the beholder from below like huge birds' nests.

The flowers of Astelia are sometimes tinged with purple; and the long sprays of berries, with intermingled colours of red, yellow, and green, are very pretty. The latter have a sweet taste, and are eaten by the Maoris. There are two species of New Zealand Astelias which grow in the open, instead of in the bush, and are consequently not epiphytic. These are linearis and nervosa, both of which are found in sub-alpine districts in the North, but at lower levels in the South Island.

The Astelias, like many other epiphytic plants, provide against a long drought, by storing up water in the thick, curved bases of their circle of leaves. In the hottest and driest summer, when even the great forest trees are beginning to show signs of drought, the climber can rarely pull down a. tuft of Astelia without a sprinkle of water-drops. These plants are natives of Australia, Tasmania, the Pacific Islands, and New Zealand. The latter country possesses seven species, of which all are endemic. The berry is 1-celled in A. linearis, and A. Cunninghamii; it is 3-celled in the other species.

A. Cunninghamii.-Leaves $2 \mathrm{ft} .-5 \mathrm{ft}$. long, $\frac{1}{2}$ in. to $1 \mathrm{in}$. broad, silky Flower scape $1 \mathrm{ft} .-1 \frac{1}{2} \mathrm{ft}$, much brinched. Perianth $\frac{1}{4}$ in. A. Solandri is. distinguished from A. Cunninghamii by its broader leaves, ( 3 in. across), and its. larger flowers ( $\frac{1}{2}$ in. in diameter). A. linearis is a small alpine species, with leaves rarely more than $6 \mathrm{in}$, in length, and long, red berries.

\section{Genus Arthropodium.}

Herbs, with long grass-like leaves, and large, showy panicles of white flowers. Perianth of 6 leaflets; stamens 6. Fruit a capsule; seeds angular, black. Roots fibrous, fleshy. A small genus, found in Australia, Tasmania, and New. Zealind. (Name from the Greek signifying jointed foot or pedicel.) $2 \mathrm{sp}$.

\section{Arthropodium cirrhatum (The Curled Arthropodium).}

A handsome plant, 2ft.-3ft. high, with shining leaves and conspicuous white flowers. Bracts leafy; leaves 1ft. long, $1 \frac{1}{2} \mathrm{in}$. broad. Flowers $3 \mathrm{3in} .-1 \mathrm{in}$. across. The stamens of this plant are exceedingly beatiful. Seen under a magnifying. 


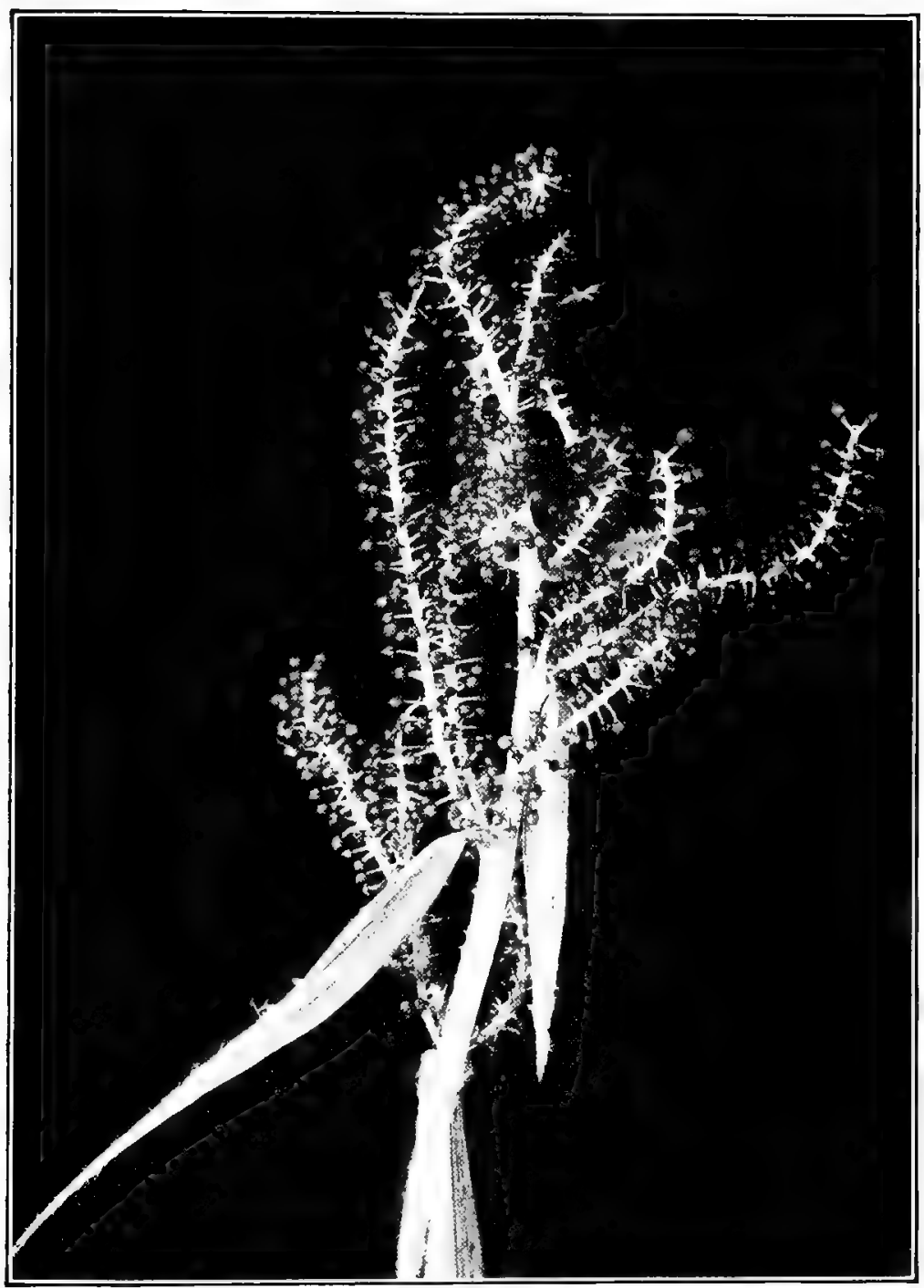

Fig. 26. Astelia Banksii Fxuit (3 nat. size) 
glass they resemble small bottle-brushes, covered with orange or pink bristles. Northern Island, growing profusely upon rocky cliffs. Fl. Nov.-Dec. (Name in allusion to the brush-like filaments.) Usually known as the Rock Lily.

\section{Arthropodium candidum (The White Arthropodium).}

A much smaller plant, usually $7 \mathrm{in}$. or $8 \mathrm{in}$, in height, with soft, grass-like leaves. Flower-stem very slender; flowers white, $\frac{1}{3}$ in. across, with recurved petals. Damp woods, both islands. Fl. Jan.-Feb.

\section{Genus Bulbinella.}

Herbs, with fibrous or bulbous roots. A large genus, found in all temperate climates. Leaves from the root, long and narrow. Flowers in racemes. Perianth of 6 leaflets; stamens 6 ; filaments of stamens bearded. Fruit a capsule; seeds black. $2 \mathrm{sp}$.

\section{Bulbinella Rossii (Ross's Bulbinella.)}

A tall, sturdy plant, sometimes reaching $4 \mathrm{ft}$, in height. Stem very thick; leaves 8in.-16in. long, recurved. Flowers yellow, asphodel-like, $\frac{1}{3}$ in. across. This plant is abundant in Lord Auckland's group, and in Campbell's Island, while the smaller species, Bulbinella Hookeri, is found in lowland and sub-alpine pastures in both the Northern and Southern Islands of New Zealand. The flowers are as large as in the former species, but the leaves and the whole plant are smaller. It is frequently-at least in the Southern part of New Zealandknown as the Maori Onion. In some places a whole mountain side may be seen covered with a blaze of yellow from the presence of myriads of racemes of this plant. Fl. Oet.-Dec.

\section{Genus Phormium.}

Large, tufted, perennial herbs, with fibrous roots, and radical isobilateral leaves. Flowers in large panicles. Perianth of 6 leaflets, tubular, red, or yellow. Stamens 6, longer than the petals. Fruit a long capsule, many seeded. A genus of two species, both endemic. (Name from the Greek for a basket, in allusion to the use of the leaves by the Maoris in basket-making). Maori name, Haraketie.

Phormium tenax (The New Zealand Flax, or Flax-Lily).

This is a remarkable species, peculiar to New Zealand and Norfolk Island. Like the cabbage-tree, it forms a distinct and unmistakeable feature of the New Zealand landscape. It is totally unlike the flax-plant known to Europeans, though the two may be compared in the strength and usefulness of their fibres. The Linaceae (Flax Tribe) constitute a family in 


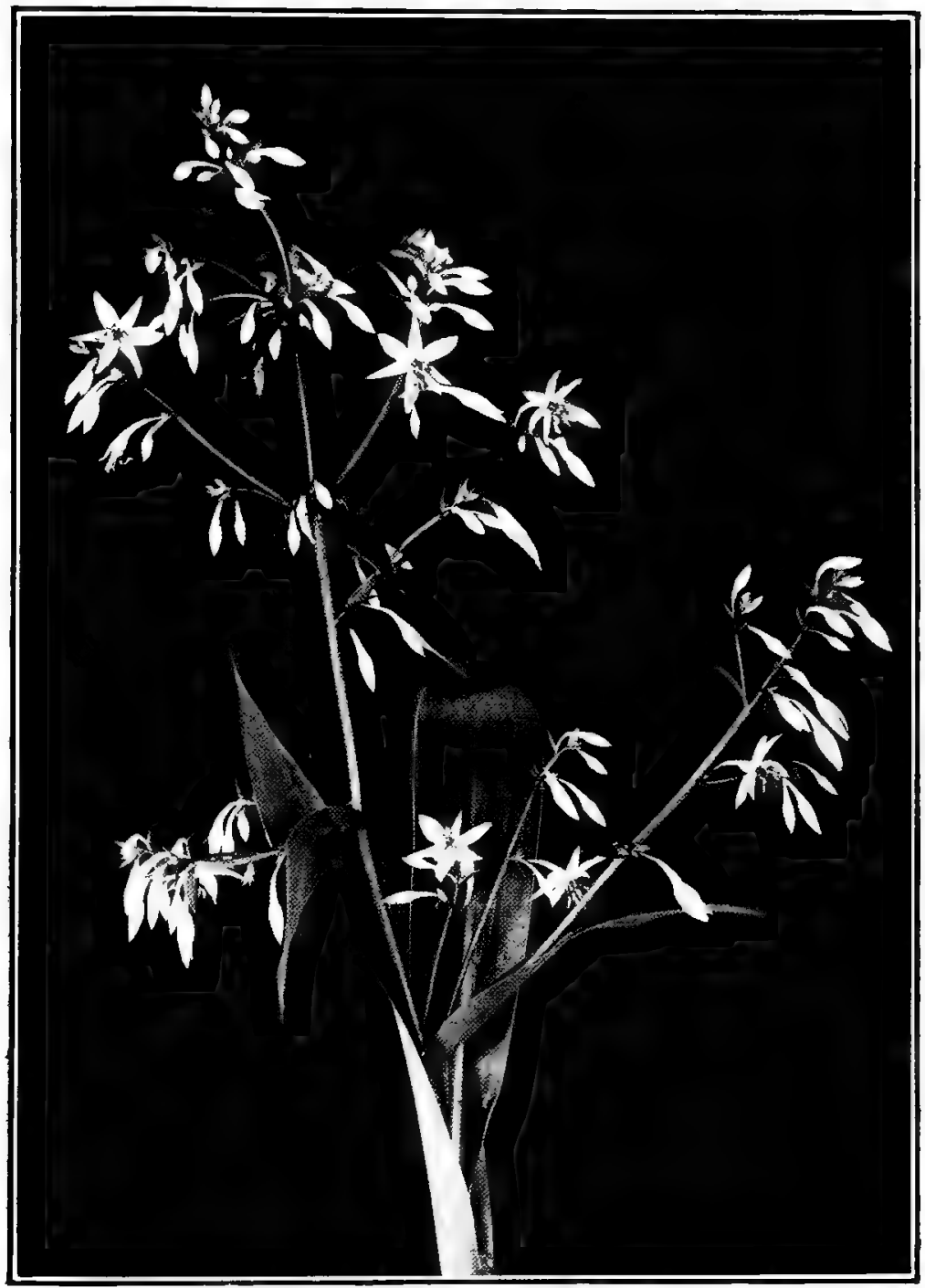

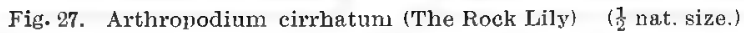


themselves, and are all small, herbaceous plants, with delicate, pale-blue petals. But the flax of the New Zealand swamps and hillsides is an entirely different plant. The coarse, darkgreen leaves are often six feet or more in length, while its flower-stem occasionally rises to a height of fifteen feet. The finest variety is found by running water, while the plant of the stagnant swamp remains comparatively small.

The settler is never in want of a piece of twine with a flax bush growing near his home. He has merely to take one of the long leaves, and tear a strip from it, and he holds in his hand a piece of string that it is almost impossible to break. The Phormium fibre is stronger than that of any other flax, but it is also more brittle when twisted. As to the treatment of it by the natives in the early days, we read in "Nicholas's Voyage," (1814), that "the natives, after having cut it down and brought it home green in bundles, scrape it with a large mussel-shell, and take the heart out of it, splitting it with their thumb-nails. The outside they throw away, and spread the rest out in the sun to dry, which makes it as white as snow. They spin it in a double thread, with the hand on the thigh, and then work it into mats, also by hand. Three wolnen may work on one mat at a time."

This plant was known in England in the early part of the nimeteenth century. In the Annual Register of 1819, it was stated that ropes made from the Phomium had been experimented with in the Portsmouth dockyards, and found to stand the test. The ropes were said to be strong, pliable, and very silky.

A Maori named Tupai visited England in the time of George III, and was amused to see a plant of flax growing in a pot under glass. It is said to have been cultivated in the open by a Frenchman of the name of Freycinet, in 1813, when it grew to a height of six feet, and bore a large spike of flowers. It seems also to have been, a little later, successfully cultivated in the British Isles, and to have ripened seeds as 
far north as the Orkneys. It can bear minjured a temperature of $15^{\circ}$ Fahrenheit, and it is only at $9^{\circ}$ that the tops of the leaves become frost-bitten. It appears to be a plant suitable for universal naturalization, on account of the varying temperature it will bear unhurt, and the fact that sheep) and cattle do not usually eat it.

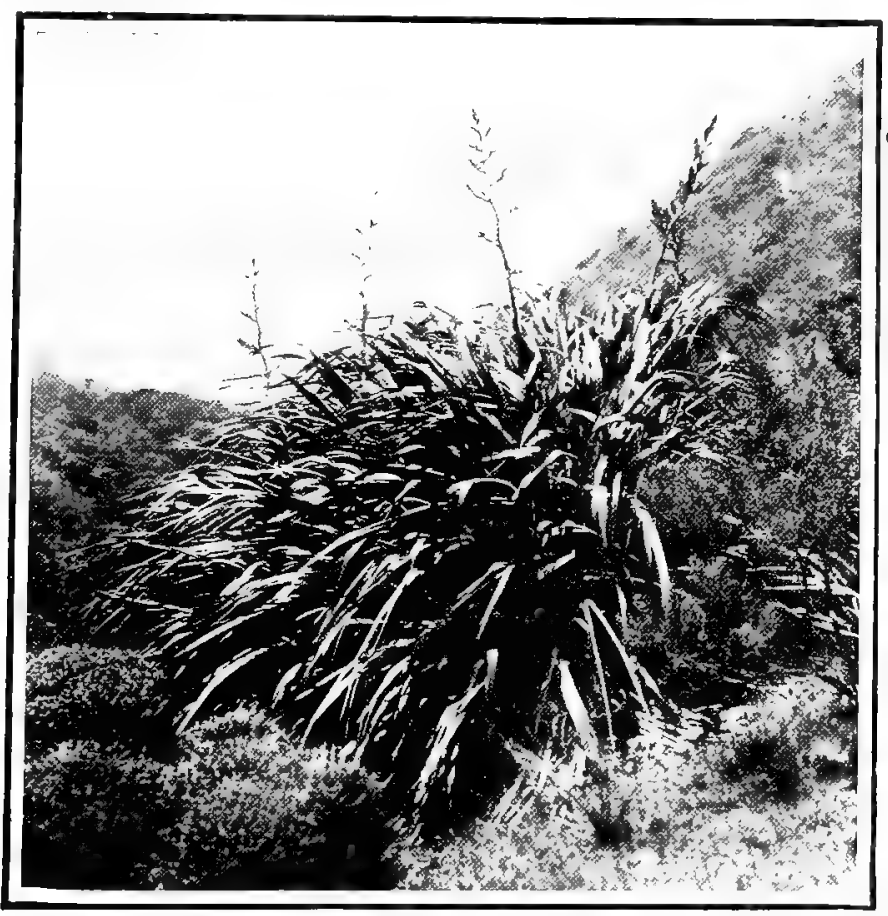

Fig. 28. Phormium tenax. (The New Zealand Flax.)

The root of the Phormium is a thick, creeping rhizome. The leaves have no footstalks, but ascend straight from the crown of the plant. The flowers are more curious than beautiful, and are of a dull, dingy red, or sometimes yellow colour. The dark stamens hang out far below the petals, and are tipped with bright yellow anthers. These blossoms secrete a great quantity of nectar, which is very attractive to birds. 
They are visited constantly by the tuis and parrots, which thus cross-pollinate them. The seeds are black, shining, flat, and packed closely in a capsule.

This plant has often been used medicinally. A pulp made from the roasted and macerated roots is sometimes applied as a poultice for abscesses, while a decoction of the same is said to act like a charm upon unbroken chilblains. The soft part at the base of the leaf is placed over wounds to stop bleeding, though some bushmen have an idea that the juice of the leaf acts as a poison to a cut, and aver that cuts obtained in the handling of the leaves in a flax-mill usually fester.

A great quantity of the flax-fibre is now exported annually, and is at present valued at $\$ 24$ per ton. The Maoris used this fibre for various purposes, such as making fishing-nets, cloth, and many ornamental articles.

Love-tokens are said to have been made by the Maoris in the early days from strips of flax-leaves.* A double slip-knot was formed, which, if tightly pulled, ran into one large single knot. The double loop was presented by the young Maori to his sweetheart, who signified her consent to his silent proposal, by drawing the two knots into one.

A flax-stick, or dried flower stem, is known to colonists as a korari, koradi, or kaladi. The first name is of course, the correct one (v. Accena). It is very light and full of a brown pith. By the Maoris of old time these stems were put to many uses.

\section{The Leaf of Phormium.}

The leaf of the flax is one of the strongest and most remarkable known. When fully grown it attains a length of from three to ten feet, with a breadth of from $3 \mathrm{in}$. to $4 \mathrm{in}$. The colour varies from light yellow-green to a deep blue-green, with a yellow or red margin. There are, however, many varieties. The Maoris recognized more than fifty. Some of the cultivated 
forms are much more richly tinted than the ordinary wild varieties. The bronze-leaved flax is perhaps the finest of those usually found in gardens. A variety, said to come from the Chatham Islands, has, along with a tinge of bronze in the leaves, beautiful crimson, almost translucent margins, and is much more pendulous and graceful than the ordinary stiff bayonet-like form. Variegated sports are common. One of them at least appears to have originated in the Jardin des Plantes at Paris. The leaf is linear-lanceolate in shape with an acute point, and is folded longitudinally from tip to base, so that at about a third of its length from the point, the two upper and inner surfaces of the blade come together, and throughout half the length of the leaf are in close contact. At the butt of the leaf, the two halves are again separated by the younger leaves, which are ensheathed by the older ones. Large quantities of gum, which have been a source of great difficulty to rope-makers, are secreted between the halves of the blade. The leaves are arranged in fans. After the fan has produced its flower, it withers away.

The minute structure of the foliage is no less remarkable, than its form and general appearance. There is perhaps no leaf on the face of the earth, that has greater powers of withstanding tension than this one. The blade is intersected longitudinally, by large numbers of plates of strong-walled fibres, placed transversely to the breadth of the leaf. Between each pair of plates there are strands of similar fibres, running along the surface immediately below the cuticle (skin). Thus a considerable amount of rigidity, accompanied by most unusual strength, is developed in the leaves. The rigidity enables them, in spite of their length, to stand vertically; and their great strength prevents them from being whipped to pieces by the wind. The tenacity of the fibres arises chiefly from the fact that the cells of which they are composed are dry, hard, filled only with air, and have very much thickened cell-walls. Schwendener has calculated that the sustaining. 
power of such cells is equal to that of the best wrought iron or hammered steel, while their ductility is from ten to fifteen times as great as that of iron. Moreover, such mechanical tissues are generally so arranged as to withstand the maximum amount of strain, though occupying the minimum amount of space in the leaf.

Habitat: Both islands, and Norfolk Island. Fl. Nov.-Janl. P. Cookianum, a small species, is found in both islands on dry hill sides. It is occasionally eprphytic.

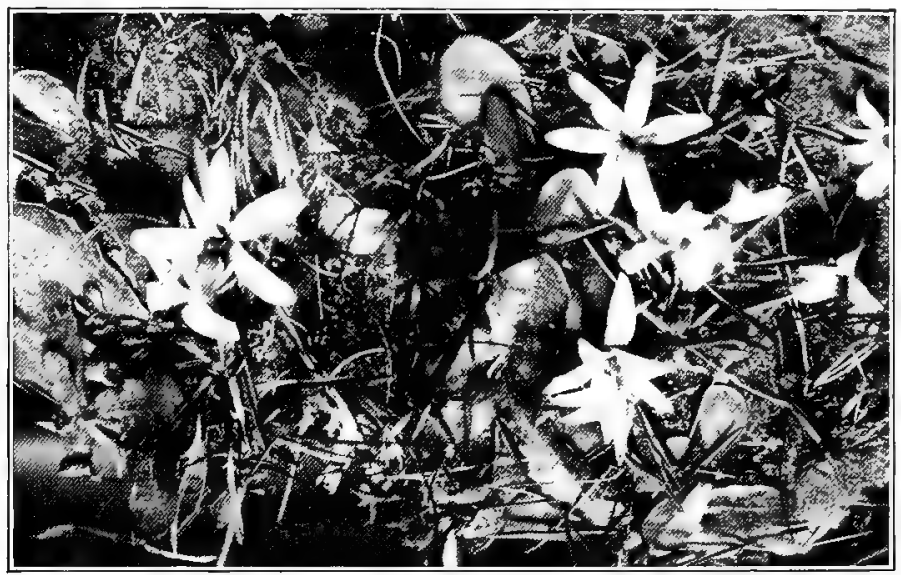

Fig. 29. Herpolirion Novae-Zelandiae.

\section{Genus Herpolinion.}

Creeping, wiry herbs, with narrow, sheathing leaves. Flower-bud enclosed in one or more spathes. Perianth 6-parted, tubular. Stamens 6. Fruit a capsule. A small alpine genus of two species, one found in New Zealand, and one in Austrilia and Tasmania. (Name from the Greek, signifying a creeping lly.) $1 \mathrm{sp}$.

\section{Herpolirion Novae-Zelandiae (The New Zeulund Herpolivion).}

This little plant is found in elevated swamps in Nelson and Canterbury, on the Taupo plains, and in lowland swamps in Otirgo and Stewart Island. The leaves are narrow and glaucous, $1 \mathrm{in},-2 \mathrm{~m}$. long; the flowers $\frac{1}{1} \mathrm{~m} .-\frac{1}{2} \mathrm{~m}$. across, white, or pale lulne, almost sessile; the bud is enclosed in a single spathe. Fl. Dec.-Feb. 


\section{Iridaceae.}

\section{The Iris Family.}

Distribution.-A large family, chiefly natives of warm and temperate regions. Saffron is obtained from Crocus sativus, and owis root is the fragrant rhizome of Iris florentina. The Flag, the Gladiolus, the Ixia, and the Crocus are well-known garden plants. This family is represented in New Zealand by the one genus Libertia.

\section{Genus Libertia.}

Herbs, with umbellate panicles of white flowers. Stamens with united flaments. Capsule rounded, leathery or membranous. Seeds angular, deeply pitted in the New Zealand species. (Named after Madame Libert, a French botanist). $3 \mathrm{sp}$.

\section{Libertia ixioides. (The Ixia-lite Libertia).}

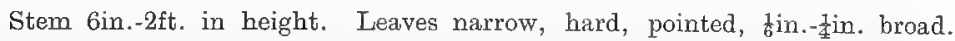
Flower-stalk panicled. Branches enclosed in spathes, bearing umbels of from 2-10 white flowers. Perianth 3 in.-1in. across; petals larger than the sepals.

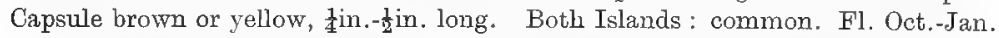

Libertia grandiflora. (The Larye-flowered Libertia).

Stem 2ft.-3ft. high. Leaves $\frac{1}{3}$ in. broad. Capsule $\frac{1}{5}$ in.- $-\frac{2}{3}$ in. long, turgid, obovoid. Both islands. Fl. Nov,-Dec.

\section{Orchidaceae.}

\section{The Orchid Family.}

Perennial herbs, terrestrial or epiphytic, with remarkably irregular flowers. Leaves entire, usually sheathing at the base. Perianth of 6 parts; sepals 3 ; petals 3 , the lower of these called the labellum or lip, usually large, spurred, and differing in form from the other two. Stamens united with the style to form a column, containing from 2-8 masses of pollen. Fruit a capsule; seeds numerous.

Distribution.-One of the largest orders of plants, consisting of nearly 5,000 . species, and represented in almost every part of the globe, except where the climate is excessively cold. The beauty and strange irregular shape of the flowers of this order are due to the variation in size, shape, and colour of the six parts of the perianth. 


\section{Its Fantastic Flower-Forms.}

"There is no order of plants," says Dr. Findlay, in his paper on Orchidaceae in the "English Cyclopædia," "the structure of whose flowers is so anomalous as regards the relation borne to each other by the parts of reproduction, or so singular in respect to the form of the floral envelope. By an excessive development and singular conformation of one of the petals, called the labellum or lip, and by irregularities, either of form, size, or direction of the other sepals and petals, by the peculiar adhesion of these parts to each other, and by an occasional suppression of a portion of them, flowers are produced so grotesque in form that it is no longer with the vegetable kingdom that they can compare, but their resemblance must be sought in the animal world." This is no fanciful, far-fetched resemblance, as might be imagined by those who have no large acquaintance with these strange flowers. Anyone, observing for the first time the bee orchis (Ophrys apifera) of the English downs, would find it hard to believe that he did not see before him the real insect, so exactly does the flower reproduce the brownish-velvety body, streaked with gold bands, and the pollen-covered legs. The Fly, the Lizard, and the Monkey Orchis are likewise natives of Great Britain.

In tropical countries the flowers of orchids, or parts of them, show many curious resemblances to various animals. Grasshoppers, nuosquitoes, dragon-flies, butterflies, swans, pelicans, the skin of the tiger and of the leopard, the eyes and teeth of the lynx, the face of the bull, the grin of the monker, the head of the serpent, the tail of the rattlesnake, frogs, lizards, even the head of the extinct Dinotherium, are all mimicked by them.

The New Zealand species are not so curious in this respect as those of most countries, though the little Silverback (Corysanthes macrantha), with its lurid purple flowers, and long antennae, has somewhat the appearance of a purple beetle or cockroach (Fig. 35). Pterostylis graminea and $P$. 
Bankisii have large, hooded, greenish flowers. Dendrobium Cunninghamii, with its many flowered racemes of pale rose and white, is perhaps our most beautiful orchid, though the. sweet-scented Earina mucronata and E. suaveolens are hardly less beautiful. The commonest one is Microtis porrifolia, which has a single, cylindrical, tubular, onion-like leaf, bearing a flower-spike with numerous small green flowers.

The family Orchidaceae is found in almost all parts of the world, but reaches its highest development in tropical regions. In the temperate zone, these plants are chiefly terrestrial, but in tropical countries they are usually epiphytic. The Neottia nidus-avis of the British woods, like our Gastrodia, is a brown, leafless saprophyte, deriving its nourishment from the decaying organic matter of the soil in which it grows. The finest forms come from the Malay Archipelago, and from South America. Collectors go to these districts to hunt for new and rare plants, and often risk their lives for the sake of getting a fresh variety. Though the New Zealand forms are none of them large and showy, yet they are full of interest to the flower-lover and the naturalist.

\section{Structure of the Orchid Flower.}

Darwin has shown that the orchid is probably a much modified, highly specialized lily. Both orchid and lily have three outer, and three inner perianth leaves, though these are probably not completely homologous, and in the case of the orchid they are generally very irregular and varied in shape. In the lily they are usually regular and sinilar. The stamens are reduced in number, generally either one or two anthers only being present. The filaments and style are fused together to form the "column," in the centre of the flower. The anthers are superior to the stigma, but are usually separated from it by an intervening platform, termed the rostellum, that assists in preventing self-pollination. The 
pollen grains are collected together into a few club-shaped masses termed pollinia. These are often provided with a small glutinous pedicel, by which they may be strongly cemented to any object with which they come in contact. The ovary is inferior, (and in this respect therefore unlike that of the lilies), and produces numerous minute seeds.

\section{Pollination of Orchids.}

Though most of the orchids require cross-pollination, and many have elaborate devices to secure it, yet if these fail, some of the species can be pollinated from their own anthers. Many Orchid flowers remain open for a long time. Thus the flower of one species of Cypripedium is said to last forty days, and of another, seventy days. This would seem to suggest that insect visits to these species are few and far between. Mr. G. M. Thomson also remarks on the infrequency of insect visits to those New Zealand orchids which he examined, though he attributes this, ${ }^{*}$ in part at any rate, to the general coldness of the previous season. In spite of all their lures, therefore, even the orchids at times are compelled to resort to self-pollination. It is impossible to do more than mention one or two of the more extraordinary devices, by means of which cross-pollination is secured amongst foreign orchids. We will then give a short account of the methods adopted by New Zealand forms. Perhaps the mode of pollination adopted by Coryanthes, as described by Dr. Crüger, is one of the most extraordinary. ${ }^{\dagger}$

"This orchid has part of its labellum or lower lip hollowed out into a great bucket, into which drops of almost pure water fall from two secreting horns which stand above it, and when the bucket is half-full, the water overflows by a spout on one side. The basal part of the labellum stands over the bucket,

*Trans. Vol. XI. 11, p. 418

tDarwin, Origin of Species, Sixth Edition, N1). 154-155. 


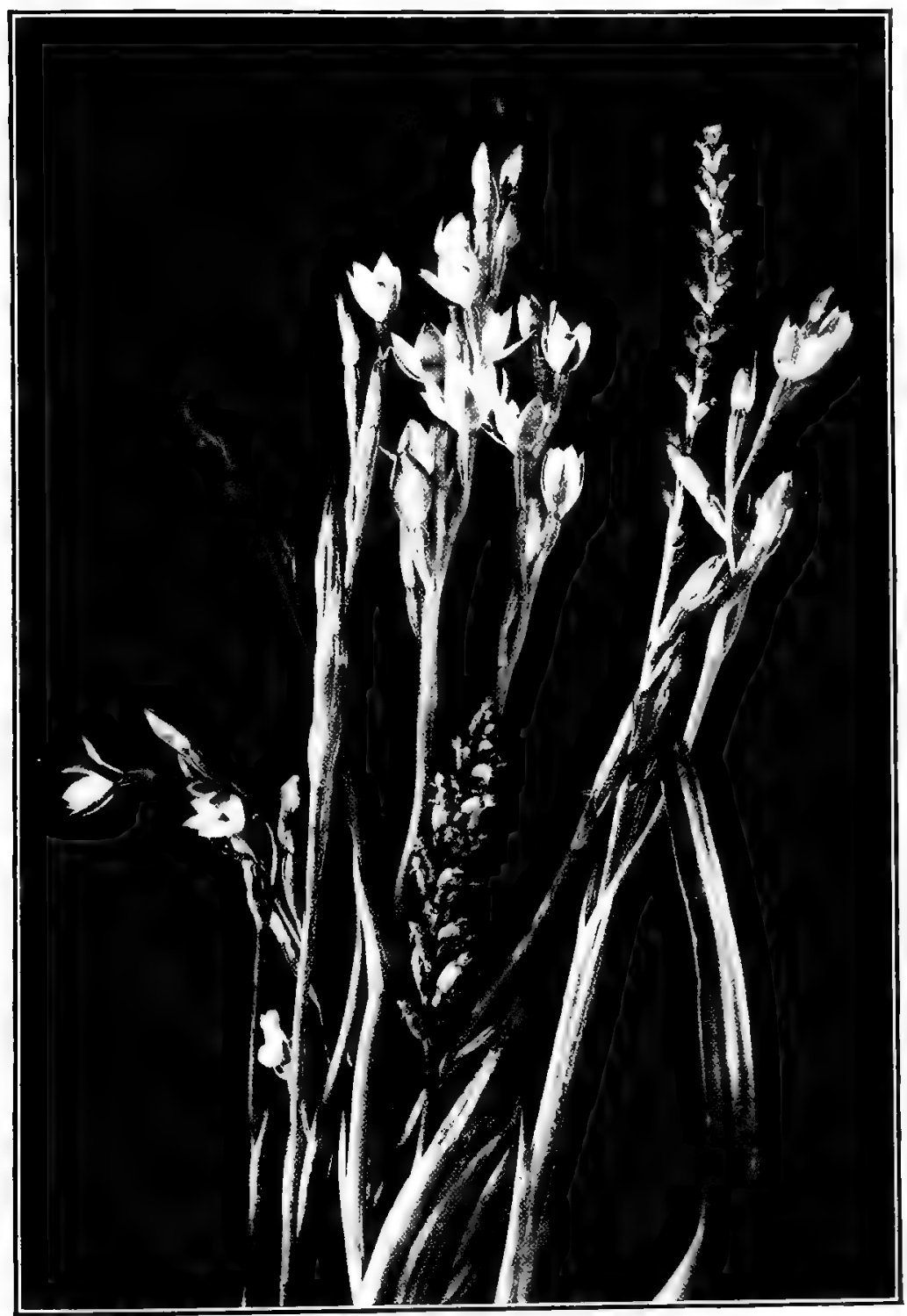

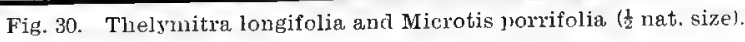


and is itself hollowed out into a sort of chamber with two lateral entrances; within this chamber there are curious fleshy ridges." The most ingenious man, if he had not witnessed what takes place, could never have imagined what purpose all these parts serve. But Dr. Crüger saw crowds of huge humble bees visiting the gigantic flowers of this orchid, not in order to suck nectar, but to gnaw off the ridges within the chamber above the bucket; in doing this they frequently pushed each other into the buckets, and their wings being thus wetted, they could not fly away, but were compelled to crawl out by the passage forming the spout or overflow. Dr. Crüger saw 'a continual procession' of bees, thus crawling out of their involuntary bath. The passage is narrow, and is roofed over by the column, so that a bee, in forcing its way out, first rubs its back against the viscid stigma, and then against the viscid glands of the pollen masses. The pollen masses are thus glued to the back of the bee which first happens to crawl out through the passage of a lately expanded flower, and are thus carried away. . . . . When the bee thus provided flies to another flower, or to the same flower a second time, and is pushed by its comrades into the bucket and then crawls out by the passage, the pollen mass necessarily comes first into contact with the viscid stigma, and adheres to it, and the flower is fertilized. Now at last we see the full use of every part of the flower; of the water secreting horns, and of the bucket half full of water, which prevents the bees from Hying away, and forces them to crawl out through the spout and rub against the properly placed viscid pollen masses and stigma."

In Catasetum, an allied orchid, the method of cross-pollination is simpler, but none the less renarkable and effective. The bees come to gnaw the ridges of the labellum, and in so doing must touch a long sensitive "antenna." This aplarently transmits a sensation to another part of the flower, - a spring is set free, 
and the pollen mass is shot out like an arrow against the back of the entering bee, which carries it off to the female flower.

\section{Pollination of some New Zealand Species.}

The methods of pollination of some of the New Zealand forms, have been described by Mr. G. M. Thomson and by Mr. Cheeseman.* It would appear from Mr. Thomson's investigations, that several at least of our native orchids are self-pollinated. Mr. Fitzgerald has shown in his "Australian Orchids," that in the genus Thelymitra all forms may be found between plants which are regularly self-fertile and are never cleistogamic, and those which are completely dependent upon insects for pollination. The New Zealand Thelymitra longifolia is a vely puzzling case. It is one of the commonest of New Zealand orchids. In the North Island it is almost everywhere abundant except in the dense bush. In the South Island it is hardly less common. According to Mr. Cheesemant "the flowers ustally open about nine o'clock in the morning, neatly reclosing about four or five in the afternoon. There is, however, considerable irregularity as to this, some varieties only opening for a short time in the widdle of the day, others remaining expanded for a much longer period." On the other hand, in the South Island, it is rare to find an open flower. Even in fine weather not more than a few per cent. of the flowers open properly. The chief reason why flowers do not open in wet weather is that rain destroys their pollen; many of them therefore close in rain or adopt ingenious contrivances for keeping their pollen dry. Now, Mr. Cheeseman has observed, (loc. cit.), that rain reduces the pollen of this plant to a pulpy mass. This is perhaps the primary reason for its closing. One would consequently expect to find it more frequently opened in the drier climate of Australia, than in New Zealand. However, observations seem to show the

* Trans. Vol. V. p. 352, and Vol, XIII., p. 291.

† Trans. Vol. XIII., p. 293. 
reverse to be true. Though the plant is well adapted for cross-pollination, insects rarely visit it. Mr. Cheeseman states, "For the last seven year"s I have made it a practice to watch beds of this orchid, and, save on two occasions, I have never seen winged insects enter the flower, and in both these cases the pollinia were not removed." Out of 218 flowers examined, only seven had lost their pollinia. Thus, it would appear, that the plant is occasionally, though very rarely, cross-pollinated. On the other hand, as the species is a predominant one, it must obviously be largely self-fertilized and often cleistogamic, thus apparently forming an exception to the general rule that it is a disadvantage to a flower to be self-pollinated. Earina, Dendrobium, and Corysanthes, on the other hand, are apparently completely dependent upon insects to secure pollination. The following description is abstracted from Mr. G. M. Thomson's account of the pollination of Earina suaveolens: "The flowers are only about one-third of an inch in diameter, white in colour, with a yellow centre, and with an almost overpoweringly sweet perfume. The labellum is 3-lobed, and stands nearly erect in front of the column. There is no nectary, but the tissue at the base of the labellum is easily punctured, and exudes beads of moisture. The column is short and erect, the stigmatic surface very concave, with the viscid rostellum projecting prominently forward above it. The anther is terminal and deciduous, and encloses four pollinia attached in pairs to a short stem, and resting on the rostellum. From the position of the parts it appears to be impossible that self-pollination could take place. The pollinia are very coherent, and lie closely ensconced in the anther case. For pollination by insects, however, the parts are very simply fitted. An insect, visiting the flower, would insert its head or proboscis into the small square aperture between the labellum and the column, and in withdrawing it would inevitably touch the viscid surface of the rostellum, and bring away the pollinia. Were these to 


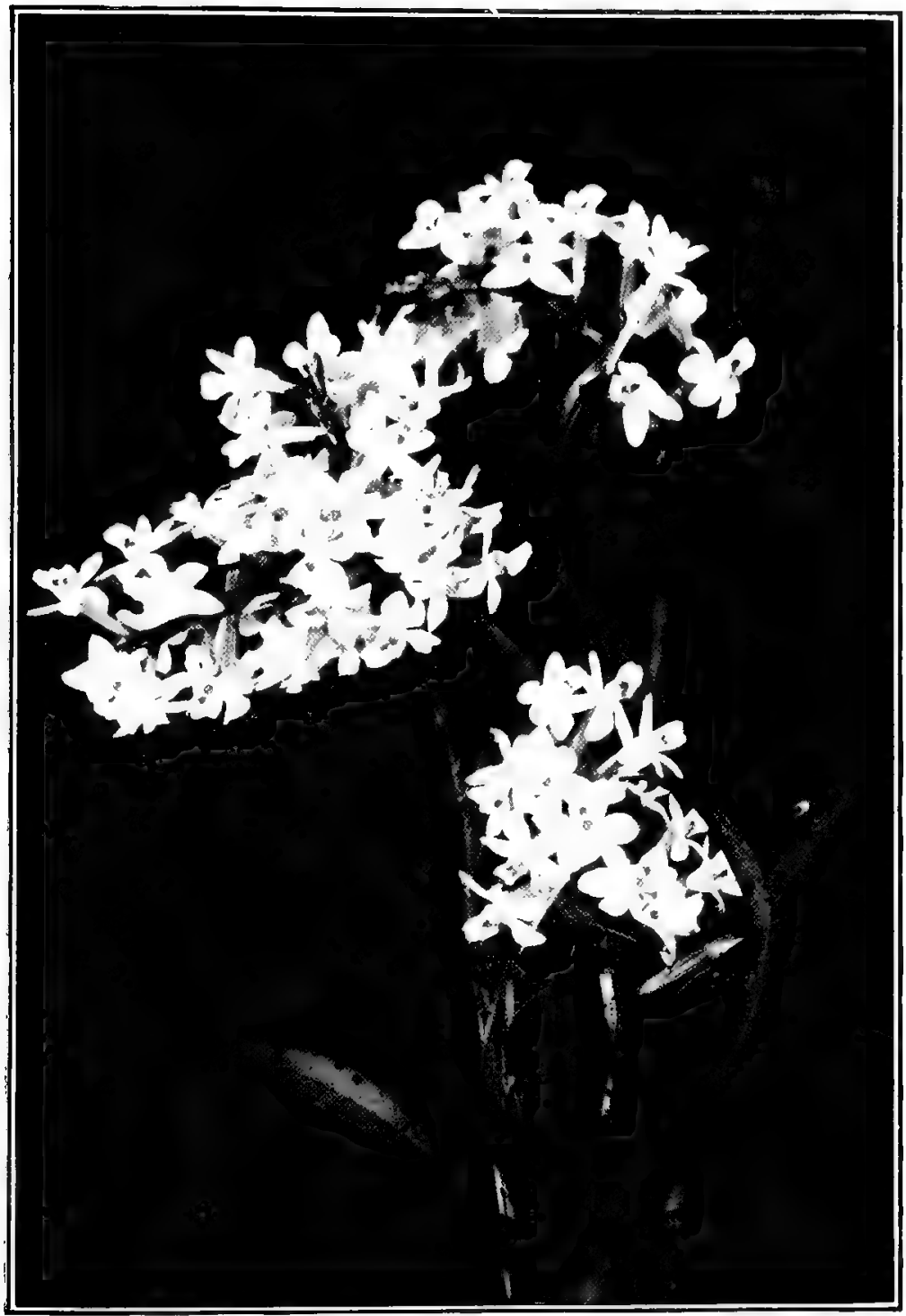

Fig. 31. Earina suæveolens (nat, size). 
be withdrawn just as they lie on the summit of the column, they would hardly be in a position to strike the stigmatic surface of another flower in the hollow below the rostellum, but in being withdrawn, the cap of the anther pulls them slightly downward and depresses them considerably, so that they are easily placed on the stigma of a second flower."

Pollination in the genus Pterostylis has been well described by Mr. T. F. Cheeseman.* The lip is sensitive, and, when touched, closes up against the column. An insect landing upon it is thus entrapped, and the only means by which it can escape is by the narrow channel left between the column and the lip. In passing along this channel, it must strike first the viscid stigma below the rostellum, and afterwards the anthers above the rostellum. The back of the insect will now be sticky, so that it will carry off with it the pollinia, or portions of them, to the next flower which it visits, and place them upon its stigma. As each plant bears only a solitary flower, it is clear that cross-pollination must be effected not only between different flowers, but between different plants. The flowers of this genus are pollinated by certain species of flies. This method of entrapping insects seems to be unique in the order. The large green hooded flowers of this genus are, in spite of their size, not very conspicuous, and it is not always easy to determine what attraction they possess for the insects.

\section{The Absorption of Moisture.}

Orchids are not only remarkable for the structure of the flower, and for their methods of pollination, but in many other ways. Thus, they have often highly specialized methods of absorbing moisture. There is in New Zealand, a minute species of Bolbophyllum, B. Pygmaum. It is not uncommon, but is frequently overlooked, as it is so inconspicuous. The genus has received its generic name, because, at the base of each leaflet, is a small bulb, in which are concealed the

Trans. Vol. V., D. 352. 


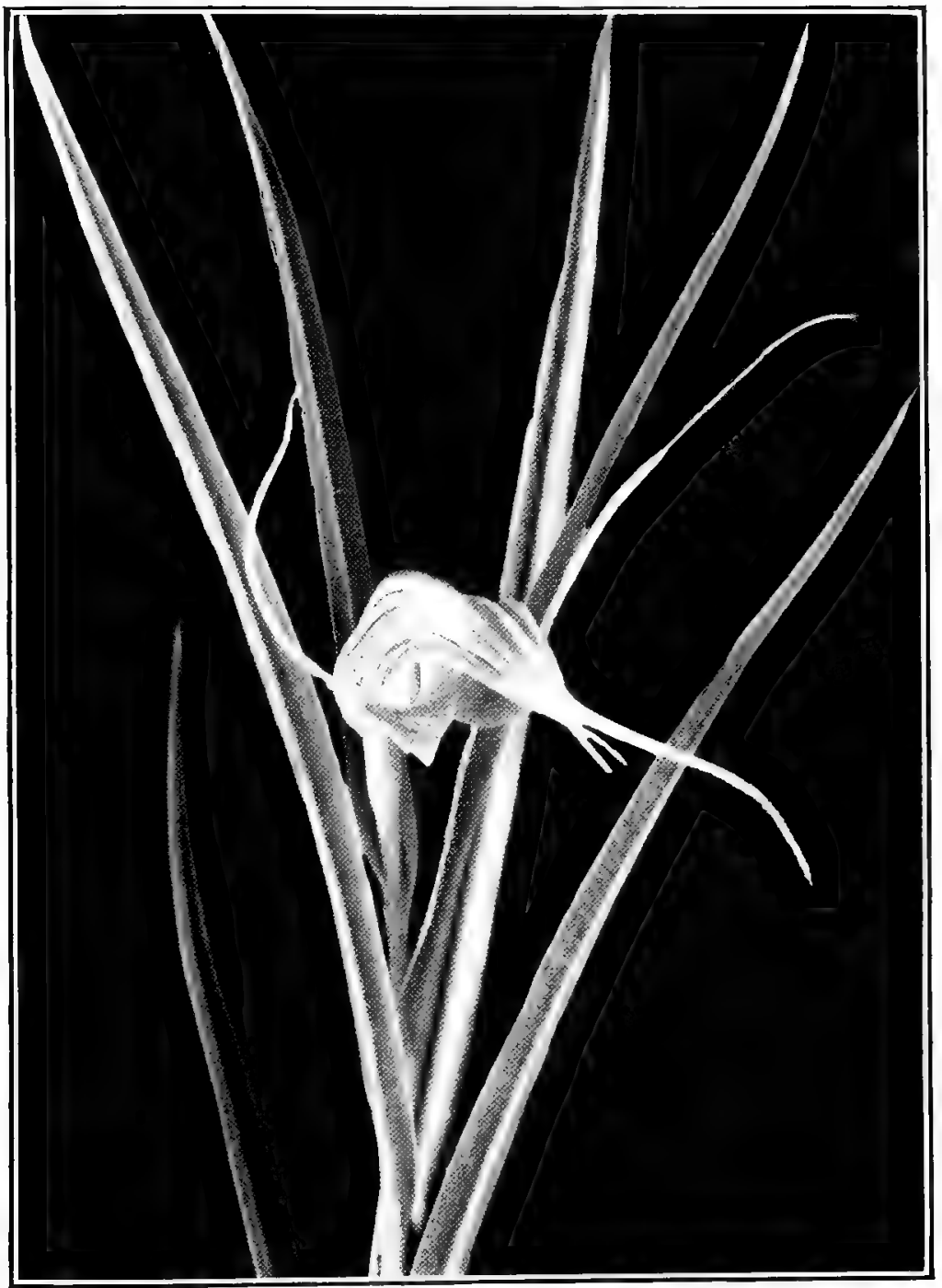

Fig. 32. Pterostylis Banksii (参 nat. size). 
stomata by which the plant transpires. The object of this arrangement is two-fold. It enables free transpiration to go on in the wet season, when the plant is surrounded by moisture that would otherwise choke the pores; and, in the dry season, the concealment of the pores checks excessive transpiration. Again, Dendrobium and Earina very frequently grow upon trees, or in the clefts of rocks. In such situations, of course, no moisture can be received from the soil; and if the leaves were thin and broad, there would be excessive transpiration, and the plant would wither. Consequently, they are narrowed, and have become rather thick and leathery. The dimensions given in Hooker's Handbook for the breadth of the leaves in these genela are: E. mucronata $\frac{1}{5}$ to $\frac{1}{4}$ in., E. suaveolens $\frac{1}{3}$ in., D. Cunninghamii ${ }_{5}^{1}$ in. Contrast these leaves with those of a shade-growing plant like Corysanthes macrantha. The latter has round flaccid leaves full of moisture, which would soon wither if exposed to strong sunlight. In Microtis, the leaf has been rolled up into a cylinder, no doubt with the object of conserving its moisture. In Bolbophyllum, the leaf has been reduced to a scale-like process.

But Earina and Dendrobium, have not only endeavoured to check transpiration through the leaves, they have also increased the root surface, and specialized it for the absorption of moisture. After clamping themselves to the rock, or to the bark of a tree, by their roots, they produce numerous other white, membranous, papery, filamentous roots. The outer surface of these roots is composed of a spongy tissue, that cannot fail to aissorb any moisture in the vicinity.

\section{Fely to the Genera.}

1. I'erennial epipluytes or rock plants. 2 Roots terrestrial, stems annual. $\quad 6$

2. Pollen granular. I'ollen waxy.

3. Stem slender, leafy, Sepals free. Dink of lip naked.

4. Leaves not on iseudolulls Leares on pseudobulbs.

Earina 1). 122

$$
5
$$

Bolbophyllum p. 124. 


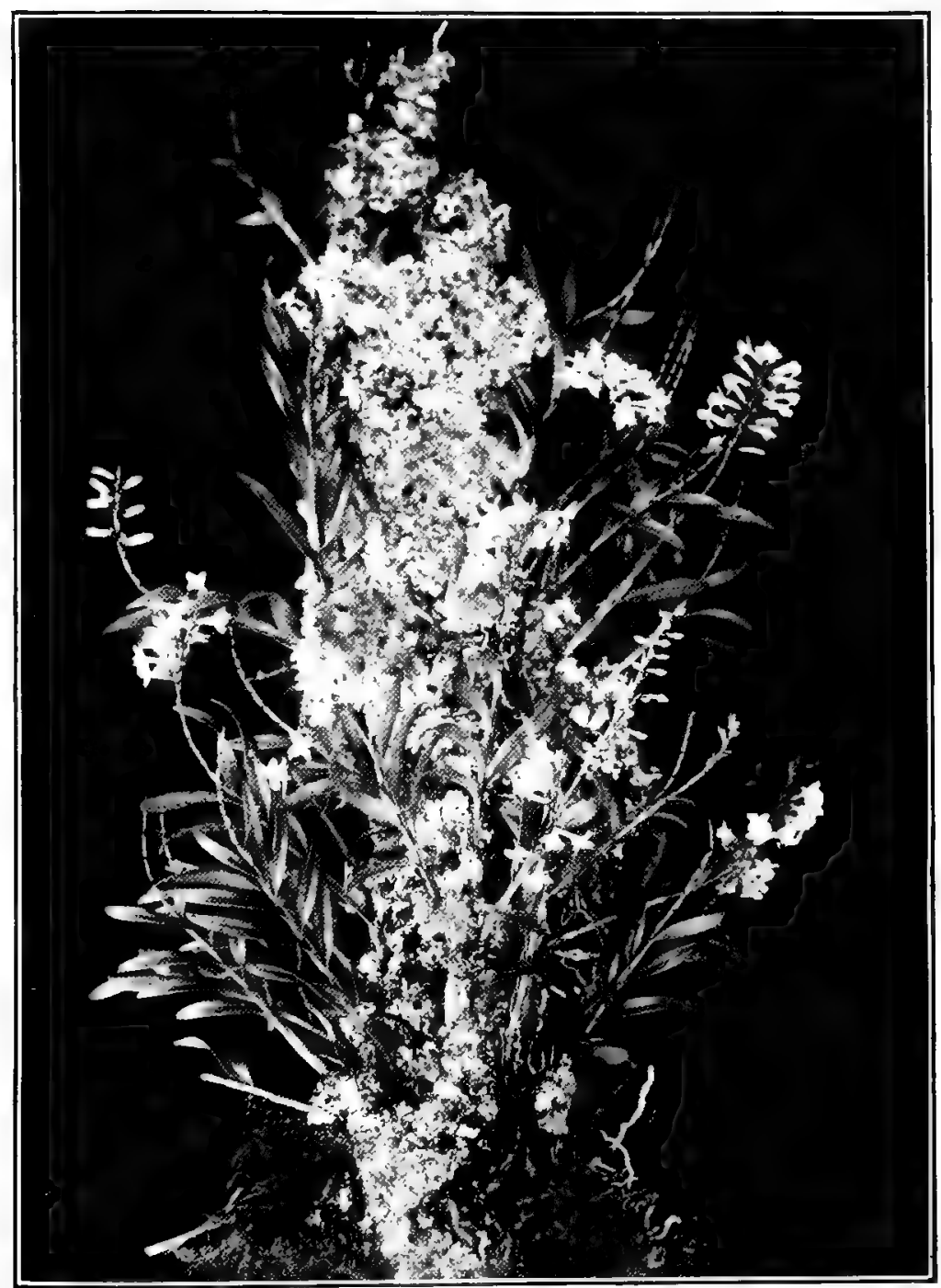

Fig. 33. Eaxina suaveolens on tree bark. 
5. Stew, slender, leafy. Lateral sepais attached to column. Lip with crests on its face. Stems very short, leafy. Lip concave, middle lobe solid.

6. Plants with 1 or more leaves.

Plants leafless. Flower's numerous, brown.

7. Leaf solitary (2 in Caladenia bifolia).

Leaves 2 or more.

8. Leaf solitary, broad, membranous.

Leaf solitary, slender, flat or terete ( 2 broad in Caladenia bifolia).

9. Flower 1.

Flowers few.

10. Flower sessile, purple, large. Sepals long, filiform.

Flower with a long stalk. Sepals broad, upper concave.

11. Sepals and petals acuminate or awned.

Sepals and petals linear, obtuse.

12. Leaf tubular. Flowers nany, minute, lip below.

Leaf rounded, linear or flat, but not tubular.

13. Flowers many, minute, with lip uppermost.

Flowers few, pink, blue or yellow.

14. Leaf flat. Flowers 1-4, pink, Lip glandular.

Leaf, rounded, thick. Flowers 1 or more, yellowish or blue. Lip, sepals, and petals all similar.

15. Flowers solitary.

Flowers move than one.

16. Flower large, green, helmeted. Lip narrow.

Upper sepal arched. Lip with large purple gland.

17. Flowers numerous. Upper sepal oblong.

Flowers several. Upper sepal helmeted.

18. Lip with 5 ridges.

Liv 3-lobed.

"Not further described.

Dendrobium, p. 124.

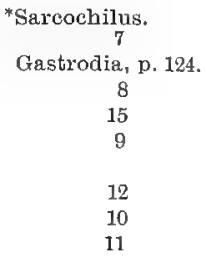

Corysanthes, D. 125

*Adenochilus.

Acianthus, p. 124.

Cyrtostylis, p. 125.

Microtis, p. 125. 13

*Prasophyllum. 14

Caladenia, p. 125

Thelymitra, p. 126.

16

Pterostylis, p. 126.

*Chiloglottis,

*Spiranthes.

${ }^{*}$ Lyperanthus.

Orthoceres, p. 127.

\section{Genus Earina.}

Epiphytic herbs. Leaves, narrow, leathery, numerous. Flowers in terminal spikes, white, lip touched with yellow. Sepals and petals almost equal in shape; lip 3-lobed. Pollen masses 4. Fruit a capsule. (Name from the Greek signifying spring-flowering).

\section{Earina mucronata (The Sharp-pointed Earina).}

Leaves strap-shaped, 4in.-6in. long, fin. broad, marked with whitish longitudinal lines. Flowers in slender panicles, white, tin. broad, lips spotted. Fragrant. Root fibrous, fleshy. Both islands. Fl. Oet.-Dec, 2 sp.

\section{Earina suaveolens (The Frayrant Earina).}

Leaves linear, alternate, 2in.-3in. long, $\frac{1}{2}$ in. broad, rigid. Flowers in short, stiff racemes, larger than in mucronata. Sepals oblong. Petals ovate, Lip broad, 3-lobed, with two orange spots. Peduncle twisted, spotted with black dots, as are the backs of the sepals. Both islands. Fl, April-June. 


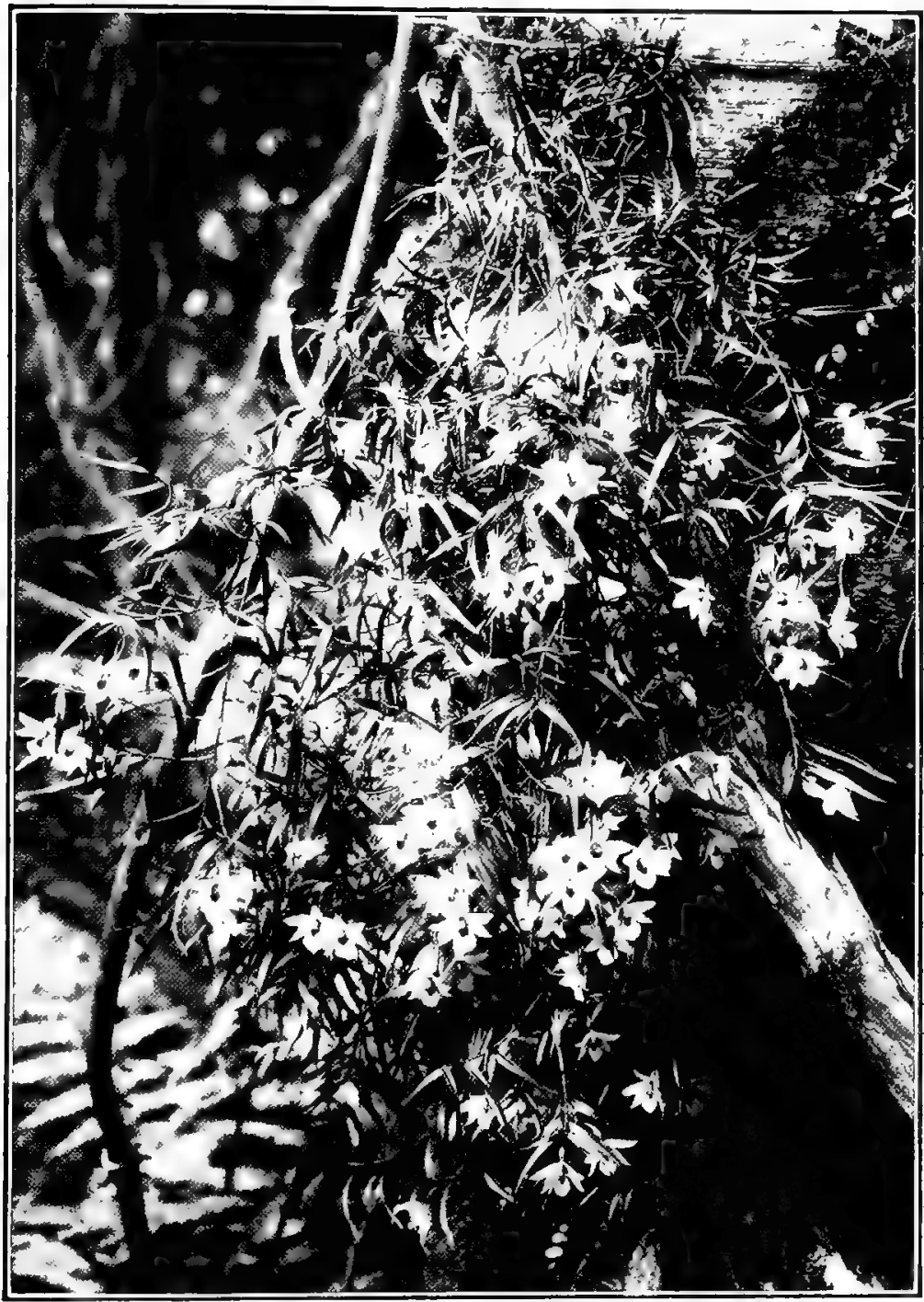

Fig. 34. Dendrobium Cunninghamii (1 nat. size) 


\section{Genus Dendrobium.}

Epiphytic herbs, rigid in habit. Leaves, narrow, numerous. Flowers large, usually racemed, rarely solitary. Petals smaller than the sepals. Lip large, 3-lobed. Pollen-masses, 4. A large genus, many of whose plants are cultivated for the beanty of their flowers. (Name from the Greek, signifying tree-life, in allusion to the epipbytic habit). $1 \mathrm{sp}$.

\section{Dendrobium Cunninghamii (Cunningham's Dendrobium).}

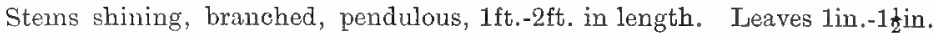
long, $\frac{1}{5}$ in. broad, pale green, striped. Flowers in short racemes, 3 in. across, pale rose-coloured. Petals as long as the sepals. Lip with a small claw. Both islands. Fl. Nov.-Feb.

\section{Genus Bolbophyllum.}

Minute, leathery, epiphytic herbs. Stem matted, bearing small tubers or bulbs, each carrying one or two leaves. Flower solitary or spiked, very similar to Dendrobium. (Name from the Greek, signifying leaf-bulb). $1 \mathrm{sp.}$

\section{Bolbophyllum pygmæum (The Py!my Bolbophyllum).}

A very minute species. Bulbs no larger than a pea. Leaf solitary, sessile. Flower solitary, minute. Both Islands.

\section{Gemus Gastrodia.}

Terrestrial, leafless herbs, with twisted fleshy roots. Stem clothed with brown scales. Flowers drooping, in racemes, brownish white. Petals smaller than the sepals. Pollen-masses, 4. Found only in Australia, New Zealand, Tasmania, and the Tndian Tslands. (Name from the Greek, signifying potbellied).

\section{Gastrodia Cunninghamii (Cunningham's Gastrodia).}

A curious plant, $2 \mathrm{ft}$, in height, with a thick, starchy root-stock, which was sometimes used as food by the natives. Flowers, 10-20 upon a spike, dirty-green, spotted with white, aromatic but unpleasant. Not uncommon in damp bush in both islands. Fl. Dee.-Feb. $3 \mathrm{sp.}$

\section{Genus Acianthus.}

Slender herbs, with tuberous roots, and one single heart-shaped leaf. Flowers large for the size of the plant, green or brown. Pollen-masses 8. (Name from the Greek signifying pointed-flower). $1 \mathrm{sp.}$

\section{Acianthus Sinclairii (Sinclair's Acianthus).}

A tiny, transparent-looking plint, with small greenish-white flowers, two to six in a raceme. Leaf deeply two-lobed at the base. Common in the North Island. Fl. Aug. 


\section{Genus Cyrtostylis.}

These are similar plants to Acianthus, differing only in the winged column, and un-awned perianth. (Name from the Greek, signifying a curved column).

Cyrtostylis oblonga has an oblong leaf, and $C$. rotundifolix, a round one. The former may be found in both islands; the latter on the east coast of the Northern Island only.

\section{Genus Corysanthes.}

Small fleshy herbs, with broad leaves, and solitary purple flowers. Petals smaller than the sepals. Pollen-masses four. Found in Australia, New Zealand, and the Malay Archipelago. The species are usually distinguished by the varying shape of the leaves, e.g. C. triloba, C. oblonga, C. rotundifolia. (Name from the Greek, signifying helmet-flowered). 2 sp.

\section{Corysanthes macrantha (The Large-flowered Corysanthes).}

This is the largest of all the species. Leaf 1 in.-1 $\frac{1}{2}$ in. broad, very thick, silvery on the under-side. Flowers $\frac{1}{2}$ in.-1in. across, deep purple, with longtailed slender sepals and petals. Lip broad, spotted, recurved. Both islands: damp bush. Also in Lord Auckland's group. Fl. Oct.-Dec.

\section{Genus Microtis.}

Frect slender herbs, with sheathing leaves. Flowers in a thick spike, green, minute. Pollen-masses four. A small genus, chiefly Australian. (Name derived from the Greek, meaning a little ear). $1 \mathrm{sp.}$

\section{Microtis porrifolia (The Onion-leaved Microtis).}

A variable plant, from 6in.-24in. high. Leaf solitary, tubular. Flowerspike 20-80-flowered. Flowers trin, long, green. Abundant in both islands. Fl. Oet.-Jan.

\section{Genus Caladenia.}

Slender, tuberons-rooted herbs. Leaf solitary (rarely 2). Scape 1-4-flowered. Column winged. Pollen-masses four. (Name from the Greek, signifying $a$ beautiful gland).

\section{Caladenia minor (The Lesser Caladenia).}

A slender, hairy plant, 2in.-8in. high. Leaf solitary, narrow. Flower

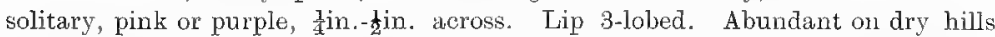
in the Northern Island. Found also in Otago. Fl. Oct.-Jan. C. Lyallii is a larger plant, with 1-2 flowers, $\frac{1}{3}$ in.-1in. broad. C. bifolia is a distinet plant, with two radical, oblong leaves, and a solitary flower, 3 in.-1in. broad. Lip. broad, entire, with two lines of glands. Found on grassy hills in both islands. 


\section{Genus Pterostylis.}

Slender, leafy, shining herbs, with tuberous ronts, and solitary green flowers. Leaves radical or cauline. Column broadly winged. Pollen-masses 4. A genus confined to Australia, Tasmania, and New Zealand. (Name from the Greek, signifying a winged column). $11 \mathrm{sp}$.

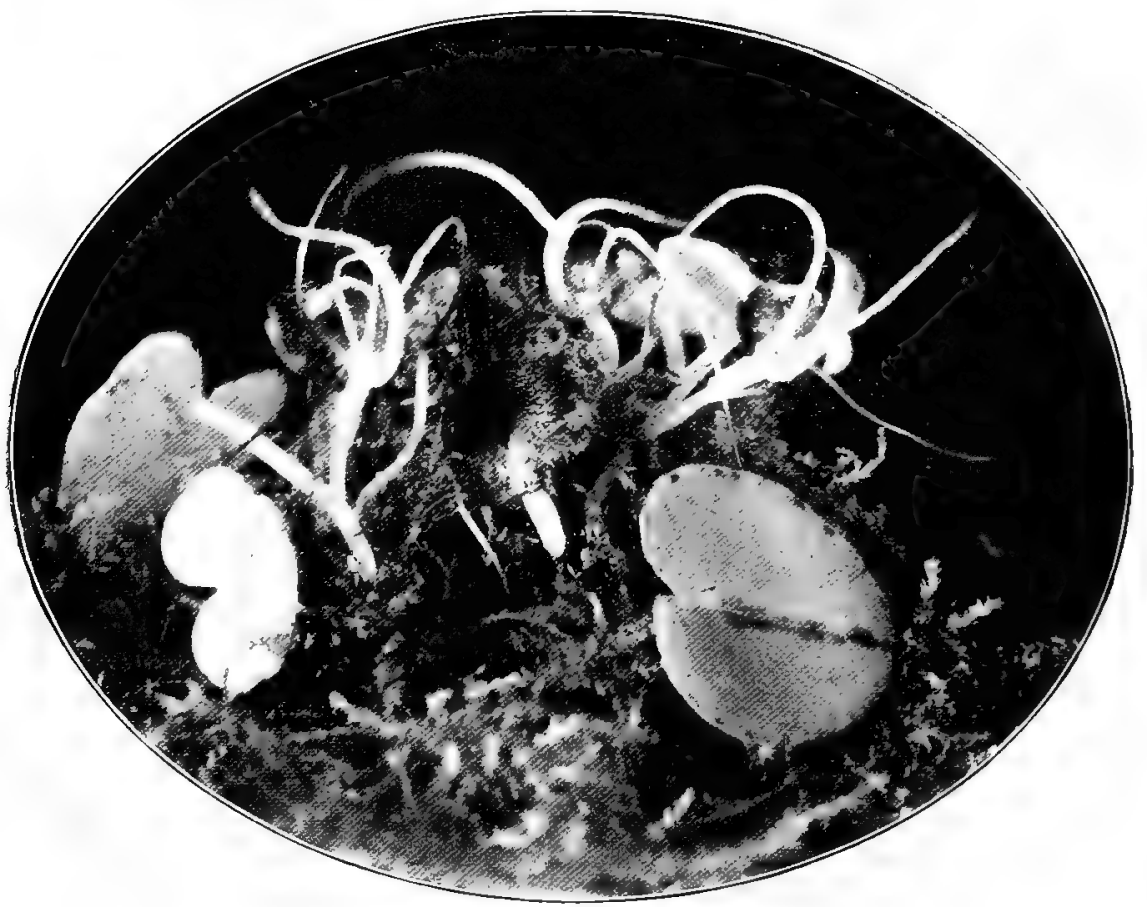

Fig. 35. Corysanthes macrantha (2 nat. size).

Pterostylis Banksii (Banks' Pterostylis).

A tall, slender herb, with numerous alternate leaves, and solitary, hoodshaped green flowers, striped with white. Stem 6in.-18in. high; flower 2 in.-3in. long. P. graminea is very similar to P. Banksii. Both islands. Fl. Oct.-Jan.

\section{Genus Thelymitra.}

Erect, tuberous-rooted herbs. Leaves 1 or 2, narrow, with a membranous sheath below. Flowers in a short spike, blue, purple, or yellow. Column hooded. Pollen masses 4. A large genus, found only in Australia, Tasmania, New Zealand, and the mountains of Java. (Name from the Greek, in allusion to the hooded column capping the anther). $8 \mathrm{sp}$. 
Thelymitra longifolia (The Long-leaved Thelymitra).

A variable plant. Leaves $\frac{1}{6}$ in.-lin. broad, leathery. Spike $2-10$ flowered. Flowers $\frac{1}{4}$ in.-3in. broad, blue or purple.

Thelymitra pulchella (The Pretty Thelymitra) is a large-flowered species; T. Colensoi (Colenso's Thelymitra) and T. imberbis (The Beardless Thelymitra) have yellow flowers.

\section{Genus Orthoceras.}

Erect, glabrous herbs, 10in.-12in. high, with tuberous roots, and radical, grassy leaves. Upper sepal hooded; lateral sepals lengthened into long tails, erect. Pollen masses 2. (Name from the Greek, signifying a straight hom $n$ ), $1 \mathrm{sp}$.

\section{Orthoceras Solandri (Solander's Orthoceras).}

Leaves very narrow, with sheathing bases. Flower-spike 2in.-6in. long. Bracts large, boat-shaped, greenish-brown. Flower $\frac{1}{2}$ in. long, livid purple. Lateral sepals $\frac{1}{2}$ in. -1 inin. long. Lip drooping, with yellow stripe. Abundant on clay hills in the North Island. Also found in Nelson.

\section{Piperaceae.}

\section{The Pepper Familix.}

Distribution.-The pepper plants are mostly natives of tropical or subtropical regions. The structure of the wood is anomalous, but it is too complicated for description here. The Piperaceae are noted for their pungent leaves. Piper nigrm, the pepper-vine, produces our table pepper. This plant bears spikes of red fruits, which, when dried by heat, become black and shrivelled. These are known as peppercorns, and are ground into powder, forming Black Pepper. White Pepper is obtained from the same fruit macerated in water. The Kawa of the South Sea Islands is a member of this family, and is closely related to the New Zealand Piper excelsum.

\section{Genus Peperomia.}

A large genus of 400 species, with two representatives in New Zealand. Stems and leaves fleshy, bright green. Flowers in erect catkins. Stamens 2. Ovary sessile; stigma sessile; berry sessile. (Name from its affinity to the Pepper). 


\section{Peperomia Urvilleana (D'Urville's Peperomia).}

A juicy creeping herb, 4in.-10in. high. Leaves alternate, $\frac{1}{2}$ in.-1in. long,

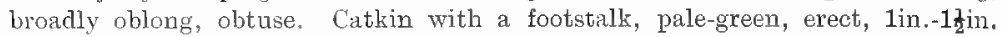
long. North Islaud: wet rocks, mossy stumps, etc. Kermadec Island, Norfolk Island. Fl. March-April.

\section{Genus Piper.}

A large tropical genus of climbing shrubs or small trees. Leaves alternate. Flowers in erect, solitary, or twin catkins, axillary, green. Stamens 2. Ovary sessile; stigmas $2-5$.

\section{Macropiper excelsum (The Lofty Pepper).}

A small tree, sometimes 20ft. in height, shining, aromatic. Leaves heartshaped, Bin.-5in. long, pointed at the tip, 5-7 nerved at the base. Leaf-stalks winged at the base. Catkins slender, Iin.-4in. long. Fruit a yellow berry. Both islands as far sonth as Banks Peninsula. Kermadec Islands. Fl. Oct.Nov. Maori name Kawakawa.

A decoction of the leaves is used by the natives to allay toothache, to cure rheumatic pains, and also to reduce swellings or inflammation of any kind. The wet leaves and twigs slowly burned produce a bitter smoke, said to be fatal to insect life.

\section{Fagaceae.}

\section{The Chief Features of the Family.}

The flowers of the order are small and inconspicuous, and as they are adapted to wind pollination, have no special devices for attracting insects. Stamens and pistil are found on the same plint, but in different flowers. The male flowers are generally borne in catkins.

Distribution.--No older family of dicotyledonous trees than this is known. It includes the birch, alder, hazel, hombeam, beech, oak, and chestnut. Closely allied to these are the willow, poplar, and walnut. The earliest oaks come from the Cretaceous, and were coeval with the first undoubted dicotyledons. The method by which the pollen tube reaches the embryo sac in some plants of the order is of a highly archaic type, known elsewhere only anong the primitive Casuariniae (she-oaks, etc.) of Australia. If antiquity, then, were a claim to representation in the New Zealand forests, this family should be conspicuous by the number of its species. It is, however, represented here only by some 


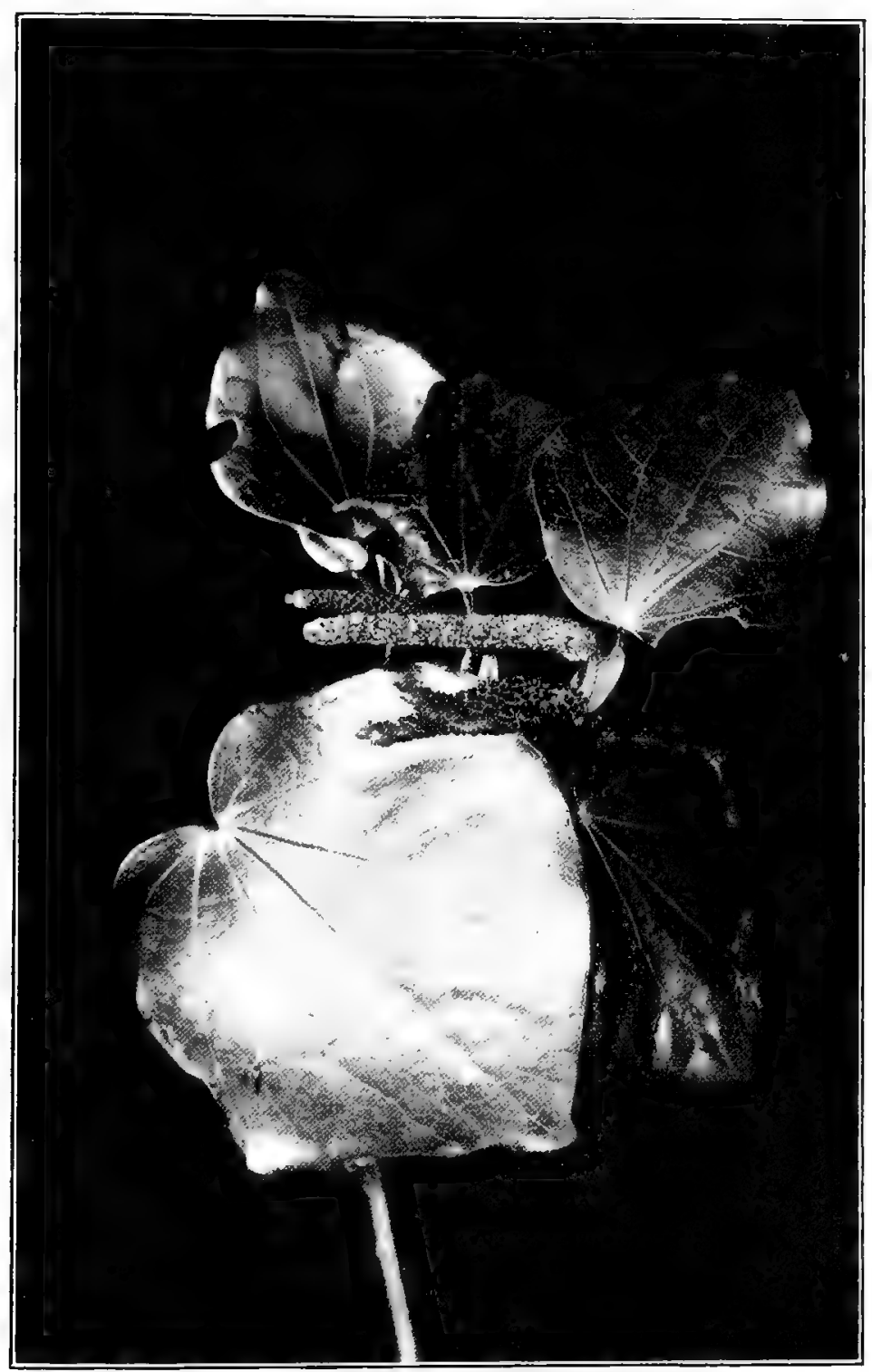

Fig. 36. Macropiper excelsum (? nat. size). 
half-dozen species belonging to the southern genus Nothofagus, which is found also in South America and Australia. In the northem hemisphere on the other hand, the family is very liargely developed, and includes most of the important deciduons trees of North America and the Eurasian Continent. The forests, therefore, of the north temperate zone are really of older type than those of south temperate regions.

In South America, however, Nothofagus in many places forms as large a component of the flora as in New Zealand, Darwin's description, in "The Vorage of a Naturalist," of the forests of Tierra del Fuego, night well have been written of some bush creek in south-western Otago. Replace Fagus betuloides by a local species, and the Winter's Bark by the closely allied Drimys axillaris, and the picture is now completely true for New Zealand.

Probably nowhere else in the southern hemisphere could one find two such similar forests, sundered by an ocean one-third of the circumference of the earth in width.

\section{The BeEch Forest.}

The beech is a most attractive tree, whether growing in countless hosts, or in solitary state. When scattered over a plain, such as the valley of the Upper Hutt, it gives the landscape a spacious and park-like aspect. It is equally as handsome, when it covers the folds of some giant alp with a garment of uniform thickness and changeless hue. Perhaps the beech forest is most beartiful when its depths are illuminated by the rays of sunset.

It often happens in Canterbury, during a north-west gale, that just before nightfall the sun drops below the heavy curtain of clouds into the clear arch of sky below, and "at evening it is light." As the level beams are thrown into the recesses of some sombre bush-clad ravine in the foot-hills, the sight is one to be remembered for a lifetime. Though quite natural, it seems, from the vividness of its spectacular effects, unnatural. The giant limbs of the trees push forth on all sides with lance-like thrust, and the inter-spaces between their wide-spreading horizontal branches, form pathways, by which the shafted light can penetrate far into the bush. The great halls of greenery are revealed in vista after vista, and in the background are seen the brown, dead leaves, that "lag the forest brook along," for in these drier districts there is little 


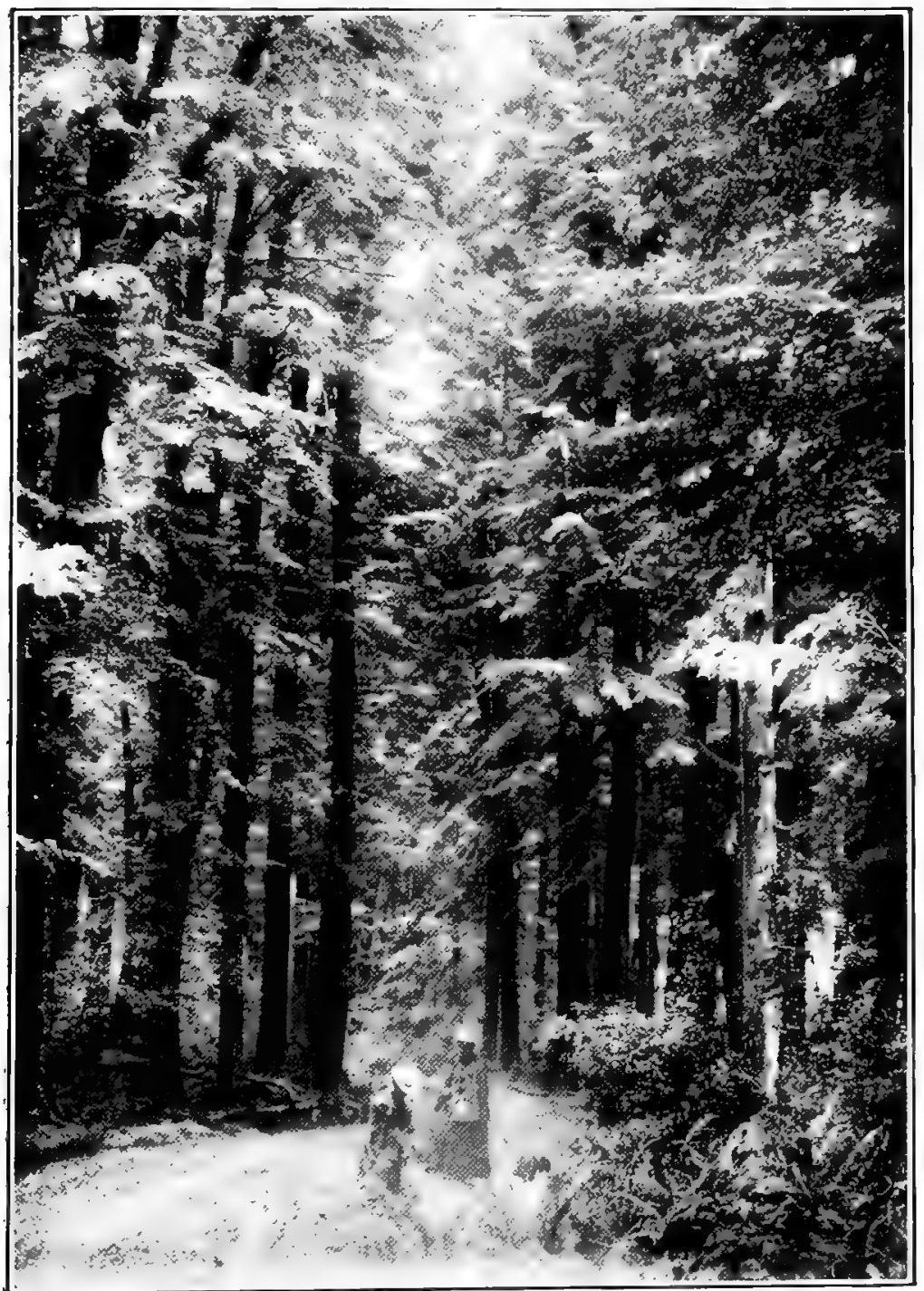

In the Beech Forest 
undergrowth. Over the countless green mosaics of the living branches, with their two-ranked twigs and leaves, the evening sunshine passes, and stirs into activity all the life within, at the same time throwing into relief the infinite detail of tracery and arabesque in bough and bole. The bearded lichens trailing from the branches are almost motionless, though the wind thunders overhead. One side of the valley is in the dimmest twilight, whilst on the other every shoot flares out in almost garish distinctness. The contrast is a violent one; but it is soon gone, and only the rosy colours of the clouds above remain to break the darkness. With sunset the north-wester always lulls for a short time, and then its roar gives place to the coo-ee of the weka and the melancholy cry of the owl.

\section{Distribution of the New Zealand Species.}

The genus Nothofagus has some half-dozen representatives in New Zealand, all forest trees known to bushmen as "birch," but more correctly termed beech. It is now futile to hope that. the more exact name will become popular ; but we might at least. expect some consistent nomenclature to be adopted through the islands. At present the various species are designated almost indifferently, white, red, black, silver birch, etc. What is the white birch in one part of the country may be the black in another. Mr. T. Kirk proposed a set of names, which might well replace the confused series now in use. Indeed, the same authority tells us that "it is not too much to say that the blundering use of common names in connection. with the New Zealand beeches, when the timber has been cmployed in bridges and constructive works, has caused waste and loss to the value of thousands of pounds." The use of the name birch in place of beech is, perhaps, somewhat excusable, as both $N$. Menziesii of New Zealand and $N$. betuloides of South America show some external resemblance to the English birch. 
Unlike most of the other New Zealand trees, the beeches form great forests in which few other plants are to be found. Ordinarily, the bush is extremely varied. Sometimes as many as forty or fifty species of trees and shrubs can be found in an acre of ground, - a greater variety than exists in the whole of the British Isles. In Europe, on the contrary, one or two species of trees generally constitute the greater part of the forest. Amongst these, the beech may be mentioned as a dominant form. Fossil evidence seems to show that the oak in many places has given way to it. We know too little of the past history of New Zealand, to enable us to determine if the beech forests are on the increase or decrease here. Dr. Cockayne considers that their distribution tends to show that they are decreasing. This may be so, but beech forests that have been cut out, if left undisturbed by man and animals, will soon replace themselves. Other forest-forming trees do not do this. The kauri, at least, is decadent, and the white pine forests are largely confined to swamps, which often dry up on the felling of the bush. Whereas the beeches are found both in wet and dry lands; though they seem to prefer the drier slopes of the mountains.

$N$. cliffortioides is a sub-alpine species only coming down to sea-level in south-western Otago. N. Menziesii is found at similar levels from Hauraki Gulf southward. N. Solandri is perhaps the most abundant of our beeches, and forms inmense forests, particularly in drier situations, throughout the islands as far north as the East Cape. On the dry eastern slopes of the Canterbury ranges there is little else to be found in the forests. $N$. fusca is more sparsely distributed throughout the islands, being found in wetter situations. It is rarer in Canterbury Province than in any other, though found in small quantity on Banks Peninsula. One remarkable feature in connection with the distribution of the beeches, is their total absence from Stewart Island. This is quite inexplicable 
at present. It can scarcely be thought that they have never existed there. Possibly they have been displaced.

\section{Genus Nothofagus.}

Shruls or trees. Leaves leathery, stipules deciduous. Miale flowers several. Perianth bell-shaped, 5-6-lobed. Stamens, 8-12, inserted round a central disk. Female catkins usually erect; flowers, 2-4, sessile, with an involucre formed of small sciles. Ovary, 3-celled; cells, 1-ovuled. Fruit consisting of from 2-4 angular nuts enclosed in a prickly 4-valved involucre. (Name, signifying the Southern Beech).

\section{N. Menziesii (Menzies'Beech).}

A large tree, 80ft.-100ft. in height, with silvery bark. Young shoots clothed with brown hairs. Leaves shining, dark green, $\frac{1}{2}$ in. long, ovate or rounded, obtnse, crenate. Fruiting involncre downy, fin.-1in. long, with soft spines, glandular at the tips. Nuts downy, 2-3-winged; wings sharp, pointed. North Island: Ruahine Mountains and Waikare Lake; South Island: from Nelson to Dusky Bay. The *Silver Birch or Red Birch. Fl. Nov.-March.

\section{N. fusca (The Duskil Beech).}

Trumk 80ft.-100ft. in height, sonetimes 12ft. in diameter. Branches downy. Leaves 1iu.-1i․ long, oblong-ovate, serrate. Male flowers 1-3; perianth 5-toothed. Fruiting involucre ovate. Nuts winged; wings toothed. North Island: mountainous districts; South Island: abundant. The ${ }^{*}$ Black Birch or Iied Lirch.

\section{N. Solandri (Solander's Beech).}

Trunk 100ft. in height, 4ft. $5 \mathrm{ft}$. in diameter. Bark white in young trees, black in old. Young shoots very downy. Leaves $\frac{1}{4}$ in.-3in. long, oblong, obtuse, entire, oblique at the base, white below. Male flowers solitary; perianth broad. Fruiting involucre, hairy or shining, fin, long; segments with scales entire or toothed. North Island: mountain forests; South Island : alt. 3,000ft.-6,000ft. The ${ }^{*}$ White Birch. F1. Nov.-Jan.

\section{N. cliffortioides (The Cliffortiu-like Beech).}

A small tree, with leaves rounded or cordate at the base, in other respects resembling N. Solandri. North Island: Ruahine Mountains; South Island: Alps of Nelison and (anterbury. (Cliffortia is a genus of the Rosaceae.) The * Henentrain Lirch.

"Tleme nawes are common but unreliable. 


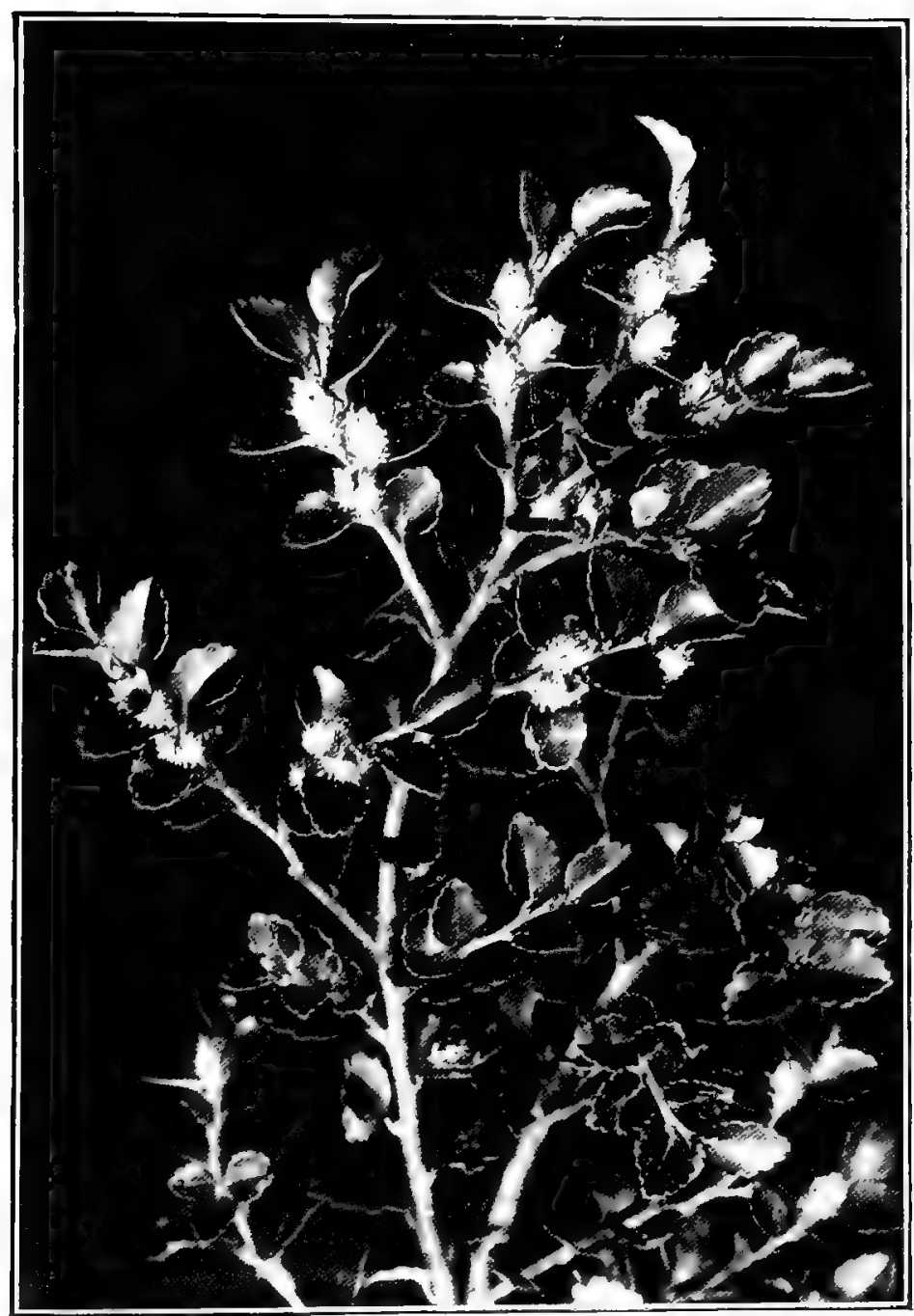

Fig. 38. Nothofagns Menziesii. Flower and leaf (3 nat, size). 


\section{Urticaceae.}

\section{The Nettle Family.}

Distribution.-A family of under 500 species found in almost every part of the globe. The Nettles are the best-known plants belonging to it. The stamens are bent down in the bud and often explode when ripe. Some of the specios yield remarkably tenacious fibres, which are used in cordage. (Name from the Latin, signifying to bum, from the burning, stinging sensation caused by the hairs of the nettles.)

Fey to the Genera.

1. Tree, juice milky, Male flowers spiked.

Shrubs or herbs, juice watery.

Paratrophis, p. 136. 2

Urtica, p. 136.

Leaves without stinging hairs. Flowers in cyures or clusters.

3. Shrubs, Leaves entire. Stamens, 4.

Herlos.

4. Hexlus, leaves crenate. Stamen 1.

Parietaria, p. 138

4

+Australina.

Herbs, with red brown leaves. Flowers in a fleshy receptacle. Elatostema, p. 138.

Not further described.

\section{Genus Paratrophis.}

Shrubs or trees. Leaves alternate, hard, evergreen. Flowers in spikes or catkins, diøecious. Perianth of \pm leaflets. Ovary, ovoid; styles, 2. Fruit a nut or drupe, 1-seeded. A small genus, chiefly tropical. $3 \mathrm{sp}$.

\section{Paratrophis microphyllus (The Small-leaved Paratrophis).}

Tree, sometimes $30-40 \mathrm{ft}$. in height. If a slit be cut in the bark of this tree, a thick, sweet, milky juice will flow from it. Leaves $\frac{1}{2}$ in.-2 in. long, oblong, toothed. Male flowers in catkins, $\frac{1}{2}$ in. $-\frac{s}{x}$ in. long; female in short spikes or clusters, whitish green. Drupe, red. Both islands. The Milk-tree of the settlers. Fl. Oct.-Nov.

\section{Genus Urtica.}

Herbs or shrubs, with stinging hairs. Leaves, opposite; flowers in axillary clusters or spikes. Calyx of male flowers 4-partite, stamens 4. Calyx of female flowers 2 or unequally 4-partite; stigma tufted. Ovary, ovoid. Ovule, erect. Fruit a small dry nut. About 30 species, natives of tropical and temperate regions. $4 \mathrm{sp}$.

\section{Urtica ferox (The Fierce Nettle).}

A tall shrub; stem woody; stinging hairs rigid, $\frac{1}{8}$ in.-1 in. long. Leaves $2 \mathrm{in} .5 \mathrm{in}$. long, variable in shape, coarsely serrate teeth ending in a hard bristle. Leaf-stalks also covered with stinging hairs. Flowers in racemes. Both islands. Fl. Jan.-March. Maori name Onga-ongr. 


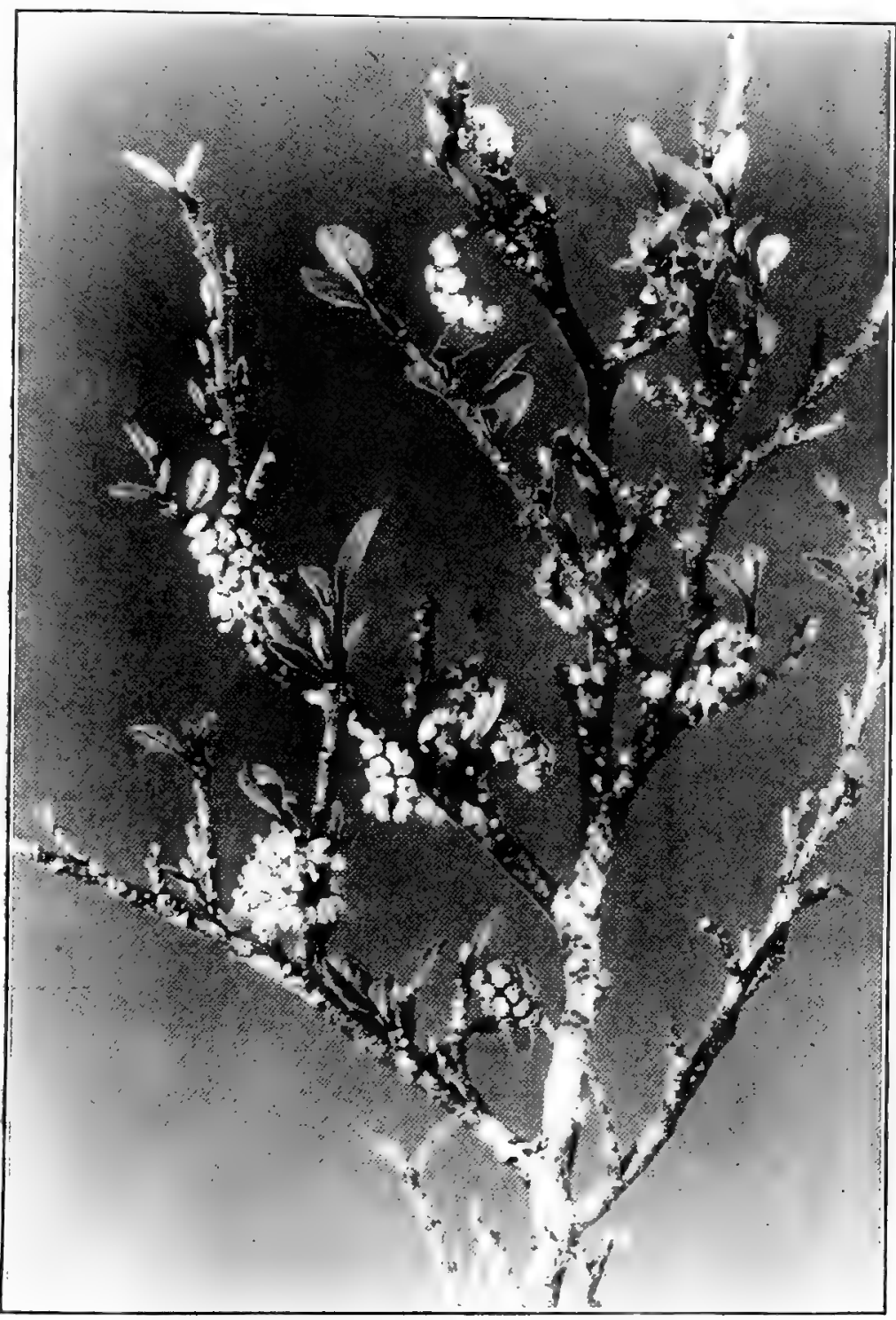

Fig 39. Paratrophis microphyllus (about nat. size). 
The stinging sensation produced by this plant will sometimes last for three or four days.

\section{Genus Parietaria}

Woak herbs, rarely small shrubs. Leaves entire, opposite, often downy. Flowers in axillary eymes. Male flowers with 4-partite perianth. Stamens, 4. Female flowers tubnlan: perianth, 4-partite. Ovary ovoid; ovule erect. Nut minute. A small but widely distributed genus; found in waste places. The Pellitory is a well-known English plint of the genus. (Ancient Latin name referring to the growth of some species on walls). $1 \mathrm{sp}$.

Parietaria debilis. (The Weak-stemmed Parietaria).

Slender annual. Stem, 6 in.-24 in. long. Leaves, $\frac{1}{4} \mathrm{in.}-2 \mathrm{in}$. long, ovate, acute. Female flowers in dense clusters. Both iskands, common. Fl. Nor,-Dec.

\section{Genus Elatostema.}

Succulent herbs, rarely shrubs. Leaves unequal-sided, bronzed or brownred. Flowers often inconspicuous, surrounded by fleshy involucres. Male flower with a perianth of 2 or 4 pointed leaflets. Female flowers with a small, imperfect perianth. Fruit a small compressed nut. A large tropical genus. 1 sp.

\section{Elatostema rugosa. (The Wrinkled Elatostema).}

A robust herb, shining or downy. Stem, $1 \mathrm{ft}$ - $2 \mathrm{ft}$. in height. Leaves, $4 \mathrm{in.}-10 \mathrm{in}$. long, alternate, sessile, acute, toothed, auricled at the base. Flowers, diœcious. Male flowers, with fleshy receptacles $\frac{1}{2}$ in. across, surrounded by bracts. Female flowers with smaller, more hairy receptacles. North Island: dimp bush, or by the sides of creelis.

\section{Loranthaceae.}

\section{The Mistletoe Family.}

Distribution.-The plants of the Mistletoe Family belong chiefly to the hottcr parts of Asia and America, though a few are found in Europe, Africa, and New Zealand. In the genus Loranthus, a cup-like expansion of the flower-stalls just below the perianth is considered by some botanists to be a calyx, and the $4-8$ loben of the porianth are regarded as petals. The members of this family are all partially parasitic, and grow on trees and shrubs.

A plant, which can get the whole or part of its carbonaceous food by robbing another, will require either no 
leaves, or leaves considerably reduced in size. Hence it is that many parasitic plants have a very much reduced stem structure and leaf area. In some of them little more than a flower is developed, cf. Cuscuta, Cassytha, Dactylanthus. Since parasites do not grow like other plants in the soil, but send out processes which penetrate into the woody tissues of their hosts, their method of germination is often quite abnormal. Very frequently also the seed leaves are poorly developed or altogether wanting, and the parts of the embryo are but little differentiated. (Contrast Avicennia.)

New Zealand is very rich as compared with Great Britain in woody parasites. In England there is only one such plant, the Mistletoe (Viscum album). It grows commonly on softwooded trees such as the poplar, silver fir, and apple. It. rarely attacks the oak, and when it did so it was an object of worship to the Druids of early Britain.

Key to the Genera.

1. Leaves 0. , branches jointed, Hattened. Leaves present.

Viscum, p. 144.

2

2. Leaves opposite. Flowers hermaluhodite,

Lorantbus, p. 139

Leaves op posite and alternate, flowers dicecions. Tupeia, p. 144.

\section{Genus Loranthus.}

An extremely interesting genus of about 200 species, all the members of which are semi-parasitic shrubs. Flowers solitary or in racemes. Calyx cupshaped, more or less toothed. Corolla tubular, petals 4 , free or united below. Stamens 4, inserted on the petals. Style slender, deciduous. $6 \mathrm{sp}$.

The genus Loranthus is widely distributed throughout tropical and sub-tropical regions, and some of the species produce handsome and brilliant flower's in great abundance. The finest of the New Zealand forms is L. tetrapetalus. It is found most frequently upon Nothofagus Solandri. No finer floral display can be seen in New Zealand than a gloomy forest of Fagus trees lit up by immense masses of scarlet Loranthus flowers, glowing like jewels among the dark green leaves of the beech. It is seen, perhaps, at its best when one rows up 
some sluggish lowland stream such as the Turakino, through beech forest, whose boughs, brilliant with Loranthus blossom, meet overhead. Tourists are very apt to mistake this plant for the rata. L. Fieldii* is perhaps as fine, but it is little known. It grows in the beech forests to the south and west of Ruapehu. Mr. Field says of it, "The Loranthus forms large bushes in the tops of the trees, and the blossoms are so abundant as almost to hide the foliage, so that each bush, when in flower, looks like a flame. I believe the largest bushes are quite ten feet in diameter, and those of six feet are common. As the blossons fall, the whole ground is sprinkled with petals. They are yellow at their bases, but shade gradually, through orange and scarlet, to crimson, and even carmine at the tips."

The flowers of this species open in a curious fashion, for which at present no explanation is forthcoming. A few open outwards from the apex in a normal way; but in most of them the petals become detached at their bases, and roll upwards and outwards (c.f. Knightia excelsa.) Their weight drags the stamens downwards, and these finally break off and fall to the ground, with the petals still attached to them. We have probably here some curious and unexplained device to secure cross-pollination; but the description given by Mr. Field is obscure at one or two points, and, as in a conjuror's trick, the facts which have not been observed, are probably the facts necessary for a solution of the problem.

$L$. micranthus is the species that is most abundant in the lowland forests. It is almost everywhere common in any piece of "bush" on the East Coast, from the Bay of Islands southwards. It has many different hosts, and is sometimes found in unexpected places. It has been obtained upon totara, Carmichaelia, Coprosma, and even upon Rubus (the bush lawyer). It also flourishes upon many introduced plants. Mr. Potts noticed it upon the plum, pear, Abutilon,

"Trans, XVII., p. 288. 
white-thorn, pink-thorn, peach, and laburmum, at Ohinitahi (Lyttelton). At Akaroa it grows abundantly, and flourishes upon the false-acacia (Robinia). The great variety of its habitats probably shows that the plant is not very dependent on its hosts for nourishment. Indeed, its mass of green, glabrous, glossy leaves look as if they could easily sustain it. Obviously, when growing on the Robinia, it must, like the English Mistletoe, sustain itself during the winter, as the false acacia is decidnous.

The means by which the New Zealand species obtain their nourishment, and their methods of germination, have not been closely observed. Mr. Potts ("Out in the Open," p. 136) has however, described with some detail the early stages in the growth of $L$. micranthus. The berries of all loranths are extremely attractive to birds. In the case of $L$. micranthus, as they ripen they become whitish, or slightly roseate, and finally assume a rich golden-yellow hue. As soon as they are ripe they are greedily eaten. Before the introduction of foreign birds, they were probably eaten by the tui and the bell-bird; now it is the blackbird and thrush that feed upon them. The seeds pass through the digestive canal of the bird, and are glued by its slimy excrement to the branches of trees. In some cases, doubtless, the viscid pulp of the berries themselves enables the seeds to adhere to the branches of the tree, so that it is not absolutely necessary that they should be eaten. "In the first stage towards development," says Mr. Potts, "the adherent seed may be seen lying on the fostering spray, quite firmly fixed, covered over with a strong coating of transparent varnish; the indication of the future growth, a smooth green speck at the large end of the seed." For some time no feeding stems are put forth. Long branches somewhat resembling rhizomes of a polypodium are then produced, and follow the course of the branch of the host, sometimes even descending the trunk of the main tree. Where these sterns cross each other they inosculate. At different points 
they send out suckers into the tree, and at these points, rounded woody lumps are formed, invested with dark-brown imembranous scales. The earlier leaves of the plant are strongly tinged with reddish purple, some are of a pale bronze wargined with claret, and the branches are of a rich warm brown. Some years elapse before the plants assume the darker shades of green.

$L$. Fieldii often puts out short rootlets which clasp the branch, and frequently grows on branches smaller than itself. "Thus," Field (loc. cit.), "one with roots from one to one and a half inches thick will grow on a branch no thicker than a man's little finger, which, of course, bends down with its weight, so that the Loranthus swings about with every breath of air." Yet it is evident that the plant is nourished by the beech tree, for, if the beech is killed, the Loranthus invariably dies with it.

There are many points of interest known with regard to the development of European species of Loranthus, and a closer investigation of New Zealand forms will undoubtedly well repay the labour spent upon it.

\section{Loranthus Colensoi (Colenso's Mistletoe).}

A large glabrous shrub. Leaves $1 \frac{1}{2}$ in.-2 in. long, broadly oblong or obovate, with a short stout petiole. Flowers $1 !$ in.-2 in. long, scarlet, in pairs, on a short, stout, 3-9-flowered peduncle. Both islands. Fl. Dec.-Jan.

L. Freldzi is a little-known somewhat similar species from the centre of the North Island.

\section{Loranthus tetrapetalus (The Four-petaled Nistletoe).}

A much branched rigid shrub. Leaves decussate, $\frac{7}{2}$ in.-3in. long, ovate or elliptic. Flowers axillary, in opposite 2 -4-flowered racemes. Petals free, scarlet, recurved at the tips. Both iskands. Common on Nothofagus Solandri. Fil. Jinl,-Feb.

\section{Loranthus flavidus (The Yellow Nistletoe).}

Leaves 1 in.-2 in. long. Racemes drooping, 10-12 flowered. Flower yellow, $\frac{1}{2}$ in. long. Both islands. 


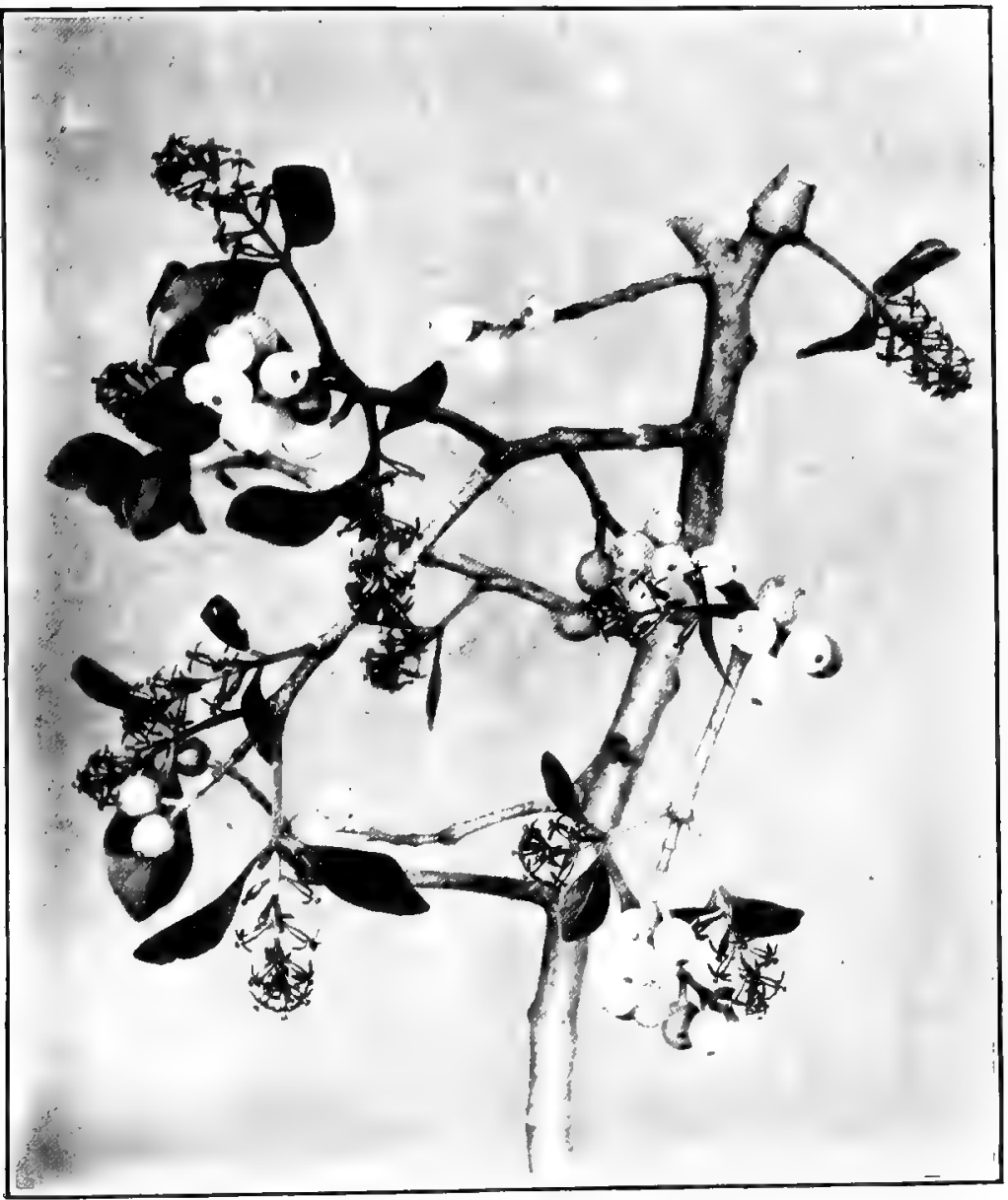

Fig. 40. Tupeia antaretica (pistillate flowers and beries) (2 na.t. size.) 
Loranthus micranthus (The Small-flowered Mistletoe).

Leaves $1 \frac{1}{2}$ in.-3 in. long, obovate or oblong. Flowers minute, green, $\frac{1}{8}$ in. long. Abundant throughout the islands. Fl. Oct.-Nov.

\section{Genus Viscum.}

Parasitical shrubs. The New Zealand species are leafless, small, with flattened, jointed branches, much constricted at the joints. Flowers very minute, unisexual, in spikes, or solitary, or whorled at the joints of the branches. Male flower : perianth 3-or 4-leaved, anthers sessile on the perianth lobes; female flower: perianth 3 - or 4-lobed. Style 0 or short, stigma obtuse. Name from the Greek. $2 \mathrm{sp.}$

To this genus belongs the Mistletoe. Round it clings many a imyth from old Keltic and Teutonic times. The New Zealand species, however, are insignificant, and seem to have been unnoticed by the Maoxis. Their mode of attachment to the host is quite unknown. The European mistletoe puts out a radicle which terminates in an attachment disk, that becomes cemented to the host. From the centre of this disk is pushed out a "sinker" into the tissues of the branch below. No further development takes place in the first year. Subsequently, there is developed an extremely complicated series of suckers, which may be compared to a rake in shape. The process is very intricate, but highly interesting.

\section{Viscum salicornioides (The Salicornia-like Mistletoe).}

A small plant, much branched, 3 in.-4 in. high. Joints $\frac{1}{3}$ in.- $-\frac{1}{2}$ in. long, rounded. Flowers very minute, solitary or few together. Perianth 3-lobed. Both islands, parasitic on various shrubs. Fl. Nov.-Jan.

\section{Viscum Lindsayi (Lindsay's Mistletoe).}

A small plant, 4 in. -6 in. high, branching, succulent. Joints of stem flat, rather longer than broad, $\frac{1}{24}$ in. broad. Flowers in spikes, $\frac{1}{4}$ in. long, very minute. Perianth 3-lobed. Parasitic on Coprosma, Metrosideros, Melicope, etc. South Tsland. Fl. Nov.-Jan.

\section{Genus Tupeia.}

Distribution.-An endemic genus of one species. It does not, like Lorrathus, send out rhizomes which fasten themselves at many points to the host, but has only one root. It is found parasitic on many different plants ; in the south, perhaps, most frequently upon Panax. In the north of Auckland, 
however, it is the tarata (Pittosporum eugenioides) which is attacked almost exclusively. Cases of double parasitism have been frequently observed in connection with Tupeia. Thus, in Riccarton Bush, Mr. J. B. Armstrong discovered Loranthus micranthus growing upon it. At Broken River, Mr. T. Kirk found Loranthus tetrapetalus growing on Nothofagus Solandri, and itself bearing $T$. antarctica.

The staminate flowers of Tupeia are found in panicles, in which the individual blossoms are not only more numerous, but larger in size than those on the pistillate panicles. Both forms are of a greenish yellow hue. The berries are beautiful and very varied in colour, ranging from white and pink to deep purple on the same branch. The flowers and leaves droop immediately the parasite is cut away from its host.

\section{Tupeia antarctica (The Antarctic Tupeia).}

Leaves $\frac{1}{2}$ in.-1! in. long, obovate, with short petioles, pale-green. Panicles 6-10 flowered. Flowers $\frac{1}{6}$ in. in diameter, greenish-yellow. Both islands. Fl. Oct.-Dec.

\section{Proteaceae.}

Distribution.-A remarkable family, found chiefly in Australia and the Cape of Good Hope. Many species are grown for their curious or brilliant flowers. The Australian Bottle-Brush (Banksia) is one of the most remarkable species. Lencodendron argenteum is the Silver-Tree of the Cape,

\section{Key to the Genera.}

A small tree. Leaves entire. Fruit a drupe. A lofty tree. Leaves serrate. Fruit dry.

\section{Persoonia,} linightia,

\section{Genus Kinightia.}

Slender, lofty trees. Leaves leathery, shining, serrate. Flowers in dense cone-shaped racemes. Perianth a club-shaped tube, the 4 segments finally separating and becoming revolute. Ovules 4. Follicle 1-celled. Seeds winged at the tip. A genus of two species, one of which is found in New Caledonia. (Named after Knight, a writer on vegetable physiology). 


\section{Knightia excelsa. (The Honey-suckle).}

A tree, sometimes reaching to the height of $100 \mathrm{ft}$. Leaves $4 \mathrm{in} .-8 \mathrm{in}$. long. stiff, roughly notched or toothed, obtuse, linear-oblong. Flowers in racemes, sessile, red, velvety, $2 \mathrm{in.}-3 \mathrm{in}$. long, $2 \mathrm{in}$. in diameter. Perianth $1 \mathrm{in} .-1 \frac{1}{2} \mathrm{in}$. long before expansion; $\frac{1}{12}$ in. diameter in the middle. Follicle woody. North Island and Pelorus sound. Fl. Nov.-Dec.. Maori name Rewa-rewa. It is sometimes called the Bucket-of-water-tree, because it is so slow of combustion.

This plant is related to the Australian bottle-brushes. It is found only in the North Island and Marlborough, and, from a distance, bears a considerable resemblance to the Lombardy poplar. Several points in the growth and development of the long tubular flowers are worthy of notice. The buds are set round a long floral axis, and the whole cluster has a strange appearance, like a bottle brush composed of red velvet. The gradual opening of these buds is very curious, and well worth watching. The top of the tube opens first, very slightly, so as to expose the tip of the style. It then splits open, for a short distance, into four separate segments at the base of the perianth, leaving the tube still for the most part closed. Finally, it bursts suddenly, and the four elastic segments thus set free, roll themselves downwards, and coil into spiral bands at the base of the perianth. The flower, now fully open, presents a strange, tangled appearance, very different from that of the bud.

The anther's, which are attached to the top of the perianth, and in contact with the style, mature their pollen, while the tube is still closed, and deposit it upon the swollen portion of the style. This would suggest a device for self-pollination, but a closer examination shows that it is, after all, an ingenious contrivance to provide for cross-pollination. The stignatic surface is minute, and depressed in a small cup at the top of the stigma. 'The flower is much visited by the tuis and bell-birds. These birds, pushing their beaks into a bunch of newly-opened flowers, receive the pollen upon the front of the head, and probably smear it over the stigmas of 


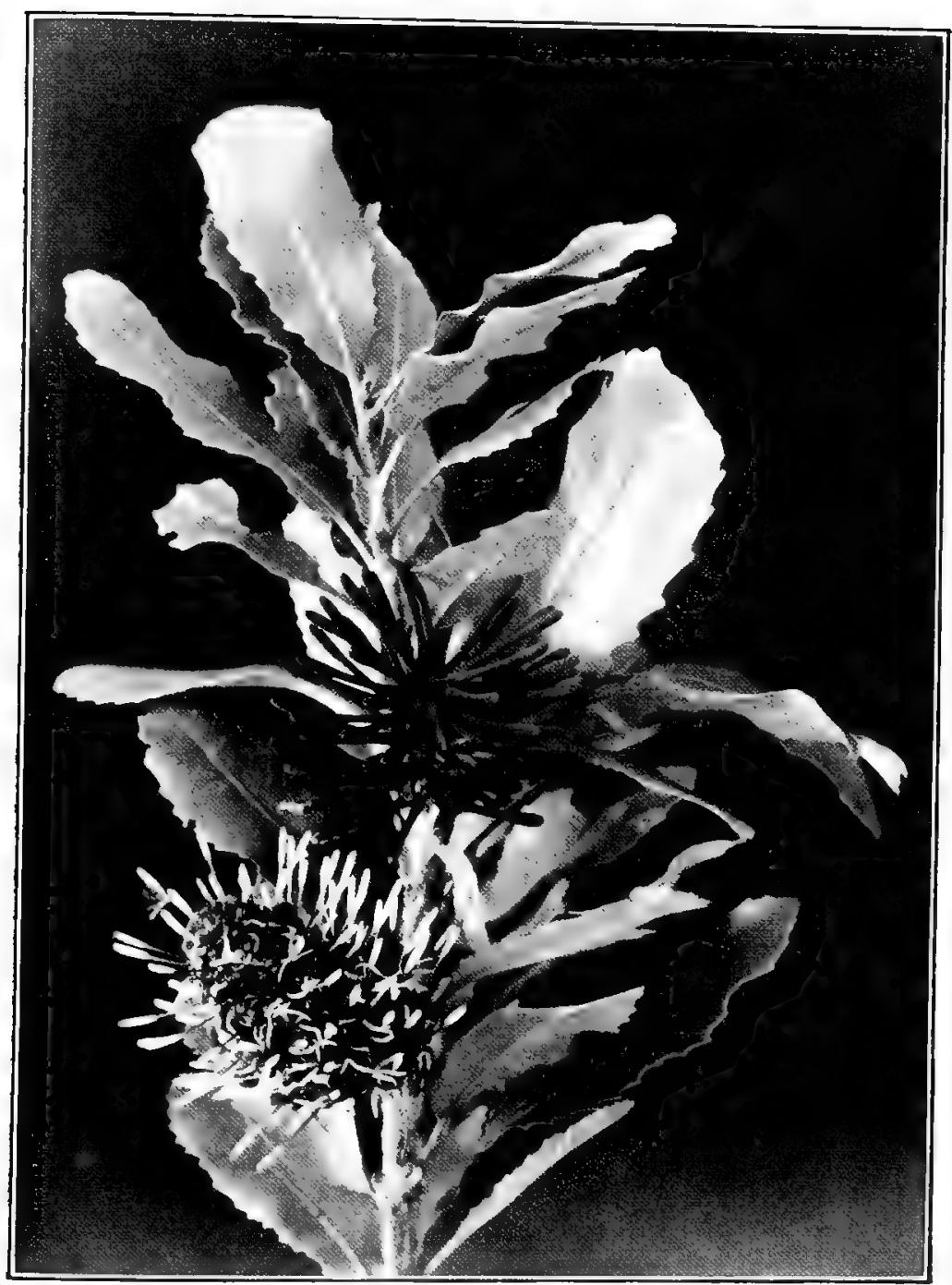

Fig. 41. Kniglitia excelsa (Bud and thower) ( nat. size). 
more fully developed clusters. The stigmas ripen later than the anthers, and there is consequently little likelihood of selfpollination. The opening of the flower, and its subsequent pollination, would afford excellent subjects of observation for a nature study class. The wood of this tree is much used for ornamental cabinet-work.

\section{Genus Persoonia.}

Shrubs or trees. Leaves alternate, leathery, variable. Flowers axillary, in short spikes or racemes. Perianth a club-shaped tube, opening by 4 segments. Ovules 1 or 2. Drupe with a 1 or 2-celled nut. A large Australian genus. (Name after Persoon, a botanist of Cape Colony). $1 \mathrm{sp}$.

\section{Persoonia toru. (The Torn or Toro).}

A small tree. Leaves narrow, 3 in. - 8 in. long, leathery, entire, polished on both surfaces. Flowers in axillary 6-10 flowered racemes, $1 \mathrm{in}$. long. Perianth $\frac{1}{4}$ in. long. Ovary sessile, shining. North Island: Auckland only. Fl, Oct.-Nov.

\section{Santalaceae.}

\section{The Sandal-wood Family.}

Distribution.-A widely distributed family. The species found in Europe and North America are herbaceous, while those inhabiting India, Australia, and New Zealand, are shrubby or arborescent. Santalum album, (The Sandal-wood), an Indian species, is much prized for the fragrance of its wood. The family is represented in New Zealand by two genera, each consisting of one species only.

\section{Genus Santalum}

Shrubs or trees. Leaves alternate or opposite. Flowers cymose, axillary, green. Perianth bell-shaped, composed of $4-5$ leaflets, hairy at the base. Stamens, 4-5. Disk, 4-5-lobed. Ovules, 2-4. Drupe, round, or shaped like a top, 1-seeded. An Asiatic, Australian, and Pacific Island genus.

\section{Santalum Cunninghamii. (Cunningham's Sandal-wood).}

A small tree, with variable leaves, opposite in young plants, alternate in mature trees, 2in. - 4in. long, dotted, veined. Flowers, $\frac{1}{5}$ in. - $\frac{1}{4} \mathrm{in}$. long, 4 - 5 lobed. Drupe, $\frac{1}{2}$ in. long. North Island : northwards from the east coast. 


\section{Balanophoraceae.}

A Family of Root Parasites.

Distribution.-A small family, chiefly tropical, of which Balanophora and Cynomorium are the principal genera. The latter was the Fungus Melitensis of the Crusaders. The New Zealand species is endemic.

\section{Life History.}

There is perhaps no more remarkable family of flowering plants than this. Its members are all root-parasites, and like all parasites, have become very much reduced in structure.

The life history of one of the Balanophoraceae is shortly as follows. The seed, which is very rudimentary, falls to the ground, and reaches a suitable root buried under the vegetable mould of the forest. It adheres to the root, and forms a little tubercle. The bark of the host is broken open, and an extraordinary series of developments takes place, that has as yet received no adequate explanation. The wood fibres of the host separate into a fan-like mass, and being diverted from their original course, pass up towards the parasite. This in its turn sends out cells and vessels, which penetrate between the ascending vascular bundles of the host; and, by the coalescence of the tissues of the two plants, an intermediate zone is formed, composed partly of the cells of each, though, in some still stranger cases, there are also developed cells whose origin cannot be definitely referred to either plant. This phenomenon somewhat resembles a natural grafting, but it is a grafting between plants of completely different types.

The tubercle now grows to the size of a fist, or larger, and short, thick, fleshy shoots are sent out from it. These do not develop true leaves, but in many cases produce scales, which surround the flower-heads. The flowers are either terminal or in spikes. The colouring of these flower shoots is often most remarkable. They are frequently fungoid in appearance. Indeed, early writers of the nineteenth century were so 
puzzled by their resemblance to fungi, that they considered them to be in sume fashion crosses between a fungus and a flowering plant. Such an idea, of course, appears ridiculous in the light of moder'n knowledge. Crosses or hybrids only occur between closely allied forms. The Balanophoraceae are true flowering plants, that have become highly specialized in order to maintain their existence. Although they mimic fungoid growths, they are no more closely related to the fungi than penguins are to fishes.

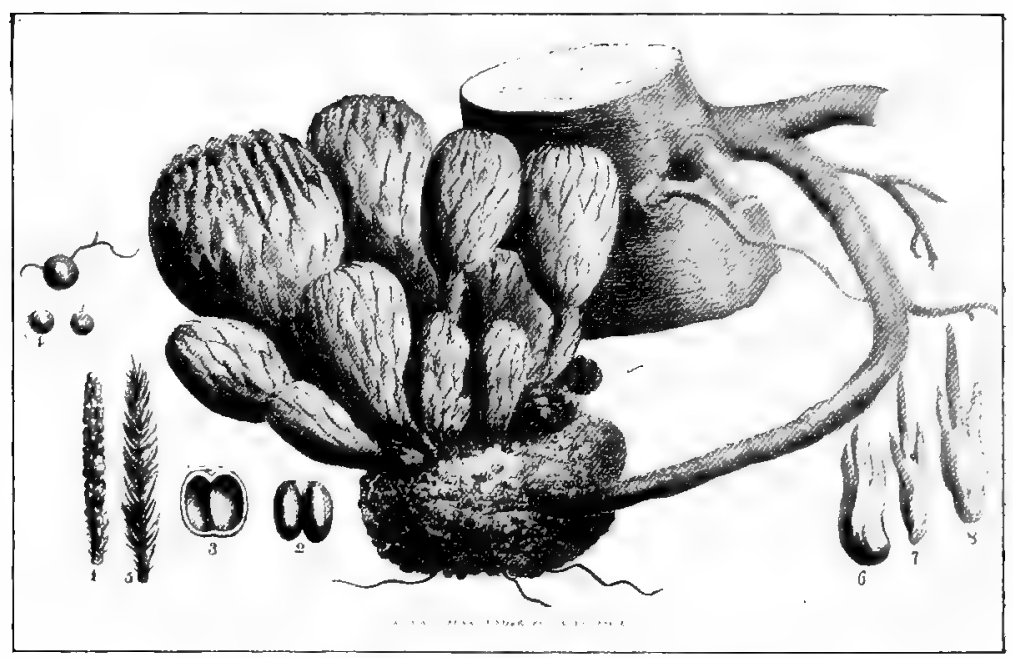

Fig. 42. Dactylanthus, from Taylor's New Zealand.

Dactylanthus Taylori (Taylor's Dactylanthus).

There is only one representative of the order in New Zealand, Dactylanthus. This solitary species forms a distinct tribe by itself. It was originally discovered in New Zealand by the Rev. R. Taylor in 1857, growing on roots of Pittosporum and Nothofagus, somewhere near the head waters of the Wanganui. Since then it has been met with on several occasions, in widely different parts of the North Island; but it is evidently not common. Mr. Taylor describes it as having an earthy and 
rather unpleasant smell". On the other hand Mr. Hill, who found it in the East Cape district, states that it was "the delicious daphne-like fragrance which it emitted," that first drew his attention to it. Our plant, indeed, is not one of the foul-smelling or fungoid forms, although the flowering stems are inconspicuous and of a dull-brown colour, and are clothed with overlapping fleshy scales. According to Taylor, the "petals of the flowers are slightly tinged with pink in the centre, but in general they are of a dirty white and brown colour."

By the Maoris the plant is called Pua-o-te-reinga (The flower of Hades). Why this term was applied to it, is not clear, but it seeus not inappropriate. It has been found on the roots of Scheffera digitata and Coprosma grandifolia, as well as on the roots of the plants already inentioned. Fusanus Cunninghamii and Euphrasia cuneata are also, it is believed, partly root parasites. (The name Dactylanthus is from the Greek, meaning Finger-flowered, in allusion to the finger-like spike).

\section{Polygonaceae.}

\section{The Buckwheat Family.}

Distribution.-A widely distributed family of plants, occurring both in arctic and tropical regions. The leaves and stems are usually acid or astringent, and frequently contain oxalic or malic acid. The Rhubarb, Sorrel, Dock, and Buckwheat are well-known members of this family.

Key to the Genera.

1. Flowers, unisexual. Flowers, hermaphrodite.

2. Stigmas, tufted. Stigmas capitate.
Múhlenbeckia, p. 152 2

Rumex, p. 152.

Polygonum 152.

*Rev. R. Taylor. New Zealand, and its Inhabitrnts, 1). 697. 


\section{Genus Polygomum.}

Very variable herbs, rarely shrubs, sometimes aquatic. Stipules often fringed. Flowers white or red, usually in spikes or racemes, sometimes axillary and solitary. Perianth 5-lobed; stamens usually 6-8. Ovary triangular. A large genus, of which the British species are known as knot-grass, bistort, etc. (Name from the Greek, meauing many knots, in allusion to the knotted stems). $3 \mathrm{sp.}$

\section{Polygonum aviculare. (The Common Knot-grass).}

Stem woody at the base. Branches hard, grooved, often prostrate, 6in. - 24in. long. Leaves $\frac{1}{2}$ in. $-1 \frac{1}{2} \mathrm{in}$. long, leathery, linear oblong; stipules silvery, ragged. Flowers small, axillary, 1-3. Nut triangular. Very common on waste ground, perhaps introduced. Fl. Dec.-March.

\section{Genus Mïhlenbectia.}

Shrubs, often climbing. Flowers usually spiked or panicled, sometimes axillary and solitary. Perianth 5-lobed, becoming fleshy in fruit, white. Stamens, 8. Ovary triangular in shape. Nut ovoid, black, enclosed in the white, fleshy perianth. A small genus found in South America, New Zealand and Australia. $4 \mathrm{sp.}$

\section{Mühlenbeckia adpressa. (The Close-fitting Mïhlenbeckia).}

A large rambling climber. Stem, twining, grooved. Leaves $\frac{1}{2}-i n$. 2 in. long, oblong or heart-shaped, 3-lobed in young plants. Flowers in spiked panicles, green, small. Stigmas, plumose. Nut black, enclosed in the white fleshy perianth. Both islands: common. Also in Norfolk Island, Australia and Tasmania. Fl. Nov.

\section{Mühlenbeckia complexa. (The Clasping Milhlenbeckia).}

Stems slender, creeping or climbing, interlacing, wiry, grooved. Leaves shining, $\frac{1}{4}$-inch - - Jinch long, rounded or heart-shaped. Flowers in spikes or panicles, few. Nut black, enclosed in the white fleshy perianth. Both islands. Fl. Nov.

\section{Mühlenbeckia axillaris. (The Axillary-Flowered Mïhlenbeckia).}

A small, variable species, with slender, tufted branches. Leaves small, shining, Trin. - lin. long, oblong, obtuse. Flowers axillary, solitary. Perianth fleshy in fruit. Both islands: chiefly in mountainous districts. Fl, Oct.-Nov.

\section{Genus Rumex.}

Herbs, rarely shrubby. Stipules ragged. Flowers in racomes or panicles, inconspicuous, green or reddish. Sepals, 6, the 3 inner enlarged. Styles 3. Fruit a triangular nut, covered by the three enlarged inner sepals. A large and widely distributed genus, to which belong the Docks and the Sorrels. 2 sp?. 


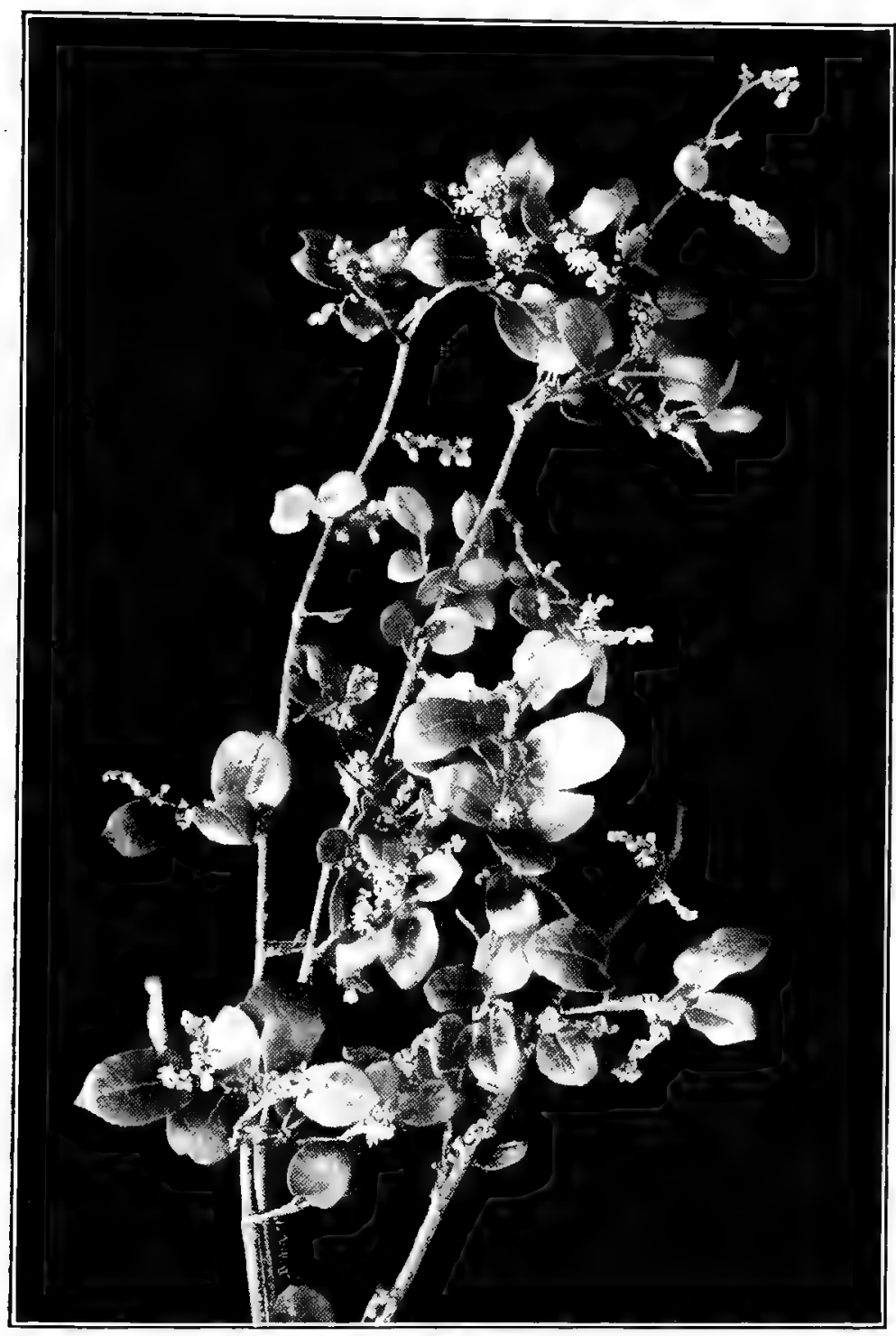

Fig. 43. Mühlenbeckia complexa $\left(\frac{1}{2}\right.$ nat, size $)$ 


\section{Rumex flexuosus. (The Tortuous Dock).}

A much branched herb, $1 \mathrm{ft}$ - $2 \mathrm{ft}$. long, prostrate, shining. Leaves 4 -in. - 8in. long, linear-oblong, sometimes waved at the margins. Flowers in distinet whorls. Lobes of perianth in fruit $\frac{1}{10} \mathrm{in}$. long, veined, sometimes with $1-4$ spines, keeled. Keel sometimes spiny. Both islands: common. Fl. Nov.March.

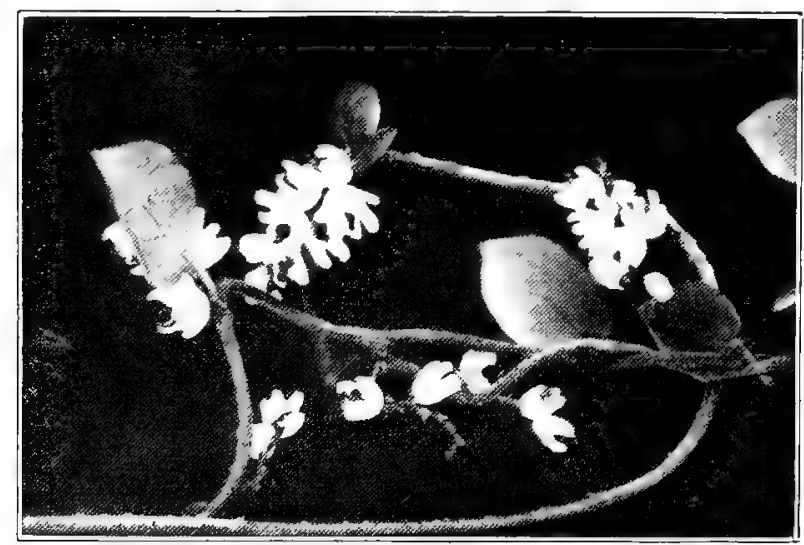

Fig. 44. Müblenbeckia axillaris. Fruit (life size).

\section{Chenopodiaceae.}

\section{The Beet Familt.}

Distribution. -A large family, distributed all over the world. Soda was at one time obtained from the ashes of those species which grow in salt marshes. Spinach (Spinacia) and beet (Beta) are used as table vegetables.

Sand-dunes, sea-marshes, deserts, and old lake bottoms are more or less impregnated with salts of sodium, calcium, magnesium, and potassium. Plants growing in such situations 
are termed halophytes, and it is in these localities that most of the chenopods are found. Wherever the ground, on drying, rapidly becomes encrusted with salt, there only halophytes can grow. Plants usually halophytic may, however, sometimes be found in soils that do not contain any specially large amount of alkaline constituents; but in such positions they often lose many of their chief characteristics.

\section{Key to the Genera.}

1. Stem leafless, cylindrical, jointed.

Stem leafy, not jointed.

2. Perianth without bracts.

Perianth with bracts, in the fewale Howers at least.

3. Perianth of male flowers without bracts.

Perianth of male towers bracteate.

4. Perianth fleshy in the fruit.

Periantb winged or keeled in the fxuit.

Salicornie, 1). 156 .

2

Chenopodium, 1. 155 .

3

tAtrijlex.

ISuaeda.

Salsola, 1). 155.

Not further described.

\section{Genus Chenopodium.}

Herbs, often covered with a mealy dust, composed of the bladder-like, readily separable cells of the hairs which cover the stems and leaves. Flowers 2-sexual, small, greenish. Perianth 3-5 partite. A large genus of way-side weeds, the fat-hens and goose-foots. (Name from the Greek signifying goose-foot). $7 \mathrm{sp}$.

\section{Chenopodium triandrum (The Triandrous Chcipopodium.)}

Stems 6 in.-12 in. high, much branched. Leaves $\frac{1}{4}$ in.- $\frac{2}{3}$ in. long, entire. Flowers minute, fascicled at the ends of the branches. Stamens 2-4. Both islands, Auckland to Otago. Fl. Nov.-Mar. This species appears to be endemic in New Zealand. The specific name "triandrum" implies that there are three free stamens.

\section{Genus Salsola.}

Herbs or shrubs, with fleshy, often prickly leaves, extremely saline. Flowers minute, axillary, 2-sexual. (Name from the Latin, signifying salt). $1 \mathrm{sp}$.

\section{Salsola australis (The Southern Salsola).}

A low woody shrub, $1 \mathrm{ft} .-2 \mathrm{ft}$. high. Leaves hard, sharp-pointed, ovate, $\frac{1}{6}$ in.- $\frac{1}{4}$ in. long. Flowers inconspicuous. Sepals and stamens usually 5. This. is, perhaps, the same as the northern Salsola kali, which, as its name implies, was at one time one of the chief sources of alkali. 


\section{Genus Salicornia.}

Succulent, jointed, leafless herbs. Flowers minute, 2-sexual, sumk in the joints of the stem. (Name from the Latin, signifying salt-hom). $1 \mathrm{sp}$.

\section{Salicornia indica (The Indian Salicornia).}

Stems prostrate. Branches ascending 6 in.-12 in. long. Joints variable in size, sometimes bright pink in colour. Branches terminating in cylindrical cones. Calyx fleshy. Stamens, 1 or 2. Fruit membranous. Both islands: stony or muddy beaches. Fl. Dec.-Feb.

\section{Caryophyllaceae.}

\section{FAmily of Pinks.}

Distribution.-A large family, distributed over cold and temperate regions. With the exception of the Pinks and Carnations, the flowers of the order are of little general interest. Many of them are British weeds, and a number of them have been introduced into the Colony. The juices possess no active properties except in the case of Saponaria, which contains the poisonous principle saponine.

\section{Key to the Genera.}

1. Sepals 4 or 5 , united or free. Sepals 2.

2. Sepals free or united only at the base. Calyx 5 toothed and nerved.

3. Petals 0. Petals present.

4. Stipules 0 . Stipules present, membranous.

( Not further described).
1

Hectorella. p. 158.

3

tGypsophila.

tColobanthins.

4

Stellaria. 1). 156.

tSpergularia.

\section{Gemus Stellaria.}

Usually weak, straggling herbs, with small white flowers, found in temperate and cold regions. Petals and sepals 4-5. Stamens 8-10. Of 80 species, 6 are endemic in New Zealand. Many others have become naturalized. The chickweeds, stitchworts, \&c., belong to this genus. (Name from the Latin, in allusion to the star-litie appearance of the flower).

\section{Stellaria Roughii (Rough's Chickweed).}

This is a very distinct species, found only in the alpine districts of the South Island. It is an erect, succulent herb, not more than four inches in height. Leaves $\frac{1}{2}$ in. $-\frac{7}{8}$ in. long. Flowers $\frac{1}{2}$ in. $-\frac{3}{x}$ in. across, terminal, solitary, green. I'etals smaller than the sepals. Seeds large, brown, hairy. 


\section{Flora of the Shingle Fans.}

The range of mountains known as the Southern Alps is a very ancient one, and comparatively dry on its eastern slopes. Consequently, there is not a sufficient amount of denudation to carry off to lower levels, the broken rock formed by the winter's frosts. Immense masses of detritus collect on the eastern flanks, forming in many places great shingle fans, which are thousands of feet in height. In these localities have been developed certain highly specialized plants not to be found elsewhere. One of these, Notothlaspi rosulatum, is elsewhere described at some length, others are Stellaria Roughii, Cotula atrata, Ligusticum carnosulum, Craspedia alpina, Lobelia Roughii. It is the first of these that we have now to deal with. It grows at an altitude of from 4,000 ft. to 6,500 ft., on the shingle slips in various parts of Canterbury and Nelson.

It is obvious that the ordinary chickweed of the garden could not exist for long at such an altitude. Such a flaccid, weak, prostrate plant would soon be broken and bruised by the rain of shingle from above, or destroyed by the heat of summer and the frosts of winter. For few, if any, plant habitats are so subject to extremes of climate and the violence of storms, as the shingle slip. In summer, the surface layers are dry, and burning hot. In winter, they are wet, and even when not covered by snow, icy cold. At a considerable depth below the surface is a stream of water, often derived from melting snow. At all seasons of the year, furious gales blow over the unsheltered surfaces of the fans. In winter, the south-west winds drive over them, laden with snow and sleet, and in summer, they are swept by the no less furious, and sometimes parching nor'-westers. Only a plant with a constitution of surpassing hardiness and vigour can live under such rigorous. conditions. One of the strangest features in connection with them, is that they endure all these hardships with little or no soil to feed upon. 
Let us consider, shortly, how this alpine chickweed has endeavoured to adapt itself to its remarkable habitat. Like nearly all the other shingle plants, it has adopted as its colour the dusky grey of its surroundings. Further, it is the only erect native chickweed, and thus, by its habit, it is to some extent protected from moving shingle. Dr. Cockayne has grown it from seed, and studied its changes of form.* Seeds collected on Mount 'Torlesse, and grown at New Brighton (Canterbury), took more than a year to germinate, and some of them a year and ten months. The first pair of leaves after the cotyledons, were spathulate, and of rather a glaucous green, with long petioles. In the adult plant the leaves are sessile and linear, and thus well protected from excessive transpiration. This reduction of leaf surface may also be regarded as a protection against excessive insolation. Even in the earlier stages of the plant both surfaces of the leaf are protected by a thick cuticle, and on the under-surface there is in addition a two-layered epidermis. Thus the colour, habit, leaf-form, and leaf-structures are all doubtless adaptations to environment.

\section{Crenus Hectorella.}

A genus of one species, which is a small, tufted, fleshy plant, with leathery, imbricating leaves. The flowers are white, nearly sessile; stems 1 in. $-1 \frac{1}{2}$ in. in height. Flowers $\frac{1}{4}$ in. long. Capsule membranous. Named in honour of Dr. Hector who discovered it in the alpine districts of Otago.

\section{Hectorella cæspitosa (The Tufted Hectorella).}

This is a curious alpine patch plant of somewhat uncertain position. It is generally included in the Portulaceae, but as Ijiels has shown, it should almost certainly be regarded as one of the Caryophyllaceae. It was originally discovered by Sir James Hector in 1\$62. The flowers are arranged in circles, on the flattened tops of the branches. It is probable that the structures which Hooker considered to be two sepals, are really sepaloid bracts, and that what he termed the corolla is a petaloid calyx. If these interpretations are correct, then the plant is closely allied to such a Caryophyllaceous plant as Lyallia of Kerguelen's Lantl.

Trans. XXXIII I. 267. 


\section{Nyctaginaceae.}

\section{The Marvel of Peru Familt.}

Distribution.-A small family of plants, principally natives of warm countries. Mirabilis dichotoma is the garden plant known as the Marvel of Peru, or the Four o'clock Plant, from its habit of opening its flowers at that hour of the afternoon. Bongainvillea spectabilis is remarkable for its large rose-coloured bracts. Pisonia is the only $\mathrm{New}$ Zealand genus. The prickly seeds of P. Brunoniana exude a glutinous substance which adheres to the wings of small birds, and makes them easy of capture. Another West Indian species has strong hooked spines on its branches, which render it an annoyance to travellers.

\section{Genus Pisonia.}

Shrubs or trees. Leaves opposite, alternate or whorled. Flowers small, green or reddish, in terminal corymbs. Perianth 5-lobed. Stamens 6-10, unequal, $1 \mathrm{sp.}$

\section{Pisonia Brunoniana (The Parapara).}

A small tree, $12 \mathrm{ft} .-15 \mathrm{ft}$. in height. Leaves opposite or whorled, $4 \mathrm{in.-}$ $12 \mathrm{in.}$ long, oblong, weak, entire. Flowers in compound cymes, hairy, 2 in.-4 in. across. Perianth $\frac{1}{6}$ in. long. Stamens 7. Perianth of the fruit sticky, ribbed, 1 in. $-1 \frac{1}{2}$ in. long. Maori name para-para, sometimes called by the settlers the Bird-catching plant. North Island: Ngunguru, Whangarei. F'. nearly all the year round.

\section{Aizoaceae.}

\section{The Mesembryanthemum Famil:}

Distribution.-A family of nearly 500 species, found chiefly in tropical and sub-tropical regions, notably in South Africa.

hey to the Genera.

Leaves ansular. Petals many.

Leaves flat, petioled. Petals absent.
Mesembryanthemum.

Tetragonia.

\section{Genus Mesembryanthemum.}

Xerophytic herbs, usually creeping, often succulent. Leaves opposite, without stipules. Flowers axillary or terminal. Calyx 5-lobed. Petals and stamens numerous. Ovary with 5 or more cells. Fruit a capsule opening in moist air only; seeds minute. (Name from the Greek, in allusion to the time at which the flower expauds.) $2 \mathrm{sp}$. 


\section{Mesembryanthemum australe (The Southern \\ Mesembryanthemum).}

Stens $1 \mathrm{ft},-2 \mathrm{ft}$. in length, prostrate, rooting at the nodes. Leaves united at the base, $1 \mathrm{in.-3}$ in. long, thick, fleshy, shining. Flower-stems short, thick. F'lowers with spreading petals, $\frac{2}{3}$ in.-1 in. across, white or pink. Petals 50-60. Styles 5-8. Ovary 5-8 celled. Both islands: abundant on the sea-shore. FI. Nov.-MIarch. Called by colonists, pigs' faces or ice-plant.

\section{Genus Tetragonia.}

Herbs, erect or trailing. Leaves succulent, alternate. Flowers axillary. Calyx 3-5 lobed. Petals 0. Stamens few or many. Styles 2-8. Ovary 2-8celled. Colls 1-ovuled. Fruit round or angular, fleshy, sometimes horned. (Name from the Greek, in reference to the angular calyx-tube.) $2 \mathrm{sp}$.

\section{Tetragonia expansa.}

An erect, branched, fleshy herb. Leaves 1 in.-3 in. long, glistening with papillæ. Flowers solitary or in pairs, sessile or with very short stalks. Calyx 4-lobed. Stamens 12-16. Styles 3-8. Ovary 3-8-celled. Fruit angular, usually with 2-4 horns. New Zealand Spinach. Kermadecs to Stewart Island: on the seashore. Fl. Dec. to Feb.

\section{Ranunculaceae.}

\section{Buttercup, Anemone, and Clematis Family.}

Distribution.-A fanily of about 700 species, found chiefly in temperate and colder regions. It includes about 50 New Zealand species. Most plants of the order contain an acrid juice which is almost invariably poisonous. Some furnish valuable drugs, e.g., Hellebore and Aconite. Others are cultivated on account of their beauty, such as Ranunculus, Anemone, Christmas Rose, Columbine, Larkspur, and Clematis.

Key to the Genera.

1. Clinbing sbrubs Herbs,

Clematis.

Petals none.

Petals present.

Caltha.

Ranunculas. 


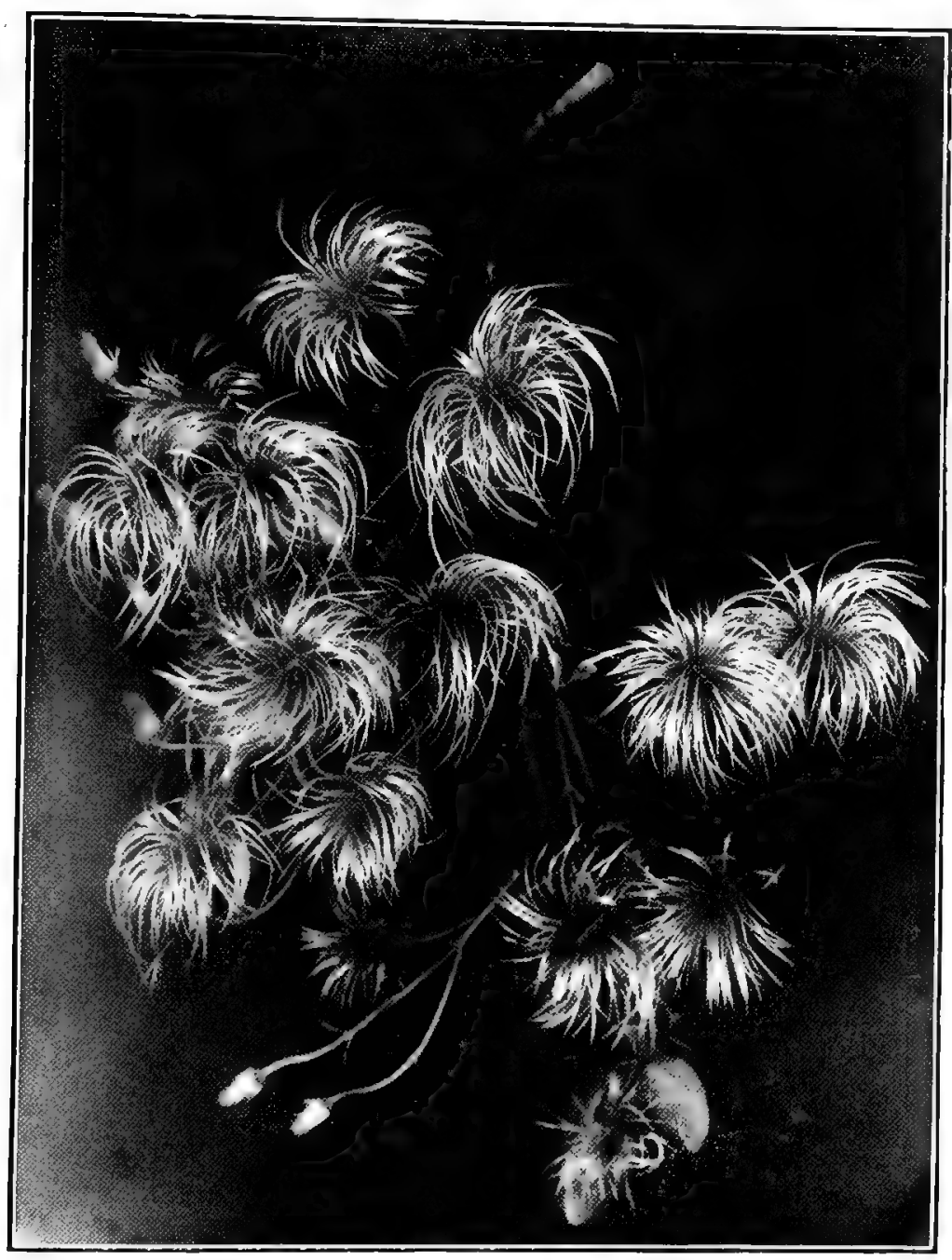

Fig. 45. Seed of Clematis indivisa (1) nat size).

"Clematis, so lovely in decline,

Whose star flowers, when they cease to shine, Fade into feathery wreaths, silk-bright, And silvery-curled."

DOMETT. 


\section{Genus Clematis.}

Shrubs climbing by twining petioles, with opposite compound leaves. Flowers dicecious. Corolla wanting, sepals petaloid. (Name from the Greek, signifying a vine-shoot). $9 \mathrm{sp}$.

Two peculiarities of New Zealand plants are well illustrated by this genus. (1) A large number of our flowers are green and inconspicuous, or at least not brightly coloured; (2) an unusually large proportion of the species have stamens and pistils on different individuals.

The genus Clematis in other lands contains many species, which are blue, purple, or yellow. New Zealand has nine species. Two of these have white flowers; in the remainder the flowers are greenish-yellow or yellowish. In none are they brightly coloured, and this lack of colour one finds throughout the flora. The New Zealand violets are white, the gentians are nearly all white, the flax proper (Limum monogynum) is white. The corresponding species in other countries are blue, or brightly coloured. Exanuples might be multiplied indefinitely (e.g., most of our Compositae, Veronicas, Pimeleas, etc., are white).

There is no doubt that the prevalence of white in the Flora is in some way connected with the paucity of insects in New Zealand. It has been said, that not only are our insect species few in numbers, but there are few individuals of each species. Such a broad statement, as this, is, however, unwarranted. It is true that we have only fifteen kinds of butterfly, and that several of these are rare, so that these insects play a smaller part in the work of pollination here than elsewhere. However, we have a considerable number of forms of night-flying moths, several of the families being well represented, and it is generally supposed that they pollinate white flowers, which are more conspicuous in the gloom than coloured ones. It also seems probable that flies play a larger part in the work of pollination here than they do elsewhere. Ton little, however, is known at present about the indigenous 


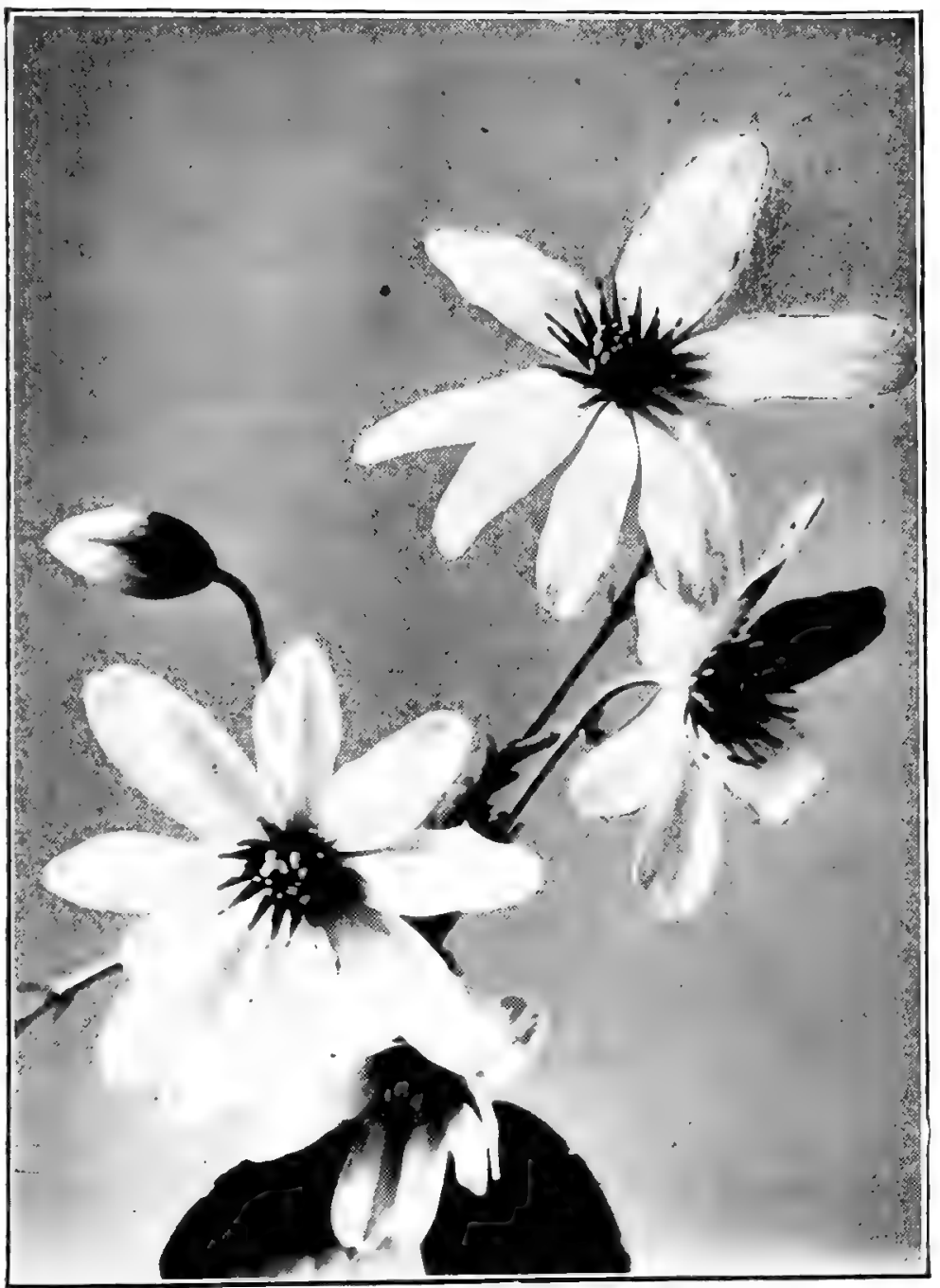

Fig. 46. Clematis indivisa-Staminate flowerg (2 nat. size).

Meek clematis, tree dweller, child of dew, Nursling of light and air!

Slow trailing stars, or showers of misty suns, Whence is the hand thou reachest wistfully

Feeling, on earth, for something not of earth? 
species in the lower orders of insects, to enable one to speak definitely about them and their relationships to flowers.

\section{Unisexual flowers.}

Perhaps in no other part of the world is there such a large percentage of unisexual flowers to be found, as in New Zealand. Genera which are hermaphrodite elsewhere, are often unisexual here. Out of 433 species examined Mr. G. M. Thomson found 46 per cent.-a remarkably high proportion-more or less unisexual." Of the remaining 54 per cent., probably only a few are self-pollinated, although the flowers are hermaphrodite. There is reason to believe that in some few cases (e.g., the willow and the oak), the unisexial condition is the primitive one; but, in many of the New Zealand plants, the presence of rudimentary organs, and the hermaphroditism of closely allied forms elsewhere, prove that suppression has taken place, and that we have here to do with a secondary and not a primitive condition.

\section{Clematis indivisa (The Entire-leaved Clematis.)}

This is one of the best-known of the bush flowers. The leaves are thick and glossy, and the flowers have no petals, the sepals acting both as protective and attractive organs. Both islands. Fl. Sept.-Oct. Maori name Pua-wananga, Piliarero.

Plants of $C$. indivisa, with their festoons of starry white flowers, looped from tree to tree, light up with delicate beauty the edges of the dark bush in the early spring. It is not to be wondered at that the northern Maoris gave to this species the name of Pua-wananga, i.e., the sacred or sanctified flower. Its. feathery wreaths of seed are almost as beautiful as the flowers, each seed in the cluster bearing a long silky, silvery plume, which enables the wind to carry it to a distance. Pairs of rudimentary leaves are found beneath each flower-stalk, and these are believed to remain undeveloped, so that the flower"

'Trans. XIII., p. 248. 


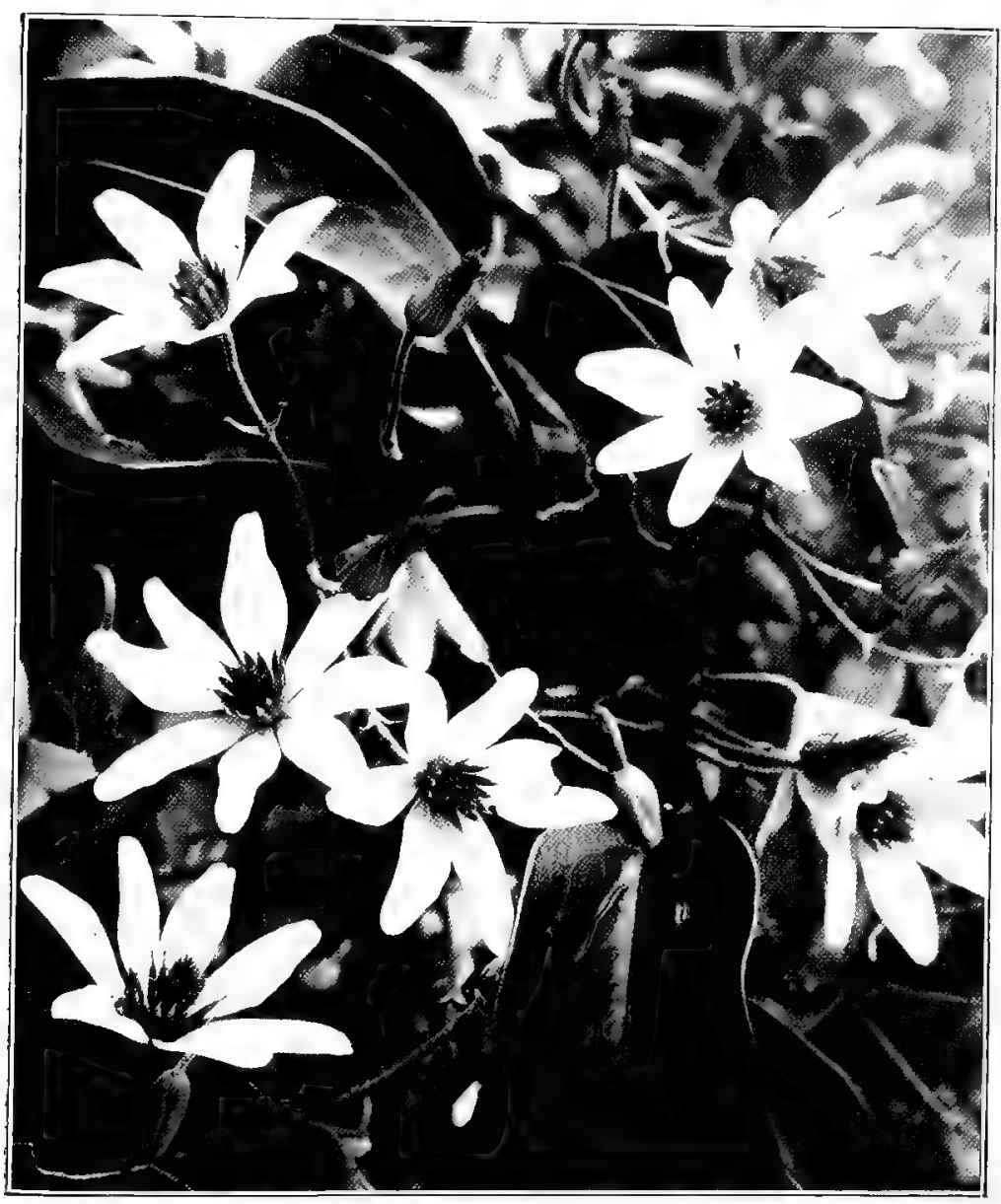

Fig. 47. Clematis indivisa-Pistillate Howers (nat. size).

Fancy could almost declare

That great Ophiucus, down-hurled

From his throne in the skiey star-world, Had been caught with his glittering gems, 'Mid those giant entangling stems. 
may not be shaded, or hidden from the sight of the insects upon which it depends for pollination.

The leaf-stems coil themselves spirally round the branches of other trees, and so drag the plant up to the sunshine, which is needed for the expansion of their flowers. When young, these leaf-stems are remarkably sensitive, and, if gently rubbed, will turn in the direction from which the friction comes. They will seize, therefore, and coil themselves around any twig or branch against which they are blown by the wind.

\section{Clematis hexasepala (The Six-sepaled Clematis).}

Very similar to $C$. indivisa, but smaller. Found throughout the islands, but not so commonly as the former. Fl. Sep.-Nov.

\section{Clematis afoliata (The Leafless Clematis).}

A remarkable plant, with leafless branches, and yellow flowers; often binding together, with its long wiry stems, the bush upon which it grows. Found chiefly in the South Island: not common. It may still be collected within a short distance of the foot of Colombo Street, Christchurch. Fl. Oct. Clenatis foetida (The Foetid Clematis) produces fragrant, greenish-yellow flowers in great profusion, on long sprays. Fl. Sept.-Nov. Clematis parvifiora (The Small-flowered Clematis)-Flowers fewer, leaves smaller and softer than in $C$, foetida. Rather local in the North Island, and rare in the South Island. Fl. Oct.-Nov.

\section{Genus Ramunculus.}

Most of the species of this genus are known as Buttercups. Sepals 3-5. Stamens many. Fruit a head of beaked achenes. $37 \mathrm{sp.}$

\section{Ranunculus Lyallii (Lyall's Ranunculus).}

Stem erect, without runners. Achenes silky, Leaves peltate, flowers. white. Alpine districts of the South Island. Fl. Jan.-March.

This stately plant is the finest species of the genus. The leaves, which are kidney-shaped in the young plants, are circular and concave in mature specimens, thus forming saucers. In them water often collects, and, as there are deep grooves over the leaf-veins, Diels considers that moisture may be absorbed at these places, but the matter has not yet bcen subjected to experiment. The plant is known to colonists as the Mountain, Shepherd's, or Mount Cook Lily. The name is 


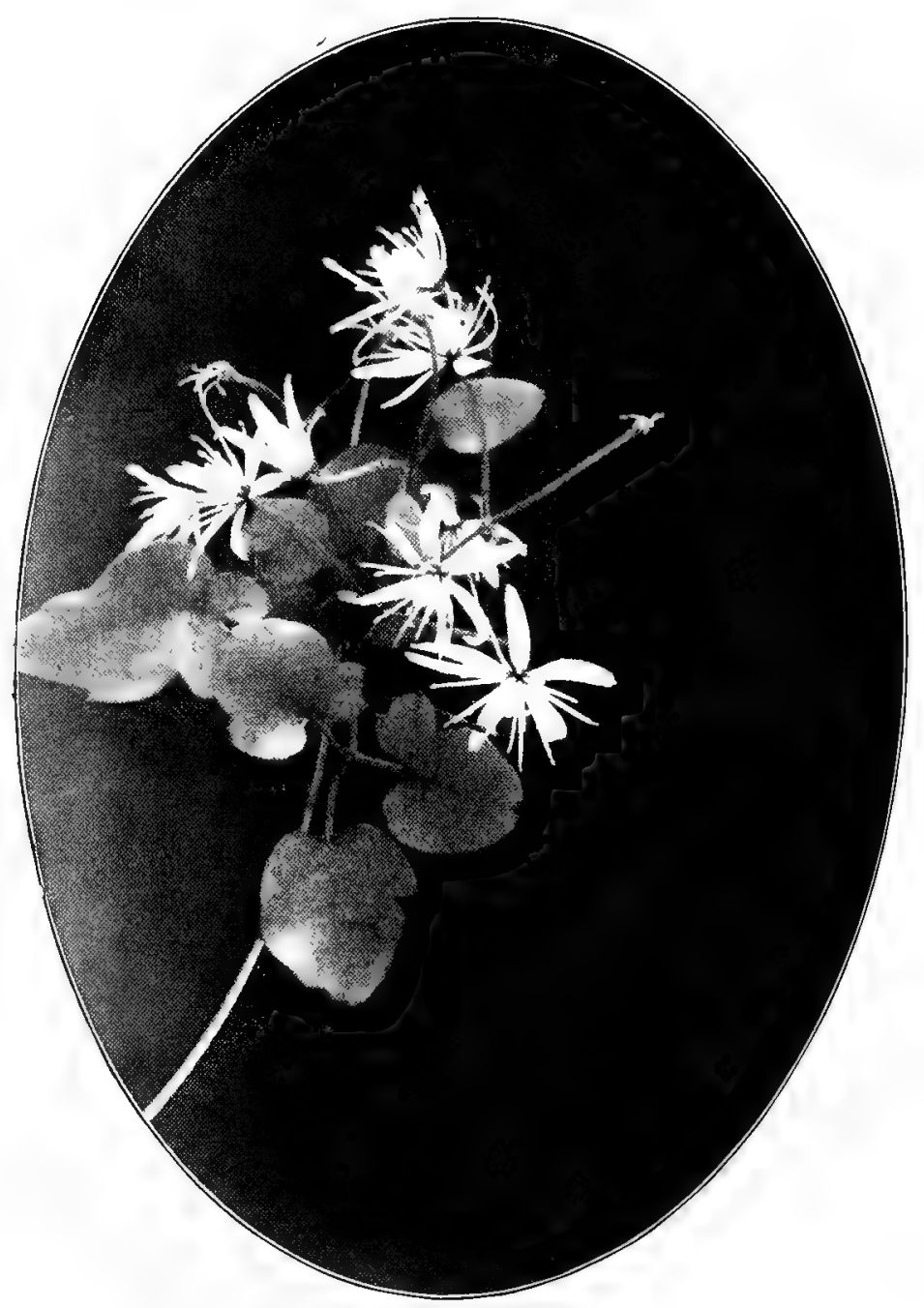

Fig. 48. Clematis parviflora ( $\frac{3}{4}$ nat. size). 
most inappropriate, as the plant is not a lily, but a large white buttercup. However, any large-leaved herbaceous native plant is called by the colonists a lily, especially if it has white Howers. For another instance of the misuse of the name, v. Chatham Island Lily, Myosotidium nobile.

Ranunculus Lyallii is not unlike the English king-cup in its habit of growth, having the same large, round, fleshy leaves and juicy stems. But the flower of the king-cup is golden, and that of the Mount Cook Lily is of a pure and waxy white. This Ranunculus grows only in the alpine districts of the South Island, and at an altitude of from 2,000 to 4000 feet. It may, however, be readily seen on Mackinnon's Pass, on Arthur's Pass, and near Mount Cook, where it forms dense patches as high up as the Ball Hut on the edge of the Tasman Glacier. It is one of the most beautiful plants in the New Zealand alpine flora-its white anemone-like flowers contrasting well with its large, dark glossygreen leaves which sometimes measure fifteen inches across. This plant and $R$. Traversii are the only species with peltate leaves. It is cultivated with difficulty, as it requires the greatest heat possible during summer, and the most severe cold in winter.

Other species which have extremely showy flowers are $R$. Buchanani (Otago lake district), $R$. Godleyanus (headwater's of the Rakaia), $R$. insignis (southern Nelson, Tararua, and Ruahine Mountains), R. nivicola (Mount Egmont). The mly similar species known ontside of New Zealand, is $R$. Bamrii of the Transvaal mountains.

\section{Ranunculus crithmifolius (The Samphive-leaved Iianunculus).}

Similar to the next species, R. Haistii, but with shining green fleshy leaves, and short 1-flowered scapes. Wairau Gorge. Known only from a single specimen.

The plant descriptions of many of the earlier botanists were often of necessity very imperfect, and, consequently, later investigators have frequently had much difficulty in identifying 
BUTTERCUP, ANEMONE, AND CLEMATIS FAMILY 169

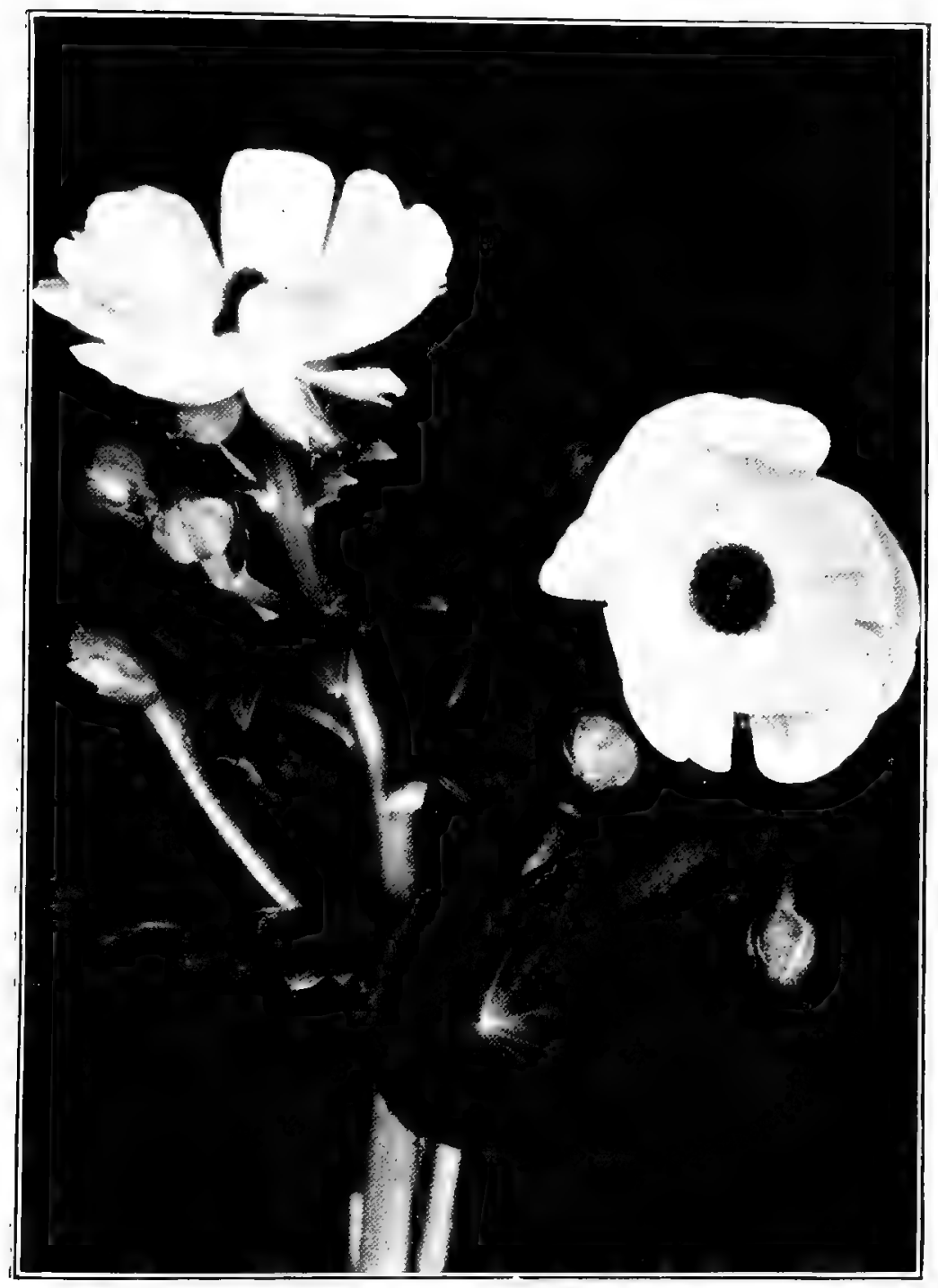

Fig. 49. Ranunculus Lyrallii ( $\frac{2}{3}$ nat. size). 
the species to which these descriptions allude. Sometimes not a scrap of the original specimens, from which the characters have been drawn up, is to be found in herbaria. Under these circumstances, it is a matter of astonishment how many of the original species have been identified with certainty. In spite, however, of all the perseverance and research of modern workers, a few of the forms apparently known to the earliest explorers, have not been re-discovered in recent times. In some cases it is probable that the plant has been redescribed under a fresh name; in a very few cases, it may be, that, by some lucky chance, the first collectors found a plant that, on account of its extreme rarity, has never been seen again. In $R$. crithmifolius we have a plant which has not been re-identified since first found by Travers on the shingle-slips of the Wairau Gorge. Even then only a single plant was seen. (cf. Cotula fitiformis, Senecio perdicioides, and Pittosporum obcordatum.

It seems more than likely, therefore, that the plant was a casual variant of some other form, than really a distinct species. If, however, the original description is to be trusted, $R$. crithmifolius is one of the most remarkable species of the genus.

Like all other shingle-slip plants, it is highly specialized; otherwise it would not be able to live in the place whence it was reported. A full description of the conditions of life in such a locality will be found under Stellaria Roughii. $R$. crithmifolius has leaves, which, on a smaller scale, closely resemble those of the rock samphire, a plant of an altogether different order. They are thick, succulent, bluish-green, and highly polished. They thus differ widely from the normal leaf-forms of the genus.

Diels compares them with the leaves of Ligusticum camosulum, which is one of the most singular species of the flora, and also grows on the same shingle-slips in the Wairau Gorge. 


\section{Ranunculus Haastii (Haast's Ramunculus).}

Stem simple, erect, without runners. Achenes glabrous; leaves few, much divided, leathery. Scape few-flowered, with leafy involucre. Perhaps the only New Zealand species with a stout, fleshy rootstock. Shingle-slips in the South Island, from Nelson to Otago. Fl. Dec.-Jan.

A similar plant to $R$. crithmifolius, but much more widely distributed. Both species, however, were said to be found together on the shingle-slips of the Wairau. R. Haastii has. flower-stalks as thick as the finger, and a stout, fleshy rootstock that burrows deep into the shingle. Thus, by increasing the succulence of its parts, it has managed to. adapt itself to an exceedingly inclement situation.

Ranunculus hirtus and Ranunculus lappaceus are the New Zealand representatives of the English meadow buttercup, whilst $R$. rivularis, $R$. acaulis, and $R$. macropus are found in swamps and pools. There axe also many introduced species.

\section{Genus Caltha.}

A genus of few species, occurring in temperate and cold regions. Perennial herbs, with large, shining, radical leaves, and yellow flowers. $2 \mathrm{sp}$.

\section{Caltha novae-Zelandiae (The New Zealand Caltha).}

A stout, fleshy plant, with heart-shaped, auricled leaves, and 1-flowered: scapes. Petals none. Sepals coloured, petaloid. Stamens numerous. Carpels 5-8. Both islands in alpine districts. Dwarf specimens are found also in Stewart Island. Fl. Oct.-Jan.

This is a little alpine marsh-marigold, interesting on account of its leaf structure. The functions of the upper and lower sides of the leaves have been largely reversed. The stomata are found on the upper surface, and the water storage apparatus on the lower. The lobes at the leaf base are usually bent upwards, or even turned right over upon the blade. A similar folding is found in the South American $C$. dioneaefolia, and in this case Goebel considers that the object of the bent leaf-bases is to secure wind-still spaces for the stomata to function in. The margins of the leaf are also 
sometimes so much inrolled as almost completely to overarch the stomatic areas.

This method of obtaining wind-calm spaces is known in other groups of plants. The leaves of many of the Papilionaceae, for example, are infolded to protect the stomatic surfaces.

In other species of the genus Caltha, normal leaf-structure is found. Thus, in $C$, andicola of the Upper Andes, the stomata are borne on the lower surface, and the leaf is otherwise of the usual type. Intermediate forms between this and $C$. nova-Zelandiae are found elsewhere. The abnormal form is evidently an adaptation to an alpine environment.

\section{Magnoliaceae.}

\section{The Magnolia Famili.}

Distribution.-The plants of this order are chiefly natives of southern North America, and of tropical and temperate Asia. Many of them are handsome shrubs, cultivated for their beauty and for the sweet scent of their flowers.

\section{Gemus Drimys.}

Sepals $2-4$; petals 5 or 6 , in two rows. Stamens many; fruit a berry. (Name from the Greek, signifying pungent). $3 \mathrm{sp}$.

\section{Drimys axillaris (The Axil-flowered Drimys).}

A small, evergreen tree, with glossy, alternate leaves, and black bark. The flowers occur in the leaf axils, or in the scars of fallen leaves, hence the name asillmis. Leaves simple, alternate, pellucid-dotted. Stamens 10-20. There is in the South Island a pungent species, $D$. colorata, which has leaves blotched with red, with a purple bloom on the under-surface and 2-seeded berries. The wood of this tree is reddish in colour, and is used for inlaid work. The lark is very aromatic, and is a tonic and astringent. A decoction of the leaves is often used by bushmen as a medicine, and has earned the name of "Mari Painkiller." Flowers yellowish-green. Fl. Oct.-Dec. Called by settlers the Pepper Tree. Haori name Horopito. 


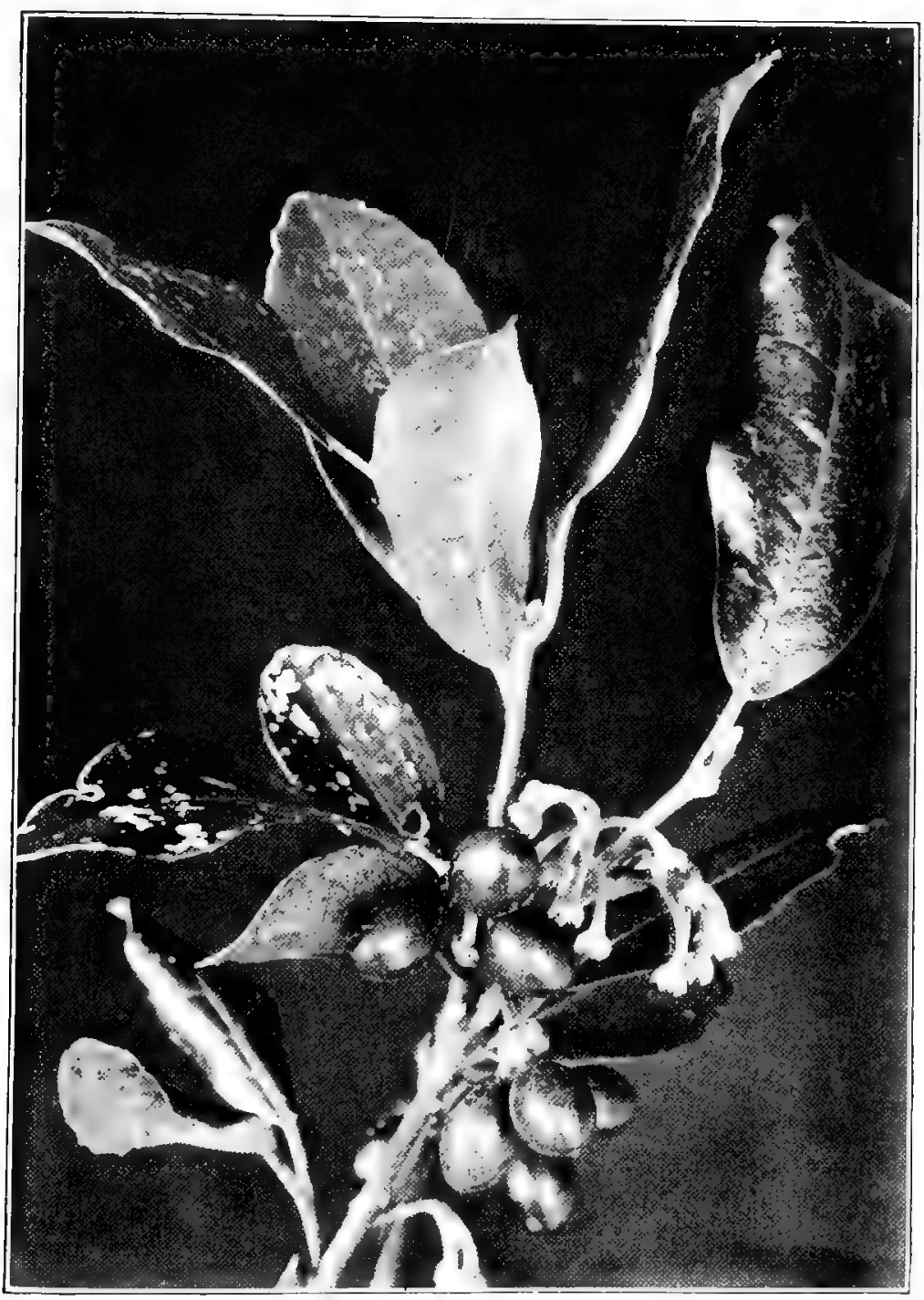

Fig. 50. Hedycarya arborea (gat. size) 


\section{Monimiaceae.}

Distribution.-A small family, chiefly tropical, found in South America, Southern India and Tasmania. Leaves sometimes aromatic.

\section{Genus Laurelia.}

A genus of 4 species, including one found in Chili and two in Australia. Trees. Leaves opposite, aromatic. Flowers diceious, in panicles. Perianth 5-8 parted. Stamens 6-20 in the male, flowers reduced to scales in the female. Ovaries 5-20, hairy. Achenes with long feathery styles. (Name in allusion to the laurel-like leaves). $1 \mathrm{sp}$.

\section{Laurelia novae-Zelandiae (The Pukatea).}

One of the loftiest of New Zealand forest trees, sometimes reaching the height of $150 \mathrm{ft}$. Trunk from $3 \mathrm{ft} .-7 \mathrm{ft}$. in diameter, flanked with thin spreading buttresses at its base. Bark pale. Leaves thick, $1 \frac{1}{2}$ in. $-3 \frac{1}{2}$ in. long, $\frac{9}{4}$ in. $-1 \frac{1}{2}$ in. wide, toothed, shining. Flowers racemed, axillary, $\frac{1}{x}$ in. across. Stamens 6-10. Achenes 6-10. North Island; northern parts of the South Island. Fl. Oct.-Nov. Maori name Pukatea.

The wood of this tree is pale-brown, tinged with yellow, and streaked with darker shades. It is much valued for boatbuilding, as it does not split, and will not readily burn. The pukatea, like the tawa, furnishes the Maori with an illustration of cowardice.

Te waka pukatea, te waka kohe-kohe.

The pukatea canoe, the kohe-kohe canoe;

i.e., The coward is like the canoe of pukatea, which, being made of soft wood, soon gets water-logged and slow of motion. The brave man is like the kohe-kohe canoe, swift and strong.

\section{Genus Hedycarya.}

Trees. Leaves opposite. Flowers in panicles, axillary, dicecious. Perimth 5-10-lobed. Anthers sessile, numerous in the male flower. Ovaries numerous, stigma sessile in the female flower. Ovule solitary. $1 \mathrm{sp.}$

\section{Hedycarya arborea (The Tree-like Hedycarya).}

Trunk $20 \mathrm{ft} .-30 \mathrm{ft}$. in height. Bark dark in colour. Leaves 1 in.-4 in. long, oblong, coarsely-toothed, rarely entire, shining or slightly hairy. Flowerpanicles hairy, shorter than the leaves. Perianth $\frac{1}{3}$ in. across, yellowish. Fruit oblong, $\frac{1}{2}$ in long, orange-red, beaked. Both Islands: as far south as Akaroa. Fl. Nov,-Dec. Maori name Porokaiwhiri or Poporo-haiwhiri. 


\section{Lauraceae.}

\section{The Laaurel Family.}

Distribution.-A large, chiefly tropical family, with only one European species (Laurus nobilis), the Sweet Bay tree. Cinnamon, Cassia-bark, Camphor and Clove Nutmegs, are all obtained from various species of this family.

Fey to the Genera.

1. Leafless twining herb.

Leafy trees.

Cassytha, p. 177 .

2. Small tree. Flowers in a 4-5 leaved involucre.

Litsea, p. 175 .

Lofty forest trees. Flowers in panicles.

Beilschmiedia, D. 175.

\section{Genus Litsea.}

Shrubs or trees, leaves usually alternate. Flowers in axillary umbels, dicecious. Perianth absent, or 4-8-parted. Stamens 6-15 in the male flowers; rudimentary in the female. Berry ovoid. $1 \mathrm{sp}$.

\section{Litsea calicaris.}

A leafy, shining tree, 30ft.-40ft, in height. Leaves 3in.-4in. long, oblong, entire, obtuse, pale brown when young. Leaves of involucre $\frac{1}{6}$ in. $-\frac{1}{3}$ in. long. Flowers 4 or 5 together, delicately fragrant. Perianth of 5-8 segments, cream-coloured. Stamens usually 12 ; anthers large, 4-valved. Berry $\frac{3}{4}$ in. long, red. North Island. Bay of Islands to east coast. Fl. Sep.-Oct. Maori name Mangeao.

\section{Genus Beilschmiedia.}

Lofty forest trees. Leaves alternate. Flowers in panicles, terminal or axillary. Perianth of 6 segments. Stamens 12, some of which are usually infertile. Berry ovoid. This genus is endemic in New Zealand. 2 sp.

\section{Beilschmiedia Tarairi (The Tarairi).}

A handsome tree, $60 \mathrm{ft} .-80 \mathrm{ft}$. in height, with large, glossy leaves. Young shoots and leaf-stalks clothed with rusty-coloured down. Leaves 3 in.-6 in. long, leathery, ovate-oblong, obtuse, sometimes whitish below. Flowers in branched panicles, inconspicuous, 1 in.-2 in. across. Perianth $\frac{1}{6}$ in. across. Fruit an oval berry, $1 \frac{1}{2}$ in. long, purple, plum-like, very attractive to birds, but, unless boiled, said to be poisonous to man. North Island: Auckland district. Fl. Nov. Maori name Tarairi.

\section{Beilschmiedia Tawa (The Tawa).}

A forest tree, $60 \mathrm{ft} .-70 \mathrm{ft}$. in height, with slender branches, and pale, usually narrow, leaves, 3 in.-4 in. long. Flowers in slender panicles, 2 in.-3 in. across, green. Perianth $\frac{1}{10}$ in. long, smooth, shining. Fruit resembling a damson, edible, $\frac{3}{4}$ in. long. North Island: abundant in hilly districts. South Island: near Cook Strait. 
The tawa seed provides the Maori with two proverbs:-

Ka malui te tawa who ki te riri!

Well done tawa kernel fighting away !

He tawa para! He whati kau taana.

A tawa pulp! He only runs away!

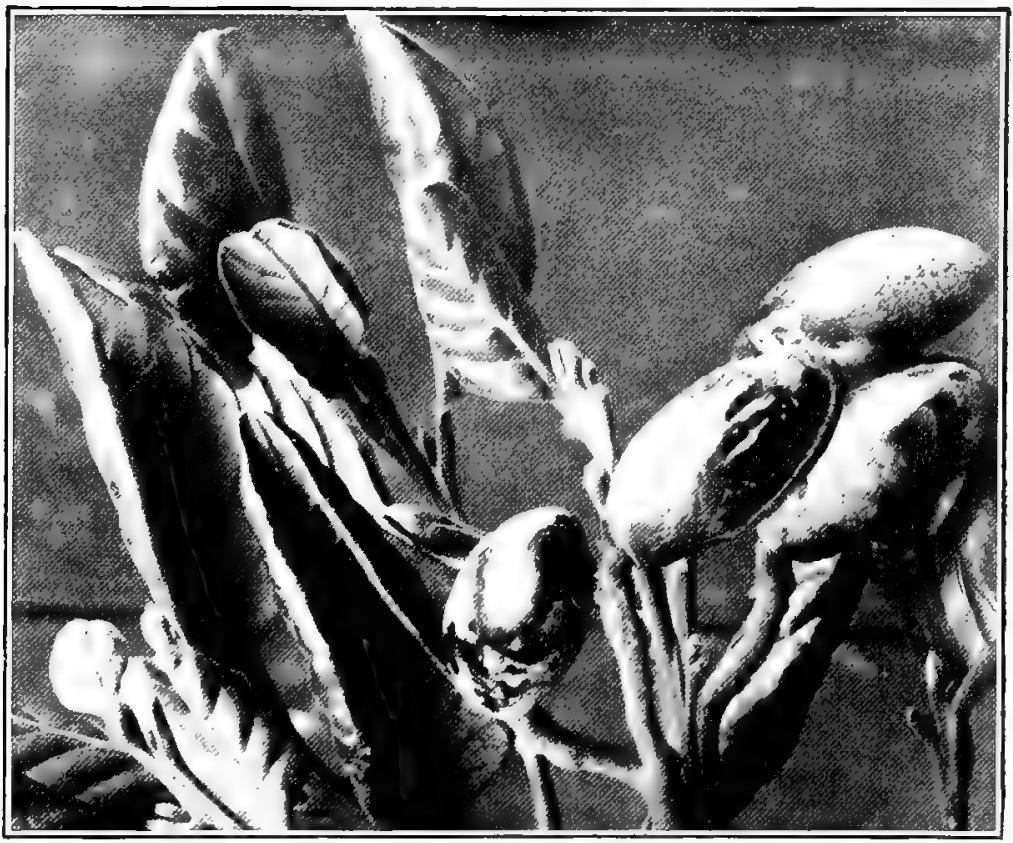

Fig. 51. Beilnchmicdin Turairi (G nat. size).

The hard date-like stone of the tawa fruit symbolizes the hero, whilst the fleshy pulp is the emblem of the coward.

\section{Genus C'assytha.}

Herlaceous plants, leaffess, parasitical upon shrubs, to which they attach themselves by suckers. Stems very slender. Flowers in heads, spites or panicles. Perianth of 6 segments. Stamens 12, 3 of which ine imperfect. Anthers 2-celled. Fruit enclosed in the Heshy perianth. A large genus, chiefl Australian. (Name from the Greek, signifying the dodder, in allusion to the resemblance between the two plants). I sp. 
Cassytha paniculata (The Panicled Cassytho).

Stems shining, $1^{\frac{1}{2}}$ in. $\frac{x}{10}$ in. in diameter, with small membranous scales in the axils. Flowers in spikes, $1 \mathrm{in},-2 \mathrm{in}$. long. Perianth $\frac{1}{6} \mathrm{in} .-\frac{1}{6} \mathrm{in}$. long, with small round bracts at the base. Ovary glabrous. Northern parts of the North Islind.

This is a widely spread genus found chiefly in warm climates. The New Zealand species is so abundant in some districts north of Auckland as to cause frequent tripping. The same form is also to be found in Eastern Australia, where the genus is highly developed. The long, twining, thread-like stems of the parasite much resemble those of the dodder, though the two plants are not closely allied botanically. Further, the methods by which they attack the host plant, and the way in which they germinate, are in both cases so much alike, that one description will suftice for both genera. (v. Cuscuta.)

\section{Cruciferae.}

\section{WALLFLOWER FAMILY.}

Distribution.-A large and useful family, comprising many plants used as vegetables (e.g., turnip, radish, cabbage, cauliflower, cress, etc.). There are nearly 200 genera and 1200 species, and these are found chiefly in cold and temperate regions. In the Tropics they are rarely seen. The juices of the plants belonging to this order are entirely innocuous. Of the seven New Zealand genera, Pachycladon and Notothlaspi present most points of interest. Both are endemic in these islands. The following genera of Cruciferae are also represented in New Zealand, Nasturtium (the water-cress); Cardanine (the bitter-cress); Sisymbrium (the hedge-mustard) ; Capsella (the shepherd's purse), and Lepidium (the pepper-wort).

\section{Genus Pachycladon.}

An endemic genus, found only in the South Island. Leaves radical, tufted. Root fleshy. Sepals, 5; stamens, 6. (Name from the Greek, signifying thick branches). $1 \mathrm{sp}$. 


\section{Pachycladon novae-Zelandiae. (The New Zealand Pachycladon).}

A stout, branching herb, found in mountainous districts of the South Island. Leaves in rosettes. Scape, 2-5-flowered. Petals twice as long as the sepals. Ascends to 5000 feet.

This is a remarkable endemic cruciferous genus of Central and South-Western Otago. There is only one species, $P$. noval-Zelandiae, unless indeed a form reported from the mountains at the head of Lake Ohau, should prove to be distinct. The foliage is arranged in the form of a rosette, i.e., there is no stem. The leaves are, therefore, all radical, and arranged in concentric circles round the flower stem. The common dandelion is a typical rosette plant. Anyone who has dug one of these weeds out of a lawn, knows what an ugly bare patch is left behind. The rosette plant so completely covers the soil beneath it, that nothing else can grow there. In the struggle for existence it successfully chokes out its competitors. However, the desire for exclusive territorial possession, cannot be the purpose of the rosette of Pachycladon, for it grows on the shingle-slips, where there is plenty of room. Positions on such exposed situations are not greatly coveted, for few plants can successfully brave the hardships of life in such localities.

It is probable that Pachycladon owes its rosette form, not to its environment, but to its ancestry. Many of the Cruciferae have this type of leaf arrangement, and it is not infrequently met with on the shingle slips. (See also Notothlaspi).

\section{Genus Notothlaspi.}

A small endemic genus, found only in the South Island. Herls, with thick radical leaves, and scapes of white flowers. Stamens 6. Pods compressed, winged, $\frac{1}{2}$ in. - 1 in. in length.

Notothlaspi rosulatum. (The Rosette-like Notothlaspi).

An erect, stemless herb. Leaves in a crowded rosette, hairy when young, glabrous when old. Flowers white, fragrant, pyramidal. Shingle beds in the alpine districts of the South Isiand. The I'en-Wiper Plant of the Settlers. Fl. Dec.Jan. $2 \mathrm{sp}$. 
This is a singular endemic genus, of the detritus fans and upper river-beds of the South Island. Kirk describes N. rosulatum "as one of the most remarkable plants known," but is surely in error when he speaks of it " as now becoming rare owing to the ravages of sheep." The plant is quite common in many sub-alpine districts, and certainly does not appear to be generally attacked by sheep. It is sometimes sought after by the settlers, and taken indoors, on account of the delicious orange-like fragrance of the flowers.

As the name implies, the leaves are arranged in a rosettea plant form not unusual in such a habitat (v. Pachycladon p. 178). The structure of the rosette, however, is very remarkable, if not altogether unique. The flower-head, as shown in the photograph on the title page, is much shorter than in the typical form, but the picture gives a much better idea of the character of the rosette than those drawn by previous writers. That given by $\mathrm{Mr}$. and Mrs. Featon in their Art Album of the New Zealand Flora is particularly misleading, evidently having been drawn by someone who had not seen the plant growing. The leaves overlap like the shingles of a roof, and the whole rosette itself is curved like an umbrella, so that only the outer edges touch the ground. Thus, all rain falling on it, quickly rolls off, and is rapidly conducted through the loose shingle to the long characteristic tap-root, which firmly anchors the plant amongst the drifting pebbles. Underneath the umbrella-like foliage is a cavity, which is not without its value in the economy of the plant. During the day, since the shingle is hot, and the under surface of the plant cool, vapour must then be condensed on the under-surface of the rosette. Thus the leaves obtain a copious supply of moisture throughout the period of insolation. At night the shingle cools down more rapidly than the plant, and condensation now takes place upon the ground. The foliage is thus kept dry, and protected to some extent from the effects of frost. 
One of the chief dangers the plant has to contend with, arises from the continual moving of the stones of the shingleslips. Indeed, its rosettes are often buried, and sometimes destroyed by them. However, specimens are not infrequently found, in which a second rosette has been developed above the original one, that had been covered by the ever-moving shingle. Obviously, the fleshy leaves, the long-tap root reaching to the wet stones below, the thick flower stem with its conical mass of low-growing, densely crowded flowers, have all been developed by the plant in its attempt to adjust itself to the perils of a difficult environment. As in other plants of the shingle-slips, the foliage is of a sandy hue, that suggests protective resemblance, but no sufficient explanation has yet been given of this assimilation of colour to habitat.

\section{Droseraceae.}

The Sundew Family.

Distribution.-A remarkable family, with carnivorous habits; usually found in marshy or sandy ground. Dioncea muscipula, the Venus' Fly-Trap of the North-American bogs, is wonderfully specialized for the catching of insects.

The Droseracea are a widely distributed family, but the greatest number of species is found in Australia. D. rotundifolia is found in almost all English bogs. The leaves of this plant, when young, are curled like the fronds of a ferm. Some of the species yield a purple dye.

\section{Gemus Drosera.}

Sepals, petals and stamens, 4, 5, or rarely 8. Flowers, white or purple, on long weak stems, Gin.-18in. in length. The leaves of the different species are very varied in shape. $6 \mathrm{sp}$.

\section{Drosera pygmæa. (The Pygmy Drosera).}

A very minute plant, with leaf rosettes less than $\frac{1}{2}$ in. across. Stem, 1 flowered, 3 in. high. Flowers white. Calyx 4-lobed; capsule 4-valved. Both islands: local. Fl, Dec.-Jan. 


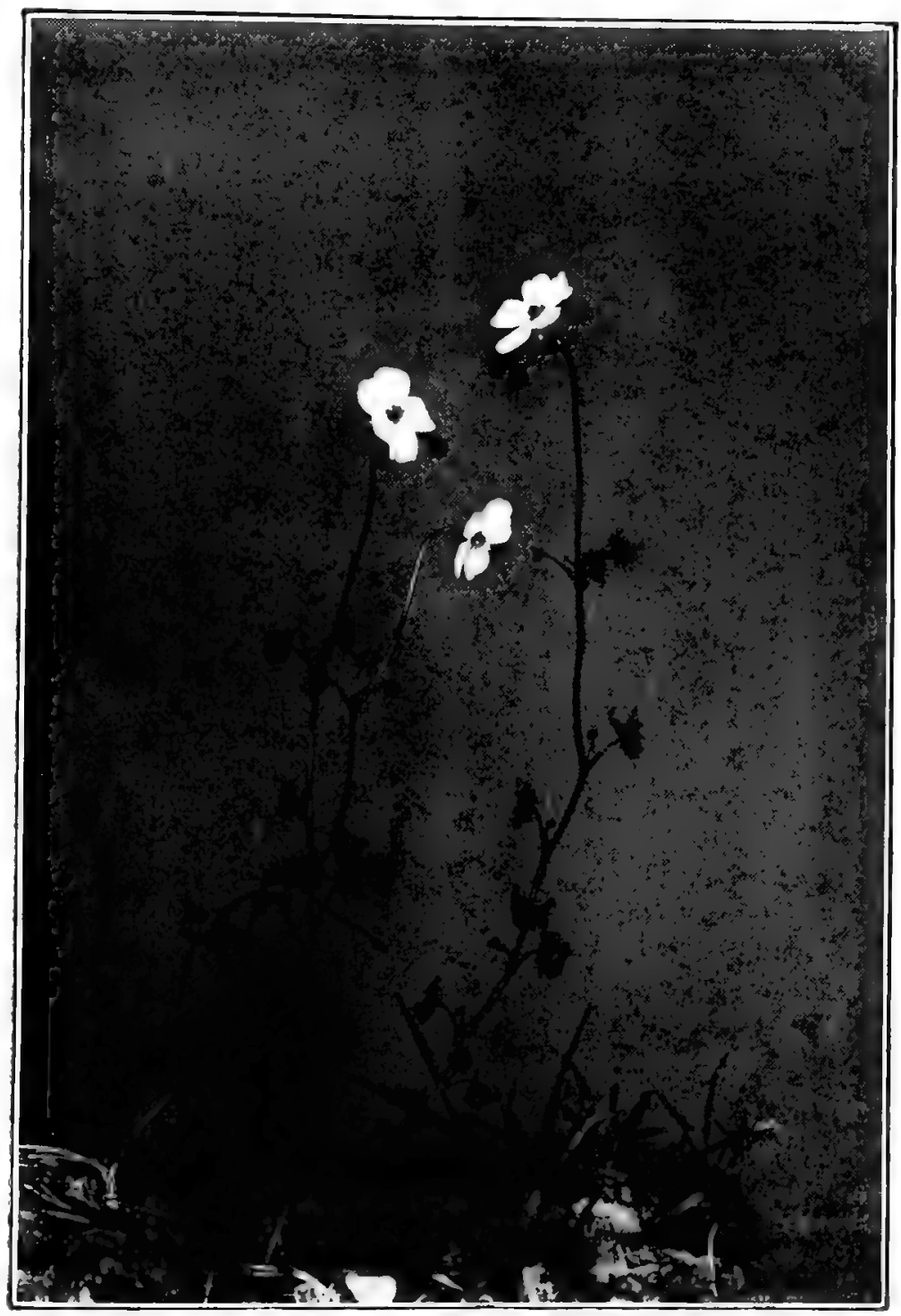

Fis. 52. Drosera nuriculata (ì nat. sizes) 


\section{Drosera spathulata (The Spathulate-leaved Drosera).}

Leaves in a rosette, each leaf from $\frac{1}{2}$-in. $-\frac{3}{4}$ in. long. Flower-stem, 1in. - 6in. long; 1-6 flowered. Petals, white. Calyx, 5-lobed; petals, 5; stamens, 5. From Mangonui to Stewart Island; local. Fl. Dec.-Jan.

\section{Drosera binata (The Twin-leaved Drosera).}

A very distinct species, with leaves like a two-pronged fork, all radical. Flowers on slender stems, white, $\frac{1}{4}$ in. - tin. across, 6 to 8 on a stem. Sepals, petals, and stamens, 4-5. Both islands; common in clay bogs. Fl. Nov.-Feb.

\section{Drosera auriculata. (The Ear-shaped Drosera).}

A pretty little plant with pink or purple flowers, growing in dry soils. The stems are slender and straggling; sometimes $2 \mathrm{ft}$. $-3 \mathrm{ft}$. in length. The rootleaves are few in number; those on the stems alternate, with two long narrow processes ou the upper part, like pointed ears. These, as well as the remainder of the leaf, are covered with the long red hairs common to all Sundews. Seen under a microscope, by artificial light, the leaf of the Sundew is a most beautiful object, and well worth studying.

\section{Insectivorous Plants.}

Plants which grow in bogs often find it difficult to procure the nitrogen necessary for their sustenance; and they have, therefore, evolved means of catching and digesting flies and other insects. Darwin was the first to investigate thoroughly, and establish the carnivorous nature of numerous plants. Many of the facts connected with them are highly remarkable, and for a full description, the great evolutionist's work on Insectivorons Plants should be consulted. In the Droseraceae, or Sundews, the upper surface of each leaf bears a number of bright red, clubbed, glandular hairs, every one with a glistening drop of viscid fluid at the upper end. These tentacles are longest round the margin of the leaf, and grow gradually shorter towards the centre. If an insect tonches the centre of the leaf, it becomes glued to the hairs, and, a few minutes afterwards, the marginal tentacles bend towards it, and seize it. The orifices of its respiratory organs become blocked up by the viscid fluid, and, finally exhausted by its struggles, the unfortunate insect dies. The amount of the secretion from the tentacles increases, 


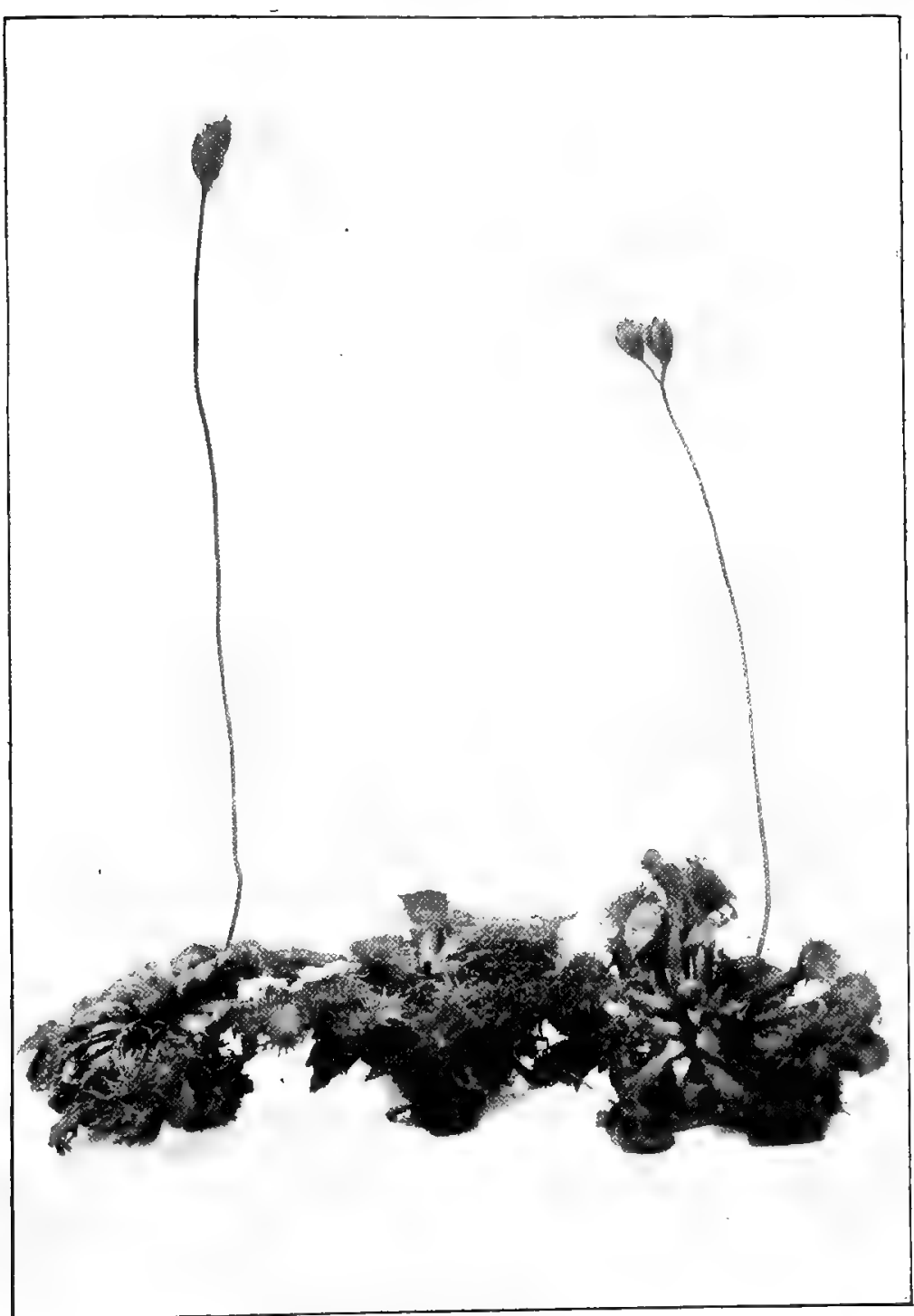

Fig. 53. Drosera spathulata ( $\frac{9}{3}$ nat. size). A. C. Smith. 
and, if the insect is large, the whole leaf becomes more or less concave, and large quantities of juice are poured ont from the glands. This juice is in many ways similar to the human gastric fluid, and accomplishes the same purpose, for, after several days, the insect is digested, and little of it is left, except the wings and horny casing. The leaf then gradually opens out, and, after a day or two, is again in a position to capture insects. The sensitiveness of the tentacles is marvellous. Thus, it has been said, that the four-thousandth part of a milligram of ammoniun carbonate is sufficient to produce motion in them, while a piece of a woman's hair about twotenths of a millimetre (i.e. less than one-hundredth of an inch in length), placed upon a gland, also caused inflection in the filament belonging to the gland. The above description deals chiefly with $D$. rotundifolia, an English and continental plant. To it alone, Darwin devoted 270 pages of his book; but he also experimented on two Australasian species-D. spathulata and D. binata. He found that functionally they differed little from D. rotundifolia. Both these species occur in New Zealand, though Darwin's specimens came from Australia. The very handsome $D$. binata, in particular, interested him very much. He refers to it as "this almost gigantic Australian species." In it the bifurcated leaf-blade, which is very long and narrow, is itself in no case inflected. Glands are borne, not only at the ends of the tentacles in this species, but " on both upper and lower surface of the blade, there are numerous minute, almost sessile glands, consisting of four, eight, or twelve cells." "* There are also on the backs of the leaves of this species, a few tentacles near the margins. These tentacles are remarkable in possessing no power of motion, but even had they this power, they are generally too short to bend round to the upper surface of the leaf. In their present situation, they seem to be of little use; and I)arwin regards these and the sessile glands, as vestigial structures, which have been lost in other species of the genus.

"Darwin "Insectivorous Plants," w. 282. 
Splendid specimens of this plant are to be found at the head of Paterson's Inlet (Stewart Island). Another well-known and readily accessible habitat is the Bluff Hill. Mr. G. Mr. Thomson experimented on specimens of $D$. arcturi, from the bogs on the top of Maungatua." He consider's that, owing to its frequent complete immersion in wet weather, it is seldom to be found in its native habitat with insects on the leaves. However, he found that four specimens of Aphis (blight) from rose leaves were completely digested in about four days' time by a single leaf of $D$. arcturi, though young leaves were easily sickened by an overdose of meat.

The method of pollination in the New Zealand species does not seem to have been observed, though it is probably of considerable interest.

\section{Saxifragaceae.}

\section{The Currant-tree Family.}

Distribution.-A large family, containing many beautiful Alpine species. The London Pride, or None-so-Pretty (Saxifraga umbrosa) is used as a border edging in English gardens. Mauy other plants of the family are cultivated in rockeries, and some are remarkable for the chalky crust which forms on the margins of their leaves. The British Grass of Parnassus (Pamassus palustris) is one of the most beautiful of bog plants. The Currant and the Gooseberry are largely cultivated for their fruits. The New Zealand genera have all woody stems.

Keyl to the Genera.

1. Leaves opposite. Leaves alterna,te.

2. Flowers in panicles.

Flowers in racemes.

3. Ovary supexior.

Ovary inferior.

4. Flowers racemose. Petals overlapping in hud. Flowers panicled. Petals touching in bud.

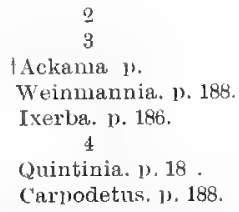

Trans. N.Z. Inst. Vol xili., p. 261.

t Not further described. 


\section{Genus Quintinia.}

Shrubs or trees with alternate leaves, and axillary or terminal racemes of white or lilac flowers. Calyx-tube 5-toothed. Petals 5; stamens 5. Seed winged. Q. serrata and Q. acutifolia are both endemic in New Zealand. (Name in honour of La Quintinie, a French Botanist). $2 \mathrm{sp}$.

\section{Quintinia serrata (The Serrated Quintinia).}

A small tree, sometimes $20 \mathrm{ft}$. in height. The young shoots are extremely viscid, and the whole plant is covered with small whitish scales. Leaves

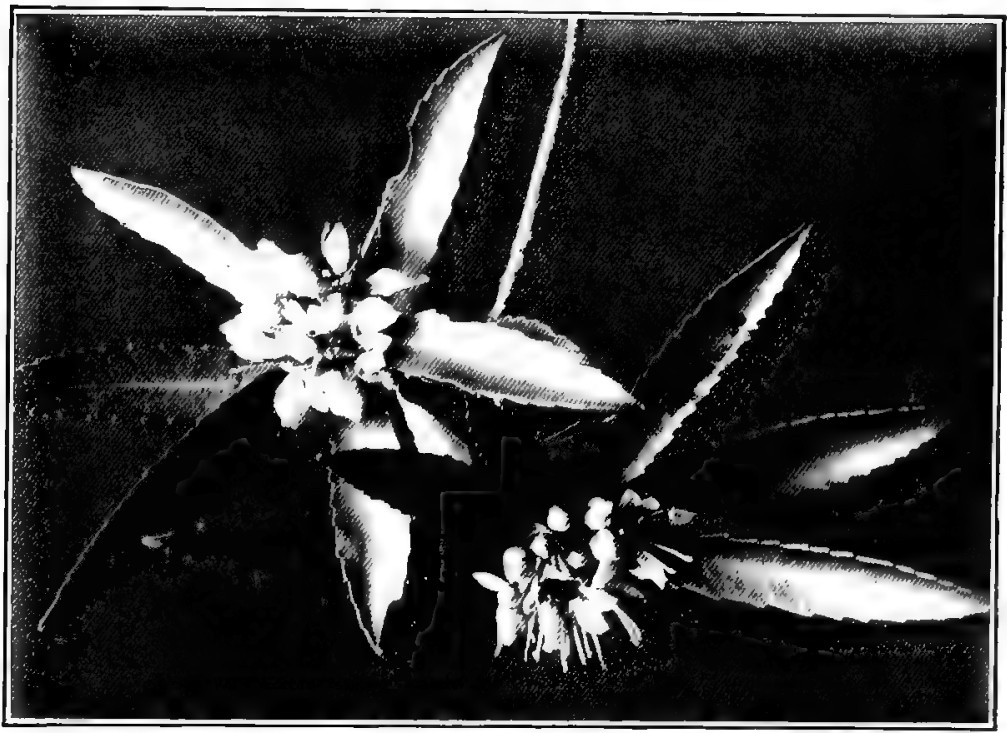

Fig. 54. Ixerba brexioides ( $\frac{1}{3}$ nat. size)

3 in.-6 in. long, oblong, roughly serrate, leathery. Flowers $\mathrm{z}$ in, in diameter, pale-lilac. Racemes axillary, 3 in.-4 in. long. Called by settlers New Zealand lilnc. Maori name, Kumarahou. North Island only: Auckland, Hawke's Bay, and Taranaki. Fl. Oct.-Noy.

\section{Genus Ixerba.}

An evergreen tree, with thick, leathery leaves, and flat panicles of white flowers. Calyx 5-lobed; petals 5; stamens 5. (Name an anaram of Brexia.) $1 \mathrm{sp}$.

\section{Ixerba brexioides (The Brexia-like Ixerba).}

A beautiful tree, sometimes $70 \mathrm{ft}$. in height. Leaves $3 \mathrm{in.}-7 \mathrm{in}$. long, coarsely-serrate, $\frac{1}{8}$ in. -1 in. broad. Flowers $1 \frac{1}{2}$ in. across. Petals waxy, white, 


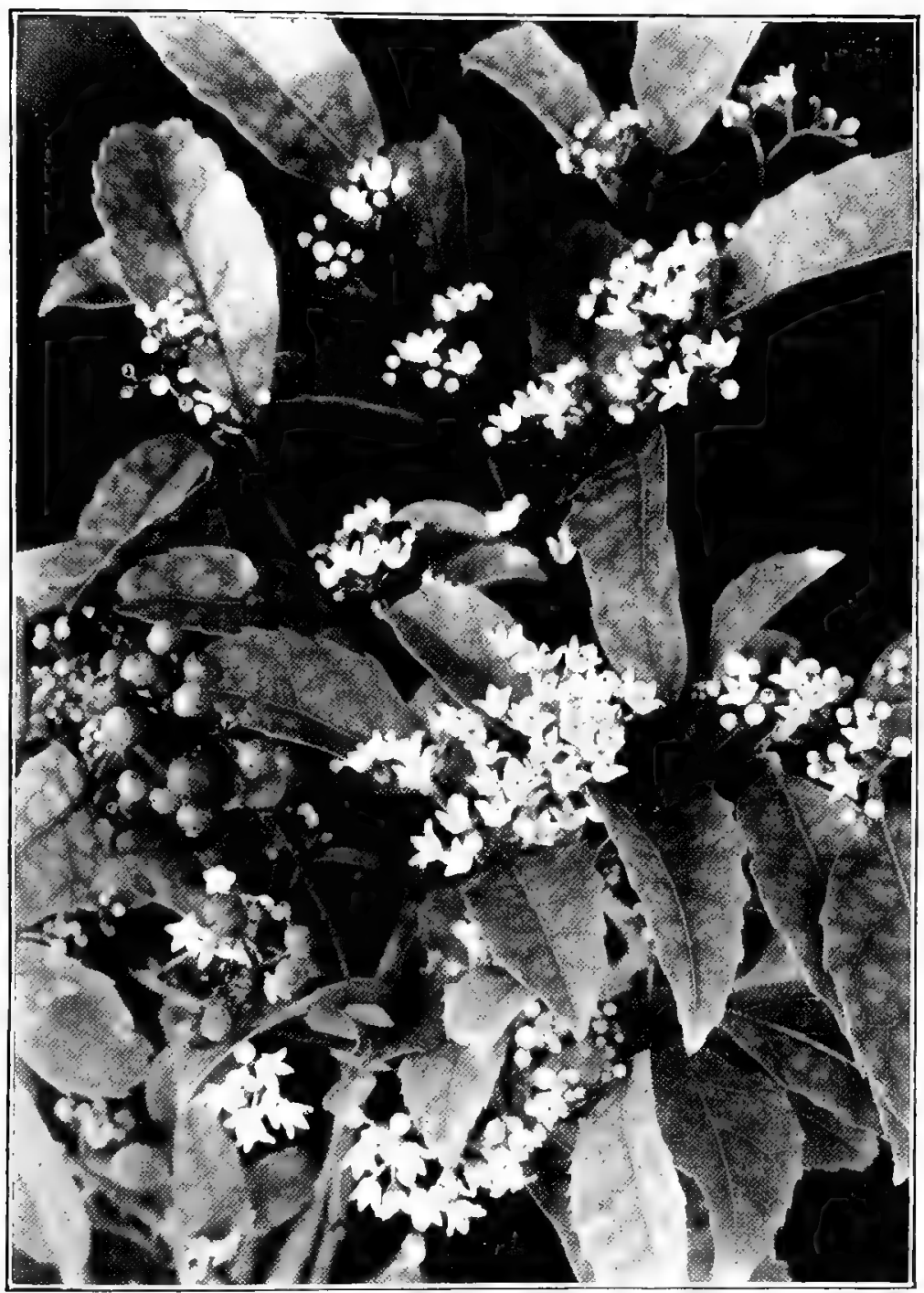

Fig. 55. Carpodetus serratus ( $\frac{2}{3}$ nat. size). 
pointed. North Island from Whangaroa to Hawke's Bay. In woods, not conmon. Maori name Tawari. Fl. Nov.-Jan.

Kirk considers this to be perhaps the most beautiful tree in the flora. This and the following genus are endemic.

\section{Genus Carpodetus.}

A shrub or tree, with alternate leaves, and axillary panicles of white flowers. Calyx 5-6 lobed; petals 5-6; stamens 5 or 6, inserted with the petals. Fruit round, fleshr, girdled by the calyx. (Name from the Greek in allusion to the fruit being girt by the calvx-limb). $1 \mathrm{sp}$.

\section{Carpodetus serratus (The Serrate Carpodetus).}

A curious, flat-topped tree, about $20 \mathrm{ft}$, in height, with branches spreading like a fan. Leaves and branches slightly hairy. Leives beautifully veined and marbled in appearance. Flowers very fragrant, small, white, in broad cymes, hidden amongst the leaves. Fruit the size of a pea, black when ripe. This fruit is very slow to ripen, taking nearly twelve months to come to perfection. As is the case with many New Zealand plants, flowers and ripe fruit may be seen together upon the tree. Found from North Cape to Stewart Island. Fl. Nov,-Mar,

The native name Puta-puta-weta is derived from the fact that the curious and repulsive insect known as the Weta usually chooses the Carpodetus as a fit tree in which to bore its holes. In the North Island, trees of this species are rarely cut down unperforated by the longitudinal galleries of these insects, which are frequently discovered in their holes. Puta-puta literally signifies full of holes. Another name by which it is known is that of Punaweta. In the Uriwera country it is called Kai-weta (i.e. weta food). The weta, or Marri Devil, is a large orthopterous insect of the genus Deinacrida.

\section{Genus Weinmannia.}

Shrubs or trees, with opposite leaves, and regular flowers. Calyx-tube 4-5-partite; petals 4-5; stamens 8-10, inserted with the petals. Fruit a capsule. A large genus of about 50 species, found chiefly in tropical countries. (Named after Weimann a German writer). $2 \mathrm{sp}$.

Weinmannia silvicola (The Forest-loving Weinmannia).

A tree with dark-coloured bark, sometimes rising to a height of $70 \mathrm{ft}$. Leaves opposite, very variable in form, unequally pinnate, or 1-3 foliolate; 
leuflets in from 1-9 pairs. Flowers in slender racemes, 2 in.-6 in. long. Single flowers $\frac{1}{12}$ in. across, white. Capsule shining. Seed with a tuft of hairs at either end. North Island. Fl. Jan.-Feb. Maori names, Tawhero, Kamahi.

\section{Weinmannia racemosa (The Racemose Weinmannia).}

A tree, from $70 \mathrm{ft}$. $90 \mathrm{ft}$. in height, with larger leaves and flowers than those of W. silvicola. Leaves coriaceons, serrate, usually 1 -foliolate, though young shoots often develop 3 -foliolate leaves. Racemes stout, erect, 1 in.-4 in. long. Flowers white $\frac{1}{6}$ in. across. Both islands. Fl. Jan.

\section{Pittosporaceae.}

\section{The "Matipo" Familt.}

Distribution.-A small family, chiefly Australian. All the New Zealand species are endemic. The North Island is richer in species than the South. Some of the Australian species are cultivated for their flowers and coloured berries.

\section{Genus Pittosporum.}

Elowers regular, axillary or in terminal umbels; dark-purple, red, or yellowish green. Petals often recurved. Capsule woody. Some of the species were known to the Natives as Mapau. $18 \mathrm{sp}$.

\section{Pittosporum tenuifolium. (The Thin-leaved Pittosporton).}

A small tree, with black bark, and flowers of so dark a purple as to ippear at times almost black. The branches give out a pungent odour when broken. Leaves pale-green below, often reddish above, undulate, $1 \mathrm{in} .-3 \mathrm{in}$. long. Capsule 3-valved. A very variable plant, of which there are four named kinds. Fl. Sept.-Nov.

This species is largely used for the formation of ornamental hedges, and is then called the "Matipo." This is a misnomer, as the Maoris apparently applied this name to a species of Myrsine. P. tenuifolium was called by them the Tawhiwhi. The fragrant gum taken from it was collected and hung round the neck in a sachet ( $v$. Aciphylla Colensoi). The plant is evidently pollinated by insects. The flowers are bright purple at first, but become darker, and finally almost 
black. Small drops of nectar are to be found at the base of the corolla. Mr. G. M. Thomson* is in error in saying that there is no perceptible fragrance. At night the flowers diffuse a sweet odour that fills the air for many yards around. This scent is evidently intended to attract night-flying insects. It is strange, therefore, that the flowers should be so dark in hue, for most night pollinated flowers are of a bright white colour.

Its dense pale-green foliage, black twigs, and shapely form, make it one of the most attractive of the smaller native trees. For some unaccountable reason, it is known to gardeners as P. nigrescens.

Pittosporum obcordatum. (The Obcordate-leaved Pittospormm).

A small tree, with divaricating branches, small leaves, and white flowers. Eruit not seen.

This plant was first collected by Raoul about 1842 . He reported it from Banks' Peninsula, and it has been sought for there by numerous later botanists, but never found. For sixty years the plant was not again met with, and was then found near Kaitaia by Messis. Mathews and Carse. As Raoul had visited this district, it is therefore very probable that the habitat given in the first place was wrong. It is the only New Zealand species with white flowers.

This error in the habitat has led Diels into supposing that the smallness of the leaves in this species is due to its inhabiting " one of the coldest districts in the wide area of distribution of the genus." Even had the plant been found at Akaroa, this statement would scarcely have been correct, for Akaroa has a mild climate, with only very light frosts. P. tenuifolium var. fasiculatum however is found in Preservation Inlet, in South-west Otago, where the climate is much more severe, while $P$. rigidum is sub-alpine.

\section{Pittosporum cornifolium (The Cornel-leaved Pittosporum).}

An epiphytal species. This is a beautiful little shrub, with small, drooping terminal umbels of delicate reddish flowers. Flowering stem and buds deep red.

*Trans. XIII. 1. 254. 


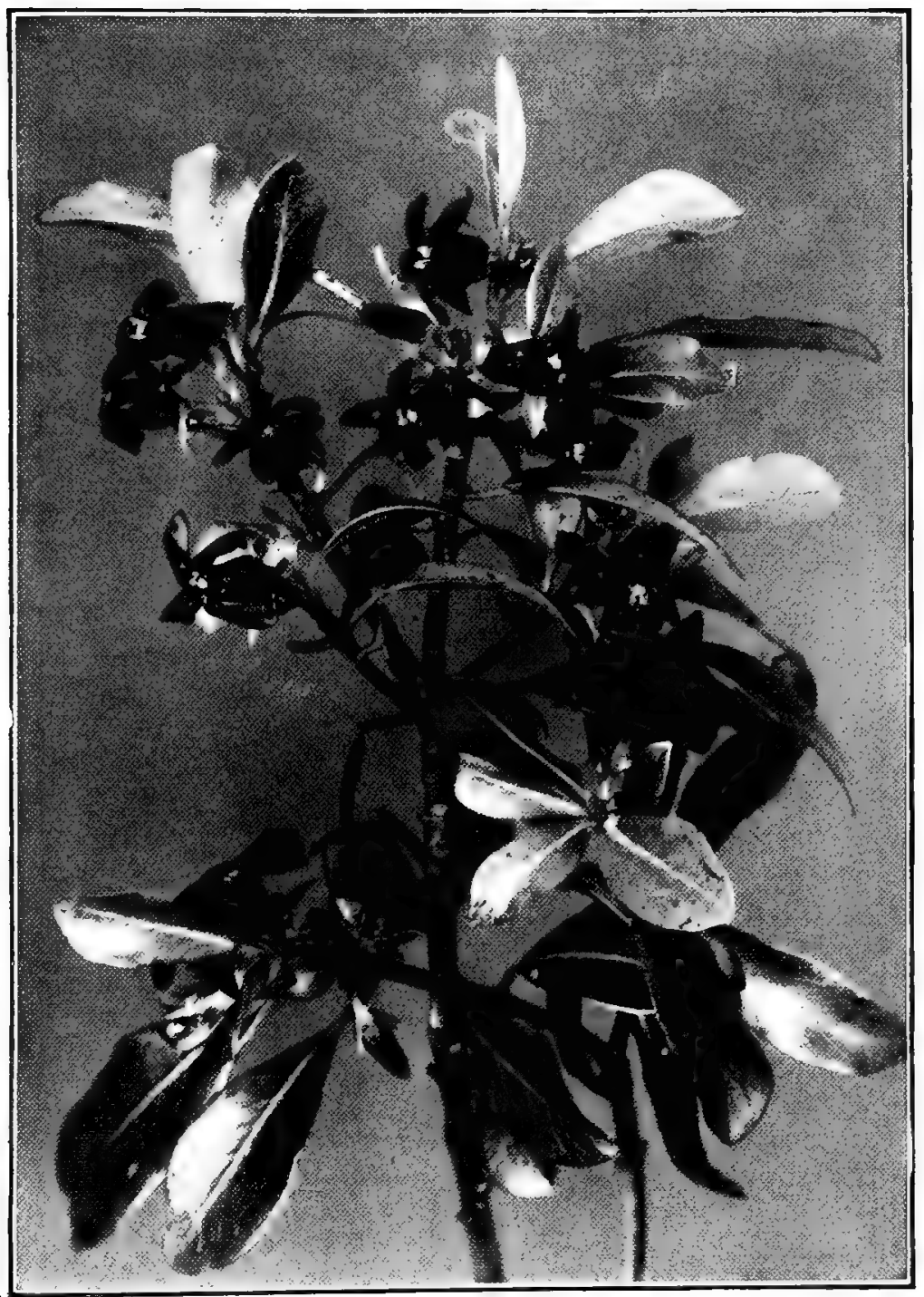

Fir. 56. Pittosporum tenuifolium (承 nat. size). 
Petals 4 or 5 , recurved through half their length bick to the stem, pale-green inside. Sepals 5, very narrow, pale-green. Leaves bright green, coriaceous in the older stage, beantifully veined on the under surface. Capsule 3-ralved; valves of a brilliant orange colour on the inside. North Island chiefly. South Island: Pelorus Sound, and Titi Island. Fl. Sept.

Pittosporum comifolium, though possessed of lather insignificant flowers of a dull purple, has very showy seeds. These,

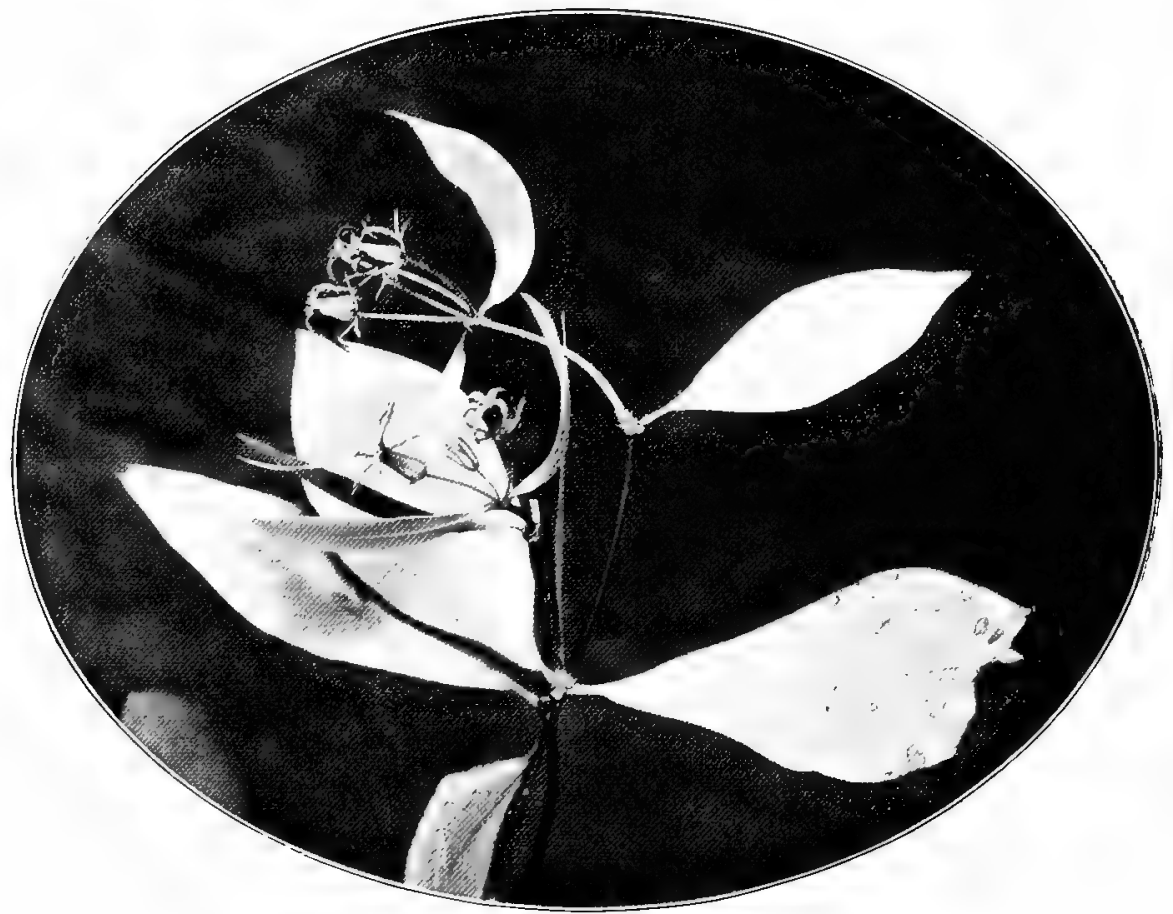

Fig. 57. Pittosporum cornifolium-Flower (z nat. size)

as in other plants of the genus, are imbedded in gluten, which, in this case, is of a yellow colour. The seeds themselves are blackish purple, and when the capsule opens, it discloses the inner side of the valves, which are of a bright orange. The combination of colours is very striking. It is probably intended to attract birds, but, apparently, no investigation has. been made to ascertain whether the seeds pass uninjured 


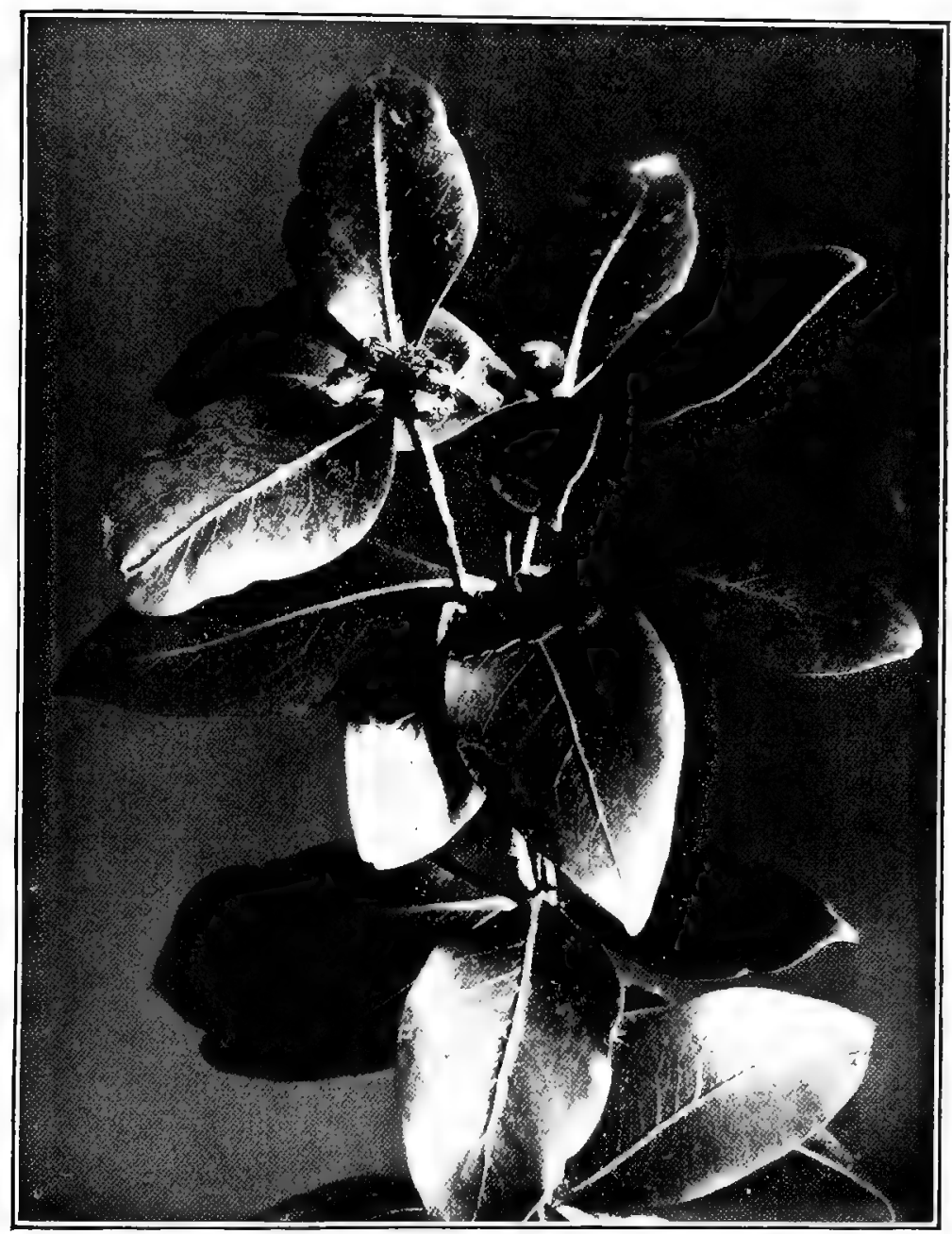

Fig. 58. Pittospornm cornifolium-Fruit ( $\frac{8}{3}$ nat. size). 
through their digestive canals, or in what way they are distributed by them.

\section{Pittosporum Kirkii (Kink's Pittosponum).}

One of the most benutiful species. Bark reddish-purple. Flowers in terminal umbels. Leares narrow-linear, 2 in.-5 in. long. Epiphytal. North Island. Ascends to nearly 3,000 feet.

\section{Pittosporum crassifolium (The Thick-leaved Pittosporum).}

A tree, with black bark. Shoots, sepals and under-surface of leaves covered with close white hairs. Leaves coriaceous. Valves downy. Flowers in terminal umbels, often solitary, deep-purple, nearly $\frac{7}{2} \mathrm{in}$. long. Capsule round, $2-4$ valved. North Island, chiefly on the East Coast. Fl. Sept.

This is a sea-side plant, and, like most species growing in such a position has the epidermis and cuticle of the leaves thickened to protect it from excessive transpiration.

\section{Pittosporum Eugenioides (The Eugenia-like Pittospornm).}

A tree sometimes $40 \mathrm{ft}$. in height, glabrous, with large corymbs of fragrant flowers of a greenish-yellow hue. Leaves $2 \mathrm{in} .-3 \mathrm{in}$. long, broadly oblong, usually waved at the margins. Bark white. Capsules 2-3-valved. Both Tslands. Fl. Sept.-Oct. Maori name Tarata. (Name from Eugenia, a genus of myrtles).

A beautiful tree whose pale-green leaves with undulating margins, emit, when bruised, a lemon-like odour. The delicate venation and light-coloured, almost white, midrib add to the beauty of the leaf. The Maoris mixed the resinous exudation from the bark with the juice of the sow-thistle, and worked it into a ball, which they chewed. In October the tree produces masses of yellowish-green flowers, whose heavy honied odour is almost sickly in its intensity. According to Mr. G. M. Thomson, the plant is probably often self-pollinated; but $\mathrm{Mr}$. Kirk points out in his Forest Flora, that, though stamens and pistils are always present, one or other is often abortive, so that the flowers are often practically unisexual.

The wood of this species, like that of the other species of the genus, is almost worthless. The tree is often cultivated for its beauty, and is sometimes-though not so often as $P$. 
tenuifolium-used to form an ornamental hedge. It is known by a variety of names amongst the colonists, such as Mapau, White Mapau, and even Maple and Lemon-tree. The Maori name seems to have been Tarata, but it is also called the Мараи.

\section{Pittosporum Ralphii (Ralph's Pittosporum).}

A somewhat similar species to $P$. crassifolium, but distinguished from it by the broader leaves with slender petioles, the shorter peduncles, and smaller capsules. Fl. Nov.-Dec.

A beautiful, somewhat laxly branched shrub $15 \mathrm{ft}-20 \mathrm{ft}$. high, found chiefly in the central district of the North Island from the Wanganui to Tolago Bay. It grows abundantly in the Christchurch Public Gardens. Its dark-crimson fascicled little flower bells with their slightly emergent yellow anther tips, resting on the downy white young foliage, make it, when in bloom, one of the most attractive of our larger shrubs. The ripe introrse anthers may often be found in contact with the viscid stigmas, so that the plant is probably frequently self-pollinated.

\section{Rosaceae.}

\section{The Rose Family.}

Distribution.-An almost universally distributed family, though most abundant in the temperate regions of the northern hemisphere. The plants of this family are remarkable for the sweetness of their fruits, and the beauty of their flowers. Hydrocyanic acid is contained in the seeds, leaves, and young shoots of the Pruneae and Pomeae, but the other tribes possess only harmless juices. The rose, the apple, the peach, the cherry, the strawberry, the plum, all belong to this wide-spread and useful family.

1. Climbing, prickly shrubs.

Key to the Genera.

Herbs with simple or pinnate leaves. Achenes many or few.

2. Herbs with pinnate leaves. Achenes 1 or 2 .

Leaves simple or pinnate. Achenes many.

3. Leaves pinnate. Styles short.

Leaves simple or pinuate. Styles elongated.

Rubus, p. 196 2

Acrena, 1). 201 3

†Potentilla.

tGeum.

tNot further described. 


\section{Genus Rubus.}

Scrambling, thorny shrubs, with alternate leaves, often palmately divided. Calyx 5-lobed, petals 5, stamens many. Fruit a cluster of fleshy drupes, on a cone-shaped receptacle. New Zealand species diœcious. (Name from the Latin for a Bramble.) $4 \mathrm{sp}$.

The New Zealand Bramble is of the same tribe as the raspberry and the blackberry, though its fruits are not so fine. Its twining stems and hooked prickles form one of the chief obstructions to a journey through the bush. These hooks are so placed as to allow the plant to slip easily up any support, though they will not permit it to be dragged down. The centre of the female flower is filled with carpels, each one of which develops in the autumn into a small red or yellow fruit. The aggregate of these little fruits forms the berry, which is pleasant to the taste, and is often made by settlers into a preserve. A sweet juice, which drops freely from the cut stems, is drunk by bushmen when thirsty. The native name, Tataramoa, signifies a heap of prickles. The Maoris have also bestowed this name upon the English furze, and upon brambles generally.

The New Zealand species of Rubus do not present the bewildering variety of form that is found in the genus in Central Europe; but they nevertheless add considerably to the perplexities of the local botanist. Nor have these perplexities been reduced by the carelessness of various writers on New Zealand plants. Thus A. R. Wallace" tells us that "In New Zealand the prickly Rubus is a leafless trailing plant, and its prickles are probably a protection against the large snails of the country, several of which have shells from two to three and a half inches long." Such an error could scarcely have been made by anyone familiar with the natural history of the country. Rubus is one of the commonest species on the edge of the forest; and the snails referred to belong to rare and disappearing species-rarely, if ever, found

\footnotetext{
" "Darwinism," Colonial Edition, p. 433.
} 


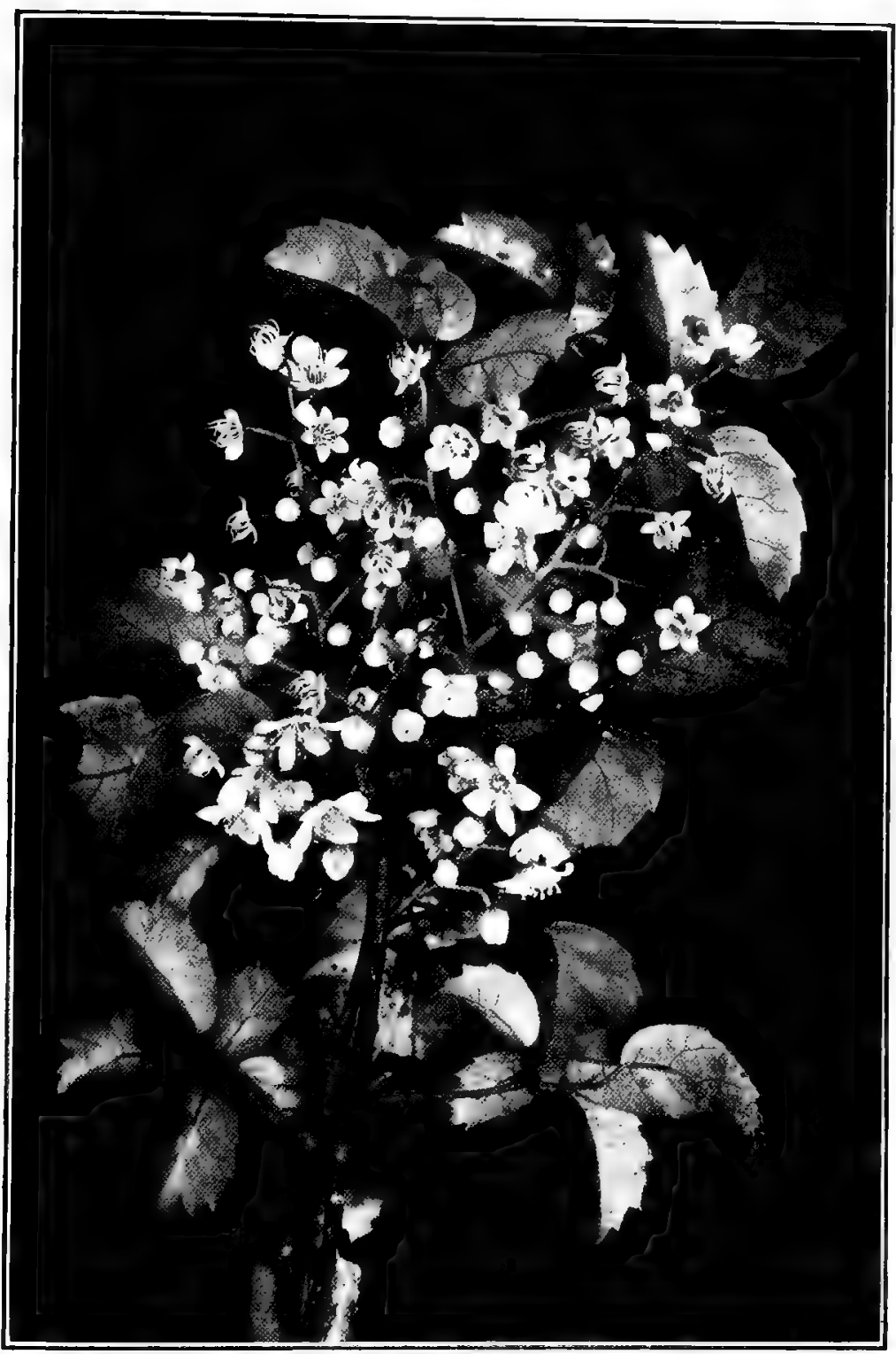

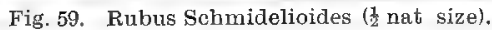


in the neighbourhood of Rubus. The correct explanation is given by $\uparrow$ Kerner. It is, perhaps, worth quoting :

“A plant distinguished by its unusually rich development of barb-like spines, and deserving special mention here, is the New Zealand bramble, Rubus squarrosus ( $R$. cissoides). Each of its leaves is divided into three portions, each being provided with a tiny blade at its apex; these three portions, as well as the leaf-stalk, are green throughout their entire length, and beset with yellow pointed prickles, which anchor so firmly in the intertwined bushes and shrubs, that a wholly inextricable tangle is the result."

The passage quoted is provided with a good illustration of a spray of $R$. cissoides.

Some confusion has also been caused in the determination of the species, by the neglect of most botanists to notice carefully enough the relation between the form of the plant and its habitat.

Dr. Cockayne has, however, given a full account of the development of $R$. cissoides* and a description of the various forms which it assumes. Like the other New Zealand species, in the forest it is a liane climbing by prickles, and there it is provided with lanceolate acuminate leaflets. The flowers are yellowish, and the fruit red. When found in the open, it is a leafless mounded bush, consisting of intertwining stems and midribs, with far more numerous prickles, than it has, when growing in the forest. This is the stage described above by Kerner. An extraordinary fact about this depauperated form is, that it has never been known to produce flowers or fruit. This is probably due to the fact that the leafless plant is merely an arrested stage in the development of the mature form. Dr. Cockayne has also suggested that the absence of flowers may be due to the destruction of the young growing points in exposed situations. 


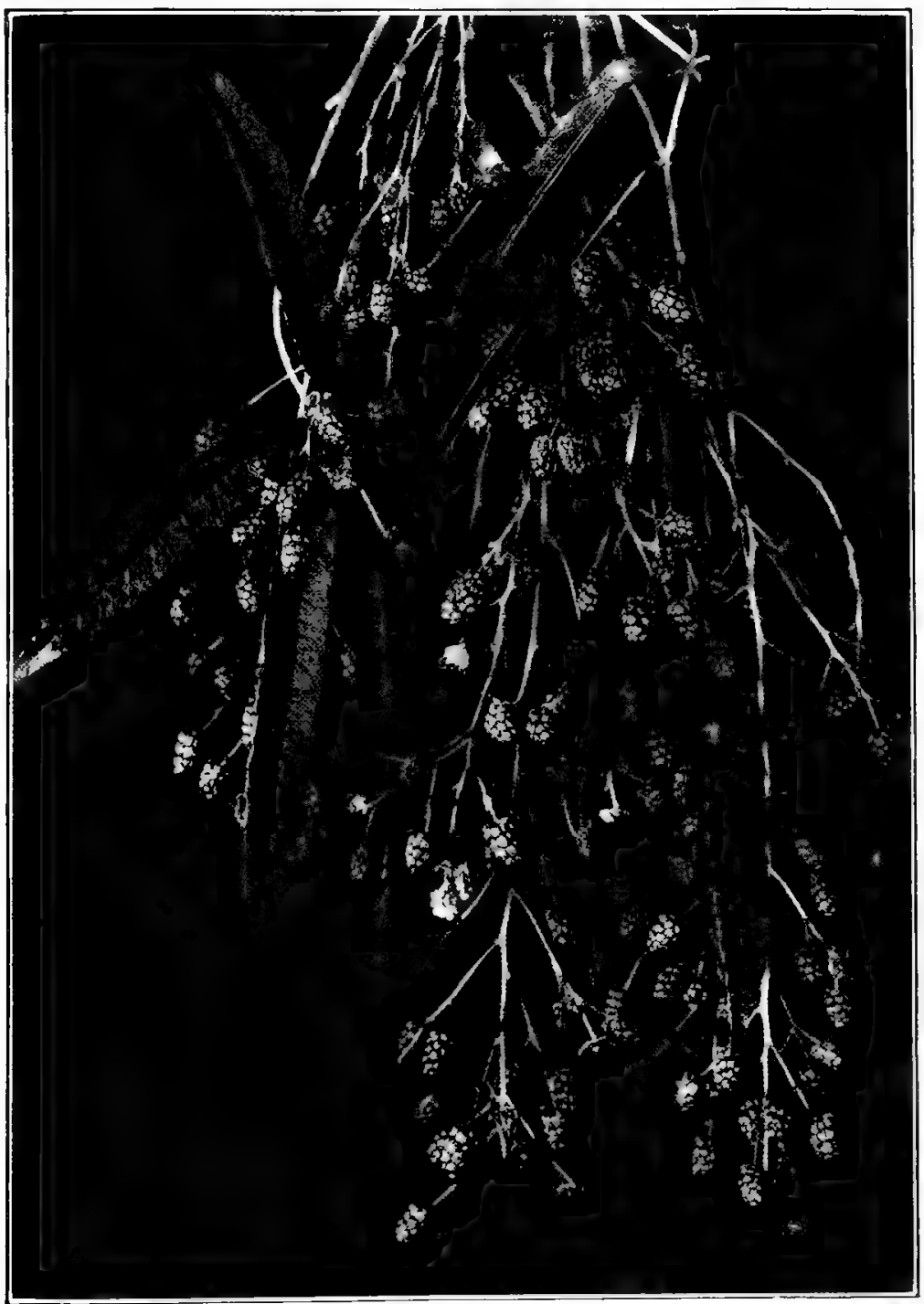

Fig. 60, Rubus australis-Fruit ( $\frac{1}{3}$ nat. size). 
Be this as it may, it is at least clear that, in one generation, the plant changes from the leafy flowering liane of the forest, to the leafless, compact, flowerless xerophyte of the open country. As this form is unable to propagate itself, it has to be perpetuated by escapees from the forest limits. The long green twining stems of this variety with their yellow hooks have a fascinating beauty, that must render the plant most attractive to all lovers of nature.

The species of Rubus are generally known to colonists as bush lawyers, apparently because it is much easier to get into their clutches than out of them. Domett, with less than his usual benevolence, refers to them as

"That vile twine of prickles fine,

Which, if it touch you, cuts and clings

Where'er you pass through brier and bush."

Yet, in spite of this general condemnation, Rubus australis is one of the finest ornaments of the fringe of the forest, when in early summer it flings its great panicles of heavily-scented, snow-white flowers over every bush and tree on the forest's edge.

\section{Rubus australis (The Southern Bramble.)}

A lofty climber. Lenves very variable; the midribs armed with sharp, hooked prickles. Leaflets usually 3-5, in long petioles, toothed. Flowers in panicles, small, pink or white, axillary or terminal, fragrant. Fruit reddish, dry. Both islands: in the bush or on its outskirts. Fl. Sept.-Dec.

\section{Rubus cissoides (The Ivy-like Bramble).}

A much smaller plant than the preceding. Stem without prickles, petioles and midribs with few. Leaflets 3-5-foliate, very narrow, sometimes reduced to midribs. Flowers in slender panieles, 2 in.-4 in. long. Petals yellowish. Eruit very crowded. Eoth islands. Fl. Sept.-Oct.

\section{Rubus Schmidelioides (The Schnidelia-like Bramble).}

A dense bush. Midrilss without prickles. Leaves usually 3 -foliolate, with a longer petiole to the terminal leaf. Leaftets oval, rounded below, coriaceous. Flowering panicles 2-6 in. in length. Petals broud, flowers ? in. across. Fruit yellow, sweet, juicy. 


\section{Rubus parvus (The Small Bramble).}

A slender, prostrate plant, with reddish stems, 12 in.-18 in. long. Leaves bronze in colour, simple, 1 in.-3 in. long, sharply toothed. Flowers few, prickles few. Fruit $\frac{1}{2}$ in.-1 in. long, red, sweet.

This is a beautiful little forest species, hitherto only found near the head-waters of several western rivers of the South Island. The leaves are most delicately veined, and in autumn turn to a beautiful bronze colour. It is, therefore, one of the few New Zealand plants that show autumn tints. Others are Fuschia excorticata and a species of Nothofagus. Here autumn lays no "fiery finger on the woods," and spring does not renew. The lack of these seasonal changes undoubtedly detracts much from the beauty of the New Zealand forests. The colours of the bush, though varied, are as a whole rather sombre, and alter but little throughout the whole circle of the year.

\section{Genus Accena.}

Perennial, prostrate herbs, with dense heads of minute flowers, and spinous fruit. Leaves pinnate, the whole plant often reddish in colour. Calyx 4-5lobed, petals none. Stamens 1-10, rarely 30-40. Calyx-tube bristly, with hooked or barbed spines. These calyces sometimes cling to the wool of sheep in such quantities as to materially damage the fleece. (Name from the Greek for a spine, in reference to the spinous calyces). Maori name Piri-piri. ${ }^{*} 6 \mathrm{sp}$.

\section{Acæna sanguisorbae (The Bidi-bidi).}

Leaflets $8-10, \frac{1}{4} \mathrm{in} .-\frac{3}{4} \mathrm{in}$. long, coarsely toothed. Flowers in globose heads, on peduncles 3 in.-6 in. long. Fruiting calyx 4 -angled, with a long barbed purple bristle at each angle. Stamens 2. Stems prostrate. Fl. Oct.-Jan. (Sanguisorba means blood-stanching, and is in allusion to the supposed properties of the European Sangicisorba or Burnet).

\section{Acæna novae-Zelandiae (The New Zealand Acana).}

Stems erect. Stamens 2 or 3 . Fruiting calyx silky, red, slightly winged. Bristles barbed, reddish purple. Flower-heads larger than in A. Sanguisorbae. Both islands. Fl. Nov.-Jan.

\section{Acæna microphylla (The Small-leaved Acana).}

Chiefly distinguishable by the absence of barbs upon the bristles of the calyx. Flower-stems 1 in.-3 in. long; heads sometimes sessile. Bristles 4, bright red. Both islands. Fl. Nov.-Jan.

\footnotetext{
*This name was applied to other small plants.
} 
The common Acena was called by the Maoris Piri-piri, but colonists frequently corrupt the Maori name, and call the plant Bidi-bidi. As a general rule, the Maori names are more incorrectly pronounced as we go southward from Auckland to Otago. This is largely due to the fact that, in the north, Europeans have been brought into closer contact with the Maoris than in the south. In some few cases, the difference in pronunciation may be due to differences in the Maori dialects. The changes that take place often follow phonetic laws-thus the Maori " $p$ " is softened into the European "b" as above, while " $r$ " is replaced by "I" or "d." Poro-poro (Solanum aviculare) becomes Bulli-bulli, and Puriri becomes Boradi. This also explains such a form as "Kowdie" pine for Kauri pine. Korari - a flax-stalk similarly becomes Koradi or even Kalladi. " $\mathrm{K}$ " is also sometimes altered into "g," thus Kie-kie (Freycinetia Bankii) becomes ghi-ghi. The last vowel in a reduplicated syllable was faintly pronounced in Maori, and often disappears altogether in the European form of the word, e.g., Poro-poro gives Bulli-bull, and Piri-piri gives Bidi-bid.

Thus it is often possible to arrive at the correct Maori form of a word from the aborted European spelling. At the same time the reader shonld be careful not to assume that the Maori plant-names given in the ordinary botanical text-books are completely reliable. Very often they are merely local Maori names, or are names applied wrongly by Europeans, or even merely fanciful terms, invented by some Maori on the spur of the moment to please his botanical inquisitor.

\section{Distribution of the Genus.}

The genus is found only in the temperate regions of the Southern Hemisphere. All the New Zealand species are endemic, with the exception of $A$. sanguisorbae and A. adscendens. These are more widely distributed. A. sanguisorbae is a sub-Antarctic form. It is known from the 
Kermadecs to the Macquaries, and also has been collected in Australia and Tristan d'Acunha, while A. adscendens occurs from Marlborough to the Macquaries, and also in Chili, Fuegia, and the Falkland Islands.

\section{Leguminosae.}

Family of the Pea, Clover, Wattle, etc.

Distribution.- One of the largest of the families, comprising between 6,000 and 7,000 species. Only 26 of these are native to New Zealand, and all of these belong to the sub-order Papilionaceae, though many others have now been introduced, such as the Broom, Gorse, Clover, etc. The New Zealand species. may all be readily recognized by their papilionaceous (butterfly-like) flowers, and long seed-pods. From this family are obtained many vegetables, (e.g. Peas, Beans, Lentils, etc.), while the Vetches and Clovers are useful for fodder. Wistaria, Laburnum and Sweet-Pea are cultivated for the beauty of their flowers. Other plants furnish valuable resins and dyes (e.g. Copal-resin, Gum-arabic, Gum Tragacanth, Balsam of Tolu, Indigo, etc.).

\section{Sub-Family Papilionaceae.}

This is an immense sub-family, abundant in most parts of the world, but poorly represented in New Zealand. Plants belonging to it are best recognized by the shape of their corollas. The flower of the pea may be taken as a typical example. There are five petals, of which the two front ones are united to form the "keel." The two side petals are called the "wings," and the back petal, which is generally large and erect, is called the "standard." Inside the keel will be found the ten stamens. One of these is usually free from the other nine, which are united. Together they encircle the pistil, which consists of a one-celled ovary, with a single style and stigma, and develops into the well-known pod (legume) of the pea. The New Zealand genera are all more or less aberrant. In Sophora the two petals forming the keel are scarcely united, the stamens are all free and the pod is 
1noniliform. In Clianthus the keel is comparatively large and the standard small. Carmichaelia is remarkable for its strange dehiscence. The pod of Huttonella, and of Notospartium, is indehiscent, whilst the three last mentioned genera, together with the aptly named Corallospartium, are nearly leafless brooms.

\section{Fey to the Crenera.}

1. Stamens all free. Flowers large, sellow. Stamens united.

2. Leafless or nearly leafless shrubs. Herbs or shrubs with pinnate leaves.

3. Stem jellow, stout, leafless. Stems green, often flattened.

4. Flowers pinkish-white, pods indehiscent. Flowers white, lilac, or variously coloured. Valves of seed pods falling away.

5. Herlss with pinnate leaves. Flowers blue or purple.

Shrubs. Flowers large, scarlet, in drooping racemes.

Solihora, p. 210.
2
3
5
Corallospartium. 4

Huttonella.

Carmichaelia, p. 204.

TSwainsonia.

Clianthus, 1). 210.

t Not further described.

\section{Genus Carmichaelia.}

Shruls witl grooved flattened branches, leafless except in very young plants. Lalyx 5-toothed; wings auricled at the base. Pods 1-12 seeded. A very remarkable genus, peculiar to New Zealand and Lord Howe's Island. The sides or valves of the seed-pod fall away when the fruit is ripe, and the tiny black or scarlet seeds are left hanging by a slender thread from the bare framework of the pod. Flowers solitary, or in racemes or fascicles, white, red or lilac. (Named in honour of the Cryptogamic botanist Carmichael). $19 \mathrm{sp}$.

\section{Carmichaelia nana (The Dwarf Camichaelia).}

A small, sulb-alpine species, alout 4 inches in height. Branches thin, flat. Leaves not seen. Flowers red, $\frac{1}{4}$ in. $-\frac{1}{8}$ in. long. Racemes 2-3 flowered. Pod oblong, $\frac{1}{3}$ in. long, with a short, straight beak. Seeds 2-4, black. Both islands: in hilly districts. Fl. Dec.

\section{Carmichaelia australis (The Southem Carmichaelia).}

A much-branched shrub, $9 \mathrm{ft} .9 \mathrm{ft}$. high. Branches very flat, with distant, alternate notches. Seedling leaves often 3-5-foliolate. Flowers striped lilac, pale or dark, fascicles 3-12-flowered, very fragrant. Pods oblong with a short beak. Seeds I-4, scarlet. North Island: common. South Island: rare. Fl. Nov,-Dec. 


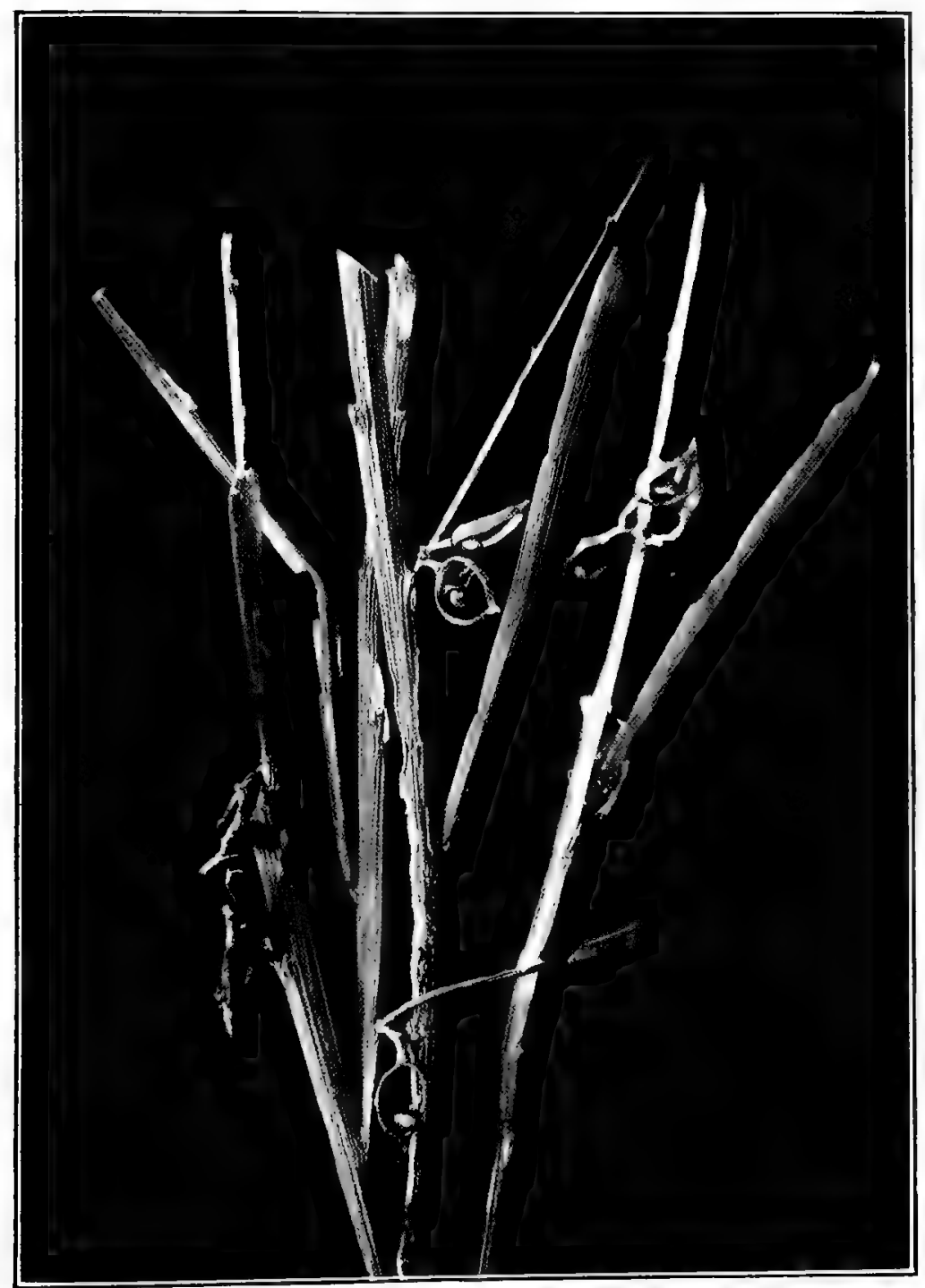

Fig. 61. Carmichaelia australis-Fruit (爱 nat. size). 


\section{Carmichaelia flagelliformis (The Whip-like Carmichaelia).}

A slender shrub, $4 \mathrm{ft}$. in height. Leaves on young plants, 3-5-foliolate. Young shoots much elongated, like whip-eord. Flowers usually fascicled, 3-7-flowered. Pod oblong, with short, stout beak. Seeds 2-4, flat mottled with yellow or red. Both islands, local in the North. Fl. Dee.-Jan.

No genus is perhaps more characteristic of New Zealand than this. The only representative outside these islands is the well-named C.ersul of Lord Howe's Island. In Carmichaelia, particularly in the dwarf species, the reduction of leaf surface has been carried almost to the disappearing point. It is probable that this reduction is due to an attempt to protect the plants from loss of moisture, and not from excessive loss of heat by radiation, as nearly all the forms of the genus are glabrous. There is evidence to show that Carmichaelia was originally a genus of leaf-bearing forest shrubs. C.exsul puts forth its many tender leaves in the moist shade of the famous palm-forests of the picturesque Lord Howe's Island. The New Zealand species, compelled to live in the dry open plains, develop leaves only in their early stages, or when growing in shade. Some of the dwarf forms (e.g. C. Enysii*), never go through a tu'ue leafy stage, but pass directly into a semi-leafy form with flattened branches, and then into the leafless mature form. They probably represent the last developed type of the genus. The flattening of the branches, which is seen in most of the species, is useful to the plant in various ways. It enables it to obtain a larger accumulating surface, without exposing this surface directly to the hot rays of the mid-day sun. Indeed the chief advantage of a flattened stem over a leaf, for the purpose of assimilation, is that the stem is in a vertical position, and, therefore, transpiration from its surface will not be so great as from the horizontal leaf-blade. Further, the flattened stem gets the full light from the rising and setting sun, when the heating effect is not excessive. In the closely allied, scarcely distinct genus Corallospartium, the stomata are

* Dr, Cockayne. Trans, XXXIII, p. 91. 


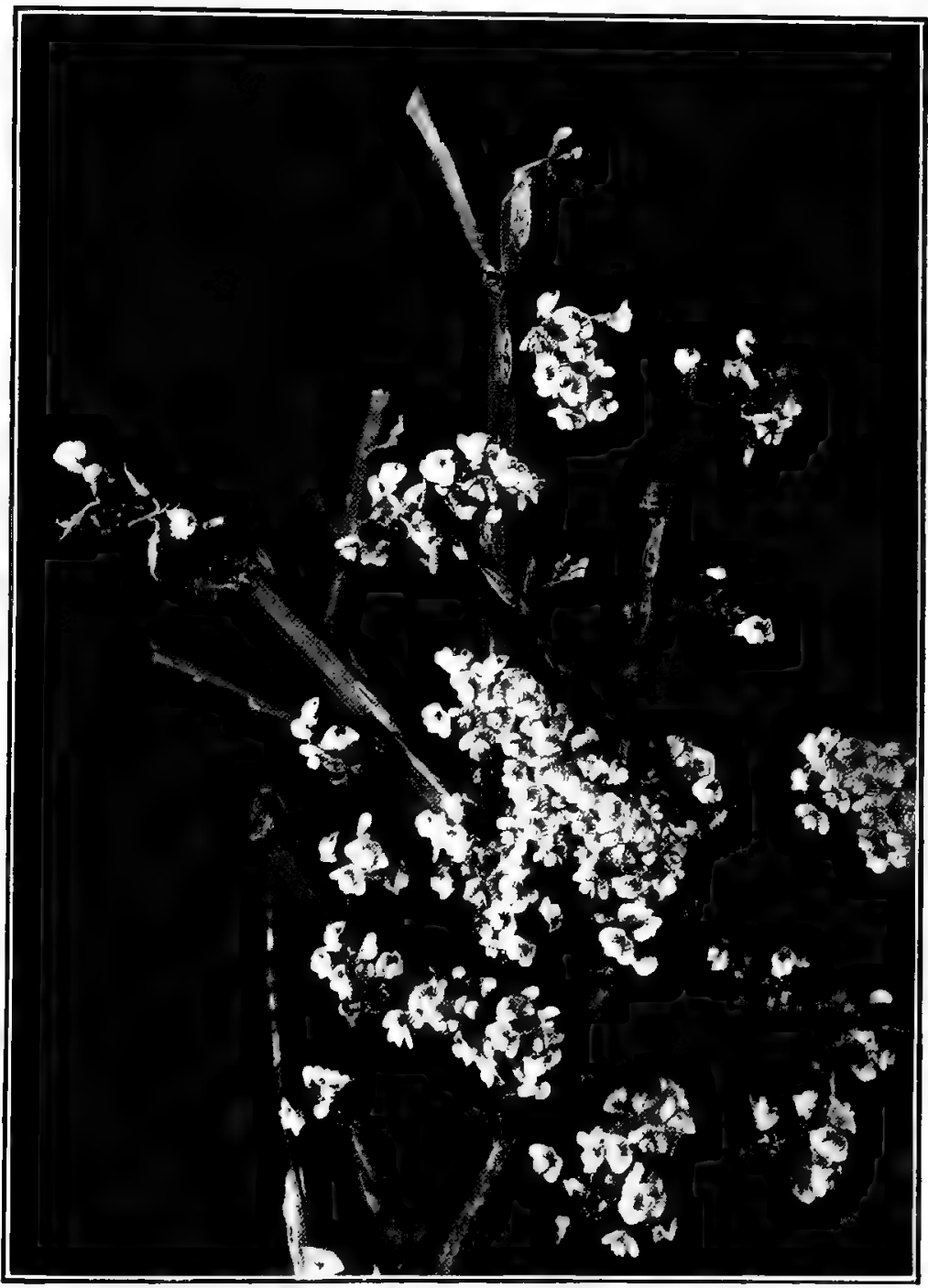

Fig. 62. Carmichaelia australis-Flowers (1 nat. size). 
protected by being sunk in hair-lined grooves in the stem. According to Diels, the stiff branches of this genus prevent any shaking which might promote evaporation; and the unusually well developed cuticle supplies further protection against excessive transpiration. The stem is of a remarkably bright yellow with deep grooves of a greenish hue running down it longitudinally.

A leafless plant, such as C. australis, with long slender, rounded branches, is sometimes termed a switch plant. The dwarf species form patch-plants (v. Raoulia) in river-beds, and on dry mountain sides. Their habit is extremely singular, and they frequently give the impression of having been comparatively tall plants that have been mown down by the scythe, or of plants that have been suddenly arrested in their growth. The squat, broad stems are singularly ungainly.

The genus is characterized by the strange method in which the pod opens to allow the seeds to escape. The sides fall away from the thickened edges, which are left on the plant, and form a frame enclosing the seeds. These seeds are suspended by slender threads, and are generally black or of a brilliant red. Sometimes they are mottled. The number in a pod varies from one to twelve. Frequently there are only one or two. Occasionally in their shape and markings they resemble lady-birds.

The flowers of Camichaelia, though small, are often very dainty in appearance, and beautiful in colour and markings. C. australis has thick clusters of delicate lilac blossoms, striped with darker lines, and possesses a sweet scent. Many of the species are yet insufficiently known.

The flowers of Huttonella, Notospartium, and Corallospartium are very similar to those of Carmichaelia. Both species of Notospartium are beautiful and graceful plants, now rare. Corallospartium is one of the most remarkable plants of the flora. Its long, yellow, coralloid, switch-like stems are almost unique amongst flowering plants. 


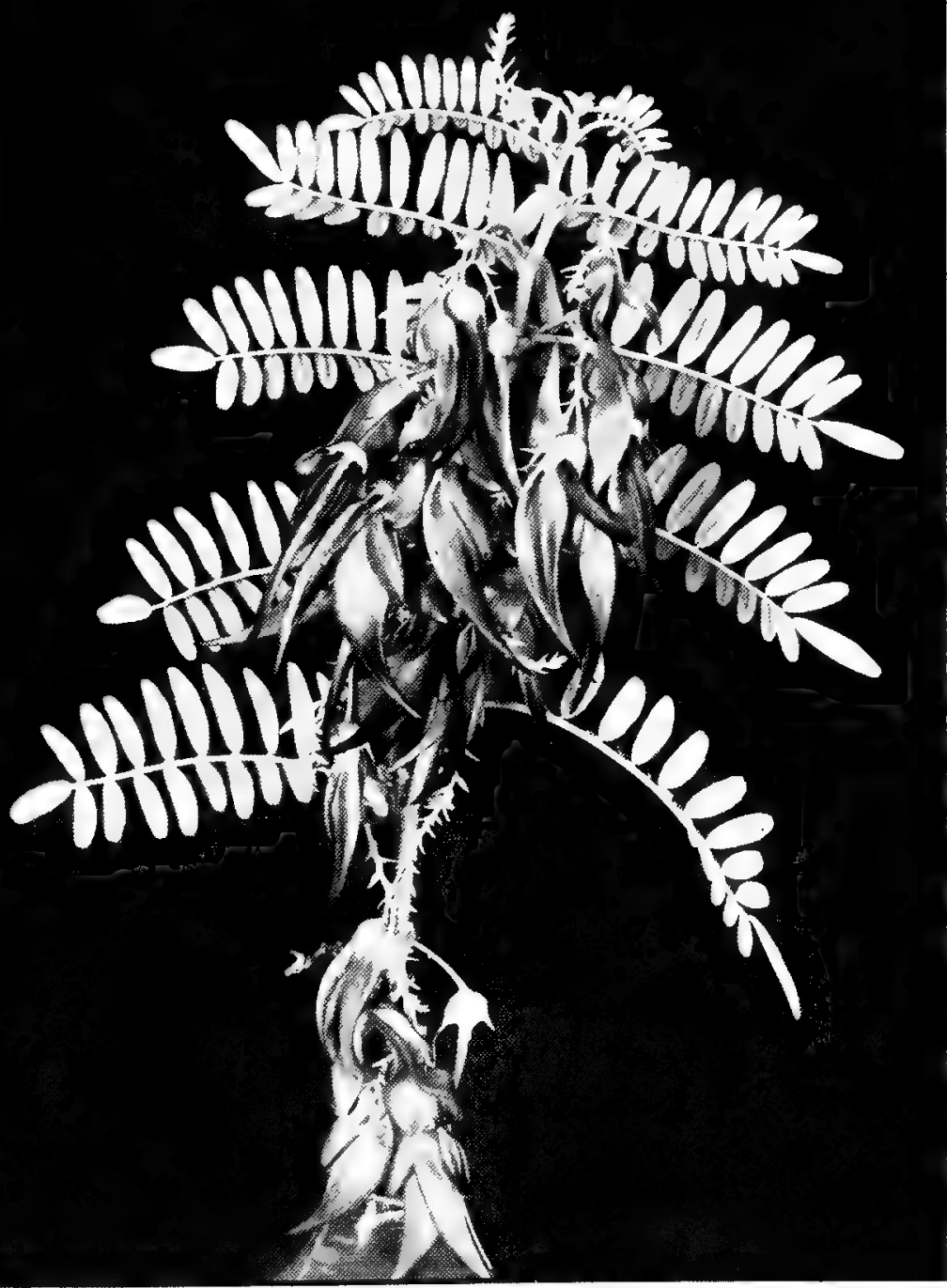

Fig. 63. Clianthus puniceus ( $\frac{1}{3}$ nat. size). 


\section{Genus Clianthus.}

A small genus of perhaps four species. The New Zealand species is endemic. Small trees with pinmate leaves, and conspicuous flowers. Calyx 5-toothed, Wings half as long as the keel. Pod oblong, 2-valved, many seeded. (Name from the Greek, signifying a reclining flower, in allusion to the recurved standard).

\section{Clianthus puniceus (The Scarlet Clianthus).}

A drooping undershrub, with silky branches. Leaves 4 in.-6 in. long, pinnate. Leaflets in 8-14 pairs. Flowers in long, pendulous racemes, bright scarlet, 2 inches in length. Auckland Province, rare; chiefly near old Maori cultivations. Fl. Aug.-Oct. This tree is known as the Red Kowhai, Parrot's Ball or Kaka's Beak. Native name Fonvari-ngutu-kaka, signifying the Parrotbeaked kowhai. It is also called in the Uriwera Country Ngutu-Kakariti, the I'arroquet's Beak. Fl. Aug.-Nov.

This is one of the most gorgeous of our flowering plants. Its flowers in their brilliancy of colour form a marked contrast to the greens, whites, and yellows, of most other New Zealand species. Though such a showy plant, it is scarcely a graceful one. The heavy, dark-green, glossy, pinnate leaves do not set off the scarlet flowers to the best advantage. However, the plant is widely cultivated, and when introduced into England in 1831 , specimens of it were sold at $\$ 55$ each. It grows well in Dunedin, but is apt to be cut back in winter by the more severe and continuous frosts of Christchurch.

The plant-always rare-is now scarcely ever seen except in gardens, and is becoming extinct on the mainland, though still to be found on the cliffs round Lake Waikare-Moana, and on the Great Barrier Island. At one time it was comparatively common in the East Cape district, and in the early days it was seen near the Bay of Islands. It would probably have been long ago exterminated, had it not been cultivated by the Maoris, and also by the Europeans. The flower's are pollinated by birds (cf. Phormium, Sophora, Vitex, etc.)

\section{Genus Sophora.}

Trees with pinnate leaves, and conspicuous flowers. Calyx inflated. Standard very broad; wings shorter than the keel. Stamens 10, free. Pod angled or 4-winged; seeds oblong. (Name from Sophero, the Arabic for at papilionaceous-flowered tree.) 


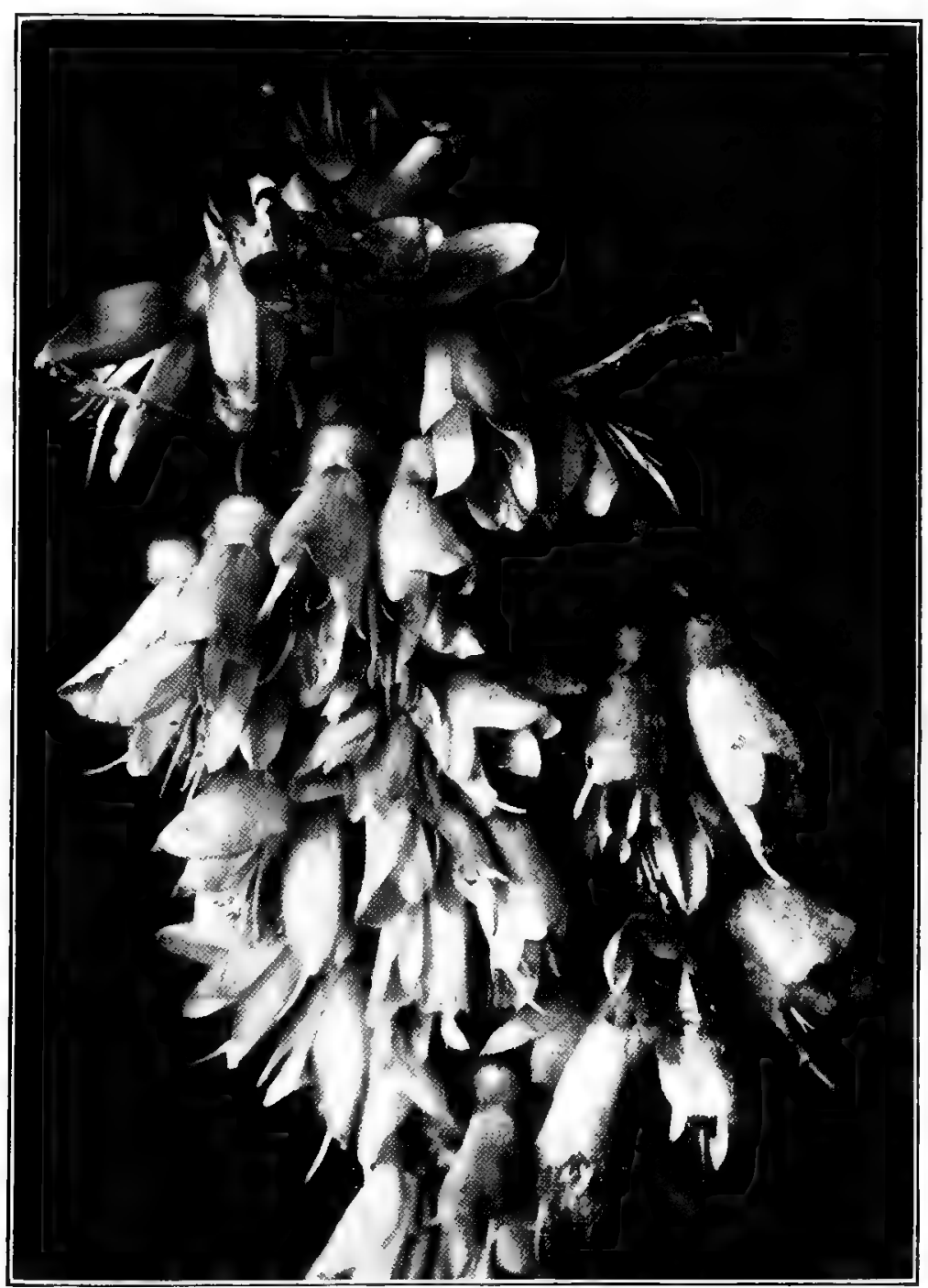

Fis. 64. Sophora tetraptera ( $\frac{1}{5}$ nat. size). 


\section{Sophora tetraptera (The Yellow Kowhai).}

A handsome tree, sometimes $40 \mathrm{ft}$. in height, with pinnate leaves and large gold-coloured blossonis. Leaves curled in bud, like the fronds of a fern. The trees are often bare of leaves in the early spring, and the flowers are produced in the axils of the leafless branches. Leaflets very rariable, in from 6-40 pairs. Calyx greenish; stamens hanging loosely below the petals. Standard scarcely reflexed. Pods $1 \mathrm{in},-5 \mathrm{in}$. long, with four membranous wings. Both islands. Fl. Sept. MIari name Kowhai.

Var. grandiflora. Trunk sometimes $3 \mathrm{ft}$, in diameter. Flowers large, deepcoloured; standard slightly reflexed. Leaflets in 10-25 pairs.

Var. microphylla. Standard not reflexed. Stamens exserted. Leaflets in 25-40 pairs. Flowers rather broader than in granditiora.

Var. prostrata. Stems prostrate. Flowers small. Stamens exserted. Leaflets in $2-4$ pairs.

We have followed the usual practice of botanists in separating the New Zealand species of Sophora into three varieties, but this discrimination is by no means satisfactory. The life histories of the various forms are at present insufficiently known, and no doubt, when they are more fully studied, several species will be created. It can scarcely be doubted but that the variety grandiflora is entitled to specific rank. Again, a common North Island form is deciduous, and produces in early spring, before the bursting of the leaves, dense masses of pale yellow blooms. S. microphylla goes through two distinct stages in its development. In the first, it is a flexuose shrub with wiry, yellowish, interlacing stems, and a few small leaves. When the plant is from eight to twelve feet in height this is gradually replaced by the mature form, which has a rounded leafy head, naked trunk, and straight brown branches. Dr. Cockayne informs us that neither the typical form, nor S. grandiftora, goes through the "scrubby" stage, but assumes the mature leafy form at once.

The distribution of S. tetraptera outside of New Zealand is generally given as South Chili, Juan Fernandez, Easter Island, and Lord Howe Island. However, it may be doubted whether one and the same species is to be found in all these widely separated districts. It has been shown again and again, that 


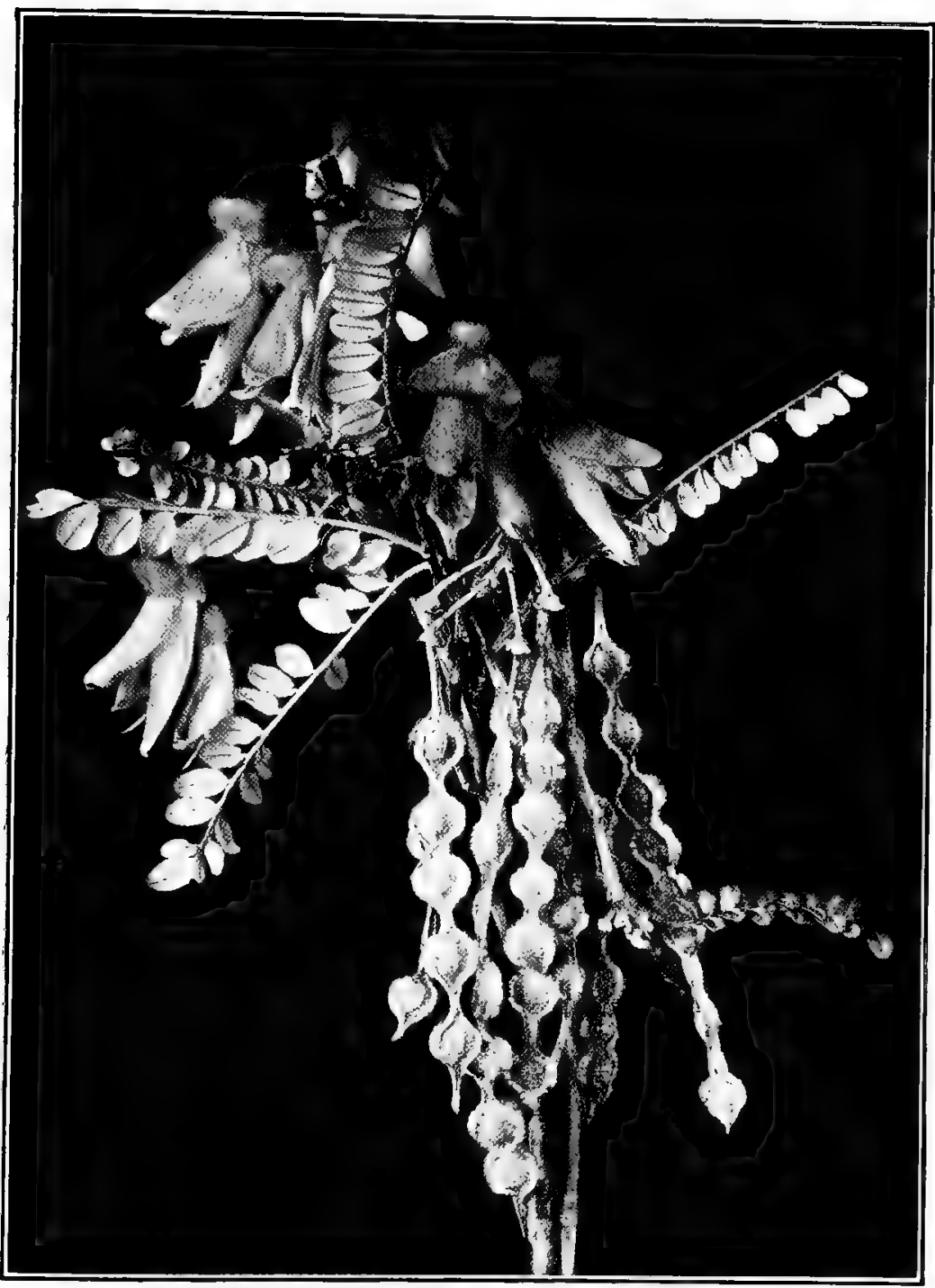

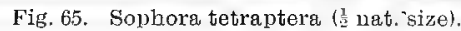


plants considered by the earliest botanists to be the same, but growing in habitats distant from each other, are really distinct species. Dr. Cockayne has clearly proved that there are at least three, perhaps more, distinct species of Sophora in New Zealand. The question at once arises, which of these are endemic in the Colony and which are more widely distributed? Until the Chilian and other forms have been closely compared with our local plants, it is impossible to say which foreign species (if any) are identical with the New Zealand forms. This much, however, may be admitted. We have in the distribution of the genus Sophora, evidence of a former closer communication with the South American Continent.

The kowhai is one of the earliest of the spring-floweringr plants. The flowers are sulphur-yellow in colour, with a calyx of old gold. At the time of opening, the corolla shows most delicate tints of green at its base, which, however, disappear when the blossoms are fully expanded. They secrete a large quantity of nectar. The tuis or parson-birds will not take the trouble to insert their brush-tongues to get at the honey, but in their hurry, tear open the flowers with their beaks, leaving the beautiful petals torn and ragged. The Maoris are said to have regulated the time of their potato-planting by the flowering of the kowhai.

The wood of this tree is handsome, and very valuable on account of its extreme durability. House blocks have been cut from felled trees which have lain from twenty to twenty-five years in the damp bush. These logs show no sign of decay, even when they have almost to be dug out of the ground. The tree is sometimes called the New Zealand Laburnum. The Maori name is said to mean yellow (the colour of the Howers).

As might have been expected, the kowhai has not failed to attract the attention of inost writers of New Zealand poetry, and it has been described in verse more often perhaps than

Treans. XXXI. p. 373. 
any other native plant. Beautiful descriptions of it are to be found in the writings of Domett, Dora Wilcox, Johannes Andersen, and others.

\section{Geraniaceae.}

(Including the Oxalidaceae).

\section{The Family of Geraniums or Cranesbills.}

Distribution.-A family of 20 genera and 750 species, found chiefly in temperate and hot climates. Many of the species have astringent and aromatic properties. Oxalic acid is obtained from the Oxalidaceae. The Geraniums and Pelargoniums are well-known garden flowers. Most of the latter are natives of the Cape of Good Hope. This family is very nearly allied to the Linaceae.

Key to the Genera.
1. Flowers irregular. Flowers regular.
$\nmid$ Pelargonimm.
Leaves lobed.
Leaves foliolate.
Geranium, p. 215.
Oxalis, p. 216 .

t Not further described.

\section{Genus Geranium.}

About 100 species. Two of the New Zealand species are endemic. Herbs with stems swollen at the joints, and stipulate leaves. Flowers regular. Fruit with a long beak. $5 \mathrm{sp}$.

\section{Geranium dissectum, var. australe (The Cut-leaved Geranizm).}

A downy plant, 1ft. - 2ft. in height. Leaves $5-7$ lobed. Flowers two on a stem, $\frac{1}{2}$-inch across. Petals, notched, pink. Seeds, pitted. Both islands, more common in the north. Fl. Nov.-Feb.

\section{Genus Oxalis.}

Flowers, regular. Stamens, 10, all fertile. Stems very slender. Leaves, 3-foliolate, the leaflets folding one upon another at night. About 240 species, found chiefly in S. Africa and S. America. O. acetosella produces cleistogamic flowers. Some tropical species have pinnate leaves. Flowers yellow, white, or pink. (Name from the Greek, signifying sharp or acid). $2 \mathrm{sp.}$ 


\section{Oxalis corniculata (The Horned Oxalis).}

A perennial herb, sometimes creeping. Leaves shining or downy. Stipules, very small. Flowers, from $1-6$ on a stem, $\frac{1}{4}$ in. $-\frac{1}{2}$ in. across. Petals yellow. Fruit an oblong capsile. Fl, Oct.-Mar.

\section{Oxalis magellanica (Magellan's Oxalis).}

This little plant much resembles the English Wood Sorrel (O. acetosella). It is smaller than coniculata, with slightly fleshy leaves, and solitary white flowers. Capsules, round. Stipules, large. Both islands: in shady places. Fl. Aug,-Oct.

Our two dwarf species of Oxalis are interesting from several points of view. On a bright day $O$. comiculata enlivens the turf with a blaze of little yellow flowers. It grows chiefly in dry sunny localities, and it is one of the last of our indigenous plants to disappear before the advance of civilization. There is no town in New Zealand in which there is such a dearth of uncultivated native plants as in Christchurch, yet this little Oxalis may be found on many of the lawns, even in the centre of the town. Hagley Park lies almost within the borders of the City, and here a few wild flowers eke out a poverty-stricken existence for the delight of the town-dweller, if he care to notice them. The list is a short one, and (excluding monocotyledons) includes Oxalis corniculata, Carmichaelia flagelliformis, Ligusticum (Aciphylla) Colensoi, Raoulia Monroi, Geranium microphyllum, Mr̈hlenbeckia axillaris and Cotula speciosa. None of them, except the little Oxalis, have brightly coloured flowers; none of them are showy or conspicuous, but every one of them is well worthy of study, and in a German town of size equal to this, would already have been monographed and examined microscopically throughout, in all its stages.

O. magellanica is found chiefly in bogs and damp woods. It is a widely distributed form, with a sub-antarctic range, being found in Victoria, Tasmania, South Chili, and Fuegia. Mr. G. M. Thomson found that the flower produced no seed 
even when the "stigna was abundantly smeared with its own pollen." It is difficult to understand how such an extraordinary characteristic as this is developed, but it is not uncommon, particularly amongst the Orchidaceae. O. corniculata is endemic.

The genus Oxalis shows well the folding of the leaves known as the "sleep of plants." The head of the petiole droops, and each blade is folded along the widrib, so that only the edges, and not the surfaces of the leaf are exposed to the sky. The position is, no doubt, as Darwin suggested, a method of protection against excessive loss of heat by radiation to a clear, cold sky; but when this has been said, many things still remain to be explained. The movement is generally stimulated by the oncoming of darkness. However, it will take place at regular intervals, for a time at least, in prolonged darkness, or in constant illumination. There is, therefore, a tendency in the plant to carry on the regular changes of position, in the absence of the stimulus; but sooner or later unnatural conditions produce disease, or an abnormal response in the leaves. The mechanism, by means of which the movements are carried on, is fairly well known. In many plants, it consists of a cushion of cells on the petiole, which can be distended or contracted by the injection of fluid into them, or its removal from them. When the cushion is in a state of turgidity, the leaf is raised; when it is flaccid, the leaf droops. The "sense-organs" -if so they may be termed-by means of which the plant can distinguish light from darkness, or variations in light, are as yet very imperfectly known. Haberlandt, however, has endeavoured to show that there are, in many leaves, transparent microscopic lenses which he terms "ocelli" (7ittle eyes), whose function is to detect the alteration in the amount of light received by the leaf, and thus, perhapss, receive a stimulus, which will automatically control the motion of the leaf.

This "Somnus plantarm," as Linnæus termed it, may be readily witnessed in $O$. corniculata. 


\title{
Linaceae.
}

\author{
The Flax Family.
}

Distribution.-A large family, found chiefly in tropical regions, and not unlike the Malvaceae in the mucilaginous character of the seeds, and the tenacity of the fibres. Linseed Oil is prepired from the oily seeds of the Linum (or flax), and the woven material known to us as linen takes its name from this plant, which produces it. The flowers of the flax are of a delicate pale-blue, and the petals fall readily.

\section{Genus Limmm.}

This is the largest genus of the order, and is usually found in temperate climates. The New Zealand species is endemic, but several other species have been naturalized.

\section{Linum monogynum (The True New Zealand Flax).}

A perennial woody herb, $6 \mathrm{in.-24} \mathrm{in}$. in height, with pale-green shining leaves, and terminal corymbs of white, mallow-like flowers. Flowers 1in, in diameter. Usually found on dry banks and cliffs, especially near the coast. North and South Islands, Stewart Island, Chatham Islands. Fl. Oct.-Jan. Native name Romhuia.

This is the true New Zealand flax; the plant which is usually so called being a lily. The only point of resemblance between the two plants is the possession by each of a strong fibre.

\section{Rutaceae.}

The Rue Family.

Distribution.-A large family, found in warm and tropical regions. These plants :me usually remarkable for their powerful and aromatic odour. The leaves contain glands filled with a bitter volatile oil. The common Rue (Ruta graveolens) is used in medicine as an anti-spasmodic. Dictamnus fraxinella, the false Dittany, is said to exhale so much of this volatile oil that the surrounding air becomes charged with it, and faint flatshes of light may be obtained on warm still evenings, if a flame be brought near the plant. Of the 78 genera comprised in the order, only two are found in New Zealand. 


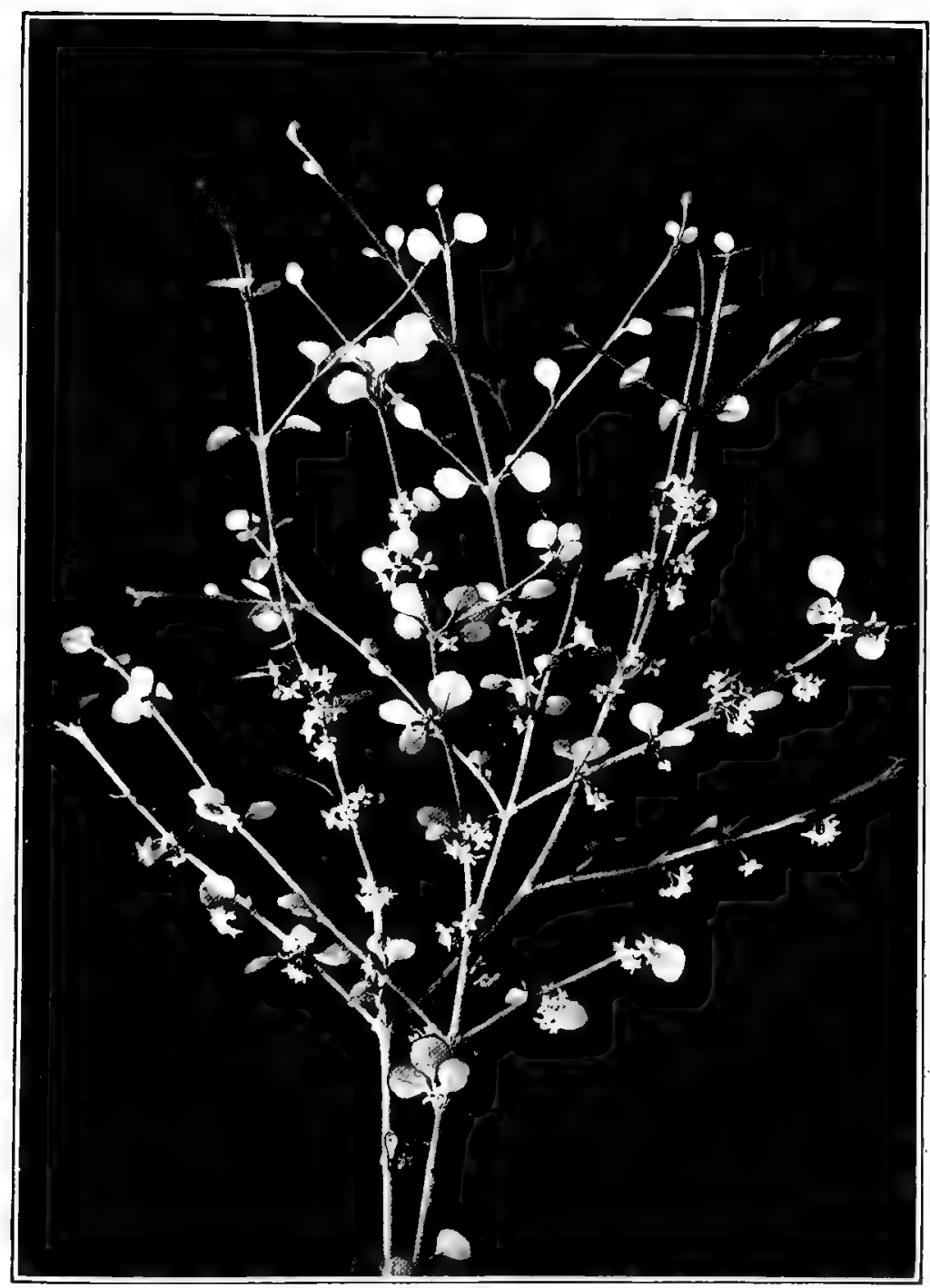

Fig. 66. Melicope simplex (1 nat. size). 
Fely to the Genera.

Seprals and petals, 5. Staniens, 10 .

Phebaliun, 1. 2:0.

Serals and petals, 4. Stamens, 8.

Melicope, 1. 2:20.

\section{Genus Plebatium.}

Shrubs, with alternate, pellucid-dotted, simple leaves, and corymbs of white flowers, Calyx small. 28 species are found in Australia, but only one in New Zcaliund.

\section{Phebalium nudum (The Naked Phebalium).}

A slender, branching shrub, with reddish bark. Leaves, 1in.-11 in. long; flowers, $\frac{1}{1}$ in.- $-\frac{1}{3}$ in, across; white, in terminal corymbs; endemic. North Island: as far south as the Thames. Great Barrier Island. Fl. Nov.-Dec. Maori name Mairehau.

\section{Genus Melicope.}

Flowers, regular. Sepals and petals, 4. Stamens, 8. Ovary of 4 carpels. Shrubs or trees, with dotted leaves, simple or ternate. Flowers terminal or axillary; small. About 15 species, two of which are endemic in New Zealand. (Name from the Greek, in reference to the lolsed glands round the ovary).

Melicope ternata (The Ternate-leaved Melicope).

A small tree, with shining yellowish-green leaves, and axillary cymes of greenish flowers. Leaves opposite; 3-foliate; leaflets, 2in.-4in. long. Flowers, fin. in diameter. Seed, black, shining. Common in the North Island; local in the South. Fl. Sept.-Oet. Maori name Wharangi. The gum of this tree is said to have been chewed by the natives.

Melicope simplex (The Simple-leaved Melicope).

A small tree, 3ft. - 12ft. high. Leaves altemate, usually simple, rarely 3-foliolate, $\frac{1}{2}$ in. - $\frac{3}{4}$ in. long. Leaf stem flattened, broad. Flowers, $\frac{1}{4}$-in. across, white or pink, fascicled on the branches. The appearance of this plant is different in every respect from that of $M$. ternata.

This is one of the few New Zealand plants that have been shown to have cleistogamic flowers (v. Viola Cunninghamii.)

Mr. G. M. Thomson found specimens of Melicope simplex on Pigeon Island in Lake Wanaka, with closed flowers that were seeding freely.* On examining them he found that the flower's were much reduced, and adapted for self-pollination. The sepals were nommal, and the petals nearly so, but of the eight stanuens found in the well-developed flower, four were

\footnotetext{
Trans. Vol. XXIV. 1). 416.
} 
either altogether rudimentary, or had the anthers apparently aborted. The other four had large anthers on short filaments. The four carpels, in place of being in contact, were completely free, and instead of having four united styles, as in the normal flower, with a single stigma, the cleistogamic flower

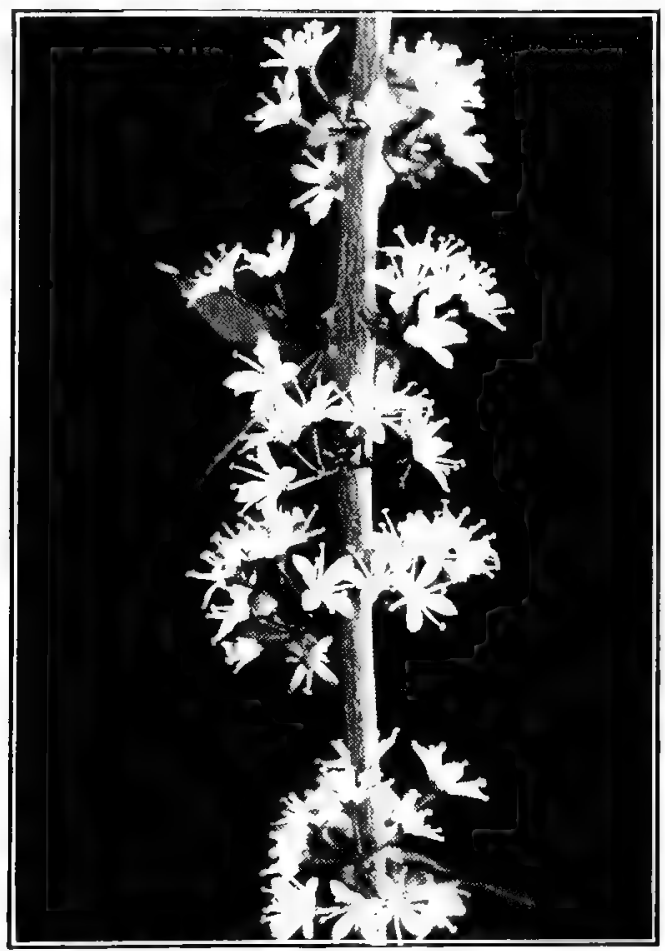

Fig. 67. Melicone simplex (life size).

had four more or less distinct styles. The flowers were pendulous, and probably the pollen matured early, and was shed into the apex of the corolla, thus reaching the stigma. As the filaments were shorter than the ovary, it was impossible for the pollen to pass directly from anther to stigma.

This plant, like several other New Zealand species, is found sometimes with hermaphrodite, sometimes with diøecious. 
Howers, an anomaly that has never been fully explained. It is probable that we have here, examples of species that are changing from the hermaphrodite to the unisexual condition, or vice versa. The problem presented is one of considerable interest and importance, and should in the future attract the attention of investigators.

\section{Meliaceae.}

The Family of Mahogany Trees.

Distribution. - A tropical family of forest trees, which includes the Mahogany, the Indian Satin Wood, and the Red Cedar of Australia. Found chiefly in Asia and Anerica.

\section{Genus Dysorylum.}

About 30 species, all large forest trees, often with a strong odour of garlic. One species alone is found in New Zealand, and that is endemic. (Name from the Greek, meaning sou or acid, in allusion to the bitter principle contained in the leaves.)

\section{Dysoxylum spectabile (The Handsome Dysoxylum).}

A tree, often $50 \mathrm{ft}$. in height, with handsome glossy leaves, unequally pimnate. Flowers $\frac{1}{2}$ in, broad, white, produced in drooping axillary panicles. The fruit is large and conspicuous, the hard thick capsule opening gradually, and showing the brilliant scarlet covering of the seeds. This extra covering is called the aril. (MIace is the aril of the nutmeg.) This tree is known to settlers as the New Zealand Cedar. Maori name Kohekohe. 1 sp.

This is one of the most beautiful trees of the New Zealand flora. Its large glossy leaves, its white, lily-of-the-valley-like flowers, springing from the bare parts of trunk or branch, and its large fruits, make it a conspricuous object in the bush of the North Island, to which it is practically confined. In the South Island it is rare, and is found only in the north of Nelson and Marlborough. The leaves are very bitter, and an infusion of them is sometimes used by bushmen as a tonic. The wood is light, and very useful for fencing posts in loose sand. In such situations it is more durable than any other New Zealand tree. 


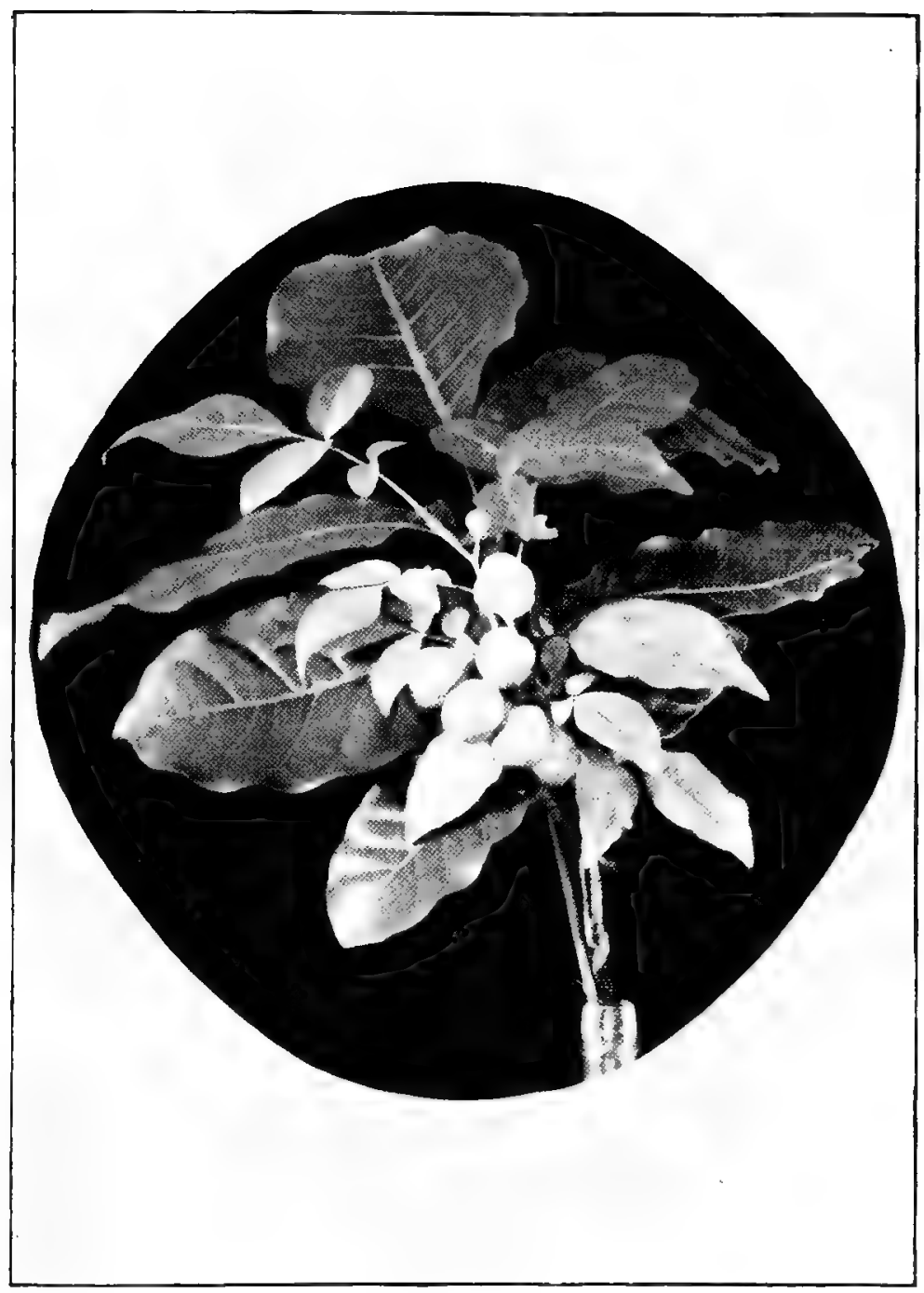

Fig 68. Dysoxylun spectabile.-Unripe fruit (t nat. size). 


\section{Euphorbiaceae.}

\section{The Sptrge FandLT.}

Distribution.--A large and interesting family of plants, with about 4000 species, but poorly represented in New Zealind. In some respects this family is alled to the Geraniaceae, but, from the absence of petals in many genera, it is placed amongst the Incompletre by Hooker. Tylophylla has flattened branches, which bear flowers on their margins. The milky juice contained in the stems of many of the species is usually highly poisonous. Some species produce resin, caoutchouc, or oil, while others yield a valuable food-starch, from which cassava, arrow-root, and tapioca are made. The Croton-oil, and Castor-oil plants are members of this fanily, while the Common Box is well-known as a garden edging. Some euphorbiaceous plants, such as Poinsettia, are cultivated in gardens and greenhouses for their brilliantly coloured bracts.

\section{Genus Euphorbia.}

Herbs with milky juice, rarely shrubs. Flowers cymose, terminal, enclosed in a perianth-like 4-5-lobed involucre, with yellowish or purple glands between the lobes. Stamens unequal, jointed in the middle. Each separate stamen of the inflorescence is regarded as a male flower. Often it is provided with a scalelike bract at its base. In the centre of this cluster of male flowers, is a single female flower, consisting of a stallked 3-celled ovary. Cells 1-ovuled. Capsule 3-lobed. Some of the African and Canary Island species closely resemble Cacti, and sometimes attain a height of $30 \mathrm{ft}$. The common weed known as the Spurge, is a European Euphorbia. 1 sp.

\section{Euphorbia glauca (The Glaucons Euphorbia).}

A shining, glaucons herb, $1 \mathrm{ft} .-2 \mathrm{ft}$. high. Rootstock woody, thick. Stem branched at the top, leafy. Leaves $1 \mathrm{in,-4}$ in. long, broadly oblong or narrow. Floral leaves broad, whorled. Involucres bell-shaped, $\frac{1}{4}$ in. across, fleshy, with 4 or 5 purple glands. Capsule the size of a pea, smooth. Botb islands: seabeaches. Common. Fl. Oct.-Feb.

\section{Sapindaceae.}

\section{The Maple and Huhse-Chestnut Family.}

Distribution.-A large, chiefly tropical, family, including many plants with poisonous properties. Some species yicld a pleasant fruit, while their leaves are highly poisonous. The nut-like fruits of the Sapindaceae lathor freely in water, and are used in the West Indies for washing purposes. The Maples and 
Horse-Chestnuts are amongst the most handsome trees belonging to the order. The North American Sugar Maple, Acer saccharinum, contains a great quantity of sugar in its sap.

\section{Key to the Genera.}

Leaves simple (in the N.Z, speries).

Leaves pinnate.

Dodonga, 1). 225.

Alectryon, p. 225.

\section{Gemus Dodoncea.}

Small trees, sometimes viscid. Leaves alternate. Sepals $3-5$, petals none, stamens 5-8. A genus chiefly Australian. Flowers terminal or axillary. (Named after Dodoens, a German botanist.)

\section{Dodonæa viscosa (The Viscid Dodoncea).}

A small hard-wooded tree, with viscid shoots. Leaves linear-oblong, entire, 1-3 in. long. Flowers in small terminal panicles, green. 10-12 stamens are found in the male flowers. Fruit dark-brown, flat, winged. Both islands: dry woods. Fl. Oct.-Nov. Native name *Ake-ake, perhaps signifying for ever and ever, in allusion to the durability of the wood. The wood was much used for native clubs, and is now valued by settlers for making mauls, as it does not spread. $1 \mathrm{sp}$.

\section{Genus Alectryon.}

A tree, with black bark, and hairy branches. Leaves pinnate, 4 in.-18 in. in length; leaftets 2 in.4 in. Flowers in erect panicles. Calyx 4-5-lobed; petals none; stamens 5-8. Fruit a capsule, coriaceous. (Name from the Greek, signifying $a$ cock, in allusion to the scarlet, comb-like aril of the seed), $1 \mathrm{sp.}$

\section{Alectryon excelsum (The Lofty Alectryon).}

A handsome tree, sometimes $60 \mathrm{ft}$. high, Flowers, fruit, and branches clothed with a rusty-coloured down. The whole of the flowering panicles appear to be of a reddish brown, from the deep colour of the anthers. The seed is black and shining, enclosed in a bright scarlet aril. An oil obtained from these seeds is said to have been used in the making of native perfumes. This tree is sometimes called The New Zealand Ash, and its timber is largely used. Maori name, Titoki. Fl. Nov.-Dee.

One of the best known of the bush trees, often comprising a large portion of the forest. It grows as far south as Banks Peninsula, where, with several other North Island forms, it reaches its southern-most habit. The prominent jet-black seed, embedded in its scarlet envelope with flattened crest and one side terminating in a spur, is one of the most attractive objects for the ordinary visitor to the bush.

\footnotetext{
*This name was applied by the Maoris to other hard-wooded trees.
} 


\section{Coriariaceae.}

\section{The Tutu Famil:.}

Distribution.-A small family of about 12 species, found in Europe, China, Japan, India, Peru, and New Zealand. The four New Zealand forms vary greatly.

\section{Genus Coniaria.}

Herbaceous plants, or small trees. Racemes erect or drooping. Flowers axillary. Leaves, $\frac{1}{4}$ in. -8 in. long. 4 sp.

\section{Coriaria ruscifolia (The Ruscus-leaved Coriaria).}

A small tree, with shining opposite leaves, and long drooping racemes of tiny, greenish flowers. These racemes are 6in.-12in. long. The flower petals become red and fleshy while the seeds are ripening, and are filled with a purple juice. Both islands. Fl. Sept.-Oct. Maori name: Tupakihi or Tutu, perhaps from Tutu, deep crimson (colour of the fruit). (Ruscus is the plant known as the Butcher's Broom).

The family Coriariaceae possesses only one genus, Coriaria, whose remarkable distribution has been given above. Of the New Zealand species, two, C. ruscifolia, and C. thymifotia, are said to be found also in South America; the identity, however, of these forms with ours has been questioned. This distribution has been used to prove a former land connection between New Zealand and South America, but the order is probably a very ancient one, and the discontinuity of distribution is more likely to be due to relict endemism, than to direct communication between these two remote districts. The family may at one time have been widely distributed over the face of the globe, and have died out in all places except those in which it is now found.

C. thymifolia is known in New Granada as the Ink-plant, as the juice of its fruit is used as a writing fluid. Rather a curious character of the genus is the formation of the fruit from the persistent petals, which become fleshy and full of purple juice. 


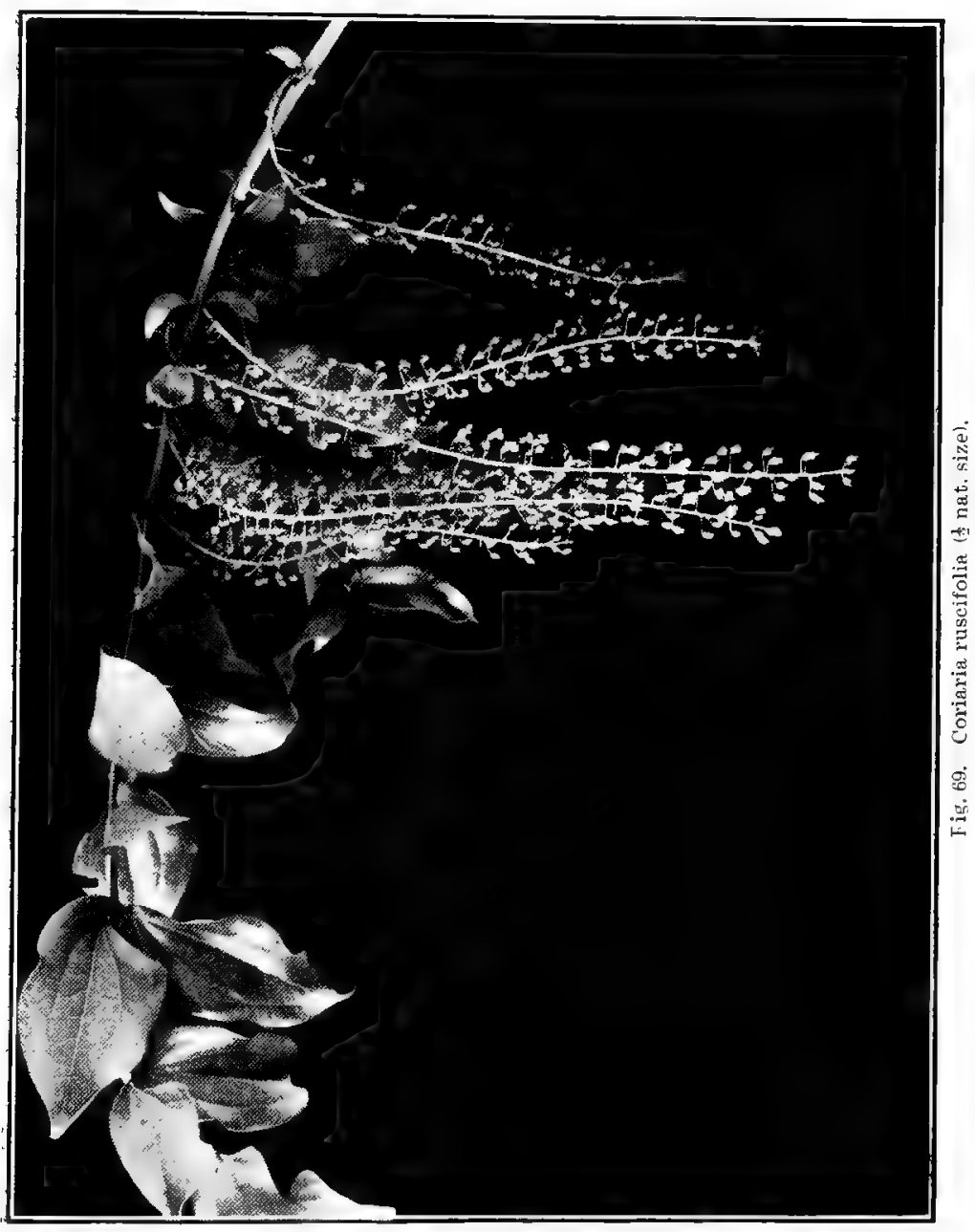




\section{EFFECTS OF THE PoIson.}

The tutu is well known as the most remarkable of New Zealand's poisonous plants. Some of the animals liberated here by Captain Cook died from the effects of eating the leaves, and in the early days of the Colony the settlers lost large numbers of their animals in this way. Thus Dr. Lauder Lindsay states in the "British Medical Review" (July 1865): "He seemed a fortunate farmer or runholder who had not lost more than 25 per cent. of his stock from toot-poisoning, whilst. in some instances, the losses were so high as 75 per cent." Sir Julius von Haast narrates how an elephant travelling with a circus, died from eating this plant by the way-side. Further, there are on record a few cases in which human beings have lost their lives from eating the shoots or berries of the tutu. The poison produces vomiting, convulsions, frothing at the mouth, and death.

It has been found that a dose of about a milligram of the extract "produces nausea, vomiting, and incapacity for work extending over twenty-four hours in a healthy, full-grown inan." ":

Various methods of treatment have been employed to counteract the effects of the poison, including the use of lime-water, ammonia, stimulants, and the inhalation of chloroform followed by sedatives and bleeding. If the experience of stock owners is to be trusted, the last mentioned is the most efficacious means of affording relief. No antidote is known. Maori children, poisoned by eating the berries, were smoked over a fire of green boughs, being shaken all the time!

There is some reason to believe that the accounts given of the effects of the poison on stock have been exaggerated. Horses have been known to eat freely of this plant without evil results. Possibly the over-driving of cattle and sheep has in many cases intensified the action of the poison.

"Easterfield and Aston: Trans. Vol, XXXIII., 1) 345. 


\section{Tutu Wine.}

Though the green shoots and seeds are intensely poisonous, the Maoris prepared from the juice of the berries a beverage, of which, according to Colenso, they drank large quantities. In the early days of the Colony the settlers also used to make a wine from the fruit, after removing the seeds. However, this wine was not above suspicion. Canon Stack relates how he drank the wine upon one occasion when travelling in company with Bishop Harper. Fortunately, neither of them did more than taste it. Shortly after swallowing it, the Canon lost all feeling in his extremities, and could scarcely retain his seat, but felt that he must fall forward on his face. A nuist came over the room, and he perceived that he was being poisoned, and must ask for an emetic. Soon, however, his feet began to tingle, and the strange sensation passed. The good Bishop was similarly affected, so, judging from this case, the beverage can scarcely be recommended for general use.

\section{The Nature of the Poison.}

The poison apparently affects the medulla oblongata, and basal ganglia of the brain. Various attempts were made to isolate the poisonous principle, and this was finally accomplished by Professor Easterfield and Mr. Aston in 1900. The results of their work will be found in the paper already referred to. At the end of their article is also a full bibliography of the subject. These workers find that " all the New Zealand species of Coriaria, contain a highly poisonous crystalline glucoside, of the formula $\mathrm{C}_{17} \mathrm{H}_{20} \mathrm{O}_{7}$." To this they give the name "tutin." The poisonous principle of tutu is, therefore, allied to the bitter substances found in many plants, such as amygdalin, found in bitter almonds; liquorice-sugar, found in the liquorice root; salicin, contained in the leaves and young bark of poplars and willows; and convolvulin, 
obtained from the jalap-root. The poisonous constituent of the European C.myrtifolia has been termed "coriamyrtin" and is distinct from "tutin," though both probably belong to the same chemical series.

\section{Icacinaceae.}

\section{The Lasianthera Familit.}

Distribution.-An unimportant tropical family, comprising 38 genera, of which only one is found in New Zealand. This genus is also found in Norfolk Island.

\section{Gemus Pennantia.}

Shrubs or trees. Tueaves alternate. Flowers in large terminal panicles. Sepals and petals 5. Stamens 5, attached to the top of the stem. Drupe small, stone three-angled. The genus is named after the Scotch naturalist, Pennant.

\section{Pennantia corymbosa (The Corymbose Pennantia.)}

A tree, 10-40 ft. in height. Leaves 1 in. to $4 \mathrm{in.} \mathrm{long.} \mathrm{Flowers} \mathrm{small,}$ numerous, waxy-white, fragrant; flowering stems white and hairy. Drupes black and fleshy. Both islands. Fl. Nov.-Dec. Maori name, Kaikomako.

This is an interesting little tree, not uncommon in many parts of the country. In its young state it is a shrub, with long, flexuous, interlacing branches, and small, distant, sessile, truncate, variable, wedge-shaped leaves. When full-grown, it is a handsome tree, $20 \mathrm{ft}$. to $30 \mathrm{ft}$. high, with broadly oblong, short-stalked, glossy leaves, about two inches in length. Only a keen student of nature would recognize in the rather ugly shrub, the precursor of the ornamental tree. The profuse, white, fragrant flowers make it well worthy of cultivation. The curious black fungus, so common on the native beeches, is sometimes found on the bark of this tree.

The seed is suspended in the ovary by a remarkable filamentous process, which originates outside the fruit, and, 


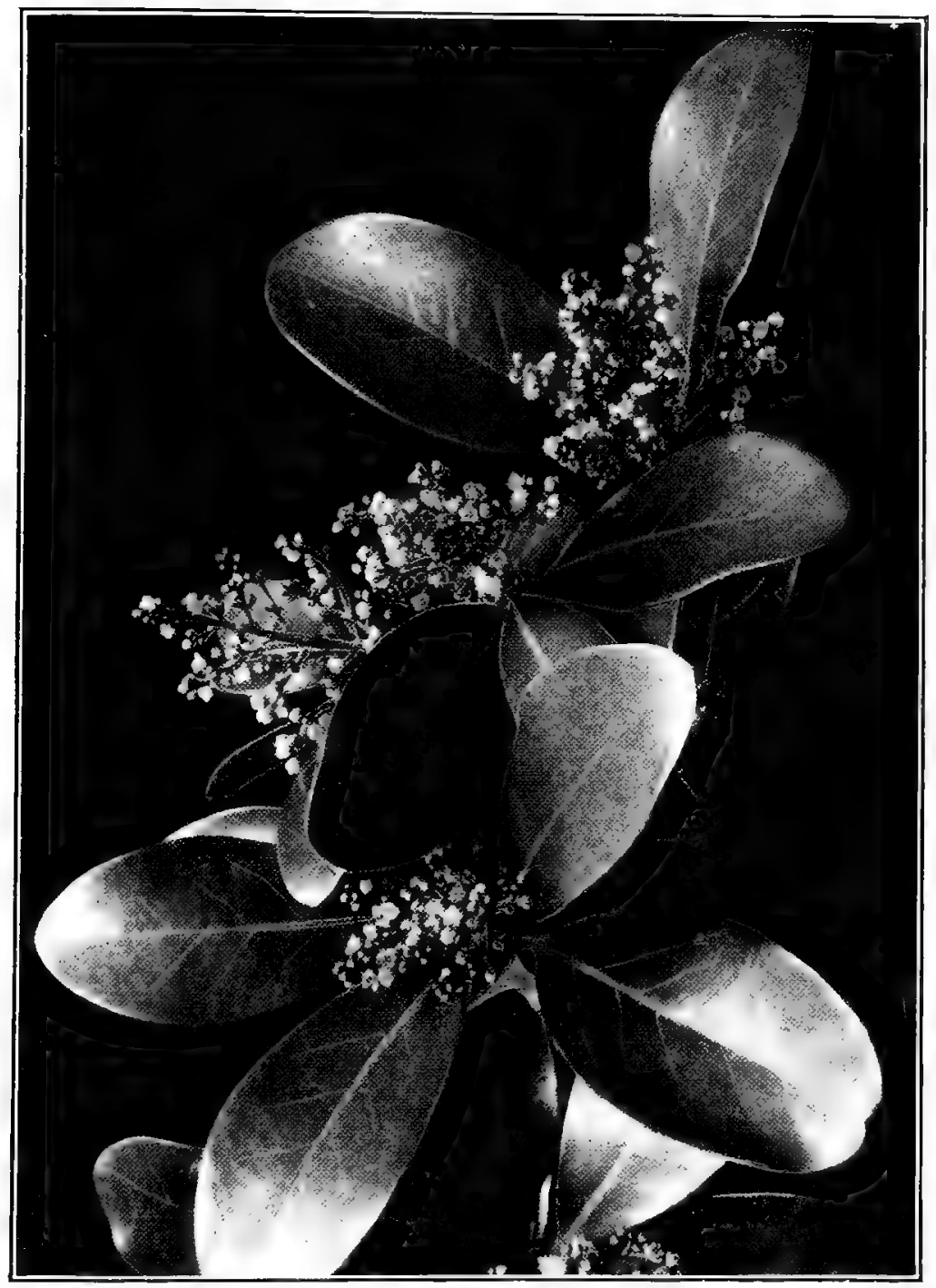

Fig. 70, Corynocarpus lævigata ( $\frac{1}{2}$ nat. size). 
after running along one of the external faces, enters by a pore near the apex.

\section{The Kaitomako in Maori Lore.}

The story concerning the origin of fire is one of the best known Maori legends. There are several variants of it. Maui, the famous hero and denigod, one evening maliciously extinguished all the household fires, so that, when morning came, it was impossible for his mother to cook the daily meal. This the hero had foreseen, and it gave him the required excuse to go to the bowels of the earth, where dwelt the dread goddess of file, Mahuika. He thus hoped to discover whence came fire. He reached the abode of the goddess by a subterranean path, and begged from her a spark to rekindle the terrestrial hearths. On receiving this daring request, the goddess pulled out one of her finger-nails, and with it there leaped forth a stream of fire. Maui carried off the flame with him, but, wishing to learn more of its origin, put it out before he had gone far. He returned to the cavern of the goddess, and told her that he had accidentally lost the fire. She drew out a second finger-nail, and Maui carried off the fire and extinguished it as before. The same trick was repeated by Maui until Mahuika had pulled out all her nails except that on one of her big toes. By this time, however, the goddess recognized that she was being tricked. So, when Maui returned for the twentieth nail, she tore it out and violently dashed it on the ground. Inmediately her dwelling was filled with flames. Maui escaped to the upper world, but was chased by the goddess with conflagration. With great presence of mind, he turned himself into a bird, but even then he was likely to have perished, for a pool of water into which he plunged, was boiling hot. Indeed, he would undoubtedly have been burned, had he not called to his assistance the gods of the wind and rain and hail. These quenched the fires, and Mahuika, appalled by the terror's of the tempest, fled shrieking to the underworld. As she went, however, Maui saw her 
throw the seeds of fire into several trees. Amongst these were the kaikomako, mahoe, totara, and pate. Thus he obtained the coveted knowledge, for if a sharp pointed kaikomako stick is worked vigorously along the surface of a flat piece of mahoe (Melicytus ramiflorus), or pate (Schefflera digitata), a groove is formed, which fills with fine dust. This, being gathered to one end of the groove, will presently smoke; and, if the worker is sufficiently adroit and strong, he will at last be able to kindle a flame.

Strangely enough, this primitive method of obtaining fire was the only one known to the Maoris. Those, who have tried it, alone know what violent exertion and care are needed to ensure kindling by these means. Smoke is readily obtained by the vigorous worker, but flame rarely ever.

\title{
Corynocarpaceae.
}

\author{
The Karaka Family.
}

Distribution. -A family of two species, one in New Zealand and the other found in New Caledonia and the adjacent islands.

\section{Corynocarpus lævigata (The Smooth Corynocarpus).}

A handsome tree, with glossy, laurel-like foliage. Leaves 3 in. -7 in. long, oblong. Flowers in erect panicles, 4 in. in length. Flowers $\frac{1}{6} \mathrm{in}$. in diameter, white. Petals concave. Fruit oblong, 1 in. in length, extremely poisonous. Found in both islands. Fl. Aug.-Dec. Maori name, Karaka. This tree is often called by settlers the "New Zealand Laurel." The Karaka forms the chief forest in the Chatham Islands, and was much used by the natives in the making of canoes.

This is one of the handsomest of New Zealand trees. The rounded, massive heads of laurel-like leaves are to be seen rising near most Maori clearings, as far south as LongLook-Out Point, on Banks Peninsula. This is its southernmost habitat, though it also grows in the Chatham Islands, 
where it is known to the natives as Kopi. It is common in many places near the coast in the North Island, where it has obviously been planted by the Maoris; and it is also sometimes to be found along river-banks, being specially plentiful in the neighbourhood of the Wanganui River. In the South Island it is rarer, though Kirk (Forest Flora, p. 173) is scarcely right in calling it "very rare," as it grows

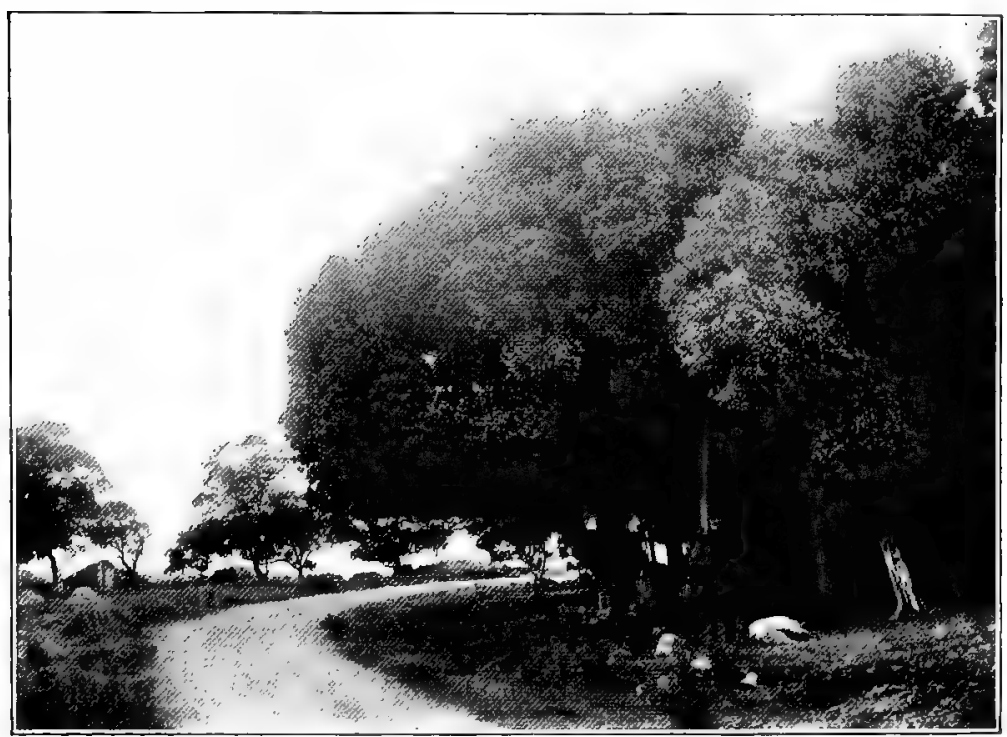

Fig. 71. Karaka Grove.

in great abundance along the coast-line north of Kaikoura in the neighbourhood of old Maori settlements.

The kernel of the orange-coloured, damson-shaped fruit was one of the staple articles of diet of the Maori. Consequently, the tree was much cultivated, and, as the young plants grow readily from self-sown seeds in the shade of the old, the karaka is very often to be found in groves. These groves, according to Colenso, were strictly tapu. His account: of the 
manner of preparation of the food, and the action of the poison is extremely interesting.

Mr. Skey investigated the nature of the poison, and came to the conclusion that it was probably a glucoside (v., under Coriaria ruscifolia.) $\mathrm{He}$ isolated the bitter principle in beantifully radiating acicular crystals, and considered that it was similar to digitaline (i.e., the drug obtained from the root of the fox-glove). (v., also under Pomaderris.)

\section{The Home of the Karaka.}

The Maoris state that they originally brought the karaka with them from their semi-mythical Eden (Hawaiki), but science contradicts this statement. Until quite recently, the genus was believed to be endemic, but it has now been found in New Caledonia and the New Hebrides, so that it is probable the plant came into New Zealand when there was a land extension to the north. It is apparently quite unknown in the Western Pacific, whence the Maoris came to New Zealand, but a very similar tree growing in Polynesia bears, it is said, the same name. It is probable, therefore, that the name karakia was attached to the New Zealand tree by the Maoris, because of its resemblance to a tree found in their former home, and not because they brought it with them. The Maoris wore chaplets of the leaves upon their heads, when they visited the graves of their ancestors on any important occasion.

\section{Rhamnaceae.}

\section{The Buckthorn Family.}

Distribution.-A widely-distributed family, occurring in warm and temperate regions. Some of the species possess edible fruits, while the bark of others yields a tonic, and is used in medicine. Yellow, green and blue dyes are also obtained from some of the fruits. The leaves of Ceanothus anericanus have been used as in substitute for tea. 
Fey to the Genera.

Leafy shrubs. Leaves alternate.

Pomaderis, p. 236.

Spinous shrubs. Leaves opposite or 0 .

Discaria, p. 239.

\section{Genus Pomaderits.}

Shrubs, clothed with a hoary stellate down. Leaves alternate. Calyx-tube divided into 5 lobes. Petals 5 or 0 . Stamens 5 . Flowers in terminal or axillary corymbs or panicles. About 22 species, found only in Australia, New Zealand, and New Caledonia. (Name from the Greek, signifying $a$ covering and the skin, the fruit being loosely covered by the calyx).

\section{Pomaderris elliptica (The Elliptical-leaved Pomaderris).}

A branching shrub, 2-10 ft. in height. Leaves 2-3 in. long, shining above, white with down on the under-surface. Cymes fragrant, many-flowered. Calyx, white. Petals crisped at the edges, greenish-white. North Island: dry hills. Fl. Sept. Native name, Kumarahou, from Kumara, a tuber-like root, and hou, growing deep or strongly.

\section{Pomaderris apetala (The Tainui).}

A small tree $6 \mathrm{ft} .-20 \mathrm{ft}$. in height, trunk $5 \mathrm{in.-6}$ in. in diameter. Lueaves, flowers, and flowering stems clothed with dense soft hairs. Cymes many-flowered. Petals none. Fruit a capsule. North Island only, rare and local. Fl. Oct.-Nov. Maori name Tainui.

\section{The Discoveri of the TaInui.}

This plant was discovered in New Zealand by Sir James Hector, and described by him in 1879* as Pomaderris Tainui. It is of special interest because of the Maori legend attached to it. When Sir James was in the Mokau district in December, 1878 , he was informed by the Maoris, that a certain tree, which had sprung from the green boughs used in the flooring of the canoe "Tainui," was still growing in that district. The Tainui was one of the six famous canoes of the Great Heke, and in it the ancestors of the Waikatos, Ngatimaniapotos, and other tribes, came to New Zealand some five hundred and fifty years ago. Sir James expressed a doubt as to the credibility of this statement concerning the origin of the tree. The Maoris then offered to show him the living specimens, which were growing on a spur between the 
Mokau and the Mohakatina Rivers. The scientist, on seeing them, was forced to admit that he had not observed any tree of the kind in New Zealand before, and the Maoris considered

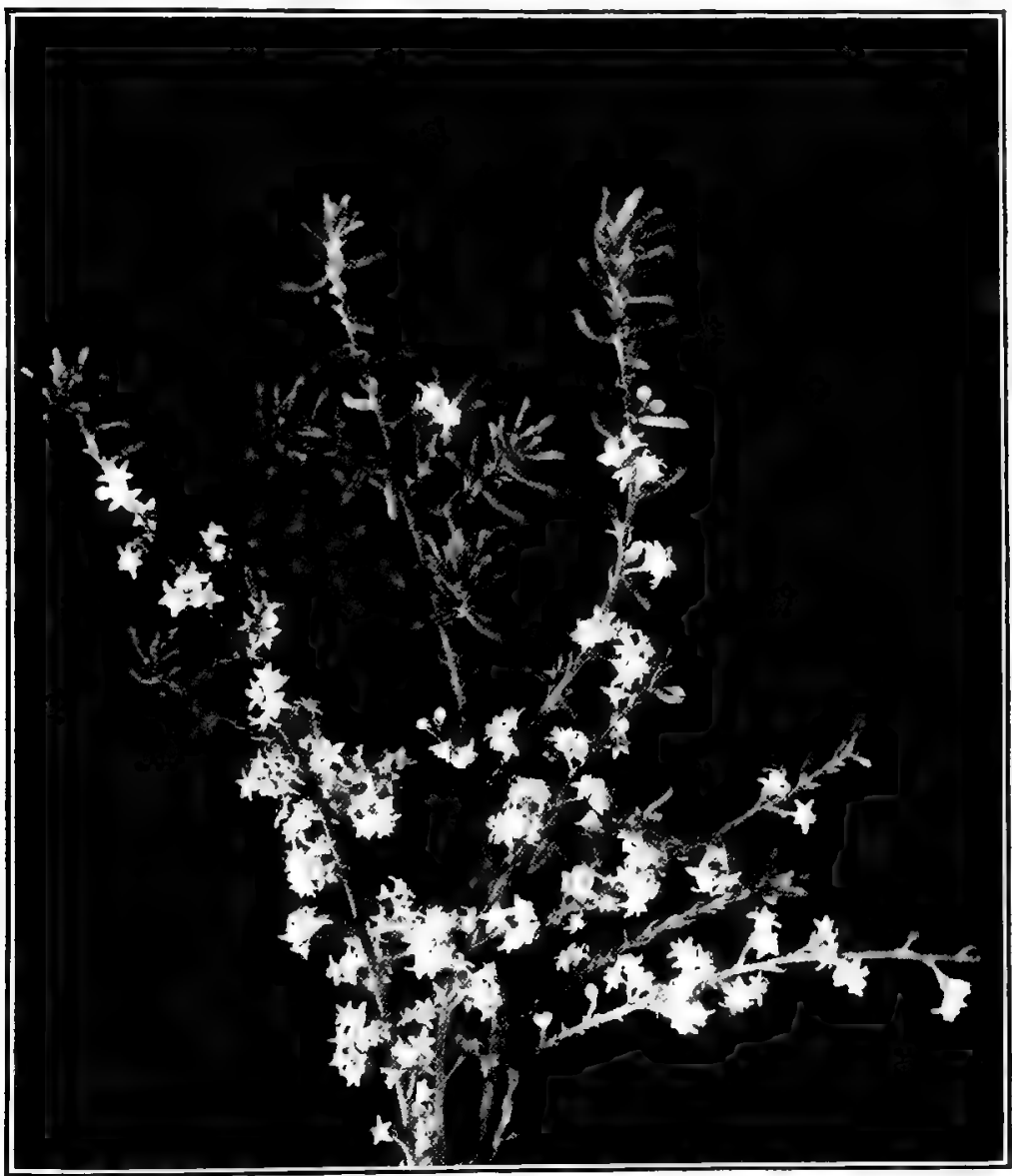

Fig. 72. Pomaderris phylicefolia (1 nat. size),

this admission was prima facie evidence of the truth of their tale. Sir James concurred in their view, and suggested that, "if we could hereafter determine the original habitat of the tree, it might give us a clue to the whereabouts of their 
ancestral home, Hawaiki, the place whence the Maoris originally migrated to New Zealand." But, unfortunately for the lover of romance, there is a sequel to the tale. When the earthen pot of tradition, and the iron pot of science, go down the stream together, it is the former which is likely to be broken. Kirk has shown (Forest Flora, p. 11) that the plant is none other than the Australian Pomaderris apetala. Moreover, the genus Pomaderris, so far as is at present known, is peculiar to New Zealand and Australia, and does not occur in the South Seas. It is obvious, therefore, that the story has grown up to explain the tree, and that the presence of the plant in New Zealand is no proof of the truth of the legend. Indeed, on examination of the tale, discrepancies in it soon appear. The species is not confined to the habitat where it was first found, nor was the "Tainui" stranded near the Mokau, but at Kawhia.

Pomaderris phylicæfolia (The Phylica-leaved Pomaderris).

A strongly scented, heath-like shrub, which grows profusely amongst the small tea-tree, upon gum-lands. The branches are thickly covered with soft hairs, and the leaves so much recurved as to appear to be round rather than flat. The flowers are axillary, in cymes of $3-5$, and are of a yellowish colour. North Island. Fl. Aug.-Oct. Maori name Tauhinu.* (Phylica is an African genus of the order, consisting of heath-like shrubs).

This plant is often abundant in the open country in the North Island, and constitutes, particularly in Auckland Province, one of the chief components of the lowland heaths. Its structure also is typical of the heath-plant. The small leaves bear their stomata on the under-surface, in wind-still tubes, formed by the inrolled margins and the rough hairs. Transpiration is thus checked, and the plant is enabled to withstand long continued insolation. Similar leaves may be found in Otearia virgata, Cassinia retorta, and Celmisia longifolia.

The roots of this plant were, according to Colenso, sometimes used for fish-hooks, when bone ones were lacking.

*This nane is also applied to Cassinia leptophylla. 


\section{Genus Discaria.}

About 14 species, of which 1 is found in New Zealand. Much branched, almost leafless, usually thorny shrubs, with twisted interlacing stems. Branches grooved. Leaves $\frac{1}{2}$ in.- $-\frac{3}{4}$ in. long. Flowers axillary, fascicled, small. Petals 0, or 4 or 5 . Stamens 4 or 5. Fruit a dry hard drupe. (Name from the Greek signifying $a$ disk, from the ovary being situated on a broad disk).

\section{Discaria toumatou (The Wild Irishman).}

A spinous bush, sometimes $20 \mathrm{ft}$. in height. Flower $\frac{1}{8}$ in. in diameter, white ; calyx, downy. Leaves, when present, fascicled or solitary in the axil of spines. North and South Islands. Fl. Dec.-Jan. Maori name Tumatakum.

\section{Xerophitic Leaves.}

It doubtless sometimes happens, that, owing to slow movements of the earth's crust, the climate of a plant habitat alters. There is reason, for example, to believe that, at some past time, the climate of the Canterbury Plains, and perhaps of other parts of New Zealand, was much more arid than it now is. Under changing circumstances, a plant has either to accommodate itself to its new environment, or give place to other and better adapted species. There are many ways in which a plant can adjust its leaf to the conditions of a desert climate. The leaf may be set obliquely to the sun, as in Eucalyptus; it may provide itself with water-storage apparatus, as in Mesembryanthemum; the leaf margins may be recurved, as in Olearia virgata; the total leaf surface may be reduced, as in many Veronicas; or again, the leaves may become spinescent, as in Aciphylla. If all these methods fail in protecting the transpiring surface sufficiently, the plant may become leafless. Then the stem has to take on the functions of a leaf, as in Carmichaelia, Clematis. afoliata, etc.

Now Discaria has nearly been reduced to these straits to prolong its existence. Such extreme measures, however, are only adopted by the plant, if other devices for protection against drought fail, or are unavailable; for a stem cannot be expected to carry on the work of assimilation as efficiently as a leaf. 
The leaves of the Wild Irishman are fairly abundant in spring, become fewer in summer, and are altogether wanting in autumn and winter. Most of the shoots are reduced to green pungent spines, sometimes with brown tips. These when old lose their chlorophyll, and become very hard and dry. They are then so strong and needle-like, that they were often used

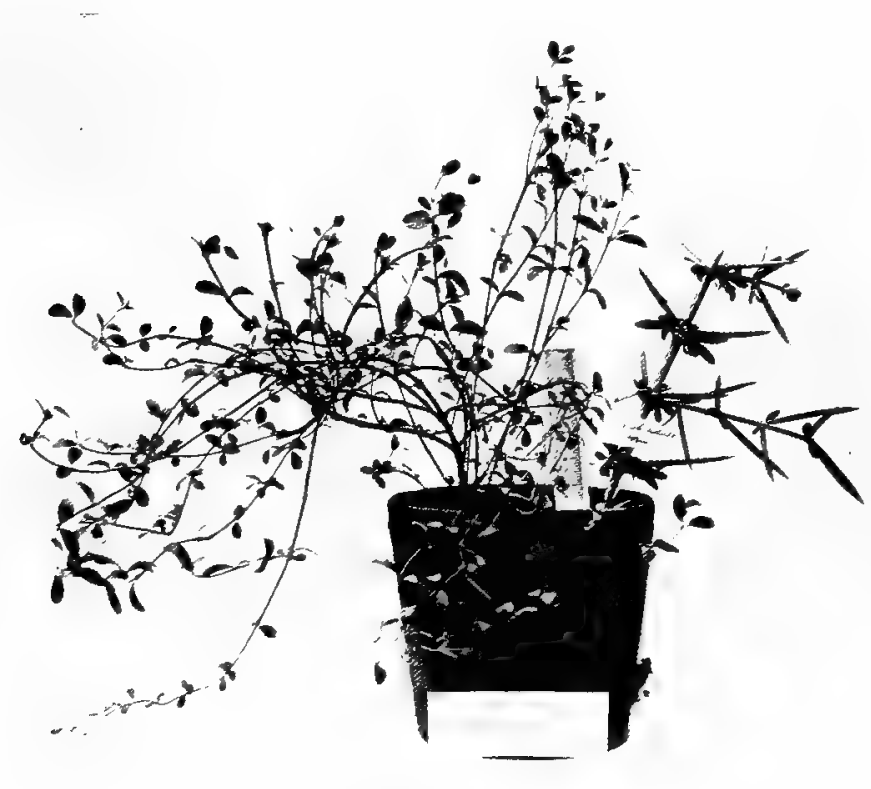

Fin. 73. Discaria toumatou (3 nat, size).

(Noist air form on the left, ordinary form on the right.)

by the Maoris for tattooing, when bone or other needles were unprocurable.

Dr. L. Cockayne's Experiment.

The small deciduous leaves, and hard green acuminate shoots of Discaria at once proclaim it a plant of dry localities. As a matter of fact, it is found chiefly on sand-dunes, on arid or clayey hill-sides, and on stony plains. That it should acquire such a highly xerophytic structure is therefore little to be 
wondered at, but the strangest part of the story yet remains to be told. Dr. Cockayne has studied its development, and has also shown by an experiment, which is probably destined to become classic, that Discaria was originally a spineless leafy plant adapted to a moist habitat." The seedling plant is erect, leafy, and bears no spines. After it attains an inch or two in height, spines begin to develop in the leaf axils, and the foliage becomes gradually sparse. If, however, the plant is now put into a warm moist chamber, no more spines will be developed, the leaves will be retained, and,-in a word,-the plant returns to its seedling form. Nor is this a temporary change, for this form will be retained as long as the plant remains in an atmosphere saturated with moisture. And in this complete suppression of the spines, Dr. Cockayne's experiment is unique. Goebel, perhaps the greatest living botanist, recently said :- " I do not think that up till now any more has been proved, than that in moist air the formation of prickles and thorns is retarded; there is no proof that it can be suppressed."' Dr. Cockayne seems clearly to have shewn that complete suppression is possible.

Such a remarkable experiment as this cannot fail to be profound and far-reaching in its effect on biological ideas of the species. As will be pointed out (v. Plagianthus betulinus, p. 256), the seedling often passes through the ancestral forms of the species in its development. We must, therefore, assume that Discaria had originally small thin leaves, adapted to a unoist climate, but has changed its characters in response to the stimulus of a drier atmosphere. Sixty years ago the dogma of the fixity of species was one of the most sacred beliefs of biologist and layman. Darwin showed us that species are not fixed; and now there are not wanting many indications, which seem to prove, that in some cases, individuals even, may show a marvellous plasticity.

*The New Phytologist Vol. IV. No. 4 On the Significance of the Spines in Discaria toumatou.

tPlant Organography Eng. Trans. Part I. pp. 263, 264. 


\section{Tiliaceae.}

The Lime-Tree Familt.

Distribution.-A family of 40 genera, and 340 species. Tilia is the only genus found in cold regions. The English Lime-tree (Tilia europeca), the typical plant of the order, furnishes the bast used by gardeners. Bast mats are made from it in Russia. From Corchorus capsularis, the Jute, the Indian tribes made their nets and fishing-lines, while another variety of the same plant was used by the Egyptians as a vegetable. It is said that one species of Aristotelia possesses fibres of such strength and toughness, as to be used as strings for musical instruments. Spamnannia africana, a pretty shrub with umbels of white flowers, and with evergreen leaves, is cultivated in Britain as a hothouse plant.

key to the Genera.

1. Fruit a spinous capsule. Fruit a drupe or berry.

2. Leares opprosite. Iteaves alternate.
Entelea, 1, 242. 2

Aristotelia, 1). 244 .

Elæeocarpus, p. "248.

\section{Genus Entelea.}

A genus of only one species, almost confined to the North Island of New Zealand. Leaves alternate, flowers regular. Sepals and petals, 4 or 5 . Stamens numerous; fruit spiny. (Name from the Greek, signifying perfect, referring to the stamens, as opposed to the imperfect ones of Spamannia). Maori names, Whan, Hanama. Fl. Oct.-Nov.

\section{Entelea arborescens (The Shrubby Entelea).}

The genus is confined to these islands, and this is its only species. The tree may, therefore, be regarded as peculiarly a New Zealand plant. Its large leaves and beautiful white flowers make it one of the handsomest of sumall trees. It used to be common along the coust of the northern part of the Nurth Island, being particularly plentiful north of Auckland and in the neighbourhood of Gisborne. It is not found nearer Wellington than Paikakariki, and in the South Island has been seen only in the Collingwood district and near the Croiselles. In some places this tree is called the New Zealand Mulberry, on account of the shape of the leaves.

These leaves are very large, sometimes nine or ten inches in length, heart-shaped, and with toothed margins. They are 
beautifully veined, soft, and fade quickly when gathered. The flowers are produced in large drooping clusters, and are of a pure white, with crumpled petals, each single blossom being about an inch in diameter. The petals are pointed, and are four or five in number. The fruit is dark-brown, and rough with long bristles. These spines are often an inch in length. It is unfortunate that this beautiful tree is now becoming rare.

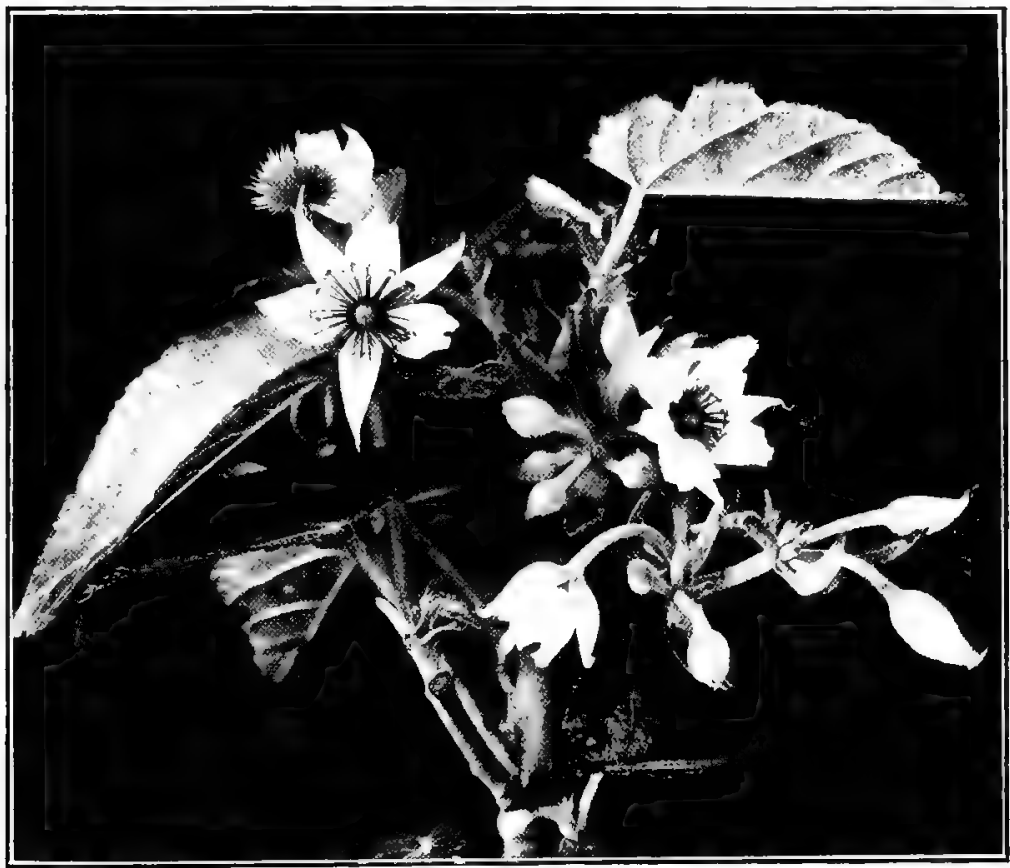

Fig. 74. Entelea arborescens-Flower and Fruit ( $\frac{2}{3}$ nat, size).

However, it is easily cultivated from seed, and will grow in any sheltered situation.

The wood is remarkably light, and was used by the Maoris in the construction of floats for their fishing-nets, and of small rafts. It is about half the weight of cork, and the whan is sometimes, therefore, termed "the cork-wood tree." Mr. T. Kirk suggested that it might be utilized for life-belts. 
This is one of the three large-leaved trees of New Zealand that by their foliage seem to suggest a tropical origin. The other two are Meryta Sinclairii and Pisonia brunoniana. Its nearest relation is apparently Sparmannia of the Cape of Good Hope. It has been suggested that the spinous character of the fruit is probably due to the need for protection against grazing animals, in the country whence it originally came. Perhaps the only other New Zealand fruit similarly protected, is the nut of Sicyos australis.

It seems, however, unlikely, that either of these plants has indued itself with bristles, as a safeguard against browsing mammalia. Bitter juices are a better protection than thorny leaves, and an edible fruit is often of more value to the plant, than one which is inedible. As a matter of fact, the spinous fruits of the whau form no protection to it, for if stock are running in the neighbourhood, all the young plants are eaten up by cattle, before they have time to develop their seeds. Indeed, were the fruit of the whau edible, the bristles upon it would be a quite insufficient defence against grazing animals, as they are often fond of sharp plants. Horses, for example, will eat dead thistles in preference to grass. Sheep sometimes eat the prickly leaves of Leptospermum scoparium, and, did they taste sufficiently pleasant, the sharp tips would not hinder stock from grazing on the plant. It is the bitter acrid juice developed in the leaves which is its chief safeguard. It seems probable, therefore, that some other reason must be sought for to explain the spinous coat of the seed of the whau.

\section{Genus Aristotelia.}

Small trees, with opposite, deeply-toothed leaves. Flowers in panicles or racemes. Fruit a berry. (Named in honour of Aristotle). $3 \mathrm{sp}$.

\section{Aristotelia racemosa (The Racenrose Aristotelia).}

A small tree $6 \mathrm{ft} .-30 \mathrm{ft}$. high, with red bark. Flowers in large panicles, varying in colour from a faint rosy flush to deep claret. Fruit, a red 3- or 4-celled berry. North and South Islands. Fl. Nov.-Dec. 


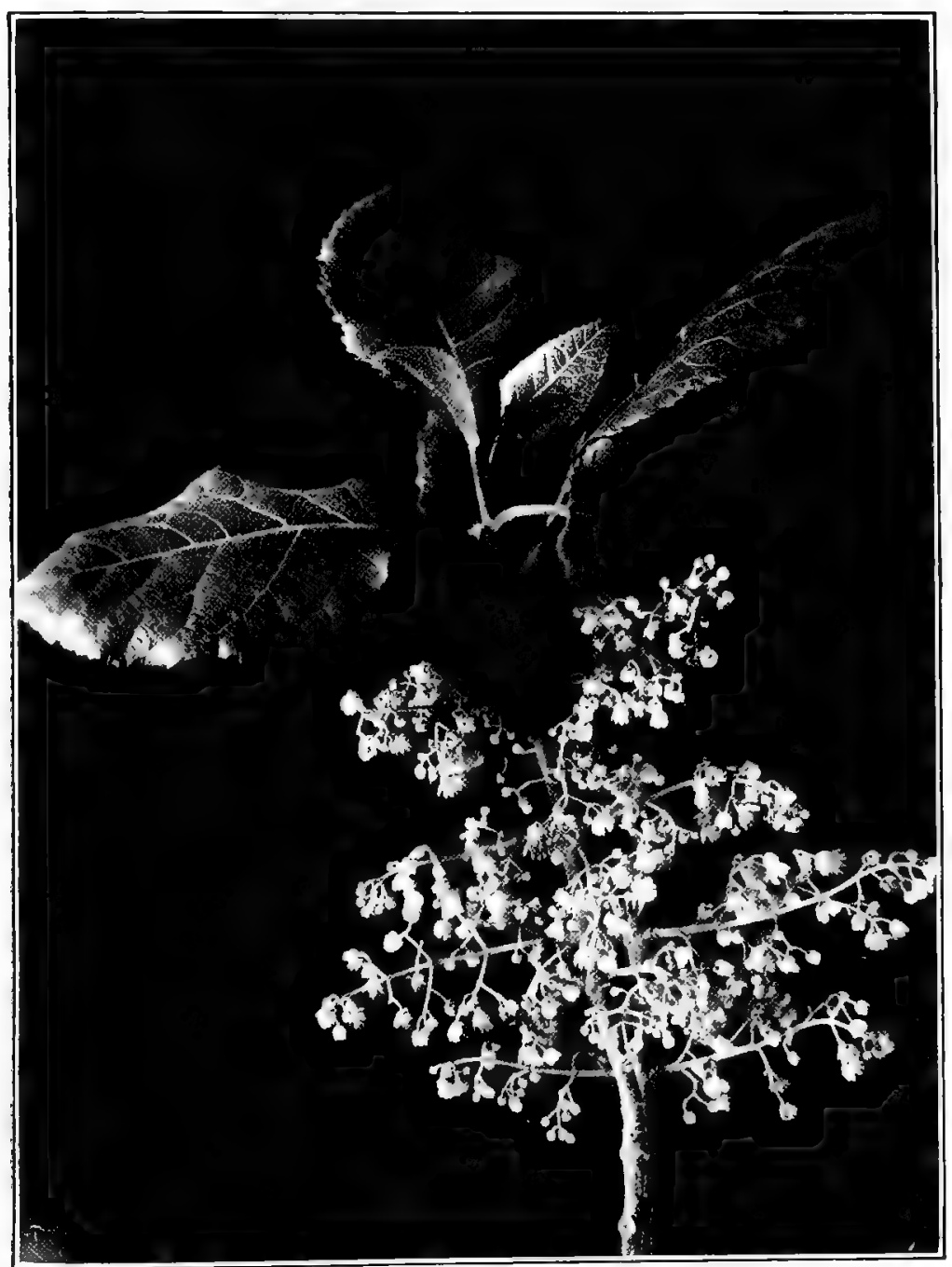

Fig. 75. Aristotelia racemosa ( $\frac{1}{2}$ nat، size). 
This is another handsome tree of the same order as the whau. It is common everywhere throughout the islands at altitudes from sea-level up to 2,000 ft. In bush clearings, it is one of the first plants to come up, and would, on this account, be termed by the Americans a "fireweed." It goes by different names in different districts. In Otago, it is the New Zealand Currant, or Moko-mok'. In Canterbury, it is called the Wine-berry. In the North Island, it is the Mako-mako. Its graceful plumes of rosy flowers make it one of the most attractive objects of the bush in Spring. The red-brown under-surfaces of its leaves flash into view with every breath of wind, and the memory of their beauty is one of the pleasantest recollections of the lover of the New Zealand bush. The genus also occurs in South America and Australia. Our species, therefore, perhaps indicate an American connection at some remote period. The wood is white, and is much used for conversion into charcoal for the manufacture of gunpowder.

\section{Aristotelia fruticosa (The Shrubby Aristotelia).}

A much-branched shrub, 3ft.-6ft. high. Flowers solitary, or in small cymes or racemes. Leaves linear, lanceolate to elliptic, oblong, entire, crenate or serrate. Fl. Oct.-Nov,

A sub-alpine plant of the most variable habit, and extreme mutability of leaf form. These changes of form may be due to the extreme sensitiveness of the plant to alteration of environment, or it may possibly be due to the fact that the plant is undergoing mutation (v. Veronica). At any rate, few of our variable species afford more promising material for experiment. Like so many other New Zealand plants, in one of its stages it resembles a twisted Coprosma (v. Plagianthus betulinus). The leaves of the seedlings are sometimes sinuilar to those of $A$. racemosa. The leaf form of the lastmentioned species, according to Dr. Cockayne, may, therefore, possibly be regarded as typical of the "common ancestral stock." 


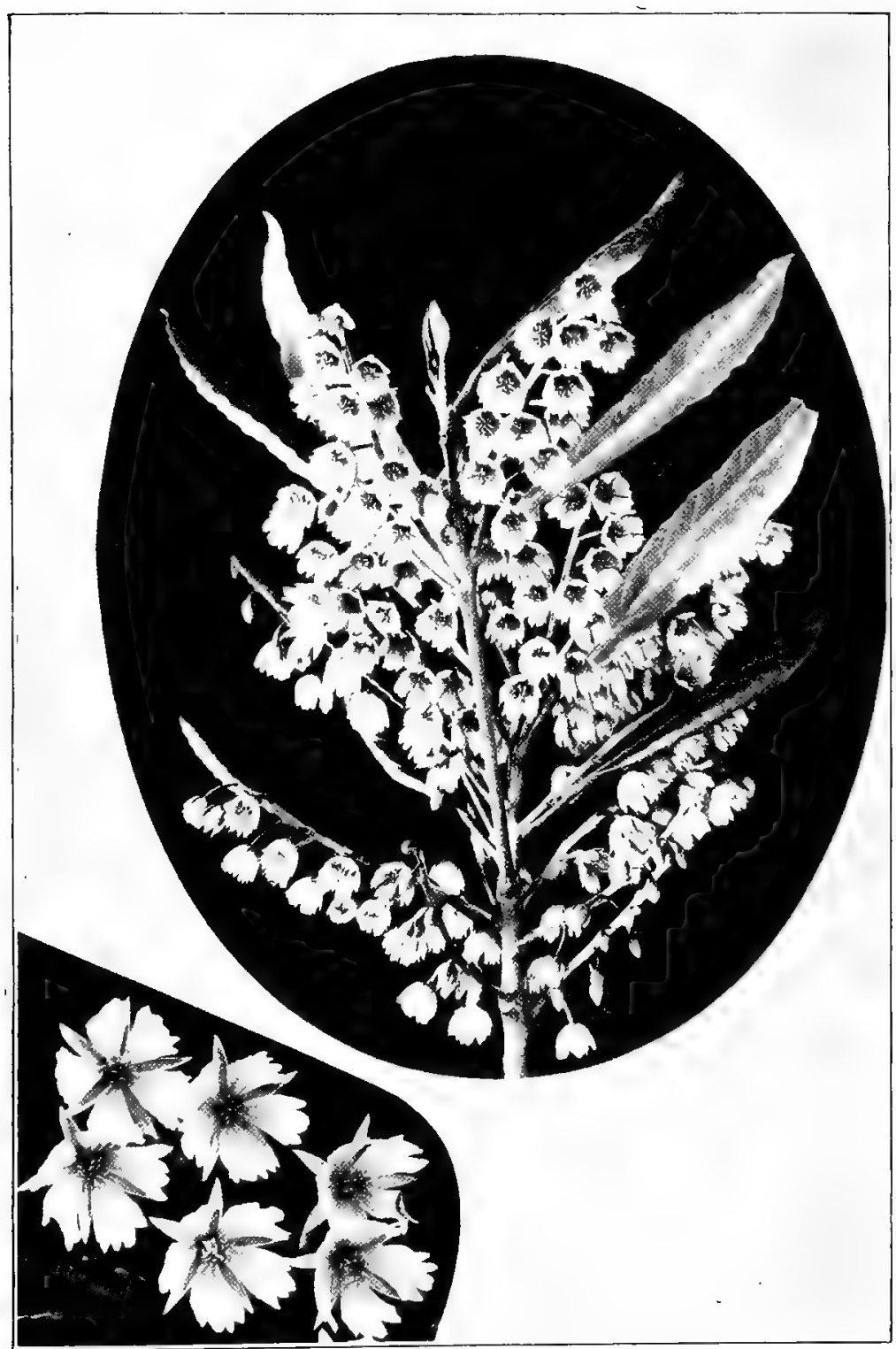

Fig. 76. Elacocarpus dentatus. (Six flowers life size) 


\section{Gemus Elceocarpus.}

Soft-wooded trees, with alternate leaves, and long racemes of white or greenish flowers. The two New Zealand species are endemic. Leaves coriaceous, serrate. Fruit a drupe. (Name from the Greek, signifying an olive and fruit, the drupe resembling an olive in appearance.)

\section{Elæocarpus dentatus (The Toothed Elacocarpus).}

A round-headed tree, with trunk 1ft.-3ft. in diameter, and oblong-obovate leaves, with recurved margin. The leaves of $E$. Hookerianus are linear, oblong or lanceolate, and the margins are flat. This distinction enables the two species to be separated. Maori name Hinau. Both islands. Fl. Oct.-Nov.

One of the most beautiful flowering trees in the New Zealand bush. In a good season, the whole tree is covered with racemes of creany, saucer-shaped flowers, each raceme having the appearance of a spray of lily-of-the-valley. The petals are deeply fringed at the edges, and the leaves are strongly notched. The fruit resembles the damson, and was used for fond by the Maoris, who greatly valued it. A chief who owned a fine grove of Hinau trees was considered a wealthy man, while to rob the grove of its fruit was regarded as a capital offence. The fruit was prepared in the following way:-It was collected into the hull of a canoe, and soaked in water. After a long steeping, the berries were rubbed between the hands, the stalks and skins strained out, and the coarse grey meal, left behind, was made into a cake, baked and eaten. This cake liad a dark appearance, and was too oily for European tastes.

Rats are very fond of the kernel of this fruit, and bore cleverly through the shell in order to obtain it.

The bark of the Hinau makes an excellent blue-black dye, and was used by the Maoris for dyeing the black threads in their garments. This bark contains over twenty per cent. of tamnin, but is not much used. The wood is difficult to burn, and might be employed with advantage where there is special danger of fire. In the Maori language hi signifies to bleed or' emit sap; nat is a shrub or tree. 


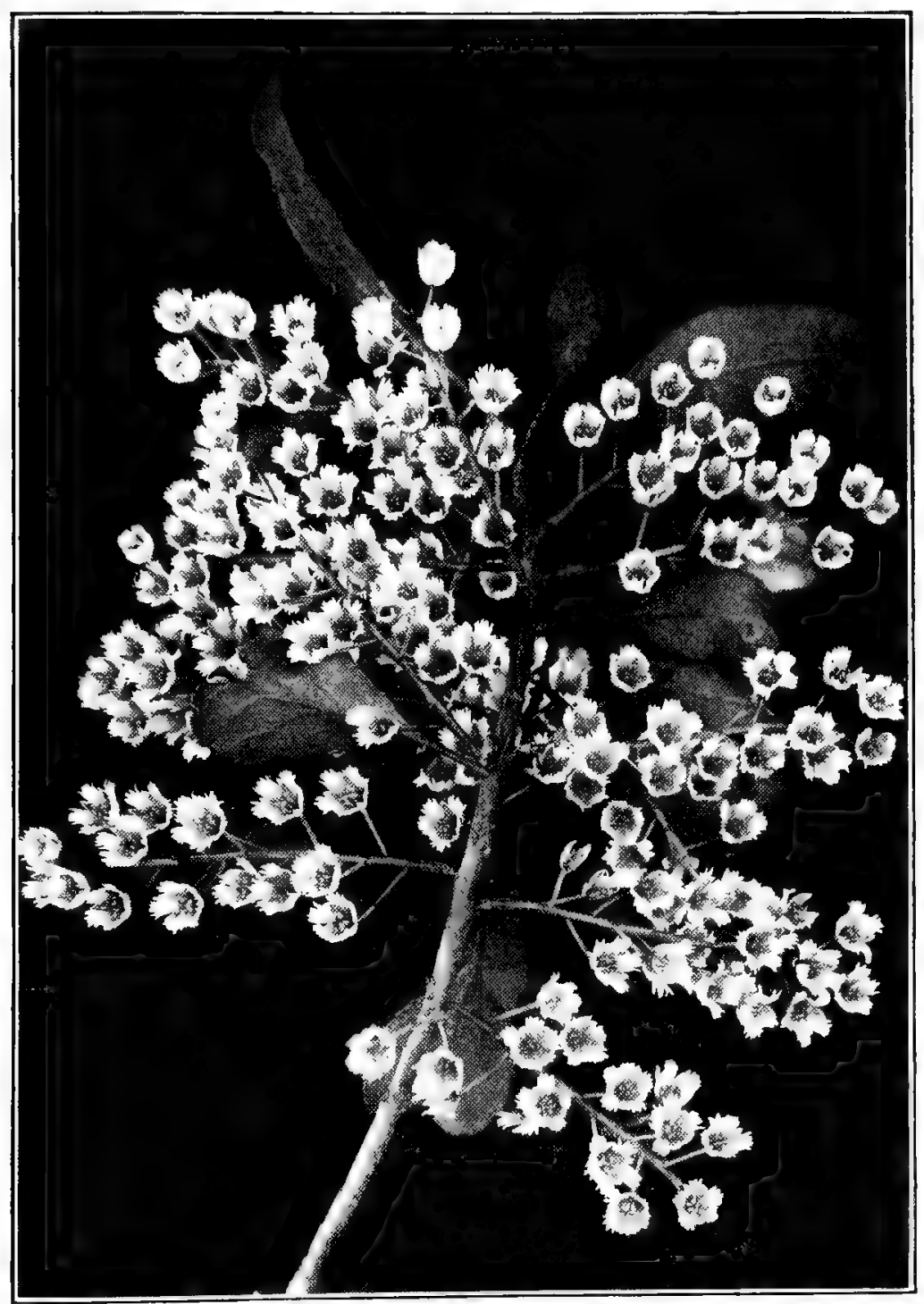

Fig. 77. Elæocarpus Hookerianus (1ife size). 


\section{Elæocarpus Hookerianus (Hooker's Elaocarpus).}

A smaller species, called Pokaka by the Maoris. The flowers do not open out so widely as those of the Hinau, and are greenish-white in colour. Drupe blue, small. Found in both islands. Fl. Nov.-Jan.

\section{Malvaceae.}

\section{The Family of Mallows and RibBon-woods.}

Distribution.-An important and widely distributed family, occurring chiefly in tropical and sub-tropical countries. Of the 60 genera belonging to the order, only four are found in New Zealand, and of these, three are endemic. The Malvaceae are generally mucilaginous, and non-poisonous. The most valuable genus is Gossypium. The delicate unicellular hairs which cover the seeds of these plants, form the cotton so largely used in mauufacture.

The Hollyhock (Althea), the tree-mallow (Lavatera), the Abutilon, and the Hibiscus, are much cultivated for their flowers. Hibiscus cannabimus is the Deccan Hemp of western India. A decoction of the Marsh Mallow is used in throat affections.

Some of the New Zealand trees of this order are noted for the strength and beauty of their inner bark, which is used for various ornamental purposes.

Key to the Genera.

1. Ovary 1 or 2 celled. Ovary 5 celled.

2. One ovule in each celi. Two or more ovnles in each cell.

5. Ovary 10-12 celled.
Plagianthus, p. 253.

2

Hoheria, p. 250 .

Hibiscus, p. 260 .

Gaya, p. 260.

\section{Genus Hoheria.}

Trees with tough inner bark. Leaves extraordinarily variable. Flowers white, axillary, on jointed peduncles. (Hoheria is a modification of the native name). Maori names Houi, Whanuhi, Houhere. $1 \mathrm{sp}$.

Plants of both this and of the next genus (Plagianthus), are popularly known as Ribbonwoods. The bast or inner bark is perforated by the medullary rays, and this gives to it a characteristic ribbon-like appearance. This genus is endemic in New Zealand.

Hoheria populnea (The Poplar-like Ribbon-wood).

The varied names given by the Maoris in different districts to this plant, are all said to spring from the same root. Whan 


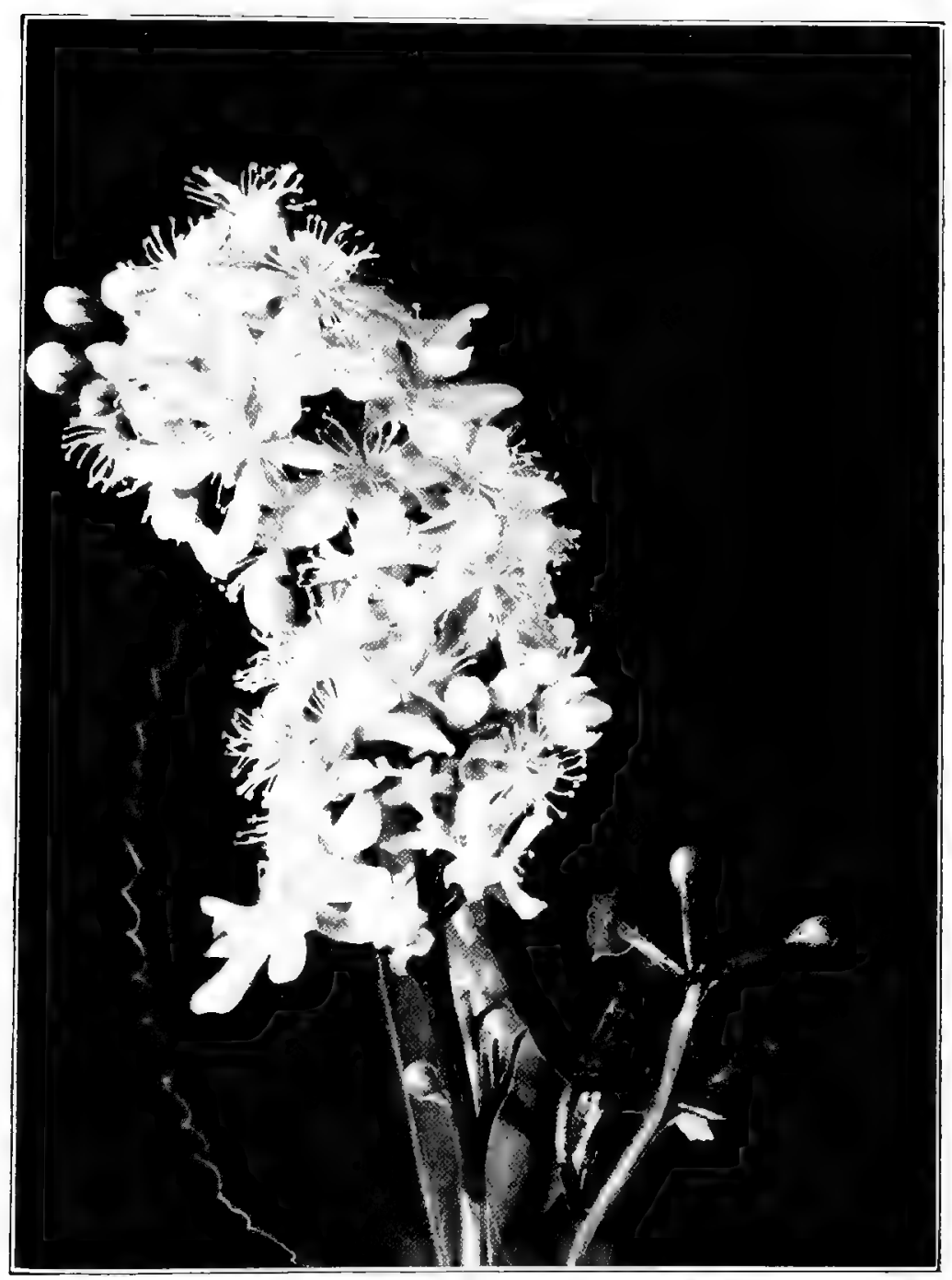

$27 T^{8}=$ Fig. 78. a Hoheria populnea, var. vulgaris (ly nat. size). 
signifies wrapped about, netted,-like lace, and the tree is so called from the character of its inner bark. The settlers name it lace-bark, ribbon-wood, or thousand-jacket. This inner fibre is remarkably tough, and is, therefore, often used for cordage. It is also beautifully perforated, and has been employed for many ornamental purposes, such as trimming for ladies' hats, basket work, etc. Lace-bark bonnets are said to have been at one time fashionable in Nelson. The houhere is one of the most beautiful of the small trees of the forest. It is covered in autumn with a sheet of white, starry flowers, which are often developed in such profusion as entirely to conceal the leaves. There is a large number of recognized varieties, but, as Dr. Cockayne has shewn, $H$. angustifolia at least should be regarded as a distinct species. It is found only in the South Island, flowers earlier than the North Island variety, and the seedling stages of each are different. When several feet in height, it becomes like one of the twisted shrubby Coprosmas (v. Plagianthus betulinus, p. 256). The branches are then wiry and interlacing, and the stems reddish, not dark brown or black as in older specimens.

Thousands of plants in this stage may be seen on the Akarra-Flea Bay Road. The North Island form does not pass through a coprosma-like stage. The two varieties illustrated will show the difference between $H$. populnea, var. vulgaris, and var. angustifotia. The former has broad, ovate, deeplytoothed leaves, while those of the latter are long and narrow. The Hoherias sometimes grow to a height of $40 \mathrm{ft}$.

The flowers are very beautiful, with snow-white petals and numerous stamens. They are produced in fascicles in the axils of the leaves, sometimes only two or three together, and sometimes in bunches of from twelve to twenty. The stamens are curiously arranged, being united, as in all the Malvaceae, into a tube, but breaking apart again lower still into separate bundles, each of which contains five or six stamens. The fruit is dry, and the seeds pendulous. 
The wood of this tree is white and very tough. It is occasionally used by cabinet makers, and makes excellent firewood. A soothing drink was made from the bark by the Maoris.

\section{Genus Plagianthus.}

Shrubs or trees, with rough inner bark, and divaricating branches. Flowers axillary or terminal. Leaves usually entire. Seeds pendulous. (Name from the Greek, signifying oblique, from the unequal petals). $3 \mathrm{sp}$.

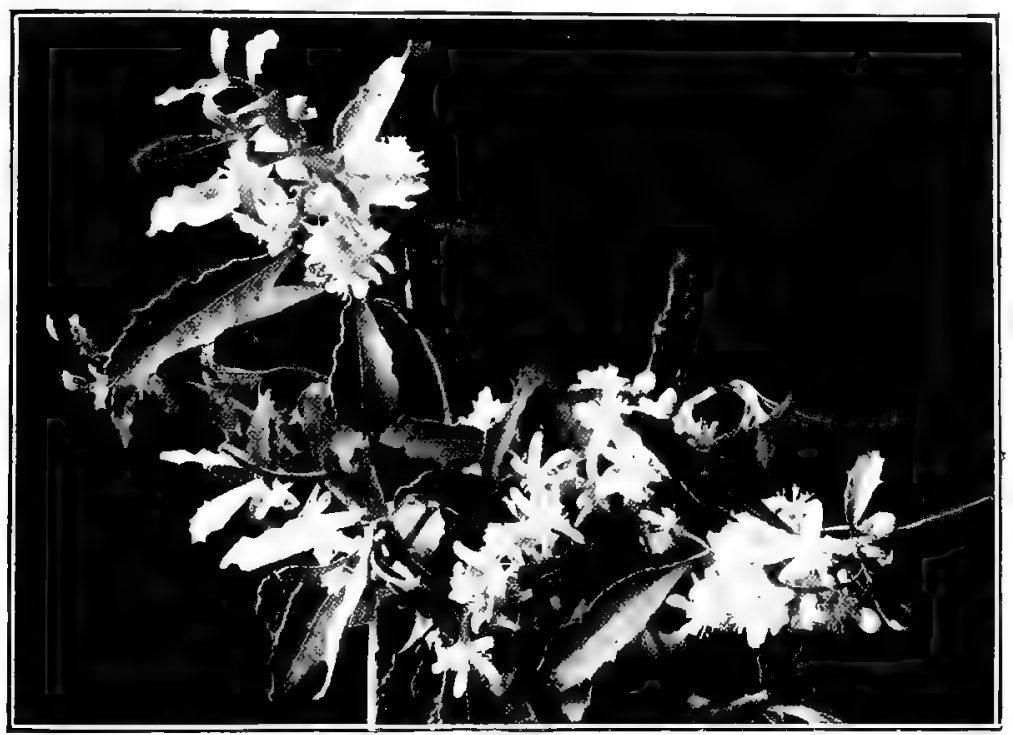

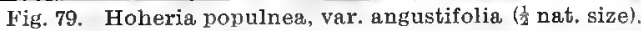

Plagianthus divaricatus (The Wide-branched Ribbon-wood).

A curious shrub, with slender, widely-branched, tough stems. Leaves and flowers both minute. Leaves fascicled; flowers white, tubular, axillary. Stamens, 6-10. Fruit a round capsule containing one or two seeds. Both islands. Fl. Oct.-Nov.

This plant is very different from the other species of the genus. It grows only by the seaside, where it forms dense bushes, which become very compact owing to the interlacing of the delicate sprays. Diels classifies it with Avicennia as a mangrove plant, and, according to him, the stout 
cuticle and leaves rich in slime, show excellently how dependent the mangroves are upon the dampness of the atmosphere for their moisture. However, $P$. divaricatus, though found at the head of tidal creeks and estuaries is really a plant of the salt meadows, and not of the tidal flats, and can scarcely be termed a mangrove.

\section{Plagianthus betulinus (The Birch-like Ribbon-wood).}

A tree, varying from $30 \mathrm{ft} .-60 \mathrm{ft}$. in height, with terminal panicles of white flowers. The young shrub forms a mass of tortuous interlacing branches. Leaves lobed, or coarsely toothed. Petals rounded at the tips. North and South Islands, Stewart Island, Chatham Islands. Fl. Jan.-Feb.

$P$. betulinus is readily distinguished from most of the other denizens of the New Zealand forests by its softer leaves, which resemble those of a deciduous tree, rather than those of an evergreen. Indeed, in most localities of the South Island, the plant does lose its leaves on the approach of winter. It has obtained its specific name (betulinus) from the resemblance of its foliage to that of the English birch. Plagianthus, however, has much larger leaves than Betulus. Owing to the presence of an inner, ribbon-like bark, it is generally called the Ribbon-wood by the colonists. The Maoris used this bark for making rope and twine for their fishing nets. It also makes a good substitute for the Raphia, used by gardeners in tying up soft plants.

\section{Strange Sreduing Forms.}

The young stages of the plant are very different from the older forms. An extraordinary proportion of New Zealand trees and shrubs pass through one or more distinct intermediate stages before reaching the adult form. In a considerable number of cases (e.g. Pennantia corymbosa, 


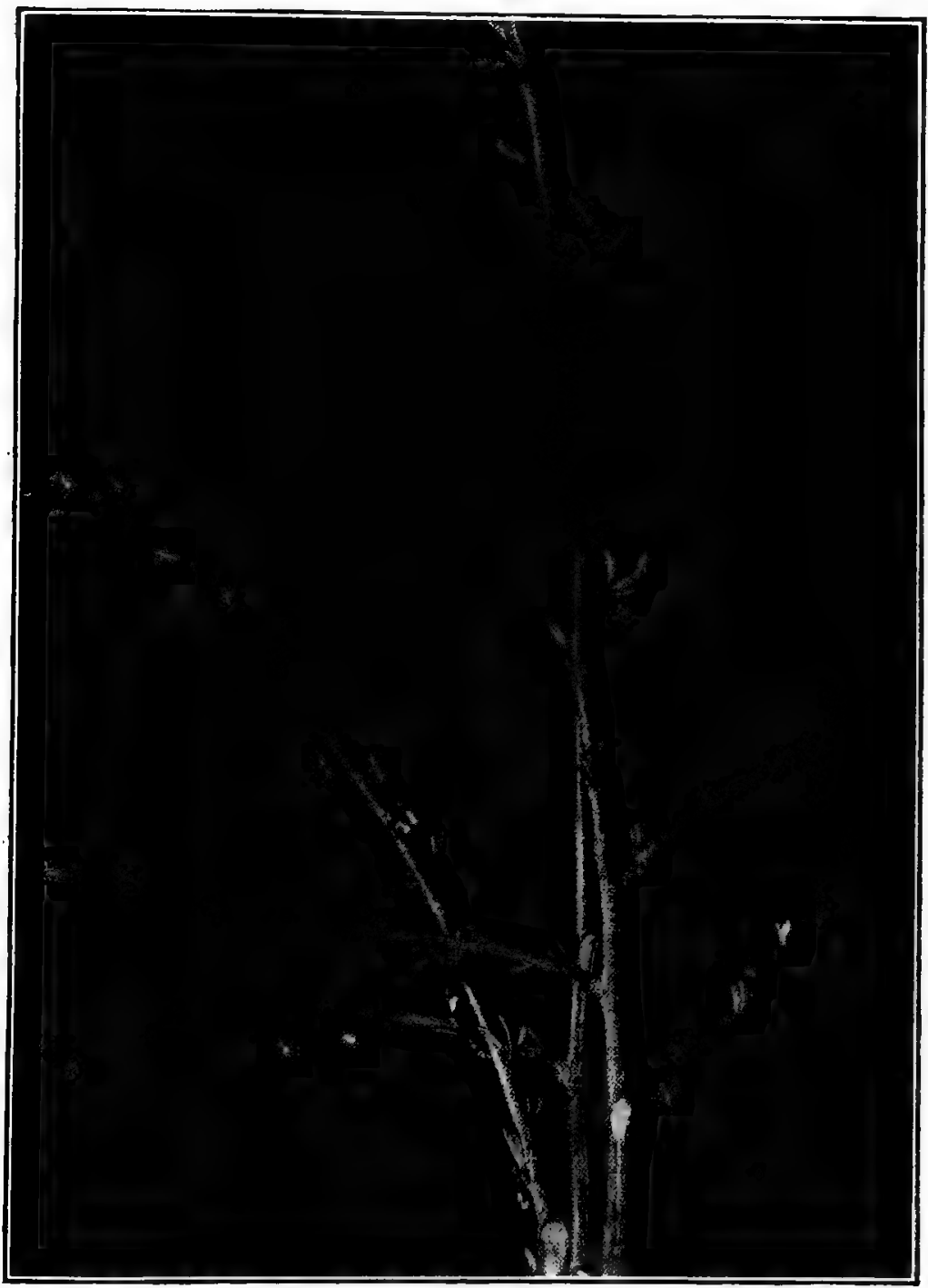

Fig. 80. Plagianthus divaricatus (with pistillate flowers). (禎 nat, size.) 
Hoheria angustifolia, Plagianthus betulims) the intermediate form, in its compact scrubby habit, and small leaves, bears a remarkable resemblance to certain Coprosmas. In other examples, the intermediate form, though not of the type of a Coprosma (e.g. Psendopanax), is simpler than either the first or third stages, which often resemble each other. These remarkable differences between the appearance of New Zealand plants in their earlier and later stages, have puzzled botanists very much. They seen to be but little known outside of our islands. Thus, Dr. Cockayne states:- "On this point I can speak with some authority, since during the past few years, I have personally raised from seed thousands of species of extra-tropical plants, and in few, save certain Australian genera and Conifers, have I noticed any marked change in leaf to take place."

\section{The Law of Recapitulation.}

Now it is generally believed that the same law of development holds in the plant world as in the animal world, i.e., that the individual in its development goes through, in order, the same stages that its ancestors have gone through, in their development. Thus, in the mammalian embryo, a fish stage and a reptilian stage are clearly to be recognized. However, this law must not be interpreted too literally, and in considering any special example, large allowances have to be made for the effect of environment, and for unknown factors. We cannot, therefore, reason backwards from embryonic to ancestral life, with any assurance of accuracy. However, the law is broadly true, and of considerable biological value. Now evolution, - unless accompanied by degeneration, usually proceeds from the simple to the complex. But,

*Trans., Vol. XXXI. ?. 356 . 
one of the difficulties that has presented itself to the investigator of the New Zealand trees and shrubs, is, that the intermediate stage is often simpler than the seedling form, and thus the usual law seems to be reversed. This puzzled Dr. Diels considerably. In reference to Pseudopanax, he states, that the most rennarkable thing about the leaf changes is, that in all similar cases there is a progression from simple to more complicated forms, but here, on the contrary, the high degree of differentiation of the young foliage suffers reduction later on. Hence, he considers, that in this case, recapitulation of the ancestral history is not probable.

\section{Dr. COCKayne's Theory.}

Recently, however, Dr. L. Cockayne has put forward a theory to account for these curious metamorphoses.* Within our limits, it is not possible to discuss this interesting hypothesis fully, though it is certainly one of the most remarkable and suggestive ever put forward with regard to our native plants.

It had already been shewn by Dr. Diels, that an unusually large percentage of the trees and shrubs in the New Zealand Flora are xerophytic in structure ( $v$. Introduction, p. 41, also Veronica, Aciphylla, Discaria, etc.). This type of plant structure seems to indicate, that the past climate of $\mathrm{New}$ Zealand was much more arid than at present. The vegetation of the Canterbury Plains in particular, is of a desert type. Such a belief is supported by the geological evidence. Captain Hutton has pointed out that during the Pliocene period, the Southern Alps were much higher than they are now. He considered that the land surface of New Zealand then extended eastward to the Chathams, and southward to the Auckland Islands. Under these circumstances the climate of the interior would approach to the continental in 
character. The plains to the east of the Southern Alps would be subjected to a great range of temperature, and great drought. Dr. Cockayne ingeniously explains the developmental stages of the present lowland plants, by reference to these past conditions. Obviously, only those plants that could develop protection against the rigours of the climate, would survive the test of such an environment. When the land again sank, the climate would become moister and more insular. Xerophytic plants, if still plastic, would again assume their original form, or, if unable to do this, would become extinct, or retire to the shingle-fans, dry rocks, and river-beds, where we now find them.

Let us now apply this hypothesis, to explain, if possible, the forms through which Plagianthus betulinus passes in its development. A seedling of this species goes through three distinct stages in reaching the mature form. (1) The stem and branches of the young plant are erect, the leaves are of definite shape, somewhat similar to those of the mature stage, but with truncate or cordate bases. (2) The seedling, now grown into a shrub, changes its appearance completely. The branches become long, drooping, twiggy, flexuous, and of a red-brown colour. The leaves are very much reduced in size, and very variable in shape. The plant nuight now be taken for one of the Coprosmas. None but a careful observer would be likely to recognize in this unkempt twisted shrub, the young form of the handsome beech-like tree.

(3) The third or nature form, already described, is a handsome, graceful tree, with large, alternate, rather flaccid leaves.

These forms, if Dr. Cockayne's theory is correct, represent in order (1) the early Pliocene type, existing when the climate was mild, before the elevation of the mountains; (2) the interwoven coprosma-like stage of the later Pliocene deserts ; and (3) the mature form of the present day, which resembles the early Pliocene type, as the climate has once more become comparatively temperate. 
Such a daring hypothesis as this, shows how botanists are beginning to believe in the extraordinary plasticity of plant life. Whatever explanation of these strange changes of form may ultimately be held, the problem suggested by the

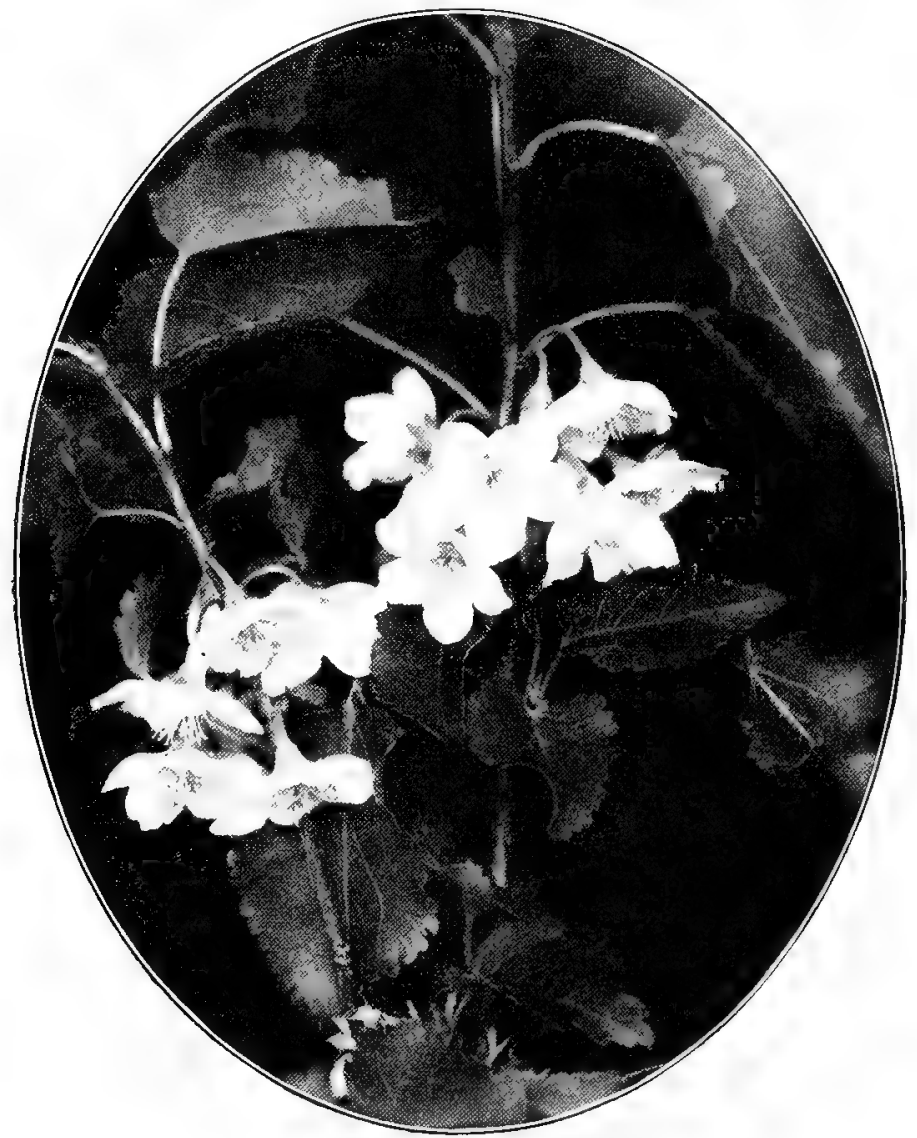

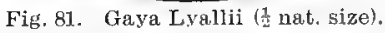

wonderful transformations, which many New Zealand plints undergo in their development, must surely give pause to any belated believers in the immutability of species. They cannot possibly have any theory to account for such unnecessary 
instability of form. Even those who believe that each species has a certain definite type form, which is independent of environment, will find themselves confronted with many paradoxes amongst antipodean plants.

\section{Genus Hibiscus.}

Herbs or shrubs, with large and handsome flowers. A chiefly tropical genus. Flowers axillary or terminal. Capsule 5-valved. (Hibiscus is the Greek name for the flower.) $2 \mathrm{sp}$.

\section{Hibiscus trionum (The Starry Hibiscus).}

An annual or biennial herb, 1-2 ft. high. Stems rough with hairs. Flowers 1 in. $-1 \frac{1}{2}$ in. in diameter, straw-coloured, with dark eye. Calyx inflated, membranous. Leaves palmately-lobed. From the North Cape to Whangarei, local. South Island: West Wanganui. (The specific name literally means of the constellation of the Wain).

\section{Genus Gaya.}

Shrubs or small trees, with large white flowers. Leaves alternate, entire. About 7 species, one of which is endemic in New Zealand. (Called after the botanist, Gay.)

\section{Gaya Lyallii (The Large-flowered Ribbon-wood).}

A beautiful shrub, found only in the mountainous districts of the South Island. This is one of the very few New Zealand trees which shed their leaves. in the winter, and show autumnal tints. The leaves are clothed with stellate hairs, and are deeply notched. South Island, sub-alpine. Fl. Feb.-March.

This plant is one of the many surprises of the New Zealand forest. The traveller, who sees for the first time its cherrylike blossoms amidst the greenery of the bush, usually regards. it as an escape from some garden. Its soft, tender, deciduous leaves are in strong contrast to the normal, hard, glossy leaf of the typical trees of the New Zealand forest, whilst its flowers are equally different from the typical, minute, greenish clusters of Nothopanax, Griselinia, Melicytus, etc.

Owing to a mistake of Sir Julius von Haast, it is generally stated that the tree is deciduous only at high levels, but the error has been recently corrected by Dr. Cockayne." The 
plant is probably deciduous even at sea-level. It certainly is so in the Christchurch Gardens, where it grows only a few feet above high-water mark.

The under-surface of the leaf of the var. ribifolia, is covered with a down of stellate hairs. As this variety is only found in drier localities, the obvious value of this covering is to enable the leaves to retain their moisture. G. Lyallii has hairs only on the veins. The two forms are never found growing together; and this discontinuous distribution, as well as other characters, seems to show that they are specifically distinct.

The inner-bark of this tree has the same lace-like appearance as that of Hoheria.

\section{Violaceae.}

\section{The Violet Family.}

Distribution.-Family of about 300 species, found both in temperate and tropical regions. The temperate forms are usually herbaceous, while those of warmer climates become shrubs or trees. The Violet and Pansy are wellknown garden flowers.

Key to the Genera.

1. Flowers irregular. Flowers regular.

Viola, p. 261. 2

2. Flowers dicecious. Melicytus, p. 264.

Flowers perfect. Hymenanthera, p. 266.

\section{Genus Viola.}

Three New Zealand species, all endemic. Petals unequal, the lower one spurred. Capsule with three valves. In most of the species of Fiola, the ordinary flowers set no seeds. The plant, however, produces, at a later stage, green-coloured, self-pollinated flowers, which seed freely.

\section{Viola filicaulis (The Thread-like Violet).}

So-called from its slender, thread-like stem, which is prostrate. Leaves alternate, shining, heart-shaped. Flowers yellowish. Abundant in both islands. Ordinary flowers Nov.-Dec.; cleistogamic flowers Jan. and Feb. 


\section{Viola Cunninghamii (Cunningham's Violet).}

Stem short, with a woody rootstock. Leaves tufted; peduncles longer than the leaves. Both islands, in damp situations. Flowers white. Produces cleistogamic flowers in the lowlands.

The New Zealand violets are practically scentless; or, if they have any odour at all, it is that of musk. The situation in which they are often found is well described in the following stanza:

"Here, in this bend of the creek, in the rushes, and long lush grassen,

Wild white violets nestle, and musk in the water weeds:

Here there is stillness and shelter, for the wandering wind as it passes

Is caught in the tall green flax, and dies in the rushes and reeds."

\section{Tnsect Pollination in the Genus Viola.}

The method of cross-pollination in the genus riola is well worthy of study. It is best illustrated by reference to the garden Pansy ( $V$.tricolor); for the flowers of the cultivated varieties of this plant are larger than those of any of the wild species, and the parts therefore adwit of readier examination. The description here given applies, therefore, to the common forms of the pansy, but it is also correct with slight modifications for the other species of the genus. The flower is unsymmetrical, and one of the petals is provided with a long hollow spur. The anthers are prolonged into a hood, or projection, which surmounts them. This forms part of the connective (i.e. the part joining two anther-cells together). In two of the stamens, the connectives are also produced backward into long narrow arms, terminating in the spur of the corolla. The stamens do not, as in most flowers, open outward, but the pollen escapyes on the inside into the ring formed by the hoods of the anthers, and falls thence on to a brush-like series of hairs on the lower petal. The pistil has a short, somewhat curved style, with the stigma in a hollow on the side of its rounded head. Just below the stigmatic surface is a small platform, or lid, the function of which will be presently clear.

The two long arms of the anthers have honey-glands on their base ; and the honey secreted by them is collected in the spur of the corolla. An insect endeavouring to get at this 
honey, therefore, will encounter with its tongue the pollen collected on the hairs of the petal, and, in drawing back its head, will force the little platform on the style against the stigmatic surface, and thus protect the flower from selfpollination. In going to another flower, the insect will naturally brush the upper side of the projecting lid, when entering the flower, and thus cross-pollination will be effected.

\section{Cleistogamic Flowers in the Genus Viola.}

Although cross-pollination is essential to the welfare of many plants, there are many others in which self-pollination results in the production of good seeds. In other cases, flowers which are usually cross-pollinated, become adapted for receiving the pollen from their own stigmas, when, from some reason or other, cross-pollination fails. Under these circumstances many plants produce what are known as cleistogamic flowers. (Cleistogamic, from the Greek, meaning concealed marriage). These are flowers which never open, but which nevertheless produce seed, as a result of the application of their own anthers to their own styles. Cleistogamy is known anongst plants belonging to widely divergent orders. Thus it is found amongst species belonging to the following genera:-Arabis, Azalea, Gentiana, Hypericum, Oxatis, Veronica, etc. Probably, however, it is better known in the genus Viola, than in any other.

Cleistogamy is generally resorted to, when wet weather prevails about the time when the flowers should open, or when the plants themselves happen to grow in moist or shady places. This method of pollination is sometimes effected by mechanisms as ingenious as those found in plants which are cross-pollinated. The petals which are no longer required for the attraction of insects, become rudimentary, or are altogether wanting. When they are present, they are generally greenish, or greenish-white. The anthers are so situated, that they come into contact with the stigma as soon 
as it is mature, or there may be a space between the anther and stigma. In this case the pollen grains put out theil tubes, which attach themselves to the stigmatic surface. Thus pollination is effected with certainty. It is obviously better for the plant to be self-pollinated, than to remain infertile. In New Zealand, cleistogamy has been studied in the genus Viola by Mr. G. M. Thomson."

In Viola filicaulis, cleistogamic flowers are often found in the months of January and February. They are borne very close to the root, on short curved stalks less than an inch in length. The sepals are normal, and the petals, in place of being irregular in shape, as they are typically in the violet, are all of the same form. The stamens are apparently all represented, and have the anthers, when present, appressed to the pistil. (However, in many cases, one or only two filaments have anthers, and in no case is the connective produced backward into a spur). The style is as long as usual, but if straight, would be beyond the reach of the anthers. It therefore lies coiled up on the top of the ovary.

In V. Cunninghamii, the reduction of cleistogamic flowers has been carried further even than in $V$. filicaulis. In the former species there is no trace of petals, and the stamens are much more rudimentary. Only two are provided with anthers, and these, enclosed in their hoods, are closely applied to the stigmatic surface.

\section{Genus Meticytus.}

Small trees, with regular flowers and alternate leaves. Fruit a berry, containing angular seeds. Found only in New Zealand and Norfolk Island. (Name from the Greek, signifying honey and a cavity, in reference to the small scales behind the anthers, at first mistaken for nectaries). $4 \mathrm{sp}$.

Melicytus ramiflorus (The Branch-flowered Melicytus).

A tree, sometimes $30 \mathrm{ft}$. in height, with white stems and greenish-yellow Howers. The latter are produced in fascicles upon the branches below the leaves, and are minute, being only $\frac{1}{8} \mathrm{in}$. in diameter. Leaves oblong, serrate. Berry violet-coloured. Both islands. Fl. Nov.-Jan. Maori names Mahoe, Ini-ini.

*Trans., Vol. XI. p. 415. 


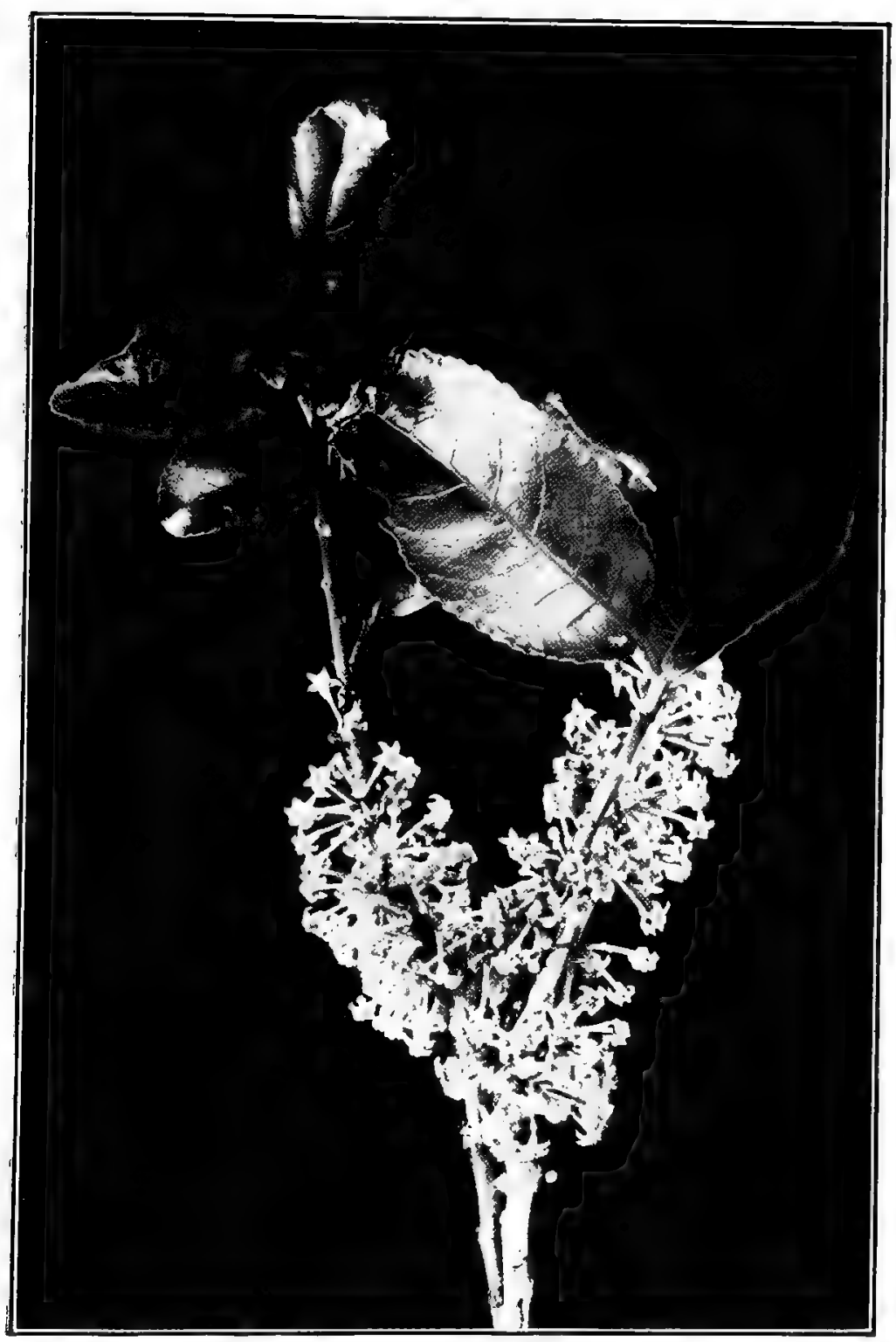

Fig. 82. Melieytus ramiflorus (a nat. size). 
A small tree, most abundant in the bush, growing to a height of $30 \mathrm{ft}$., with a rounded head, and many short, brittle branches. It sends up a large number of young saplings, or suckers, from the ground at the foot of the trunk. The leaves are alternate, with toothed margins, and the flowers are produced, either in the axils of the leaves, or upon the bare branches. The male and female flowers are found upon separate trees. The fruit is a violet coloured berry, containing black, angular seeds, and is a favourite food of the wild pigeon. Though so much smaller than many of the forest trees, the mahoe is a noticeable object in the bush, as its straight, thin trunks are often covered with a white fungoid growth, which is like a coating of whitewash. This was one of the woods used by the natives, in the making of fire by friction. In the South the plant is generally known as the Ini-Ini, in the North it is called the Mahoe. On Banks Peninsula it is sometimes called the Cow-leaf, as cows are very fond of its foliage.

\section{Genus Hymenanthera.}

A small genus of woody shrubs, found in New Zealand, New South Wales, Tasmania and Norfolk Island. The foliage differs considerably in the different species. The leaves may be toothed or entire, fascicled or alternate; the flowers solitary or fascicled. Name from the Greek, signifying united anthers.

\section{Hymenanthera crassifolia (The Thick-leaved Hymenanthera).}

A low shrub, with rigid, twisted branches, and white bark. The flowers are small and axilary; the berries purple and white, 1 in. in diameter. Maritime rocks in both islands, and up to 2,000 ft. near the coast. Fl. Oct.-Dec.

This plant frequently forms a dense cushion of short rigid spinous branches, closely appressed to a rock or stone. The berries and flowers are produced on the underside of the branches, and are completely invisible from above. 


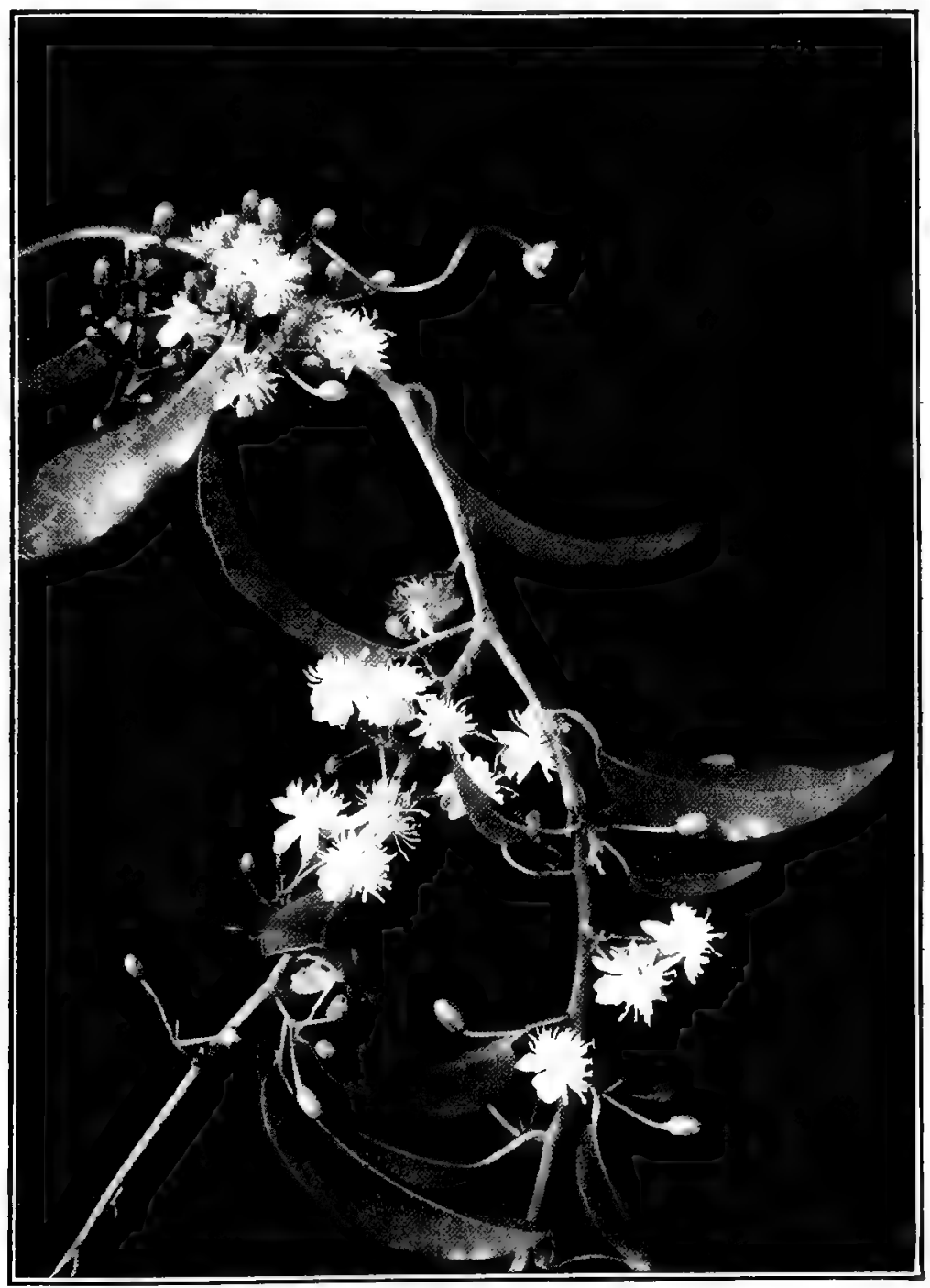

Fig. 83. Passiflorat etrandra ( $\frac{1}{2}$ nat. size). 


\section{Passifloraceae.}

\section{The Passion-Flower Family.}

Distribution.-A fairly large family, chiefly natives of the West Indies, and of tropical America. The New Zealand species is endemic. The fruit of some of the species is edible, and contains numerous small seeds enveloped in mucilage. The Passion-flower and the Tacsonia are beautiful and well known garden and greenhouse plants.

\section{Genus Passiftora.}

Climbing plants, with slender, elongated tendrils. Calyx-lobes 4-5. Petals 4-5, rarely 0; stamens 4-5. Fruit juicy. Seeds black. 1 sp.

Passiflora tetrandra (The Tetrandrous Passion-flower).

A slender climber, with glossy leaves $1 \frac{1}{2}$ in.-4 in. long, and delicate flowers, $\frac{1}{2}$ in.- 1 in. across. Sepals and petals 4 . Flowers cymose, green, with beautiful coronas of white or yellow filaments. Fruit very handsome, bright orange, $1 \mathrm{in} .-1 \frac{1}{2} \mathrm{in}$. in diameter, many-seeded. In both islands, on the edge of the bush. Banks Peninsula the southern limit of many species. Fl. Nov.-Dec.

This, our only passion-flower, finds its southernmost habitat on Banks Peninsula. Here, in the warm, sheltered, almost sub-tropical valleys of the various bays, several native plants are found which do not occur further south. Amongst them may be mentioned the titoki, the nikau palm, the karaka, the true pepper (Macropiper), and the ake-ake (Dodonaa). At one time, a piece of bush ran from the hills across the plains in a north-westerly direction, to beyond Papanui. The only fragment now left of this forest is Deans's Bush, which also contains several of the plants just mentioned. The passionflower still grows wild there, and in a sheltered gully, known only to a few, near Sumner. In more remote portions of the Peninsula it is not uncommon. There is still a grove of karakas at Long-look-out Point, originally, perhaps, planted by the Maoris. Scattered trees are to be found elsewhere in the neighbourhood. The nikau forms a forest in, and gives its name, to a beautiful bay on Akaroa Harbour. The titoki is the chief component of a handsome forest remnant near 
Kaituna. The ake-ake is not uncommon in several places. Many specimens of it may be seen near the Maori village at Rapaki.

According to Colenso, the dried wood of the passion-flower formed an excellent slow match, by means of which the Maoris were able to carry a spark from village to village.

\section{Thymelaceae.}

\section{The Daphne Family.}

Distribution.-A family of about 500 species, most of which are natives of Australia and South Africa. The flowers of Daphne are sweet-scented, and the berries of some of the species are poisonous. The Lace-bark tree of the West Indies is a member of this family, and the fibre of other Indian and Chinese: species is made into paper.

\section{Key to the Genera.}

Stamens, 2

Stamens, 4.

Pimeler.

Drapetes (not further deseribed).

\section{Genus Pinelea.}

Erect or prostrate shrubs, with opposite leaves, and terminal heads of white or yellow flowers. Perianth tubular, 4-lobed, Stamens 2. Fruit dry or pulpy. A genus peculiar to Australia and New Zealand. (Name from the Greek, signifying fatness, in allusion to the oily seeds). $12 \mathrm{sp}$.

\section{Pimelea longifolia (The Long-leaved Pimelea).}

A shrub, $2 \mathrm{ft} .-6 \mathrm{ft}$. in height. Leaves numerous, shining, $1 \mathrm{in} .-2 \mathrm{in.} \mathrm{long,}$ $\frac{1}{4}$ in.- $\frac{1}{2}$ in. broad, flat. Flowers silky, fragrant, white, $\frac{1}{2}$ in. long. Stamens exserted. Nut enclosed in the tube of the perianth. Abundant in the North Island; found also in the northern parts of the South Island.

\section{Pimelea arenaria (The Pinelea of the Sand-dunes).}

A small, silky, shining plant, white, with soft hairs. Stem 8 in.-24 in. high. Leaves close-set, spreading, $\frac{1}{4} \mathrm{in} \cdot-\frac{1}{2} \mathrm{in}$. long, oblong or rounded, hairy, silky, and shining. Flowers white, silky, $\frac{1}{4}$ in, across. Fruit pulpy, edible. North Island: sand-dunes. Fl. Jan.-April. 


\section{Pimelea prostrata (The Prostrate Pimelea).}

A very variable species, often with erect, ascending branches. Stems 2 in. -10 in. long, hairy, Leaves variable, $y_{2}^{x}$ in.- $-\frac{1}{3}$ in. long ; floral leaves slightly larger. Flowers $\frac{1}{8} \mathrm{in} .-\frac{1}{6} \mathrm{in}$. long, hairy or silky; the lobes of the perianth shorter than the tube. Fruit usually fleshy. Both islands: abundant. Fl. Oct.-Narch.

\section{Pimelea virgata (The Twiggy Pimelea).}

A small erect shrub, $1 \mathrm{ft} .-2 \mathrm{ft}$. in height. Leaves spreading $\frac{1}{2}$ in.-1 in. long, narrow, oblong, silky or shining. Floral leaves similar. Flowers in a small head, 8-10 together, $\frac{1}{4}$ in. Iong, silky; lobes broad. Nut dry or pulpy. Both islands: common.

The genus Pimelea is exclusively Australasian. It consists of a number of Veronica-like shrubs. The species are very variable, and pass into each other. $P$. arenaria is a halophyte (v. 1. 42) of the sand-dunes, which has a clothing of wool and sunk stomata, for the purpose of hindering transpiration. The cell-structure is similar on both sides of the leaf, which hangs down more or less vertically. A similar arrangement of leafcells is found in other plants of the sand-hills. In such situations they are exposed to much wind, fierce and longcontinued sunshine, and extremes of drought. Special adaptations are clearly required in order to enable a plant to exist under such conditions. $P$. arenaria, like most of the sand-dune plants, has long roots. Other species are found in the heaths, and some reach sub-alpine elevations.

\section{Myrtaceae.}

\section{The Mrrtle Famili.}

Distribution.-A large family of about 2000 species, chiefly tropical. Many of them abound in aromatic oils, while others furnish gums.

The flowers of this family are very similar to those of the Rosaceae, the main distinction between them being that the carpels are more or less free, particularly in the stigmatic region, in the Rosaceae; whilst in Myrtaceae, the carpels are completely united, the union extending to the stigmas. Many of the 


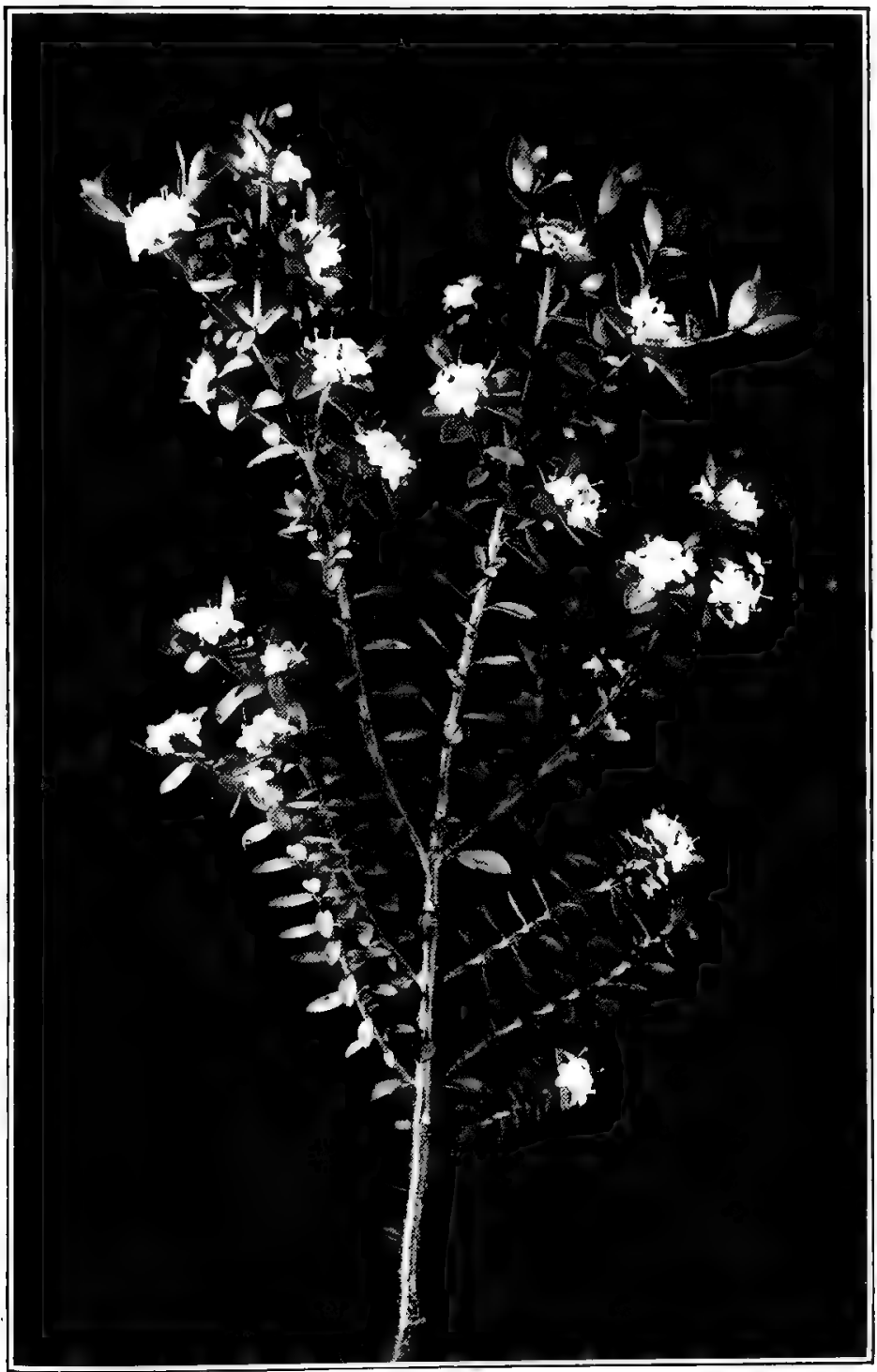

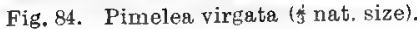


myrtles, also, have glands in all their parts, which secrete ethereal oils that give the plants an aromatic odour. This is, perhaps, the most striking character of the family. The corolla is usually white, and the filaments, which are often a bright red, serve as the chief organs of attraction for insects. Cloves are the flower buds of a species of Eugenia. Another species of the same genus furnishes the fruit from which allspice is obtained. The guava is the fruit of Psidium guava. The only European species is the well-known Myrtle.

The oil of eucalyptus, obtained from $E$. globulus, is antiseptic in its action. This tree is often planted, on account of its rapid growth, for the purpose of drying up swamps, and thus keeping off malarial fevers.

Key to the Genera.

1. Fruit a capsule. Fruit a berry or drupe.

2. Leaves alternate. Leaves opposite.

3. Seeds solitary. Seeds 2 or more.

\author{
2 \\ 3 \\ Leptospermum, p. 272. \\ Metrosideros, p. 278. \\ Eugenia, p. 288. \\ Myrtus, p. 288.
}

\title{
Genus Leptospermum.
}

Shrubs or trees, with alternate, entire leaves. Flowers regular, white or pink. Calyx 5-lobed, petals 5 ; stamens numerous. Capsule woody. About 28 species, of which 3 belong to New Zealand, and 20 to Australia.

\section{Leptospermum scoparium (The Manuka Broom).}

A shrub or tree, sometimes $30 \mathrm{ft}$. in height. Leaves leathery, hard, with

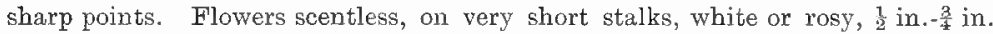
across. Capsule bursting by 4 or 5 valves, very woody. Maori names Manuka, Kahitatoa. Colonists' name, 'Tea-Tree. Both islands. Fl. Nov.-April.

This is the most abundant of New Zealand shrubs. It is the colonial counterpart of the English broom and gorse, and is as beautiful as either of these. One of the loveliest sights of the land is a great valley at Christmas-time, clad with Leptospermum in full flower. From the distance of a mile or two, the country seems to be spread with a sheet of snow, so profusely does the plant flower. A variety is known which has the petals splashed with deep crimson. It is often cultivated in gardens, and vies in beauty with many more pretentious blooms.

To the Maoris the tree was known as the manuka. By the settlers it is generally called tea-tree. It has acquired this name because early voyagers and colonists sometimes used its 


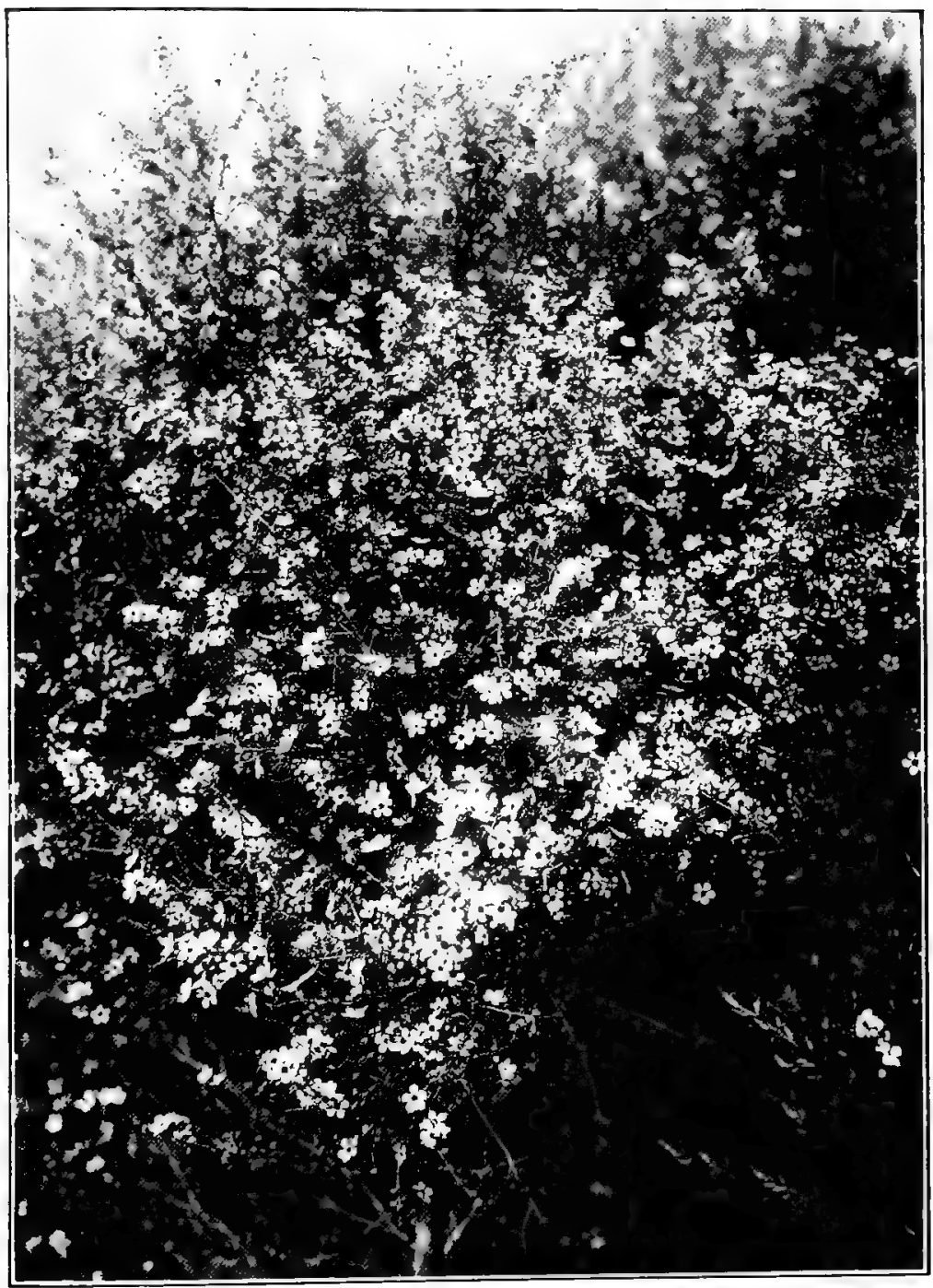

Fig. 85. Leptospermum scoparium. 
pungent leaves in place of tea. Indeed, the whole plant, including leaves, flowers, fruit, and young shoots, is highly aromatic, and the oil which it contains, will perhaps, in future, be put to some useful purpose.

The flowers are generally hermaphrodite, but are sometimes imperfect or unisexual. A branch may occasionally be found bearing flowers which are staminate only, while on the lower portion of the same branch last year's seed capsules are borne. The capsule is hard and woody, of a reddish-brown colour. Very small specimens occasionally bear flowers. A plant. was once observed, not more than half-an-inch in height, which bore a flower and duly developed seed. The flower appeared to be actually lying upon the ground.

The wood of this tree is largely used for fences and firewood. The Maoris made use of it for their paddles and spears, and a bunch of the twigs makes an excellent broom.

\section{Leptospermum ericoides (The Heath-like Manuka).}

A larger tree than the preceding. Leaves narrow, acute, glabrous or silky, fascicled. Flowers $\frac{1}{3}$ in. across, white, very fragrant. Maori name Manukarauriki. Both islands. Fl. Nov.-Jan.

This is nearly, but not quite as common a plant, as the previous one. Like the former species, at high levels, in wind-swept localities, it becomes prostrate, and is reduced to a few inches in height. In suitable positions, however, it grows to be a larger tree than $L$. scoparium, sometimes attaining a height of sixty feet, and a diameter of one to three feet. Its timber is hard and durable, and is used for jetty piles, spokes of wheels, fence-rails, and other purposes. It is also much sought after for firewood, and this has led to the cutting out of all the larger trees over wide areas, so that in many places it is now impossible to procure it. To many old settlers, however, the odour of burning manuka logs brings memories of the pleasant winter evenings of times long past. 


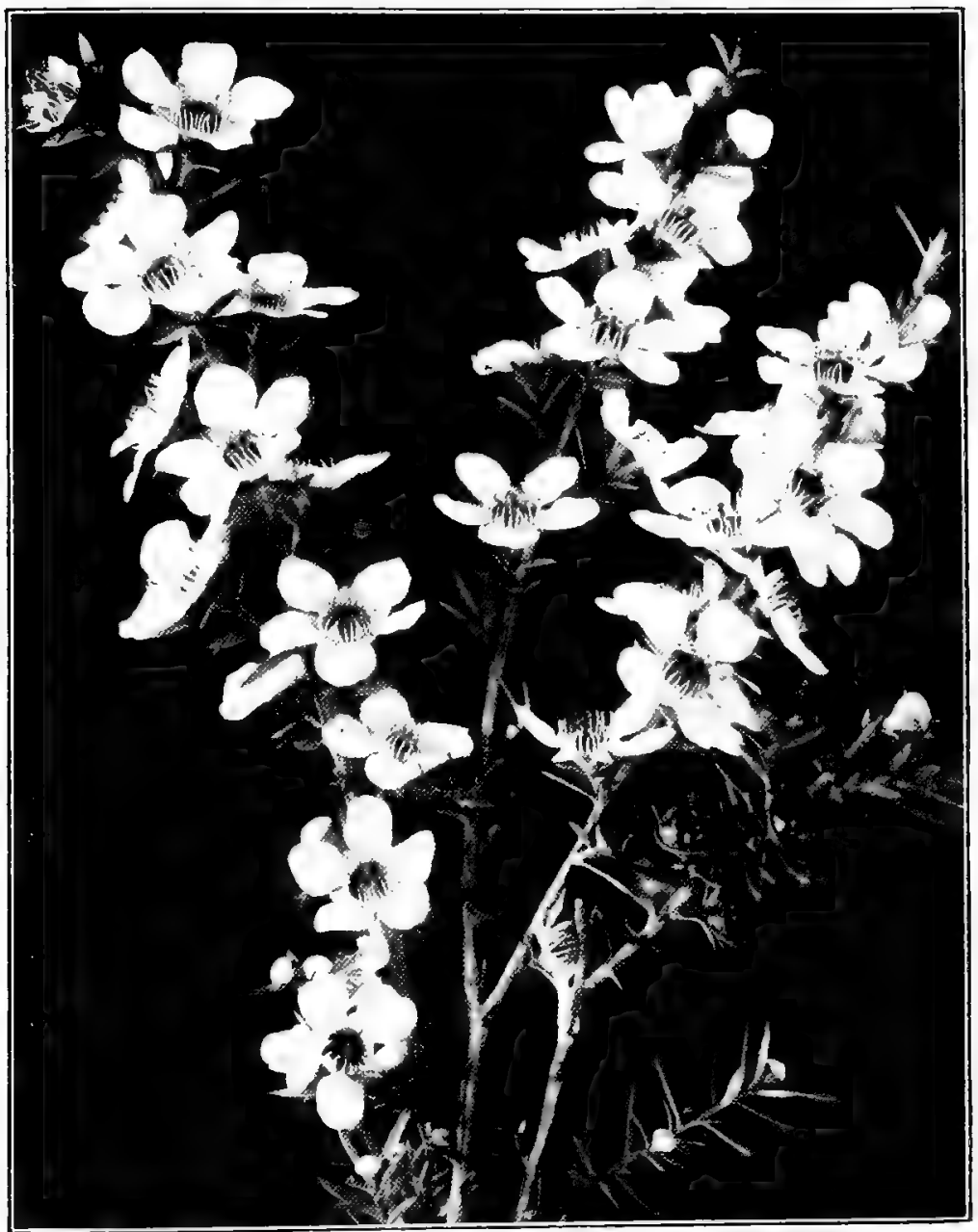

Fig, 86. Leptospermum scoparium (life size). 
Older trees of both species have their trunks covered with a light brown bark, that readily strips off, and is frequently used for fire-kindling. For the camper-out, Leptospermum provides fragrant bedding, easily collected, and not readily surpassed for comfort.

There is little undergrowth in the manuka copse, and the ground below it becomes carpeted with dead leaves, almost as in a pine forest. There are, perhaps, several reasons for this lack of undergrowth. The plant often grows on poor ground; the resinous leaves may, like the pine needles, make bad mould; and the shrub itself probably exhausts the soil. Yet sometimes certain orchids are found below it, which are rare elsewhere, and various other plants seem to prefer the manuka grove as a habitat.

Mr. G. M. Thomson has discussed the probable origin of the New Zealand species. L. scoparium, with sharp leaf tips, is found abundantly in south-eastern Australia; but $L$. ericoides, with less pungent points to its leaves, is endemic. Mr. G. M. Thomson states that the rigid, sharp-pointed leaves of the former indicate that the species originated in a land, where there were herbivorous mammalia, for he considers that "such sharp-pointed leaves are probably so developed in order that they may be as obnoxious as possible to grazing animals." * As the genus has come to us from a northern land, where possibly marsupials and other grass-eating animals were abundant, this explanation seems feasible. It also appears to receive confirmation from the fact that the endemic species has less prickly leaf-tips than the one with wider distribution. However, there is another, and, perhaps, simpler interpretation of such sharp-pointed leaves. They may be due inerely to leaf-reduction, produced as a means of protection against excessive transpiration (v. Aciphylla, Veronica, Discaria). Indeed, that the modification, in the case of 


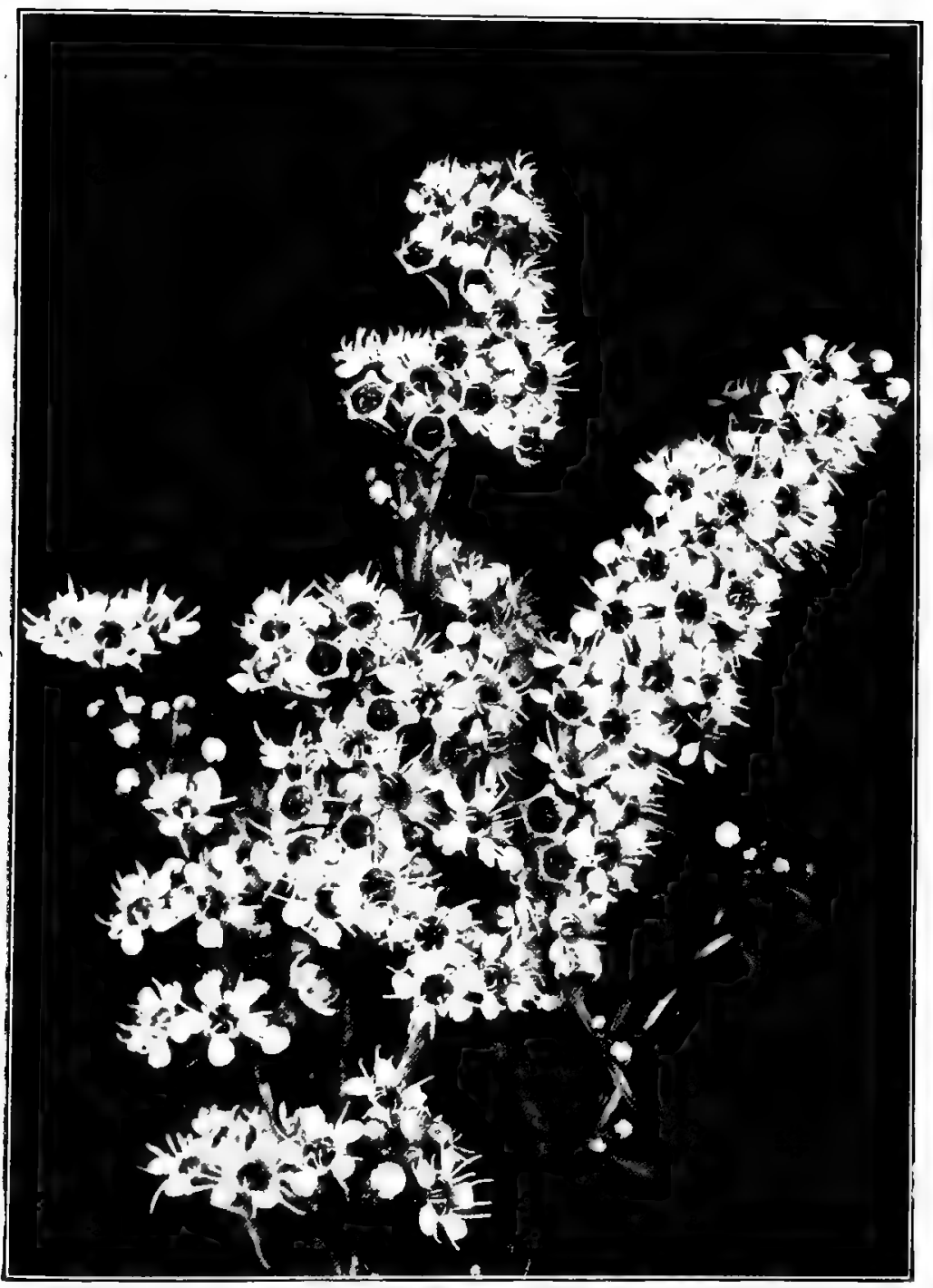

Fig. 87. Leptospermum ericoides (life size) 
Leptospermum scoparium, is climatic rather than defensive, is shown by the fact, that, in certain mountain localities, the leaves become less rigid, more rounded, and less acute. (See, however, under Entelea for a further discussion of the matter.)

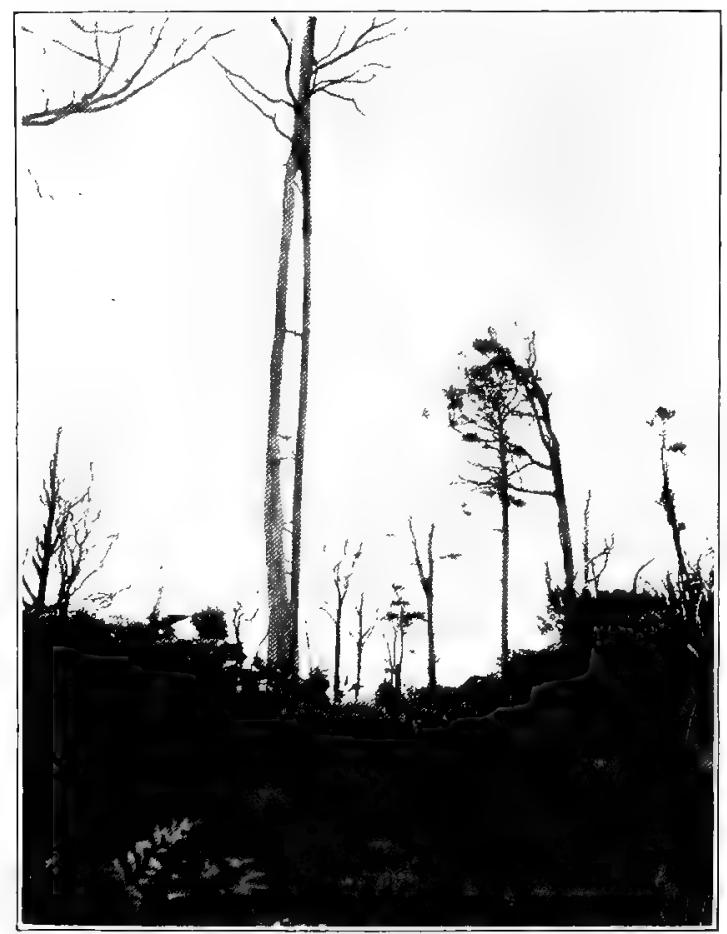

Fig. 88. Metrosideros robusta, showing encircling roots.

\section{Genus Metrosideros.}

Shrubs or trees, often climbing. Leaves opposite, leathery. Flowers in terminal cymes, umbels, or racemes, white, pink, or scarlet, often very showy. Calyx 5-lobed; petals 5, small. Stamens numerous, very long, white or scarlet. (Name from the Greek, meaning iron-hearted, in allusion to the iron-like hardness of the timber). Plants of the genus are usually known to the colonists. by the Maori name Rata. $11 \mathrm{sp.}$ 


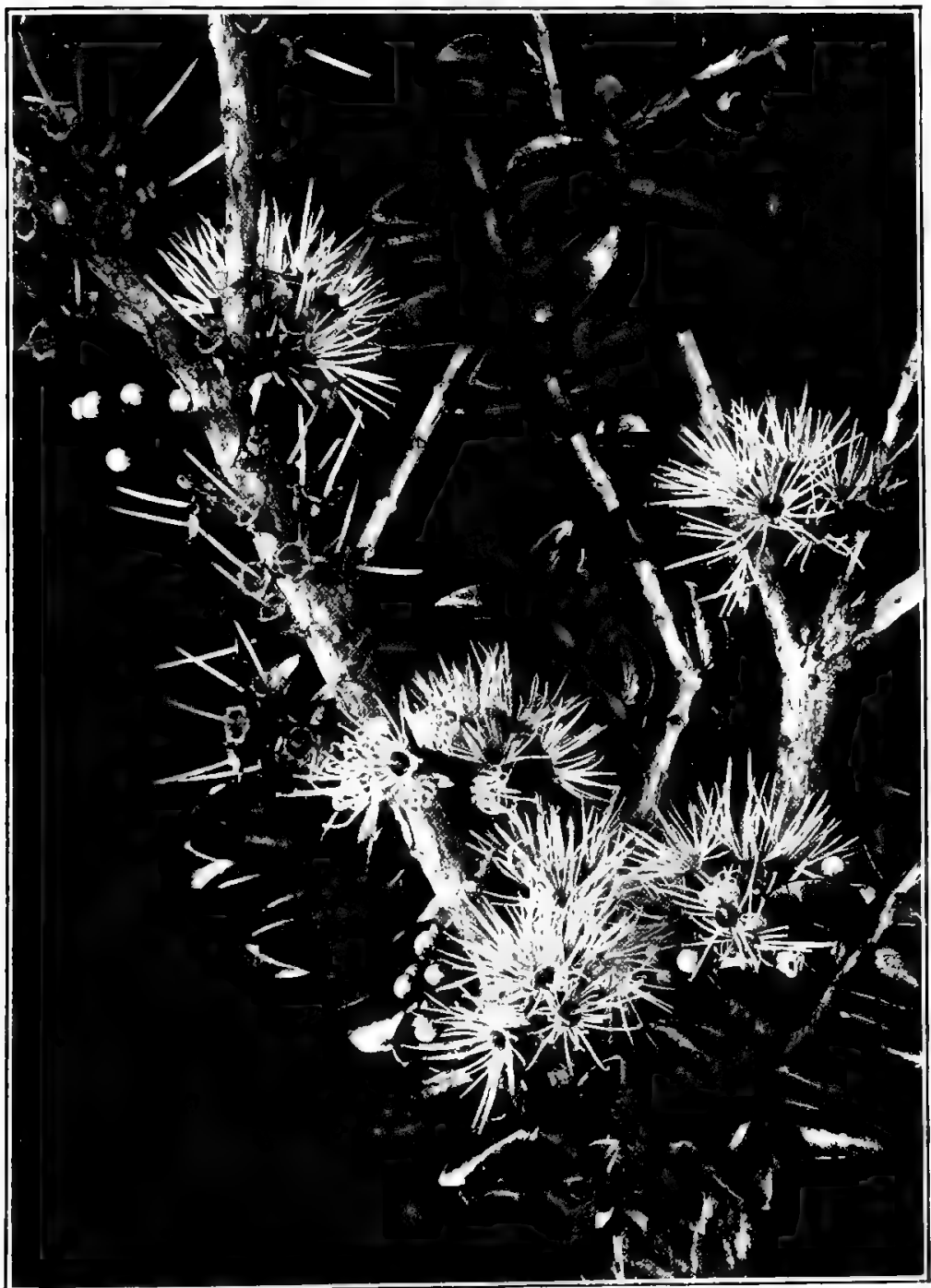

Fig. 89. Metrosideros hypericifolia ( 


\section{Metrosideros florida (The Flowery Rata).}

A shrub, or lofty climber. Leaves $1 \frac{1}{2}$ in.-3 in. long, oblong, obtuse, entire, shining. Flowers in large terminal cymes. Petals yellowish, or pale pink,

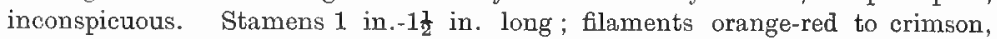
anthers golden. Fruit a woody capsule, half the length of the calyx-tube. Both islands: common on forest trees. Fl. Nov.-April. Maori names: Aha, Akatawhiwhi, Pua-tawhiwhi. English name Rata-vine.

The rata-vine is one of the most remarkable climbers of the New Zealand forest. The stem is sometimes six inches in diameter, and climbs to the tops of the highest trees. It is often confused with Metrosideros robusta, but it is the latter, not the former, which strangles its support.

Bushmen quench their thirst with the juice of the rata-vine. A slit is cut in the wood, and the bark left hanging, when a clear juice drops freely from the cut. A piece of rata-wood four feet in length, and three inches in diameter, was kept in a workshop for three weeks, until apparently quite dry. Then a cut was made lengthwise in it, and it yielded a gallon and a half of liquid. This juice was of a clear, bright, pinkish hue, and tasted somewhat like dry cider. The inner rata-bark is used to heal sores, and to stop bleeding. It is sometimes boiled with the bark of the rimu and the kauri, to make a lotion for the sore backs of horses. According to the Maori tradition, the bark of this, as of other trees, when required for healing purposes, should be cut from the side upon which the sun rises.

\section{Metrosideros hypericifolia (The Hypericum-leaved Rata).}

A straggling climber. Bark ragged; branches 4-angled. Leaves sessile, $\frac{1}{3}$ in.-3in. in long, oblong, shining, rather membranous. Flowers small, in lateral cymes or racemes. Petals white or pink, $\frac{1}{3}$ in. $-\frac{1}{2}$ in. long. Capsule $\frac{1}{8}$ in. long. Thamp bush, in both islands. Fl. Nov.-Jan.

\section{Metrosideros lucida (The Shining Rata).}

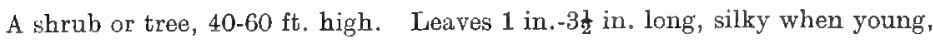
shining when mature, pointed at both ends. Flowers in short terminal cymes. Petals small, scarlet. Stamens nearly an inch long, scarlet. Both islands; Lord Auckland's group. Fl. Dec.Jan. A variety with yellow flowers has been found on Arthur's Pass. 
Metrosideros lucida, the rata of the South Island, is known as the iron-wood in Otago. It grows in masses on the slopes of the Southern Alps, and in a good rata year, adds much to the beauty of the scenery. New Zealanders speak of the Otira Gorge at such a time as one of the sights of the world, but their patriotism has perhaps led them to overpraise it a little. Yet, when in January, the flanks of a great mountain range are ablaze with

\footnotetext{
"Flowers, that with one scarlet gleam Cover a hundred leagues, and seem To set the hills on fire!"
}

the sight is one which many would travel far to see. In Canterbury, on the eastern slopes of the Alps, this rata is rare. It apparently cannot stand a dry climate. It is much more common on the east coast of Otago, south of Dunedin, where it frequently overhangs the sea-cliffs, though it does not root in the same fantastic manner as the pohutukawa.

In the Auckland Islands, it is the chief component of a forest, as fantastic as any that was ever goblin haunted. It reminds one of the sunless forest of Undine, or of the still more terrible forest of the Seventh Circle of the Inferno:-

"Where no track

Of steps had worn a way, not verdant there
The foliage, but of dusky hue, not light
The boughs and tapering, but with "knares deformed,
And matted thick: fruits there were none, but thorns
Instead, with venom filled."

The rata, as its common name, ironwood, suggests, produces an extremely hard timber, with qualities similar to those of other members of the genus.

Metrosideros albiflora (The White-flowered Rata).

A climbing shrub. Leaves shining, 1 in.-3 in. long, narrowed at both ends. Flowers in terminal cymes. Petals small, white. Stamens very slender. Capsule $\frac{1}{3}$ in. long. North Island: in forests. Fl. Dec.-Jan. 
The long twining stems of the rata vines were used by the Maoris for various purposes; and references to them appear in several legends. Metrosideros albifiora (the Akatea) gives rise to the Maori equivalent of Nil desperandum. Thus an ancient proverb runs:

\section{"Rangitihi upoko i takaia ki te akatea."}

Rangitihi's head was bound up with the akatea.

Rangitihi was a hero of old who had his head split by his enemy's club. With splendid courage he bound the broken skull round with akatea, and, encouraging his fleeing men, led them on again. This time it was to victory.

\section{Metrosideros robusta (The North Island Kata).}

A tree, $50 \mathrm{ft} .100 \mathrm{ft}$. in height. Trunk sometimes $10 \mathrm{ft}$. in diameter. Leaves 1 in. $-1 \frac{1}{2}$ in. long, oblong, obtuse, leathery, shining. Flowers in large terminal cymes. Petals small, scarlet. Stamens 1 in. long, scarlet. Capsule $\frac{1}{\frac{1}{4}}$ in. $-\frac{1}{3}$ in. long. North Island. Fl. Dec.-Jan. Maori name Rata.

This is the North Island rata. It is often described as twining round some forest tree, ensheathing it, and finally killing it by a close embrace; this account, however, misrepresents, if it does not traduce, $M$. robusta. It does not begin life as a climber, though there are species which do so, e.g., Metrosideros florida; but it very often germinates as an epiphyte high up in the forks of a tree. The seeds are minute, and readily blown about by the wind, so that they may thus be driven to a considerable elevation. As the young plant develops, it sends down roots towards the ground. These roots inosculate, and slowly enclose the stem of the supporting tree, which at last is crushed by the grip of the rata (v. Fig. 88). This, at least, is the generally accepted explanation. It must, however, be confessed that the details of the process have hitherto escaped observation. Apparently the only tree which can resist this iron hug is the puriri-the strongest and toughest of all New Zealand trees. It may sometimes be seen bursting the encircling roots of the epiphyte. 


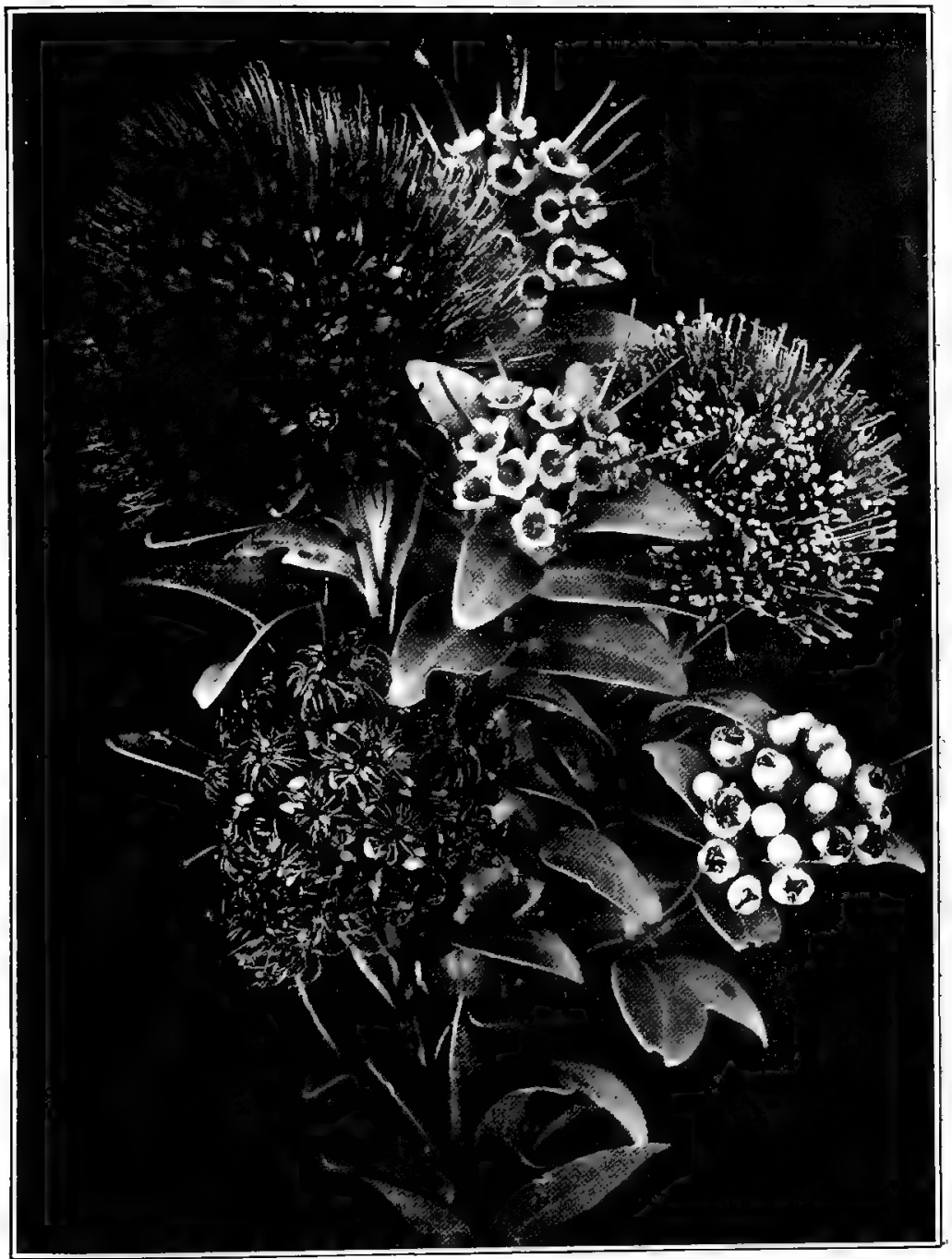

Fig. 90. Metrosideros robusta-Ruds and flowers (2 nut. size). 
The crimson stamens of the rata give to it, as to other species of the genus, a most attractive appearance when in flower. Though not so gorgeous as the pohutukawa, it is, perhaps, brighter in colour than the more southern $M$. lucida.

The Maoris have a proverb about the flower, which is a curious commentary upon their ideas of truthfulness.

Keiwhawhati noa mai te rau o te rata!

Don't pluck and fling about to no purpose the blossoms of the rata !

According to Colenso, this means :

Don't become ashamed when your lying is detected.

The timber of the rata is hard and durable, but scarcely so valuable as that of the pohutukawa. Like other species of the genus, it makes excellent firewood; and a green rata tree once kindled in the bush will sometimes smoulder for months.

\section{Metrosideros tomentosa (The Downy Rata).}

A handsome tree, sometimes $70 \mathrm{ft}$. in height, with spreading branches. Branchlets and under surfaces of leaves covered with short, dense white hairs. Leaves 1 in. 3 in. long, variable in shape, with recurved margins. Flowers in large terminal cymes, brilliant scarlet. Buds snow-white, woolly, petals small, scarlet, stamens 1 in. $-1 \frac{7}{2}$ in. long, scarlet. Capsule woody, 3-lobed and 3-valved. North Island: cliffs on the sea-coast. Fl. Dec.-Jan. Maori name Polnutukawa.

M. tomentosa rarely grows far from the sea or an inland lake. It finds a foothold in all sorts of impossible looking plates. Often it clings to the side of a cliff, and puts forth long twisted roots that attach it to the rocky wall. Specimens may frequently be found hanging from the top of a bank, with the roots above, and the branches almost dipping into the sea below. Oysters may sometimes be gathered from these pendent branches. When growing on level ground, great bunches of red, fibrous rootlets may occasionally be seen hanging from the boughs. These do not reach the ground, and their function is unknown. 


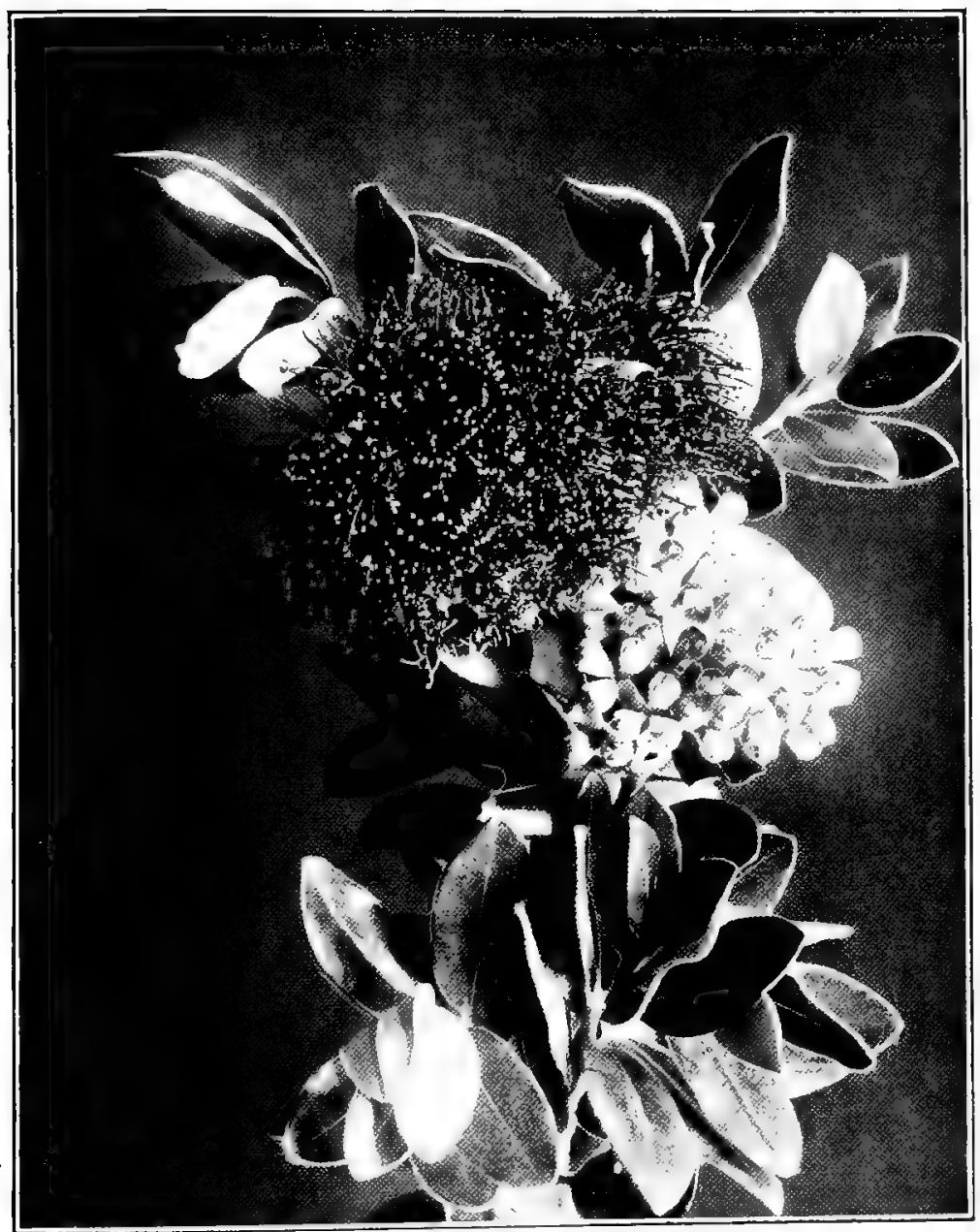

Fig. 91. Metrosideros uomentosa (f nat. size). 
The usual habitat of the pohutukawa is well described in the following lines:-

\footnotetext{
"The stony faces of the cliffs thus rent

Showed twisted strata, strangely earthquake bent, Running on each side circularly up-

A great grey hollow like a broken cup !

From crest and crevice, tortuously flung

Those monstrous iron-hearted myrtles hung-

Stiff snaky writhing trunks, and roots that clave

And crawled to any hold the ramparts gave."
}

"Ranolf and Amohia," p. 474.

Thus Domett, with his affluence of epithet, describes the tree as it clings to its rocky stronghold. Surely it was some vague perception of its fantastic shape and ocean-loving nature, that led the Maoris to think that a bough of pohutukawa was the last earthly hand-hold of the spirit when it leapt off from the world above into Reinga (the underworld). For it was believed by them in olden times, that the ghosts of the dead travelled northward along the mountain ranges, until they came to the ridge of "wild rocks " running out to sea in the extreme north, known as Cape Reinga. Passing along this to the very extremity of the land, they came at last to a giant pohutukawa, with a great limb overhanging the rocks of ocean. To this branch the spirits hung for some time, reluctant to leave the upper world. At length, through a sea-weed fringed cavern, they plunged into the gloomy realms of Po. But time changes all things. So many were killed in the war's of Hongi, that the great branch became bent downwards by the number of spirits who thronged it. When Mr. Cheeseman visited the Reinga in 1895, the famous "Spray-sprinkled": tree was still to be seen. It however bore marks of extreme old age, and the projecting branch had long before been broken off. Only its whitened stump remained. And little wonder, for though the wars of Hongi killed their thousands, European customs and European civilization have killed their tens of thousands.

"Pohutukawa is said to mean slray'sprinkled. The name therefore is singularly" alt. 


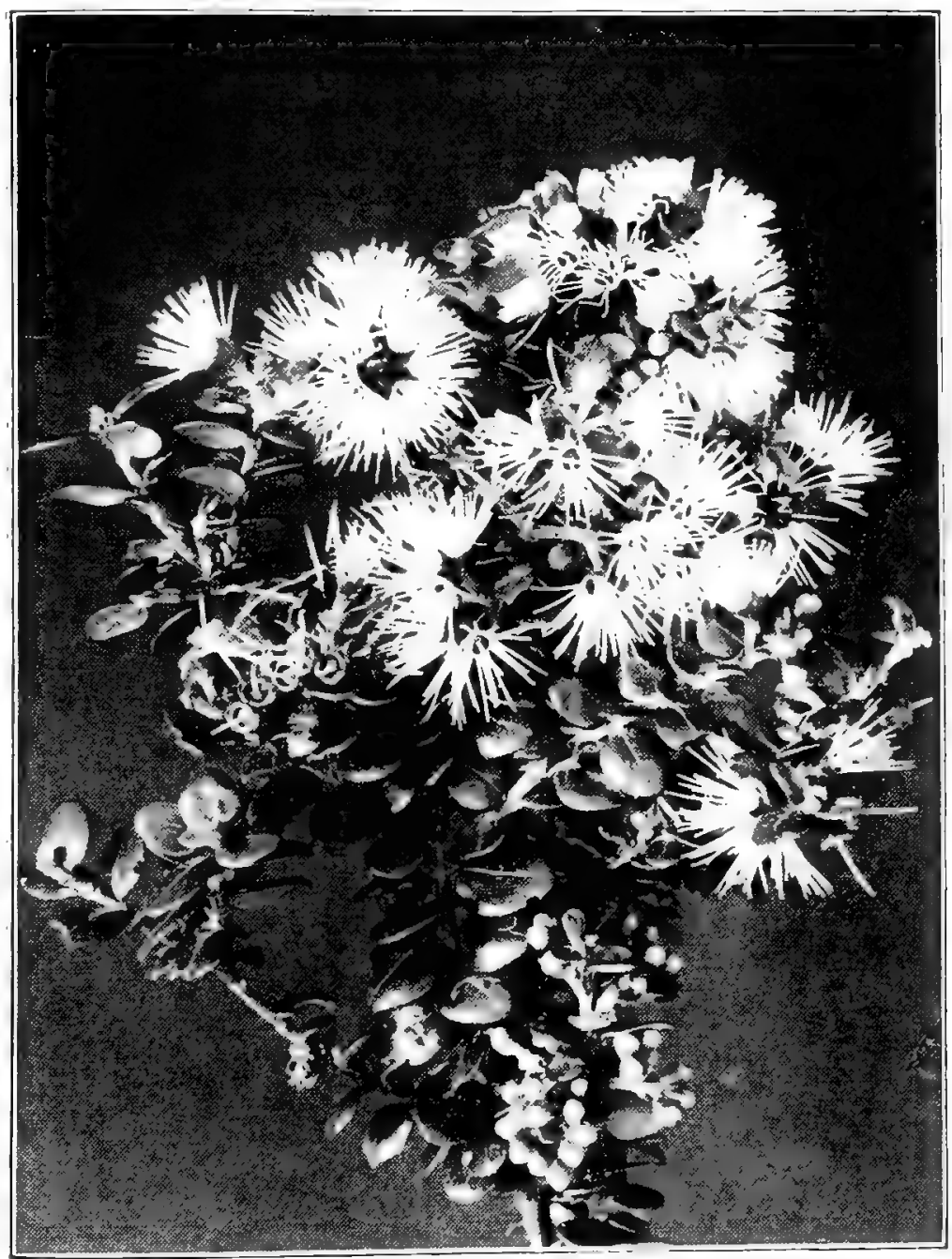

Fig. 92. Metrosideros scandens (life size). 
By the settlers, the tree is often known as the Christmas Tree, because it flowers about the end of the year. Kirk considers it to be "perhaps the most magnificent plant in the New Zealand Flora." The timber of the pohutukawa is extremely hard and durable.

\section{Metrosideros scandens (The Climbing Rata).}

A climbing shrub. Leaves $\frac{1}{3}$ in. $-\frac{-}{2}$ in. long, sessile, broadly oblong, obtuse, shining, the under-surface covered with glandular dots. Flowers in cymes, 3-flowered, axillary. Petals small, white. Stamens $\frac{1}{2}$ in. long, white. Capsule $\frac{1}{6}$ in. long. Both islands. Fl. Feb.-March. Maori name Aka.

\section{Genus Eugenia.}

Shrubs or trees. A genus very similar to Myrtus. The only New Zealand species is endemic. Calyx 4-5-lobed; petals $4-5$, often deciduous. Stamens numerous. Fruit a berry.

\section{Eugenia Maire (The Maire).}

A tree, $20 \mathrm{ft} .-50 \mathrm{ft}$. high. Bark white; branchlets 4-angled. Leaves $1 \mathrm{in.-2} \mathrm{in}$. long, oblong, lanceolate, pointed at the tip. Flowers in axillary or terminal corymbs. Calyx 5-toothed; petals 5. Berry red. North Island and north of South Island. Fl. June-July. Maori name, Maire Tawhaki.

\section{Grenus Myrtus.}

Shrubs or trees. Leaves opposite, evergreen, dotted with glands. Flowers axillary, solitary, or in small cymes. Calyx-lobes 4-5; petals 4-5; stamens numerous. Fruit a berry. A chiefly tropical and sub-tropical genus. The four New Zealand species are all endemic.

\section{Myrtus bullata (The Embossed Myrtle).}

A shrub or small tree. Leaves reddish-brown, swollen between the veins, $\frac{3}{4}$ in.-2 in. long. Calyx 4-lobed. Flowers $\frac{1}{2}$ in. $-\frac{3}{4}$ in. across. Petals white, Berry red. Both islands: rare in the South. Fl. Dee-Jan. Maori name Ramanama. The leaves of this plant are very beautiful, and much used by florists in making nosegays and button-holes.

Myrtus obcordata (The Obcordate-leaved Myrtle).

Leaves $\frac{1}{4}$ in. $-\frac{1}{2}$ in. long; flowers $\frac{1}{4}$ in.- $-\frac{1}{3}$ in. across. Calyx 4-lobed. Berry red, black, or vinlet. Both islands, rather local. Fl. Dec.-Jan.

Myrtus pedunculata (The Pedunculate Myrtle).

Branchlets 4-angled. Calyx and poduncles shining. Leaves rounded at the tip. Calyx 5-lobed. Berry small, yellow or red. Both islands. Fl. Dec.-Jan. Maori name Rohutu. 


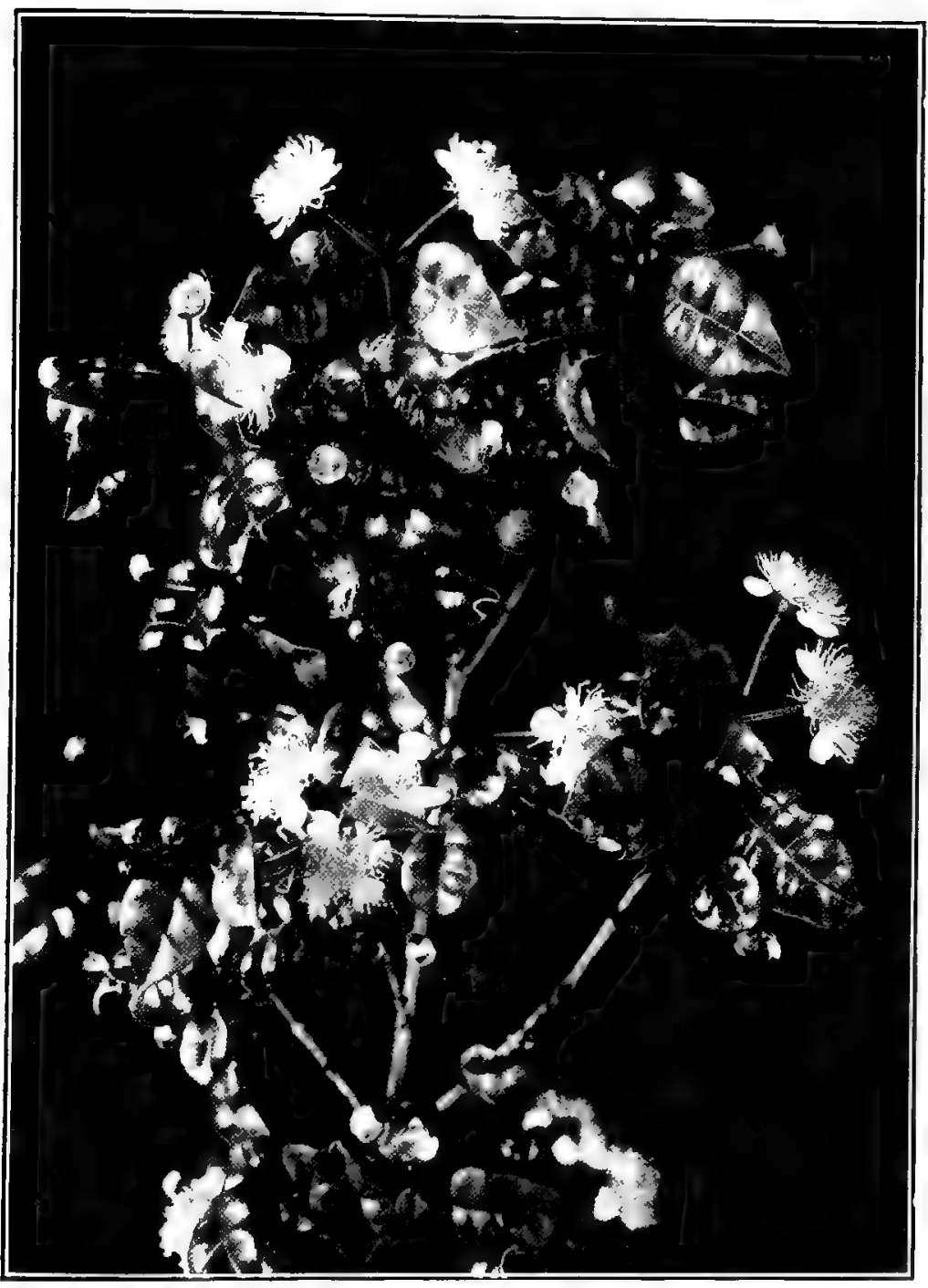

Fig. 93. Myrtus bullata (a nat. size). 


\title{
Onagraceae.
}

\author{
The Fuchisia Family.
}

Distribution.-A considerable family, chiefly iuhabitants of temperate regions. Some of the species possess slightly astringent properties, and others, of the genera Fuchsia, Clarkia, and Fnothera, are cultivated for their flowers.

Key to the Genera.

Herbs. Fruit a capsule.

Shrubs or trees. Fruit a berry.

Epilobium, p. 294.

Fuchsia, 1). 290.

\section{Genus Fuchsia.}

Shrubs or trees. Bark thin, papery. Leaves alternate. Flowers solitary, axillary, trimorphic. Calyx with 4 segments; stamens usually exserted. Fruit a berry, black or purple. (Named after Fuchs, a German physician). $3 \mathrm{sp.}$

This well known and closely defined genus is represented in New Zealand by three species. The flowers of the New Zealand forms, though not without beauty of their own, have scarcely the attractiveness of the ordinary garden varieties. However, Fuchsia procumbens (generally known to gardeners under the synonym Fuchsia Kirkii) is often to be found in cultivation in our gardens and greenhouses. It lacks the graceful, pendulous flower-stalks, which enhance so much the beauty of the cultivated forms, but it is a very dainty little species. The sharp contrast between the beautiful waxy yellow of the calyx, and the intense pure blue of the pollen, would make it noticeable anywhere. Any other colour but yellow is rare in pollen, and such a bright hue as this has probably some definite though unknown significance. It is of the same colour in the two other New Zealand species. It is also extremely viscid. This no doubt enables it to cling readily to any insect which may enter the flower. The tui and the korimako may sometimes also be seen with their foreheads smeared with it, for the flowers are cross-pollinated by them. The viscidity is due to the development by the pollen grains, of structureless drops of a glutinous fluid, that very readily draws out into long fine threads. A similar secretion 


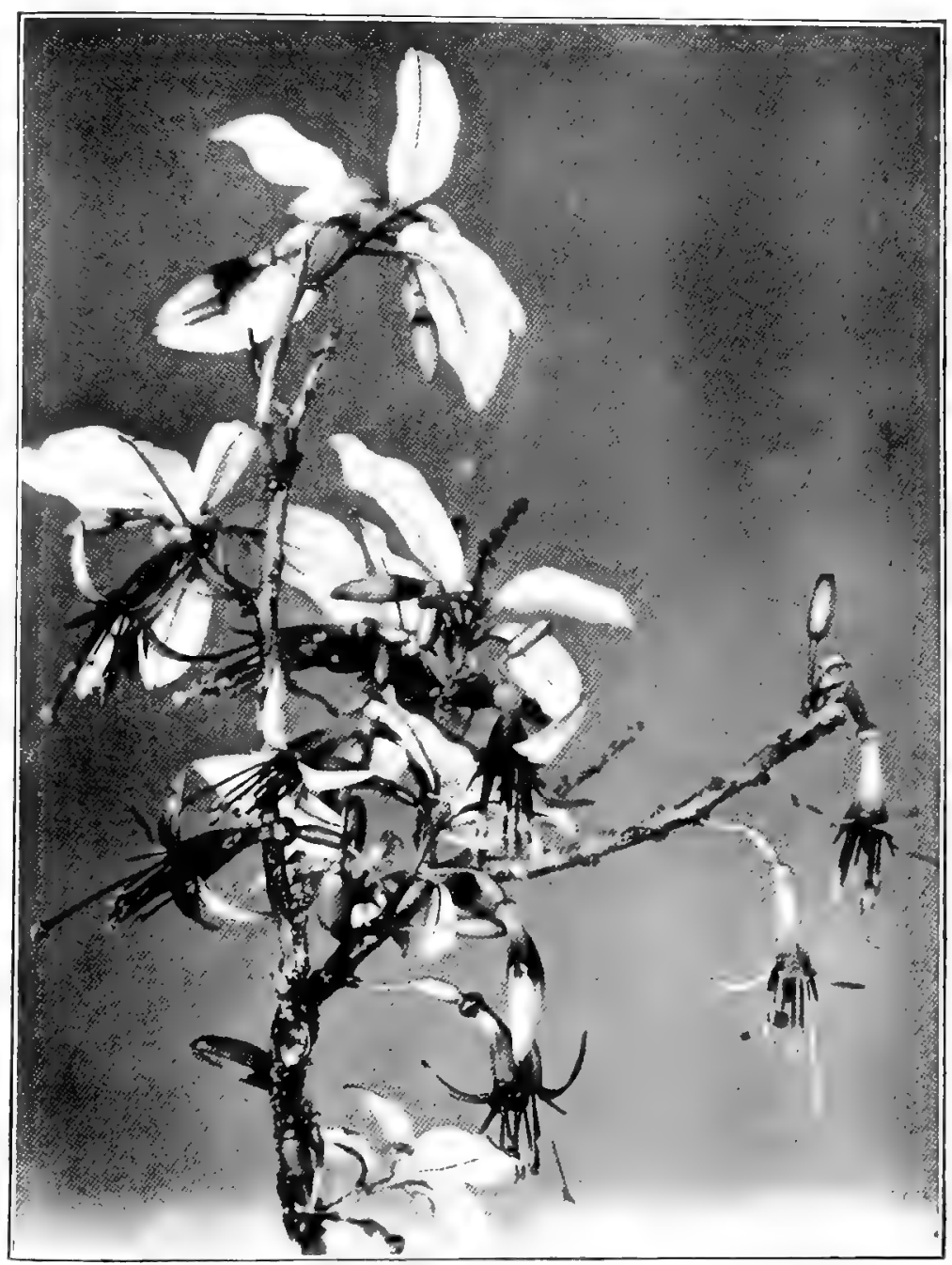

Fig. 94. Fuchsia excorticata (3at. size). 
may be found in the pollen grains of the evening primrose, Godetia, Clarkia, and some species of Epilobium.

All the New Zealand forms of the genus Fuchsia are endemic, and the only other known species come from South America and Mexico. Thus our Fuchsias well illustrate the former connection existing between New Zealand and South America (v. Introduction p. 36).

But, for botanists, the chief interest of the New Zealand forms lies in the methods by which cross-pollination is attained. It has long been known that in flowers of certain plants, dimorphism or trimorphism exists, i.e., stamens and styles are found of two, sometimes of three different lengths. It was not, however, until Darwin had investigated the matter, that a complete explanation of these variations of form was forthcoming. In his work on the "Forms of Flowers" he has dealt with this subject very fully. The common English meadow primrose is the first plant which he discusses, and it is usually taken as the type of a dimorphic flower. If a number of primrose flowers are examined, it will be found that in some the anthers are placed at the top of the corolla tube, and in others they are attached inside the tube half-way down its. length. Those flowers which have the anthers at the rim of the corolla tube, have a style which is concealed within the tube, and the other flowers, with the short stamens, have a style which protrudes from the tube. In other words, long stamens go with a short style, and vice versa. Now a bee pushing its way into a flower with short stamens, gets the pollen on to its tongue, but, if it goes into a flower with long. stamens, the pollen sticks to its head. The pollen from its head can clearly only be placed upon the stigma of a flower with a long style, while that from the tongue, must, on the other hand, be placed upon the stigma of a flower with a short style. Thus cross-pollination is inevitable. It has further been shown that the primrose is infertile with its own pollen, so that its existence is dependent upon the presence of insects. 
Mr. G. M. Thomson was the first to show* that the New Zealand fuchsias have several forms of flower in the one species, but the late Mr. T. Kirk investigated the matter more fullyt. He showed that in each of the three New Zealand species of Fuchsia there are three forms of flower, and in some cases, also, intermediate forms. In every case, however, there are eight stamens, and a single style with a globose stigma. The differences in the flowers of the various species may thus be shortly summarized :-

Fuchsia excorticata.-(1) Long-styled form. The style is more than twice the length of the calyx-tube. The stamens are almost without filaments, attached to the calyx-tube. The pollen grains, if present, are yellow, and apparently abortive. The flower is therefore a female one.

(2) The mid-styled form. The style is about one and a half times the length of the calyx-tube; the anthers have long filaments, but are shorter than the style; the pollen is well developed, and of a deep mazarine blue. This flower is hermaphrodite.

(3) The short-styled form. The style is little, if any, longer than the stamens, which are about the same length as in the second form. The pollen is well developed. The flower is hermaphrodite.

Fuchsia Colensoi.-Only the long-styled and mid-styled forms are known in this species, but Kirk "entertains no doubt" of the existence of a short-styled form.

Fuchsia procumbens.-There is a long-, short-, and midstyled form; but the stamens are of the same length in each case.

The exact significance of these forms is not well known, and would form an interesting subject of investigation for students. All the forms of $F$. excorticata are found in the same district, but on different plants. The long-styled form is obviously pollinated by the short and mid-styled forms; and it 
produces fruit wore abundantly than either of the other forms. This makes it probable that forms with short styles are not self-pollinated. However, the evidence on the point is unsatisfactory. Kirk failed to find fruit in any quantity on $F$. procumbens, and explained its absence by the statement that the three types of $F$. procumbens were not growing in the same district; but Dr. Cockayne informs us that it fruits as readily as the other species. Obviously, a full explanation of the characteristics of this flower has yet to be given.

The timber of $F$. excorticata is heavy, and difficult to work, but very strong and durable.

\section{Fuchsia excorticata (The Tree Fuchsia).}

A shrub or tree, $10 \mathrm{ft} .-45 \mathrm{ft}$. in height. Leaves $1 \frac{1}{2} \mathrm{in.}-4 \mathrm{in}$. long, silvery beneath, lanceolate or ovate-lanceolate, acute, obscurely toothed. Flowers drooping, 3 in.- -1 in. long. Calyx dark-purple; petals red-purple. Pollen-grains blue. Berry oblong. Both islands; Stewart Island. Fl. Aug.-Dec. Maori name Kotulutuku or Kolutuluutu, and of the fruit, Konini.

\section{Fuchsia Colensoi (Colenso's Fuchsia).}

A smaller species, often not more than $1 \mathrm{ft}$. in height. Petals minute. From the Waikato to Stewart Island. Fl. Oct.-Feb.

\section{Fuchsia procumbens (The Prostrate Fuchsia).}

A slender, prostrate plant, 6 in.-18 in. long. Leaves ovate or cordate, $\frac{1}{4}$ in. $-\frac{1}{2}$ in. long. Flowers $\frac{1}{2}$ in. $-\frac{3}{4}$ in long, solitary, axillary, erect. Petals 0 . Berry shining, pale-red. Auckland: sandy or rocky places. Fl. Nov.-Feb. (Otten called by the synonym $F$. Kirtii).

\section{Genus Epilobium.}

Herbs, rarely woody. Leaves opposite or alternate. Flowers in axillary or terminal spikes or racomes. Sepals 4, petals 4, stamens 8. Fruit a 4-valved capsule. Seeds crowned with tufts of white hairs. New Zealand possesses about 32 species, 27 of which are endemic. (Name from the Greek meaning upon a pod, in reference to the position of the flower).

The genus Epilobium has been recently nonographed by Prof. Haussknecht of Jena. There are about 160 species, chiefly in temperate and arctic regions. The English species 
are known as IVillow-herbs. The Epilobiums are generally comparatively insignificant, though often dainty little plants. Many of them show interesting devices for securing pollination.

\section{Haloragidaceae.}

\section{The Family of Mare's Tails.}

Distribution.-A small family, widely distributed, but of little importance. All the British species are aquatic. The flowers are inconspicuous, and often devoid of petals. The Haloragidaceae are closely related to the Fuchsia family, but the flowers in the former are often much reduced.

\section{Genus Haloragis.}

Herbs, erect or creeping. Leaves usually opposite. Flowers usually axillary, rarely in spikes or panicles. Calyx-lobes 4 ; petals 4 or 0 ; stamens $4-8$. Fruit a small nut, 2-4-celled. $5 \mathrm{sp}$.

\section{Haloragis erecta* (The Erect Haloragis).}

An erect or sub-erect herb, $1 \mathrm{ft} .-3 \mathrm{ft}$. high. Stem 4 -angled; leaves opposite, $\frac{1}{2}$ in. $-1 \frac{1}{2}$ in. long, coarsely serrate. Flowers minute, green, in drooping, terminal racemes. Nut 4-angled, green. Both islands: dry hills, Stewart Island. Fl. Nov,-Jan. (H. alata of Cheeseman, etc.)

\section{Genus Myriophyllum.}

Aquatic or marsh plants. Leaves usually whorled, much dissected when submerged. Flowers small, axillary, white. Pistillate flower destitute of petals. Stamens 4-8. Fruit, 2-4 1-seeded nuts. (Name from the Greek, signifying $a$ thousand leaves, from the deeply-cut foliage).

Myriophyllum elatinoides (The Elatine-like Myriophyllum).

Leaves 4 in a whorl. Flowers white, on a leafy spike, 2 in.-6 in. long. Fruit of 4 minute nuts.

This species may be taken as typical of a water plant. It grows submerged in ponds and streams, and, consequently, requires a very different structure from a land-growing plant.

${ }^{*}$ Das Pflanzenreich (Engler), under Haloragidaceae. 
Where water is at all times available without stint, obviously, an elaborate root system is not required. Hence, water plants have few roots, and sometimes none at all. In the latter case they float (e.g. Utricularia protrusa) ; at other times the roots are merely hold-fasts, for in many water plants there is a thin epidermis, so that water can be taken in all over the whole surface of the plant by osmosis. Consequently, also, water conducting tissues in the stem are not required; and, as no firm tissues are needed to keep the plant upright, woody fibres are always wanting in the stem, which is maintained in position by the buoyancy of the water. In most water plants there are large air chambers, which reduce the specific gravity of the plant, and assist to float it. It is therefore very flaccid, and, when removed from water, collapses. The leaves, too, are generally cut up into many narrow segments. In many of the Ranunculi, a submerged leaf may be much divided, whereas a leaf growing in air on the same plant remains undivided. In many water plants, the ratio of leaf surface to leaf bulk, is at least a hundred times greater than it is in certain xerophytes. Taken altogether, the structure of a submerged plant is simple, as compared with one of the same order, growing on land.

In most cases, the flower stem is elevated above the water before flowering commences. In Limosella, which lives in rain pools, if the plant should happen to be submerged at the time of flowering, the flowers become cleistoganic ( $v$. Viola, p. 264) and self-pollinated. The perianth is, of course, watertight, and so the pollination takes place in air. Plants, the pollination of which takes place in water are extremely rare. Amongst them, however, may be mentioned the grass-wrack, (Zostera), which may be found throughout the colony, on the inud-flats of the sea-shore. However, in Zostera, the pollen grain has a unique structure.

In Myriophyllum, the flowers are raised to the surface of the water. Most of the species are monocious, and, as in all 
other monoecious plants, the pistillate flowers mature before the staminate ones, and so cross-pollination is inevitable.

\section{Genus Gunnera.}

Creeping herbs, with small, inconspicuous flowers. Sepals 2 or 3 ; petals 2 , 3 , or 0 ; stamens 2 or 3 . Ovule solitary. Fruit a small drupe. The New Zealand species have no petals. (Named after Gunner, a Swedish bishop and botanist).

\section{Gunnera monoica (The Solitary Gunnera).}

Tufted, creeping. Leaves $\frac{1}{3}$ in.- $-\frac{2}{3}$ in. across, crenate, kidney-shaped. Flowers in slender panicles. Perianth of two narrow segments; stamens 2. Drupe $\frac{1}{12}$ in. long. Both islands. Fl. Oet.-Nov.

\section{Cornaceae.}

\section{The Cornel or Dogmood Family.}

Distribution.-A small and unimportant family, ohiefly found in temperate regions. Aucuba japonica, the variegated laurel, and the Cornelian Cherry, Cornus mas, are cultivated in gardens. Two or three of the species are said to possess tonic properties.

$$
\text { Key to the Genera. }
$$

Leaves white underneath. Flowers perfect.

Leaves glossy. Flowers unisexual.
Corokia, p. 297.

Griselinia, p. 298.

\section{Genus Corokia.}

Shrubs or trees, with alternate leaves, silvery beneath. Calyx 5-toothed. Petals, 5, silky, yellow. Stamens, 5. This small genus is peculiar to New Zealand and the Chatham Islands. (Name from the Mrori). $3 \mathrm{sp}$.

Corokia buddleoides (The Buddleia-like Corokia).

A small tree, with long narrow leaves, shining above, and downy beneath. Flowers in slender panicles. Corolla tin. long, yellow. Drupe, orange-red. 
North Island: Maugonui to East Cape. Fl. Dec. Native name Korokiataranga.

\section{Corokia Cotoneaster (The Cotoneaster-like Corokia).}

A rigid shrub, with interlacing black branches. Leaves alternate or fascicled, oblong or ovate. Petals yellow, broader than in Corokia buddleoides. Drupe $\frac{1}{1}$ in. across, red. From the North Cape to the Bluff. F1. Oct.-Nov.

\section{Genus Griselinia.}

Shrubs or trees, often epiphytic. Leaves very thick and glossy, oblique, leaving a scar when they fall. Calyx 5-toothed; petals 5 . Stamens, 5. Staminate and pistillate flowers on separate trees. The New Zealand species are endemic. $2 \mathrm{sp}$.

\section{Griselinia Iucida (The Shining Broadleaf).}

From $3 \mathrm{ft} .-30 \mathrm{ft}$. in height, often epiphytic. Leaves 4 in.-8 in. long, very thrck, shining. Flowers in axillary panicles, green or yellow, 3 in-6 in. long. Petals 0. Drupe dark-purple. Both islands, but more common in the north. Fl. Nov.-Dec, (Native name Puka. A name given to any broad-leaved tree).

\section{Griselinia littoralis (The Broadleaf).}

A tree, sometimes 60ft. in height, differing from Griselinia lucida in its terrestrial habit, and smaller, less glossy leaves, which vary from 1 iu.-3 in. in length. Flower panicles small. The pistillate flowers possess 5 petals. This tree, though often crooked in growth, is valued for its timber, which is very durable. Both islands. Fl. Sept.-Nov. 


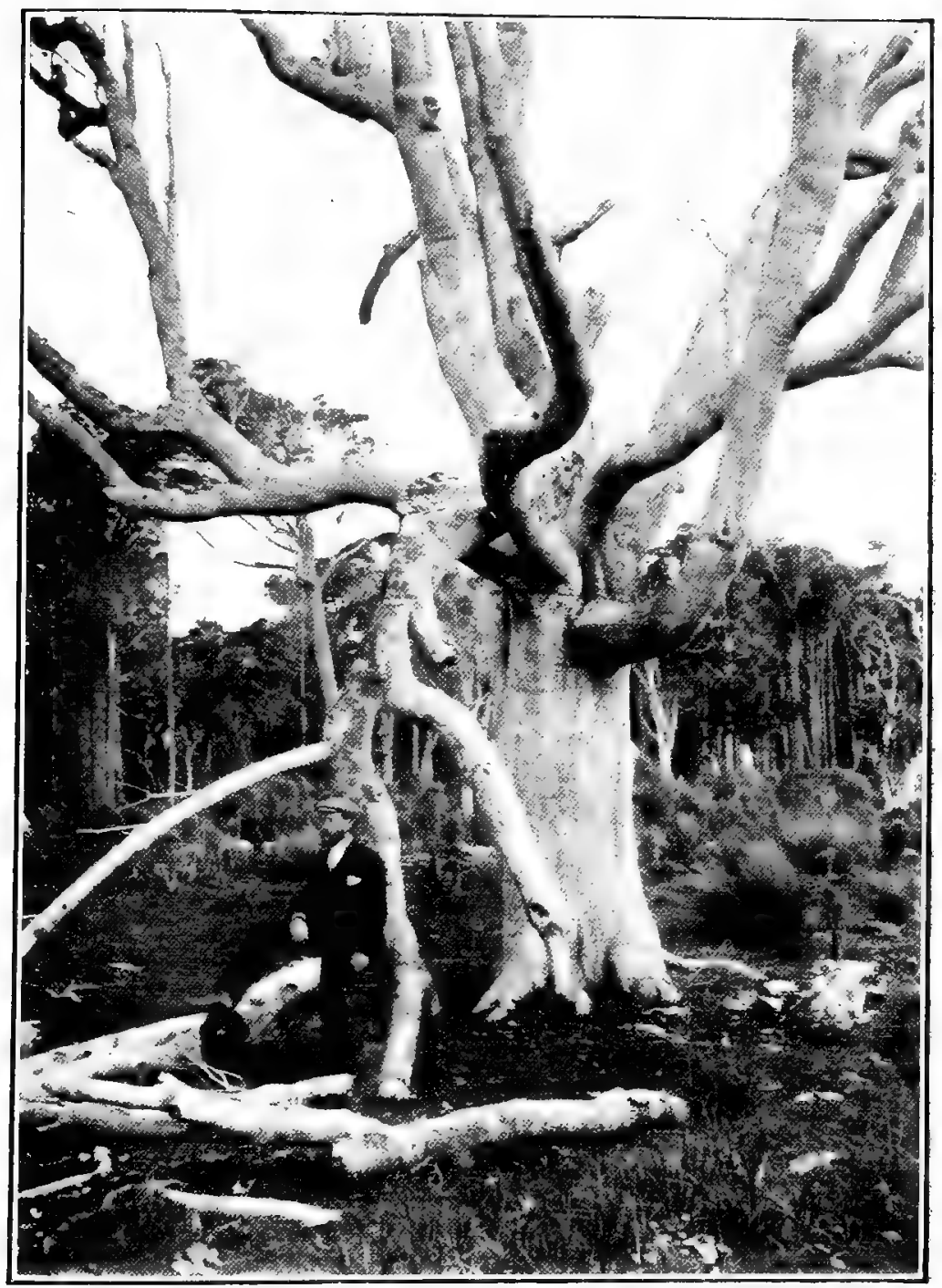

Fig, 95. Griselinia littoralis. 


\section{Araliaceae.}

\section{The Family of Araliads, or Ivyworts.}

Distribution.-This family is closely allied to the Umbelliferae, but is chiefly tropical in its distribution, though some species are found in Canada, N.W. America and Japan. The New Zealand species are all endemic. The British Hedera Helix, the Common Ivy, is well-known, and much cultivated. The berries are emetic and purgative. Tetrapanax papyrifera furnishes the rice-paper of the Chinese. The stems of this plant, which is found only in the island of Formosa, are filled with a pure white pith, from which the paper is made. This pith is also used in the making of artificial flowers. Some of the species of Aralia have slight medicinal properties.

1. Heris,

Key to the Genera.

Shrubs or trees.

2. Leaves 9 in.-20 in. long, entire, glossy.

Leaves smaller, simple or digitate.

3. Flowers in simple or compound umbels. Flowers in large panicles.

4. Styles distinct, tips recurved, ovary 2 -4-celled.

4. Styles united into a cone. Ovary 5-celled.
Stillocarya, p. 300.

2

Meryta, p. 312.

3

4

Schefflera, p. 312 .

Nothopanax, p. 304.

Pseudopanax, p. 306.

\section{Genus Stilbocarpa.}

A genus of two species, endemic in New Zealand. Leaves radical, large. Flowers crowded, conspicuous. Petals, 5; stamens, 5 ; styles, 3 or 4 . Fruit, round; axis hollow. Cells, 1 -seeded. (Name in allusion to the shining fruit).

\section{Stilbocarpa polaris (The Polar Stilbocarpa).}

A large herbaceous plant. Leaves, $6 \mathrm{in.-12} \mathrm{in}$. broad; round or kidneyshaped, thick, rough with lairs, lobed, coarsely toothed. Leaf-stalk 12 in.-18 in. long, with a lobed sheath. Flowers in terminal or axillary umbels, 4 in.-9 in. across. Corolla $\frac{1}{1}$ in. across, yellow, with a purple eye. Fruit the size of a peppercorn, shining. Auckland, Antipodes, Macquarie, and Campbell Islands. Fl. Dee,-Jan. Maori name t'unui.

\section{Stilbocarpa Lyallii (Lyall's Stilbocarpa).}

A robust herb, $1 \mathrm{ft} .-3 \mathrm{ft}$. in height. Stems horizontal, giving out long arched trailing branches, which tend to root at the tip. Leaves radical, shining above, hairy beneath, round or kidney-shaped, lobed, toothed. Flowers in unbels, purplish-red, 3 in.-12 in. across. Petals, 4 ; stamens, 5. Fruit round, black, shining; cells 1-seeded. Consts of Foveaux Straits, Stewart Island, The Snares. Fl. Dec.-Feb.

We have followed Engler and Prantl (Pfanzenfamilien IIT., 8, 57) in placing Kirk's Aralia Lyallii under the genus Stibocarpa, thus restoring it to the position originally given it by $\mathrm{M} \Gamma \mathrm{r}$. J. B. Armstrong. 
All the outlying islands of New Zealand, if not mere rocks, contain one or more species of plants not found on the mainland. Thus the Chatham Islands possess one

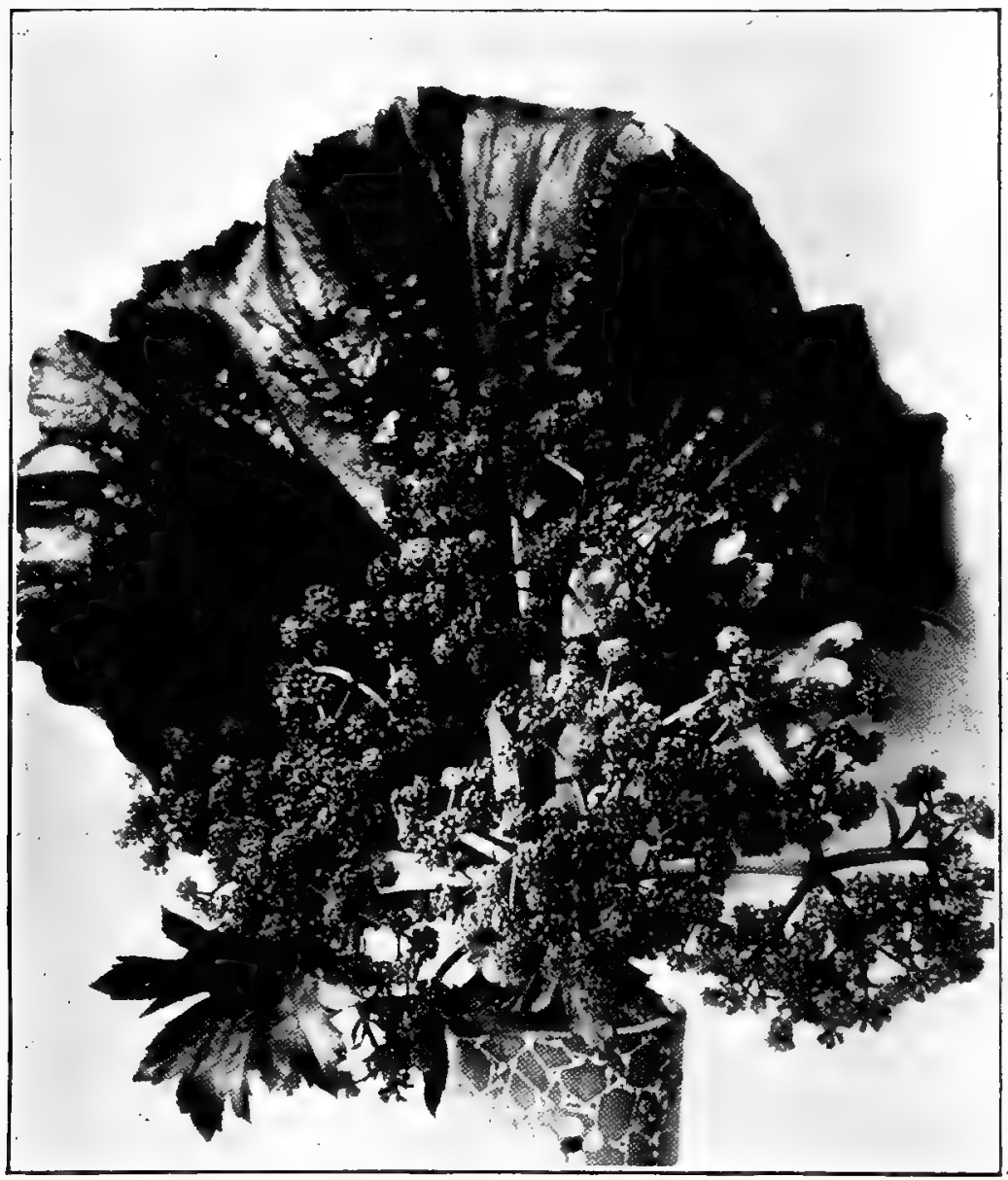

Fig. 96. Stilbocarpa polaris.

genus, Myosotidium, and about thirty species of flowering plants and higher Cryptogams not found elsewhere. Dr. Cockayne gives the following numbers for the endemic species. 
of flowering plants on the Southern Islands out of a total number of 14:3:-Auckland Islands, 10; Campbell Island, 7; Antipodes Islands, 3; Macquarie Island, 3; Snares Islands, 2. In addition to these, there are no less than 29 species not found on the mainland, but growing on more than one of the southern Islands. On the three Kings Islands five species are endemic, and three others are known only from other outlying Islands (Cheeseman). In the Kermadecs only 5 species out of 115 are endemic,-a smaller percentage than might have been expected.

Stilbocarpa polaris, the plant under discussion, is found on the Auckland, Campbell, Antipodes, and Macquarie Islands. It must not be confused with the equally fine S. Lyallii, which is found on Stewart Island, and the islands of Foveaux Straits. A full discussion of the origin of these remarkable forms, found only in isolated spots of the earth's surface, would be out of place here; but the subject is of so much interest and importance, that it cannot be passed over without some slight reference to theories regarding it. It is obvious that these plants may be divided into two groups, (1) those that are very closely related to mainland forms, (2) those that are not closely related to any species of the mainland. Amongst the latter are some of the most magnificent plants of the Flora (e.g., Pleurophyllum speciosum; Myosotidium.)

Now, there are two possible explanations of the distribution of species limited to narrow areas and solitary islets: (1) it may be due to relict endemism, that is to say, the plant was once widely distributed, but has for some reason or other become almost extinct, and now exists only on outlying islands, or in remote corners of the mainland. Thus, to take an example from the human race, the limitation of the once widely distributed Kelts to Brittany, Wales, Treland, and the North Scotland, is a case of relict endemism. (2) If, however, the species has been developed on the off islands, or outlying peninsulas, owing to special conditions existing there, then we 


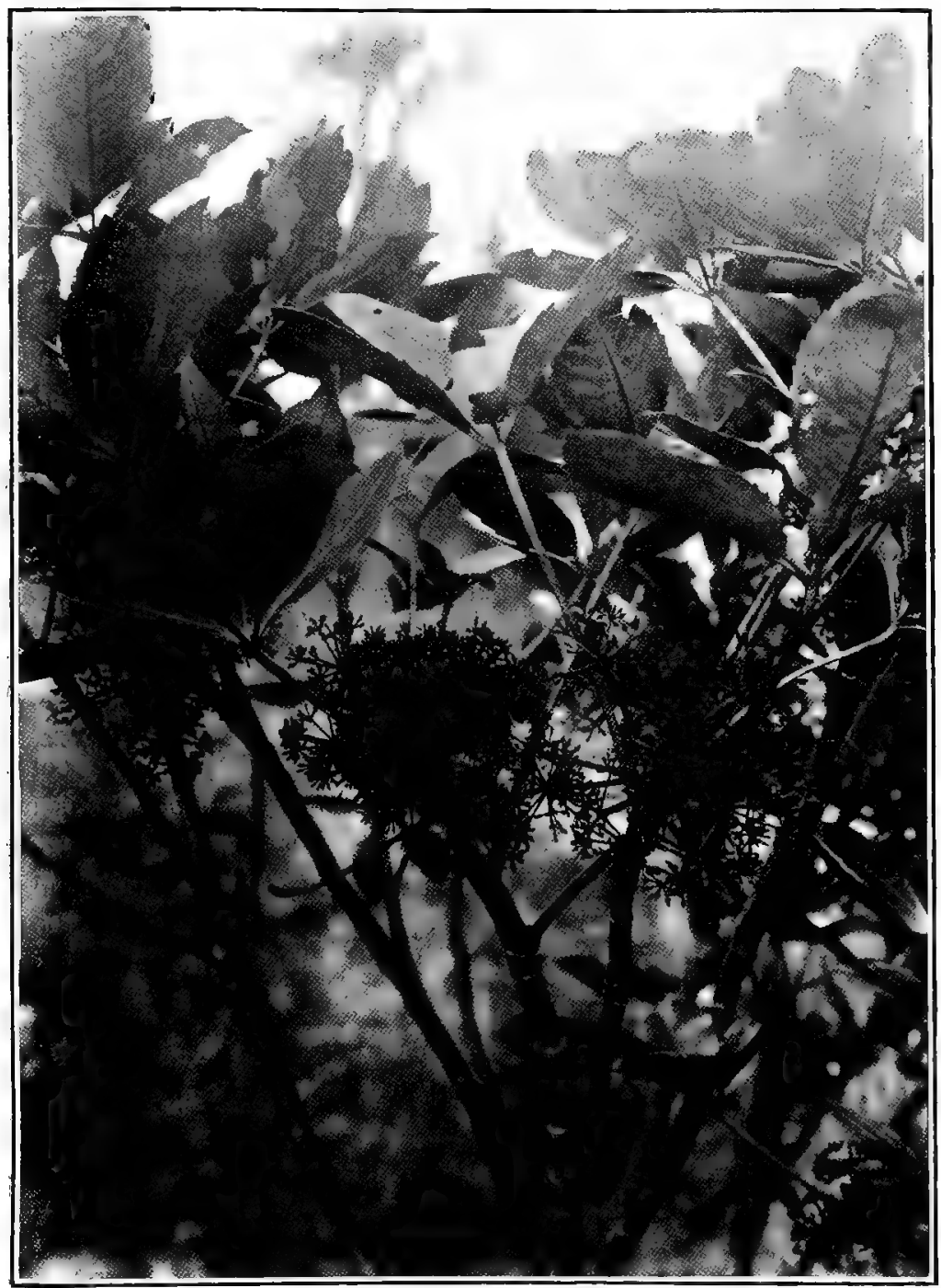

Fig. 97. Nothopanax Colensoi (1 nat. size). 
have a case of initial endemism. Now it is often difficult to say which explanation should be adopted, in a given case. If the plant is closely allied to one existing on the mainland, we probably have a case of initial endemism. If, however, it belongs to a type not represented on the mainland, it is more likely that we have to do with an example of relict endemism; and that the species was once widely distributed, and now, having been almost exterminated, finds a sanctuary only in inaccessible localities and remote islands. In some cases Palæo-botany comes in to give us assistance in solving the problem. Thus, fossils show us that the genus Agathis was once widely distributed, though now restricted to Auckland province (where the Kauri is found), to the Malay Archipelago, and to Queensland. Thus in the Kauri we have a clear case of relict endemism. The older botanists, however, generally neglected this method of explaining restricted distribution, in favour of the hypothesis of initial endemism. There can, however, be but little doubt that forms like the one under consideration, are more likely to have been at one time widely spread, than always to have been restricted to their present habitats. Though Stilbocarpa is a genus endemic in these islands, yet it is closely connected with the widely distributed genus Aralia. On the mainland, Stilbocarpa is now confined to South-western Otago, but, as it must have reached that district from the outside, it has certainly, at one time, had a wider distribution.

S. Lyallii sends out runners, which pass under stones and through crevices in the rocks, rooting in suitable localities. It is thus able to cover wide areas. This characteristic also readily distinguishes it from S. polaris, which is without runners.

\section{Genus Nothopanax.}

A remarkable genus of shrubs or trees, showing much variation in leafform. All the New Zealand species are endemic. Flowers in umbels, racemes, or panicles, green, inconspicuous. Petals and stamens 5. Ovary 2-4-celled. 
Fruit fleshy, 2-5-celled, 1-seeded. (Name from the Greek, signifying a remedy for everything, in allusion to the Chinese drug Ginseng, obtained from a plant of this family, and believed by the Chinese to possess healing virtue of a miraculous kind. The prefix notho signifies southern). $7 \mathrm{sp}$.

\section{Nothopanax lineare (The Narrow-leaved Nothopanax).}

A shrub, $5 \mathrm{ft} .-8 \mathrm{ft}$. in height. Leaves of two forms : (1) linear, erect or spreading, $6 \mathrm{in.}-9 \mathrm{in}$. long, $\frac{1}{1}$ in.- $-\frac{1}{3}$ in. broad, leathery, broad, sharp-pointed, with a noticeable midrib; (2) linear lanceolate, crowded at the tips of the branches, $1 \frac{1}{2}$ in. $-3 \frac{1}{2} \mathrm{in}$. long, very leathery, acute or obtuse. Flowers in small terminal umbels. Fruit urn-shaped, 3-5-celled and seeded. South Island: Southern Alps; rare. Nelson to Southland. Fl. Jan.-Feb.

\section{Nothopanax simplex (The Simple-leaved Nothopanax).}

A small tree, $5 \mathrm{ft} .-20 \mathrm{ft}$. in height. The most variable of all the species. Leaves: (1) Ovate, serrate, on long foot-stalks ; (2) 5 -foliolate, leaflets petioled, linear, lobed, or pinnate-partite; (3) 3-foliolate; leaflets sessile, lanceolate; (4) 1-foliolate, oblong, 2 in.-5 in. long, serrate, or almost entire. Flowers in short terminal or axillary compound umbels. Fruit compressed; 1-seeded. Both islands; Stewart Island; Auckland Islands. Fl. Nov.-Jan.

\section{Nothopanax Edgerleyi (Edgerley's Nothopanax).}

A tree, 20ft, - 40ft. in height. Leaves of two forms: (1) 3-5-foliolate; leaflets oblong-lanceolate, acute, pinnatifid or lobed, purple beneath ; (2) 1 foliolate, 3 in.-9 in. long, oblong-lanceolate or obovate, membranous, shining. Petioles jointed to the blade, 1 in.-4 in. long. Flowers in axillary compound umbels, racemose. Styles 3 or 4 . Fruit small, round, purplish-black, 3-4seeded. Both islands; Stewart Island. Fl.-Jan.-Feb. Maori name Raukawa. The leaves are aromatic, and were used by the Maoris in the making of perfumed oils.

\section{Nothopanax anomalum (The Anomalous Nothopanax).}

A shrub, 6ft. - 12ft. high, with rough divaricating branches. Leaves of two forms : (1) 3-foliolate, with stipules at the base of a widened petiole, in the mature stage leaflets rarely pinnatifid; (2) 1-foliolate, with secondary stipules at the base and apex of the flattened petiole. Flowers small, in small axillary umbels, 2-10-flowered. Styles 2, recurved. Fruit $\frac{1}{8}$ in.- $\frac{1}{6}$ in. in diameter, compressed, mottled. Both islands. Fl. Dec.-Jan. Maori name Wawa-paliu.

\section{Nothopanax Colensoi (Colenso's Nothopanax).}

A shrub, $10 \mathrm{ft} .-20 \mathrm{ft}$. in height. Leaves $3 \mathrm{in} .-9 \mathrm{in}$. long, $3-5$ foliolate, with a 2-lobed sheath. Leaflets 2 in. -6 in. long, thick and leathery, roughly toothed; veins indistinct. Flowers in heavily scented terminal umbels. Fruit roundish, compressed, 2-celled and 2-seeded. Styles 2. Both islands: as far north as the Thames. Fl, July-Oct. Maori name, Raukawa. 


\section{Genus Pseudopanax.}

Shrubs or trees, with shining leaves, extremely variable in form during different stages of the tree's growth. Flowers in umbels, panicles, or racemes. Staminate flowers with 5 petals and 5 stamens. Pistillate flowers without petals, ovary 5-celled. Fruit rounded, fleshy. (Name signifying a false Panax). $6 \mathrm{sp}$,

\section{Pseudopanax crassifolium (The Thick-leaved Lanceleoud).}

A spreading tree, $20 \mathrm{ft} .60 \mathrm{ft}$. in height; trunk $10 \mathrm{in.}-20 \mathrm{in}$. in diameter. Leaves polymorphic. Flowers in terminal compound umbels. Stamens, 5; styles 5 ; seeds 5 . Fruit round. The leaves and wood of this tree send out an umpleasant odour. The timber is used for fencing posts, sleepers, piles, etc. Both islands; Stewart Island. Var. unifoliolatum is common in the Auckland district, but rare elsewhere. Fl. Feb.-April. Maori name Horoekn.

\section{Pseudopanax ferox (The Savage Lancewood).}

A small tree, $15 \mathrm{ft} .-26 \mathrm{ft}$. in height. Leaves of 3 forms. (1) Of seedlings, narrow, linear-lanceolate, acute, toothed, brownish. (2) Of unbranched shrubs, $12 \mathrm{in.}-18 \mathrm{im}$. long, $\frac{1}{2} \mathrm{in}$. broad, the tips tumed downwards towards the stem, very thick and leathery; roughly toothed; teeth sharp, hooked. (3) Of mature trees, $3 \mathrm{in} .-5 \mathrm{in}$. long, $\frac{1}{4}$ in.-繶 in. broad, linear-obovate, thick, rigid, pointed. Flowers in terminal umbels; staminate flowers in 6-10 racemes, with 4 petals and 4 stamens. Pistillate umbel compact, ovary 5-celled. Fruit oval, shining, larger than in $P$. crassifolizm, 1-seeded. Both islands. Much rarer than the preceding species.

This is an endemic genus, distinguished chiefly by the remarkable metamorphoses through which the foliage of the species $P$. crassifolium and $P$. ferox passes. Many New Zealand plants show strange vicissitudes in their leaf-developinent, but in none are they stranger than in these. Yet, curiously enough, no account of their minute structure has yet been published, though the leaves of many other species have been microscopically examined. In no other genus, perhaps, are the leaf forms so well worthy of the student's research; so different are they in the juvenile, from the mature stages, that, on several nccasions, the earlier botanists put the mature and immature forms of the same plant, in different genera. $P$. crassifotium was discovered on Cook's first voyage, and, in Dr. Solander's MS., the young form is called Xerophylla longifolia, while the mature is termed 


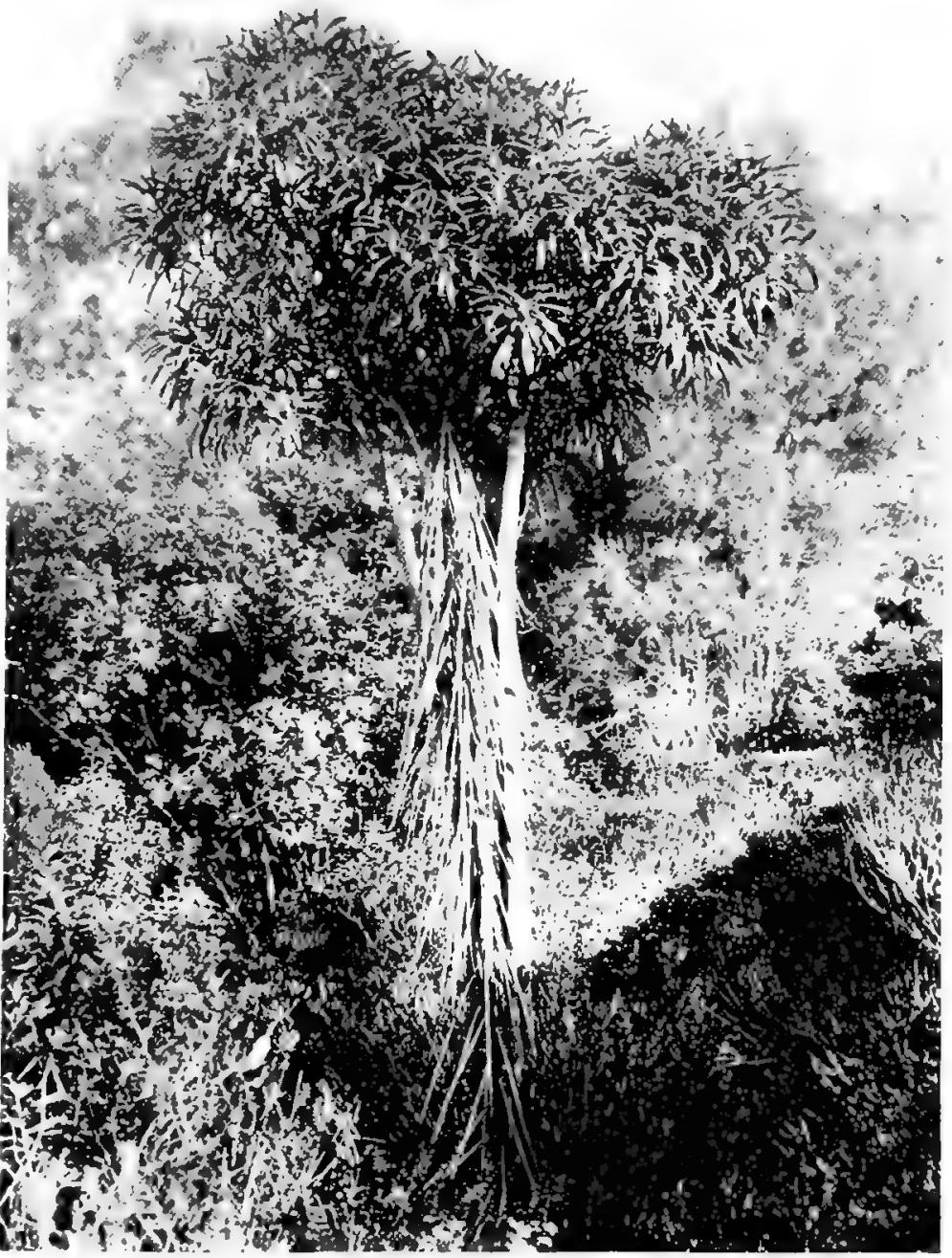

Fig. 98. Pseudopanax crassifolium. (Tree with deflexed and mature leaves.) 
Aralia crassifolia. Even so late as 1867, Sir J. Hooker,---the greatest of all systematists,-described the mature state as Panax crassifolium, and the young state as $P$. longissimum, and yet he had had the plant under cultivation at Kew for fifteen years.

The seedling forms of $P$. crassifolium have been described

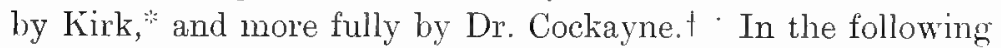
description, drawn up from specimens gathered by us in the Kaipara district, the chief stages are lettered. (a) The cotyledons are persistent, with prominent swollen midrib, and reddish, slightly recurved margin. (b) The first leaf is somewhat leathery, linear-oblong, green, often blotched with pale-brown, one or two inches in length, and irregularly coarsely toothed, with a leaf-stalk one-third the length of the blade. (c) The second and third leaves are linear-lanceolate, with minute distant teeth. The upper surface is black-green, spotted with pale brown, whilst the under surface is lighter in colour. The midrib is raised on both surfaces. (d) The fourth and few succeeding leaves are linear, spreading, and pointed slightly upwards, with stout, distant teeth, quite different from the serrations of the first leaf. The tips are yellowish, the upper surface black, with green shining through it, often marked with paler brown blotches. The leaves are now quite stalkless, and clasp the stem with a slightly smaller leaf-sheath. (e) This stage is the most remarkable, and remains permanent from fifteen to twenty years. The leaves are rigid and deflexed, and surround the top of the tree like the ribs of a half-closed umbrella. They are of great length, and extremely narrow. Kirk measured them up to 43 in. in length. Their average width is about half-an-inch. They are very thick and leathery in texture, with sharp tips, and distant marginal teeth. The midrib is highly developed, occupying nearly a third of the leat surface, and is yellowish in colour. The blade is a polished metallic black, faintly tinged 


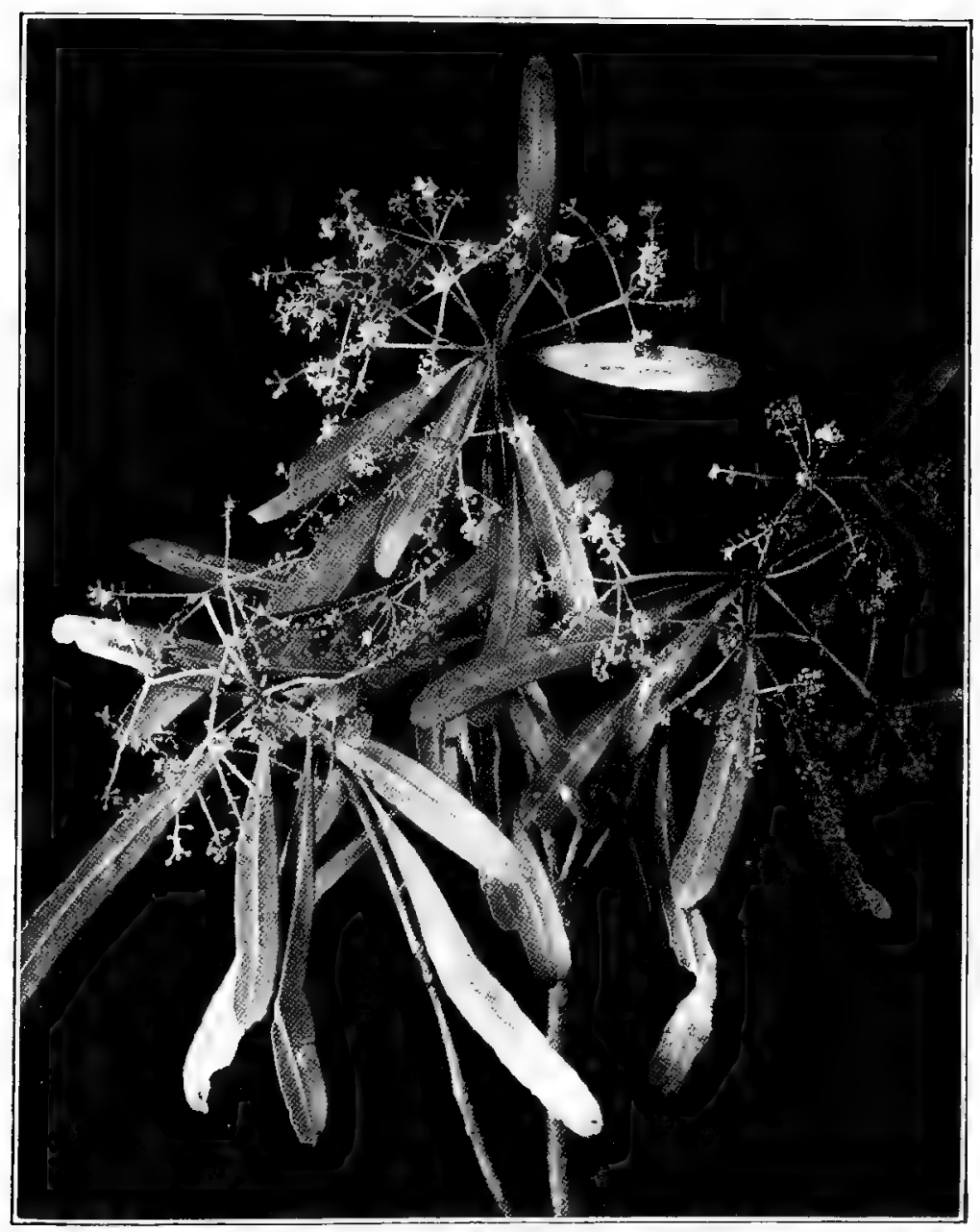

Fig. 99. Pseudopenax crassifolium-Flower. ( $\frac{1}{3}$ nat. size.) 
by the underlying green, and sometimes blotched with green or brown near the teeth. In this stage the stem is usually simple, and reaches a height of from fifteen to twenty feet. (f) After a long period of growth, these simple linear leaves are followed by dark-green compound leaves, consisting of three to five leaflets, $8-10 \mathrm{in}$. long, with petioles several inches in length. These leaflets are not so thick and rigid as those of stage (e), and the stalks are not yet more than half-an-inch in length. (g) The succeeding leaves are of a similar type, but have longer petioles, and the leaflets are broader and thicker. If the stem is branched, the plant now occasionally flowers. (h) This is the final stage. The leaves again become simple, but are, at first, not otherwise different from the previous stage. The following leaves, however, become very hard and thick, the teeth gradually become fewer and more distant, and sometimes disappear altogether. The leaf of the mature plant is from $4 \mathrm{in}$. to $6 \mathrm{in}$. in length, linear, almost or quite entire, hard and thick, dark green with prominent midrib, jointed to a short, thick petiole. Probably such an extraordinary series of changes in the leaf-form of any tree is unique. It must not be supposed that all the species go through as many transformations as $P$. crassifolium, though all of them show many variations in leaf shape. In P. crassifolium, var. unifoliolatum, the deflexed leaf-form passes by imperceptible gradations into the final stage, and there is no. trifoliate stage. The later deflexed leaves become, in this case, very coarsely toothed, incised, and expanded at the tips, before adopting their final form. If the head of the tree is destroyed, shoots are developed at the base, and these again reproduce the long, black, toothed leaves of the juvenile form; but the leaves in this case are frequently not deflexed, but horizontal. Kirk's statement that the large toothed simple leaves pass, as. a rule, more gradually into the mature state in the South Island than in the North, (Forest Flora, p. 60), scarcely secms 


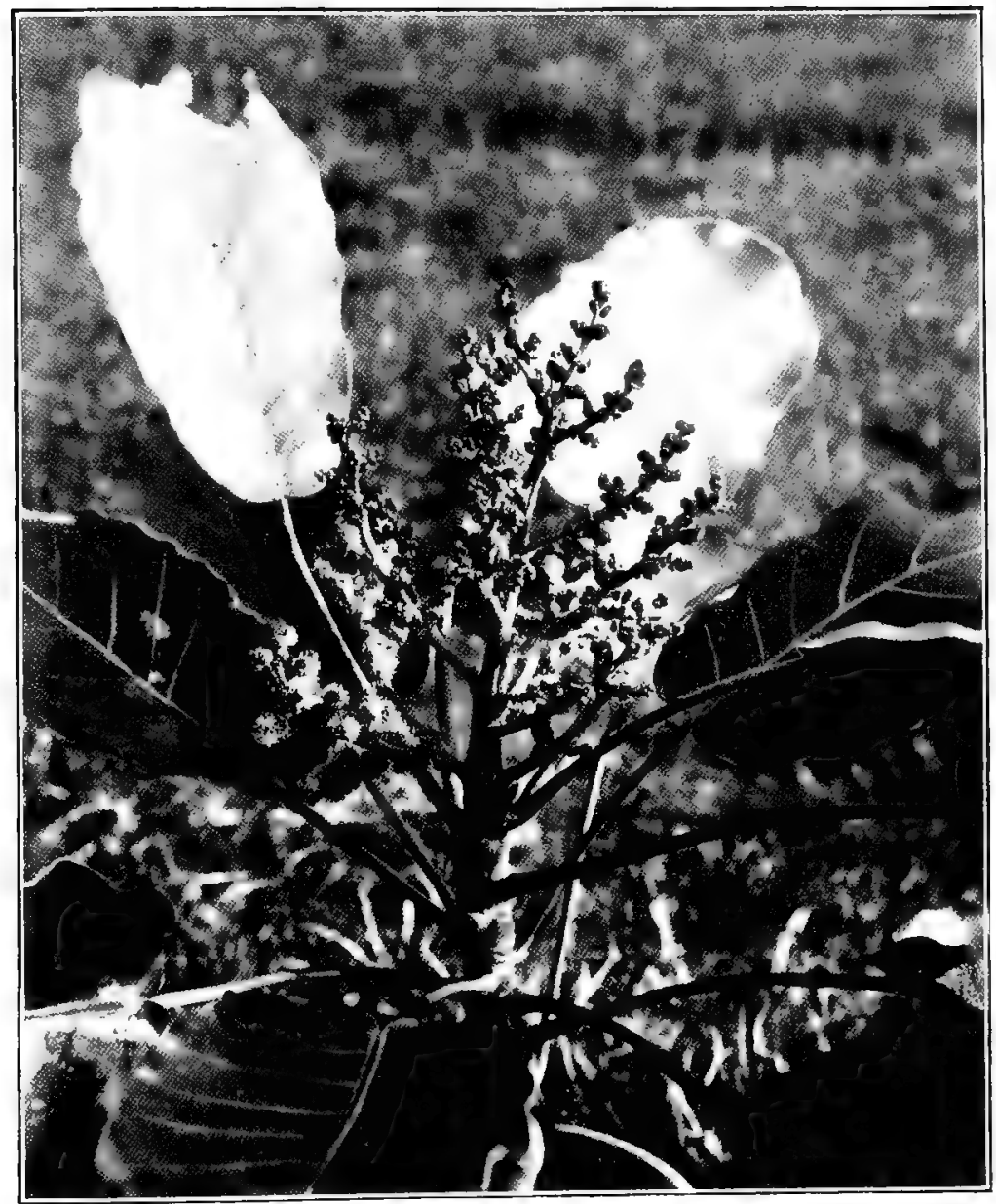

Fig. 100. Meryta Sinclairii ( $\frac{1}{3}$ nat. size). 
to be accurate, as in the Kaipara district, at least, the prevailing variety is $P$. unifoliolatum.

\section{Genus Meryta.}

A geuus of about 16 species, of which one is endemic in New Zealand. Branches resinous. Leaves large, glossy. Flowers in terminal panicles, sessile. Staminate flowers with a $3-5$-toothed calyx; petals and stamens $4-5$. Stamens longer than the petals. Fruit an oblong berry.

\section{Meryta Sinclairii.}

A handsome tree, from $12 \mathrm{ft} .24 \mathrm{ft}$, in height. Leaves very glossy, alternate, 9 in.-20 in. long, 4 in.-10 in. broad, margin waved, nerves prominent. Flowers in erect panicles, greenish-yellow. Staminate flowers in fours, each with 4 stamens. Pistillate flowers solitary or crowded, petals 5-6, styles 3-6, unfertile stamens 5-6. Fruit $\frac{3}{8}$ in. long, oblong, black, shining, 3-6-celled, 1-seeded. Three Kings Islands, Taranga Island. Rare. Fl. June.

\section{Genus Schefflera.}

About 20 species, of which one is endemic in New Zealand. Shrubs or trees, with digitate leaves. Flowers umbellate, in racemes or panicles. Calyx 5-toothed. Petals and stamens 5. Styles 5-10. Fruit round, fleshy, 5-10celled, 5-10-seeded.

\section{Schefflera digitata.}

A small tree, $10 \mathrm{ft} .-20 \mathrm{ft}$. in height. Leaves 5-10-foliolate, with sheathing petioles; leaflets petioled, membranous, toothed, $3 \mathrm{in.}-7 \mathrm{in.}$ long, oblonglanceolate, sometimes pinnatifid. Umbels $\frac{1}{4}$ in.- $\frac{1}{2}$ in. across. Fruit purplishblack, $\frac{1}{12}$ in. $-\frac{1}{10}$ in. in diameter. Both islands: abundant. Stewart Island. Fl. Feb.-March.

\section{Umbelliferae.}

\section{The Parsley and Carrot Family.}

Distribution.-A large and widely distributed family of plants, which, from their varying properties, may be divided into four groups :-

(1) Those which possess a poisonous watery sap, such as the Hemlock; (2) those which contain aromatic oils, such as the Caraway and Anise; (3) those which yield gum-resins, such as Asafotida; (4) those whose roots, stems, or leaves are edible, and are used as vegetables, such as Celery, Carrot, Parsley, etc. Of the New Zealand genera, Aciphylla and Ligusticum are the most important. 


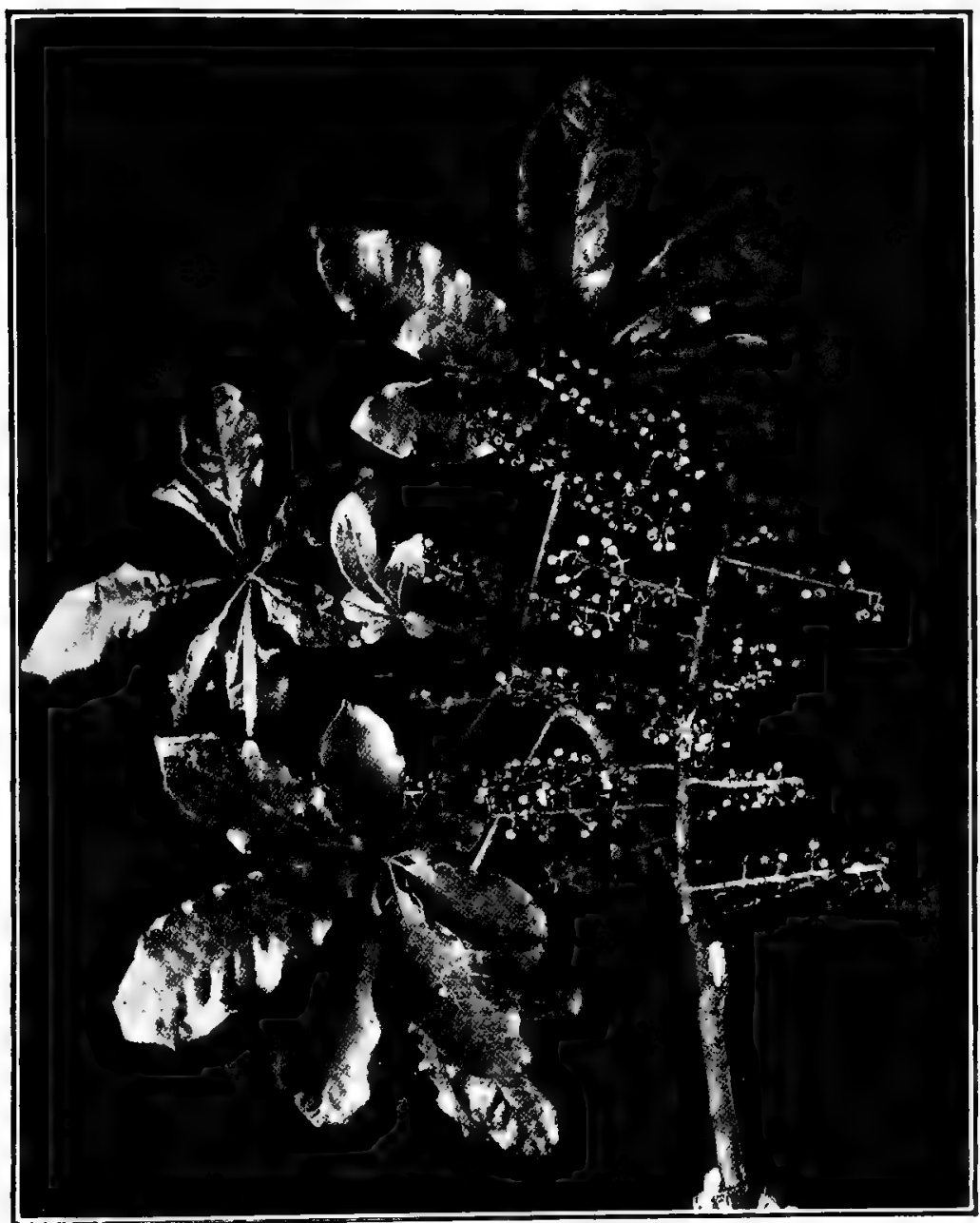

Fig. 101. Schefflera digitata ( $\frac{1}{2}$ nat. size). 


\section{Key to Genera.}

1. Umbels simple or irregularly compound, fruit without oil-cavities. Umbels usnally compound. Oil-cavities present.

2. Fruit conipressed laterally, or constricted at the narrow surface of junction of the two carnels.

Fruit with broad surface of junction, almost cylindrical.

3. Stems (in the New Zealand species) usually creeping. Leaves radical.

4. Fruits flat.

Fruits scarcely broader than thick.

5. Unbels usually compound, primary ridges only present. Untbels compound, secondary ridges present, often more strongly develoved than the primary.

6. Stems creeping. Unubels simple. Stems erect, sub-erect or elimbing. Umbels componnd or irregularly compressed.

7. Carpels winged. Carpels not winged.

8. Stens erect or climbing. Carpels with two broad lateral wings. Carpels with 3 or 5 wings on each face.

9. Unuels compound.

Umbels in erect spikes or panicles.

10. Ribs 5. Glabrous herbs with lateral or terminal umbels.

Ribs 5. Usually a hairy plant, umbels borne on a scape.

11. Fruit bristly,

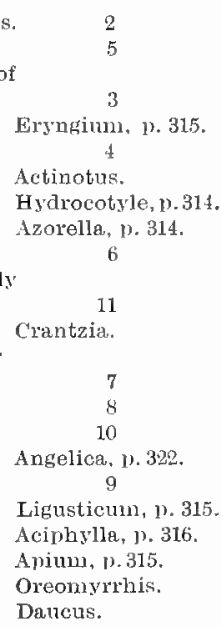

Daucus, Oreomyrrhis, Actinotus, and Crantzia are unimportant genera, with inconspicuous flowers, and will not be further noticed here.

\section{Genus Hydrocotyle.}

A rather large genus of small, creeping herbs, with inconspicuous green flowers. Leaves round or kidney-shaped, often 3-7 lobed. (Name from the Greek, signifying water, and a salver, in allusion to the shape of the leaves in some species). $9 \mathrm{sp.}$

\section{Hydrocotyle novae-Zelandiae (The New Zealand Hydrocotyle)}

Leaves obscurely 5-7-lobed; umbels 5-12-flowered, Carpels with one rib. Both islands. Fl. Nov.-March.

\section{Hydrocotyle asiatica (The Asiatic Hydrocotyle).}

Leaves kidney or heart-shaped, almost entire, Umbels 2-4-flowered, rarely 1-flowered. Carpels with 3 ribs. Both islands. Fl. Oct.-March.

\section{Genus Azorella.}

Tufted herbs, with simple or divided leaves. Umbels simple or irregularly compound. Fruit sub-quadrate, 5-ribbed. A genus of about forty species, of which nine are endemic in New Zealand.

This is an Antarctic genus of cushion plants. Azorella selago has a typical sub-Antarctic distribution Acana (cf. p. 203), being found in Macquarie Island, Tierra del Fuego, Port 
Famine, Hermit Island, Kerguelen's Land and the Crozets. Most of the New Zealand species grow on the sub-alpine moors, where our sub-Antarctic genera are generally to be found. Some of the Chilian Azorellas are so compact and covered with hairs, that, at a short distance, they bear a considerable resemblance to madrepore corals.

\section{Genus Eryngium.}

Thistle-like herbs, with rigid, prickly, often glaucous leaves. Umbels reduced to heads. Flowers mixed with bracts. The roots of the British Seil Holly (Eryngium naritimum) are candied and used as a sweetmeat. Some of the species are cultivated in gardens for the sake of the delicate blue colour of the whole plant. (An old Greek name for a kind of Thistle.) $1 \mathrm{sp.}$

\section{Eryngium vesiculosum (The Vesiculate Eryngnum).}

A small rigid herb, 2 in. -5 in. high. Leaves toothed, spinous. Flower-heads axillary. Both islands: sandy beaches. Fl. Dec.-Jan.

\section{Genus Apium.}

Glabrous herbs. Leaves pinnate; umbels compound, terminal or lateral. A small genus, to which belongs the Celery of our gardens. (A Latin name for the Wild Parsley and similar plants). $1 \mathrm{sp}$.

\section{Apium prostratum (The Prostrate Parsley).}

Leaves very variable, sessile or stalked, alternate, or radical and fascicled. Flowers white, rays 3-12. Both islands: common. Fl. Nov.-March.

\section{Genus Ligusticum.}

Erect herbs, usually glabrous and aromatic. Leaves pinnate or decompound. Umbels compound, rarely simple. Flowers white or red. Carpels with 3-5 winged ridges. Oil-tubes often obscure. (Name from Liguria, the home of the officinal species). All the New Zealand species are endemic. $17 \mathrm{sp.}$

\section{Ligusticum latifolium (The Broad-leaved Ligusticum).}

A robust plant, $3 \mathrm{ft} .-5 \mathrm{ft}$, in height. Stem 3 in.-4 in. thick at the base, radical leaves $1 \mathrm{ft} .-2 \mathrm{ft}$. long, coriaceous, 2-pinnate. Bracts large. Umbels 2 in. -3 in. across; crowded. Flowers reddish. Fruit 6 in. long. Carpels with 5 primary ridges, rarely 4 or 3 . Auckland and Campbell Isles. Fl. Dec.-Jan. A magnificent species. 


\section{Ligusticum piliferum (The Bristly Ligusticum).}

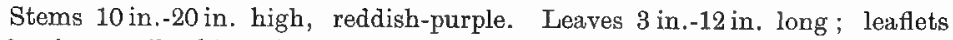
6-12 pairs, sessile, $\frac{1}{2}$ in.-1 in. long, ovate, toothed, 2-3-lobed to the base, margins of teeth tipped with bristles. Umbels 2 in.-3 in. across. Flowers white. Carpels 3-winged or one 5-winged. South Island: mountainous districts. Fl. Feb.-March.

\section{Ligusticum carnosulum (The Fleshy Ligusticum).}

Leaves and umbels all from the root. Leaflets cut into fleshy lobes $\frac{1}{4}$ in.- $\frac{2}{3}$ in. long. Umbels glaucous, compound. Involucral leaves in 3-5 segments. ('arpels 4-ridged. South Island: rare and local. Fl. Jan.

This is a remarkable shingle-slip plant, which, according to Diels, "shows in the numerous irregular windings of the thick stem, traces of the never ceasing battle with the shingle." Whenever the shoot is buried, it turns again to the nearest point of the surface, and works its way up to daylight. The leaves do not begin to develop until the stem has grown above the accustomed level of the shingle-stream. The stem remains quite naked below. The umbels are so shortly stalked, that the flowers remain within the protection of the foliage, which does not open out until the seed is ripe and ready to escape. The leathery leaves can withstand a considerable rain of shingle, and so great is their flexibility, that Diels compares them to little india-rubber tubes, whose fine division secures the freest mobility to the individual sections.

\section{Genus Aciphylla.}

Frect, rigid, perennial herbs. Leaves with sheathing bases, pinnate or 2-3 pinnate, with dagger-shaped segments. Flowers in long spikes or panicles. Bracts linear. The New Zealand species are all endemic. Besides these, two species are also found in Australia. (Name from the Greek, meaning needleleaved). $13 \mathrm{sp.}$

The genus Aciphylla is found in New Zealand and Australia only. All the New Zealand species are endemic, and most of them are characterized by long, sword-like, spinous, radical leaves, which form a dense tuft of lance-like spikes, a foot or two in height. The long flower stalks are clothed with 


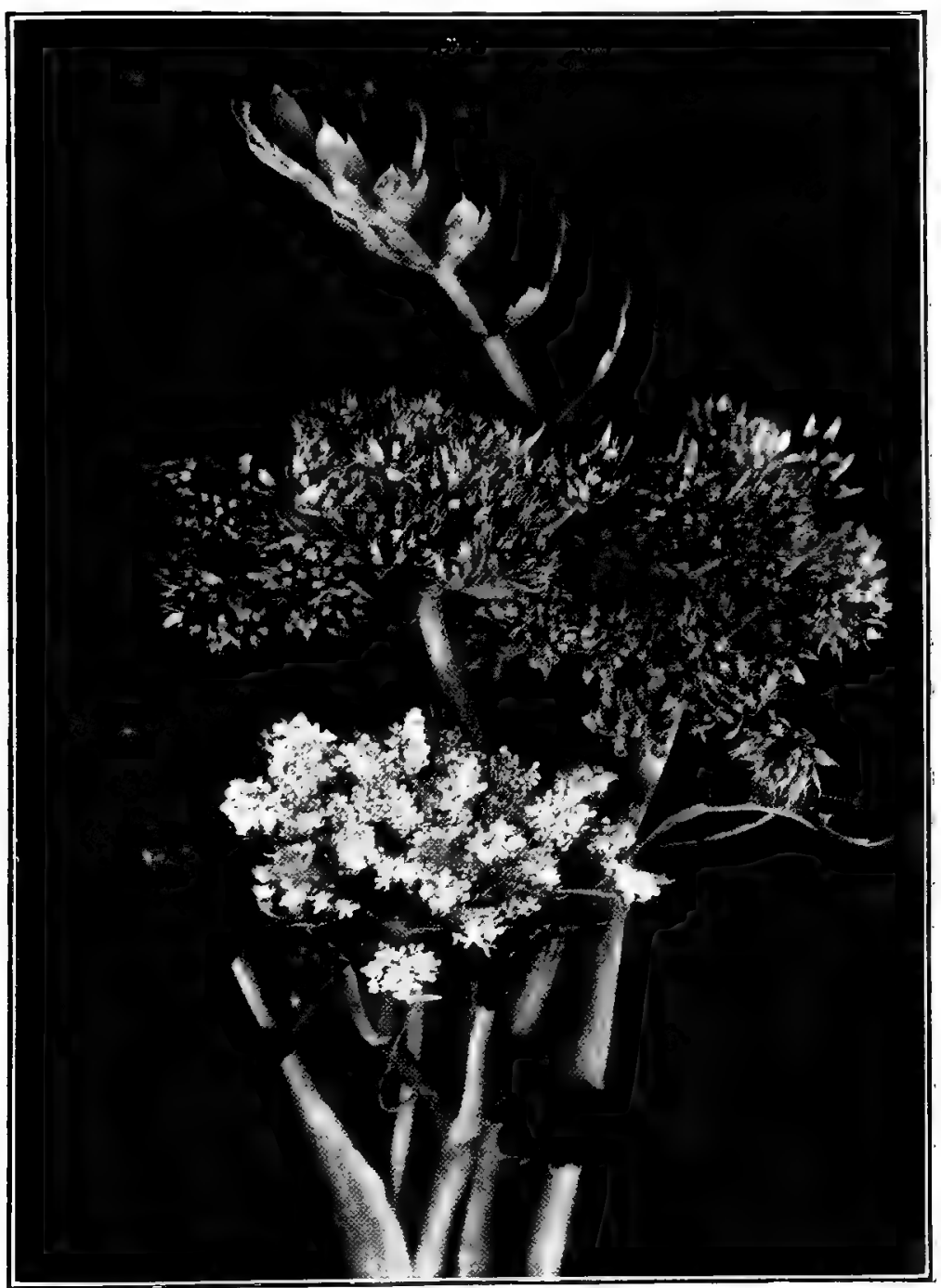

Fig. 102. Ligusticum piliferum ( $\frac{1}{2}$ nat. size). 
similar spinescent bracts, guarding the flowers with veritable chevaux de frise. No plant could be better defended against the attacks of grazing animals, and the earlier botanists naturally concluded that the purpose of the spines was protective. One thing puzzled them. Why should plants, which were indigenous to a land where no animals browsed, be guarded by such terrible thorns? There was no satisfactory answer to this question, though Wallace even goes so far as to suggest that "they may have gained their" spines to preserve them from being trodden down by the moas, which for countless ages took the place of mammals in New Zealand." However, the trend of recent investigation is to show that the spines are not protective, but the natural results of modifications resulting from the struggle against drought.

Many New Zealand plants at some stage or other of their existence are of a xerophytic type, (v. Introduction, p. 41) and perhaps no better example could be found than Aciphylla. Why so many of our plants should be xerophytic is a puzzle to botanists, but a fuller discussion of the question will be found under Plagianthus betulinus (pp. 254-258).

That the leaves shonld be reduced to spines in Aciphylla is especially remarkable, because the leaves of other members of the family are often large, and well developed. Those, however, of A. Colensoi and A. squarrosa are in the seedling form quite flaccid and grass-likel, while, according to Mr. Cox of the Chatham Islands, the leaves of $A$. Traversii are so soft that sheep eat them greedily. On well stocked stations the plants therefore suffer severely, and are soon exterminated. These anomalies of leaf-form tend to show that the ancestors of the genus Aciphylla were of a normal type.

If further argument were required to show that the spinous leaves of Aciphylla are really drought-forms, and not protective

\footnotetext{
* "Darwinisun," Colonial Edition. p. 433

('ockayne: Trans, XXXIII., 1), 279.
} 


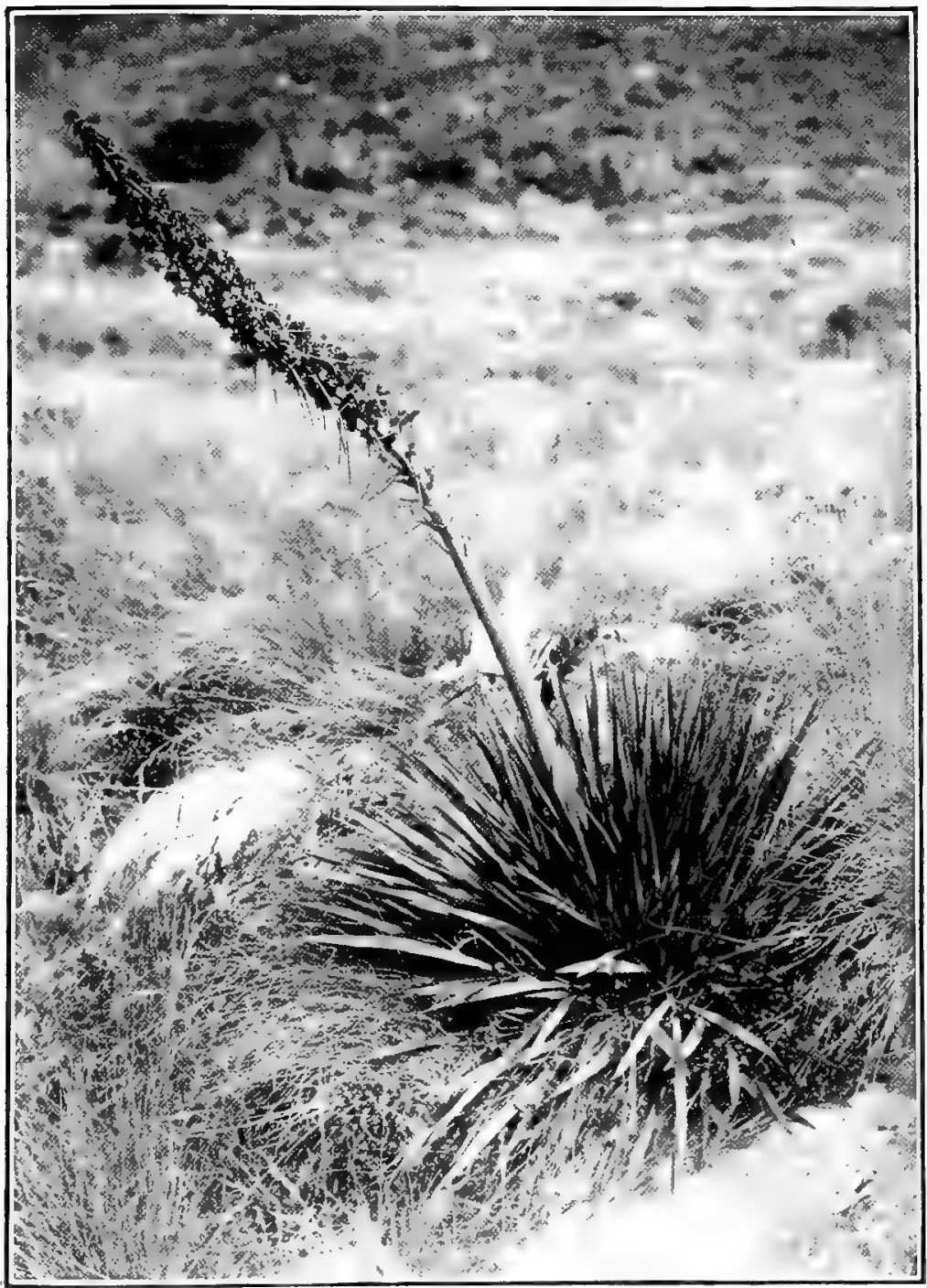

Fig. 103. Aciphylla Colensoi. 
against grazing animals, it is to be found in the fact that Aciphylla quickly disappears on country over which stock runs. By a curious irony of fate, the protection of the spines, when needed most, is wanting." The young plants are greedily eaten by cattle and sheep, and so, as the old plants die off, no others are allowed to grow up and take their place. Rabbits, too, attack the mature plants and destroy them. They are small enough to eat a single leaf, without danger from its neighbours.

\section{Aciphylla Colensoi (Colenso's Spaniard).}

Plant $2 \mathrm{ft} .-8 \mathrm{ft}$. high. Leaves $1 \mathrm{ft} .-2 \mathrm{ft}$. long, $\frac{1}{2}$ in.- $\frac{3}{4}$ in. broad, spinous, greenish-yellow. Leaf-sheath also provided with a pair of simple or divided spines, the whole forming a mass of bayonet-like spikes. Umbels arranged in a stout, erect, leafy raceme. Both islands. Matori name, Taramea. Fl. Nov.-Dec.

\section{Aciphylla squarrosa (The Rongh Spaniard).}

A much smaller plant than the preceding, and greyer in colour. The leaf segments are also narrower, being only $\frac{1}{18}$ in.- $\frac{1}{8}$ in broad, and the fruit is much smaller. Haori name, Furi-Kuri; Colonists' name, Spaniard or Wild Spaniard.

This plant yields a semi-transparent resinous gum, which afforded the most prized scent in use among the Maoris. The species is not found in the lowlands, and in the North Island is generally alpine or sub-alpine. Hence the gum was only obtained with some labour and difficulty. Certain observances also had to be carried out in collecting it. According to Colenso, $\uparrow$ it could be collected only by maidens, and then only after the proper prayers and charms had been said by the priest (tohunga).

There is a dainty little Maori lullaby, in which the name taramea occurs with those of other odorous plants :-

\footnotetext{
"Taliu hei piripiri

Taku hei moki-moki

Taku hei tawhiri

Taliu kati touramea."
} 


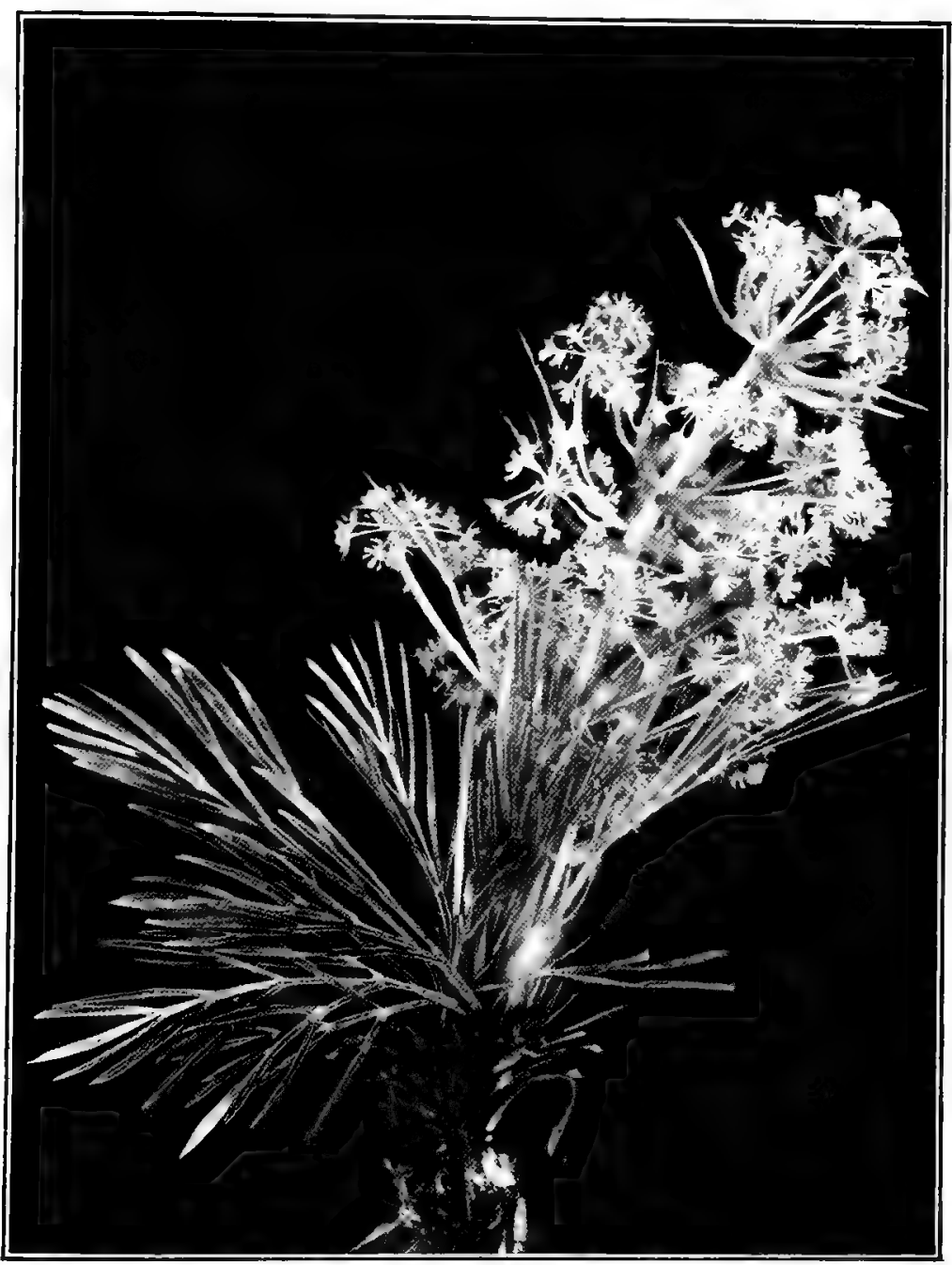

Fig. 104. Aciphylla Monroi (la nat. size). 
Colenso thus translates it :-

“My little neck satchel of sweet scented moss,

My little neck satchel of fragrant fern, My little neck satchel of odoriferous gum,

My sweet smelling neck locket of sharp pointed taramea."

The gum of the taramea was collected at early dawn; and with it were mixed the fronds of moki-moki, (the fern Doodia caudata), and of the piri-piri, (certain species of Hepaticae), the fragrant resin of the tawhiri, (Pittospontm tenuifolium), the oil of the miro, (Podocarpus ferruginea), and the flowers of pa-totara (species of Lencopogon and Gauttheria). The mixture was subjected to heat for some days; and then strained through a sieve made of the plumes of the toi-toi (Arundo conspicua). It was afterwards placed in carved boxes, where the mats of the chiefs were kept, or was used as a satchel by girls, in the way described by Colenso.

\section{Aciphylla Monroi (Monro's Spaniard).}

A small, flaccid species, 6 in.-18 in. high. Leaves $3 \mathrm{in.-5}$ in. long, shining, pinmate. Scape slender, soft. Umbels in an open branched panicle, in the axils of flaccid, 3-5 parted bracts. Flowers yellowish. Fruit $\frac{1}{5}$ in. long. Carpels 5-ribbed, or one 3-ribbed. South Island: alpine or sub-alpine districts. FI. Dec.-Narch.

\section{Genus Angelica.}

Erect or climbing herbs. Leaves pinnate or 2-3-pinnate. Flowers in umbels, white. Fruit compressed. Primary ribs 3: wings 2. A small genus of about 25 species. (Thus named on account of its supposed healing properties). $5 \mathrm{sp}$.

Angelica geniculata (The Jointed Angelica).

Stems $2 \mathrm{ft} .4 \mathrm{ft}$. long, forming tangled masses, scrambling over other shrubs. Leaves when young, 3-lobed; entire in the mature state, ovate, slightly crenate. Flowers white, in terminal or axillary umbels. Carpels 3-4 ribbed, 2-winged; oil canals present. Both islands. Fl, Dec.-Feb.

\section{Angelica Gingidium (The Native Aniseed).}

A herbaceous plant, with radical pinnate leaves, oblong in outline. Flowers white, umbels compressed, 1 in.-3 in. in diameter. Both islands. Fl. Nov.-Dec.

The whole plant is highly aromatic. It is greedily eaten by sheep, and, though originally very abundant, is often almost exterminated by them in accessible places. The plant is known to shepherds and runholders as Aniseed. 


\section{Ericaceae.}

(Including Epacridaceae).

\section{The Heath Family.}

Distribution.-A considerable family, often with astringent properties. Some species are narcotic and poisonous, while a few produce edible fruits. Many are cultivated for the beauty of their florvers. In Australasia they are represented chiefly by the Epacridaceae.

The headquarters of the family are in Cape Colony, where there are at least 400 species of heaths. These are small evergreen shrubs, which grow in great abundance, and form the chief vegetation of open plains and dry hill sides. An assemblage of such plants, from its prevailing constituents, is generally also termed a heath. Naturally not all the plants in a heath belong to the order Ericaceae. The typical heath plant, however, whether belonging to this order or not, has small, dry, hard leaves, often sharp-pointed, and with inrolled margins. The Scotch heather may be taken as an example.

In New Zealand, in addition to various genera of Ericaceae (e.g. Gaultheria, Leucopogon, Epacris, Dracophyllum) there may be found in the heaths, particularly in the South, Cassinias, Olearias, Coprosmas, and some other shrubs. In the Auckland province, Pomaderris phylicafolia and Pimelea are found along with the true heaths, Leucopogon fasciculatus and Epacris pauciflora. Everywhere however, Leptospermum, is the chief component of the heath associations of New Zealand.

By far the commonest plant of the order here, is Lencopogon Frazeri, which is found throughout the islands on dry open ground from sea-level to 5,000ft. Its small orange drupe is sometimes eaten, and has a sweetish taste. Gaultherias are found in both North and South Islands. The white fruit of $G$. antipoda is known as the snow-berry in Otago, and is occasionally eaten. Like most of the other products of the New Zealand bush, it cannot be recommended to the epicure. The white, fleshy, outer portion, consists of the calyx, which has remained persistent, and become juicy. According to Hooker, the fruit is strangely variable, dry dehiscent capsules being found on the same spray as the 
berries. No other observer seems to have noted the occurrence of this curious phenomenon. It certainly is very rare, if existent. Its little white bell-like corollas make Gaultheria the prettiest of our common heaths.

Mr. G. M. Thomson has tried to prove the existence of a correlation, between the pungent tips of the leaves, in certain species of this order, and the presence of herbivorous animals. Leucopogon Frazeri, which has sharp-pointed leaves, is found, not only in New Zealand, but also in Australia. L. fasciculatus, which he erroneously states to be without pungent leaf-tips, is endemic. Of five species of Archeria two formd in New Zealand, and one in Tasmania, have rounded apices to the leaves, whereas the two Australian species have sharp-pointed tips. It is possible, that the acute apices of the Australian plants, may be a protection against grazing animals, but it is just as likely, that they may be an adaptation to the drier conditions of the Australian climate. The fact that many of the endemic species of the genus Dracophyllum have leaves with pungent tips, seems in favour of the latter hypothesis.

This genus has its headquarters in New Zealand, with a few outlying representatives in Australia and New Caledonia. Plants belonging to it are generally known to. colonists as grass-trees, though this term is also applied in Otago to the lance-wood (Pseudopanax). The name is. doubtless due to the long grass-like leaves of most of the species. The broad-leaved species, $D$. Traversii of the South Island, and D. latifolium, found chiefly in the kauri forests. of the Auckland province, are known as nei-nei, and might. almost be taken for a kind of cabbage-tree. D. latifolium produces a great spike of handsome red flowers. D. subulatum and $D$. Urvilleanum are components of the heaths, the former being found only in the North Island. $D$. longifolium is a common sub-alpine tree in the South Island, reaching sea-level in Southern Otago and Stewart Island. The leaves of $D$. 


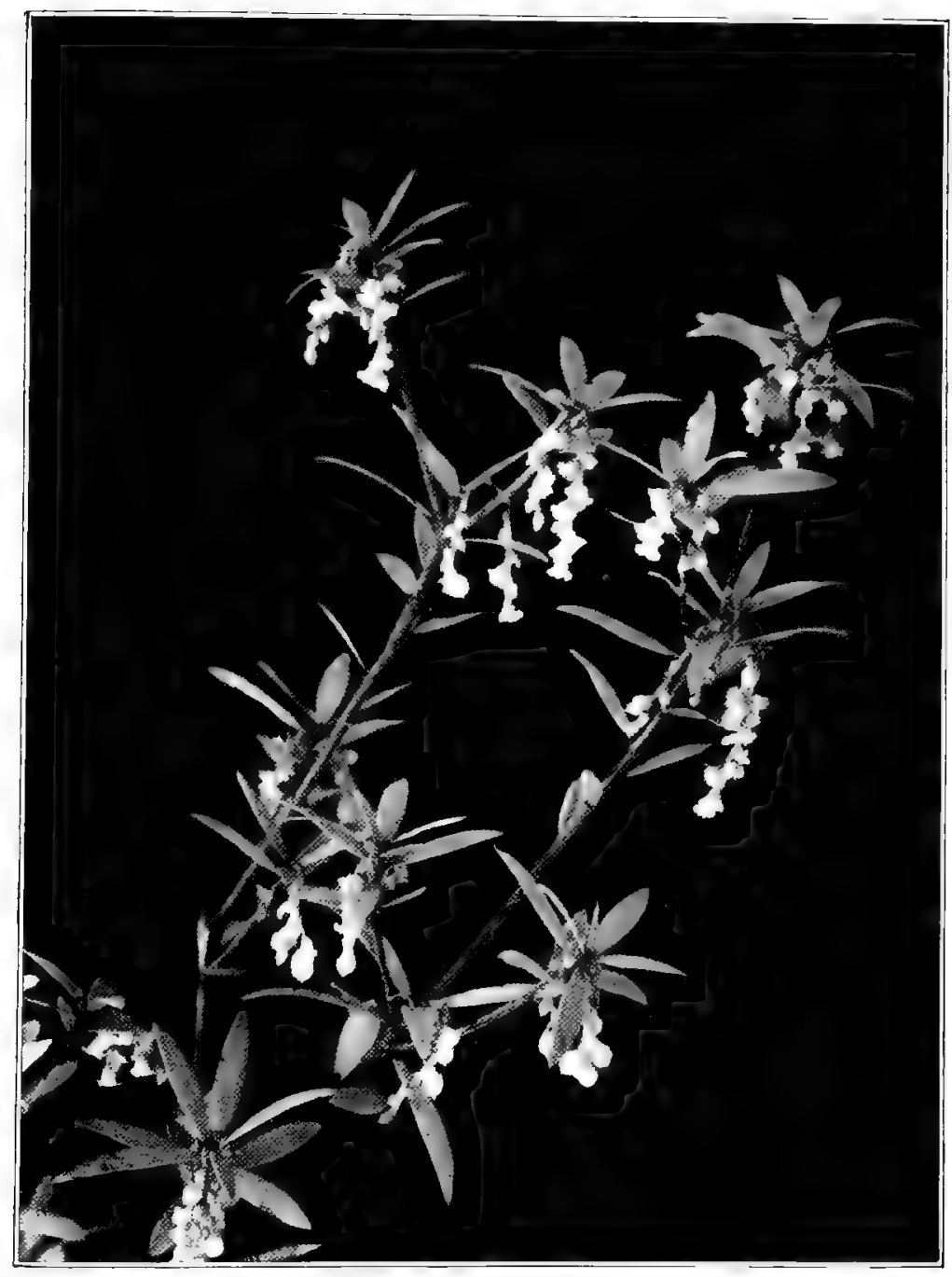

Fig. 105, Leucopogon fasciculatus (is nat. size.) 


\section{latifolium were sometimes used by the Maoris in the manufacture of specially fine garments.}

Key to the Genera.

Sub-family Ericeae. Stamens, hypogynons; anthers, 2-celled, opening by pores.

Fruit \& false berry.

Gaultheria, p. 326 .

Sub-family, Epacrideae. Stamens, epipetalons; anther's, 1-celled.

1. Fruit a drupe.

Fruit, a many-seeded capsule.

2. Fruit with a 1-10-celled bony nut; cells with one pendulous seed.

Fruit with 5 or more minute 1-seeded nuts.

3. Pedicels covered with imbricating bracts.

Pedicels with few bracts, close to the calyx.

4. Leaves with broad sheathing bases.

Leaves without sheathing bases.

5. Flower solitary. Bracts, as in Styphelia.

Flowers racened. Bracts few or 0 .

2

4

3

* Pentachondra.

Styphelir, p. 328.

Leucopogon, p. 328.

Dracollhyllum, 1. 330 . 5

Epacris, D, 326.

*Archeria.

*Not further described.

\section{Genus Gaultheria.}

Shrubs with alternate, rarely opposite leaves. Corolla bell-shaped or urnshaped. Stamens 10, anthers opening by pores, each pore provided with 1 or 2 awns. Disk cup-shaped, 10-lobed. Ovary 5-celled.

A genus of about 100 species, found in America, South-Eastern Asia, Tasmania, and New Zealand. G. procumbens furnishes the Checker-berry of the United States.

\section{Gaultheria antipoda (The Snow-berry).}

A very variable, erect, or prostrate bush. Branches with scattered black or yellow-brown bristles. Leaves bard, shortly stalked, orbicular-oblong, lanceolate. Flowers small, white or pink, usually solitary. Corolla $\frac{1}{10}$ in. in length or more. Berry pink or white, $\frac{1}{2}$ in. in diameter. Both islands: common at all elevations. Colonists' name Snow-berry. Fl. Oct.-Nov.

G. rupestris (the Rock Snow-berry) is a similar plant, also very variable, with flowers usually in racemes. It is not so common as the previous species.

\section{Genus Epacris.}

Small shrubs. Leaves usually closely imbricating, but not sheathing. Corolla tubular or bell-shaped, lobes not bearded.

\section{Epacris pauciflora (The Few-flowered Epacris).}

A twiggy shrub, $1 \mathrm{ft} .-4 \mathrm{ft}$. high. Leaves coriaceous, $\frac{1}{8} \mathrm{in} .-\frac{1}{4} \mathrm{in}$. long, concave, oblong-lanceolate, narrowing suddenly at the tip. Flowers collected at the tips of the exect branches, white. Corolla with a very short tube. 


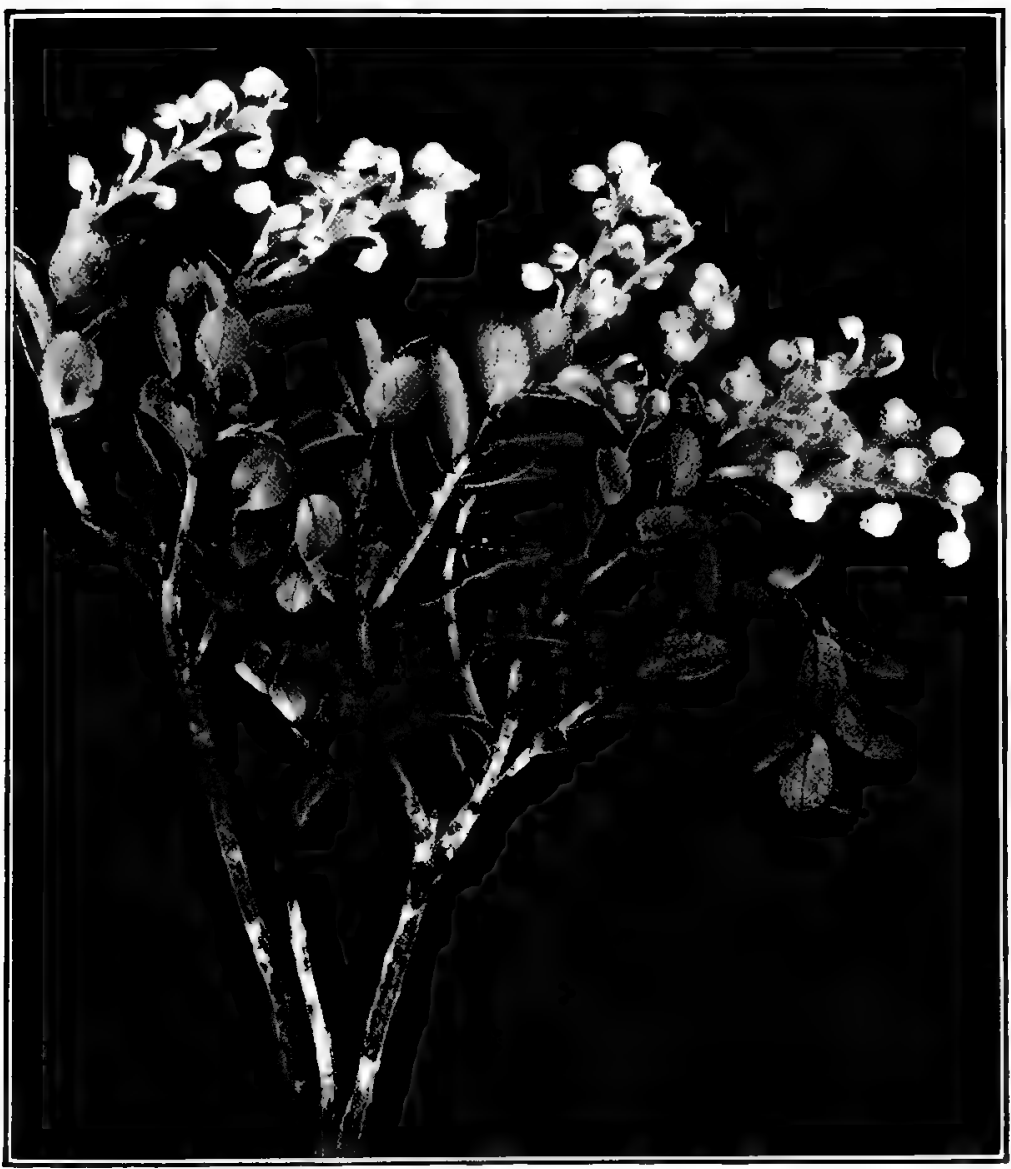

Fig. 106. Gauitheria rupestris ( $\frac{3}{4}$ nat. size). 
Auckland to Nelson. Fl. Sept.-Nov. A handsome plant, whose rod-like inflorescence of white flowers is one of the most beautiful objects of the Northern heaths.

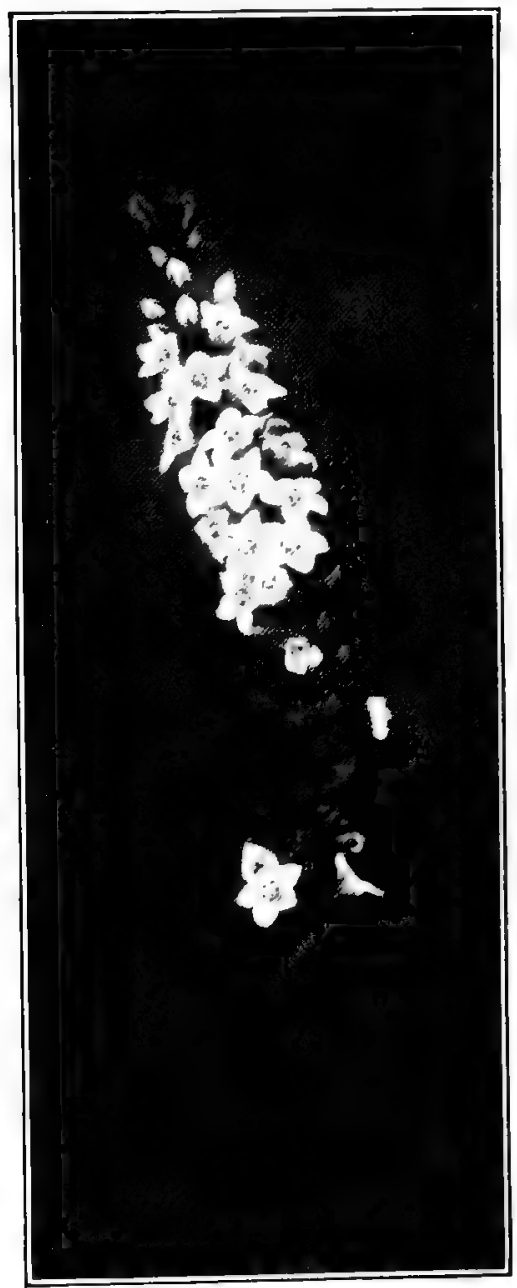

Fig. 107. Fpacris panciflora (3at. size.)

\section{Genus Leucopogon.}

Shrubs, leaves imbricating or scattered. Flowers white or pink, solitary, or in racentes or bundles. Corolla tubular, lobes spreading, heirded. An Australian and Malayam genus of about 130 species, sometimes included in Styphetia. Name from the Greek, signifying white beard, in allusion to the bearded loles of the corolla). $3 \mathrm{sp}$.

\section{Leucopogon fasciculatus}

(The Bundle-Howered

\section{Leucopoyon).}

A sluxub or small trce, leaves somewhat whorled, spreading, $\frac{1}{3}$ in.$1 \mathrm{in.}$ long, linear-lanceolate, pointed, obscurely veined below. Flowers in fascicled spikes. Abundant in the northern heaths. Fl. Oct.-Nov.

\section{Leucopogon Frazeri}

\section{Frazer's Leucologon.}

A sinall, erect or prostrate, straggling plant, 2 in.-6 in. high. Leaves elose set, $\frac{1}{6}$ in. $-\frac{1}{1}$ in. long, linearoblong, with pungent tips. Flowers solitary, axillary, rather large, redclish-white. Fruit an orange coloured edible drupe, Extremely abundant in all dry situations. Fl. Oct.-Jan. Marori name Pu-toturt.

\section{Genus Styphetia, Sim.}

Shrubs. Leaves rigid, pungent, p:rallel-veined below. Flowers small, white or rellowish. Corolla fumel-shaped, or urn-shaped. A genus of the Pacifie Islands and Australasia, with about 30 species. (Name from the Creek, meining hard or rough, in reference to the leaves). $5 \mathrm{sp}$. 


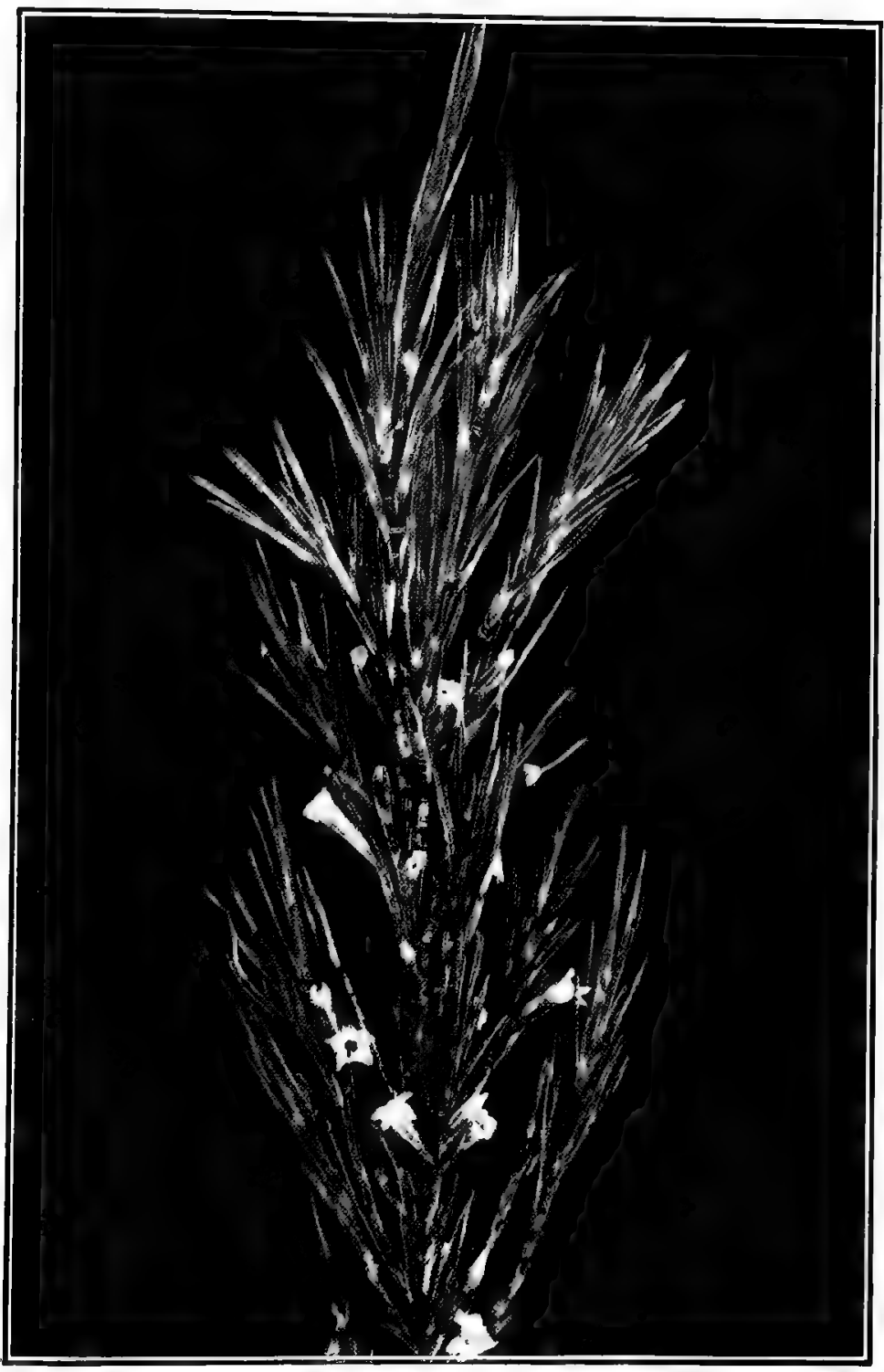

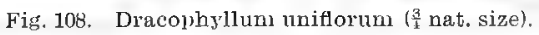




\section{Styphelia acerosa (The Prickly Styphelia).}

A shrub or small tree, with blackish branches. Leaves about $\frac{1}{6}$ in.- $\frac{1}{2}$ in. long, acerose, linear. Margins often recurved, with 3-7 parallel veins on the under side. Drupe white or red, $\frac{1}{8}$ in. $-\frac{1}{3}$ in. in diameter. Abundant throughout the islands, variable. Fl. Oct.-Nov. Maori name Mingi-mingi. (Cyathodes acerosa of Cheeseman.)

S. robusta is a very distinct and handsome species from the Chathams. S. empetrifolia is a sub-alpine species. These shrubs have a slight resemblance to young plants of the genus Podocarpus.

\section{Genus Dracoptryllum.}

Shrubs or trees. Leaves long, rigid, grass-like, with sheathing bases, and generally crowded to the ends of the branches, which are marked by the ring-scars of the fallen leaves. Flowers in racemes or spikes, rarely solitary. Corolla tubular or bell-shaped, generally white. Anthers 5, sessile at the mouth of the column. Disk of 5 erect scales. (Name signifying dragon-leaved, in allusion to the resemblance of the leaves to those of the Dragon-tree of Teneriffe, $v, p .92$ ).

A strange genus of Australasian and New Caledonian Epacrids, known to Colonists as Grass-trees. $18 \mathrm{sp.}$

\section{Dracophyllum latifolium (The Broad-leaved Grass-tree).}

A shrub or tree, from $10 \mathrm{ft},-25 \mathrm{ft}$. high, branches given off in whorls.

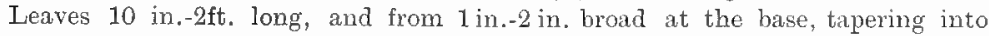
drooping points, and forming a head resembling that of the cabbage-tree. From the centre of this head rises a large cylindrical panicle of closely packed red flowers, from 6 in.-18 in. long. The flowers themselves are minute, about $\frac{1}{3}$ in. long. Both islands: common in Auckland, but rarer towards the South : in the South Isiland, only in Nelson and Westland. Fl. Jan.-Feb. Maori name Nei-nei.

This singular plant is replaced in the mountainous districts of the South Island, by the closely allied Dracophyllum Traversii.

\section{Dracophyllum Iongifolium (The Long-leaved Grass-tree).}

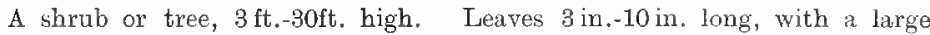
sheath at the base, which is suddenly contracted into a narrow blade, $\frac{1}{8}$ in. $-\frac{1}{6} \mathrm{in}$. broad. The flowers are white, in crowded racemes, 1 in.-2 in. long. Each flower has a large brown bract at its base. North Island, rare, becoming more conmon towards the South. In Campbell Island it forms the chief portion of the woody vegetation. Fl. Oct.-Dec.

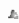

\section{Dracophyllum uniflorum (The One-flowered Grass-tree).}

A stout, erect shrub. Leaves $\frac{1}{2}$ in.-2in. long, $1 \frac{1}{1}$ in. $-\frac{1}{8}$ in. broad, pungent. Flowers solitary, $\frac{1}{4}$ in. $-\frac{1}{3}$ in. long, almost hidden by the sheathing bracts. An alpine species of the South Island. Fl. Dec.-Feb. 
Other species of Dracophyllum are D. Urvilleanum, somewhat resembling $D$. longifolium, but much smaller. It is found in both islands. D. rosmarinifolium (The Rosemaryleaved Grass-tree) is a small, often prostrate, alpine species of the South Island, with obtuse leaves and with the flowers solitary or in pairs. D. subulatum is an allied form with pungent leaves, found only in the North Island.

\section{Myrsinaceae.}

\section{The Myrsine Family.}

Distribution.-An unimportant fanily, chiefly tropical. A few, however, reach Cape Colony, New Zealand, and Florida. They are only to be distinguished from the primroses by their fruit and habit. They differ from the Sapotaceae in not having a chambered ovary. According to $\mathrm{Mez},{ }^{*}$ the family contains some 900 species and 32 genera. These plants are, however, of little economic value.

Key to the Genera.

Petals completely free.

Petals more or less united, sometimes only at the base, but more often through a third of their length.

Suttonia.†

See, however, Cheeseman's "Flora," for remarks on this nomenclature.

\section{Genus Suttonia.}

A large genus of trees and shrubs. Flowers usually fascicled, small, Calyx 4, rarely 2 or 0 . Petals 4, deciduous. Fruit a drupe. (Named in honour of Sutton, an English botanist.)

\section{Suttonia divaricata (The Divaricate Suttonia).}

A straggling bush. Leaves and flowers very small, the former $\frac{1}{3}$ in. long, the latter 1 in. in diameter. Drupe round, depressed. Both islands: damp bush. Also Lord Auckland's Group. Fl. Oct.-Nov.

\section{Genus Rapanea.}

Sepals small, 4-5; sometimes almost free, sometimes united at the base. Petals 4-5, generally papillose on the margin. Stamens inserted on the throat of the corolla, sessile. Fruit spherical, dry or fleshy. Trees or shrubs, with entire, rarely toothed leaves.

${ }^{*}$ Cockayne, Trans. XXXV. p. 355 


\section{Rapanea salicina (The Willow-leaved Rapanea).}

A small tree, sometimes $40 \mathrm{ft}$. in height, with narrow, shining lewves, $4 \mathrm{in.-}$ 6 in. long, produced chiefly at the tips of the branches. Flowers in numerous small fascicles on the bare brauches, whitish-green, $\frac{1}{12}$ in. broad. Berry red, $\frac{1}{4}$ in. -1 in. long. Botb islands. Fl. Aug.-Sept. Maori name, Toro.

The timber of this tree is of a red colour, and is boautifully veined. It is much used by calinet-makers, but is not sufficiently durable for outside work.

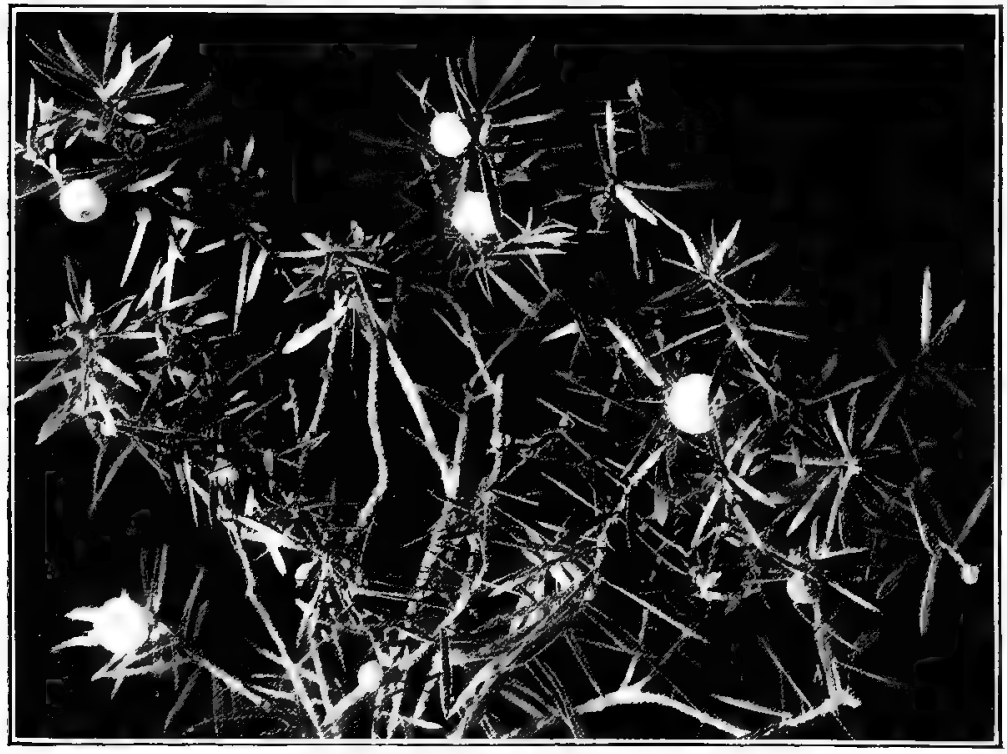

Fig. 109. Styphelia acerosa ( $\frac{2}{5}$ nat. size).

\section{Rapanea Urvillei (D'Urville's Rajanea).}

A small tree, sometimes $20 \mathrm{ft}$. in height. Leaves reddish-brown, with. waved margins, 1 in. $-1 \frac{1}{2}$ in. long. Flowers small, white, in fascicles on the lateral branchlets. Berry $\frac{1}{6}$ in. long, black. Fl. Dec.Feb. Native name Mapau, Mapou, or Matipo. The name Matipo is generally applied by Europeans to Pitfosponum tenuifolim, but this is apparently the plant to which the Maoris attached the nane. It bears some resemblance to Pittosporm temifolium, but can be readily distinguished by the reddish colour of the leaves. Common in both islands. 


\section{Primulaceae.}

\section{The Primrose Family.}

Distribution.-This is a family of wide distribution, but chiefly found in temperate regions or alpine districts. The species possess no economic value, but many are cultivated for the benuty of their flowers. The Primrose, the Auricula, the Polyanthus, and the Cyclamen are well-known garden plants. The little alpine Soldanella is remarkable for its heat-producing powers. This delicate little plant generates warmth sufficient to melt the ice above it, so thit it can raise its blue-fringed bells into the air for the purpose of attracting pollinating insects. New Zealand possesses only one representative of the Primulacea, the inconspicuous and mimportint herb Samolus.

\section{Genus Samolus.}

Herbs, with alternate leaves, and regular flowers. Calyx 5-toothed; corolla 5-lobed; stamens 5, alternating with 5 staminodia. Capsule 5-valved. (According to Pliny, the name is Druidical for a healing marsh plant.) $1 \mathrm{sp.}$

\section{Samolus littoralis (The Sea-side Samolus).}

A small creeping herb. Leaves thick, shining, $\frac{1}{6}$ in.-1 in. long; spathulate, often recurved. Flowers $\frac{1}{4}$ in. $-\frac{1}{3}$ in. across, white. Both islands: by the seacoast. Fl. Nov.-Jan.

This little genus is remarkable for its wide geographical range, being found in wet, gravelly places almost everywhere. It is also interesting, as being the only group in the family known to possess staminodia. In all the other genera the stamens are antipetalous, i.e., they are situated opposite to the petals; and it has been suggested that possibly this is due to the suppression at some time of an outer whorl of stamens, still present in Samolus as staminodia. S. littoralis frequently carpets the salt meadows, and produces a profusion of white flowers, which are in beautiful contrast to the brown-green of the leaves. 


\section{Oleaceae.}

\section{The Olive Family.}

Distribution.-A family of nearly 400 species, occurring chiefly in tropical and warm temperate regions. This family includes two British species, the Ash (Fraxinus) and the Privet (Ligustrum). The Lilac (Syringa vulgaris) is a wellknown garden plant. From the Olive (Olea) a valuable oil is obtained.

\section{Genus Olea.}

Trees or shrubs. Leaves usually opposite, entire, leathery. Flowers axillary, inconspicuous, racemed or panicled. Staminate flowers with a 2-4-lobed calyx. Petals absent. Stamens 2 ; anthers large, exserted. Pistillate flowers with an unequally 4-lobed calyx. Ovary 2-celled. Fruit a drupe, 1- or 2-celled.

\section{Olea Cunninghamii (The Maire).}

A large tree, with whitish branches. Young shoots downy. Leaves 3 in.6 in. long., linear-oblong, obtuse, leathery. Flowers greenish-white, 10-15 together. Raceme $\frac{1}{2}$ in. $-\frac{3}{4}$ in. long, erect. Drupe $\frac{1}{2}$ in. long. North and east of the North Island. Fl. Oet.-Nov.

\section{Olea lanceolata.}

Smaller in all its parts than O. Cunninghamii. Bark white. Leaves 2 in.4 in. long, acute, with raised veins. Racemes 6-10-flowered, slightly hairy. Flowers minute. Berry crimson, $\frac{1}{2}$ in. long, North Island: bush. Fl. Oct.Dec.

\section{Loganiaceae.}

\section{The Nux-Vomica Family.}

Distribution.-An essentially tropical family, but extending to North America, Australia, and New Zealand. Many of the plants contain powerfully poisonous principles, notably so the genus Strychnos. Strychnos nux-vomica, the poison-nut of the East Indies, yields the poisonous drug strychnine. The Upas tree of Java is also well known as containing a deadly poison. 


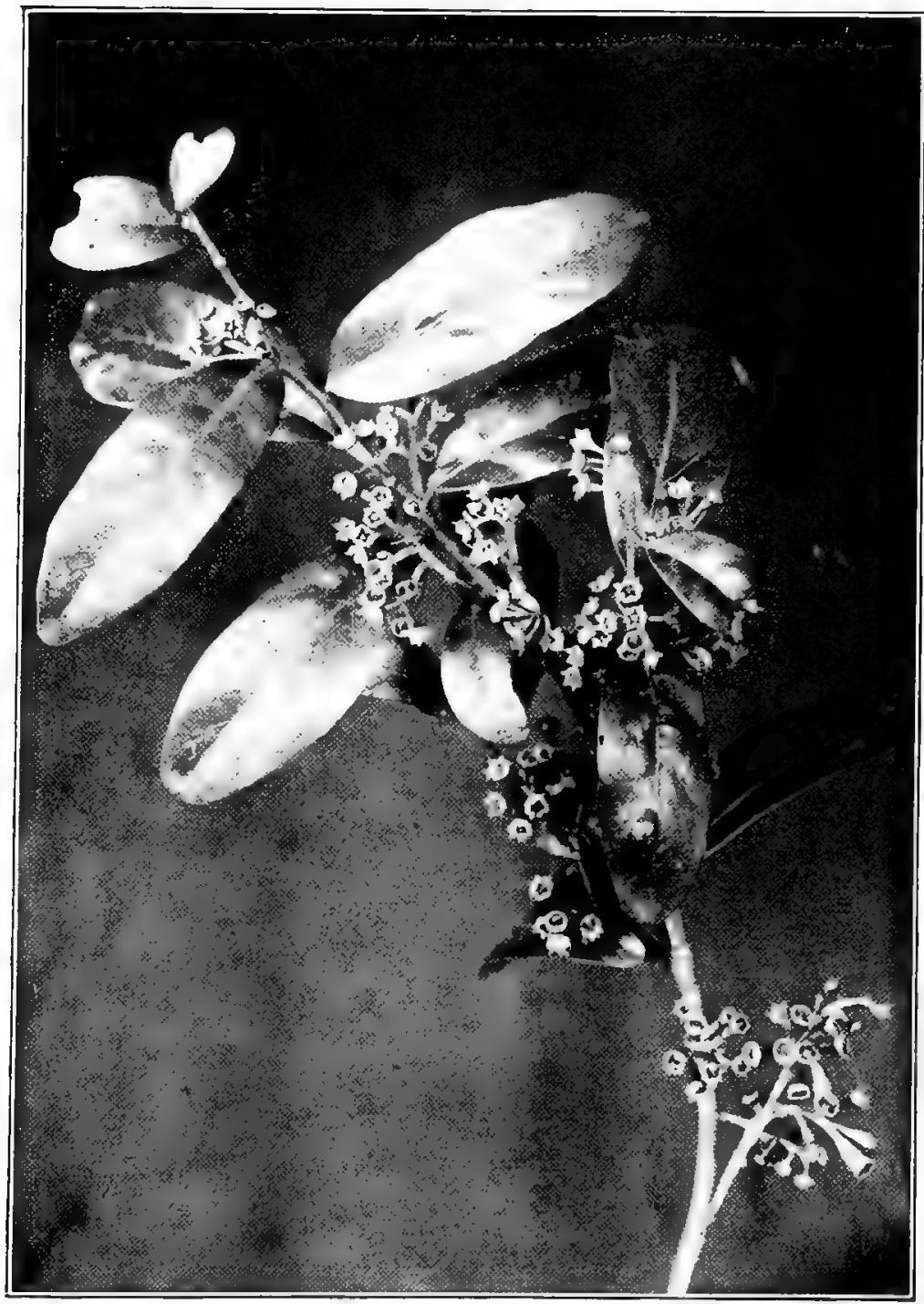

Fig. 110. Olea Cunniaghamii (1 nat. size)。 


\section{Gems Geniostoma.}

Shrubs. Flowers small, axillary. Calyx 5-cleft. Corolla bell-shaped, 5-parted. Stamens 5. Fruit a capsule. The genus is also found in Madagasicar and the Bourbon Islands, and in the Asiatic and Polynesian Islands. (Name from the Gruek, signifying beaded mouth, in allusion to the hairs at the mouth of the (corollit). $1 \mathrm{sp}$.

\section{Geniostoma ligustrifolium (The Privet-leaved Geniostoma).}

A small tree, with shining, pale-green leaven. Leaves 1 t 1 in.-3 in. long, ovatewblong, membranous, pointed. Flowers in short corymbs on the branches, 1 in. across, green or white. Corolla lobes reflexed. Stigma large, 2-lobed. Capsule round, pointed, $\frac{1}{5} \mathrm{in}$. in diameter, valves separating from the placuntiferous axis. North Island: not uncommon. Fl. Sept.-Oct.

\section{Gentianaceae.}

\section{The Gentian Family.}

Distribution.-The plants of this family range over the entire globe. They contain a bitter tonic principle, which is used medicinally. The New Zealand species are chiefly alpine, but the little pink Centaury (Erythrea Centanimm), an introduced plant, is common on waste ground throughout the Colony. The Gentians are the most striking flowers of the European Alps.

\section{Key to the Genera.}

Flowers large, ovary with one style. Flowers swall, ovary with 2 styles.

Gentiana,p. 336 .

"Sebrea.

"Not further descrilsert.

\section{Gemus Gentiana.}

Erect herbs, with opposite leaves, and solitary or cymose flowers. Calyx 4-5-cleft. Corolla bell-shaped, 4-5-cleft. Flowers blue, yellow, or white, large and conspicuous. 6 sp.

Gentiana saxosa (The Gentian of the Rocks).

An erect herb. Stem-leaves few. Flowers large, 2 in. long, white, numerous. Root-lenves usually in a rosette, $\frac{1}{2}$ in.-3 in. long, often thick and fleshy. Both islands: in mountainous districts. Fl. Fob.-March.

\section{Gentiana cerina (The Waxy Gentian).}

A trailing horb, with shining leaves, and thick fleshy stems. Flowers crowded at the ends of the branches, $\frac{1}{2}$ in. long. Corolla white, striped with reddish-purple. Auckland Islands. 


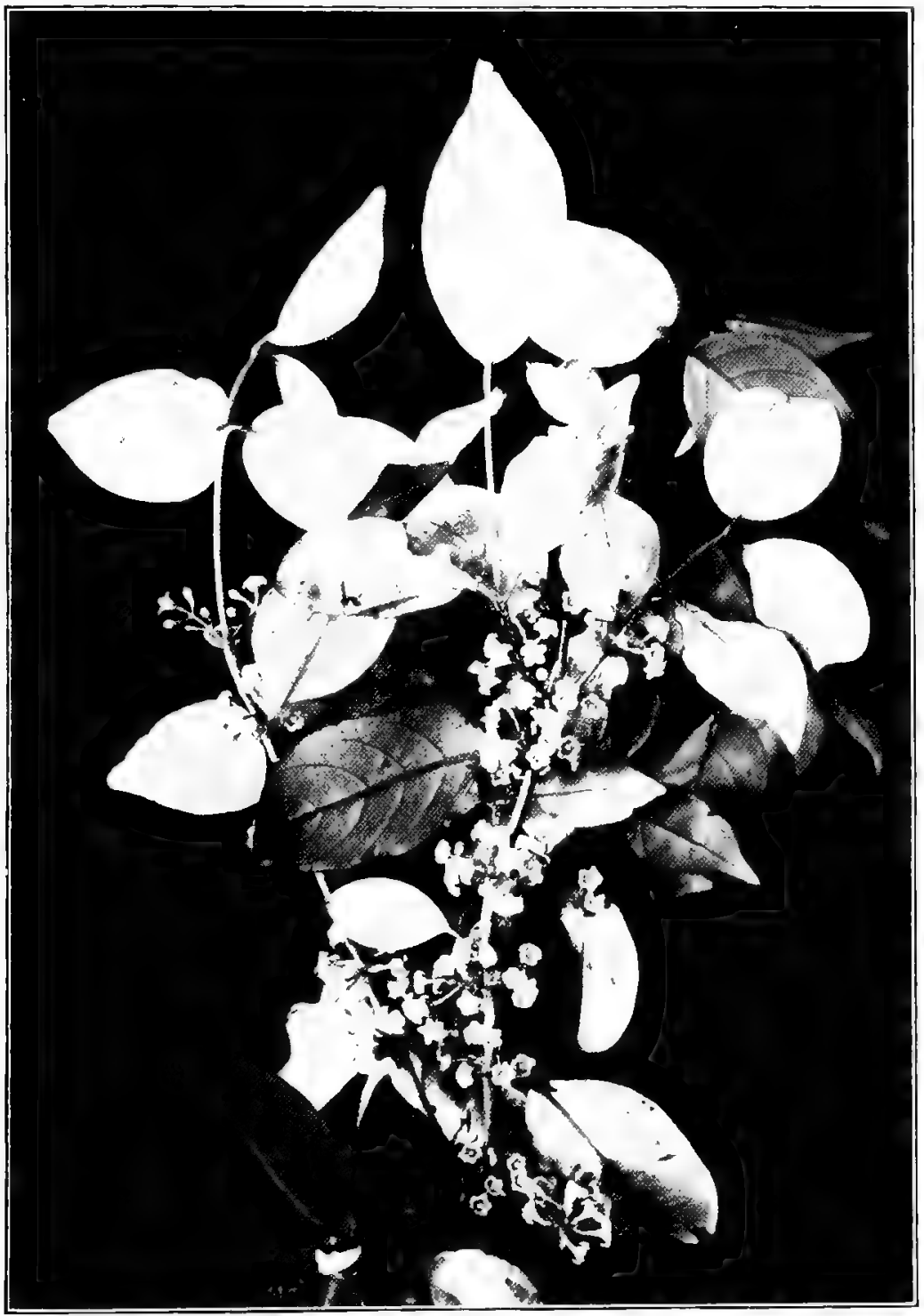

Fis. 111. Geniostoma ligustrifolium ( $\frac{1}{g}$ nat. size). 


\section{Colour in Gentians.}

The flowers of this genus include some of the brightest gews of alpine regions. The corolla differs much in hue in different species, but no finer shades of blue are known than those of G. verna and G. clusii. They surpass in beauty all the blues of lower levels. Ruskin, in his matchless diction, writes of the "Star Gentian in its uncontested queenliness, wholly without similitude." The yellow gentian, with its spires aflame on the crown of an Alpine pass, stirred Matthew Ainold to unwonted admiration.

Indeed, nearly all the species foreign to New Zealand are brilliantly coloured. Of sixteen species found in the Andes and Peru, half are red, four purple, two blue, one yellow, and one alone white. But, as has already been pointed out (v. Clematis, p. 162), flowers which are brightly tinted elsewhere, are in New Zealand very frequently pure white. When we come to examine the New Zealand species, of which there are about ten, we find that they are all, if true to type, white. Some, occasionally, however, exhibit shades of red, purple, violet, and pale lemon; hut the deep blues, yellows, or purples, so characteristic of the gentian elsewhere, are here unknown. Strangely enough, the most brilliant of our species is Gentiana cerina of the Auckland Islands. Like so many other Auckland Island plants (v. Pleurophyllum), it has a depth of hue unkmown amongst plants of the same genus on the mainland. According to Kirk, $*$ it is one of the most beautiful plants in the flora. The corollas vary in colour from a pure waxy white, to white with a vertical stripe, purple, reddish-purple and violet. It is in other respects, also, an extremely variable plant; and, like most of the gentians, very interesting botanically.

*Trans, Vol. XXVII. p. 339. 


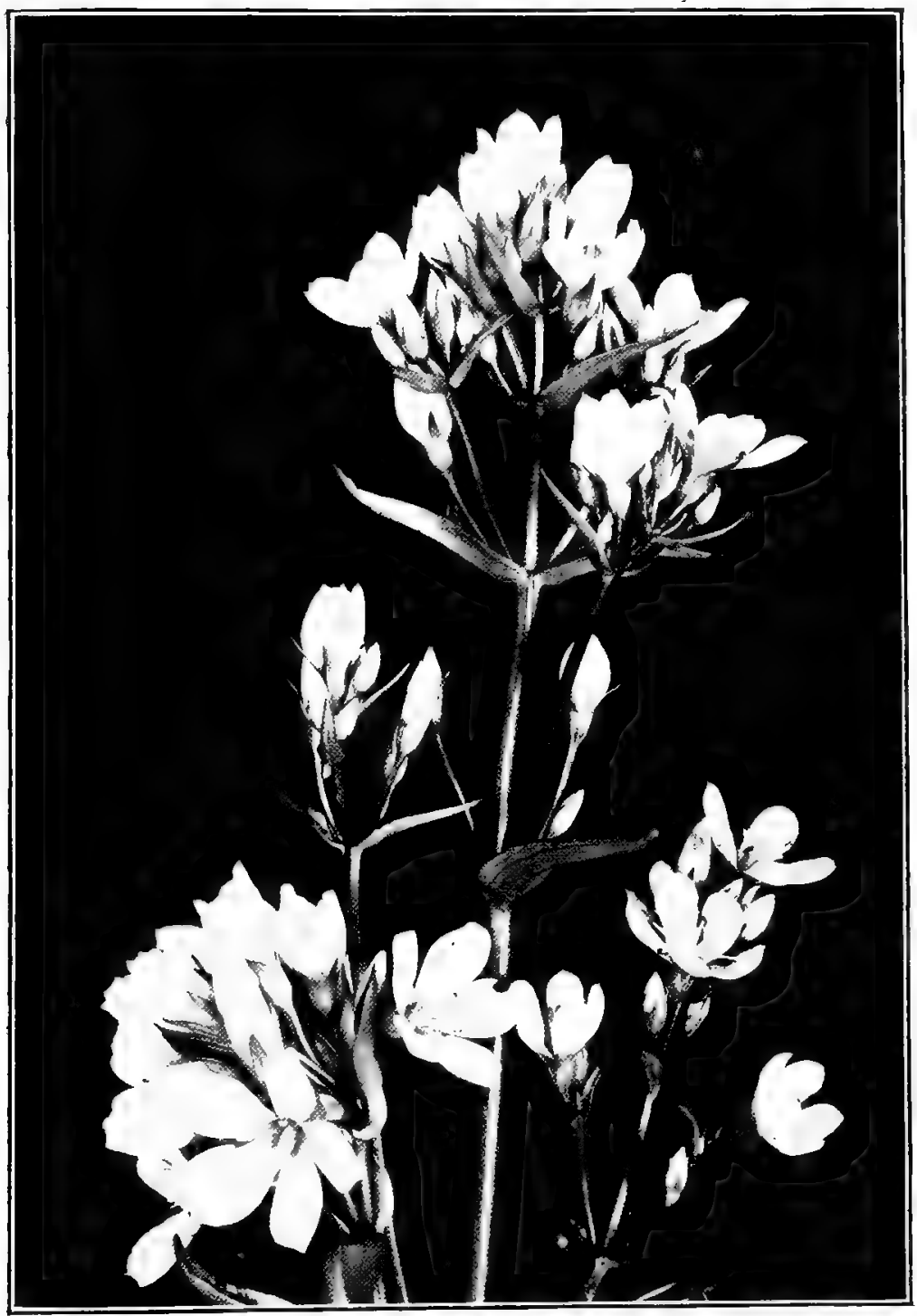

Fig. 112. Gentiana corymbifera (life size). 


\section{Apocynaceae.}

\section{The Periwinkle Family.}

Distribution. A large family of about a thousand species, chiefly tropical, of which the Periwinkle (Vinca) is the only British genus. Many of the plants possess more or less poisonous properties, though some have edible fruit. The Oleander, every part of which is poisonous, is cultivated for the beaty of its flowers.

\section{Genus Parsonsia.}

A small genus (about 10 species) of climbing plants. Leaves remarkably variable. Flowers in panicles. Fruit of two, long, narrow, pod-like capsules. Seeds silky-haired. (Named in honour of Parsons, a botanist). 2 sp.

\section{Parsonsia heterophylla (The Varied-leaved Parsonsia).}

Stems as thick as a quill, shining. Leaves leathery, 1 in.-2 in. broad, oblong, or lanceolate, 3 in.-4 in. long, with lobed margins. Flowers white, scented, $\frac{1}{4}$ in. long. Anthers within the corolla. Both islands, Fl, Nov.-Dec.

\section{Parsonsia capsularis (The Cupsulute Pursonsia).}

Stems slender. Leaves usually 2 in.-3in. long, narrow. Panicles fewflowered. Corolla in in. long, white, red, or rarely yellow. Anthers protruding beyond the corolla. Both islands. Fl. Nov.-Dec.

There can be but little doubt that the New Zealand species are insufficiently defined. It is probable that there are still one or more undescribed species in the country. The young plants, with their long, narrow, leathery, red-brown leaves, will not be recognized, unless their development has been watched. The beantiful fragrant panicles of white or red jessamine-like flowers are much sought after, by visitors to the bush. 


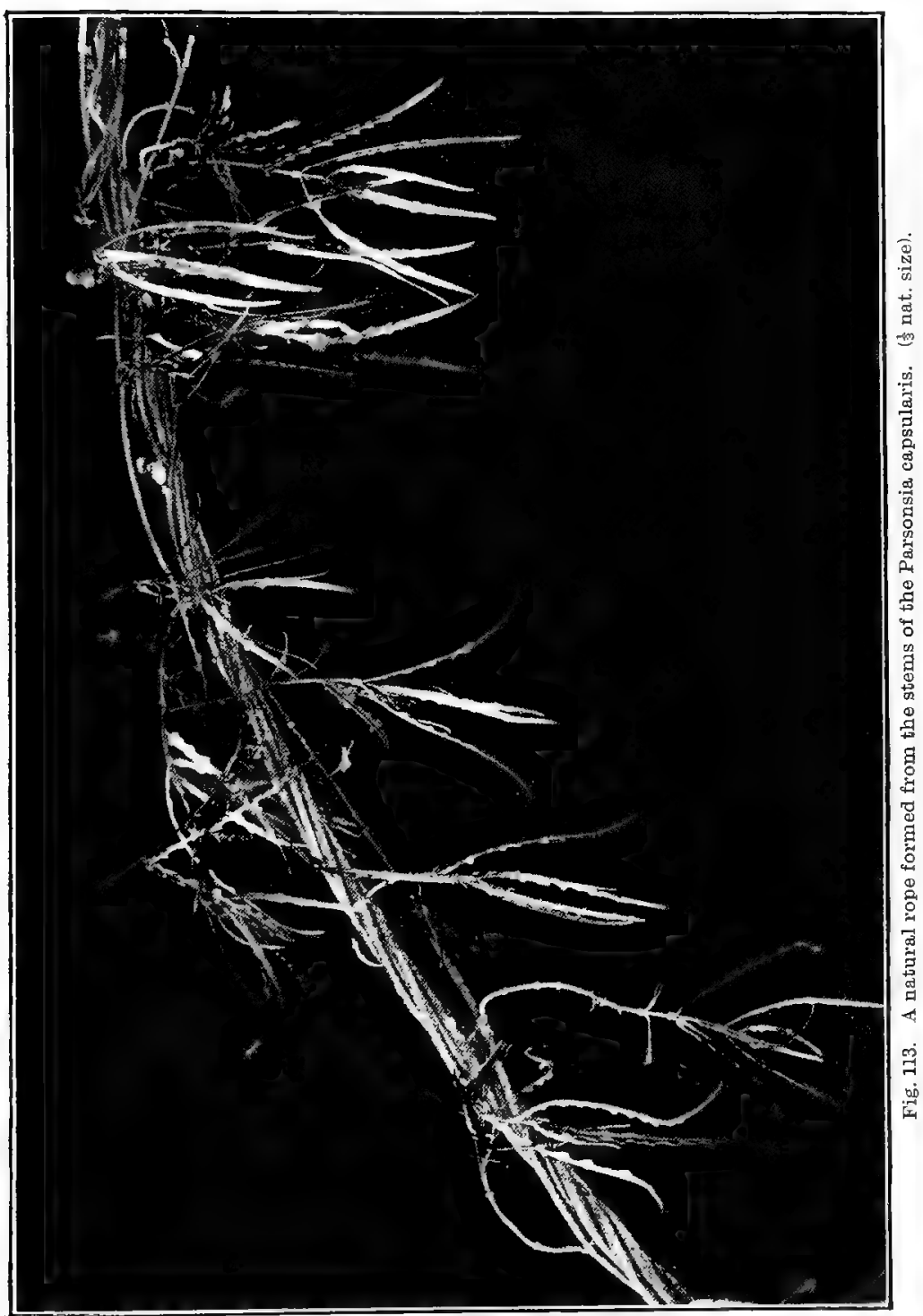




\section{Convolvulaceae.}

\section{The Bindweed Family.}

Distribution.-A large family, chiefly tropical. The large rhizomes frequently contain an acrid, milky juice, sometimes used for medicinal purposes. The flowers are usually large and ornamental. The Kumara or Sweet Potato, which was introduced into New Zealand in very early times, belongs to this family. From the roots of Erogonium, jalap is obtained.

\section{Key to the Genera.}

1. Stems leafy, prostrate or twining. stems leafless, twining, prarasitic.

2. Corolla plaited, Style 1.

Petals overlapping in bud. Styles 2.

3. Stigunas 2.

Stigwa 1-, 2-, or 3-lobed.

4. Ovary inperfectly 2-celled. Bracts large, enclosing the calyx.

Ovary I-celled, bracts small or wanting.

2

Cuscuta, p. 344.

3

Dichondira, p. 344 .

4

*Tpomcea.

Calystegia, ก. 342 .

Convolvulus, 1). 342

* Not furtber described.

\section{Genus Convolvulus.}

Perennial herbs, with milky juice, climbing by means of their twining stems. Flowers fumnel-shaped, white, pink, or rarely blue. Sepals 5 ; corolla 5 -angled. Stamens 5. Fruit a capsule. $1 \mathrm{sp}$.

\section{Convolvulus erubescens (The Btushing Convolvulus).}

Stems prostrate, 2 in.-12 in. long, never twining. Leaves variable in shape, usually oblong-hastate or cordate. Flowers white. In Australian specimens. they are often rose-coloured. Both islands, in dry places. Fl. Nov.-Dec.

The species of this genus and the next are often widely distributed. $C$. erubescens is closely allied to the English $C$. arvensis, and is found chiefly on dry hill sides. It is common near Sumner (Christchurch). Calystegia sepium is another plant, which, though sometimes rose-coloured elsewhere, is always white in New Zealand (cf. Wahlenbergia). The name erubescens therefore, as applied to our species, is not significant.

\section{Genus Calysteria.}

Closely allied to the previous genus, and sometimes united with it, but. distinguished by the characters given in the Key to the Genera. $4 \mathrm{sp}$.

Many species are cultivated for theix large showy flowers. In the bud, the corolla is spirally twisted. The anther lobes, 
as in the gentians, separate at the base, and thus assume the shape of an arrow head. They produce large pollen grains. These, however, are considerably exceeded in size by the pollen of the melon and marrow. Insects alighting on the long projecting style, smear it with pollen from the flowers they have visited, and so cross-pollination is effected. This at least is the method probably adopted in most of the species. However, C. sepium in Europe is chiefly pollinated by a particular species of hawk-moth (Sphinx convolvuli), and the areas of distribution of the plant and moth largely correspond. Still, the plant often does not set seed. It would be interesting to examine the process of pollination of the $\mathrm{New}$ Zealand species, and find what insect takes the place of the European moth.

\section{Calystegia sepium (The Bindweed).}

Stem slender, climbing. Leaves 2 in.-4 in. long, oblong, deeply lobed at the base, lobes rounded or truncate. Bracts enclosiug the calyx longer than the sepals. Corolla bell-shaped, 2 in.-4 in. broad, white. Both islands, becoming less common towards the South. Fl. Dec.-Feb.

A very handsome plant, which becomes a mischievous weed in gardens. It not only sends up thousands of suckers which exhaust the soil; but also strangles and smothers with its entwining stems and large leaves, any other plant which may be near.

C. sepium was known to the Maoris as "pohue," and the roots were used by them for food. This is strange, as those of the English plant supposed to belong to the same species, are considered purgative. A similar case is that of Solanum nigrum, a cosmopolitan plant, whose leaves are usually considered poisonous, and yet were used by the Maoris as greens. As is well known to gardeners, the Convolvulus is abundantly provided with roots, hence doubtless the Maori proverb given by Colenso :--

"He nui pohue toro ra raro."

The Convolvulus (roots) are many and spread below.
The thoughts of man's mind are many and secret. 


\section{Calystegia Tuguriorum (The Smuller Bindweed).}

Corolla $1 \mathrm{in.}-2 \mathrm{in}$. across. A very similar plant to the proceeding, but smaller in all its parts, and generally not climbing, but sprawling over bushes at the edge of the forest and elsewhere. Both islands. Fl. Dec.-Jan.

C. Tuguriorum is one of the brightest of way-side flowers. It may often be found clambering over clumps of Mïhlenbectia or Rubus, by the roadside. Its large snowwhite blossoms form one of the chief floral ornaments of the later summer.

Calystegia soldanella (The Soldanella-like ('alystegia).

Stems prostrate, often buried beneath the sand; leaves fleshy, rounded or kidney shaped; flowers solitary, almost as large as in the previous species, pale rose-coloured, or red, striped vertically with yellow, or yellowish white. Both islands: abundant on sandy beaches. Native name Nihi-nihi. European name Seca-bindweed. Fl. Dee.-Feb.

\section{Genus Dichondra.}

A genus found in Australia, Tasmania, South America, and Nerv Zealand. Calyx 5-parted; corolla 5-lobed. Fruit a capsule. $2 \mathrm{sp}$.

\section{Dichondra repens (The Creeping Dichondra).}

A small, prostrate herb, with silky leaves, and small yellow flowers. Calyx longer than the corolla.

\section{Gemus Cuscuta.}

Parasitic plants, adhering by suckers to their hosts. Leaves 0. Flowers in small clusters or racemes, white, pink or yellow. Stems thread-like, of ten red in colour. Calyx petaloid, 4-5-parted; corolla 4-5-Iobed; stamens 4-5. Cuscuta europaea is a most beautiful little plant, with bright red stems, and waxy-white clusters of flowers.

This is a genus of twining leafless parasites, found in all parts of the world. Only one New Zealand form is known, and it is rare. The clover-dodder (C. trifolii) has, however, been introduced from Europe, and is proving a pest in some localities. The seeds in this genus develop on damp ground. No cotyledons are formed, but the young plant is a spirally twisted thread. It germinates late in the year, when there is already plenty of vegetation about it. As it grows, the upper and of the plant keeps on revolving from right to left, while the 
lower end fastens itself to the soil. As the seedling contains little or no chlorophyll, and does not produce cotyledons, it obvionsly must cease to grow as soon as the reserve material contained in the seed is exhausted, unless it has by this time come in contact with some other plant, from which it can obtain nourishment. If, within four or five days after germination, it does not meet with some support, the filament falls to the ground, but may retain its vitality there for several weeks, "waiting for something to turn up." Extraordinary as it may appear, the dodder seems to be quite unable to put out suckers or rootlets of any kind to obtain nourishment from the damp earth. Should, however, it touch a living plant in the course of its gyrations, it makes two or three coils round it. It is apparently able to distinguish between a dead and a living support. Wherever a coil touches its prop, a row of small protuberant suckers appears, which forces itself into the tissues of the host, and extracts nutriment from it. When this attachment is made, the portion of the plant below the lowest series of suckers, dies. It has now severed its connection with the ground. If it has the good fortune to find a host with juicy tissues, it quickly puts forth a net-work of intertwining threads and tendrils, that justify the name of "Hell-bind," sometimes given to it. The development of Cassytha p. 177 is very similar to that of Cuscuta.

\section{Cuscuta densiflora (The Dense-flowered Cuscuta).}

A small plant, with matted, thread-like stems, and crowded racemes of flowers, $\frac{1}{8}$ in. long. It is found only in the South Island, and much resembles the Brazilian C. racenosa. Port Underwood, South Island. 


\section{Boraginaceae.}

\section{The Borage Familt.}

Distribution.-A large family, found chiefly in temperate regions. It is represented in New Zealand by three genera only. The rough, bristly leaves were considered by Linnæus to be so characteristic of the family, as to allow of his giving to it the name of Asperifolia or Rough-leaved Plants. The economic uses of the family are unimportant, but the flowers of many of the species are of a most beautiful blue colour. Myosotis palustris, the Watex Forget-me-not, is one of the best known plints of the order.

Key to the Genera.

$\begin{array}{ll}\text { Nuts large. } & \text { Myosotidinu, p. } 347 . \\ \text { Nuts minute. } & \text { Myosotis, M. } 346 .\end{array}$

\section{Genus Myosotis.}

About 30 species in all. Herbs, annual or perennial. Root-leaves stalked; stem-leaves sessile. Flowers in racemes. Calyx 5-lobed; corolla 5-lobed; mouth partly closed by 5 small scales. Nuts shining. $4 \mathrm{sp}$.

The genus Exarrhena, formerly considered distinct, is now included in Myosotis. The forget-me-nots of New Zealand are little likely to give rise to such a wealth of romance and poetry, as that which cluster's about the European species. Myosotis capitata, best known from the Auckland Islands, is the only one of a deep blue colour, and even a white form of it is known. $M$. austratis and $M$. uniflora have, strange to say, yellow flowers. Those of $M$. macrantha are purple or white. The flowers of the remaining species are generally insignificant and without any depth of colouring.

Myosotis spathulata (The Spathulate-leaved Myosotis).

A weak, prostrate herb. Leaves $\frac{1}{2} \mathrm{in}$. long, slightly rough. Flowers $\frac{1}{1}$ in. across, solitary, white, with a yellow eye. Both islands: in stony places.

\section{Myosotis capitata (The Capitate Myosotis).}

A robust plant, 6 in.-18 in. high. Leaves softly hairy, with broad petioles. Flowers in dense racemes, blue or purple, $\frac{1}{1} \mathrm{in}$. long. South Island: Otago. Aucklaud Islands. The specific name has reference to the fact that the flowers are crowded together, so as almost to form heads like those of the Composites. 


\section{Genus Myosotidium.}

Large fleshy herbs, $1 \mathrm{ft} .-3 \mathrm{ft}$. in height. Leaves large, ovate, parallel-veined. Flowers regular, in dense 1-sided racemes. Calyx 5-lobed; corolla 5-lobed; throat closed with 5 swellings. Stamens 5. Fruit large, 4-angled, winged. $1 \mathrm{sp.}$

\section{Myosotidium nobile (The Chatham Island Lily).}

Leaves thick and shining, bright green. Flowers in a dense head, 2 in.-5 in. across. Corolla $\frac{1}{2}$ in. $-\frac{2}{3}$ in. broad, azure blue, with purple eye. Fruit the size of a hazel nut. Chatham Islands only.

It is remarkable how many of our large-leaved plants are to be found only on the off-islands. Awnongst such may be mentioned Meryta Sinclairii of the Northern Islands, Stilbocarpa polaris, Ligusticum latifolium, Pleurophyllum speciosum of the Southern Islands, and Myosotidium of the Chatham Islands. Other species, with leaves of more than average dimensions found chiefly in the Southern Islands, are Olearia Lyallii and Stilbocarpa Lyallii.

Myosotidium is one of the noblest species in the flora, but is fast becoming extinct in its original home. It soon disappear's wherever stock are running, and is now scarcely to be found anywhere, except at the foot of cliffs, and in similar inaccessible positions. At one time it was mistakenly supposed to be found upon the Snares, as well; but it is probable that Stilbocarpa Lyallii seen from a distance, was mistaken for it.

As most of these large-leaved forms have probably at some time been more widely distributed (v. Stilbocarpa polaris, 1. 301) it would seem that on the New Zealand mainland, such plants are in some way at a disadvantage in the struggle for existence. There are no herbaceous plants in the North $\mathrm{Or}^{*}$ South Island, amongst the dicotyledons, with leaves as large and handsome as those of Myosotidium. Amongst the most conspicuously large-leaved forms are Colensoa, Ranunculus Lyallii, and allied species of buttercup. There are, however, two or three shrubs or small trees in the North Island, (Brachyglottis rangiora, and Pisonia Brunoniana), and one in the South, (Senecio Hectori), with leaves that reach a foot or 
more in length. The whau (Entelea arborescens), also has leaves of more than usual size. Of these species Brachyglottis is the only one that is common. Entelea is becoming rarer every year, and Pisonia is local in its distribution, being confined to Auckland Province. Obviously then, the large flaccid leaves, characteristic of the Tropics, are not suitable for our colder climate, though they seem to have been more common in New Zealand once, than they are now.

Myosotidium, indeed, would still flourish in the Chatham Islands, were it not for the interference of man. Unfortunately, it is more exposed to the attacks of enemies than most members of the family. It differs, in the lack of barbed bristles on the nuts, from the allied genus Cynoglossum, and from most Boraginaceae, in the absence of the coarse hairs, which is their marked characteristic. It has been suggested that the lack of bristles and hairs is due to the fact that Myosotidium has been evolved in the Chatham Islands, where it has not required such protection; but it is perhaps just as reasonable to suppose that Myosotidium may have existed elsewhere, and that it has been exterminated in other districts owing to its lack of protection, or, more probably, to the unsuitability of its huge leaves for its habitat.

The plant is much cultivated in gardens in New Zealand, and is then known as the Chatham. Island Lily. A much better name would be the Giant Forget-me-not. The great, dark-green, glossy leaves form a striking contrast to the masses of deep-blue flowers. It may be noted that blue flowers are extremely rare in the New Zealand flora. Indeed, the brightest blues are to be found in the flowers of the outlying islands. No Veronica of the mainland has such a depth of colour as Veronica Benthami of the Auckland Islands. There is no such blue to be found amongst the native flowers of either the North or South Island. Solanum aviculare is violet to magenta, and Wahlenbergia is sometimes pale-blue. The flowers of Colensoa and Lobelia are also more or less 
distinctly blue, but the intense azure of the alpine gentian, or the borage, is entirely absent from the mainland flora.

Little is known of the significance of blue in the floral world. Kerner considered that the indigos of the order Boraginaceae may, in many cases, be due to the fact that the plants live amongst faded yellow-grasses, with which blue provides an excellent contrast. New Zealand, however, does not furnish further evidence for this theory, for in accordance with it, one would expect to find blue a common colour in the tussock country; but this is not the case. Herman Mueller considered that bees preferred a deep violet-blue to any other colour, and claimed that it was the latest colour evolved. The presence of blues like those of Myosotidium and Veronica Benthami in the outlying islands, and their absence in New Zealand, does not appear to support his claim.

\section{Verbenaceae.}

\section{The Verbena Family.}

Herbs, shrubs or trees. Leaves opposite, rarely alternate, without stipules. Flowers regular, or irregulax. Calyx 4-5-parted, corolla 4-5-lobed, often 2-lipped. Stamens usually 4 or 5 , often in pairs. Ovary 2-4-celled; cells 1-2-ovuled. Fruit a drupe; or separating into 4 1-seeded nutlets.

Distribution.-The Vebenaceae are found chiefly in tropical or sub-tropical regions. They possess no important properties, though some are slightly aromatic. The Verbenas of our gardens are American in their origin. The Lemon Plant is a South American species. Vitex littoralis, the New Zealand Puriri, and Tectona grandis, the East Indian Teak, furnish timber of a very durable character. 
key to the Genera.

1. Corolla 2-lipped.

Corolla regular.

2. Trees. Leaves 3-5 foliolate. Flowers pink or red.

Shrubs. Leaves simple. Flowers white.

3. Maritime trees. Leaves opposite. Flowers yellow-brown.

Leaves alternate, pellucid-dotted. Flowers white, lilac-spotted.

4

3

Vitex, p. 350.

Teucridium, p. 350 .

Avicennia, p. 351 .

Myoporum, p. 362 .

\section{Genus Vitex.}

Shrubs or trees. Leaves 3-5-foliolate. Flowers in axillary, or terminal and paniculate cymes. Calyx and corolla 5-lobed, corolla 2-lipped. Stamens 4. Drupe 4-celled. $1 \mathrm{sp.}$

\section{Vitex lucens (The Puriri).}

A fine tree, from 50ft. to $60 \mathrm{ft}$. in height, often called the New Zealand Oak, on account of the strength and durability of its timber. It is not injured by damp or exposure, and is therefore extremely valuable for ship-building purposes. The logs are often perforated with large holes, but these do not affect the timber, except in so far as it has sometimes to be cut to disadvantage. These holes are made by a soft-bodied grub, which develops into the puriri moth. The leaves of the puriri are handsome, being of a bright, glossy green, the leaflets 3 in.-4in. long. The flowers are in axillary panicles, 4-8 together, pink or red, irregular in shape, and with exserted stamens. The roots of the puriri never penetrate deeply into the ground, but lie near the surface, so that the tree is easily blown over in a gale of wind. It is endemic in New Zealand, and is restricted to the northern part of the North Island. It is easily cultivated, and flowers more or less all the year round.

\section{Genus Tencritium.}

Shrubs, stem 4-angled, slender. Leaves opposite, entire. Flowers solitary, axillary. Corolla 2-lipped; stamens exserted. Ovary 4-lobed, 2-celled. Fruit a small, rough, 4-lobed nut, consisting of 4 1-seeded achenes. (Name in allusion to its resemblance to Teucrim, the Wood-sage or Germander). $1 \mathrm{sp.}$ 
Teucridium parvifolium (The Small-leaved Teucridium).

A shrub, 2ft.-5ft. in height, forming close thickets; branches and leaves slightly hairy. Leaves roundish or oval, $\frac{1}{6}$ in. long. Calyx bell-shaped, with 5

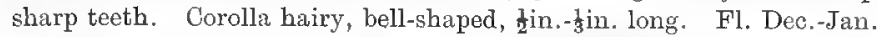

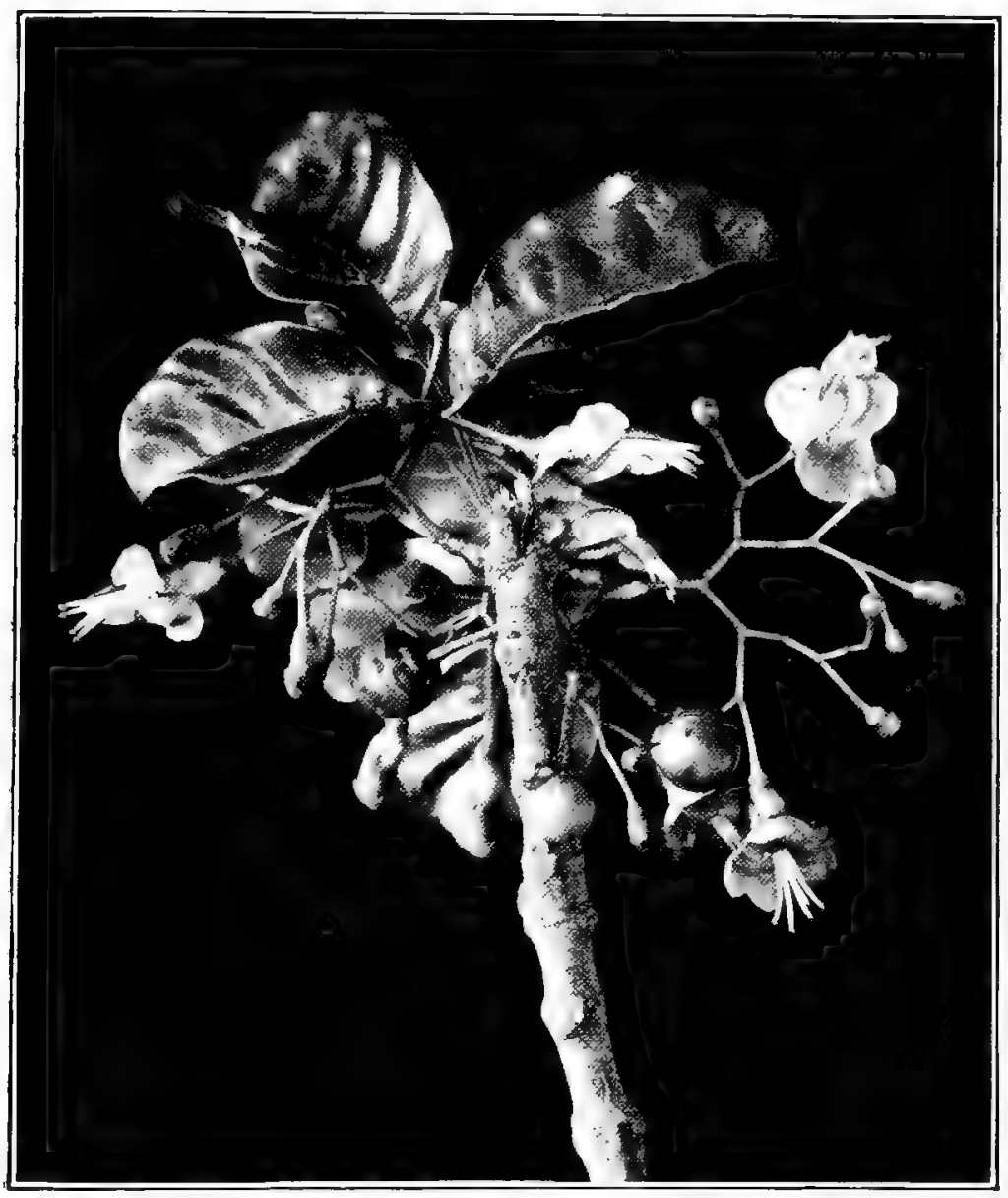

Fig. 114. Vitex lucens ( $\frac{1}{2}$ nat. size).

Genus Avicennia.

Maritime trees, with branching roots. Leaves opposite, entire, hoary. Flowers in capitate panicles, sessile, surrounded by bracts. Calyx 4-5-parted Corolla leathery, small, 4-5-lobed. Stamens 4, short. Ovary 2-celled. Fruit an 
oval nut, 1-celled, 1-seeded. Seed a large embryo, cotyledons very broad and thick. (Name in memory of a celebrated Oriental physician). 1 sp.

\section{Avicennia officinalis (The Mangrove).}

A tree, with spreading branches, growing in salt creeks and estuaries. Leaves 2in.-3in. long, oblong, obtuse, leathery. Flower-panicles yellowishbrown, corolla $\frac{1}{1}$ in. long. North Island: as far south as Thames River. Fl. May-June. Mari name, Manawa. (Forster originally uamed this plant $A$. resinifera, from the belief that the gum chewed by the natives came from this source. This gum was perhaps kauri-gum. Lindley, in his "Vegetable Kingdom," when speaking of the Nangrove, improves upon Forster's statement thus: "It exudes a lind of green aromatic resin, which furnishes a miserable food to the barbarous natives of New Zealand." The source of the error may be traced to Crozet's "Voyage to Tasmania" ; v. Ling-Roth's Translation p. 36).

This is the mangrove of the Auckland Coast. It is to be found on all tidal flats north of Kawhia on the West, and of Tauranga on the East Coast. The species, however, is not endemic, but occurs also in Australia, throughout Melanesia and Malaysia to India, and sporadically as far North as Mount Sinai in the Red Sea. It is replaced by another species of the same genus elsewhere in the tropical world. Mangroves have been generally regarded as the pariahs of the forest, and A. officinalis has not escaped the usual condemnation. Thus, the following impassioned but somewhat inaccurate description of it occurs in one of the earliest of New Zealand novels:-

"Oh! those mangroves. I never" saw one that looked as if it possessed a decent conscience. Growing always in shallow stagnant water, filthy black mud, or rank grass, gnarled, twisted, stunted, and half bare of foliage, they seem like crowds of withered, trodden down old criminals, condemned to the punishment of everlasting life. I can't help) it if this seems fanciful. Anyone who has seen a mangrove swamp will know what I nean."

Doubtless, however, much of the evil reputation of the mangrove forest, is due to the fact that, to its presence, has long been elroneously attributed the prevalence of malaria in tropical river estuaries. Miasmatic vapours were supposed to arise from the pestilential mangrove swamps, and spread their 


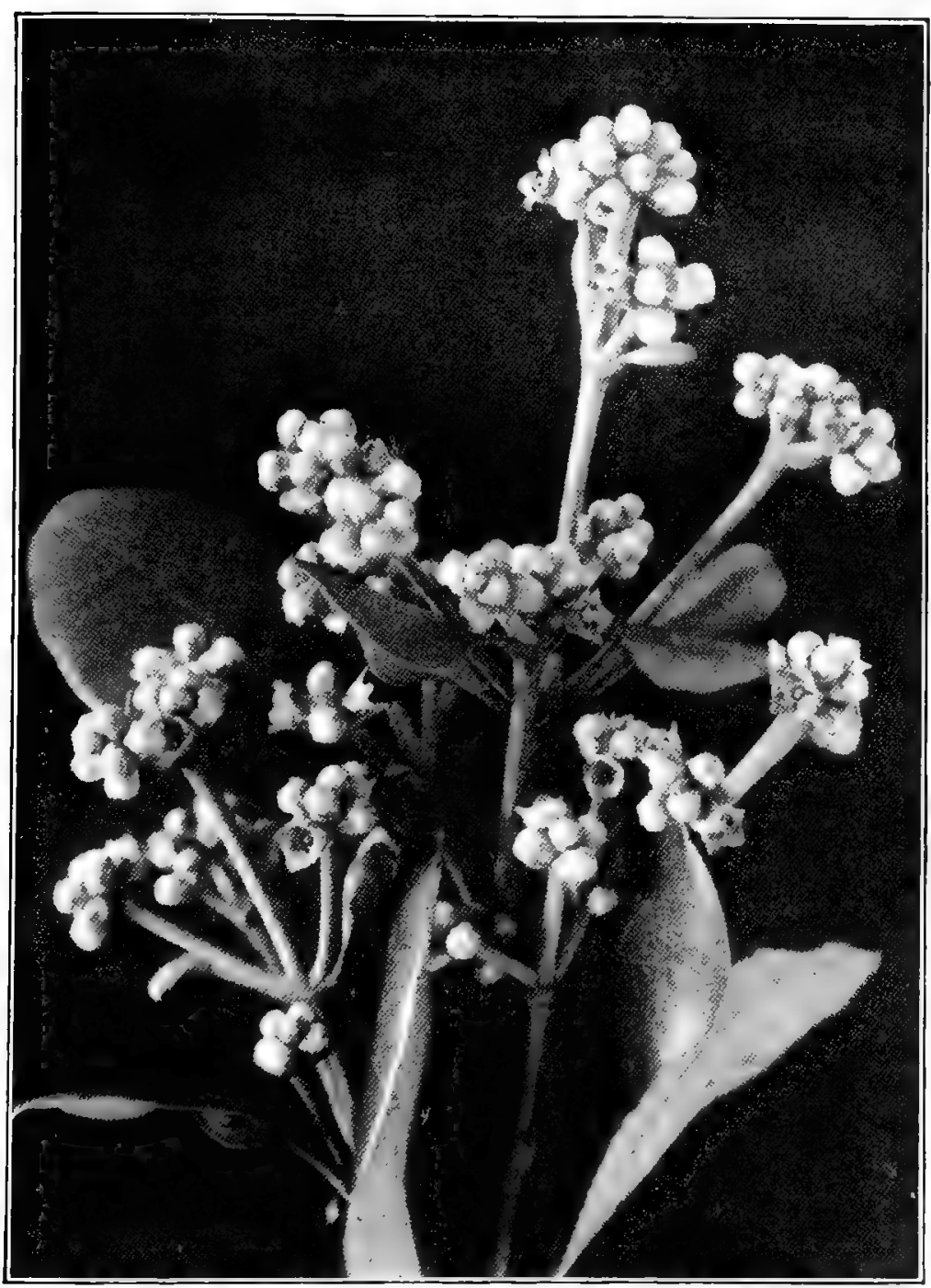

Fig. 115. Avicennia officinalis. The Flower (1ife size). 
contagion around. Science had not then burdened the misguided mosquito with sins of transmission, as well as of commission. Fortunately, New Zealand does not possess the malaria carrying mosquito (Anopheles), and so her mangrove forests, in spite of their foul appearance, are no more dangerous to human life than any other part of the country. Indeed, at high tide, a mangrove swamp is often a pleasant place to punt in, for then the somewhat sickly odour of the mud, is replaced by the fresh smell of the sea.

Nor is the New Zealand mangrove so ugly, as those of more tropical regions. The gruesome conception of the mangrove forest existing in the minds of most people, is doubtless derived largely from the well known word picture of Kingsley's "Westward Ho." The passage begins: "The night mist began to steam, and wreath upon the foul beer-coloured stream," etc. Then follows a description of the hoarse night raven; the loathly alligators lounging in the slime; the sad-coloured mangrove-hens wailing sadly; and the great purple crabs crawling over the snake-like roots. Of these hideous accessories, only the mangrove-hen (the weka), and the crabs, are to be found in New Zealand.

\section{Life in the Mangrove Swame.}

The twisted and gnarled stems and roots give to the tree an unwarranted appearance of age, so that even the youngest mangrove looks old. Barnacles and oysters fix themselves upon the roots which are uncovered by the withdrawal of the tide; eels wriggle in and out of their holes, and the mass of fibrous rootlets which forms a mat beneath the mud, provides dwelling places for innumerable blue and red crabs. These are sought after, not only by the sober-hued wekas, but also by the beautiful kingfishers. A dark-coloured fish, with curious flexible dental plates, may frequently be seen swimming over the flats at low tide, so that there is no lack of life in the swamp. 
The Roots of the Mangrove.

A tree which grows in salt water must, of necessity, have roots differing much from those of a tree growing on land, and the root structure of Avicennia, as of all mangroves, is replete

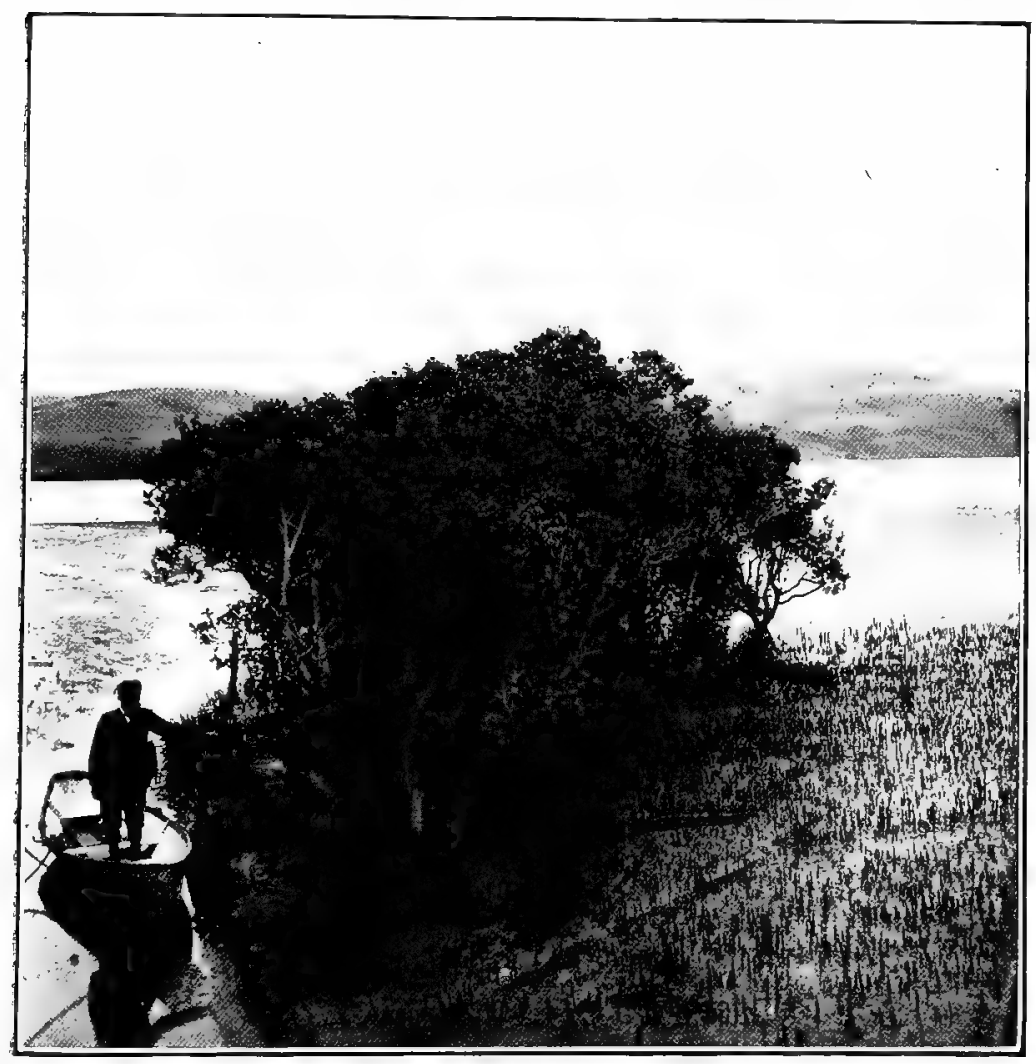

Fig, 116. Mengrove trees, showing aerial roots.

with points of interest. Botanically speaking, the root is the result of the development of the rootlet of the embryo, and it would seem an easy matter, therefore, to distinguish between root and stem. In many cases it is so, but there are some plants in which the root simulates a stem (v. Metrosideros 
robusta, p. 282), and many in which the root produces shoots. As a result, it is very often difficult to determine whether a plant structure is a root or stem. Ordinarily, the stem produces shoots bearing leaves, grows upwards, and, especially in herbaceous plants, contains green colouring matter (chlorophyll). On the other hand, the root does not usually produce shoots, does not contain chlorophyll, and grows downwards. These distinctions suffice in most cases, but not in all. Thus, the tuber of the potato is a stem which grows underground, and its shoots are under ordinary circumstances reduced to buds ("eyes"). Many plants have creeping underground stems (rhizomes) e.g., Solomon's Seal. On the other hand, some roots are aerial (v. Dendrobium, p. 124), or produce shoots, e.g., suckers of the white poplar, plums, etc. There is only one point which can be certainly relied upon to distinguish a root from a stem. A root never directly produces. leaves. A stem does.

Now, the roots of the Rhizophora, a tropical mangrove, are not derived from the rootlet of the embryo, but from the stem of the plant-so, on account of their mode of origin, they are termed adventitious roots. i.e., roots not formed in the natural manner. They are obviously used to stay the plant, and give it foothold in the soft mud. Avicennia has few of these supports, but makes use of its roots in a way that is almost unique. Kirk (Forest Flora, p. 272) tells us that, "At low water their naked trunks are exposed, and the mud is seen to be thickly studded with erect shoots from $1 \mathrm{ft}$. to $3 \mathrm{ft}$. high, given off from the tangled roots." He has here fallen into error. The structures described are not shoots, but upward growing roots containing chlorophyll, and are not more than a foot in height. They never produce leaves, and only very rarely fork or branch. They must therefore be regarded as roots which have lost their most characteristic reaction, and which grow upwards instead of downwards. As they contain chlorophyll, it is probable that they assist in the work of 


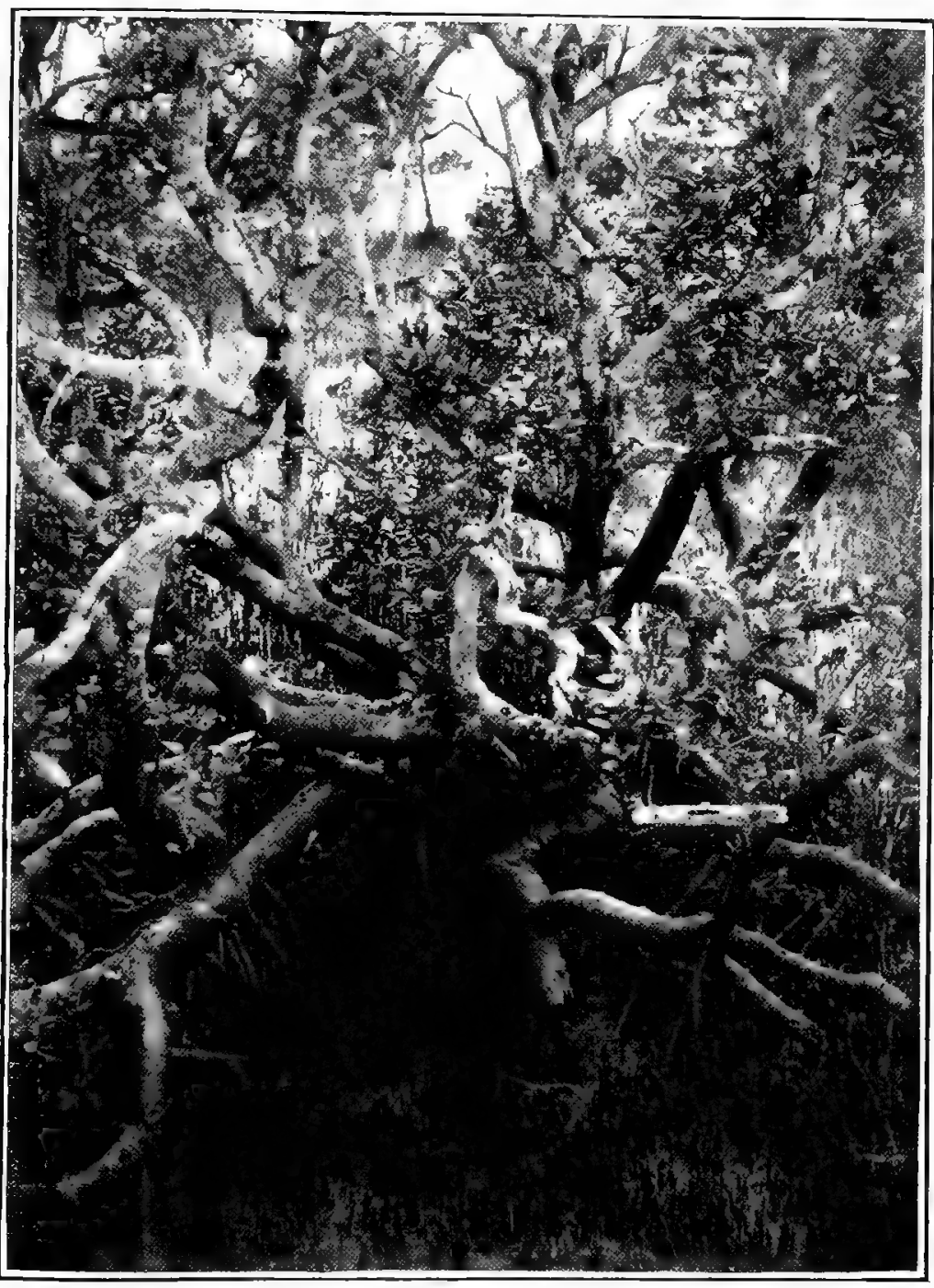

Fig. 117. Mangrove roots. 
nourishment. But they have a more remarkable function than this. If they are closely examined, they will be found to be studded with pores, similar to the lenticels found in the branches of many trees. These pores are for the purpose of allowing air to enter and leave the internal tissues of the plant. The mangrove, growing in the tidal mud, where little or no oxygen can get to the roots directly, turns the tips of its roots into the air, and by this ingenious means obtains its necessary supply of oxygen. Nor is this the only adaptation of the root to its altered environment. Most rootlets are provided with a small shield at the tip, technically known as. the "root-cap." This protects the tender, growing point as it forces its way between the particles of the soil. Such protection would be superfluous in plants rooting in water, -in the mangrove, and in many marsh-growing plants, it is wanting.

But the grey-green, asparagus-like pegs which arise from the thickly interlaced network of fibres, also serve another purpose. One cannot but notice the similarity in their appearance and arrangement, to the breakwaters formed of single posts, which may be seen in many English seaports. They run sometimes in straight lines, sometimes in curves, and sometimes in vandykes. Usually, they are from two to four inches apart, but in some places the anud is so thickly studded with them, that it would be scarcely possible to slip a pencil between. When the tide is coming in, or when a flood comes down the creek, these vertical pegs greatly break the force of the water. They are exceedingly elastic, and spring back at once into an upright position if a heavy weight is placed upon them and then removed. Not content with keeping back the flood, they gather in theix myriad rootlets, as in a sponge, all the silt and sediment that is brought down by the rivers. The thick mud settles and cakes among the root fibres, while the pegs hold back any sticks, straws, or rubbish afloat in the water. The fibrous matting between the pegs is rarely laid bare, save after a heavy flood, and spreads widely, 


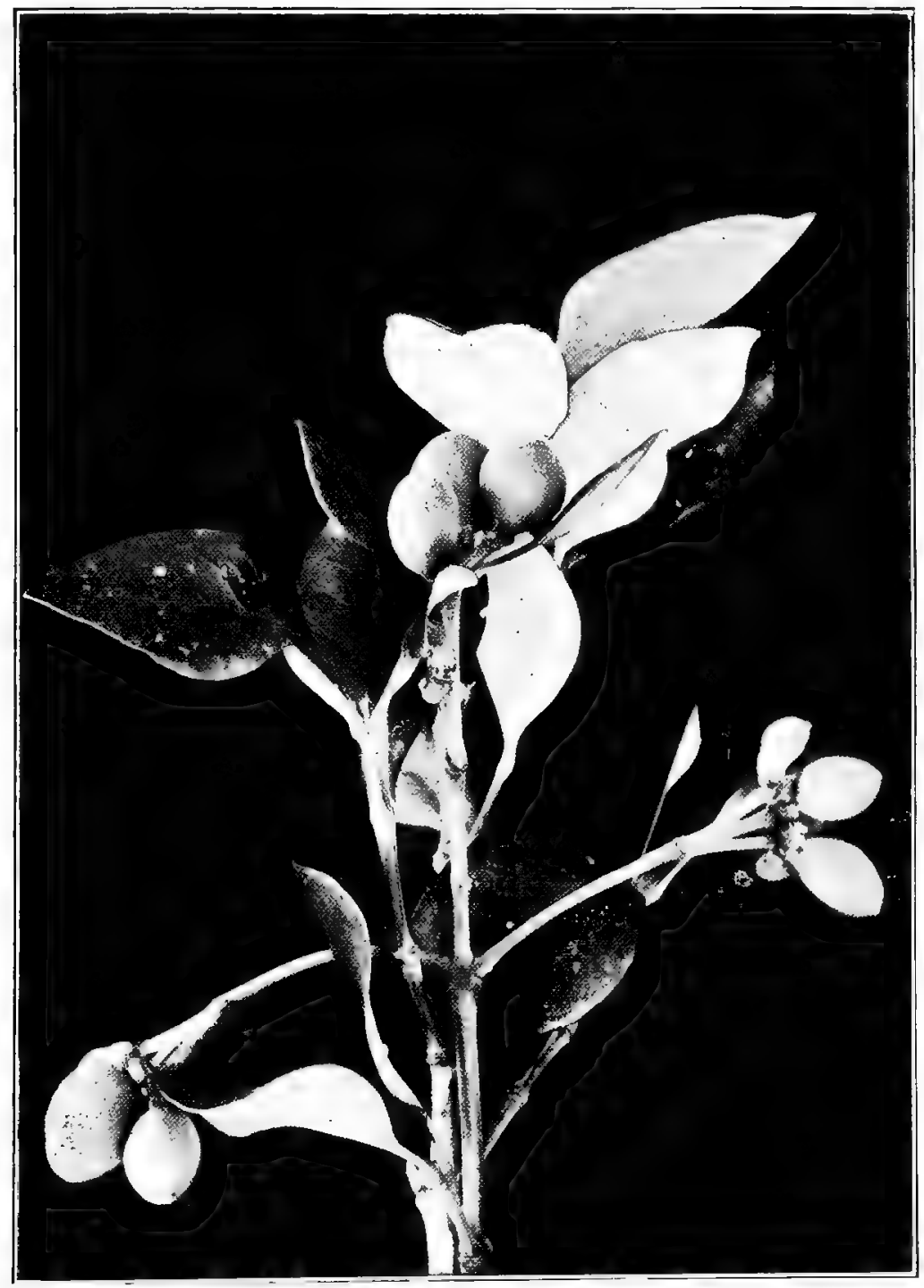

Fig. 118. Seeds of Avicenuia officinalis. 
forming a huge disk that prevents the mangrove from being: upset. The tree is further propped up by a number of stilt roots. These, however, are not so large or so long as in the typical mangrove (Rhizophora mangle) of the tropics.

The trees, thus buttressed, stayed, and fixed by their varied roots, stand firm in the highest tide and the strongest flood, and gather about them material for a rich soil, which gradually becomes suitable for cultivation. Then they step farther out into the water and begin their work again. So far' as can be roughly estimated, the mud-flats are thus raised by the action of the mangroves, on an average, a little over an inch each year. This rate of speed is probably only that of the present time, as it must have been much slower in past years, before the bush was so extensively cut. Since the clearing of the land, slips have become much more frequent, and hence the rate of deposition is now faster than before.

\section{The Germination of Avicennia.}

It is obvious that, if the seed of the mangrove fell undeveloped into the mud below the tree, it would be liable to be carried off by the rising tide. To avoid this fate, the embryo in many mangroves passes through no resting stage, but continues to grow until its weight breaks it away from the seed-case and from the tree. Thus the young plant of Rhizophora mucronata sometimes attains the length of two feet, before it falls from the parent tree. It then drops vertically downwards, and its weight and club-shaped form cause it to penetrate for some distance into the mud, where it remains standing in an upright position. According to Schimper, within the short space of a few hours, it produces roots which fix it firmly in position. Mediæval travellers, not content with this marvellous series of adjustments to environment, spoiled the story by stating that the mangrove trees 
gave birth to barnacle-geese, which dropped from the seeds placidly into the water below them-a truly appalling metamorphosis!

With all their ingenious contrivances, the young Rhizophoras, however, may sometimes be found cast up in the drift left by the falling tide on the shore. In Avicennia the embryo is provided with two large fleshy cotyledons, which present the extraordinary and almost unique feature of being unaccompanied by any trace of a rootlet.

Although well developed, it does not fall from the husk before it leaves the tree. The whole seed drops to the mud. There it splits and allows the embryo to escape. The plantlet, as in Cuscuta (v. p. 345), shows wonderful vitality. As the cotyledons possess a large food supply, the embryo may remain drifting with the tide for weeks without a holdfast, and yet survive. Generally, however, it quickly attaches itself to the mud by putting forth four or five adventitious rootlets, which are so arranged as to give the maximum support possible. They are stout, stiff, and divergent, and penetrate the mud at an angle of $50^{\circ}$ or $60^{\circ}$ with the surface.

The descriptions given of the germination of the mangrove in Dendy and Lucas's Botany, Kirk's Forest Flora, and other standard works, are quite erroneous. Kirk's description, also, contains various other errors, in addition to those already pointed out. He states that the tree only attains its greatest luxuriance in deep water. On the contrary, the tree never grows in deep water, and its luxuriance depends laxgely on the depth of the mud in its vicinity. The wood is described as being white, straight in the grain and perishable, whereas it is brown and durable, with the tissues arranged in layers which cross each other diagonally, thus making it difficult or impossible to split, except on the round.

Much work has yet to be done on the development and germination of the embryo in Avicemia. 


\section{Genus Myopomm.}

Shrubs or trees. Leaves alternate, entire or serrate, pellucid-dotted. Flowers axillary, solitary or in fascicles. Calyx 5-lobed; corolla 5-lobed, stamens 4. Ovary 2-5-celled; cells 1-, rarely 2-seeded. A genus found chiefly in Australia and the Pacific Islands. (Name from the Greek, in reference to the leaf glands). $1 \mathrm{sp}$.

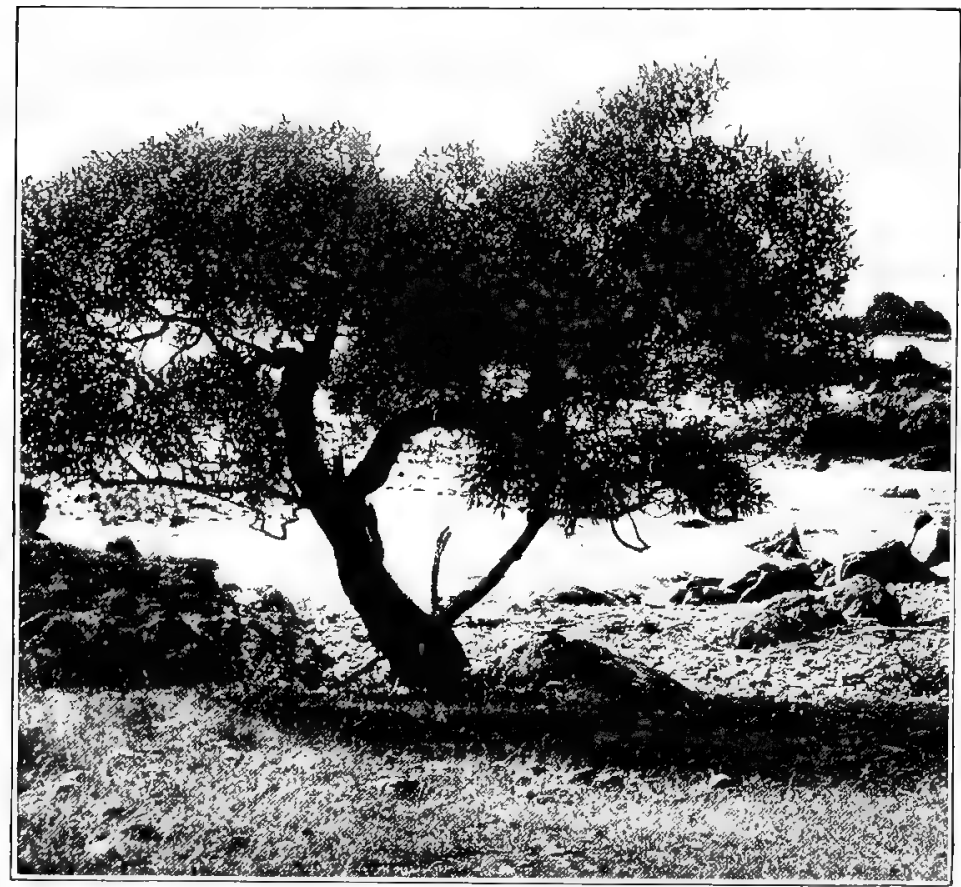

Fig. 119. Ngaio tree on the sea-heach.

\section{Myoporum Iætum (The Ngaio).}

A small tree, $10 \mathrm{ft} .-20 \mathrm{ft}$. in height. Leaves $2 \mathrm{in.}-4 \mathrm{in}$. long, lanceolate, acute, partially serrate, bright-green, shining. Flowers 2-6 together. Corolla $\frac{1}{3}$ in. $-\frac{2}{3}$ in. broad, white, spotted with lilac. Drupe lin. long. Both islands: usually near the sea-shore. Fl. Oct.-Dec.

The Ngaio tree is well known throughout the islands. Though not restricted to the sea-coast, it is seldom found far inland. At times it may be met with growing almost within high-water mark. When young, it is a beautiful, 


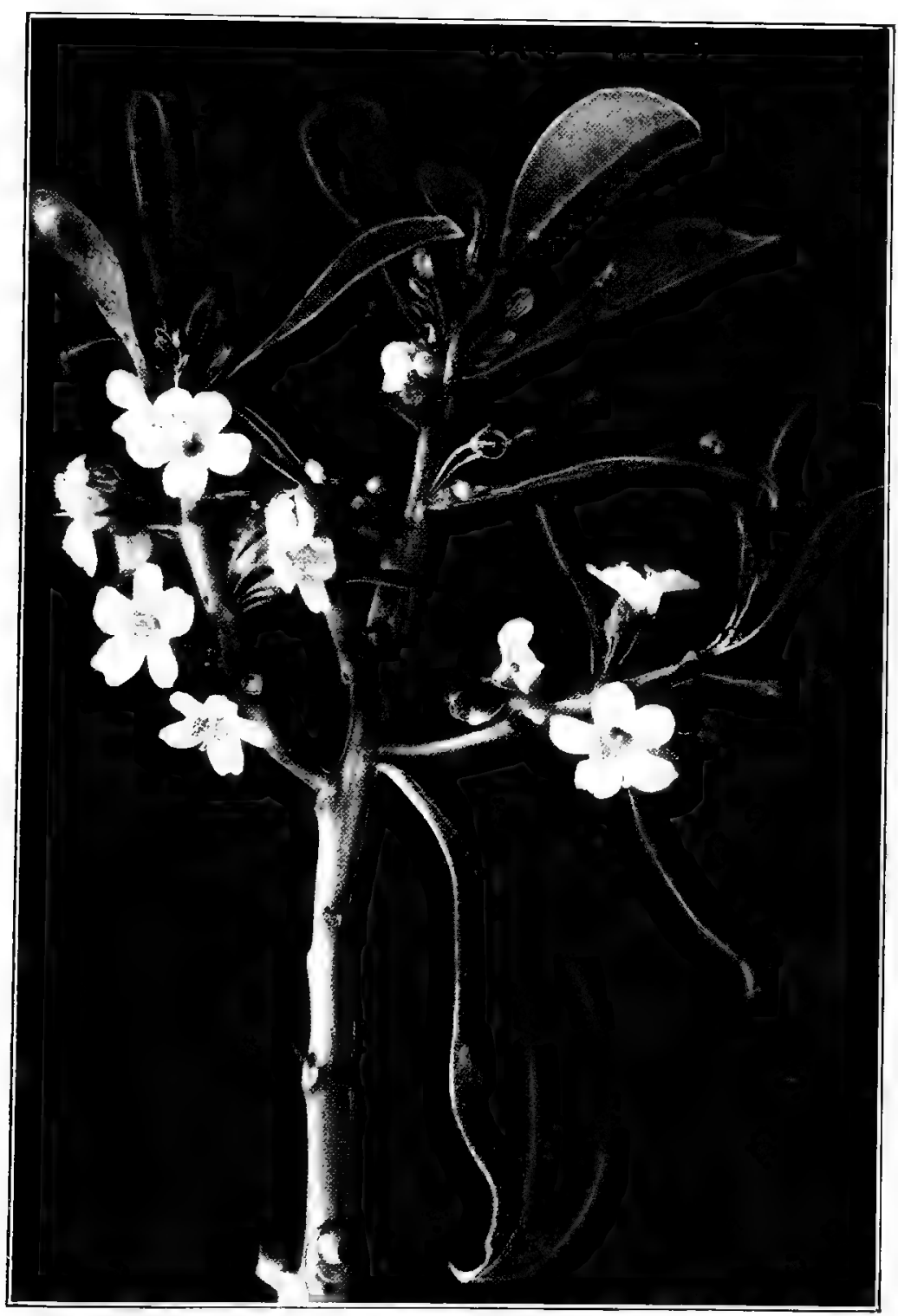

Fig. 120, Myoporumo lætum (life size). 
shapely bush; but, as it grows older, the lower branches get broken off, and the tree becomes gnarled and distorted. The black buds are protected by a gummy secretion. The leaves are full of translucent oil-glands, which give them a highly characteristic appearance. These glands, though most conspicuous in the leaf, are found in other parts of the plant, and indeed similar secreting spaces are found throughout the order. Their function is apparently unknown. As the upper epidernis is often lens-shaped over the glands, it is possible that they way in some way or other be related to the light reaction of the leaf.

According to Colenso, a decoction, made from the leaves of Myoporum, was used by the Maoris to protect the face and hands from the bites of sand-flies and mosquitoes.

\section{Labiateae.}

\section{The Thrme Family.}

Distribution.-A very large family, chiefly found in temperate regions. The species are often aromatic, the leaves containing volatile fragrant oils. These leaves are much used for flavourings, or as ingredients in perfumes. Some of the species are medicinal. The Lavender, Mint, Rosemary, Sage, Patchouli, Marjoram, Penny-royal, Thyme, Basil, and Horehound, all belong to this family. Some exotic species of Salvia are cultivated for the beauty of their flowers. The family is represented in New Zealand by two unimportant genera.

\section{Key to the Genera.}

Calyx almost equal. Stamens equal. C'alyx 2-lipped. Stamens in pairs.

Mentha, p. 364. tScutellaria.

tNot further described.

\section{Genus Mentha.}

Perennial, strongly aromatic herbs. Flowers in whorled cymes, often forming dense heads. Calyx 5-toothed; corolla 5-lobed or 2-lipped. Stamens, 4. Nuts smooth, dry. Several British species have been introduced into New Zealand. (Name from the Greek). 1 sp. 


\section{Mentha Cunninghamii (Cunningham's Mint).}

A slender, prostrate, fragxant herb. Stems often matted, hairy. Leaves $\frac{1}{6}$ in. $-\frac{1}{2}$ in. long, rounded or oblong, obtuse, pellueid-dotted. Flowers axillary,

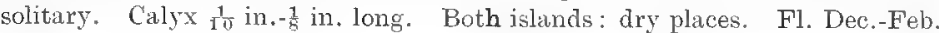

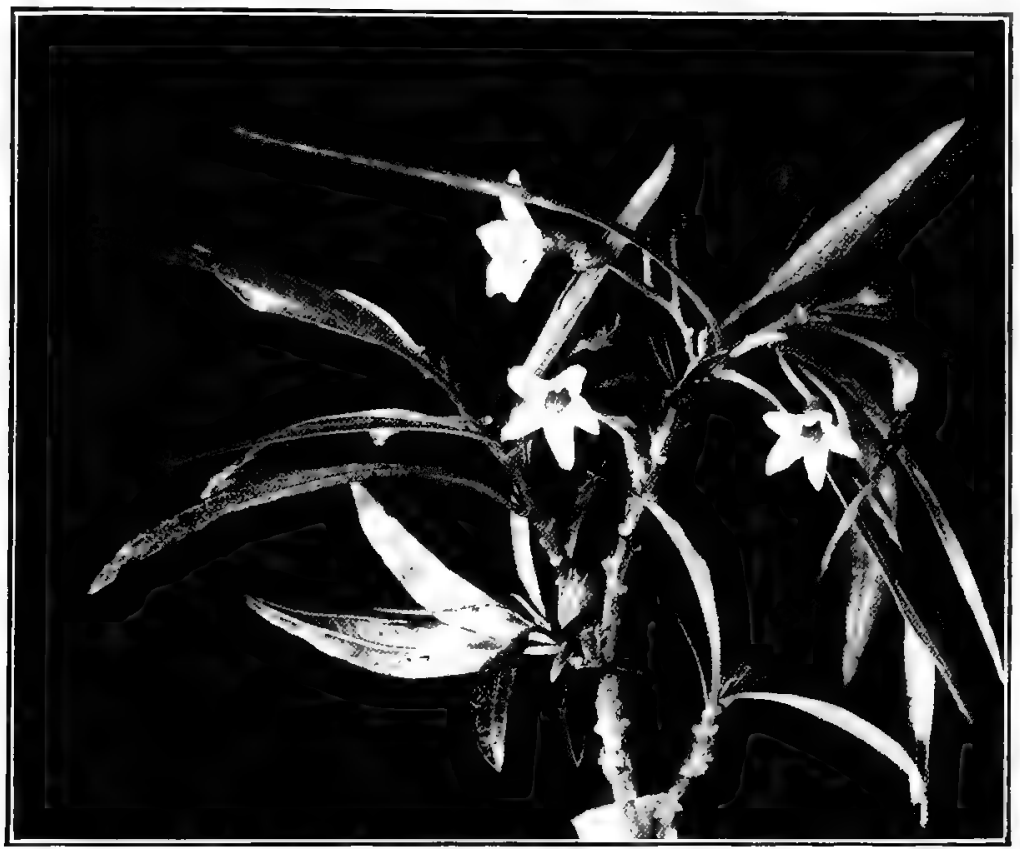

Fig. 121. Solanum aviculare ( $\frac{1}{2}$ nat. size).

\section{Solanaceae.}

\section{The Nightshade Family.}

Distribution. - A large family, chiefly tropical. A few of the species furnish edible fruits or tubers, but the greater number are narcotic and poisonous. The most important of all the species is Solanum tuberosum, the Potato. This plant contains a small quantity of the narcotic principle solanine, which, however, is destroyed by cooking. The Tomato, the Egg-plant, the Capsicuns, the Cape Gooseberry, and the Winter-cherry, are all members of this family. Datura, Nicotiana, and Petunia are cultivated for their flowers. The Henbane (Hyoscyamus niger), the Mandrake (Mandragora officinalis), and the Deadly 
Nightshade (Atrupa belladoma), possess strongly narcotic and poisonous properties. The last-named plant furnishes the valuable drug atropine. Solanum is the ouly genus found in New Zealand.

\section{Genus Solanum.}

Herbs, shrubs or small trees. Flowers regular, blue, purple, or white. Calyx and corolla 4-5-loled; stamens 4-5. Anthers usually exserted, forming a cone in the centre of the flower. Berry round or oblong, 2-celled, many seeded. (Latin uame for the night-shade, found in Pliny). $3 \mathrm{sp}$.

\section{Solanum aviculare (The Poro-poro).}

A branched leafy shrub. Leaves $4 \mathrm{in.-10} \mathrm{in}$. long, oblong or lanceolate, entire, or lobed, or pinnatifi, membranous, shining. Flowers cymose, 3-10 together, usually dark-purple. Anthers spreading. Berry oval; edible. Both islands, Norfolk Island, Tasmania. Fl. Dec.-March. The plant is often called by the settlers, the Bulli-bull (v. Acrena, p. 202).

\section{Solanum nigrum (The Black Nightshade).}

A common weed. Stems, $1 \mathrm{ft} .-3 \mathrm{ft}$. high. Leaves $1 \mathrm{in.}-4 \mathrm{in}$. long, ovate, rarely lobed. Flowers $\frac{1}{4}$ in. $-\frac{1}{3}$ in. across, in umbels, white. Berry $\frac{1}{4}$ in. $-\frac{1}{3}$ in. in diameter, black or red. Both islands. Fl. all summer.

\section{Scrophulariaceae.}

\section{The Snap-dragon Famili.}

Distribution.-A large and widely-distributed family. It is well represented in New Zealand by about 100 species. A few of the species are partially parasitic; some produce deadly poisons, and many are cultivated for the beauty of their flowers. The Veronica, Fox-glove, Snap-dragon, Mullein, and Calceolaria are well-known garden plants. The powerful drug digitalin is prepared from the Fox-glove. The leaves of Scrophularia nodosa, Verbascum Thapsus, and Veronica officinalis have also been used medicinally.

The corolla in this order is two-lipped, but the lips are closed, not open, as in the Labiatae. The flowers of the snap-dragon (Antirrhinum), monkey musk (Mimulus), and Calceolaria, are typical of this order, while those of the Veronica are less so. From their structure, it is obvious that 
most of them are insect-pollinated. The monkey-musk is especially interesting, as it shows very marked stigmatic movements. When an insect pushes its way into the flower, its head comes into contact with the style, which terminates in two flaps, between which lie the stigmatic surfaces. They immediately close, and thus protect the stigma from receiving pollen from its own stamens, as the insect withdraws from the flower. If they have not been pollinated, the lips of the stigma re-open in about five minutes, and remain open until again stimulated, but as soon as the influence of the pollen is felt, they remain permanently closed. Other members of the order show similar movements.

Calceolaria Sinclairii is a beautiful plant found growing beside streams, from Hawke's Bay to East Cape. It produces erect panicles, a foot in length, of white flowers, spotted with purple. The pretty little Mazus radicans is not uncommon in boggy places, in both islands. The upper lip is purple and bi-lobed; the lower is tri-lobed with a "wide band formed of three rows of brownish-yellow hairs leading down to the honey cavity." This of course is a guide-line for insects entering the flowers. The style is found immediately under the upper lip, and bears at its apex a pair of stigmatic plates. These are sensitive, as in the monkey-musk, and close rapidly on being irritated. The flowers are very fragrant. The most important genus in New Zealand is Veronica, which is more fully described below.

Key to the Genera.

1. The teeth of the upper lip cover the lateral teeth in the bud. The teeth of the upper lip covered in the bud by one or both of the lateral teeth.

2. Fertile stamens, 2.

Fertile stamens, 4.

3. Corolla inflated. Stigma with more or less rounded head. Corolla not inflated. Stigma of 2 blades.

4. Stigma of 2 blades.

Corolla minute, stigma not divided.

5. Corolla swollen at the throat. Corolla not swollen at the throat.

2

7

3

4

Calceolaria, p. 368. TGratiola.

5

$\mid$ Mimulus.

Mazus, p. 368.

tNot further described. 
6. Stigma flattened, large,

Glossostigma, p. 368 .

Stigma club-shanerl.

7. Stamens, 2.

Stamens, 4.

8. Stigma with a rounded head.

Stigma dilated.

†Limosella.

Veronica, p. 369.

8

Ourisia, p. 384 .

Euphrasia, p. 386.

Tot further describerl.

\section{Genus Calceolaria.}

Soft-leaved herbs. Flowers in short racemes. Calyx 4-cleft; corolla 2lipped. In the American species, the lower lip only is inflated, but in the New Zealand species both lips are swollen. Capsule 2-valved. A large South American genus. (Name from the Latin for a stipper). $2 \mathrm{sp}$.

\section{Calceolaria Sinclairii (Sinclair's Calceolaria).}

An erect, slender herb, with coarsely-toothed leaves, and branched panicles of small white flowers, spotted with purple. Corolla $\frac{1}{3}$ in. across. Capsule $\frac{1}{6}$ in. long. North Island: East Cape, Hawke's Bay. Fl. Dec-Feb. A charming plant, well worthy of frequent cultivation.

\section{Genus Mazus.}

Herbs. Flowers usually racemose, terminal. Calyx campanulate. Corolla 2-lipped, upper lip 2-lobed, lower 3-lobed. Stamens 4. Capsule 2-valved. (Name from the Greek signifying a breast, erroneously given in allusion to the supposed swollen corolla). $2 \mathrm{sp.}$

\section{Mazus pumilio (The Dwarf Mazus).}

Scape 1-6-flowered. Leaves fascicled. Corolla blue, 1 in.-11 in. across. Both islands, as far south as Canterbury.

\section{Genus Glossostigma.}

Tufted, prostrate herbs. Laaves spathulate. Flowers solitary. Calyx 3-5-lobed. Corolla 2-lipped, 5-lobed. Stamens 2-4. Stigma large, dilated. Capsule 2-valved. (Name from the Greek in allusion to the tongue-shaped stigma). $2 \mathrm{sp}$.

\section{Glossostigma elatinoides (The Elatine-like Glossostigma).}

A minute plant, 1 in.-2 in. long. Stems rooting at the nodes. Lenves $\frac{1}{8}$ in.$\frac{1}{4}$ in. long, entire. Flowers $\frac{1}{4}$ in. long. Stamens 4. Both islands: damp places.

This is an interesting, moss-like, swamp-plant, differing from a Mimulus in the minute corolla, and in the large tongue-shaped stigma. As in Mimulus, the stigma is 
sensitive, but its movements are quite different from those of the two-armed style of the latter plant. The method of pollination of the Glossostigma, which is remarkably interesting, has been described by Mr. Cheeseman.*

\section{Genus Veronica.}

A genus of about 200 species. Herbs or shrubs, rarely trees, with opposite leaves. Flowers in axillary racemes, usually blue, purple, or white. Sepals 4-5; corolla 4- (rarely 5-) lobed. Stamens 2. Capsule 2-celled. (The name is Greek, signifying the sacred picture. A European species is said to bear upon its petals a representation of Christ). Maori name Koromiko. $84 \mathrm{sp}$.

Distribution.-A large European and Asiatic genus, which reaches its highest development in New Zealand, where there are more than 80 species already recorded, while doubtless others still remain undiscovered. Since the publication of Hooker's Flora, the two independent genera, Pygmea and Logania, have been amalgamated with it, and this has helped somewhat to swell the list of species, until now it outnumbers that of any other native genus. Nowhere else do the Veronicas constitute such a large and prominent portion of the flora. Many of them are handsome shrubs, and nearly all of them have somewhat conspicuous flowers. They may be found almost anywhere from the sea-coast up to Alpine heights, except on dry open flats, like the Canterbury Plains, where little grows but the tussock grass. They may well therefore be considered one of the most representative genera of the Flora.

\section{VARIATION IN VERONICA.}

As might be expected, in no other local genus, are the species so difficult of discrimination. They show such an extreme variability, that it is possible to describe only the chief forms. From a piece of ground a few yards square, may sometimes be taken a dozen specimens, all showing differences of shape and structure, that in another genus would entitle them to varietal, or even to specific rank. To increase the dificulties of the systematist, many of the species, - particularly those belonging to the whipcord section,-alter largely under cultivation and change of environment. Most large genera show variability, but this one to such an excessive extent, that it compels one to doubt the possibility of defining the species 
by morphological characters alone. Each variety will require to be grown from carefully selected seed, and its whole life history known, before its claim to distinctiveness can be properly determined. Until this has been done, no satisfactory list of species can be prepared.

An enquiry into the causes of this Protean fickleness of form would lead us too far afield. No biological problems however, are more fascinating, or more important, than those presented by the variation of individuals within a species; several of them may therefore be mentioned here. (1) How far is hybridism responsible for variation? (2) To what extent does change of environment induce variation? (3) Does variation take place by imperceptible gradations, or by small leaps and bounds? (4) How far are variations, induced during the life-time of the individual, inherited by its descendants? These questions have absorbed the attention of many naturalists for years. Vast quantities of information have been collected concerning them. They seem to have been studied, theoretically at least, from every point of view, yet it is questionable whether we have acquired a deeper insight into them than Darwin had, when he wrote his "Origin of Species," now nearly fifty years ago. (1) Some aftirm the importance of hybridization in producing variation, while others deny it. (2) Change of enviromment probably induces greater variation than was at one time considered possible. Nature is infinitely plastic (v. Discaria, p. 240). (3) The third question has recently been asked anew by the famous botanist, Prof. Hugo de Vries, of Annsterdam; and he has adduced a considerable amount of experimental evidence, to shew that new species do not arise by imperceptible changes out of the old, but that a large number of similar and concomitant, though perhaps minute, variations are found in certain individuals of the species, and from these individuals a new type arises. Such a discontinuous variation he terms a unutation, and species producing them are said to be mutable. 
(4) The fourth question stated above may be termed Weismann's problem. It has caused more discussion than any other Darwinian question, and has divided evolutionists into

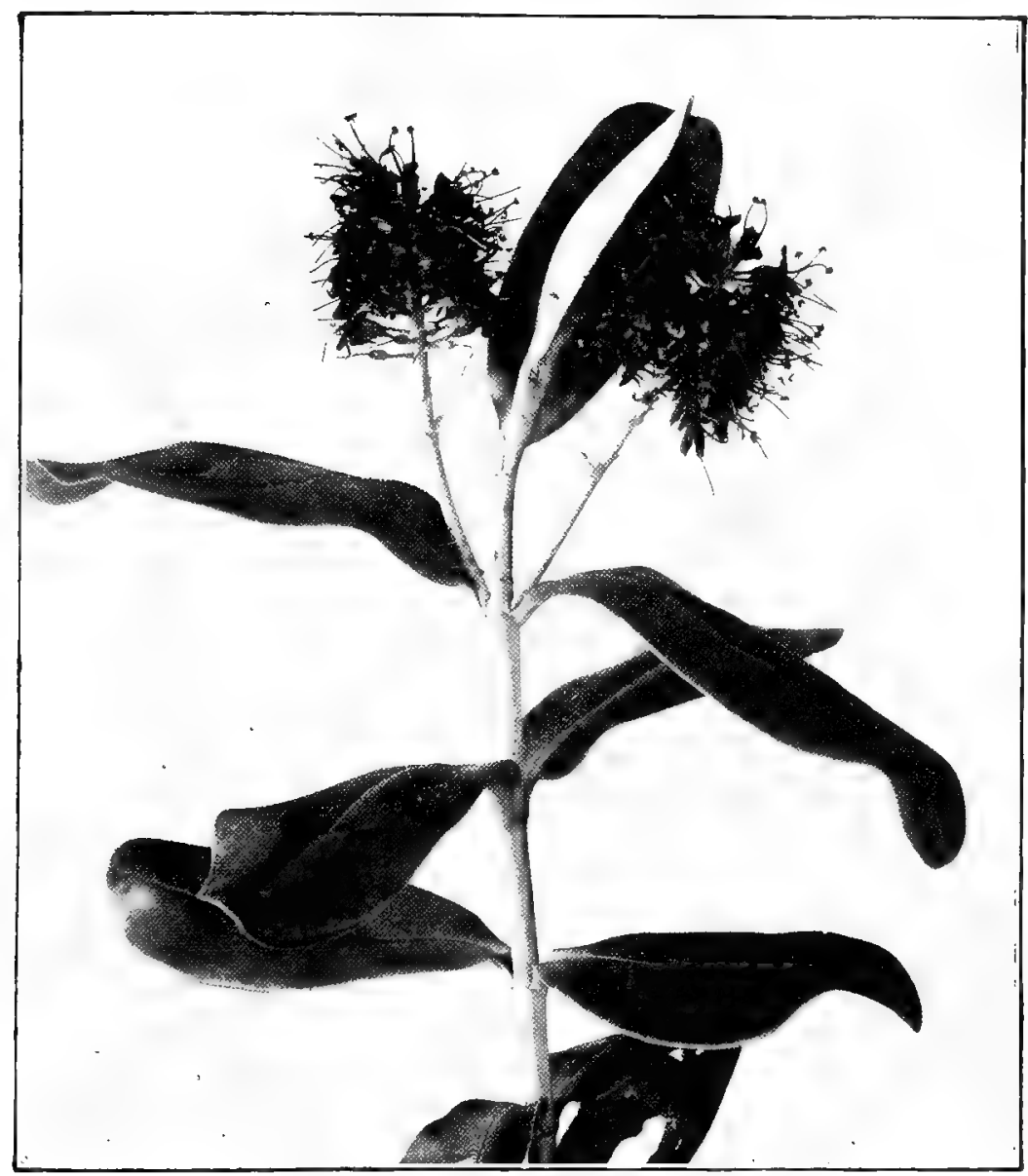

Fig. 122. Veronica speciosa ( $\frac{1}{2}$ nat. size).

two camps. It is by no means solved as yet, though perhaps at times we feel that we have a glimmering of the solution.

These, and other similar problems, are of the highest interest to biologists, and not without their bearing on human life, but 
they cannot be discussed further here. They are mentioned merely for the sake of pointing out that the students of the New Zealand Flora have oplortmities, such as are granted to few, of studying such questions. The great variety of enviromment to be found in the islands, the extreme sensitiveness of many species to change of habitat, the fact that representatives of a single genus like Veronica can be found at all altitudes from the sea-shore to snow-line, the wonderful variety of forms, in this and other genera, to be found in a single locality, all combine to afford the New Zealand student of plant ecology, a field for investigation perhaps unsurpassed within the same area, in any other part of the Globe.

\section{IVHIP-CORD VERONICAS.}

For our present purposes, we nay roughly divide the New Zealand Veronicas into four sections. (1) Shrubs with normally expanded entire leaves; (2) shrubs with minute scale-like leaves, often imbricating, and closely appressed to the stem; (3) shrubs with toothed, generally fleshy leaves; (4) herbs or semi-herbaceous plants with creeping slender stems. The second of these divisions only, will require consideration here. This includes the remarkable species often spoken of as the whip-cord veronicas, on account of the close resemblance of their stens to a piece of green whip-cord, or the plaited thong of a whip-lash. It has also been termed the "mimetic" series. Some resemble a cypress so closely as to deceive any but the expert botanist; others mimic the tamarisk, and another might well be taken for a lycopod. There are few, if any, more remarkable forms than these amongst our flowering plants. Various endeavours have been made to explain their extraordinary appearance,-an appearance, however, that is largely shared by certain species 
of Helichrysum belonging to the sub-genus Ozothamnus (v. fig. 121). A partial clue to their origin is to be found in the fact that all species of this section, under certain circmustances, put forth leaves of a type, widely distinct from, and much more normal, than the scale-like plates with which they are usually covered. A similar phenomenon appears in many other aberrant plants. Other New Zealand species which

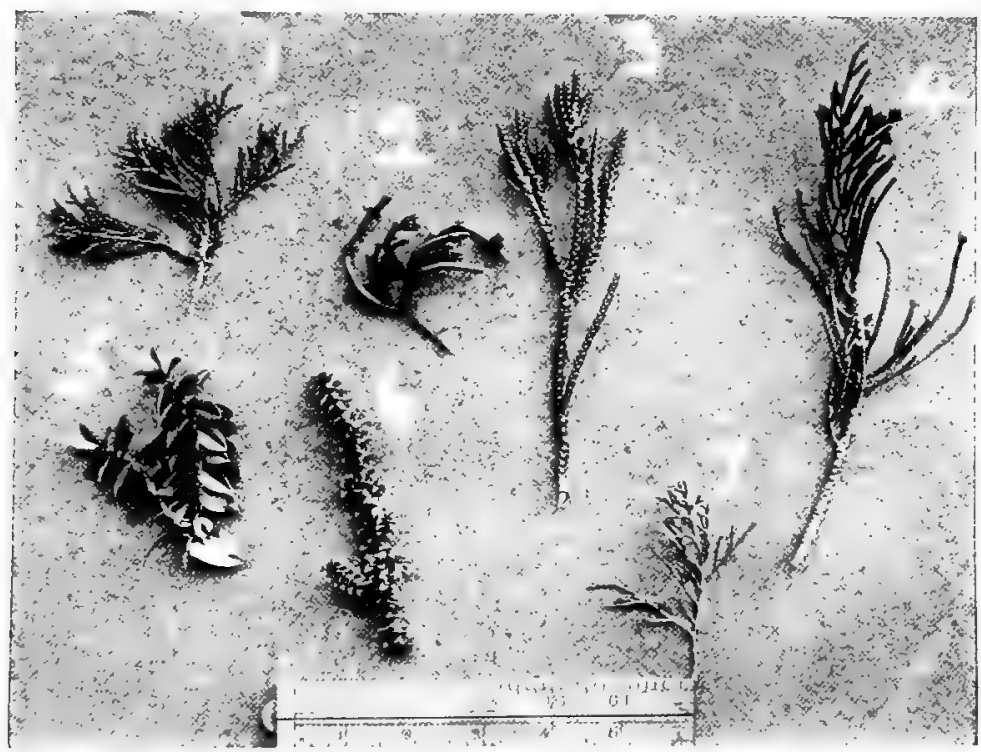

Fig. 123. 1. V. propinqua. 2. V. tetrasticha. 3. V. Hectori, 4. V. Arunstrongii. 5. V. elliptica. 6. V. epacridea. 7. V. cupressoides

show a like heterophylly, as it may be termed, are Helichrysum (Ozothammus) coralloides, Raoulia bryoides, and Raoulia mammillaris. There can be but little doubt that, in each case, the larger leaved form is the ancestral one. It may therefore be expected, in accordance with the ordinary law (v. p. 256), that the seedling form in its development would pass through a stage with large leaf-surfaces. Such a stage is often termed a "reversion shoot." Reversions 
to the earlier form are, however, not necessarily confined to voung plants, but are also somedimes found upon the mature specisuen.

Lnfortunately. lut httle attention has hitherts been given to the leaf-forms of the whip-cord Veronicas. Prof. Goebel,

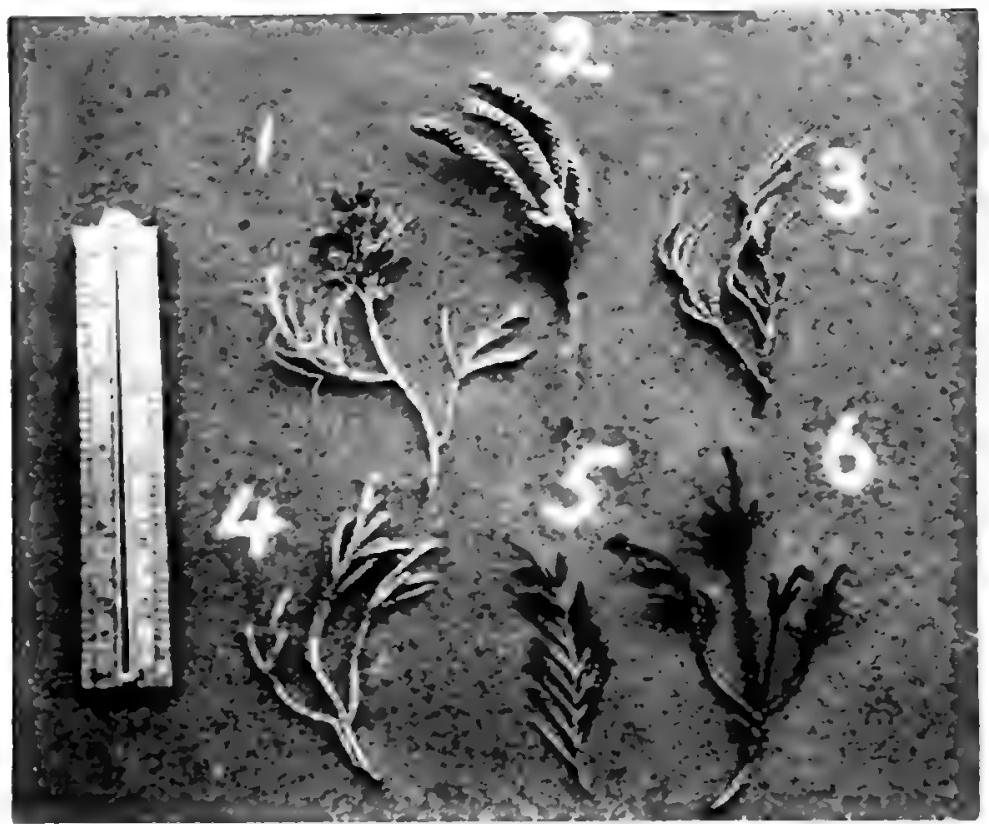

Fig. 12. 1. Helichrysum microphyllun. 2. H. coralloides, 3, H. nicrophyllum (var.) 4. Veronica 1ycopodioides. 5. Libocedrug Bidwillii.

6. V. Tetrasticha.

the famous botanist of Munich, was the first to study them "xperimentally, and, after him, Mr. R. Brown, of christehurch. showed how extremely plastic these strange forms are. It is to be regretted, that the latter has not published an account. of his experiments, in some accessible scientific periodical. Recently, however, Dr. Cockayne, in his valuable studies on the germination of New Zealand seedlings, has carefully investigated the younger stages of a considerable number of species of Veronica. 
He has found, that in several cases at least, the seedling passes through a stage with large leaves, unlike those of the mature form. The development of Veronica tetrastich a may be taken as an example. It is a beautiful little sub-alpine plant, with tetrangular stem and cupressoid leaves. Dr. Cockayne collected seeds of it, from plants growing on shingle slips on the Craigieburn Mountains. They were planted, and found to be slow of germination, and the remarkable conclusion was come to, that, "between the juvenile and mature plants, so far as observed, there is no resemblance." The adult plant has minute, overlapping, dark-green leaves, appressed to the stem, narrowly triangular in shape, with broad sheathing bases that meet round the stem. They are fleshy, concave on the upper surface, and flat on the lower, and often bear a row of marginal hairs. On the other hand, the first leaves produced subsequently to the cotyledons, are spathulate, with or without petioles, " pale-green above and purplish beneath, covered above and beneath with erect, stout-hooked, white hairs, with hooks turned upwards towards the apex of the leaves." The base only of the leaf is appressed to the stem, the rest of it being spreading, with the apex curving downwards. The leaves, though succulent, are scarcely fleshy. So far as the other whip-cord veronicas have been observed, similar differences between the young and mature forms have been noticed. Perhaps the most remarkable result of Dr. Cockayne's researches, was the proof that the seedling form remains permanent, so long as the plant is kept in a warm moist atmosphere.

Various theories have been put forward to explain the depauperated leaf forms of these veronicas. Prof. Henslow compares them to Tamarix, Thuja and Cupressus, ${ }^{+}$and says, with regard to the origin of all such plants, that: "such forms are due to precisely the same causes; the same or homologous organs put on precisely the same morphological

*Trans, XXXI., p. 377 .

TThe Orisin of Plent Structures, p. 108. 
features, in response to the similar and direct actions of a like environment, so that all these species have arisen without any aid from natural selection whatever." Without entering into the wider question as to the method of evolution, which is obviously outside of the scope of this work, it may at once be admitted, that the remarkable reduction of leaf surface in these plants, is a direct response to altered environment, but surely Prof. Henslow is wrong in suggesting that the reduction in the size of the leaf is due to the alpine habitats of the species, as most of them are plants of the upper river terraces, rather than of the high alps; and they often grow in clefts of rocks, on shingle slips, and in other arid situations, so that their deparperated leaves are more likely due to their xerophily than to the rigours of an alpine habitat. It must be remembered that the rertical distribution of these species was but little known when Hooker's Handbook of the New Zealand Flora was published, and Professor Henslow has apparently relied largely on the altitudes given there.

\section{Veronica speciosa (The Handsome Veronica).}

A stout shrub, with angular branches. Leaves oblong, thiok, shining, 1 in. -4 in. long, 1 in.-1 1 in. broad. Flowers in dense racemes, deep purple, $\frac{1}{3}$ in. in diameter. Stamens long. Capsule $\frac{1}{4}$ in. long. North Tsland: Hokianga (now extinct). Fl, Oet.

A rare and beautiful form with crimson flowers, which flomrishes best, when in reach of the sea spray. It was formerly found at Hokianga Heads, but is apparently now extinct in that locality. According to Mr. Rutland, it is however, still to be found in Titirangi Bay, Marlborough; but this habitat requires confirmation. Many varieties of this plant are cultivated in gardens. The glossy green leaves, and large racemes, densely packed with flowers, make it a very attractive shrub. As in other sea-side plants, the leaves are protected by a two-layered epidermis. 


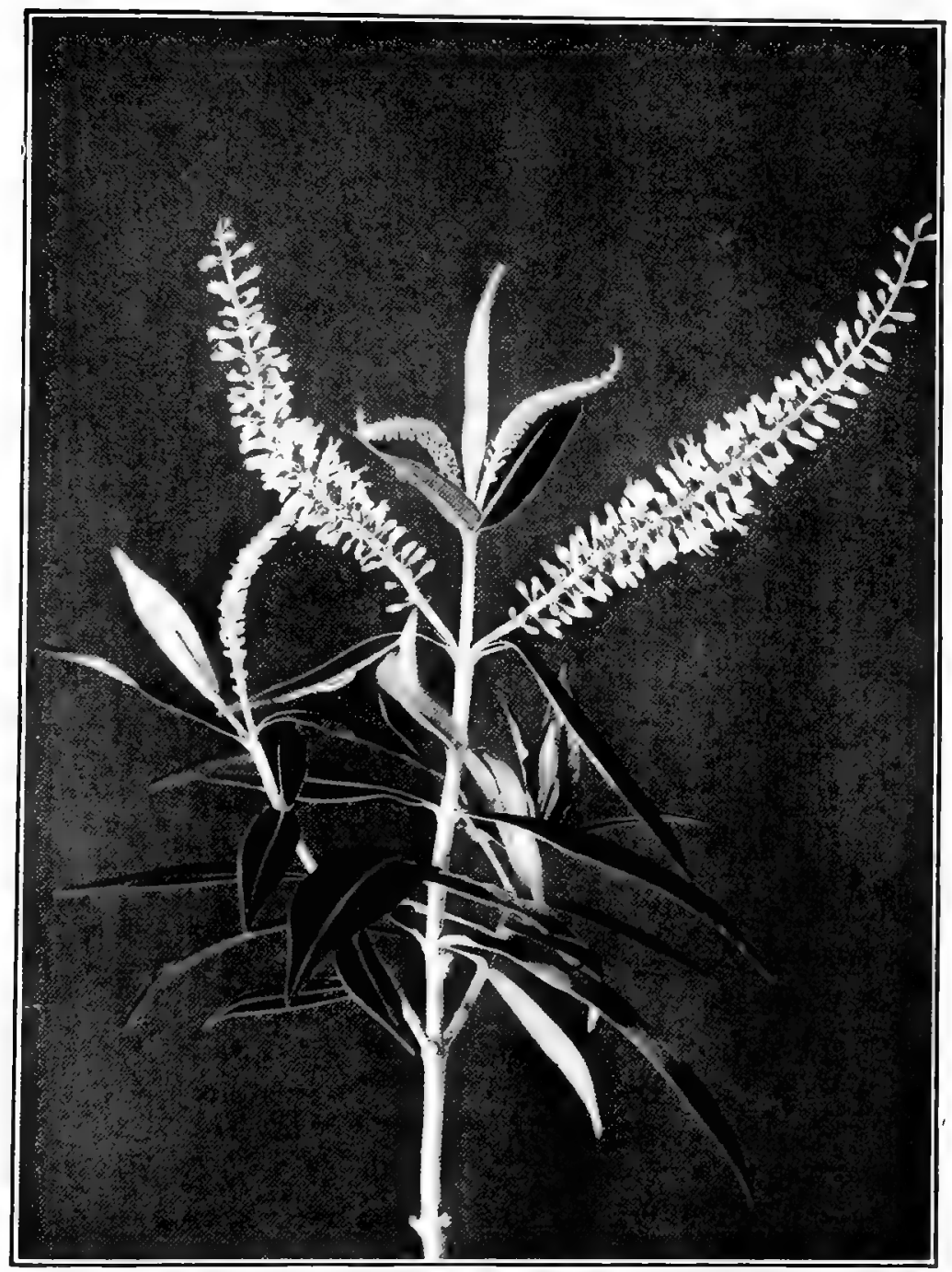

Fig. 125. Veronica salicifolia ( $\frac{1}{3}$ nat. size). 
Veronica salicifolia (The Willow-leaved Veronica).

A large shrub; branches cylindrical. Leaves linear, 2 in.-6 in. long, shining. Flowers variable, in long racemes, white, mauve, or bluish-purple. Corolla $\frac{1}{1}$ in. $-\frac{1}{4}$ in. diameter. Capsule $\frac{1}{8}$ in. long. Both islands, abundant. Fl. Dec.-Jan. Miaori names, Kokoromitio, Foromitio.

Of all the species of the genus, this is probably the most abundant. It is amost everywhere common throughout the islands, and along with various hybrids between it and I'eronica speciosa and Veronica macrocarpa, is much cultivated in gardens. There are a number of allied species, which are only being gradually separated from it by botanists. The Howers are usually white, and produced in densely packed racemes several inches in length. The leaves are much used as a remedy in cases of diarrhoea.

\section{Veronica Traversii (Travers's Veronica).}

A small shrub. Leaves $\frac{3}{4}$ in.-1 in. long, $\frac{1}{6}$ in. $-\frac{1}{3}$ in. broad, leathery, flat. Racenes 1 in.-2 in. long. Corolla $\frac{1}{1}$ in. diameter. Capsule $\frac{1}{5}$ in. long. South Islind: river-beds (Cinterbury); Southern Alps; Olago. Fl, Jan.-Eeb.

Dr. Cockayne* raised a number of young plants of this species, from seeds gathered from a single parent plant. The seedlings showed marked differences amongst themselves. It is, of course, possible, that this may have been due to hybridization, which, according to Hooker at least, occurs frequently among the veronicas. In order to eliminate the probability of error from this cause, capsules were collected from three other plants, and their seeds on germination showed the same variability. No two seedlings seemed to be alike; hence Dr. Cockayne came to the conclusion, "that the individual does not nearly produce itself true from seed." Young plants, however, derived from the same parent, were more like each other, than they were like the descendants of any other plant. Dr. Cockayne informs us that he is not altogether satisfied with the accuracy of these results, and considers that the experiments should be repeated, with 
further precautions against error, such, for example, as the artificial pollination of the plants employed.

Such a variable species as this is likely to give evidence of some value for or against de Vries's Mutation theory (v. p. 370), and it also throws some light on the wonderful range of forms of Veronica sometimes found in a single locality. So

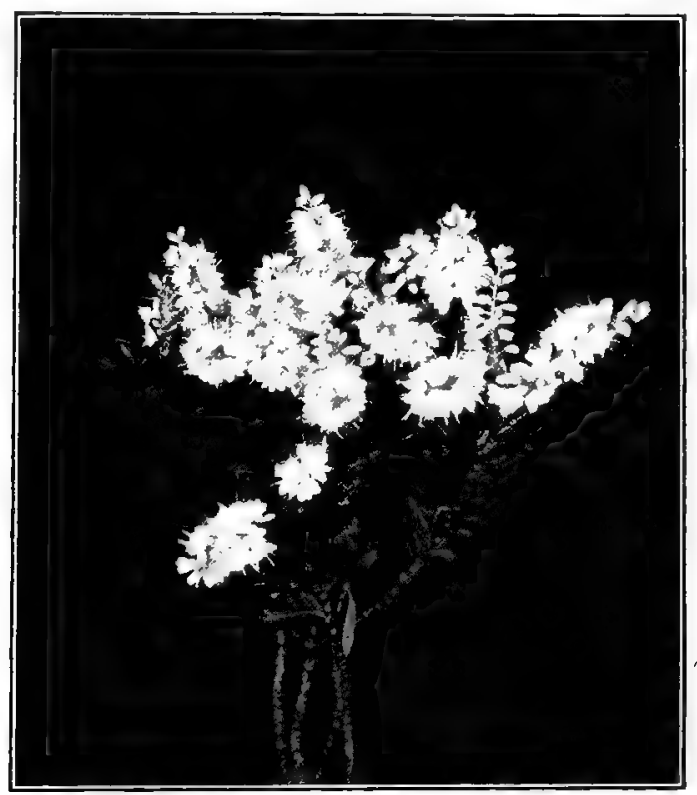

Fig. 126. Veronica Traversii ( $\frac{1}{1}$ nat. size).

numerous ar'e these, and so difficult of discrimination, that Baron Müller once proposed to solve all difficulties, by lumping together nearly twenty distinct types under one specific name!

Veronica monticola (The Mountain-loving Veronica).

Leaves close-set, more or less overlapping, $\frac{2}{3}$ in.-1 in. long, $\frac{1}{3}$ in.- $\frac{1}{2}$ in. broad, narrowed into a short, thick petiole, slightly concave above, but not keeled

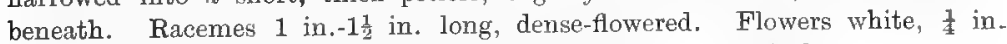
across. Mountain districts from Nelson to Otago. Fl. Dec.-Feb. 


\section{Veronica lycopodioides (The Lycopodium-lite Freronica).}

A large, erect shrub. Branches 4-angled, leaves closely imbricate, $\frac{1}{10} \mathrm{in}$. long. Flowers in dense heads at the tips of the branches, white. Corolla $\frac{1}{5}$ in across. South Island: Southern Alps, Macaulay River, Wairau Gorge, Lindis Pass, Otago. This plant is one of the whip-cord veronicas referred to on $p .372$. Fl. Dec.-Mar.

Teronica tetrasticha, Veronica Hectori, Veronica salicomioides, and I'eronica cupressoides belong also to this class of veronicas, having the same closely inbricated leares.

\section{Veronica epacridea (The Epacris-like Veronica).}

A simall, rigid shrub. Leaves closely imbricate, recurved, rendering the branches 4-angled in appearance. Flowers without stalks, in pairs among the upper leaves, forming an oblong head. South Island: Tarudale, Southern Alps, Mit. Darwin, Wai-au-ua Valley, etc.

This species belongs to the rock-growing group of veronicas. Dl. Cockayne says of the seedling: "The whole plant is very succulent and soft. Such structure is an admirable provision against drought, growing as it does on solid rock or shingleslips, for it cannot put down a long root in search of water, as the adult plant can; nor is there so much danger of its drying up with excessive transpiration, since, being of very low stature, the large stones of the shingle-slips, or the fissures of the rock, where alone the seed can germinate, will protect it from drying winds. The same remark would apply to Veronica tetrasticha, a companion plant. It is curious that this soft, succulent form of leaf is the permanent form of Veronica Haastii, a closely allied plant, restricted to regions subject to the western rainfall."*

\section{Veronica Lavaudiana (Lavaud's Veronica).}

A small, stout herb. Stem at first prostrate; branches ascending. Leaves 直 in. $-\frac{2}{3}$ in. long, broad, leathery. Flower-spikes $\frac{1}{2} \mathrm{in}$. long, in corymbs 1 in, -2 in. broad. Corolla $\frac{1}{3}$ in. across, white or purple. South Island: Banks Peninsula. Fl. Nov.

This beautiful little Veronica was one of Raoul's discoveries. He named it after Lavaud.! It belongs to the third section of veronicas, i.e., those with toothed and rather fleshy 


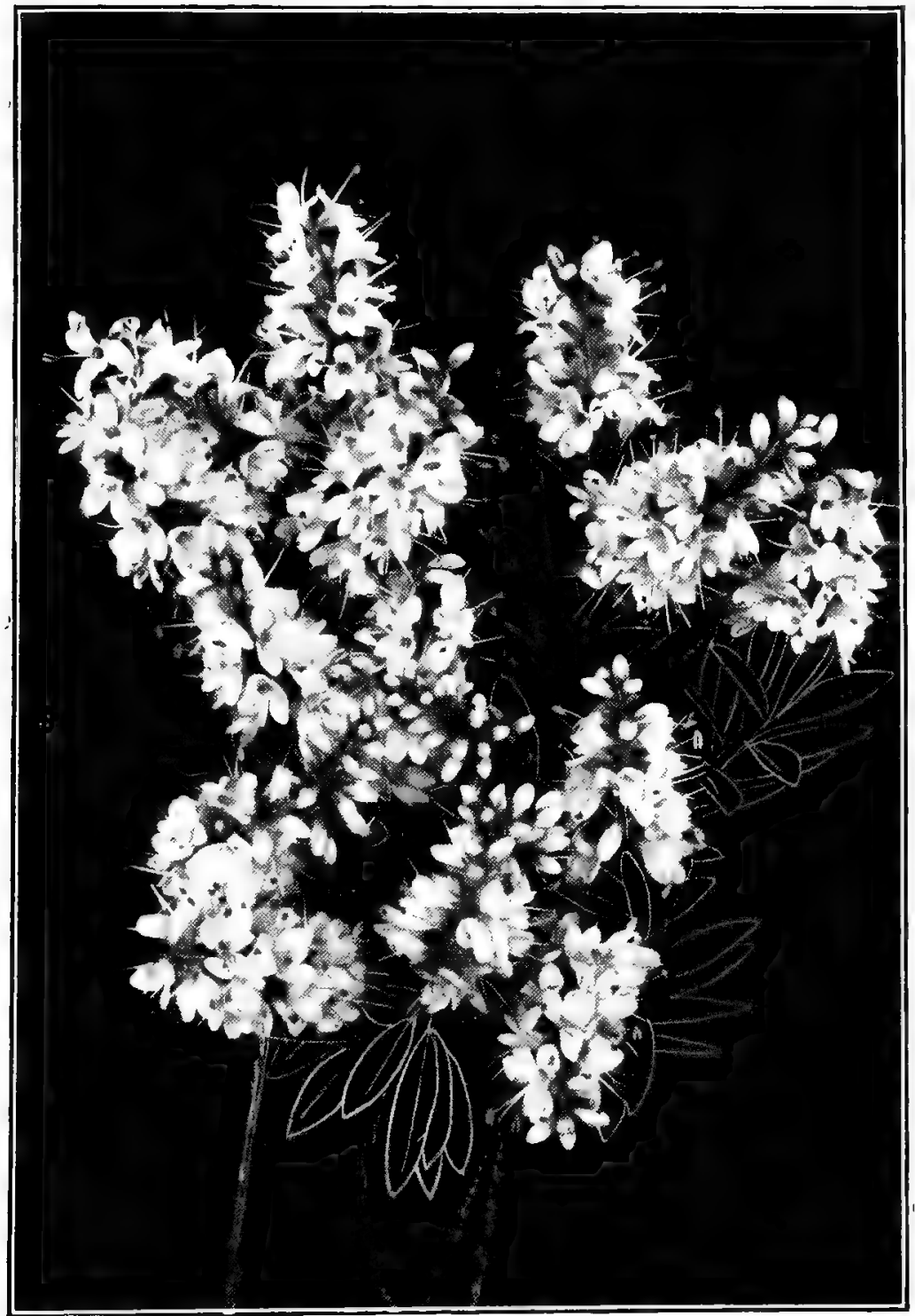

Fig. 127. Veronica monticola (life size). 
leaves. They are nearly all rock-growing plants, and are generally found in limited and discontinuous areas. Veronica Lavaudiana is an extremely rare species, being found in only a few localities on Banks' Peninsula. It is still to be seen on Dover Castle, The Giant's Causeway, and on some other isolated rocks, that rise like islands from a sea of tussocks on the tops of the Lyttelton Hills. These cliffs afford a sanctuary to several other rare species. Unfortunately, the frequent grass fixes, and grazing animals, are together causing much

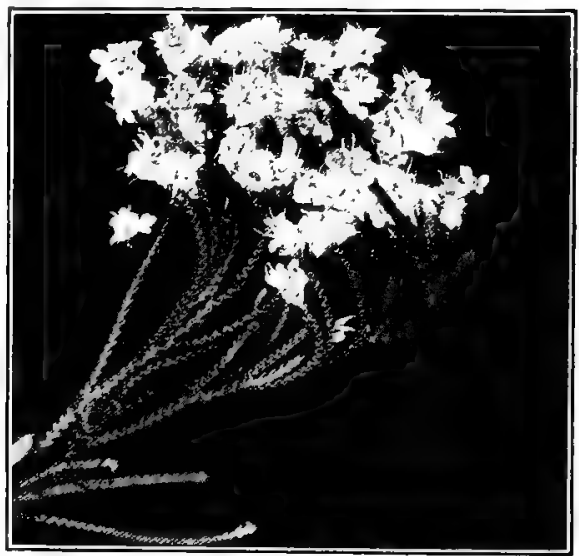

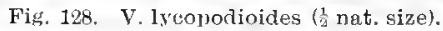

havoc anoongst native plants upon these hills, and the only ones that appear likely to survive are those that can exist on the bare faces of inaccessible cliffs. Amongst the rare forms of the Peninsula may be mentioned Senecio saxifragoides, Cetmisia Mackaui, and Veronica Lanaudiana, all of them interesting and handsome species.

V'eronica Lavaudiana bears pink buds, and beautiful white blossoms, that open in late October, after the cultivated spring flowers are past, and before the annuals have cone into bloom. Coming as it does between the seasons, it is sometimes of considerable value to florists in the preparation of wreaths, 
and floral decorations. Unfortunately, however, it is not well known, and is in cultivation only in a few gardens near Christchurch.

Veronica Hulkeana, on the other hand, is not infrequently to be seen listed in gardeners' catalogues. It is an allied species from the mountains and river gorges of eastern Nelson,

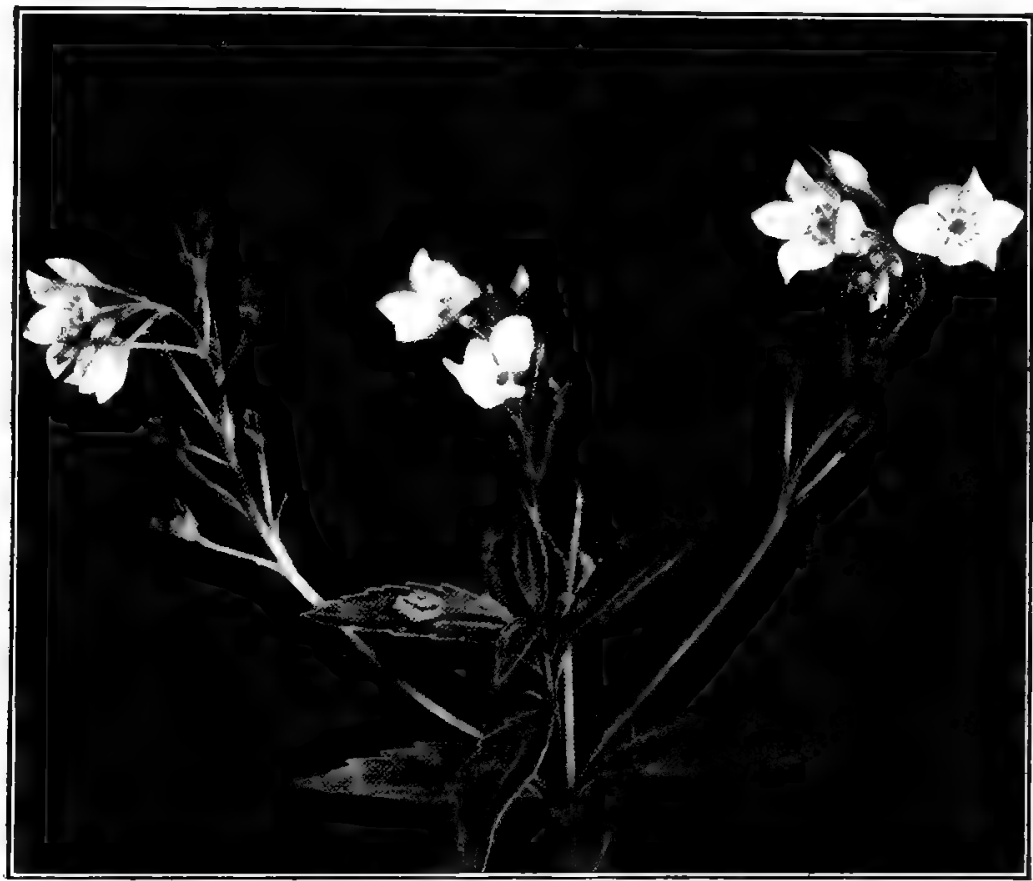

Fig. 12. Veronica cataractae (life size).

and bears long sprays of lilac-coloured flowers in loose panicles, sometimes a foot in length. It is one of the handsomest and most graceful species of the genus.

\section{Veronica cataractae (The Waterfall Teronica).}

A small, slender herb. Stems prostrate at the base, and ascending. Leaves very variable, oval or oblong, $\frac{1}{2} \mathrm{in} .-6 \mathrm{in}$. long, serrate. Racemes very slender, few-flowered. Corolla $\frac{1}{2}$ in. $-\frac{3}{x}$ in. broad, white with red spots. Stamens short. North Island: East Coast, Ruahine Mountains. South Island: Westem Otago. Fl. Feb.-March. 
This species may be taken as a type of the herbaceous section of the genus. The flowers are very pretty, the petals being white, spotted with dark-red at the entrance to the throat. The species is often cultivated, particularly in gardens in and around Dunedin. These, and the allied species, approach more closely to the European forms, than do the other New Zealand veronicas. It is strange, however, that they should be separated from their congeners by a hemisphere, for the veronicas do not grow in the tropics. It is difficult to say if the veronicas covered at one time all the intervening area, or whether they have spread from north to south, or south to north. Certainly, the greater development of the genus in the south, lends some colour to the latter surmise, but general opinion has regarded northern forms as coming south, and not vice versa.

\section{Genus Ourisia.}

Alpine herbs with perennial roots. Calyx 5-lobed; corolla 5-cleft; stamens 4. Capsule 2-valved. (Named in honour of Ouris, a French Governor of the Falklands). $8 \mathrm{sp.}$

\section{Ourisia macrophylla (The Large-leaved Ourisia).}

Stem erect. Leaves all from the roots, hairy, 1 in.-6 in. long. Flower-stem $2 \mathrm{in.}-30 \mathrm{in}$. in height. Flowers in umbels. Corolla $\frac{1}{2} \mathrm{in}$. long. Capsule $\frac{1}{4}$ in. long. Both islands: mountain ranges. Fl, Jan,-Feb.

\section{Ourisia cæspitosa (The Tufted Ourisia).}

Stem creeping. Leaves opposite, numerous, round, $\frac{1}{2}$ in. across. Flowertem $2 \mathrm{in} .-4 \mathrm{in}$. long, $1 \mathrm{in} .-6 \mathrm{in}$. flowered. Corolla $\frac{1}{3} \mathrm{in.}-\frac{1}{2}$ in. across, white, Capsule $\frac{1}{\text { in }}$. long. Both islands: Ruahine Mountains, Southern Alps, Otago. El. Fel,-March.

\section{Ourisia glandulosa (The Glandular Onrisia).}

A small, stout herb. Leaves closcly imbricating, $\frac{1}{2} i n .-1$ in. long, $\frac{1}{2}$ in. $-\frac{3}{2}$ in. broad, thickly covered with rough glandular hairs. Flower-stems 1 in.-2 in. long. Flowers 1 in. - in., white, $\frac{1}{3}$ in. $-\frac{3}{4}$ in. acrosis. South Island: MIt. Sealy, Southern Alps, Otago Like district. Fl. Jan.-Feb.

A genus of distinctly Antarctic distribution, found in the inountains of Tasmania, New Zealand, South America and 
Fuegia. The beantiful white flowers, and large cordate leaves, bear some slight resemblance to those of the Chinese Primrose, and it is possibly on this account that O. macrophylla is called by colonists, the New Zealand Prinurose. The leaves decrease in size, and become more coriaceous, the higher up'

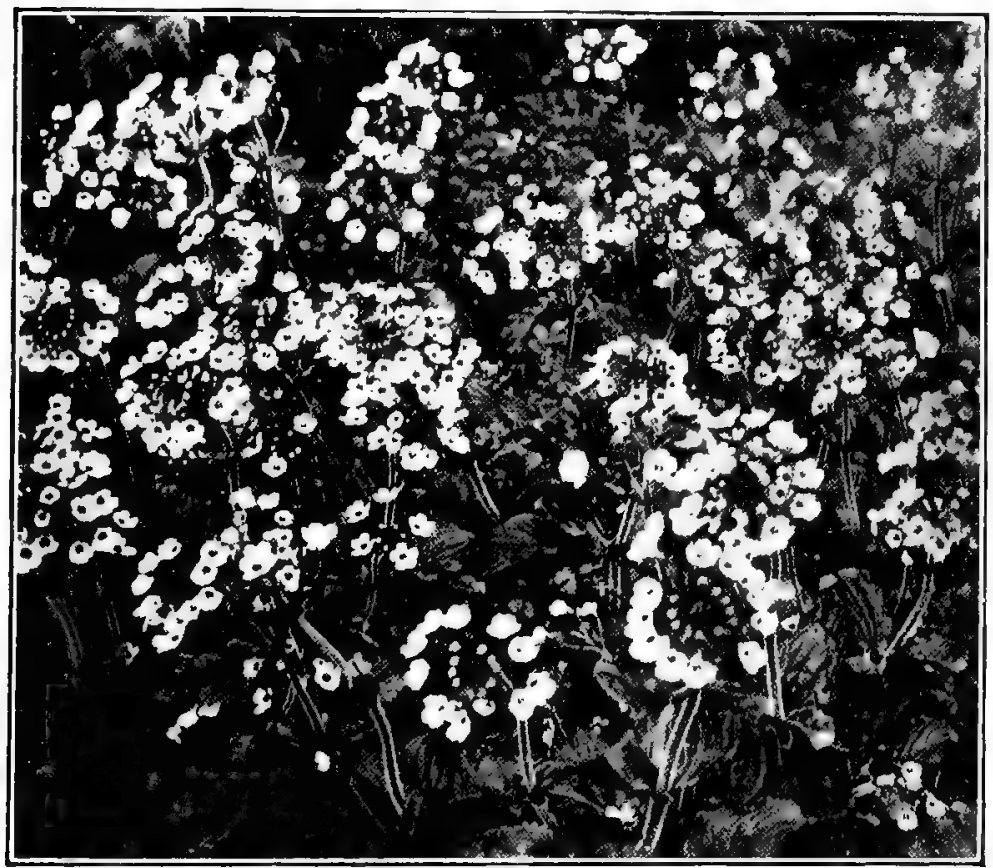

Fig. 130. Ourisia macrophylla (f nat. size)

the mountains the plant is found. Thus Ourisia macrophylla, with large, tender leaves, up to six inches in length, is found in damp shady places at lower altitudes, reaching nearly to sea-level in Stewart Island. In Ourisia Colensoi, found on the tops of the Ruahine Range in the North Island, and at an altitude of 3,000 feet in the Waiau Mountains in the South Island, the leaves are half an inch or less. In Ourisia caspitosa, found on the Southern Alps at altitudes of from 
3,500 to 6,000 feet, the leaves are thickly coriaceous, and only $\frac{1}{4}$ in.- $\frac{1}{2}$ in. in length, whilst Ourisia glandulosa, found at the height of 5,000 feet in the Otago lake district, has become reduced to a patch-plant.

\section{Genus Euphrasia.}

Herbs, with opposite leaves. Calyx 4-lobed, rarely 6. Corolla 2-lipped, 5-cleft. Stamens 4. Capsule oblong, 2-valved. A small genus, chiefly found in Australia and New Zealand. The European species are partially parasitic. (Name from the Greek for joy, in allusion to its reputed virtue). $8 \mathrm{sp.}$

\section{Euphrasia antarctica (The Antarctic Eyebright).}

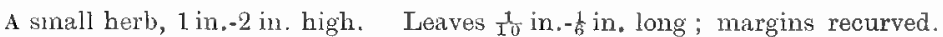
Flowers $\frac{1}{6}$ in.- $-\frac{1}{1} \mathrm{in}$. across. Both islands: in alpine situations. Fl. Jan.-March.

The genus Euphrasia belongs to a group of plants which are nearly all root-parasites. (v. Dactylanthus, p. 150.) The New Zealand species are also doubtless parasitic, though they have not as yet received any close investigation. The Euphrasia seedlings develop first of all normally, but, on the secondary rootlets, there are produced small round nodulesnot unlike those on the roots of a leguminous plant. Their function, however, is completely different. When they come in contact with the root of another species, they put out short absorption-cells, which penetrate the tissues of the host.

They are mostly little known alpine plants; often tufted, or moss-like. The genus owes its English name to the once prevalent belief that the juices of one of the species removed blindness, or at least improved the sight of the eyes.

\section{Gesneriaceae.}

\section{The Gloxinia Family.}

Distribution.-A large, chiefly tropical family, possessing no important properties, but much cultivated for the bcauty of its flowers. Some of the South American species are epiphytic. Gloxinia is one of the best-known stove-plants. The Calabash tree of $\mathrm{N}$. America, Crescentia Cujete, bas edible fruits. Tho fumily is represented in New Zealand by a genus of a single species. 


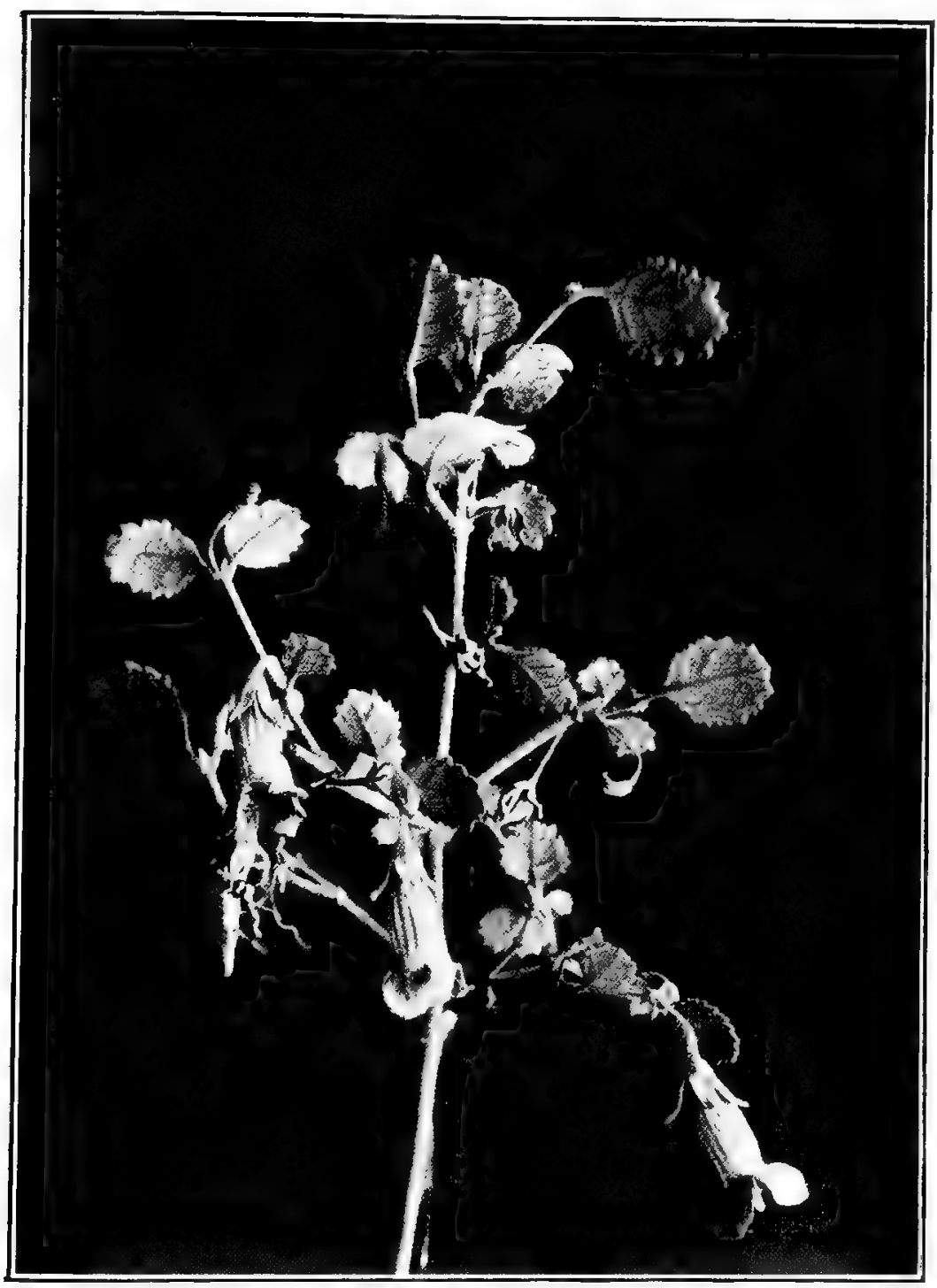

Fig. 131. Rhabdothamnus Solandri. 


\section{Genus Rhabdothammus.}

A slender, twiggy shrub, $2 \mathrm{ft},-6 \mathrm{ft}$. high, with opposite leaves, and pretty yellow and red striped flowers. Sepals 5 ; corolla bell-shaped, 2-lipped, Upper lip 2-lobed, under 3-lobed. Stamens 5, one rudimentary. Anthers combined. Ovary 1-celled; ovules numerous. Capsule 2-valved; seeds minute. (Name from the Greek, signifying a twiggy shrub). 1 sp.

\section{Rhabdothamnus Solandri (Solander's Rhabdothamnus).}

Stem hairy. Leaves round or broadly oblong, $\frac{7}{2}$ in. $-\frac{2}{3}$ in. across, toothed, rough, membranous. Flowers terminal or axillary; corolla $\frac{2}{3}$ in. long, orange-red. North Island: as far South as Wellington. Fl. Oct.-Nov.

This is the only New Zealand representative of the large tropical family Gesneriaceae. Mr. Petrie has recently" studied the pollination of the flower, which presents various points of interest. It seems probable that it will have to be added to our list of bird-pollinated species, which is already comparatively long.

\section{Lentibulariaceae.}

\section{The Butterwort Family.}

Distribution.-A widely-dispersed family, of which the two principal genera. are Pinguicula and Utricularia. The leaves of plants of the former genus contain it principle which will render milk solid without forming whey, hence the name Lutterwort.

\section{Genus Utricularia.}

Herbs usually aquatic and floating, with no true roots; the root stock giving off long, root-like capillary branches, Calyx 2-partite; corolla 2-lipped; stamens 2, capsule 2-valved. Flowers yellow, white, or purple. Name from the Latin, meaning a little bladder, in reference to the small spherical traps with which the plants are provided, for the purpose of catching insects, etc. $6 \mathrm{sp}$.

Few plants, surely, can show a more complete series of adaptations to their environment than these. The bladders float the flower to the surface of the pond, so that pollination 
may take place above the water, and also collect nitrogenous material; the filamentous leaves of some species are an adaptation to the aquatic habitat; the shape, colouring, and arrangement of the parts of the flower secure crosspollination where possible, whilst, if this fails, self-pollination ensues as a result of a delicate readjustment of the position of stigma and anther; and, finally, isolation by water, secures the plants from attacks by creeping insects, and insures the visits of flying insects, which, alone, are likely to be useful to them.

Utricularia Protrusa.-A floating, slender plant, with a scape of yellow flowers. Leaves finely divided; stem bearing minute bladders. Bogs in the North Island. Utricularia novae-Zelandiae has white flowers, and entire radical leaves. This plant was discovered growing upon damp rocks in Palliser Bay. Utricularia monanthos is not more than $1 \mathrm{in}$. in height, with a single, purple flower. The rhizomes bear minute bladders. It has been found in the South Island, and also in Tasmania.

\section{Rubiaceae.}

\section{The Madder Family.}

Distribution.-A large and widely distributed family of about 4500 species, divided into two tribes, the Cinchonoideae and Coffeoideae. Most of the species are found in warm and tropical regions. Coffee is obtained from the seeds of Coffea arabica, and Quinime and Peruvian Bark from plants of the genus Cinchona. Ipecacuanha is prepared from the rootstock of Cephaelis Ipecachanha, a native of Brazil. Bouvardia is cultivated for its flowers. The New Zealand plants belonging to the family have all inconspicuous flowers, and are often wind-pollinated, though most foreign species are insect-pollinated.

\section{Key to the Genera.}

1. Trees or shrubs. Fruit a berry-like drupe. Herbs, leaves opposite or whorled.

Coprosma, p. 390.

2

2. Creeping herbs, with opposite leaves and red berries. Slender, erect, or trailing herbs with whorled leaves.

Nertera, p. 398.

3

3. Corolla wheel-shaped.

Corolla funnel or bell-shaped. 


\section{Genus Coprosma.}

Shrubs or trees, very variable in size and appearance. Leaves opposite, rarely whorled, often pitted on the under-surface, in the axils of the veins. Flowers regular. Calyx 4 -5-toothed or lobed ; corolla campanulate or funnelshaped, 4-5-lobed. Stamens 4-5. Anthers exserted. Styles divided into from 2-4 lobes, usually long. Drupe round or oval. (Name from the Greek, signifying excrement, in allusion to the smell of one or two species.) $39 \mathrm{sp}$.

New Zealand has no more highly developed, or characteristic genus, than Coprosma. The name is derived from the Greek, and refers to the evil odour that the leaves of certain species give out, when bruised. Anyone who has forced his way through scrub, formed of the well named C. fotidissima, knows that the smell from it becomes in time almost insupportable. The stench is somewhat suggestive of carbon bi-sulphide, but apparently no attempt has yet been made to determine its source. There are some forty species in the genus, ranging in size from small prostrate shrubs, to trees of $20 \mathrm{ft}$. to $30 \mathrm{ft}$. high. In some parts of New Zealand the scrub consists chiefly of Coprosma. The most characteristic species of the genus are twiggy shrubs, which frequently cover the ground so thickly, that it is impossible to force a way through them. Oftentimes, the only method of getting past the coprosma-scrub is to walk over the top of it. This method of progression, however, is not a very satisfactory one, as there is often much risk of falling through, up to the neck. The shrubby coprosmas generally produce small, round, or linear leaves, less than an inch in length. It must not, however, be imagined that all shrubs with small leaves and twiggy interlacing branches, belong to this genus.

It has already been pointed out that there is a considerable number of species of plants, which, in a juvenile stage of their existence, assume a coprosma-like appearance (v. Hoheria angustifolia, p. 256.) Other plants, in their mature forms, also often resemble the coprosma type, e.g., Olearia virgata, Myrtus pedunculata, Paratrophis, etc. 


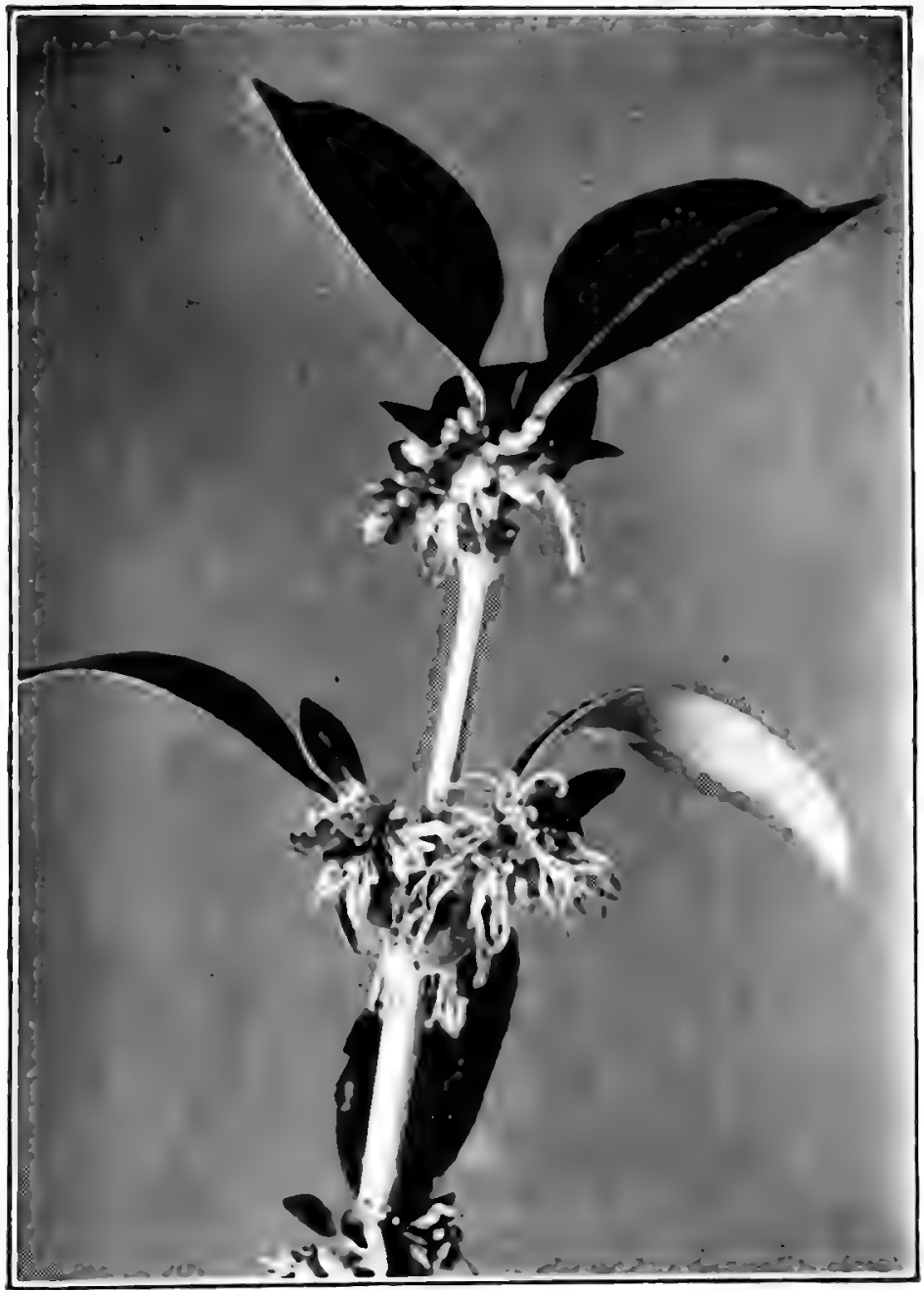

Fig. 132. Coprosma lucida ( $\frac{2}{3}$ nat. size). 
The larger species of Coprosma bear little resemblance to coprosma-scrub. They have often leaves several inches in length, which are of a brighter green than those of the shrubby forms. Some of these are well known plants, and are frequently cultivated. Thus $C$. lucida, which with several other arboreous species, is known as Haramu, is frequently found in gardens, being valued on account of the beauty of its small orange-red berries. It has been suggested that the seeds of this and of C. Baueri might be ground for coffee, as the genus is not far removed from that of the coffee plant. Indeed, a member of the Wellington Philosophical Society once provided his fellow members with "coffee" from the latter plant. This drink was said to possess a splendid aroma, but the experiment does not seem to have been repeated.

C. Baueri is much used for hedges in Wellington and Melbourne. In the former place it is generally known as taupata (sometimes naupata); in the latter it is called the lookingglass plant. It is a sea-side plant with bright glossy green leaves, which possess a two-layered epidermis. In this respect it differs from many other species of the genus.

Veronica speciosa, another sea-side plant, differs similarly from many of the other veronicas. $C$. Baueri seems to flourish best, when in reach of the ocean spray. The stipules of this and of other species possess an apical gland, which secretes a viscid fluid that protects the tender leaf bud. Similarly, the bud scales of the horse-chestnut are covered with an extremely sticky secretion, that protects the bud in winter.

In many of the species there are developed in the axils of the lateral veins, and the midrib, small pits that have given rise to much investigation, $*$ but their function is still unknown.

\section{Pollination in Coprosma.}

Probably the flowers of all species of Coprosma are windpollinated. Pistillate and staminate flowers are formed on

"Greensill: Leaf structure of Coprosma, Trans, XXXY., p, 342. 


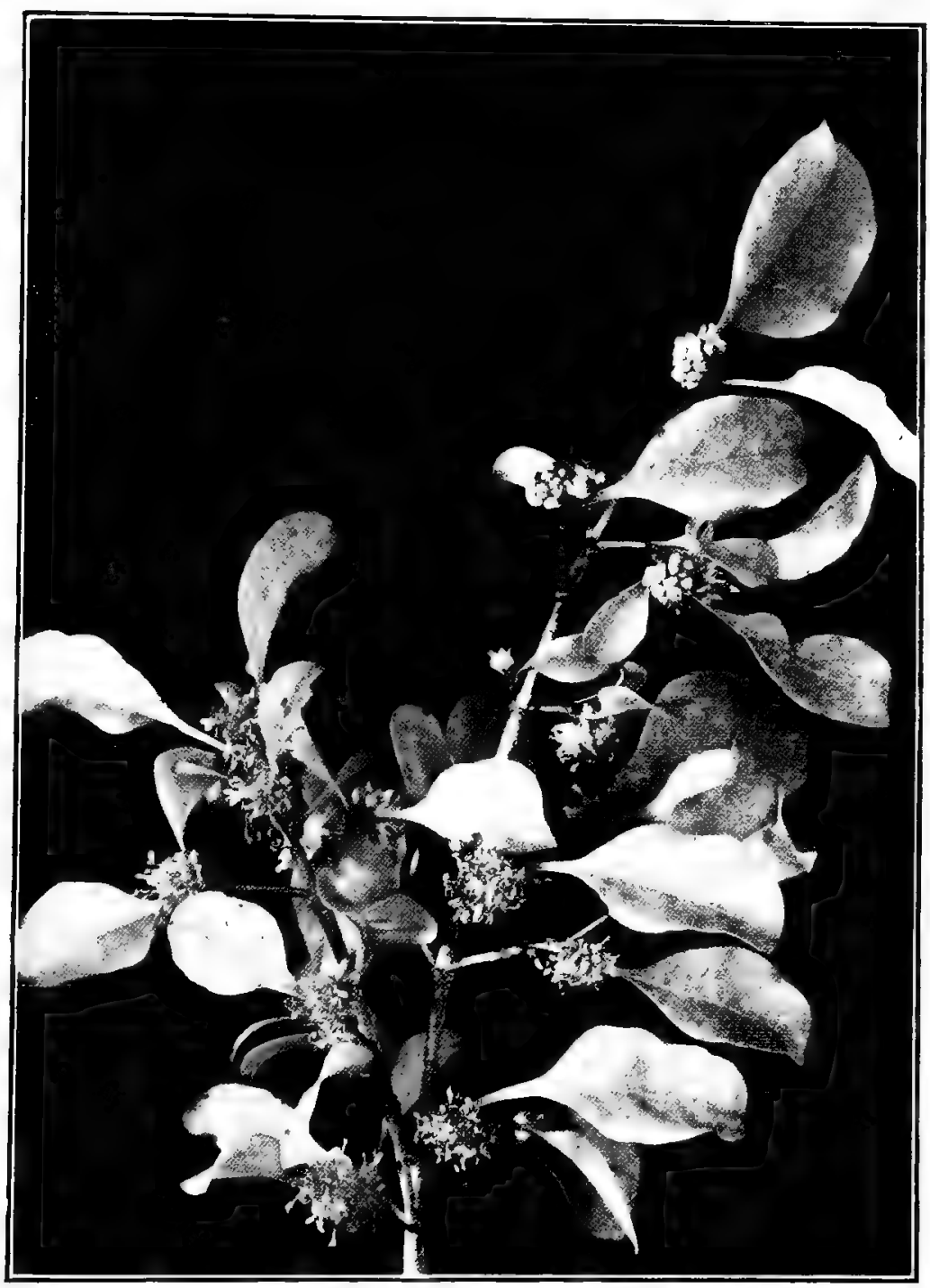

Fig. 133. Coprosma arborea ( $\frac{3}{2}$ nat. size). 
different plants; and vary little in different species. In their insignificance, their protruding stamens with pendulous anthers, and dust-like pollen flying in clouds, they are typical of wind-pollinated plants. Insects are seldom seen on the flowers, though, according to Mr. Cheeseman," a small fly visits the male flowers of C. propinqua, possibly to feed on the pollen, but, as it is never seen on the female flowers, it can be of no use in the work of pollination. The styles are long and projecting, and are covered with stigmatic protuberances, which are well calculated to catch the wind-blown pollen.

\section{FruIT.}

The fruit is a berry, containing generally two plano-convex seeds. It may be of various colours, and is often very pretty. The pale-blue transhucent fruits of $C$. acerosa, var. brunnea, are very attractive, and are often eaten by children. In $C$. spathulata the drupe is black, in C. lucida-as already statedorange-red, in other species (e.g. C. Cunninghamii) it is colourless and translucent, in $C$. rhamnoides the immature fruit is bright-red, and finally becomes black. In C. obconica it is yellowish white, and broader than it is long: thus the characters of the fruits are valuable, in discriminating the species. The flowers throughout the genus are useless for this purpose, as they are so much alike.

\section{Coprosma grandifolia (The Large-leaved Coprosma).}

A shrub, $6 \mathrm{ft} .-15 \mathrm{ft}$. in height. Leaves $4 \mathrm{in.}-8 \mathrm{in}$. long, $1 \frac{1}{\mathrm{~s}} \mathrm{in.}-3 \mathrm{in}$. broad, acute, membranous, not shining. Flowers in terminal or lateral fascicles, sessile, green. Calyx minute; corolla narrow, funnel-shaped or tubular. Drupe $\$$ in. long, orange-red. North Cape to Buller River. Fl. April to June. Maori name, Rautekan.

\section{Coprosma lucida (The Kar(mmu).}

Glossy-leaved, except in var, obovata, $2 \mathrm{ft} .-15 \mathrm{ft}$. in height. Leaves $2 \mathrm{in} .-5 \mathrm{in}$. long, oblong, acute, coriaceous. Calyx 4-5-toothed. Corolla 4-5-lobed; stamens 4 or 5 . Styles very long, slender. Drupe $\frac{1}{3} \mathrm{in}$. long, orange-red. Both islands. Fl. Sept.-Nov. 


\section{Coprosma Baueri (The Taupata).}

A shining shrub, from $1 \mathrm{ft} .-20 \mathrm{ft}$. in height. Leaves almost fleshy, ovate, glossy, margins often recurved. Stipules broad. Staminate flowers in dense heads; calyx 4-toothed; corolla 4-lobed. Pistillate flowers $3-5$ only; calyx and

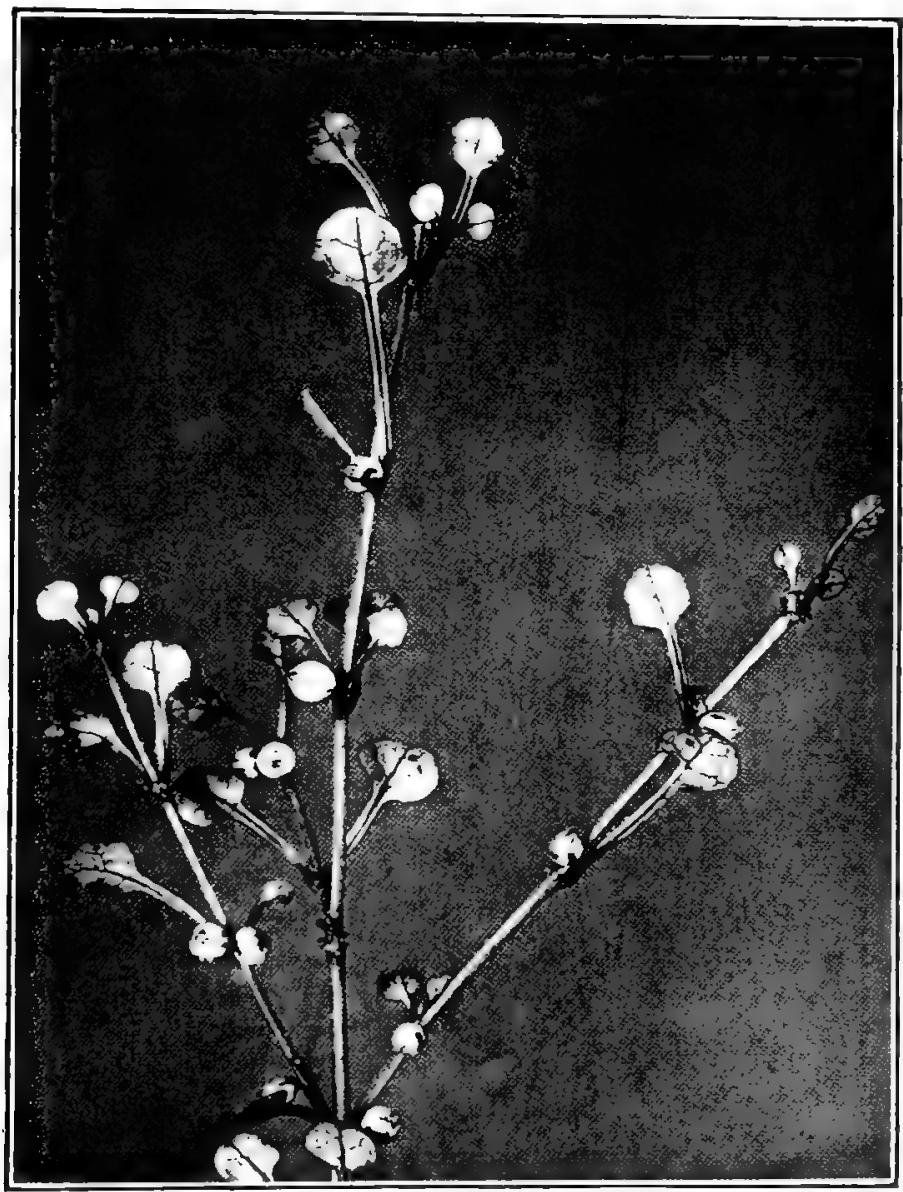

Fig. 134. Coprosma tenuicaulis with berries ( $\frac{2}{3}$ nat. size).

corolla 4-toothed. Drupe $\frac{1}{4} \mathrm{in},-\frac{1}{3}$ in. long, orange-yellow. North Cape to Greymouth: sea cliffs. Norfolk, Kermadec, and Chatham Islands. Fl. Sept.-Nov, Maori names, Taupata and Naupata. 


\section{Coprosma robusta (The Robust Coprosma).}

A stout shrub, $2 \mathrm{ft} .12 \mathrm{ft}$, in height. Bark pale-brown. Leaves shining, 1 in. -5 in. long, $x_{3}$ in.-2 in. broad; margins often slightly recurved. Flowers in dense heads. Calyx and corolla 4-5-toothed or lobed. Drupes thickly set, 1 in. long, red or vellow. North Island and northern part of South Island, Chatham Island. Fl. Sept.-Nov. Maori name, Fakaram or Karamu.

\section{Coprosma arborea (The Tree Coprosma).}

A small tree, $15 \mathrm{ft} .-30 \mathrm{ft}$. in height. Leaves $1 \mathrm{in.}-2 \mathrm{in}$. long, $\frac{1}{2} \mathrm{in.}-1 \mathrm{in}$. broad. Petioles winged, reddish below. Flowers in round heads, sessile, greenish-white, on arrested axillary shoots. Calyx and corolla 5-lobed Pistillate flowers 4-10, in round clusters. Drupes in dense heads, 1 in. in diameter, translucent, finally black. A most distinct species. North Island: as far south as the Lower Waikato. Fl. Oct.-Nor.

\section{Coprosma rotundifolia (The Round-leaved Coprosma).}

A spreading shrub, $4 \mathrm{ft} .-12 \mathrm{ft}$. in height. Bark pale; young shoots hairy. Leaves in pairs, distant, 1 in.-1 in. long, ovate, round or oblong, membranous, downy. Flowers sessile, axillary, solitary or fascicled, greenish-white. Stiminate flowers withont calyx; corolla deeply $4-5$ cleft. Pistillate flowers with 4-5-toothed calyx, and 3-4-lobed corolla. Drupes usually in pairs, roundish, $\frac{1}{6}$ in. broad, red. Both islands: in thick bush. Fl. Sept.-Oct.

\section{Coprosma areolata (The Areolate Coprosma).}

A slender shrub, $6 \mathrm{ft} . \mathbf{- 1 5} \mathrm{ft}$. in height. Branches often fastigiate. Leaves $\frac{1}{1}$ in. $-\frac{2}{3} \mathrm{in}$. long, ovate or oblong, acute, thin, membranous, flat, with large spaces between the veins. Flowers axillary, solitary, or in clusters of $2-4$. Staminate flowers with spreading lobes, $\frac{1}{6}$ in. across, pale-mauve or pink. Pistillate flowers

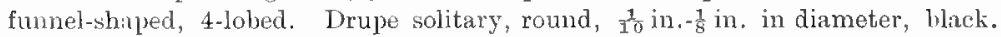
Both islands. Fl. Sept.-Oct.

\section{Coprosma parviflora (The Small-flowered Coprosma).}

A rigid shrub, $4 \mathrm{ft} .14 \mathrm{ft}$. in height. Bark pale-brown; young shoots hairy. Lcares $\frac{1}{1}$ in.-3in. long, leathery, fascicled, linear-oblong or obovate; veins faint. Flower's solitary, or 2-4 together, $\frac{1}{12}$ in. $\frac{1}{10}$ in. long. Drupe round, white, or tinged with violet; finally black. Both islands: abundant. Fl. Nov.-Jan. A very variable species.

\section{Coprosma acerosa (The Acerose Coprosma).}

A low shrul, $1 \mathrm{ft.}-4 \mathrm{ft}$. in height. Stem prostrate or sub-erect, with

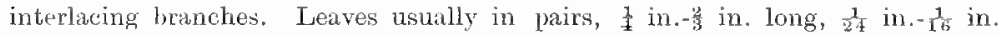
bruad; veins faint. Flowers on minute terminal branchlets. Staminate flowers solitiry, or 3-4 together, without calyx; stamens 4 . Pistillate flowers solitary, $\frac{1}{12}$ in.- $\frac{1}{1} \mathrm{in}$. long, tubular, 4-lobed. Drupe round or oblong, $\frac{1}{1}$ in. $-\frac{1}{1}$ in. long, clear, white, or pale-blue. Both islands: sea-coasts or river-valieys. 


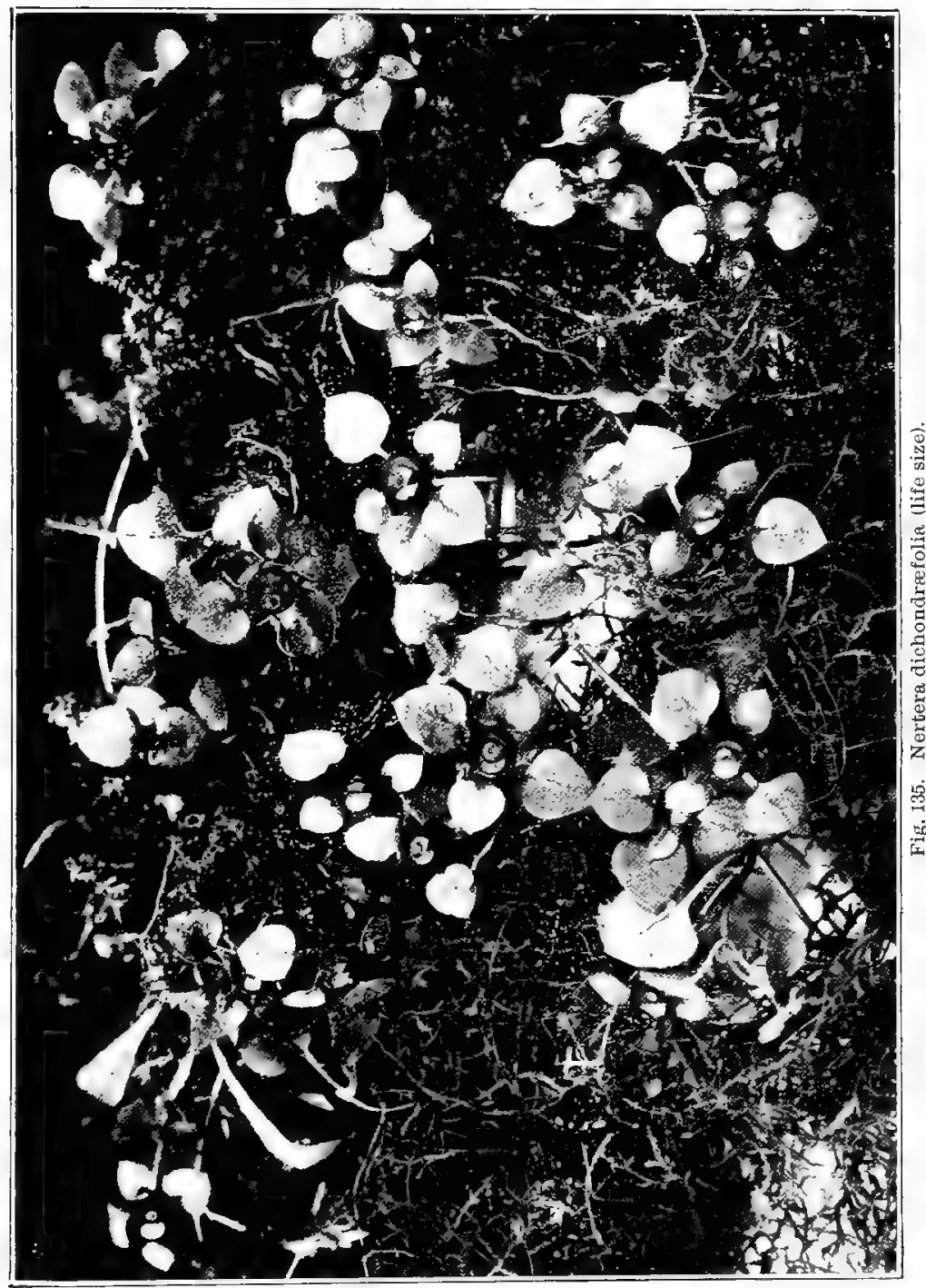




\section{Coprosma propinqua (The Kindred Coprosma).}

A thickly-branched shrub, $6 \mathrm{ft} .-20 \mathrm{ft}$. in height. Bark brown; young shoots

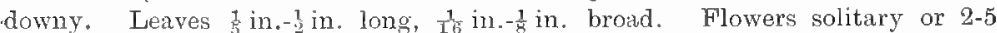
together; fascicles involucrate. Staminate flowers usually fascicled; calyx 0; corolla $\frac{1}{5}$ in.- $\frac{1}{6}$ in. long. Pistillate flowers $\frac{3}{12}-\frac{1}{1}$ in. long, 3-4-lobed. Styles short. Drupe round, opaque, $\frac{1}{3} \mathrm{in}$. long, usually changing from yellow or white to black. Both islands: damp places. Fl. Sept.-Oct. Maori name Hingimmgi.

\section{Coprosma linariifolia (The Narrow-leaved Coprosma).}

A slender shrub or tree, $4 \mathrm{ft}-20 \mathrm{ft}$. in height. Young shoots downy. Leaves not fascicled, $\frac{1}{2}$ in. $-1 \frac{1}{2}$ in. long, $\frac{1}{5}$ in. $-\frac{1}{3}$ in. broad, flat, rather membrawous, veins faintly seen. Flowers terminal, on small branchlets. Staminate flowers in small fascicles; calyx 0 ; corolla $\frac{1}{5}$ in. $-\frac{1}{1} \mathrm{in}$. long. Pistillate flowers solitary, $\frac{1}{10}$ in. $-\frac{1}{8}$ in. long. Calyx 4-5-lobed; lobes long. Drupe broadly-oblong, 考 in. $-\frac{1}{4}$ in. long, translucent, fnally black. Both islands. Fl, Oct.

\section{Coprosma fœtidissima (The Fœtid Coprosma).}

A slender, twiggy shrub, $6 \mathrm{ft}$.-10 ft. in height, or a small tree $20 \mathrm{ft}$. in height. Branches interlacing, young shoots downy. Bark pale-red or grey. Leaves variable, distant, $\frac{3}{4} \mathrm{in} .-2 \frac{1}{2} \mathrm{in}$. long, $\frac{1}{4}$ in.- $-\frac{3}{4}$ in. 'broad; midrib obvious. Flowers axillary or terminal, sessile, fuchsia-like, solitary or in pairs. Staminate flowers $\frac{1}{2} \mathrm{in.}-\frac{1}{3} \mathrm{in}$. long, funnel-shaped, $4-5$ to 8 or 10-lobed, rarely 6-lobed. Stamens as many as the lobes. Pistillate flowers 3-5-lobed. Drupe $\frac{1}{4}$ in.- $\frac{1}{3}$ in. long; yellow or red, rarely white and translucent. Odour of shrub strong and unpleasant. Both islands, Chatham, Stewart, Auckland, and Camplell Islands. Fl. Aug.-Oct.

\section{Genus Nertera.}

Prostrate soft-leaved herbs. Stipules minute. Flowers terminal or axillary, solitary, sessile. Calyx 4-toothed; corolla 4-5-lobed; stamens 4-5; anthers exserted. Fruit a fleshy drupe. $4 \mathrm{sp}$.

\section{Nertera depressa (The Oblate-bervied Nertera).}

A perennial herb, growing in patches. Stem rooting at the nodes. Leaves round or ovate, shining. Flowers terminal. Drupe red, depressed. Both islands: Stewart and Aucklimd Islands. Fl. Oct.-Jan.

\section{Nertera dichondræfolia (The Dichondra-leaved Nertera).}

Stem creeping, hairy, 3 in.-2 ft. long. Leaves dull-green, membranous, hairy, ovate or cordate. Stipules acute. Flowers and fruit larger than in N. demessa. Both islauds. Stewart Island. Fl. Oct.-Dec. (Dichondra is a genus of (onvolvulaceae, $q . v$.) 


\section{Caprifoliaceae.}

\section{The Honeysuckle Family.}

Distribution.-The Caprifoliaceae are natives chiefly of the northern parts of Europe, Asia, and America. They are more rare in the Southern Hemisphere. Their uses are unimportant, but many of the species are cultivated for the beauty and fragrance of their flowers. The Guelder Rose, the Honeysuckle or Woodbine, the Elder, the Snowberry, the Laurustinus, the Leycesteria, and the Weigelia, all belong to this family.

The only genus by which the family is represented in New Zealand is that of Alsenosmia, which is endemic.

\section{Genus Alsenosmia.}

About 4 species, very difficult to determine on account of their variability. Shrubs with alternate leaves, and fragrant, drooping flowers. Calyx 4-5-toothed; corolla 4-5-lobed; stamens 4-5. Berry crimson, 2-celled. Minute tufts of reddish hairs are produced in the leaf-axils. (From the Greek for a grove and $a$ sueet-smell, in reference to the delicious odour of the species).

\section{Alseuosmia macrophylla (The Large-leaved Alsenosmia).}

A shrub, $4 \mathrm{ft} .-10 \mathrm{ft}$. in height. Leaves $3 \mathrm{in.-7-in.} \mathrm{long,} \mathrm{oblong,} \mathrm{often} \mathrm{glossy.}$ Flowers drooping, solitary, or in 1-3-flowered fascicles. Corolla $1 \frac{1}{2} \mathrm{in}$. long, crimson. Berry $\frac{1}{3}$ in. long, crimson. Both islands: rare and local, Fl. Oct.-Nov.

\section{Alseuosmia quercifolia (The Oak-leaved Alseuosmia).}

A slender shrub. Leaves $1 \mathrm{in.}-4 \mathrm{in}$. long, oblong or ovate-lanceolate, variable, entire or lobed, almost membranous. Flowers solitary, or in fascicles of 3-6. Corolla $\frac{1}{2}$ in.- $-\frac{3}{2}$ in. long; tube red, lobes greenish. Stigma often longer than the petals. Both islands: rare and local. Fl. Oct.-Dec.

\section{Cucurbitaceae.}

\section{The Melon and Cucumber Family.}

Distribution.-A large family, chiefly tropical. Many of the species furnish fruits and vegetables, such as the Melon, Cucumber, and Pumpkin. The plants contain a strong purgative, which, in some species, is so concentrated as to render them poisonous; in others, however, this substance is so diffused, especially under cultivation, that the plants become useful as food. 


\section{Genus Sicyos.}

Anuual creeping herbs. Calyx 5-toothed, corolla 5-lobed. Filaments 3-5, anthers united. Staminate flowers racemed, pistillate panicled. Fruit small, leathery, 1-seeded. Tendri]s branched. (Name from the Greek, signifying $a$ cucumber.)

\section{Sicyos australis (The Southern Sicyos).}

A glabrous herb, with stems $2 \mathrm{ft} .-10 \mathrm{ft}$. long. Leaves 5-7-lobed. Flowers green, $\frac{1}{3}$ in. across, axillary. Fruit a nut, with barbed spines. Both islands: very rare. Fl. Dec-March. Found also in the Kermadecs and Norfolk Island.

This is one of the many climbing plants of New Zealand. Sicyos clinubs by tendrils, as also do Clematis and Passiffora. The tendril-bearing plant has a great advantage over other forms of climbers. It can grip hold of smaller projections than can be seized by a twining stem, and can climb up great tree-trunks by this means, when such a stem would fail altogether to ascend. Nature rarely develops a new organ for a new function, but generally modifies an old one to do the work. Thus, we find that tendrils are merely modified leaves or stems, or even roots. In Clematis, it is the petiole that forms the tendril; in Passifiora tetrandra, and Sicyos, the tendrils are probably modified branches. The twining of a tendril is cansed by its outer side growing more rapidly than the inner, and thus producing curvature. The tendrils of Sicyos are unusually sensitive, and, a few minutes after they touch an obstacle, the tips will completely encircle it. The tendency to curve is also communicated to the rest of the tendril, so that it coils up like a corkscrew. Now, as both of its ends are fixed, it is clear that the torsion would soon cause it to snap, if some provision were not made to guard against such an accident. This misfortune is ingeniously prevented, by the reversal of the spixal. One part of the tendril coils from right to left, while the other part is twisted in the opposite direction. A short straight portion unites the two coils. There are several advantages in the reversed spiral. If a tendril is twisted an equal number of times in opposite directions, then there is no strain from the 
torsion, and the tendril can be pulled straight without any twists being left in it. If, on the other hand, a continuous spiral is strained, the convolutions can be effaced, but kinks are left in it, and a break is likely to ensue at any one of them. In a strong wind, therefore, the continuous spiral would be broken, whilst the plant with tendrils in reversed spirals " rides out the gale with a long range of cable paid out." The coiling of the tendrils brings the plant and its support close together in calm weather, and enables them to separate somewhat in a storm. The reversed spiral is not uncommon in nature. It is frequent in the twining stems of Mühlenbeckia. It is often found where a long band, whose ends are fixed, has to be packed in a short space, e.g., the intestines of the tadpole, the pond mussel, and the colon of a ruminant. It may be well seen in the tendrils of Sicyos australis.

From this short account, it may be gathered that the tendril is one of the most perfect of Nature's contrivances. Those who wish to pursue their investigations further, should read Darwin's classic work on Climbing Plants.

\section{Campanulaceae.}

(Including Lobeliaceae.)

\section{The Canterbury Bell Family.}

Pollination.-The flowers of this family approach in type those of the Composites. The anthers ripen first, and the style receives pollen shed by the anthers, while the stigmas are closed. The flower afterwards becomes female, and, if not insect-pollinated, self-pollination takes place in a similar way to that described under Compositae. (For further details, see Wahlenbergia). 
Key to the Genera.

Sub-Family Campanuloideae: Flowers regular. Anthers usually free. Corolla bell-shaped, stamens free.

Sub-Family Lobelioideae: Flowers irregular. Anthers united.

1. Fruit, a coriaceons capsule, 2-ralred at the top.

Fruit a berry.

2. A tall herb, with flowers in racemes, and large leaves.

Small creeping plants with prostrate stems.

Wahlenbergia, p, 402.

Lobelia, p. 403.

2

Colensoa, D. 404.

IPratia.

1 Not further described.

\section{Gemus Wahlenbergia.}

Erect or ascending, generally glabrous, milky herbs. Flowers terminal, drooping in the bud, white or blue. Calyx-lobes 3-5; corolla bell-shaped, 5-lobed. Stamens 5, epigynous, with filaments dilated at the base. Ovary 2-5celled. Style simple, hairy at the top. Stigmas 2 or 3 . (Named after a Swedish botanist.) This genus largely takes the place in south temperate regions of the North Tenperate Campanula. 3 sp.

\section{Wahlenbergia gracilis (The Graceful Blue-bell).}

A slender annual. Stem $1 \mathrm{in.-24} \mathrm{in}$. high, angular, branches terminating in slender 1-flowered peduncles. Leaves $\frac{1}{2}$ in.-2 in. long, radical, spathulate, petioled, toothed; cauline sessile, linear oblong. Flowers variable in size and form. Corolla $\frac{1}{6}$ in.- in. long; blue, purplish, or white. Abundant throughout the islands, up to $4000 \mathrm{ft}$. Fl. Oct.-Mar.

W. saxicola has larger and more beautiful flowers, and is common in the lilly and sub-alpine districts of Otago.

$W$. gracitis is one of the commonest of flowers in dry situations on open plains, and grassy hill-sides. It might be described as the New Zealand blue-bell, except that the application of the term to a flower, which is more often white than blue, is scarcely appropriate. The colour, though commonly a dingr white, varies in shade from white to deep blue. In Tasmania and Australia, where the plant is also abundant, the colour of the corolla is generally brighter than in New Zealand specimens. $W$. cartilaginea is a curious little sweet-scented mountain species, found in Nelson. The coriaceous petioles, with cartilaginous margins, short stout scapes, and low habit, are highly characteristic of an alpine plant. 
The method of pollination in the genus is typical of that of the order. The anthers ripen before the stigmas, and the pollen is discharged on to the hairs on the outside of the style, which at this time is closed, but afterwards divides into two arms. The pollen is carried up by the growing style, but cannot reach the stigmatic surfaces, which are closely pressed together. On the hairy tip of the style it is presented to incoming insects, which remove it to other flowers. Honey is secreted at the base of the style by a disk, and is, in most Campanulaceae, protected by the expanded base of the filament, so that it can only be obtained by an insect which can insert its proboscis into the narrow slit, between two adjacent stamens. This arrangement, and the drooping habit of the flower, show that plants of this family are specially adapted for bee pollination, though other insects may also visit them.

As the pistil ripens, the two arms of the style separate, disclosing the papillose stigmas, and finally become recurved. They are right in the way of any insect which may enter the flower, or endeavour to obtain the honey at the foot of the bell. Thus cross-pollination is likely to be effected; but, if this fails, then the recurvature of the stigmas against the pollen-covered surface of their own styles, will secure selfpollination; so that, in one way or another, fertilization is ensured. The flowers of Pratia, Lobelia, and Colensoa, are similar to those of Wahlenbergia. In Pratia, the white corolla is provided with purple guide-lines, leading back to the honey-glands at the base of the flower.

\section{Genus Lobelia.}

Erect or ascending, milky herbs. Leaves alternate. Flowers racemose or axillary. Corolla-tube split to the base down the back, 2-lipped; ovary 2-celled. Capsule usually dehiscing by 2 valves at the top. (Named after a Flemish botanist). A large and widely-spread genus, of which several species are commonly grown in gardens. $3 \mathrm{sp}$. 


\section{Lobelia anceps (The Doubtful Lobelia).}

A herb, 6 in.-12 in. high. Stems triangular. Leaves 1 in.-3 in. long. spathulate or oblong. Flowers $\frac{1}{4}$ in. long, pale blue, on short axillary peduncles. North Island, and northern part of South Island. L. Roughii is a remarkable alpine and sub-alpine species, from the mountains of Nelson.

\section{Genus Colensoa.}

This genus is separated from Lobelia, on account of the berried fruits. $1 \mathrm{sp}$.

\section{Colensoa physaloides (The Physalis-iike Colensoa).}

Stem flexuose, branched, $2 \mathrm{ft} .-3 \mathrm{ft}$. high, woody at the base. Leaves alternate, membranous, ovate, with petioles 3 in.-6 in. long. Racemes 6-12flowered; corolla 1 in.-2 in. long, blue. Berry $\frac{1}{2}$ in. in diameter. Northern parts of Auckland province. (Physalis is the Cape Gooseberry).

\section{Goodeniaceae.}

\section{The Goodenia Family.}

A small family of chiefly Australian and Polynesian plants, differing only from the Campanulaceae in the absence of milky juice, and in the presence of a pollen-cup ( $v$. Sellier $a)$.

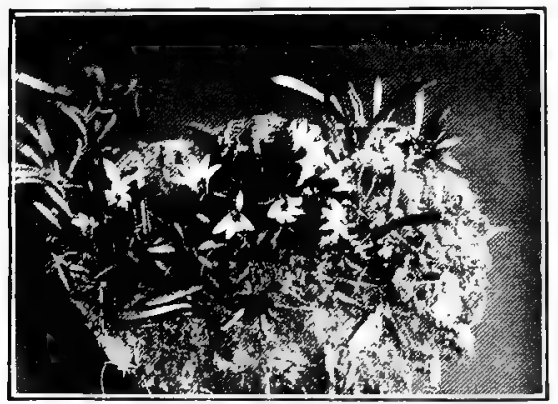

Fig. 136. Selliera radicans ( $\frac{1}{4}$ nat. size).

\section{Genus Selliera.}

Small, hairless, rather fleshy, creeping herbs. Corolla 1-lipped, split posteriorly to the base. Stamens 5, epigynous, anthers free. Ovary 2-celled, style simple, carrying at its apex a small 2lipped cup. Fruit a berry. $1 \mathrm{sp.}$

\section{Selliera radicans}

\section{(The Rooting Selliera).}

Stems juicy, 2 in.-10 in. long. Leaves $\frac{1}{2}$ in.-Bin. long, spathulate, obtuse, entire, petiole half-clasping the stem. Flower-stalks solitary, or several together, 1- or 2-flowered. Flower $\frac{1}{3}$ in. long. Berry very variable in size. FI. Nov. Jan. Both islands, abundant in the salt meadows. 
The plant is found abundantly in the salt marshes along the coast line; often forming, with Samolus littoralis, a carpet starred with white flowers, just above high water mark, on the edges of the estuaries and salt-water lagoons. Its method of pollination is most interesting;".

The little white flower has a curiously one-sided appearance, and the casual observer almost invariably thinks that half the corolla is torn away.

\section{Compositae.}

The Daisy, Dandelion, and Thistle Family.

Distribution.--This is the largest family of flowering plants, comprising 12,000 species. Some of the species contain a milky, acrid juice. Under cultivation, many of the Compositae produce so-called "double" flowers, e.g. the disk florets, usually tubular, tend to become ligulate or rayed. This is seen in the Daisy, the Chrysanthemum, the Dahlia, etc.

The Chicory, the Endive, the Artichoke, and the Lettuce, are also members of this family.

\section{Contrivances for Pollination and Seed Dispersal.}

A family which includes nearly ten per cent. of all the known flowering plants must be one which is well fitted to survive in the struggle for existence, and is likely also to represent a highly developed type. Indeed, the Composites are generally regarded as being at the head of the Vegetable Kingdom. It is worthy of note that the majority of the species are herbs, though, amongst the New Zealand forms, there is an unusually large percentage of shrubs. Very often they are plants with radical leaves.

In such a successful family, it might be anticipated that the various devices for pollination and distribution of the seed would cause diversity of structure, but the characters of the 
flowers and seeds are remarkably constant. This is, doubtless, due to the fact that the contrivances employed for pollination and seed-distribution, though comparatively simple, are yet highly efficient. The family may be contrasted in this respect with the Orchidaceae, (q.v.). In spite of there being many and most complex adaptations for pollination among the orchids, yet their flowers are often sterile, and species have to rely for survival upon the occasional production of large numbers of seeds in a single capsule. In the Composites, on the other hand, each pistillate floret produces only one seed, and many florets are abortive. Nevertheless, some of the species (e.g. dandelions, thistles, etc.) are amongst the most abundant weeds known. No plants are more often victorious in competition with their rivals, or better adapted for offensive warfare.

The chief contrivances by which the success of the family has been procured are the following. The involucral bracts replace the calyx, and protect the flower-head as a whole in the bud, and also as a rule bend up and enclose the young fruit. The sex of the florets varies in different species. Commonly, however, the ray florets are pistillate, and the disk florets hermaphrodite. Not infrequently, however, the florets of the ray are sterile, and therefore only of value in attracting insects. The first obvious gain in the massing together of the flowers in heads is conspicuousness. Another advantage is that insects may pass from flower to flower without loss of time.

Cross-pollination is thus effected in the family. Honey is secreted by a ring of glands round the base of the style. When the flower opens, the style-arms are closed. The stamens ripen first, and the pollen falls upon, and is carried up by the still growing style through the anther ring. Any insects now visiting the flower must come in contact with it on entering, and remove some of the pollen. Finally, the arms of the style expand, and expose the now mature stigmas. Should these 
fail of insect pollination, they frequently curl back, until they touch the pollen collected on the style itself, and thus effect self-pollination. These stages may be readily followed in the

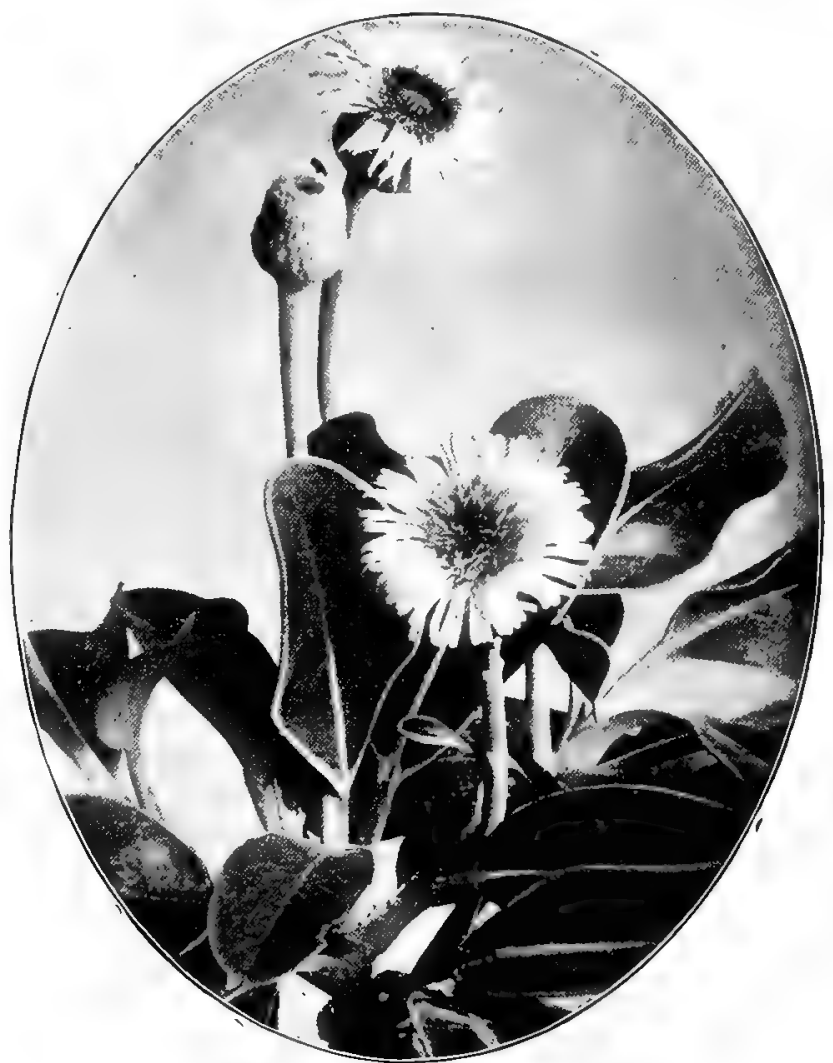

Fig. 137. Olearia insignis ( $\mathrm{gat}$. size).

dandelion. ( $c f$. also Campanulaceae, p. 403). After pollination, the calyx tube usually grows upwards, bearing on its summit a parachute of bristles or hairs (the pappus). In this way the well known "clock" of the dandelion is formed. The pappus hairs vary considerably in character, and generic distinctions are sometimes based upon their differences. The 


\section{seed, thus provided with down, may be floated for long distances by the wind.}

\section{Key to the Genera.}

1. Flowers of the disk not strap-sbaped. No milky juice.

All flowers strap-shaped. Milky juice present.

2. Anthers obtuse at the base, or shortly tailed.

Anthers sagittate at the base, or long tailed.

3. Stignus flattened with marginal rows of papillae, and terminal hairy unreceptive portions.

Style arms usually truncate, rarely produced into appendages, generally with a crown of long hairs at the base.

4. Pappus 0 or obscure.

Papluns present.

5. Achenes contracted into a short beak.

Achenes obtuse or truncate.

6. Achenes rounded or slightly flattened.

Achenes much flattened. Ray-tlorets in 2 or more series.

7. Surubs or trees.

Herbs with radical leaves.

8. Florets 1.

Florets niore then 1.

9. Herbs with heads on erect racemose scapes.

Herbs with solitary terminal heads.

10. Head solitary on a slender peduncle.

Heads deeply sunk amongst the apical leaves.

11. Pappus 0, ox abortive.

Achenes usually crowned with a bristly pappus.

1.. Heads pedunctulate, or mossy alpine herbs.

Heads axillary, sessile, not mosslike herbs.

13. Heads vedunculate.

Alnine herbs with sessile or sub-sessile heads.

14. Outer florets small, two lipped. Anthers shortly tailed. Shrubs.

Outer florets filiform, ligulate or tubular.

15. Herbs, outer florets in two or three series, filiform.

Herbs or shrubs, inflorescence terminal, outer florets ligulate or tubular.

15. Anthers sagittate.

Anthers usually with long, slender tails.

17. Annual or verennial herbs.

Shrulss, cusbion like, or with alternate leaves.

1r. Paplous bristles capillary, in 1 series, often slightly united at the base.

Pappus hairs as long as the florets, plumose, head conpound with a common involucre.

11. Cushion-like, or tufted plants.

Unrisht shruls with alternate leaves.

20. Pappus, or at least some of it, of plumose bristles. Pappus of simple bristles.

21. Achenes angled, spinulose, and prolonged into a beak. tchenes rounded, narrowed above and not beaked.

2

20

3

16

4

11

5

6

Lagenophore, p. 410.

Brachycome. p. 410.

7
10
8
9

Olearia Forsteri, p. 415.

Olearia, p. 411.

Pleurophyllum, p. 417.

Celmisia, p. 418.

Vittadinia, p. 411 .

Haastia, p. 423 . 12

14

13

Centipeda.

Cotula, p. 434

Abrotanella.

Brachyzlottis, p. 435 . 15

Erechtites, p. 434.

Senecio, p. 436.

Helichrysum, p. 430.

17
18
19

19

Gnaphalium, p. 425.

Craspedia, p. 433 .

Raoulia, p. 425.

Cassinia, p. 433.

Picris.

\section{1}

Taraxacum.

Crepis.

The genera Centipeda, Abrotanella, Picris, Crepis, and Taraxacum (the dandelion) are not further dealt with. 


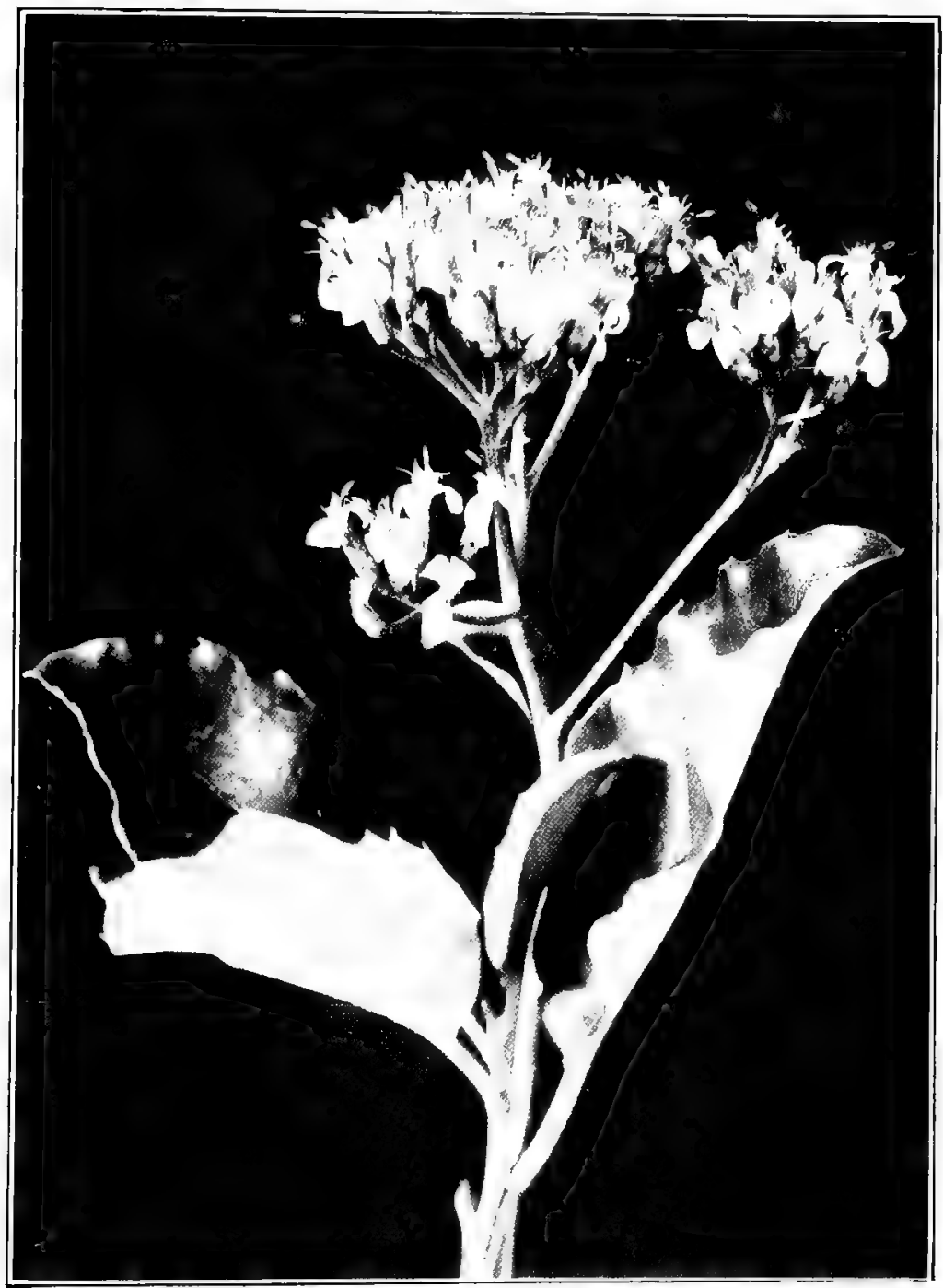

Fig. 138. Olearia furfuracea (life size). 


\section{Genus Lagenophora.}

Small, perennial, daisy-like herbs. Leaves radical, rarely cauline. Rayflorets white, rarely purple. Disk-florets yellow. Achenes compressed, sometimes with a short beak. Pappus 0. (Name from the Greek, signifying $a$ flagon and to bear, in allusion to the form of the achenes). $6 \mathrm{sp}$.

\section{Lagenophora Forsteri (Forster's Lagenophora).}

Leaves roundish, obtuse, lobed or crenate. Flower-stem 1 in.-6 in. long, slender. Heads $\frac{1}{4}$ in. $-\frac{1}{2}$ in. across. Ray-florets numerous, white. Achenes beaked. Both islands. Kermadecs, Stewart Island, Chatham Island. Native Daisy: Maori name Papataniwhaniwha. Fl. Oct.-Jan.

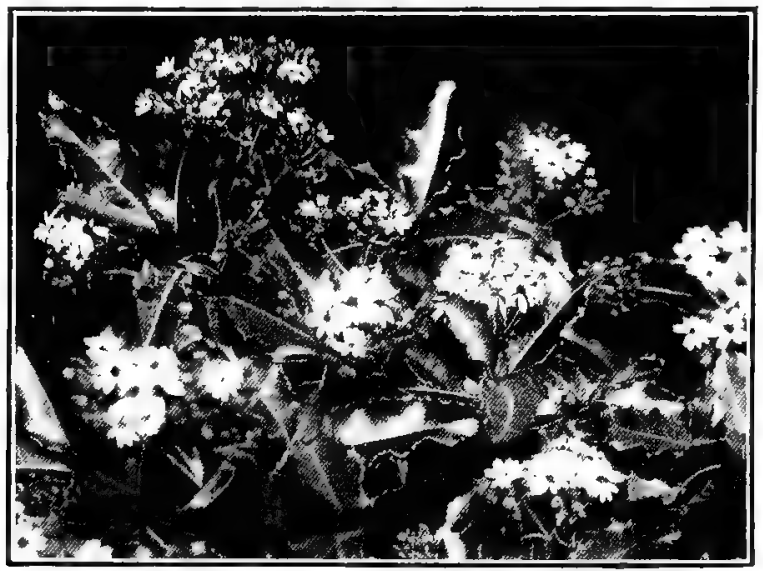

Fig. 139. Olearia ilicifolia (1 nat. size).

\section{Genus Brachycome.}

Small, tufted, perennial, daisy-like herbs. Leaves mainly radical. Diskflorets numerous; ray-florets in 1 series, white, blue or purplish, revolute. Achenes flat, with winged margins or 4-angled; beak 0 . Pappus of short bristles or 0 . (Name from the Greek, signifying short-haired, in allusion to the pappus). $5 \mathrm{sp.}$

\section{Brachycome Sinclairii (Sinclair's Brachycome).}

A shining herb, with radical leaves, 3 in.-3 in. long, rounded at the tip, entire, lobed, pinnatifid. Flower-stems 2-6. Heads $\frac{1}{3}$ in, across. Bracts of involucre green, or with purple margins. Achenes very small, shining. Native Daisy. Both islands. Fl. Dec.-Feb. 


\section{Genus Vittadinia.}

Herbs, with a woody rhizome. Ray-florets numernus; disk-florets fewer. Achenes narrow, compressed, ribbed. Pappus unequal. A geuus of about thirteen species, chiefly natives of the Sandwich Islands. $1 \mathrm{sp}$.

\section{Vittadinia australis (The Southern Vittadinia).}

Stems 3 in,-10 in. high. Branches slender, leafy. Leaves $\frac{1}{3} \mathrm{in},-\frac{1}{3} \mathrm{in}$. long. Head solitary, terminal. Rays white. Fl. Oct.-Feb.

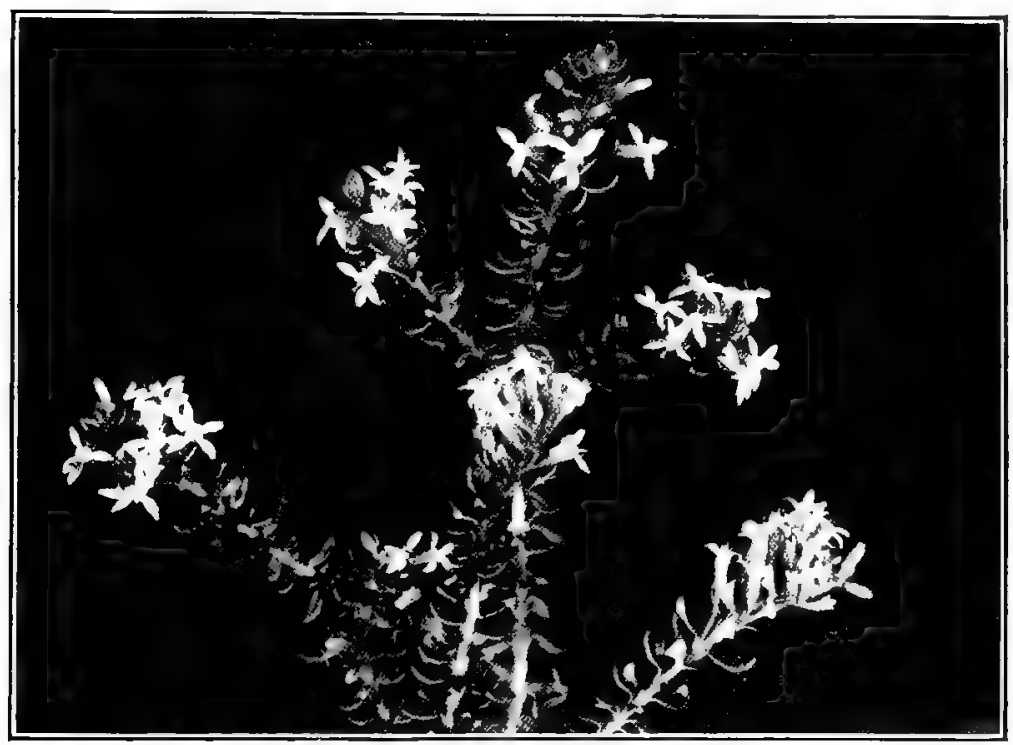

Fig. 140. Olearia nummularifolia ( $\frac{2}{3}$ nat. size).

\section{Genus Olearia.}

Shrubs or trees. Leaves very hard, leathery, usually white or buff-coloured on the under-surface. Heads terminal or axillary, varying much in size. Florets usually numerous, 5-lobed. Anthers 5. Pappus of one or more rows of hairs. Achenes ribbed. (Name from Olea, the Olive, in allusion to the shape of the leaves, in some of the species.) $35 \mathrm{sp}$.

Distribution.-This is a large New Zealand and Australian genus of shrubs and trees. All the New Zealand forms, however, are endemic, thus indicating that the Australian species have long been separated from ours by the Tasman Sea. Some of the most beautiful of the New Zealand shrubs belong to this genus. As in most genera with many species, a great amount of variability is found. Thus Dr. Cockayne* points out that in O. semidentata of the Chatham 
Islands, the leaves show great variation in several respects. The proportions, and actual size, not only vary largely, but some bear abundant tomentum on the upper surfaces, there being none in others. Three plants growing side by side in the vicinity of Lake Rangatapu might readily have been taken for distinct species, yet the conditions under which they were growing appeared to be the same.

In large genera, such as Veronica and Coprosma, the variability is so great that it is most difficult to fix the limits of the species. The same difficulty presents itself in Olearia; but will to some extent be removed when our knowledge of the genus is fuller than at present. Several species are known only from a few specimens, and others are extremely local in their distribution. This is the more remarkable, as the pappus with which the seeds are provided is eminently calculated to scatter the species widely. Some of the finest plants in the genus are endemic in the off-islands. Thus $O$. semidentata is found only on the Chatham Islands. It bears handsome flowers of a bright purple, whose colour is a striking contrast to the white of other species. According to Mr. Cox, a white-rayed form is, however, sometimes found. But this is not the only Olearia endemic to these islands. O. Chathamica, which somewhat resembles the magnificent $O$. angustifolia and $O$. Traversii, with opposite leaves, are also found nowhere else. The latter was originally mistaken by Dieftenbach for the Mangrove (Avicennia officinalis), which it slightly resembles. Many specimens of it are to be seen in the Christchurch Gardens, and there are also several wellgrown plants beside the Hereford Street Bridge in the same town. O. operina is only known from the Sounds on the West Coast of Otago. O. angustifolia-a beautiful plant, whose flowers have white rays and a violet disk is found chiefly in exposed places near Paterson's Inlet (Stewart Island), though it has been reported from south-west Otago. O. Traillii, another noble species, is known only from one or two localities on the mountains at the head of Paterson's Inlet; O. Lyallii is endemic in the Snares and Auckland 


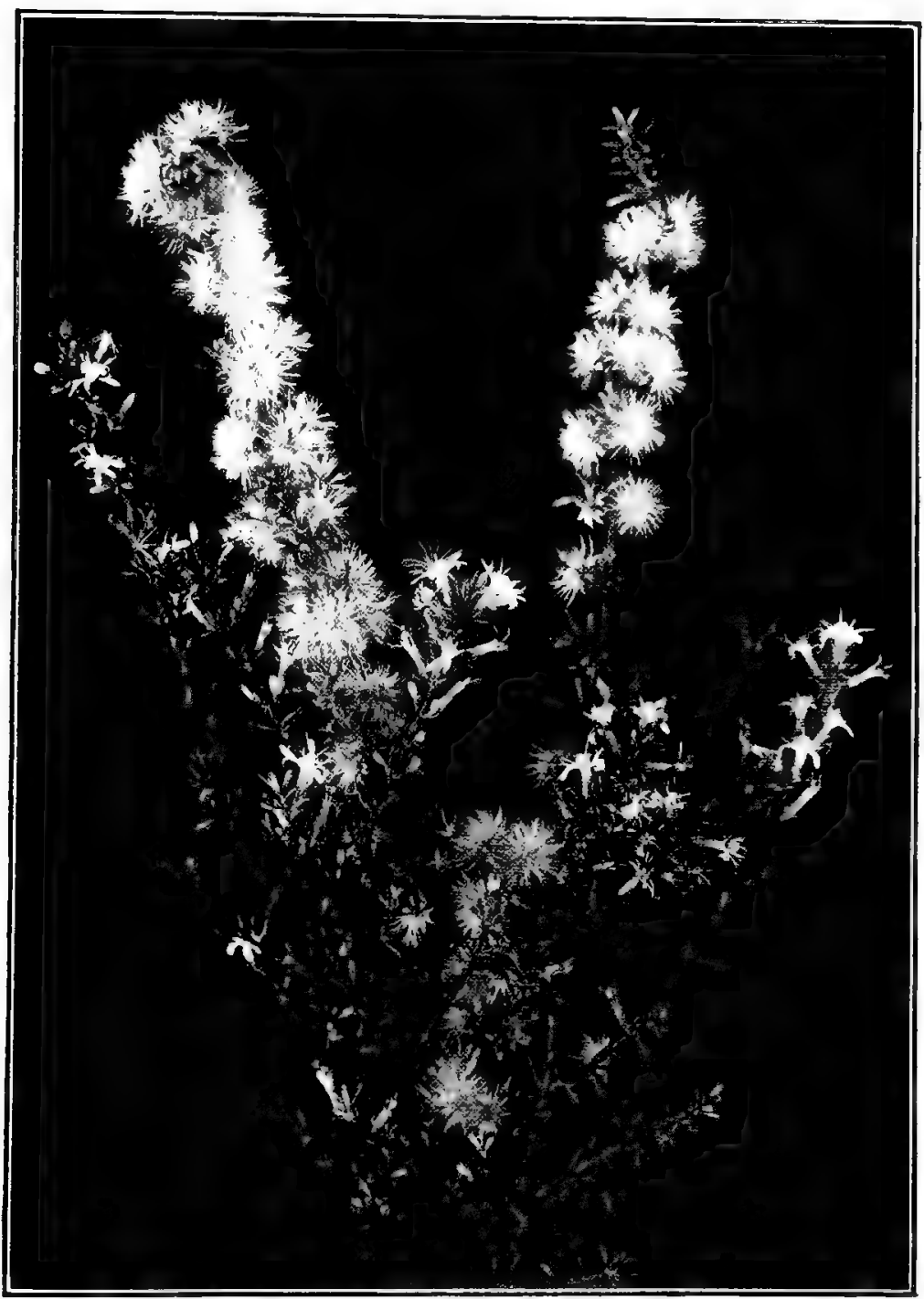

Fig. 141. Olearia virgata, var. aggregata (a nat. size). 
Islands, where it forms thickets. It is a plant with large leaves, green on the upper surface, and covered with a white tomentum below. The effect of the wind on a forest of such plants has been well described by a New Zealand poet (Mr. A. H. Adams).

\footnotetext{
"As the leaves to a fiercer gust lean,

The wind throws their undersides

Upwards to sight;

And the foam of the forest-sea flashes to white, Out over full fathoms of green."
}

O. Buchanani appears to be known from one specimen only, and cones from an uncertain locality in the North Island. O. Allomii is a distinct species from Great Barrier Island. O. angulata has only been reported from the North Cape district. There is considerable reason for believing that this locality was in recent times, - geologically speaking, - an island, and, as such, it appears to have possessed several endemic species in addition to this one, e.g., Cassinia amona, Haloragis cartilaginea, and a Coprosma. Several other species of Olearia are, apparently, very rare.

This remarkable development of endemic species in the offislands of New Zealand, undoubtedly suggests that we have in these, new forms originated by isolation. The distribution of the genus, therefore, well illustrates initial endemism, and may be contrasted with such a form as Stilbocarpa polaris (v. p. 301), which illustrates relict endemism.

\section{Olearia semi-dentata (The Toothed Olearia).}

A small, slender shrub, $1 \mathrm{ft} .-2 \mathrm{ft}$. in height. Leaves white below, thin, $1 \mathrm{in} .-2 \frac{1}{2}$ in. long, $\frac{1}{4} \mathrm{in} .-\frac{1}{3} \mathrm{in}$. liroad, acute, partially serrate. Heads numerous; ray-florets purple. Chatham Islands, Fl. Nov,-Dec. A bog plant.

\section{Olearia insignis (The Remarkable Olearia).}

A shrub, $1 \mathrm{ft} .-8 \mathrm{ft}$. in height. Leaves $3 \mathrm{in.}-5 \mathrm{in}$. long: $1 \mathrm{in.}-4 \mathrm{in}$. broad, very thick, shining above, white below. Heads terminal, $3 \mathrm{in}$ across. Rays narrow. Achenes silky. Pappus-hairs in one series. The finest species of the genus. South Tsland: Nelson and Marlborough. Fl. Dec.-Jan. 
This is a straggling plant growing in the crevices of the rocky banks of the Clarence, Conway, and several other rivers. The leaves are white underneath, and a beautiful glossy green shines through the greyish bloom of the upper surface. The white involucral bracts are in a large series of rings, and forn a cup-like envelope to the flower, similar in shape to that of the Scotch thistle. The large, beautiful, daisy-like flowers, with their ragged white rays, seem strangely out of place in

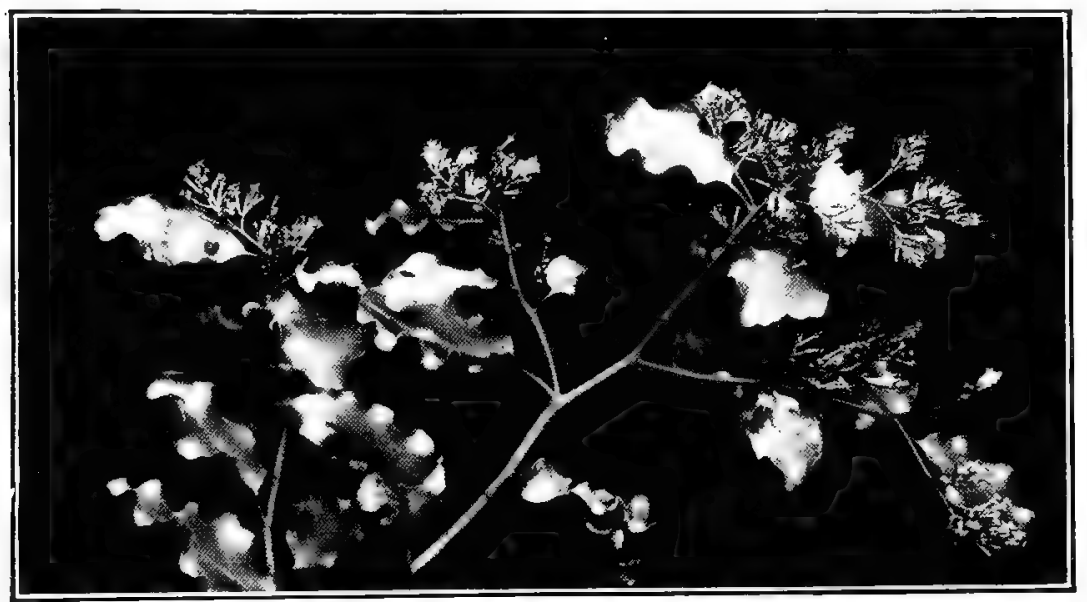

Fig. 142. Olearia Forsteri ( $\frac{1}{4}$ nat. size).

the blaze of the sun on the dry, burning, rocky walls of some river gorge.

Olearia furfuracea (The Bran-like Olearia).

A shrub or tree, $6 \mathrm{ft} .-20 \mathrm{ft}$. in height. Leaves $2 \mathrm{in.}-3 \mathrm{in}$. long, $1 \frac{1}{4} \mathrm{in} .-2 \frac{1}{2} \mathrm{in}$. broad, obtuse, rarely acute, margins often unequal at the base, silvery below. Branches velvety, twigs grooved. Corymbs large, loose. Heads 1 in. long; florets 8-12. Ray-florets white; pappus white. Achene slightly hairy, angled. North Island: Auckland, Taranaki, Mokau River. Fl. Sept.-Oct. A bush plant.

\section{Olearia nitida (The Shining Olearia.)}

Leaves less leathery than in $O$. furfuracea, and more ovate in shape; very silvery below. Heads $\frac{1}{6}$ in. $-\frac{1}{1}$ in. long, numerous. Florets 16-20. Both islands. Fl. Dec.-Jan. A bush plant. 


\section{Olearia macrodonta (The Large-toothed Olearia).}

A small tree, $6 \mathrm{ft} .-20 \mathrm{ft}$. in height. Leaves and branchlets whitish. Leaves 2 in. -4 in. long, 1 in, $-1 \frac{1}{2}$ in. broad, acute; veins divergent. Corymbs large: heads $\frac{1}{4}$ in. long; florets $8-12$; rays $3-5$. Achenes ribbed, hairy. Both islands: mountainous places. Fl. Jan. The whole plant emits a musky scent.

\section{Olearia ilicifolia (The Holly-leaved Olearia).}

Leaves glaucous, musk scented, 3 in.-4 in. long, th in.-妾 in. broad, acute margins with spinous teeth, yellowish below. Corymbs large, musk-scented. Disk-florets 5-6: rays 5-7. Achenes ribbed, hairy. Both islands. Fl. NoviJan. Nuch cultivated.

\section{Olearia moschata (The Musky Olearia).}

A shrub or tree, $5 \mathrm{ft} .-14 \mathrm{ft}$. in height. Leaves white below, $\frac{1}{3} \mathrm{in} .-\frac{3}{4} \mathrm{in}$. long, obtuse, leathery. Cormbs $2-4$ times as long as the leaves. Heads few, florets 12-20, rays 7-12, long, white. Achenes ribbed, silky. South Island: local, Fl. Jan.-March.

\section{Olearia avicenniæfolia (The Avicenia-leaved Olearia).}

Branches grooved. Leaves $1 \frac{1}{2}$ in. -4 in. long, $\frac{3}{4}$ in. $-1 \frac{1}{2}$ in. broad, narrowed at both ends, white below. Heads small. Ray-florets 1, rarely 2, ray broad: diskflorets 2. Achenes silky. Pappus-hairs in one series. South Island: Stewart Island. Fl. Jan.-Feb, Much cultivated.

\section{Olearia virgata (The Thiggy Olearia).}

A twiggy shrub, often forming thickets. Leaves $\frac{1}{4}$ in. $-\frac{1}{2}$ in. long, opposite, leathery, white beneath. Heads $\frac{1}{4}$ in. across; florets 7-12, white. Achene slabrous. Pappus white or reddish. Both islands. Fl. Nov,-Jan. A plant of the open country or seashore.

\section{Olearia Forsteri (Forster's Olearia).}

Stem $5 \mathrm{ft} .-20 \mathrm{ft}$. in height. Leaves $1 \frac{1}{2} \mathrm{in.}-3 \mathrm{in.}$ long; $1 \mathrm{in.}-2 \mathrm{in.} \mathrm{broad,}$ leathery, oblong, white below, obtuse, margins waved. Heads numerous, ressile, shining. Anthers exserted. Both islands. Fl. Apr.-May. Maori name Akiraho, A plant of the open country, or edge of the bush.

\section{Genus Pleurophyllum.}

Large, succulent herbs. Leaves mainly radical, with strongly-marked ribs. Flowers in racemes, on a long scape. Florets numerous. Achene marked with lines, and set with stiff hairs. Pappus-hairs in 3 series. Name from the Greek, meaning ribbed-leaved). $3 \mathrm{sp}$. 


\section{Pleurophyllum}

(The Handsome Pleurophyllum).

Leaves all radical, 6 in.18 in. long, $6 \mathrm{in.}-10 \mathrm{in.}$ broad, usually flat upon the ground, forming a large rosette, bristly above, woolly below. Flower stems with several leafy bracts. Heads $8-20,1 \frac{1}{2}$ in. $-2 \frac{1}{2}$ in. across. Ray-florets purplish-white, handsome. Achenes covered with stiff hairs, all lying in one direction. Pappushairs not thickened upwards. Auckland and Campbell Islands. Fl. Dec.Jan.

\section{Pleurophyllum criniferum}

(The Hairy Pleuro-

$$
\text { phyllum). }
$$

Radical leaves, $1 \mathrm{ft} .-4 \mathrm{ft}$. long, 4 in. - 12 in. broad, entire, with long sheathing petioles, white beneath, slightly rough above. Nerves 7-15; margins with a few distant teeth. Scapes $2 \mathrm{ft}$. - $6 \mathrm{ft}$. high, grooved. Stem-leaves sessile, white. Heads 15-30. Ray-florets inconspicuous. Achenes as in P. speciosum. Pappushairs slightly thickened upwards. Antipodes Islands. Auckland and Campbell Islands. Fl. Dec.-Jan.

The Auckland Islands contain a magnificent assemblage of herbaceous

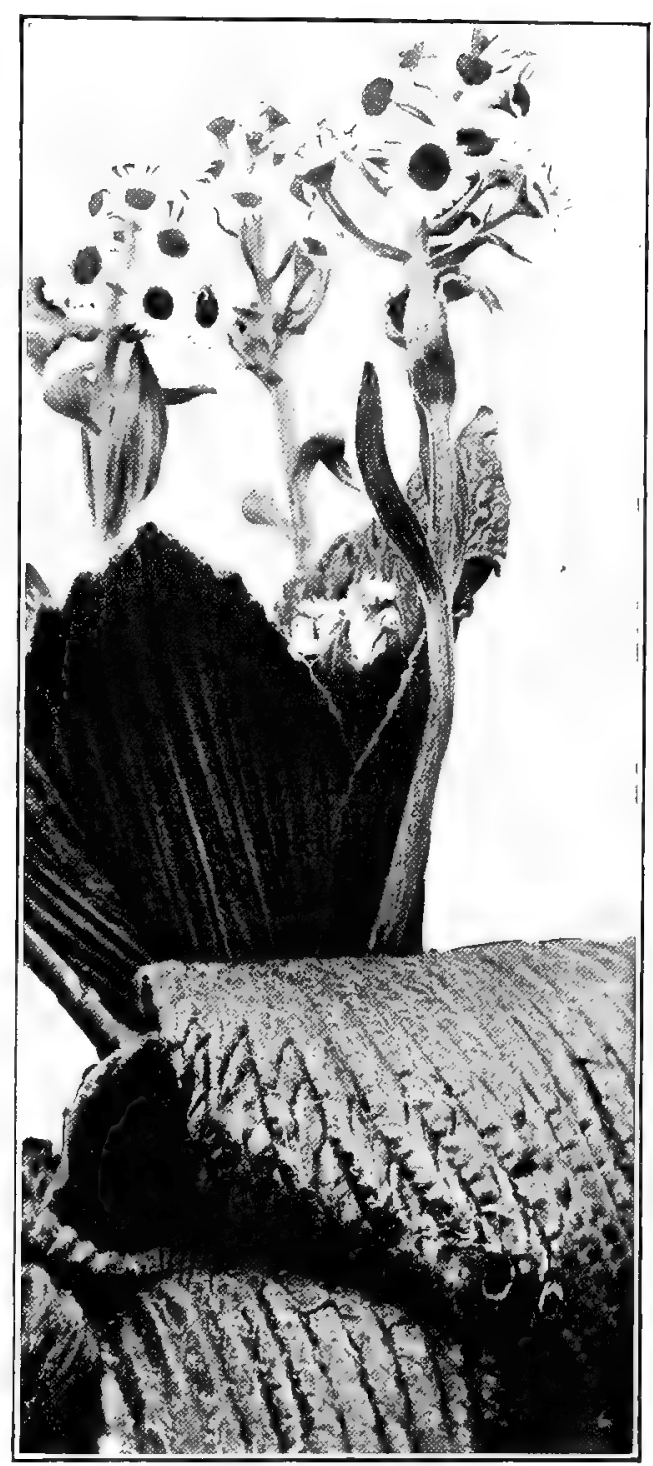

Fig. 143. Pleurophyllum speciosum. 
plants, unrivalled in beauty on the mainland of New Zealand. Amongst them. are several species belonging to the endernic genus Plewoplyllum. The general appearance of these plants is well described by Kirk.*

\section{Genus Celmisia.}

Herbs, aster-like, with radical, simple leaves, more or less clothed with silky ol cottony hairs. Stems 1-flowered. Heads large. Ray-florets white. Pappus of 2 series of rigid bristles. Achene glabrous or silky. A beautiful genus, of which all but 2 species $(C$. longifolia, and $('$. Lechleri) are endemic in New Zealand. Of these, $C$. longifolia is found both in New Zealand and Australia, and $C$. Lechleri is a doubtful Peruvian species, $43 \mathrm{sp}$.

\section{Celmisia coriacea (The Leathery Celmisia).}

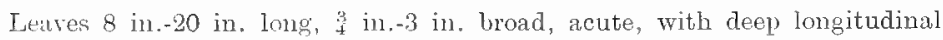
furrows, sheathing at the base, woolly above, silvery below. Flowering-stem $6 \mathrm{in},-36 \mathrm{in}$. high. Head $1 \frac{1}{2} \mathrm{in} .-4 \mathrm{in}$. across; bracts numerous, cottony. Achene

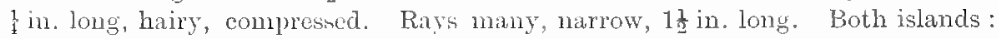
mountainous districts. The Mountain Daisy. Fl. Dee-March.

\section{Celmisia Monroi (Monro's Celmisia).}

Leaves 3 in.-7 in. long, $\frac{1}{3}$ in.-3 in. broad, acute, white with wool. Sheath half as long as the blade. Flower-stem very woolly. Heads $1 \mathrm{in}$. $-1 \frac{1}{2}$ in. across. Rays few, spreading. Achene glabrous. Both islands. Fl. Dec.-Jan. A species nidway between $C$. coriacea and $C$. longifolia.

\section{Celmisia longifolia (The Long-leaved Celmisia).}

Leaves 1 in.-16 in. long, $1^{1}$ in.-. below. Head $\frac{1}{2}$ in.-11 in. broad, bructs often black at the tips. Achene glabrous or silky. Both islands; Stewart Islind. Fl. Dec--MIarch.

\section{Celmisia vernicosa (The Varnished Celmisio).}

Leaves in rosettes, sessile, $1 \mathrm{in},-4 \mathrm{in}$. long, $\frac{1}{6} \mathrm{in.}-\frac{1}{4} \mathrm{in}$. broad, thick, rigid, vonetimes slightly serrate at the tip. Flower-stem $1 \mathrm{in.-8}$ im. high, with broad lracts. Disk-florets purple, rays white. Achene roughly hairy. Very shining in all its parts. Auckland and Campbell Islands. Fl. Nov.-Dec.

Closely allied to the genus Olearia, and differing from it chiefly in habit, is the genus Celmisia. There are some forty species in New Zealand, which, with one exception, are all endemic. The flowers are white, daisy-like, and often very beautiful. Most of the species are found in sub-alpine regions, and hence are temed by the settlers, Mountain Daisies. The leaves are frequently set in a rosette, and are often stiff

"Rejort of the dustralamian Astociation, 1891, 11. 220. 


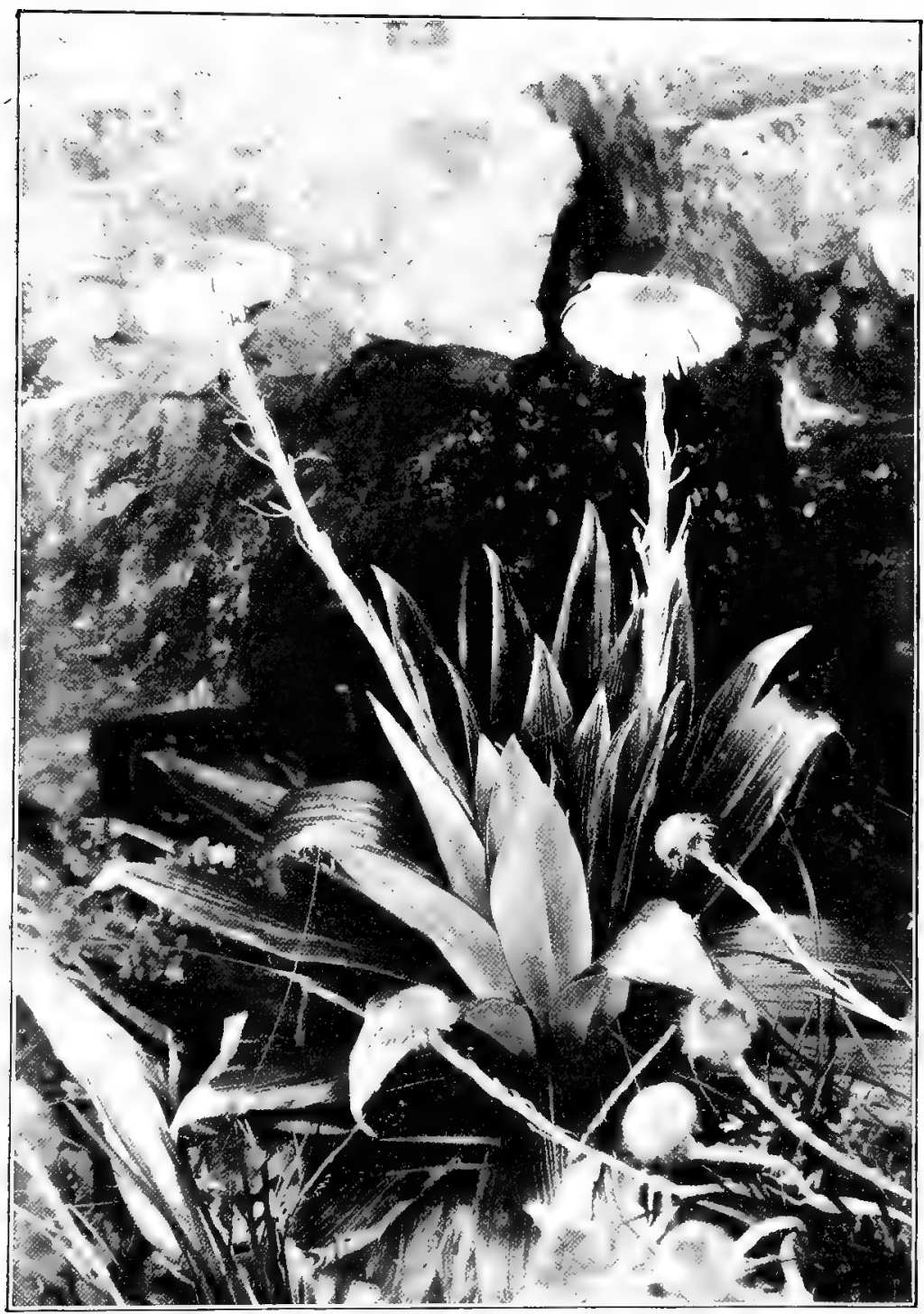

Fig. 14t. Celnisia coriacea (f nat. size). 
and sword-like. They are usually covered with a brown, silvery, silky, hoary, gold-coloured, snowy, or buff tomentum, which makes them extremely attractive in appearance. In some cases, the midrib is also brightly coloured. Thus, in Celmisia Traversii, the leaves and flower stems are covered with a rich brown velvety coating of hairs; the midrib is a deep purple, and the sheath is covered with a silky, snowwhite tomentum. Several species are frequently to be found in cultivation, in rockeries and alpine gardens.

The leaves in most species are constructed so as to avoid excessive loss of water by transpiration. For example, those of $C$. coriacea are stiff and leathery. The lower side is covered with a thick silvery felt of hairs, which also covers the upper sides of the young leaves. As they grow older, however, the tomentum of the upper-side becomes woven into a thin skin that lies close to the surface of the leaf. Underneath this pellicle, lies the two-layered epidermis used for waterstorage. The sheaths are covered with a loose felt, whose thin walled hairs probably absorb the water that runs down to them from the surface of the leaves. This may be of special value to the plant when the ground is frozen in winter, and water cannot reach it through the roots. According to Kirk, shepherds use the tomentum of this plant for lamp-wicks.

C. Lyallii is even more admirably adapted than C. coriacea for an alpine habitat. Indeed, Diels considers the structure of its leaf unique amongst dicotyledons. It has narrow linear leaves, that might be readily mistaken for those of a grass, and which Diels compares in structure to those of a steple grass. True palisade cells are wanting, and are replaced by a chlorophyll-bearing parenchyma of small rounded cells, similax to that found in the leaf of an iris or grass. It is curions that this structure should have been adopted, in a plant of an order so widely divergent from the grasses, but many composites have leaves which externally resemble those of a grass, though it would be very difficult, perhaps impossible, to 


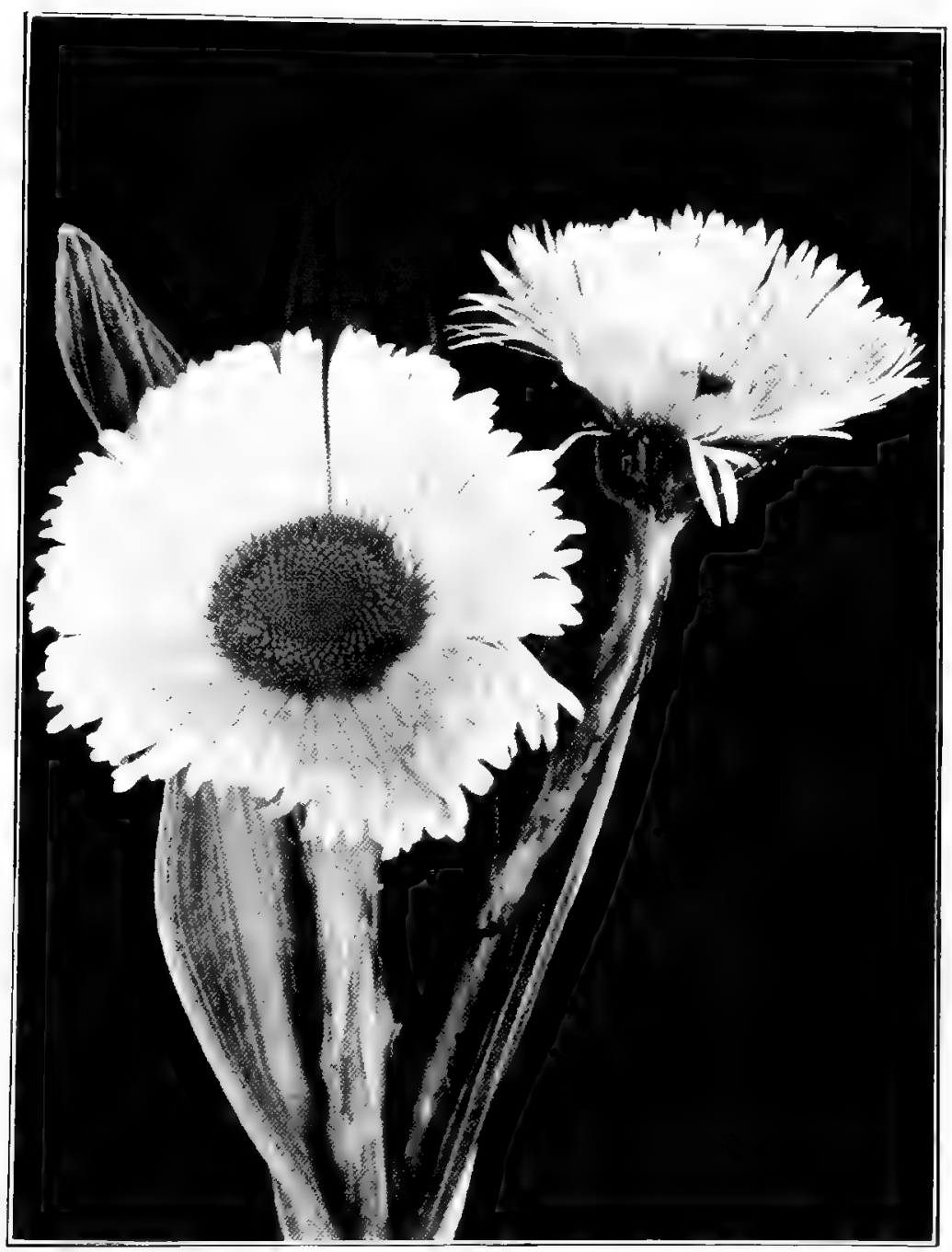

Fig. 145. Celmisia coriaced ( $\frac{2}{3}$ nat. size). 
find one with an internal structure similar to that of the leaf of C. Lyallii. Probably the large palisade cells were insufficiently protected from transpiration, and hence the adoption of the grass-like leaf. The stomata are in hair-filled, longitudinal grooves, on the under surface of the leaf, and thus the exposed transpiration surface is reduced to a minimum.

We have here, therefore, a remarkable example of the principle, that the shape, and general appearance of the foliage, depend to a greater extent upon environment, and less upon heredity, than is generally supposed.

In C. sessiliflora the leaves are reduced to an inch or two in height, and the plant forms broad masses surrounding the flower heads, which are sunk anongst the apical leaves; and in $C$. argentea the leaves have become needle-like and involute. The leaves are also reduced to needles in $C$. lateralis and C. Taricifolia. It is such remarkable adaptations as these, that have enabled Celmisia to become one of the dominant genera of the New Zealand sub-alpine meadows.

Though so highly characteristic of mountain regions, the genus is also found on the lowlands, and by the sea-shore. C. longifolia, for example, in one of its rnany forms, is found throughout New Zealand, from the sea-coast, up to the height of about 5,000 feet. C. Mackaui, however, another very distinct form, is only known with certainty from one spot on Banks Peninsula. There, however, it is fairly plentiful, and is scarcely libely to suffer extinction, unless at the hands of too enthusiastic collector's, so that perhaps it will be wiser not to disclose the exact position of its habitat.

Some of the Celmisias, like many Olearias and other Composites, have varnished leaves. Some also closely resernble the Andean Asters and Erigerons, and this, doubtless, more because of similarity of habitat, than because of affinity. 


\section{Genus Haastia.}

Tufted, woolly shrubs, forming dense masses, sometimes several feet across. This genus differs from Raoulia in having tailless anthers. Flower-heads large, solitary, sunk amongst the upper leaves. Ray-florets female. Disk-florets

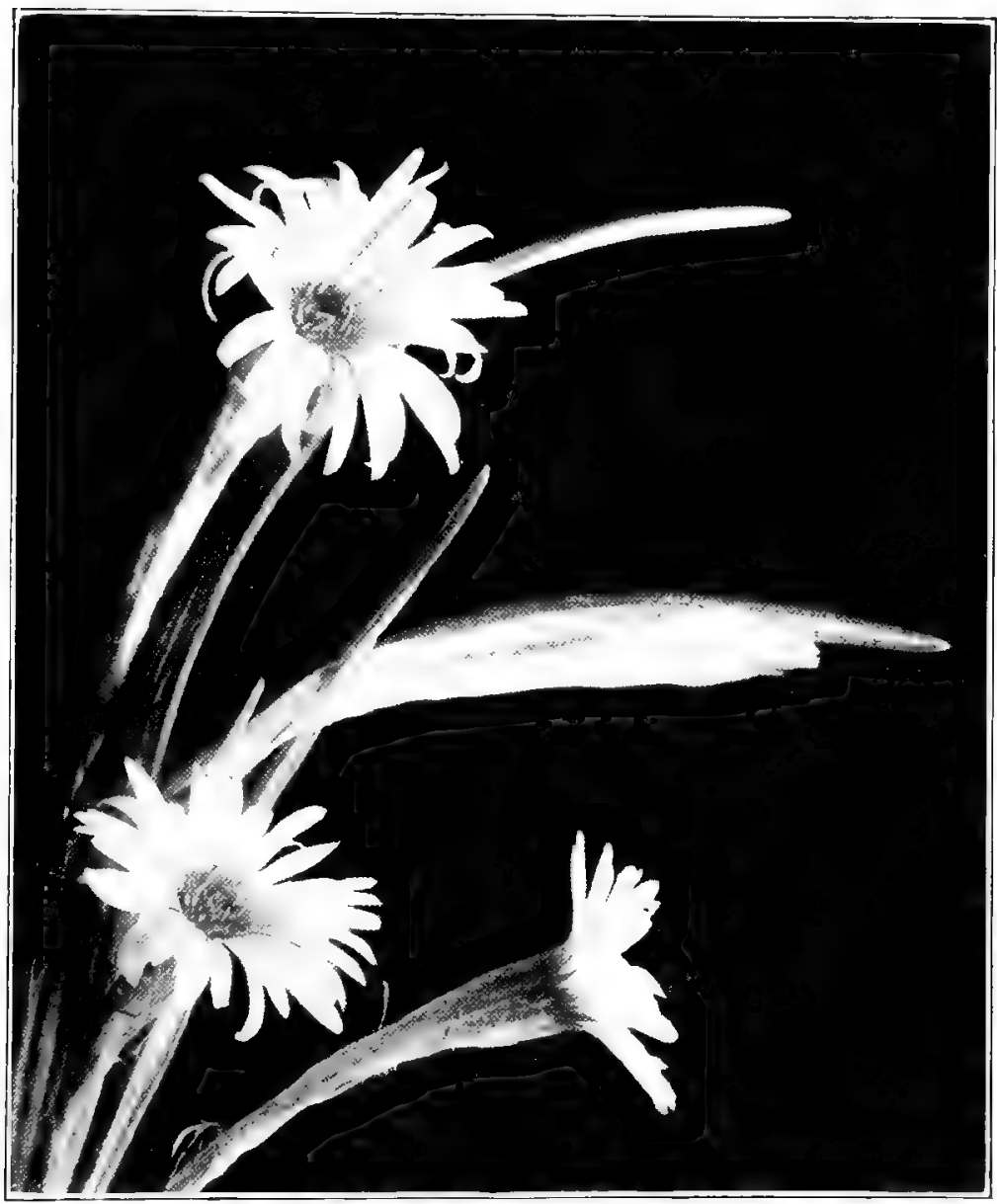

Fig. 146. Celmisia longifolia, var. (洽 nat. size).

numerous. Achene shining, narrow, sometimes ribbed. Pappus-bairs rigid, white. (Name in honour of Sir Julius von Haast). This genus is endemie in New Zealand. $4 \mathrm{sp}$. 
Haastia pulvinaris (The Cushion-like Haastia).

Rootstock woody : plant forming a cushion 3 in. $-5 \mathrm{ft}$. across. Leaves tawny or buff-coloured, with thick, close wool, densely imbricating. Heads $\frac{1}{3}$ in. $-\frac{1}{2}$ in. across. Rays very short. Achene shining. Pappus-hairs free to the base. South Island: mountainous districts. Fl. Jan.-Feb. Colonists' name, Vegetable sheep.

Harstia pulvinaris has been more closely studied than any of the others. It is sometimes incorrectly described as belonging to the shingle-slips, but is really a rock-plant. Though often found at the edges of the fans, and sometimes even surrounded by detritus, it will, if examined, be found rooted to the under-Iying rock. It has been found only on the mountains of South Nelson, and exists there at an altitude of from 5,000 feet to 6,000 feet; it is therefore a true alpine, and, like other alpines, has had to devise special means of protection against the rigours of the climate.

\section{Habrt.}

Haastia is a shrub, but it is as unlike a typical shrub as possible. It has no little twigs to be broken, or slender branches to sway in the wind. It is a compact, low-growing cushion plant, often covering an area of from twelve to twenty square feet. The branches are all of the same height, and so closely fitted together, that it is impossible to thrust a pencil point between them. The wind may sweep round the plant, but it cannot nove or shake it. The leaves of Haastia, however, are its most unique characteristic. They are from $\frac{1}{3}$ in. to $\frac{1}{2}$ in. in length, and so closely packed together as to be matted into a cushion, and indistinguishable from each other, while attached to the plant. Whenever they are exposed, they are thickly felted with long, slender, woolly hairs, that give the plant its characteristic appearance, and its popular name of vegetable sheep. On the tip of the leaf, as might be expected, the covering of wool is densest. One value of this covering is clearly to protect the plant from the intense cold, to which it is exposed. Indeed, its whole structure is evidently not only 
intended "to keep the cold out," but also to protect it from loss of heat by excessive radiation, to the clear cold skies of winter.*

\section{Genus Gnaphalium.}

Woolly or cottouy herbs. Leaves alternate. Heads small, solitary, fascicled, or in corymbs. Florets all fertile, bracts usually white. Achene small, hairy. Pappus-hairs in 1 series, sometimes united at the base. (Name from the Greek, referring to the wool with which the plants are covered). $10 \mathrm{sp}$,

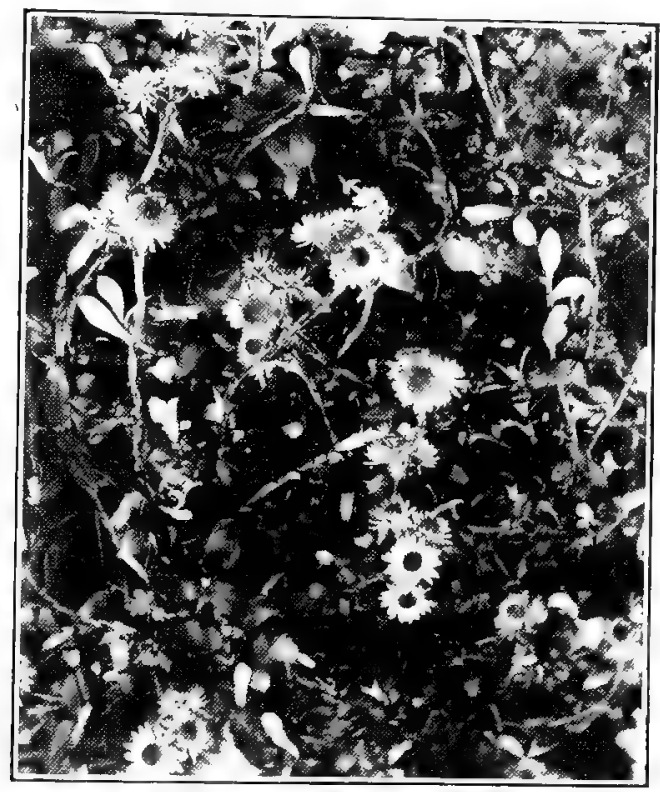

Fig. 147. Gnaphalium trinerve.

\section{Gnaphalium luteo-album (The Yellowish-white Gnaphaliun).}

Annual or biennial. Leaves narrow, $\frac{2}{3}$ in.-2 in. long, woolly, the upper ones without foot-stalks. Heads fascicled, $\frac{1}{6}$ in. $-\frac{1}{1}$ in. long, yellowish-brown. Bracts shining. Achene dotted with pits. Both islands; Stewart Island. Fl. Dec.March. A common weed.

\section{Genus Raoulia.}

Small, tufted, alpine herbs, often growing in dense masses. Leaves very small, imbricate, often silky or woolly. Hends small, terminal, solitary.

\footnotetext{
"v. Trans, XXXII., p. 150 .
} 
Disk-flurets numerous, outer Horets in 1 or 2 series. Pappus of 1 row of hairs. Achene small, oblong. A small genus almost confined to New Zealand. (Named after Raoul, the French botanisth. $17 \mathrm{sp}$.

\section{Raoulia Haastii (Haast's Raoulia).}

A prostrate herb), much tufted. Branches not more than 1 in. high. Leares closely inbricating, $\frac{7}{10}$ in. long, oltuse, coriaccous. Plant glabrous, sometimen with a few loose hairs. Heat $\frac{1}{6}$ in.- $-\frac{1}{5}$ in. long; florets 6-8. Achene slightly hairy. South Island. Fl. Nov.-Dec.

\section{Raoulia eximia (The Extraordinary Raoulia).}

Stems $1 \mathrm{ft}$. in height, forming cushions, sometimes several feet in length. Rootitock woody. Leaves $\frac{1}{3}$ in. long, ilmost hidden by dense tufts of white

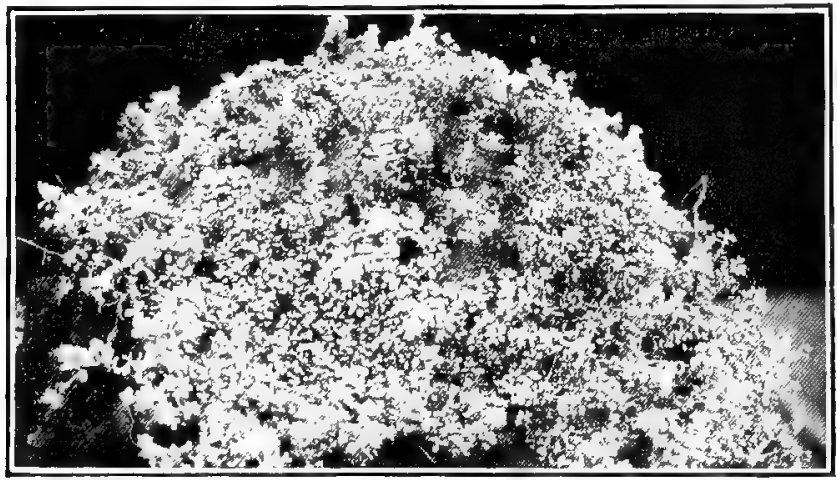

Fig. 148. I Cushion Plant (Raoulle anstralis).

velvety hairs. Heads numerous, terminal, sunk among the leaves. Achene silky. Pappus few-haired. Tegetable sheep. South Tsland: mountainous districts. Fl. Jan.

\section{Raoulia mammillaris (The Breasted Raontia).}

Stems $1 \mathrm{ft} .-2 \mathrm{ft}$. in huight, forming knobby grey patches, sometimes sereral feet in length. Leaver ${ }_{1}^{3} \mathrm{in.}, 1 \mathrm{in}$. long, imbricate, cottony or woolly. Heads $\frac{1}{6}$ in. long, terminal, sunk amongst the leaves. Florets alout ten. Achene compressed, silky. Pappus few-haired. Tegetable Sheep. South Island: mountainous districts.

\section{CUSHION-PLANTS.}

Plants which grow in low, compact masses, are frequently called "cushion-plants," and sometimes "patch-plants." In 


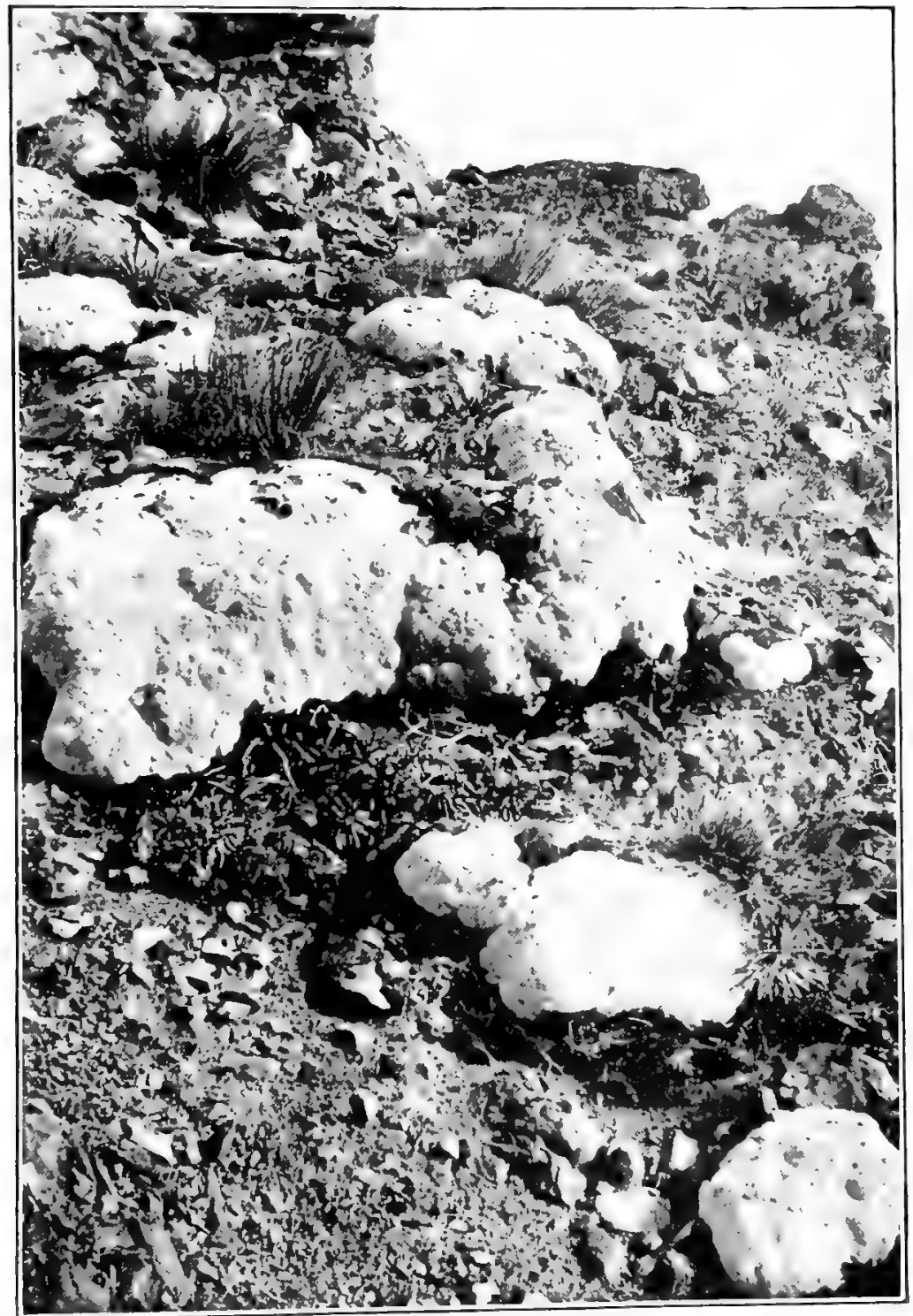

Fig. 149. Reoulia mammillaris. 
many parts of the world there are no examples of these curious and interesting forms of vegetation, except amongst the mosses. In New Zealand, however, there is quite a large number of phanerogamic cushion-plants. The most typical examples are to be found in the genera Raoulia and Haastia. When species of these genera are covered with woolly hairs,

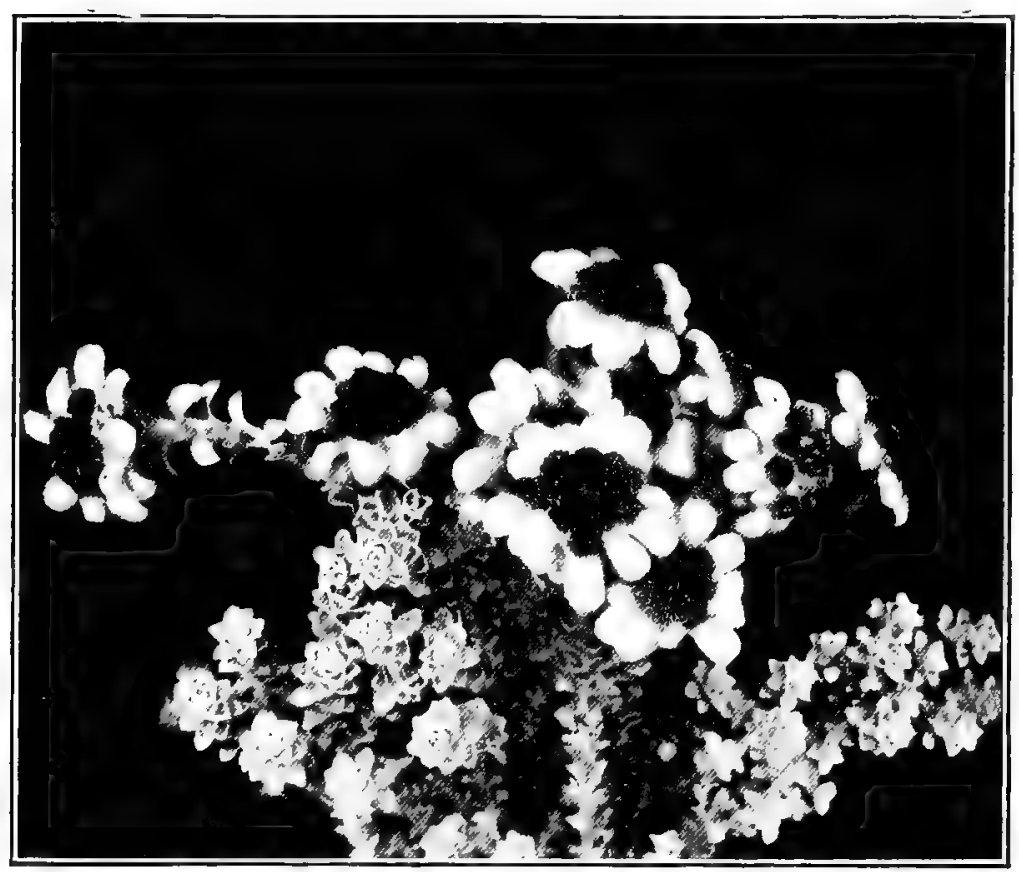

Fis. 150. Helichrysum grandicens (部 nat, size).

they lnay, from a short distance, so resemble a sheep, as to deceive the unwary. Hence has arisen the name, "vegetable sheep," which is applied to the species of Harstia, and to several species of Raoulia. The New Zealand forms of cushion-plant are found chiefly in stony river-beds (e.g. of the Wainakariri, Rakaid, Waitaki), on rocky mountain sides, and also on shingle-fans. Their curious forms of leaf and stem 


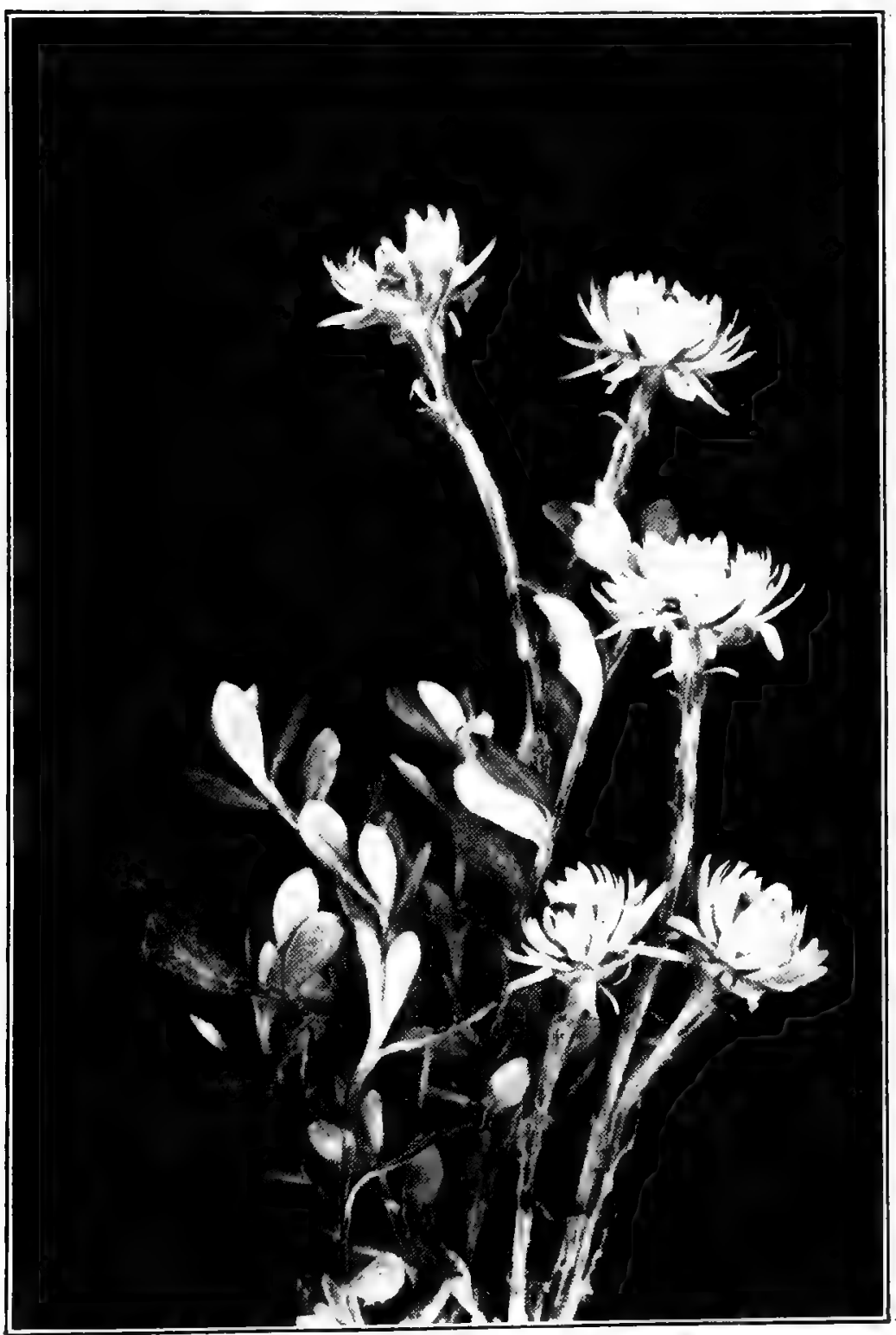

Fig. 151. Helichrysum bellidioides (life size). 
have been developed, probably, as a protection against drought and excessive radiation (v. Haastia pulvinaris, p. 424). In other parts of the world, patch-plants are found chiefly in alpine districts. Their occurrence in low-land regions, as in New Zealand river-beds, is exceptional. In the Swiss Alps they are represented by certain species of Androsace and Saxifraga, which, however, are rather rosette-plants, than true cushion-plants. They are most abundant in the Andes, where, according to Schimper, their representatives are forms of most diverse affinity. This really shows that the common habit of the various cushion-plants is due to environment, and not to relationship. Indeed, the conditions of life in some parts of the Andes, are so similar to those in the Southern Alps, that the vegetation in these widely separated districts is externally much alike. A New Zealander, suddenly put down in the Andes of Peru or Bolivia, might still think himself at home, on account of the similarity of the plant forms about him, to those of his native land. This resemblance, however, is only in small part due to actual affinity, and much more to parallelism of evolution, resulting from similarity of surroundings.

The New Zealand Raoulias are often very beautiful, owing to their symmetry of form and leaf arrangement. Some are coralloid in appearance, though resilient to the tread, like a good carpet. They grow where other forms of life cannot find a footing, and thus have generally plenty of roon to develop their own individuality.

\section{Genus Helichrysum.}

Herls or small shrubs. Leaves altermate, woolly. Heads solitary or in corymbs. Bracts of the involucre often appearing like petals. Disk-florets 4-5-tonthed. Ray-florets few. Pappus-hairs simple, or studded with short bristles. About 16 species in Now Zealand, all endemic. (Name from the Greek, signifying an everlasting flower) $16 \mathrm{sp}$.

\section{Helichrysum selago (The Selago-like Everlasting).}

A shrub, $4 \mathrm{ft} .-9 \mathrm{ft}$. in height. Leaves closely imbricate, leathery, concave, woolly. Hear terminal, sessile, solitary, not sunk amongst the leaves. Florets 


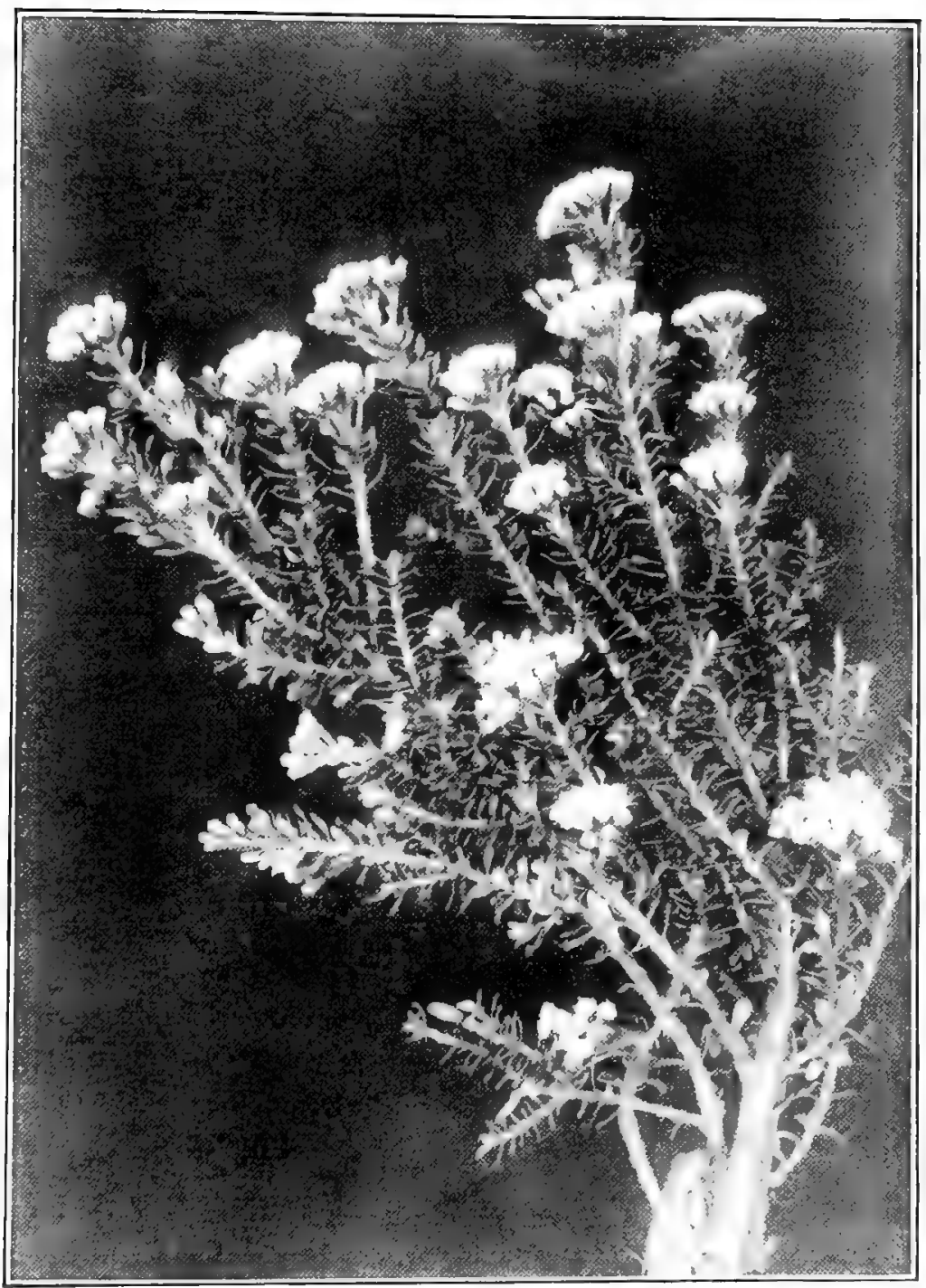

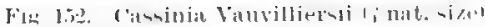


mumerous. Achene slightly hairy. Pappus-hairs not thickened upwards. South Island : Kaikouras, Mount Torlesse, Otago. Fl. Jan. (Selago, a South African genus of plants.)

\section{Helichrysum grandiceps (The Neu, Zealand Edelueiss).}

A tufted herb. Stems $1 \mathrm{in.}-7 \mathrm{in}$. high. Leaves closely imbricating, silverywhite on both surfaces, $\frac{1}{4}$ in $-\frac{1}{8}$ in. long, tips often recurved. Heads terminal, surrounded with leafy bracts, white with wool. Florets numerous. Achene hairy, Pappus-hairs slightly thickened upwards. South Island: mountainous districts. Fl. Jan,-March. Very similar to the Swiss Edelweiss, differing only in the rounder shape of the leaves and bracts.

Helichrysum is a large genus, found in most parts of the world. It includes the plants known as Immortelles, which owe much of their beauty to the scaly bracts collected round the flower-heads. These involucres may be snow-white, golden-yellow, or rose-red. The sacred flower, which the Greek pilgrims bring from Mount Athos, is $H$. virgineum. $H$. arenarium is well known in the Rhine Valley. The genus is closely related to Raoulia and Haastia on the one hand, and to Gnaphalium on the other. The New Zealand species are all endemic, and are usually divided into three sub-genera. Sub-genus (1) Yerochlaena consists of herbs with daisy-like flowers; (2) sub-genus Ozothammus consists of shrubs, sometimes of a most extraordinary appearance, while the plants of sub-genus (3) Leontopodioides much resemble the Swiss Edelweiss, Gnaphalium leontopodium. H. grandiceps is the Edelweiss of the Southern Alps. Probably the most remarkable species of the genus is Helichrysum (Ozothammus) coralloides (fig. 123). It is a rare, sub-alpine rock-plant, with thick, fleshy, closely appressed, overlapping, grey, shiny leaves, which give the plant the appearance of being dead and withered, though it may be in active growth. H. depressum presents a somewhat similar appearance. The living plant might readily be taken by the jasser-by for a bush of leafless twigs, that had been dead for months. In $H$. coralloides the tips of the leaves are hard, brown, and scale-like, and suggest strongly the appearance of the bracts of a pine cone. Indeed, 
a branchlet of this species might well be taken for a small pine cone, or for an umusually hard and membranous unopened catkin. Unfortunately, the leaves have not hitherto received any close examination, and so no account of their microscopic structure can be given. The interstices between the bases of the leaves are closely packed with felted hairs. On the outer surfaces the tips of the hairs are brown-red; elsewhere they are white.

\section{Genus Cassinia.}

Shrubs. Leaves small, entire, often rusty-coloured below. Heads terminal, in corymbs or panicles. Florets tubular. Achenes papillose. Pappus-hairs in 1-t-rows, slightly thickened at the tips. (Name in honour of M. Cassini, a French botanist). $5 \mathrm{sp}$.

\section{Cassinia leptophylla (The Narrow-leaved Cassinia).}

Stems $5 \mathrm{ft} .-12 \mathrm{ft}$. high. Branches and under-surfaces of leaves clothed with white tomentum. Leave $\frac{1}{15}$ in. $-\frac{7}{10}$ in. long, obtuse, margins recurved. Heads in corymbs, 1 in. $-\frac{1}{4}$ in. long. Florets 6-10. Both islands. Colonists' name Cottonwood, Minori name Tauthmu.

\section{Cassinia Vauvilliersii (Tauvilliers' Cassinia).}

Stems $2 \mathrm{ft} .-8 \mathrm{ft}$. high. Branches covered with viscid yellowish tomentum. Leaves $\frac{1}{\frac{1}{4}} \mathrm{in} .-\frac{1}{3} \mathrm{in}$. long, coriaceous, obtuse, glutinous. Heads in round corymbs $\frac{1}{3}$ in. loug, Both islands.

\section{Cassina fulvida (The Yellow Cassinia).}

Stems $2 \mathrm{ft} .-5 \mathrm{ft}$, high, with slightly viscid yellow tomentum. Leaves $\frac{1}{6}$ in. $-\frac{1}{3}$ in. long, sessile, obtuse, glutinous above, clothed with yellow tomentum. Heads $\frac{1}{6}$ in. $-\frac{1}{4}$ in. long, in corymbs. Florets 6-10. Scales among the florets few or 0 . Both islands. Fl. Sept.-March.

\section{Gemus Craspedia.}

Erect, leafy, perennial herbs, with globose, woolly heads. Leaves radical and altemate. Florets 5-12, tubular, 5-toothed, intermixed with transparent seales. Achene silky, oblong. Anthers 2-tailed. Pappus of 1 row of soft feathery hairs. (Name from the Greek, signifying a fringe, in allusion to the white hairs upon the margins of the leavesi). $1 \mathrm{sp}$.

\section{Craspedia uniflora (The One-flowered Craspedia).}

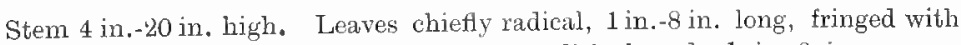
white hairs. Head rounded like a ball, or disk-shaped, $\frac{1}{4}$ in.-2 in. across. Florets yellow or white. The whole plant is usually clothed with a white, woolly, or cottony tomentum, but is sometimes glabrous. Both islands. Fl. Dee.March. Several species seem to be included under this name. 


\section{Gemus Cotula.}

Peremial herls, often succulent, sometimes aromatio. Stens prostrate or creeping. Leaves radical or alternate, usually pimatifid. Heads small,

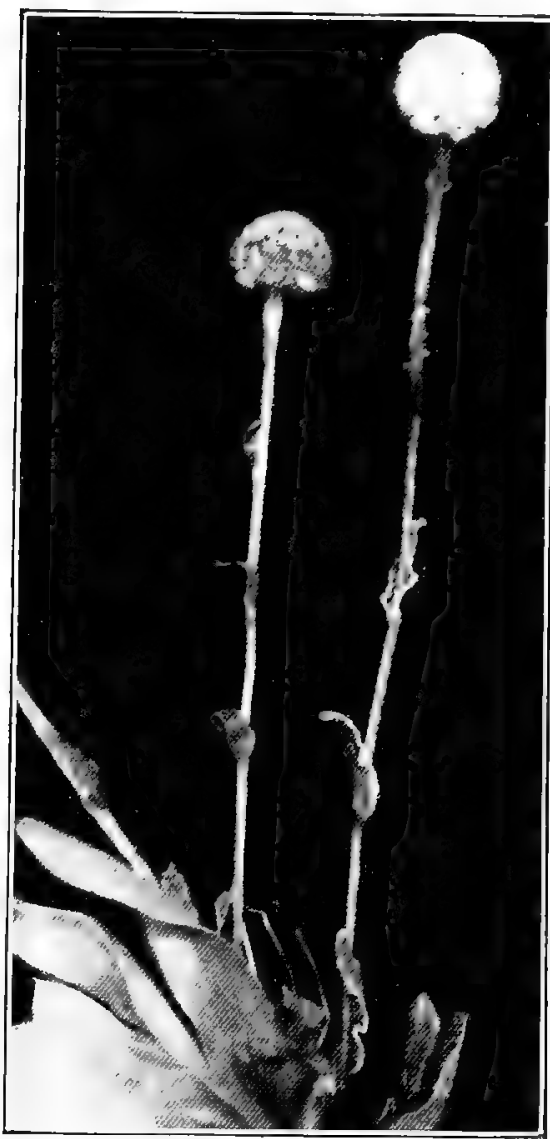

Fis. 153. Craspedia uniflora (籴 nat. size).

of which 3 are endenic in New Zealand. teminal or axillary. Florets t-5-toothed. Anthers without tirils. Achenes compressed, sometimes winged. Pappus 0 . About 50 species, of which 19 are endemic in New Zeuland. (Name from the Greek, signifying a cup, in allusion to the shape of the involucret.

\section{Cotula Coronopifolia}

(The Coronopus-leaved

('otula.)

Stems fleshy, creeping, rooting at the nodes. Branches 3 in.$10 \mathrm{in.}$ high. Leaves $\frac{1}{2}$ in. $-2 \mathrm{in}$. long, sheathing at the base, lobed or pimnatifid. Heads $\frac{1}{3}$ in. across, yellow. Ray florets in 1 series: corolla 0, Achene flat, winged. Both islands; marshy places. Fl. Sept.-March, English manıe Yellow-button. (The English Coronopus is the Wart-Cress. The name is originally from the (ireek, meaning raven-footed).

\section{Genus Erechtites.}

Erect, glibrous, or cottony herbs, $1 \mathrm{ft} .4 \mathrm{ft}$. in height. Leaves simple or pimatifid. Heads in corymbs. Rirys 0. Florets tubular, 3-5-toothed. Anthers without tails. Pappus in many series of small, soft hairs. Alout 7 species, (A Greek name for gronndsel).

\section{Erechtites prenanthoides (The Prunithes-like Erechtites).}

Leaves $2 \mathrm{in} .-6 \mathrm{in}$. long, narrow, hairy or shining, the upper ones sessile, with trothed auricles. Hends in loose corymbs. Florets about $18 \mathrm{in}-20 \mathrm{in.}$ DiskHarets 4-loled. Achenes angular. Pappus-hairs rigid. Both islands. Fl. ().t.-Jan. (Prenanthes is a European and West African genus of Composites). 


\section{Genus Brachyglottis.}

Shrubs or trees. Branches and under surfaces of leaves white with tomentum. Heads numerous, in large panicles. Achenes short, papillose. Pappus-hair seriate. $2 \mathrm{sp}$.

\section{Brachyglottis repanda (The Wavy-leaved Rangiora).}

Stems $8 \mathrm{ft} .-20 \mathrm{ft}$. in height. Leaves $1 \frac{1}{2}$ in.-6 in. Iong, soft, dull green above, milky-white below, wavy in outline. Flower-panicles drooping, usually terminal. Heads $\frac{1}{7}$ in. $-\frac{1}{6}$ in. long, whitish, bracts of involucre shining. North Island chiefly. Fl, Aug.-Oct.

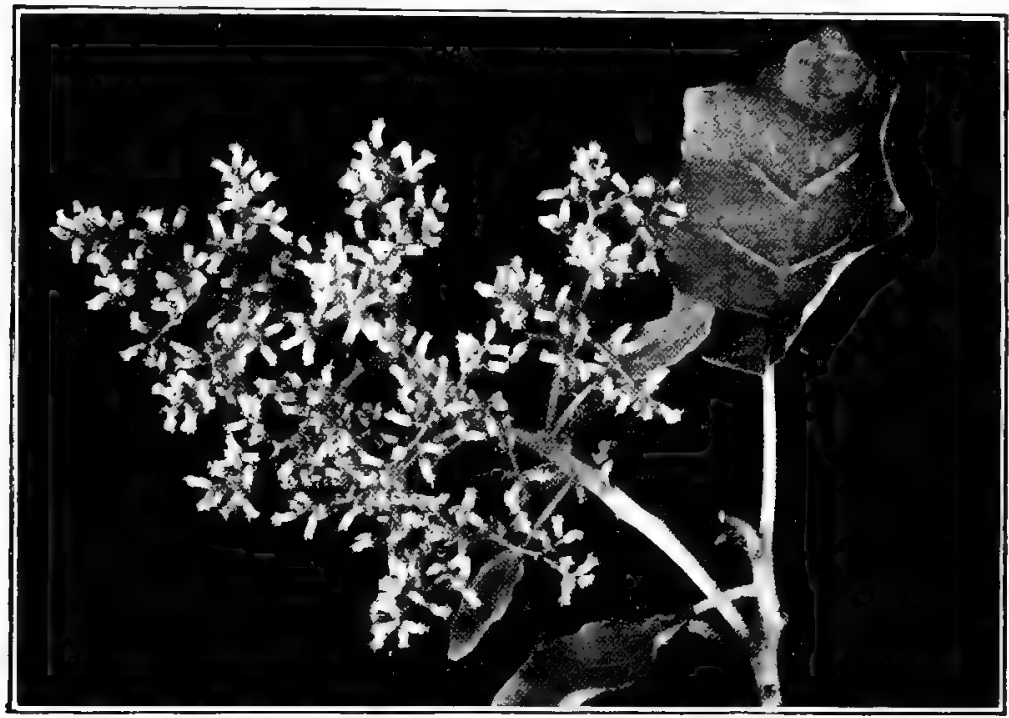

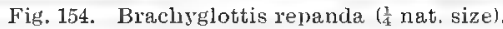

Brachyglottis Rangiora (The Rangiora).

Stems $8 \mathrm{ft} .-14 \mathrm{ft}$. in height. Leaves $6 \mathrm{in.}-9 \mathrm{in}$. long, glossy, often unequal at the base. Flower panicles axillary or terminal, with an entire ovate leaf at the base of the branch. Involucres purple. North Island chiefly. Fl. July-Sept.

Plants of this genus are well known to the Mauris, under the name Rangiora. The leaves were much used by them for application to wounds, and old sores. Possibly the poisonous principle found in them is antiseptic, and thus the wound was cleansed by the use of the leaf. Horses are not infrequently poisoned by eating the foliage of Brachyglottis. The late Mr. Skey endeavoured to isolate the poisonous principle, but failed 
to do so, though he obtained some curious reactions with the balsamic exudation from the stem of the freshly cut shrub."

The leaves of Brachyglottis rangiora are very handsome, and rival in size those of Entelea or Neryta. The flowers are produced in large, heavily scented plumes, and are very attractive to bees.

\section{Genus Senecio.}

Herbs, shrubs or trees, with alternate leaves. Heads terminal; flowers solitary, or in corymbs or panicles. Florets yellow; rays rarely white or purple. Disk-florets tubular. 5-toothed. Pappus of one or more rows of hairs. Achene round or angular. (Name from the Latin, signifying an old man, from the white hairs of the pappus). $30 \mathrm{sp}$.

\section{Senecio lautus (The Elegant Senecio).}

Stem sometimes prostrate, $3 \mathrm{in.-24}$ in. loug. Lenves fleshy, $1 \mathrm{in.-2}$ in. lony, often auricled at the base, narrow, toothed, lobed or pimnatifid. Heads in corvmbis, $\frac{1}{4}$ in. $-\frac{3}{4}$ in. across. Rays $10-15$, yellow. Achene grooved, shining or hairy. Pappus soft, white. Both islands: Stewart and Chatham Islands. Fl. Oct.-March.

This is a genus of world-wide distribution, and very varying habitat, of which the common groundsel is generally regarded as the typical form. In New Zealand it is well represented, and includes among its species some of our most beautiful shrubs. The prevailing white of the New Zealand flora is generally modified in this genus to yellow. There are over thirty indigenous species, which, with one exception, are also endemic. As in Olearia, many of these forms, though provided with excellent means of distribution, are extremely local. S'. glaucophyllus is apparently only known from the limestone rocks of Mount Arthur in Nelson, and S. Pottsii from a single habitat in the Upper Rangitata. S. perdicioides, (niginally discovered by Banks and Solander, and then lost for nearly a hundred years, is found only in the East Cape district. The remarkable $S$. Huntii is confined to the Chathaus, S. Muelleri to an island in Foveaux Straits and to the Snares, S. antipodus to the Antipodes. Perhaps the only one which can be said to be abundant, is the multiform S. lautus, though S. bellidioides, and one or two other subalpine species are comparatively common. The handsome 


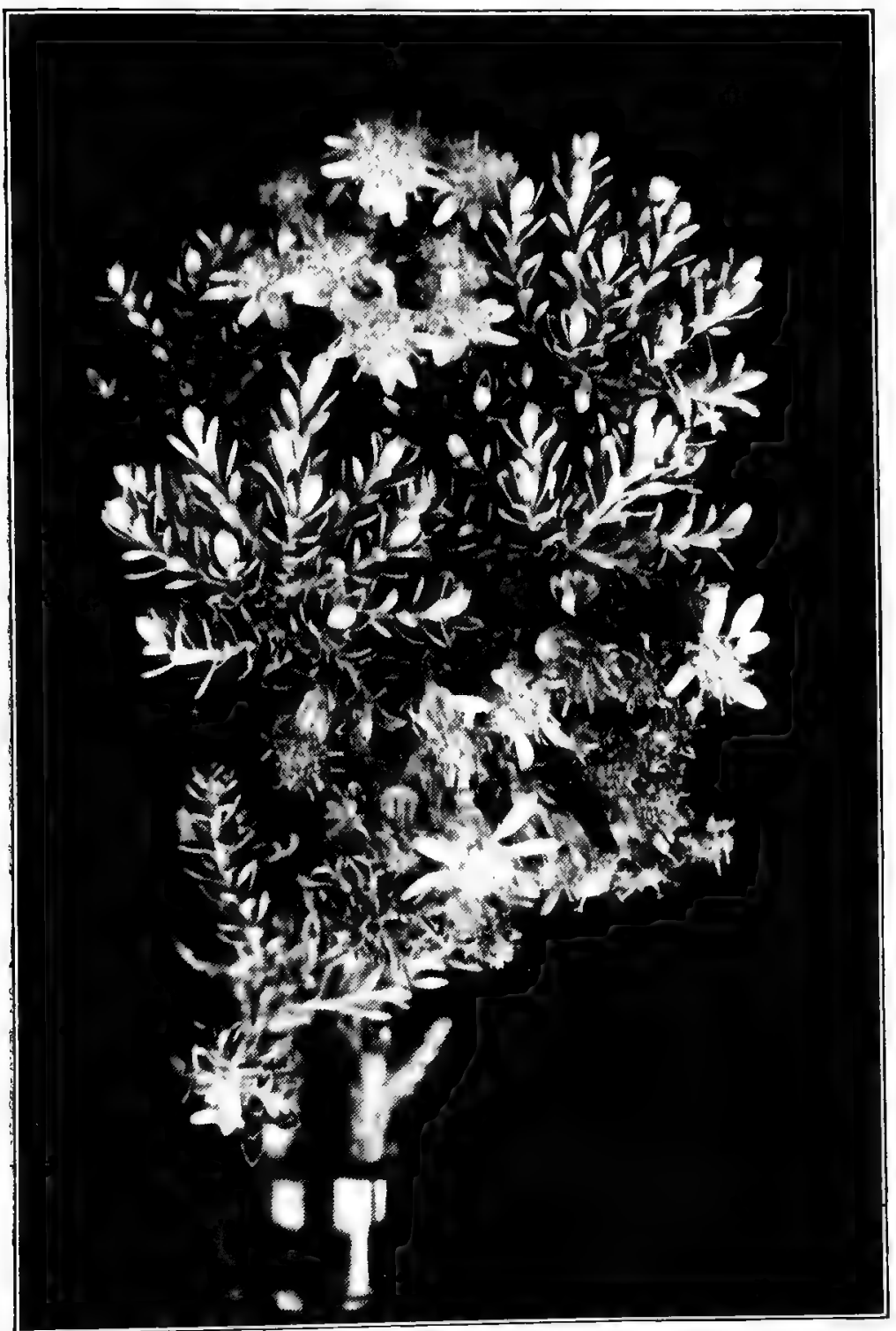

Fig. 155. Senecio cassinioiỏes (nat, size) 
S. saxifraguides, supposed by Kirk to be confined to Banks Peninsula, is undoubtedly the typical S. lagopus of Raoul (Choix 21. T, 17). It still produces its large-leaved rosettes on the southern faces of cliffs, where Raoul found it, near Akaroa. It is also plentiful behind Lyttelton, often growing in altogether inaccessible localities, and it is the only Senecio which haunts these situations on the peninsula. It may be found in flower from early spring to late autumn; but

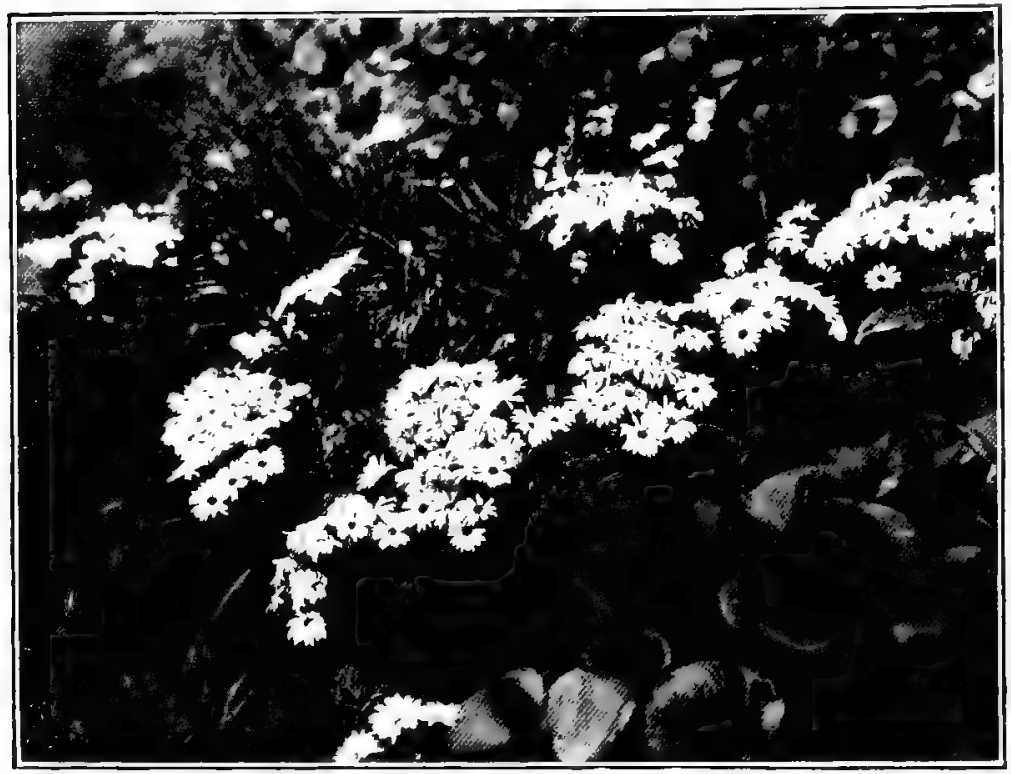

Fig. 156. Senecio Lyallii ( $\frac{1}{7}$ nat. size).

its blossoms are produced in greater profusion in summer. S. sciadophilus is an interesting liane, the only New Zealand climber of the genus. It is known from only a few scattered habitats in the South Island. It may occasionally be seen in the neighbourhood of Akaroa, covering the green top of some tree with its network of yellow flowers. S. rotundifolius is the mutton-bird scrub of Stewart Island. Its leaves are much used by tourists for post cards, the white tomentum of the underside affording a suitable surface for writing. 


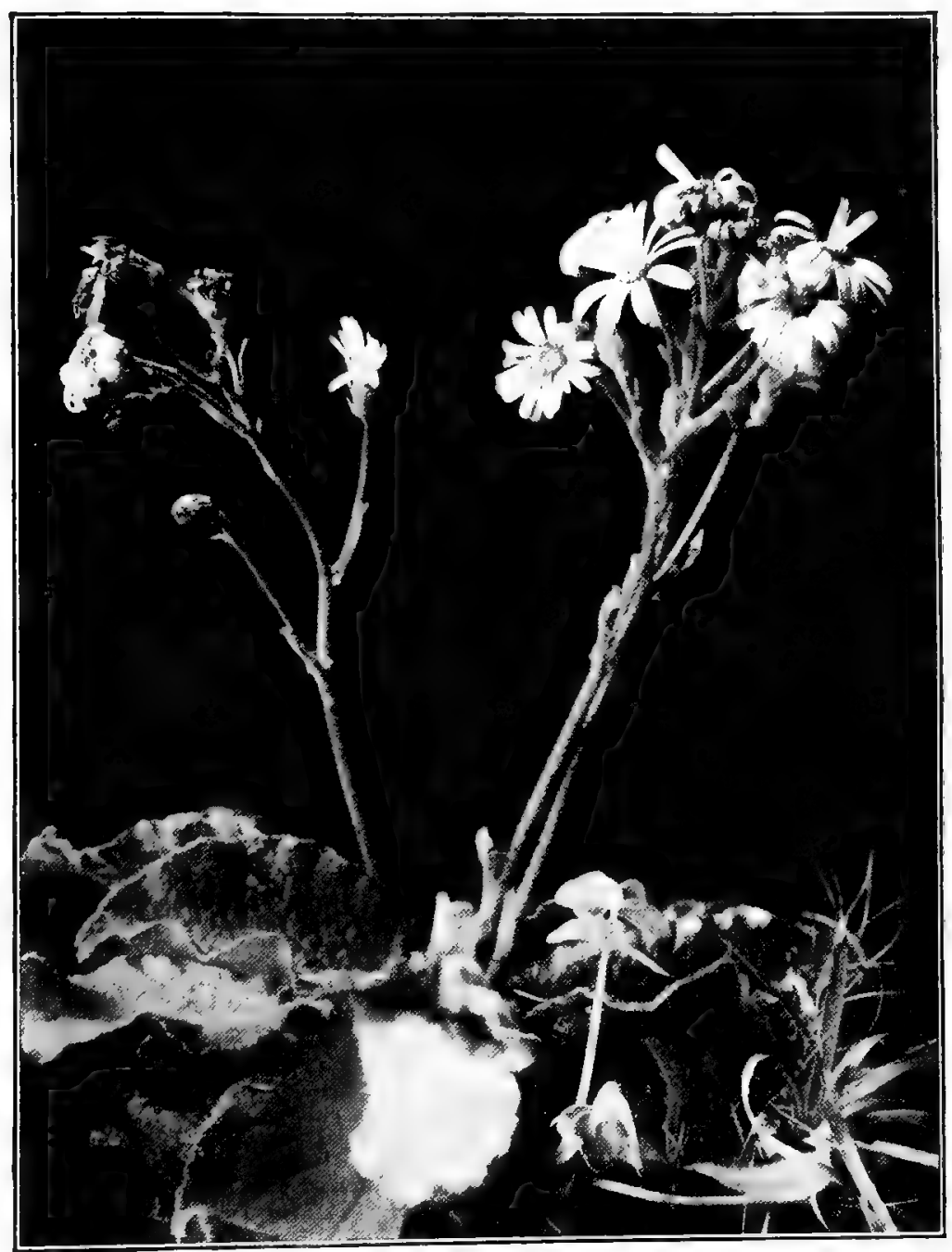

Fig. 157. Senecio saxifragoides (1 nat size). 


\section{GLOSSARY.}

ABERRANT, differing from the usual structure, varying from the ordinary type.

Abortive, imperfectly developed.

lcerose, needle-shaped, with a stiff point.

Achene, a swall, hard, dry fruit, which does not open spontaneously.

Acicular, slender, or needle-shaped.

Acrid, harsh, biting.

Acuminate, narrow, tapering to a point.

Acute, sharply pointed, but not drawn out.

Albuminous, containing albunien, a form of fond material stored within the seed.

Annual, a term applied to plants which perish in one year.

Antler, $v$. J. 43.

Apex, the growing point of a stem or root, the tip of an organ.

Apical, at the point of any organ or structure.

Appenduge, a part added to another, e.g. leaves are appendages to a stem.

Appressed, kept under, lying flat for the whole length of the organ.

Arborescent, attaining the size or character of a tree.

Aril, a menbranous or Heshy seedcovexing, formed by an expansion of the stalk attached to the ovule, often brishtly coloured.

Assinilation, v. 1\% 39.

Auricled, having ear-shaped appendases.

Awn, a bristle-like appendage, especially occurring in grasses.

Axil, the rugle formed between the lianch and trunk, or between the stem and the leaf.

Axillary, growing in an axil.

Axis, en imasinary line, round which the ormans are developed. Floral axis, that part of the stem or lranch upon which the llowers are horne.

BAst, the inner, filmons lark of a tree.

Bearded, havin r tufts of liairs.

Berry, a pulpy fruit containing seeds.

biennial, a term used of rlants which live throush two years.

H]ade, the expanded portion of a leaf.

Bract, an undeveloped leaf on a flower stalk.
CALTX, 1,1 , 44 .

Cambinm, a layer of tissue formed between the wood and the bark, producing wood on the inside, and baxk on the outside.

Campanulate, bell-shaped.

Capitate, arranged in a head.

Capillary, slender, bair-like.

Capsule, a dry seed-vessel, which splits olen spontaneously for the puxpose of shedding its seeds.

Carpel, n. p. 43.

Cartileginous, hard and tough, (as the skin of ац apple-pip).

Catkin, a pendulous spike of flowers, of one sex only.

Cauline, belonging to the stem, applied to leaves borne on the stem, as distinet from those that spring near the root.

Cell, an independent unit of protoplasm, usuall $\mathrm{y}^{\mathrm{r}}$ contained in a membranous envelope.

Cellulose, the material composing the cell wall, the carbohydrate which is the basis of naper.

Chlorophyll, the green colouring matter contained in plant-cells.

Cleistogamic, having flowers which never expand, and which are necessarily, therefore, self-pollinated. v. p. 269.

Compressed, more or less fiattened.

Cone, the fruit of a pine tree, formed of woody bracts.

Connective, that part of the anther which separates the two lobes.

Cordate, a term applied to heart-slaped leaves, with the petiole at the broad end.

Coriaceons, tough, leathery.

Corolla, e', N. 44.

Coronu, a series of out-growths from the corolla, either free or united, which may appear like an additional ring of petals or stawens.

Coryulb, a flat-topped panicle of flowers.

Cotyledon, a seed leaf, the first leaf jroducer by a young plant. 2. 1. 47.

Crenate, a leaf form in which the margin is divided into rounded teeth.

Cruciferous, in the form of a cross.

Cupressoid, cypress-like.

Cuticle, the outermost skin covering the epidemis. 
Cymae, a broad and flattened branched flower-cluster of which the middle flower opens first.

Cymose, bearing, or relating to cymes.

Dechuous, applied to those parts of a flower which fall when the fruit is formed, or to trees whose leaves fall in autumn.

Decompound, several times rivided.

Decussate, in pairs, alternately at right angles.

Deflexed, bent, or turned abruptly downwards.

Dehiscent, opening spontaneously when ripe, as seed capsules.

Depressed, sunk down, hollowed, as if flattened from above.

Dicotyledon, a plant with two seedleaves.

Digitate, fingered, a compound leaf in which all the separate parts spring directly from the apex of the petiole. as in Scheffera.

Dilated, expanding into a blade, as though flattened.

Dimcious, 2 , p. 44.

Dimorphism, v. p. 292.

Disk, a circular developnent, usually of the receptacle within the flower, sometimes consisting only of a ring of prominences, which secrete nectar.

Dissected, applied to a leaf, divided into nuulerons irregular portions.

Divaricating, spreading asunder at a wide angle, oxtremely divergent.

Drupe, a stone fruit, such as a plum. (The fruit of Rubus is an aggregation of drupes).

Ecologr, the study of plant-life in relation to environment.

Embryo, the rudimentary plant formed within the seed.

Endemic, confined to a certain locality, peculiar to a country.

Entire, applied to a leaf of which the margin is not indented.

Epidermis, v, 1) 40 .

Epigynous, placed on the ovary, applied to corolla and stameas.

Epipetalous, seated on the petals.

Epiphyte, v. pp. 20, 21.

Epiphytic, growing on other plants by way of support.

Exserted, protruding beyond, as stamens beyond the tube of the corolla.

Exstipulate, without stipules.

Fasciole, a dense cluster of flowers, leaves, stems, or roots.
Filament, a slender thread, the stalk of the anther. v. p. 43 .

Filiform, thread-like.

Flaccid, woak, flabby.

Flexuous, bending alternately in different directions.

Floret, a smail flower, one of a cluster of compound flowers.

Florula, a small flora, the botanic account of a small district.

Foliaceous, leafy, leaf-iike in texture.

Foliate, clothed with leaves.

Foliolate, movided with leaflets.

Follicle, a fruit of one carpel, opening by the inner or anterior seam.

GLABROCS, smooth, shining, without hairs.

Gland, an organ for secreting oil or other liquids on the surface of some part of the plant. It sometimes ends in a hair or bristle.

Glandular, bearing glands.

Glaucous, sea-green, covered with a bloon, as a cabbaste-leaf.

Gluten, a tough nitrogenous substance occurring in grain after the removal of starch.

Glutinous, covered with a sticky exudation.

HALOPHYTE, v. pp. 42 and 155.

Hastate, spear-shajed.

Herbaceous, a term applied to plants without a woody stem.

Hermenhrodite, $v, \mathrm{p}, \mathbf{4 4}$.

Heterophylly, the occurrence of leaves of more than one form upon the same stem.

Hoary, grey with fine bairs.

Host, the plant from which a parasite draws its nourishnent.

Hybrid, a plant obtained by the application of the pollen of one species to the stignia of another.

Hydrophyte, a water-plant. v. p. 42.

Hypogynous, seated beneath the ovary.

IMBRICATE, overlapping, like the scales of a fish.

Indehiscent, applied to fruits which do not open along regular lines to liberate the seed.

Indigenous, native to a country.

Inferior, below some other organ;e.g., caly $x$ below ovary.

Inflorescence, the arrangement of the flowers and flower-stalks.

Inosculate, to grow together at points.

Insolation, exposure to the direct rays of the sun. 
introrse, turned inwards.

Involume, a circlet of lracts, placed around a Hower-cluster.

Involucratie, having an involucre.

Involute, having the marrins of the leaves rolled inwarts.

Irregular, unssmnetrical, wanting in resularity of form.

LANCEULAT3, narow and tapering, like the hear of a lance.

Latera1, fixed on or near the side of an orkan.

Legume, a two-ralved seed-ressel, oneninf down both seams.

Lenticel, an orening occurring in the l rark of a plant throunh which water vapour is given off.

Liane, a woody climber, v. pr. 16-19.

Ligneous, roody

Linear, narrow, several tines longer than wide.

Lobe, any division of an orfan, especially a rounded division.

MEsophrte, a plant which avoids both extremes of moisture and drought. v. P. 42 .

Moniliform, netklace-shaped, like a string of beads.

Monocotyledon, a plant producing only one seed-leaf. v. p. 82 .

Moncecious, $v$. 1. 44 .

Nectary, the organ in which honey or nectal is secreted.

Node, that part of a stem from which leaves, branches, ox leaf-buds are given off.

Nodule, a small knot, or rounded body.

Nut, a bard, one-seeded fruit, with woody covering.

OBovaty, applied to leaves that are ovate, with the broader part towards the alex.

Obscure, uncertain, hidden.

Obsolete, scarcely aprarent, alusost vanished.

Obtuse, blunt or rounded at the end.

Orbicular, applied to a leaf with a circular outline.

Osmosis, the mixing of liquids through a nembrano separating them.

Ovary, that part of the pistil which contains the ovules. v. 1) 43 .

Ovate, egg-shaped, applied to a solid body, as a fruit.

Ovule, the young seed in the ovary x. p. 43.
Pamatr, apmlied to leaves with fiv lolves.

Papillae, soft superficial flands or protuherances.

Papillose, covered with payillae.

Pappus, thistledown, the tufts of hair on achenes or fruits, the calrx ot counposite Horets.

Parasite, $v, 1), 20$.

Pedicel, a Hower-stalk, the support of $\mathrm{r}$ siugle Hower.

Peduncle, the general wann for the stalk of a flower or flower cluster.

Pedunculate, on a peduncle.

Pellicle, a small slin, the outer cuticular covering of plants.

Pellueid, partially or wholly transparent.

Peltate, target-shaped, applied to leaves at tached by their lower surface to the stalk, instead of by the margin.

Perianth, v. p. 45.

Perigrnous, inserted round the ovary.

Persistent, remaining till the part which lear's it is wholly matured, as the leaves of evergreens.

Petal; v. 1). 44 .

Petaloid, like a petal, having a floral envelope resembling petals.

Petiole, the footstalk of a leaf.

Phanerogennic, $v$. p). 49,428 .

Phylloclade, a flattened branch assuming the form and function of a leaf.

Ihyllode, a petiole taking on the form and function of a leaf.

Pinnate, with leaflets arranged along cach side of a common petiole.

Pinnate-partite, pinnately parted, with the lobes extending more than halfway to the mid-rib.

Pinnatifid, cut into lobes extending about half-way from the wargin to the miclrib.

Pitted, marked with small depressions,

Pistil, v. 1). 43.

Plecenta, the ortan which bears the ovules in an ovary.

Placentiferous, bearing mlacentae.

Plumose, feathery, as the pappus of thistlest.

Pollen, v. 1) 43.

Pollination, v. pp. 43, 44.

Pollinia, $v$, p. 112.

Polymorphic, with several or various forms.

Pome, an inferior fruit of several cells, of which the apple is the type.

Protandrous, having the anthers wature before the pistils in the same flower,

Protogynous, having the pistils receptive before the anthers have ripe pollen.

Puberulous, minutely downy with hairs. 
QUamRate, four-sided, scuare, o1 nearly sifuare.

RAC'EMI; an inflorescence in which the flowers are born on pericels alont a single, undiricted axis.

Racemose, having racenes, raceme-like.

Radical, applied to leaves or flowers springing from or very near the rootstock.

Radicle, the rudinentary root of the entrio.

Receptacle, the point of the peduncle (above the calyx) upon which corolla, stamens, and ovary are inserted; also applied to the axis upon which a head of capitate flowers is situated.

Regular, uniform, symmetrical.

Revolute, having the unargins rolled outwards.

Rhachis, or rachis, the axis of an inflorescence, or of a compound leaf.

Rhizome, a stem of rootslike appearance, prostrate or underground, moducing roots below and stems above.

Rosulate, collected into a rosette.

SagitTatr, applied to a leaf shaped like an arrow head.

Saprophyte, a plant which lives upon dead organic matter.

Scandent, climbing.

Scape, \& leafless flower-stalk arising from the ground.

Sepal, v. p. 45 .

Sepaloid, resembling a sepal.

Series, a row.

Serrate, with regular pointed teeth, like a saw.

Sessile, without a stalk.

Simple, consisting of a single piece.

Spadix, a spike with a fleshy axis.

spathe, a large bract enclosing a flowercluster.

Spathulate, oblong, with the lower part narrow and tapering.

Spike, an inflorescence bearing sessile Howers along a common axis.

Spinulose, with winute spines.

Sporadic, occurring here and there in a scattered manner.

Stamen, v. 1), 43.
Staminodia, false stanens, bearing no anthers.

Stellate, star-shaped.

Stinina, v, 1) 43.

Stipule, a leaf or scale-like ampendage at the base of the leaf-stalli.

Stoma, stomata, v, p. 39

Style, v. 1. 43

Sulb-quadrate, nearly square.

Sucker, a shoot of subterranean oritin.

Superiox, growing or mlaced above, usually applied to the ovary when free from the calyx; or to the calyx when it appears to be alove tho ovary.

TERETF, circular in transverse section, cylindric, and usually tapering.

Ternate, in threes, as three in a whorl or cluster.

Tetrangular, four-antited

Tetrandrous, having four stamens, free from the pistil.

Toinentum, short, soft, dense, cottony hairs.

Transpiration, v. 1) 40.

Trimorphic, occurring in three forms.

Truncate, al)ruptly terminated, as though cut off at the end.

Tubular, bollow and cylindricel.

Tumid, having a blistered appearance. swollen.

UNDULATE, wavy in outline.

Unbel, a flower cluster in which several pedicels of about the same length sprins from one point, like the ribs of an umbrella. An umbel is simple, when each of its branches bears a single flower: compound, when erch ray bears a secondary umbel.

Unicellular, formed of one cell.

VASCULAR, relating to or furnished with vessels.

Venation, the mode of veining.

Vernation, the older of unfolding fron leaf-buds.

Volnte, rolled uiv.

WHORL, the arrangement of any organs in a circle around an axis.

Winged, with a membranous expansion attached. 


\section{INDEX.}

Abrotanella, 40 s

Absorption of moisture, 118

Acrena, 45, 54, 106, 201, 202,314, 366

, adscentens, 37, 202, 203

. alabra, 54

". microphylla, 201

" novae-Zelandiae, 201

". sannuisorbae, 37, 201, 202

A cinnthus Sinclairii, 124

Aciphylla, 216, 239, 257, 276, 312, 316, 318 .

$$
321
$$

, Colensoi, 189, 318, 320

, Momroi, 322

". squarrosa, 318,320

, Truversii, 318

Actinotus, 314

Adams, Mr. A. H., quoted, 6, 11, 414

Affinities of New Zealand Hora, 30, 31

Affinities of South American flora to that of New Zealand, illustrated

Aluthis, 58, 60, 304

$$
\text { by Fuchsia, } 292
$$

\section{1, australis, 62}

Aizoacere, 50,159

Aka, 280,288

Akatawhiwhi, 280

Akatea, 282

Ake-uke, 225, 268, 269

Akiraho, 416

Alectryon, 55,225

, excelsum, 225

Alline vegetation, $22-24$

Alps, Sonthern, 157

Alvine leaf-forms, deseribet by Ruskin, 23 Alseuosmia, 5*, 62, 399

" macrophulla, 399

. quercifolia, 399

Alterations in climate, 239

A]terations in leaf-form, due to moist habitat, 241

Alternanthera, 55

Anemone Fanily, 160

Aniseed, 32.2

Angiosperins, 43, 47

Angelica, 322

. deniculuta, 328

,. aingitiom, 322

Angiospermae, 49

Annuals, absence of, in New Zealand, 42

Antarctic element in New Zealand flora. 25

Antinuity of New Zealand flora, 27-30 A jium, 315

. $\quad$ rostratum, 315
Apoeynacege, 340

Aralia, 300, 304

, crassifolia, 307

." Lyallii, 300

Araliaceae, 50,300

Ancheria, 323

Aristotelia, 242,244

, fruticosa, 246

, racemosa, 9, 42, 244, 246

Armstrong, Mr. J. B., referiedito, 145, 300

Arthropodium, 100

" cantidum, 102

, cirrhatum, 100

Arundo conspicua, 5, 323

Ascarina, 56

Ash, New Zealand, 225

Asplenium, 7

Assimilation, explanation of, 39

Astelia, 62, 98, 99, 100

1. Cunninghamii, 21, 100

, linearis, 100

. nervosa, 100

1. Solandri, 21

spicata, 21

Auckland Island forest, description of, 281

Australian Bottle-brushes, 146

," element in N.Z. Hlora, 25, 32-34

Avicennia, 139, 253, 351-361.

. offinalis, 352

". germination of, 360

Azorella, 314,315

, selago, 314

Balanophoraceae, 149,150

. fungoid appearance of, 149,150

, germination of, 149

Beeches, 8, 10

Beech Forest, 130

Beet Fanuily, 154

Beilschmicaia, $\mathbf{1 7 5}$

, Tarairi, 175

"Tawa, 175

Bidi-bidi, 202

Bindweeds, 342, 344

Birches, 29, 134

Bird-catching plant, 159

Bitter juice as safeguard against browsing animals, 244

J3lack Pine, 69

Blue colour, significance of, in flowers, 348,349

Bolbophyllum, 118, 120, 124

. myamarum, 21124 
Bovadi, 202

Borage Family, 346

Boraginaceae, $53,346,348$

Botanical Introduction, 38

lotting Henssler, Mr. W. refered to, 31

Hottle-brusb Fanily, 147

Bottle-brusbes, Australian, 145, 146

Brachucome, 410

1. Sinclairi, 410

Brechyglottis, $348,435,436$

, Rangiora, 347,435

bracken fern, 3 , as a food, 6

Bramble, 196

Bristles, as motective organs, 244

Broadleaf, 70, 296

Brown, Mr. R., of christchurch, refered to, $37 \pm$

Buchanan, referred to, 23

Bucket-of-water tree, 146

Buckthorn Family, 235

Buckwheat Family, 15:

Bulbinella, 102

. Hookeri, 102

.. Russii, 102

Bulli-bull, 202, 366

Bush, The, 8, tropical appearance of, 10, Melanesian orisin of, 8 , naturel permanence of, 10

Bush lasyer, 19, 200

Bush sarsayarilla, 90

Buttercul, Family, 160, 166

Butterflies, pollination 1,y, 162

Butterwort Faunily 388

Cablage-tree, $4,8,9,28,48,89,93,95,96$. 98

Caluatenia, 125

. bifolia, 125

, Lyallit, 125

minor, 125

C'alceotaria, 36, 366, 368

, Sinclairii, 367,368

C'ulitriche, 56 anturtier, 36

Caltha, 171, 172

, novae-Zelandire, 171, 172

Calustegia, 342

, sepium, 342, 343

.. soldrmella, 344

, Tuouriornom, 344

Campanulaceae, 52, 401, 403, 407

Canterbury Bell Fanily, 401

Campifoliaceae, 399

Crevex sectr, 5

Cromichaelia, 140, 204, 206, 208, 239

, arstralis, 204,208

. Enysii, 206

.. ersul, 206

.. Alugelliformis, $206,21 \mathrm{t}$

. mana, 304
Carporletus, 56, 188

, serratus, 56, 188

Carrot Family, 313

Caryophyllaceae, 51, 55, 156, 158

Cassinia, 32, 323, 433

"1 amoena, 114

" fulvida, 433

"Teptophylla, 433

, retorta, 238

, Vauvilliersii, 43:3

Cussutha, 55, 139, 176, 345

". paniculuta, 177

Catrasetum, pollination of, 114

Cedar, New Zealand, was

c'elery Pine, 76

C'thisid, 23, 418,422

1. argentea, 422

1. coriacea, 418,420

, lavicifolia, 422

" lateralix, 422

"Lecheri, 418

, Iongifolia, 238,416

. Luallii, 420,423

. Mrachani, 382, 42.2

., Moniroi, 416

. sessilitiont, 422

"Traversit, $4 \geq 0$

"rernicosa, 418

Centiperle, 405

Chatham Island Lily, 16\%, 347, 348

Cheeseman, Mr. T. F., referred to, 48,57 , 115, 116. 118, 286, 365,105

Chenopodiaceae, $5.5,154$

C'7nenopotium, 55, 155

"trianlrum, 15.5

Chickweeds, 156, 157, 158

Chloroulasts, 39,40

C'hristmas Tree, 288

classification, key to, 49

C'lassification of Plants, t6

C'leistogarnic flowers, 116, 2200, 221, 263 . $\quad$ in Viola, 263,264

C'leistogajny, 296

C'linate, effect of on plants, 239

Clinate, variation in, 257

clinuatic reserves, 12

Climbing plants of New Zealand, 400

C'limbing I'lants, mofusion of, 10

Climbing stem, advantages of, 18

clematis, 19, 162, 400

clematis, colonr of, 162

Cl'matis sed, description of, 164

Cl'matis afoliater, 166, 239

, Theraspula, 166

.. intivisa, 164, 166

. perviftora, 166

ctiunthus, 201, 210

"puriceus, 210

CIover-dodder, 344

Clover Family, $20{ }^{\circ}$ 
C'Jub-mosses of N'ew Zealand, 8, 27

Cockayne, Dr, L., referred to, $10,23,133$, $156,194,206,212,214,246,252$, $256,-257,258,260,294,301,321$, (fontnote' $371,375,378,380$, 411

" Dr., on Diservitu, 240,241

Colenso, Dr., referred to, 238, 284, 321, 322, 343,364

Colensort, 347, 318, 40:3, 104

" physalnide's, t04

Colour in gentians, 334

C'oloux in New Zealand finwers, 162, 349.436

('ompositar, 29, 52, 346, 401, 405, 406, 422

$\because$ colours of, $16 \%$

, sub-alyine, $2 \cdot 2$

Conif + rue, 58, 60, 70, 256

Connection letween New Zealand and Australian Floras, 25

Continental islands, 26

Convolvulaceae, 53, 342, 398

Convolvwlus, 19, 342, 343

" erubescems, 342

Coprosma, 22, 140, 246, 256, 258, 323, 300, 392,414

Cowrosma, fruit of, 394

Coumesma, pollination of, 392

coprosmer areoluta, 39ti

. acerosa, 394, 396

. arborea, 396

, Buueri, 392. 395

.. C'unninthemii, 394

,. fatirissiuna, 390,398

, aromilifolin, 151, 394

. limmitolia, 398

lucivita, 392, 394

obenmica, 394

parvition, 396

propinqua, $394,39 \mathrm{~K}$

" rhamnotrles, 394

". relusta, 396

.. rotumlifolio, 396

.. sprothulatu, 394

". temlicaulis, 395

Cormllospartium, 204. 206, $20 \mathrm{~m}$

Corlulme, 28, 92, 98

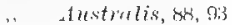

Junk:sii, 98

.. indivisa, 98

.. jumilio, 98

('oriaria, 52, 226, 229

.. ruscifolia, 226 , 23.

.. thymifoliat, 226

('oriariaceae, 226

Cork-wood tree, 243

Cornaccae, 51, 297

Comel Fawily, 297

c'ofokirt, 297

, budrlleoules, 297

- cotomeaster, $29 \mathrm{~m}$
Corynocarlucene, 233

Corynocarpus, 52

$$
\text { 1. lapvigata, } 233
$$

Comysunthes, 116, 120, 125

"macroutha, 110, 1.25

cottontwood, 4:33

Cotula, 434

"atrata, 157

. coronopifolia, 434

, tiliformis, 170

, speciosa, 316

Cow-leaf, 266

Cranesbill, 215

Crantzia, 313

crasperia, 4:33

. alpina, 157

" unithort, 4:33

C'renis, 408

Cross-pollination, 14, 112, 106

Cross-pollination in Compositae, 406

,. in Viole, 262

.. in Hahlenberaia 403

C'nucifere, 52, 177

C'riticr, Dr., quoted, 112

('ucurbitaceqe, 379

('ucumber Family, 399

('upressoid leaves, 375

Currant tree Faunily, 18.;

Currant, New Zealand, 246

Cuscutu, 53, 139, 177, 341, 345, 361

cuscuta densitora, 345

trifolii, 311

". fermination of, 344,345

('ushion jiants, 424, 426, 428

('mathordes, 32 ?)

C'rcadeae, 28

C'mmalossum, 34s

Cupriperlium, 11.3

Curtostylis, 1:5

', oblongu, 125

"rotuntifolia, 12:5

Drertylum, 58,74

. La,rifolium, 58, 76

, cumessinum, 74

Dortylunthus, 54, 56, 139, 150, 151, 386

"Tulori, 150

Daisy Family, 405

. Mountain, 416

"native, 410

Dandelion Family, 405

Dandelion, 407, 408

Duththomiar, 4

Davhne Family 269

Darwin, refered to, 111, 183, 184, 292, 370, 401

Literus, 314

Deciduons trees of New 7erland, 9,260

Inntrobium, 116, 120,124,356

"Cuninthemii, 21, 111, 134 
Destruction of forest, 12,13

Jianella, 9s

$$
\text { .. intermesliat, } 98
$$

I) ichomtret, $53,34 t$

$$
\text { "repens, } 344
$$

Dicotyledounus plants, 47,49

Diels, Dr, referred to, 21, $41,158,166,170$,

Dinorphisni, 292 $190,20 \%, 253,257,317$

Iiscarit $41,54,55,239,241,257,276,370$

$$
\text { " toumatou, 9. } 239
$$

Dispersal of seeds, devices for, 45

$$
\text { , in compositae, 405-6 }
$$

Dodier: 176, 345

I) orlorat , 225, 268

$$
, \quad \text { riscosa, } 225
$$

Dogwood Family, 297

Donlett, wuoted, $8,16,20,161,286$

J)ood lia concriate, 322

J) mcophnllum, 323, 324, 330

". latifolium, 324, 330

.. longifolium, 324, 330, 331

.. rusmarinifolium, 331

. subulatum, 325, 331

"Truersii, 325

, uniflonum, 330

i) Urvilleanum, 325

Drimus, 51,172

.. axillaris, 130,17.

. coloritu, 172

Lrosera, 52, 180

Droseraceae, $51,180,18:$

Inosera arcturi, 185

$$
\begin{array}{ll}
. \quad & \text { auriculata, } 182 \\
. & \text { binate, } 182,184 \\
. & \text { pummera, } 180 \\
. \quad & \text { rotundifolia, 180, } 184 \\
. & \text { spathulate, 182, } 184
\end{array}
$$

Dissorylum, 52, 22:

$$
\text { spectabile, } 68,222
$$

Earina suateolens, 21, 111, 116, 120, 122

$$
\text { "micronatat, 21, 111, 120, 122 }
$$

Edelweiss, New Zealand, 432

Edible fruits, 244

Elarocarpus, 248

$$
\text { , dentatus, } 248
$$

" Howerionus, 246,250

\section{Elatine, 51}

Elatostema, 13内

$$
\text { . rugasum, 21, 13\% }
$$

Emerson, R. W, quotation frown, 1

Endemic plants of New Zealand, 1, 2, 31

Endenism, initiø., 304 relict, 302

Engler, Prof., referred to, 30

Entelea, 9, 42, 48, 242, 278, 348, 436

"arborescens, 242, 348

Environment in New Zealand, varied, 2 Epacridaceae, 323
Eptoris, 35, 323, 3.65

$$
\text { "xacifora, } 323,32 t
$$

Hullobium, 292, 294

Eniphytes, 16, 20, 21

Ericaceae, 53, 303

Evechtites, $4: 34$

$$
\text { " prenanthoides, } 4: 34
$$

Exymginu, 315

$$
\text { , vesiculosum, } 315
$$

Fttinshausen. Baron von, referred to, 30

Fugrnia, 194, 288

$$
\text { " mative, } 288
$$

Enphorbie, 55, 224

$$
\text { , gliuca, } 234
$$

Euphorbiaceae, 224

Euphrowia, 346

$$
\begin{aligned}
& \text { antarctica, } 386 \\
& \text { cuneata, } 151
\end{aligned}
$$

Fvermeen leaves in New Zealand, 9

Examhent, 346

Exocarous, 55

Experinents, Dr. Cockayne's, 240

Eycurinht, 386

\section{Fasaceae, 128}

Fern country, 6

Ferns, number of in New Zealand, 7

Fern-trees, 9, 27

Festuca duriuscula, 4

Field, Mr., quoted, 140, 142

Films-ferns, 7

Findlay, Dr, quoted, 110

Fire, orisin of in Maori legend, 232 .. method of obtaining by Maoris 233

Fireweed, 246

Fitzserald, Mr., referred to, 115

Flax, New Zealand, 18

Flax-Lily, 102

Flax Tribe, 102

Flax Faunily, 218

Flax, treatment of by natives, 104

Flies, pollination by, 162

Flora, Melanesian element in, 8

. differences between Aumtralian and New Zealand, 33

Floral envelopes, 44

Flower, descrilution of a, 43

Flower of Hales, 151

Flowering plants, number of in Sew Zealand, 31

Follase, voisonous, 435-6

Forest, types of, 15,16

. destruction of, 12,13

. Passing of the, by the Hon. W. P. Reeves, 13-15

Forket-me-nots, 346,348

Fossil botany of New Zealand, 28, 30

Iryeycinetia, 49

. Bunksii, 80, 202 
Frost, native trees susceptible to, 11 Fruits, edible, 244

Fruit, used as food by the Maoris, 248

Fuchsia, 8, 9, 36, 292

Fuchsia, Fanily, 290

$$
\text { . pollination of, } 290-294
$$

Fuchsia Colensoi, 293, 294

" excorticata, 201, 293, 294

" Eirkii, 290, 294

," procumbens, $290,293,294$

Fungus on birches, 230

Fusamus Cunninghamii, 151

Gastrodia Cunninghamii, 122, 124

Gaulheria, 322, 323, 325, 326

. antipora, 323, 327

, epiphyta, 21

i. rupestris, 327

Gaya, 260

, Lyallii, 9,260, 261

"Lyallii, var. vibifolia, 261

Geniostoma, 330

, linustrifolium, 336

Gentiana, 263, 336

.. cerina, 336, 338

. clusii, 338

, sacosa, $336^{\circ}$

" vernu, 338

Gentianaceae, 53, 336

Gentian Fanuily, 376

Gentians, colour of, 162

(revaniaceae, 51, 215, 224

(terrnium, 215

" dissectum, nrer, austorte, 215

" microphullum, 216

Gevanimu Fandily, 215

Germination of Avireme 360

" of Balanophoraceae, 149

," of Chickweed, 158

, af Cuscutut, 344,345

" of Kauri, 62

". of Loncuthus, 141

Gesneriaceae, 386, 388

Glossostigma, 368

elatinoides, $36 t^{\prime}$

Gloxinia Fanils, 386

Gmohalinom, 425, 432

" leontoporlinm, 432

" luteo-ulbum, 425

Goeluel, Prof., referred to, 171, 241, 374

Goodeniaceae, 52, 404

Goodenia Family, 404

Grass-trees, 329

Green tlowers, number of in N.Z, , 29

Greensill, Misis, referred to, 392

Griselinia, 51, 260,298

1. littoralis. 70, 298

i. lucisltr, 21, 298

Groundse1, 434, 436

(Tllard-cellsi, 40
Guilds Plant, 16

Gum, fragrant, of taramea, 321,322

, Kauri, 64, 66

Gunnera, 54, 297

$$
\text { , monoica, } 297
$$

Gynmospermae, 46,49

Haast, Sir Julius yon, referred to, 23,228 260

Haastia, 423, 424, 428, 432

$$
\text { " pulvinaris, 424, } 430
$$

Haberlandt, Dr., referred to, 38

Hades, Flower of , 151

Haloplyytes, 42, 155

Heloragidacere, 51, 54, 295

Haloraris, 295

$$
\begin{aligned}
& \text { alata, } 36,295 \\
& \text { " cartilarinea, } 414 \\
& \text { " erecta, } 295
\end{aligned}
$$

Harakeke, 6

Hauama, -42

Heath Fannily, 323

Hector, Sir James, referred to, 158, 236

Hectorella, 158

$$
\text { . caspitosa, } 158
$$

Hedley, Mr. C., referred to, 34

Hediscarma, 174

$$
\because \text { arborea, } 174
$$

Helichrysum, 372, 430

$$
\begin{aligned}
& \text {, comalloines, } 373,432 \\
& \text { 1. dewessum, 432 } \\
& \text { " gramticeps, } 432 \\
& \text {, selago, } \mathbf{4 3 0} \\
& \text { " vingineum, 4:2 }
\end{aligned}
$$

Holl-lind, 345

Hewsley, Mr. WT. Bottins, referred to, 37 Henslow, Prof., referrect to $375,37 b$

Herpolivion, 108

$$
\text { . noval-Zelandice, } 108
$$

Hibise'ts, 260

$$
\text { "Trionum, } 260
$$

Hill M[r, refered to, 151

Hina u, 4, 9, 28, 248

Hoherie, 9, 250, 253,261

" aregustifolia, 390

" populnea, 250

" populnea, nar, vulgaris, 252

Honersuckle, 146

Honeysuckle Fanily, 399

Hooker, Sir ,oseph, referred to, 2, 33, 34 57, 323

Horoeka, 306

Horolyito, 172

Horse-Chestnut Fannily, 224

Houi, 950

Houhere, 250

Hutton, Captain, referred to, 25, 30, 36, 37

Huttonella, 204, 20s

Hybrids, 150 
Hul rocotyle, 314

$$
\begin{aligned}
& \text { " Americame, } 36 \\
& \text {, disutica, 31t } \\
& \text { " novere-Zelamilare, } 314 .
\end{aligned}
$$

Hydrollhytes, 42

H!menenthera, 266

$$
\text { .. cressifoliat. stb }
$$

H!lmenomhlullum, 7

Hum,ricum, 50, 263

Itrinaceat, 230

I('é-p)lant, 160

Inconnletae, s.2

Inconspicnous flowern, numler of in X.K. 9. 29

Ini-ini, sut. striti

Initial endemism, 304

Ink-plant, 206

Insects, pancity of itr N.Z. 160

Insect pollination in Irolu, stiz

Inseretivorous plunt, 18:

Introuluction, General, 1

$$
\text { . Botanical, } 38
$$

Innutubility of mecien, theory of, coniluateri, 250

Inomere, 19

Iridaceae, $10 x)$

Iris Family 109

Irislzuran, Wild, 2:30

Iromwond, 261

Islank, Oxeanic and Continental, 26

Islandin, outlying, thore of

Irvmorts, :300

Ixplut, 52, 14th

$$
\text { 1. brexinith's, 18ti }
$$

Fialnkatea, $16,70,-72$

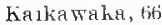

Kaiknmakn, 230, 233

Kai-weta, 1 ind

$$
\text { in Manri lore, } 2: 32
$$

Kakarqunu, 39t

Laka's Betk, 210

Kalladi, m

Kannali, 18 i

Kara1111, 394, 3915

Karaka, $233,23,264$

Karaka Fanily, 233

$$
\text { in Mrovi lore, } 235
$$

Kitraka polmoning, 235

Keralıt1, 392

Kare-ao, 90

Kanri, 60, 62, 304

Kanni st1un, 12, 64, 65

$$
\begin{array}{ll}
\because \quad \text { pine, } 202 \\
, \quad \text { timber, } 63
\end{array}
$$

Latraka, 66

Kawakawa, 128

key to Classification, 49

Kermt'l, referred to, 198
Kie-kie, 80, 20

hirk, Mr. 'T', referred to, 57, 13*3, 179, 188 , $194,234,234,243,293,310,338$ $358,361,420,438$

Knightia, 145

$$
\text { , ircelser, } 1411,146
$$

Knot-grass, 152

Kohe-kole, in Mrori proverb, 174, 222

Kolutuhutu, 294

Fokoronition, 378

Kopi, 234

Foredi, 2(t)

Korari, 202

Korokia-taranca, 내

Korouniko, :369

Kotukutuku, 294

Kowdie l'ine, 20:

Kowhai, yellow, 3t, 212, 214

$$
\therefore \quad \text { red, } 210
$$

Kowhai-nsntu-kaka, 210

Linnara, 72

Kinnaraluon, 186, 236

huri-kuri :321

Laliateac, 53, 364, 36ti

Labmom. Yew 7ealand. 214

Lacelark, "252

Lagenophor't Forsteri, 410

Lance wond, 306

Larye leaved plants, 317

Lasiantluer Fandily, 230

Lamraceac, 55, 175

Lanrel Fanily, 175

Laurel, Now Zealand, :3:3

Lanomlia novete-Zelamblina, 174

Leaf, description, 39

Leaf, dicotyledonons structure of, 39

Leaf, moditications in $41,62,69,76,78,93$, $106,11 \times, 120,139,246,252,256$. $258,276,296,305,317,319,324$. $373,400,422$

Leatless plants, $198,204,344$

Ledres, evergret'n in New /ealand, ?

Legends, Maori, 70, 232, 236

Leguminosae, 51, 203

Lemon tree, 195

Lentibulariacege, 385

Leptospermmm, 272, 276, 323

, :coperium, $244,272,274,27 x$

" ericoides, $27 \pm$

Letcologom, 322, 32.3, 32k

, fusiculatus, 323,325, 324

Hrewer, 323, 325,334

Lianes, 16-19, 99

Libertist, 50, 109

$$
\text { " irisintes, } 1 \mathrm{itg}
$$

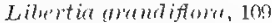

Libsereflins, biti

." Bullullie, bit

" doniatura, biti 
Linustium, 313,315

, cermosulum, 157, 170, 316

.. Colensoi, 216

., lutifolium, 315, 347

, piliferum, 316

Lilac. New Zealand, 186

Liliacene, 50, 88, 96

Lily, Chathan Island 347,348

Lily, Monntain, 166

Lily Fauily, , 48

Linne tree Fannily, 24:

Limuselli, 296

Linaceat, $102,215,218$

Lindsay, Dr. Lauder, referred to, 228

Limum, 52, 218

\section{monкmини, 162, 218}

Litseat atiderris, 175

Lobelia, 348, 403, 404

$$
\text { "rences } \left.x^{2}\right), 404
$$

. Rotuhit, 157, 404

Lolseliacere, 401

Lovalisation of species, 3

Lutunia, 369

Lotaniaceae, 53, 335

Lomaria, 7

Lonking-glass plant, 392

Toranthaceae, 51, 54, 138

Isominthus, 138, 139, 140, 142

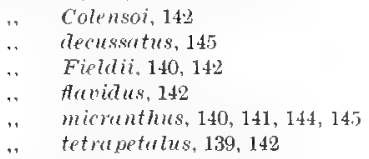

Luzurata mavineste, 92

Lunlliu, 158

I,ycolyods, $8,27,28$

Muciopuger, 56,268

$$
\text { " excelsum, 128 }
$$

Madiler Fanily, 389

Maśnolia Fanily, 170

Masnoliaceae, $17:$

Mahoe, 243, 264, 266

Malungany trees, 220

Mahnika, letend of, 232

Maire, 335

Mairehan, 220

Maire-tawhaki, $2 b x$

Nako-nuko, 246

Mallows, 250

Malvaceee, $50,21 \%, 2511,252$

Manawa, 352

Mangean, 17.5

Mantroves, $8,253,254,35 \%, 361$

Mangrove ronts, 35.5

$$
\text { " swants, life in, } 354
$$

Nanuka, $3,12,22,272,274$

$$
\begin{aligned}
& \text { Jrooms, } 274 \\
& . \quad \text { ramiki, } 274
\end{aligned}
$$

Maori flower names, pronunciation of. 202

Mari Onion, 102

. legend, of Kahikatea, 70

. legend, of Kaikomako, 232

. legend, of Trinni, 236

" lullaby, 3⿻0

"Painkiller, 17:

, proveris, quoted, 174, 176, 282 284,343

, scents, 321

" traditions, 280,286

Mapan, 189, 195. 332

Maple, 195

$$
\text { " Family, 224 }
$$

Nare's Tails, 295

Marsh Marigold, 171

Marvel of Peru Family, 159

Matai, 69,70

Matipo, 332

Maui, legend of, 232

IMrzus, 368

$$
\text { , pumilio, } 36 \mathrm{~K}
$$$$
\text { " radicans, } 367
$$

Medullary rays, 82

Melanesian element in New Zealand Hora, 8

Melanesian aftinities of New Zealand. Hora, 31,34

Meliaceate, 222

Welicope, 20

$$
\begin{aligned}
& \Rightarrow \quad \text { simple } x, 200 \\
& \Rightarrow \quad \text { temata, } 220
\end{aligned}
$$

Welicytus, 260, 261

$$
\text { ". romitions, } 233,264
$$

Melon Family, 399

Wentha Cunninghemii, 365

Weryta, 54, 312, 436

$$
\text { . Sinclairii, 244, 312, } 347
$$

Wesembrymthemum, 159, 839

$$
\text { " australe, } 160
$$

Mespmbryuthemum Family, 159

Hesophytes, 42

Metwsideras, 9, 27s

" albiflorr, 281,242

"Colensai, 281

" florida, 280,282

" Thpericifolia, 280

" lucida, 280, 281

, mbusta, 21, 282, 35t

. serrutens, 268

" tomentosi, 284

Michotis, 120,125

" norrifoliu, 111, 125

Mimulus, 366,368

Xingi-ningi, 329,398

Mint, 365

Miro, 68,322

Mistletoe family, 138

Vistletoe, 142, 144 
Moki-moki, 321, 322

M[oko-wok', 246

Monimiacere. 55, 174

Monocotyledons, 49

, description of, 47

. extuples of. 48

Jountain Daisy, 418

Mountain Lily, $166^{\circ}$

Moths, pollination 1y, 162

Movement in plants, spontaneous, 38

Miihlenbeckik, 9, 19, 152, 344, 401

, arppressa, 152

, axillaris, 152, 216

, complexa, 152

Mulberry, New Zealand, 242

Millle1, Baron von, referred to, 379

Mutation of species, 370

Mutation theory, de Vries, 379

Mutton bird seruh, $4: 38$

M yoporum, 54, 36*2, 364

"latum, 362

Myosatidium, 301, 302, 347, 34k nobile, 168,347

Myosotis, 29,346

" australis, 346

. copitata. 346

, macrantha, 346

, spethulata, 346

, unitlora, 346

Myosurus aristuta, 36

AIyriophyllum, 295, 296

" elatinoides, 295

Mrrsinaceae, 52, 331

Mrsine, 53, 189

, Family, 3331

Mrrtaceae, 50,970

Mrytue, 272

Myrtus, 22, 288

. bullnta, $28 \mathrm{H}$

. obcorlata, 288

," pedunculatr, 288, 390

Iyrtle Fannily, 270

Native Daisy, 410

Natural permanence of Bush, 10

Natuluata, 392, 395

Nei-nei, 329

Nertera, $39 x$

. depressa, $39 \mathrm{~s}$

" diehondraefolia, 394

Nettle Family, 136

New Zealand Arbor V'ita, $66^{\circ}$
1. Ash, 225
.. Bramble, 196
Cedar, 68, 222
Club-rmosses, 8
, Currant, 246
". Edelweiss, 4.32
, Flax, 88, 102, 218
, Laburnum, 214

New Zealand Laurel, 233

, Lilac, 186

" Hora, affinities of, 30, 31

"ffora, Antarctic element in, 35-37

" Hora, antiquity of, 27-30

.. flora, Australian element in, 25, $32-34$

"Hora, foreign elements of, 35

.. Hora, orifin of, $24-26$

.. Hora, South American element in, 25

, Howers, coloux of, $162,333,349$

.. Mulberry, 242

. Oak, 350

.. Primrose, 385

. Suinach, 160

Nightshade Family, 365

Nigger-heads, 5

Nihi-nihi, 344

Nikau Palm, 9, 48, 80, 84, stis

," abnormal, 86

" whares, 84

Nitrogen, needful for plants, 18:

Ngaio, 362

Ngawaka, 66

Ngutu-kakariki, 210

Nothofugus, 16, 29, 130, 132, 134, 150, 201

" betuloirles, 132

i) cliffortioiles, 15, 133, 131

, fusca, 133, 134

.Menziesii, 132, 139, 137

. Solandri, 15, 133, 134, 139, 142, 145,

Nothopanar, 144, 260, 304

$\therefore$ anomalum, 305

.. Colensoi, 305

. lineare, 305

" simplex, 305

Notothlaspi, 177, 178

1" rosulatum, 157, 178, 179

Notospartium, 204, 208

Number of flowering plants in New Zealand, 31

Nux-Tomica Eamily 3:35

Nyctaginaceae, 159

Oak, New Zealand, 350

Oceanic islands, 26

O)

. Cunninghrmii, 334

, lanceolutu, 334

Oleaceae, 335

Olearia, 22, 35, 323, 411, 414,418,422, 436 Allomii, 414

" ammalata, 414

". avicenniafolia, 416

, Buchanami, 414

" Colensoi, 9

" Forsteri, 416

, furfuracea, 415

1. Ilicifolia, 416 
Olearia, insignis, 414

$\begin{array}{ll}\text { " } & \text { Linalli, } 347 \\ " & \text { macrodonta, } 416 \\ " & \text { moschata, } 416 \\ " & \text { nemida, } 415 \\ \text { " } & \text { virgata, } 238,239,390,416\end{array}$

Olive Farnily, 335

Onge-onga, 136

Onagraceate, 51, 290

Orchid Farvily, 109

Orebidaceae, 29, 35, 50, 109, 406

Orchids, fantastic foruss of, 110

" mollination of, 112,115

. structure of flowers, 111

Oreomurhis, 314

Origin of fire, Maori lesend of, 232

, of New Zealand flora, 24-2f;

" of New Zealand Aora, theories of, 34

Orthoceras Siolantri, 127

Osmosis, 296

Ourisin, 384

$\because \quad$ crespitose, 384,385

, Colensoi, 385

., glamiulose, 384, 386

, macrophylla, 384, 385

Oxalic acid, 215

Oxalidacea $\theta, 52,215$

Oxalk, 215, 216, 217, 2b;

, cormiculuta, 216

, megellemiea, 37, 216

Ozothammus, 372,432

Parhucladon, 177, 179

.. novae-Zelamalue. 178

Pahautea, 168

Palm, 8

Palmacene, 80

Palm Family, 80

Palur-lily, 93, 94

Palnus, vancity of in New Zealand, 28

Palu tree, 28

Pandanaceae, 80

Pemataniwhaniwha, 410

Papilionaceae, 172, 203

Papjus, 407

Para-para, 15:

Parasites, 16, 199, 314

Paratrophis, 136, 300

Paratrophis microuhyllus, 136

Parietaria, 55, 138

$$
\text { . debilis, } 138
$$

Parroquet's Beak, 210

Perrot's Bill, 210

Parsley Fauily, 372

Parsonsia, 19, 53, 340

, chesularis, 340

" heterophylla, 340

Passifloracene, 51, 268
Pussiffora, 29, 268, 400)

, tetrandim. 268,400

"Passing of the Forest," 13

Passion flower, 19, 268, 400

Pateh plants, $158,206,426,428,430$

Pate, 233

Pa-totara, 322, 32s

Pea-family, 203

Pennantia, 52, 230

$$
\text { "cormmbosa, } 256
$$

Pen-wiper plant, 178

Peneromia, 56, 1:27

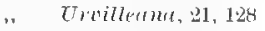

Penuer-tree, 172

Percentage of misexual Howers in New Zealand, 164

Periwinkle Family, 340

Persoonin toru, 1 th

Petrie, Mr. D., roferred to, 3:0, (footmots. 384

Phebalium murnm, 2010

Phormium, 4b, 102, 104, 105, 106, 107, 210

Phormium Cookumum, 108

Phormium tenux, $48,88,90$

Plyllockartus, 58, 60, 76

1) alvinus, 78

". trichomanoidte. $7 \mathrm{~b}, 7 \mathrm{~s}$

Picris, 408

I'ikiarero, 164

Pimelea, 162, 269, 270,323

" avenaris, 269,270

, longifolia, 269

, prostruta, 270

, irratu, 270

l'ine, 8

Pine Family, 58

Pink Fantily, 15ti

Piperaceae, 157

Piper, 128

11 excelsum, 127

I'ixi-piri, 201, 320, 322

Pisoniat, 5H, 159, 348

" brononiana, 159, 244, 347

I'its in Coprosma leaver, 392

Pittomporaceae, 189

Pittrsporum, 45, 52, 150, 189

, comifolitur, 21, 190, 192

1. cressifolium, 194

.4 eugenioires, 145, 194

". Kirkii, 194

"nirrescens, 190

., obcordatum, 170, 190

"Rrlphii, 195

". rigulum 190

, tenuifolium, 189, 194, 195, 322, 3392

". tenuifolium, var., fusiculatum. 190

Plagiunthas, 250, 253, 254

". betulinus, 9, 41, 241, 246, 254, 256. 258,318 
Plagianthus divaricatus, 253, 254

l'lant srouls, 41

Plant guilds, 16

Plantago, 63

Plant life, 38

l'lants of shingle slips, 157,170

Plants, sense organs in, 217

Plants, sleep of, 217

Plents spontaneous motion in, 38

Plasticity of forms of plant life, 259

Pleurophyllum, 338, 216, 418

. crinitum, 417

, sheciosum, 302, 347, 417

Poa ccespritosa, 4

Podocaryus, 68, 329

" daciyatioirles, 70

" ferrugines, 68,322

" rivalis, 68,69

,. spicata, 69

, totura, 69

l'oline, 34:3

l'ohutukama, 9, 284, 286, 288

Poison of tutu, 228

l'okaka, 9

1. karaka, 235

1 rangiora, 435,436

1'ollination of Catusetum, 114; Convolrulus, 343; Coprosma, 392; Coryanthes, 112; Eamina suareolens, 116; Fuchsia, 290, 291; Ënightiat excelsu, 146; Helicone simplex, 220, 221; Orchids, 112; Phormium, 106; Pittosponm Rulphii, 195; P. tenuifolium, 190; Thelmmitra longifolia, 115; Pterostylis, 118; Utricularia, 389; Wahlenbergia, 403

I'ollination by birds, 106, 210, 214, 290, 388

" by butterflies, 162

" by flies, 162

1, by motha, 162

i. by frind, 128, 392

Pollination, processes of, 43,44

"Cross, in Compositae, $406^{\circ}$

, cross, in Jiola, 262

" cross, in Wahlenbergia, 403

.. self, explained, 44, 263

., self, in Compositee, 407

" self, in Thelymitra, 115

I'olypods, 7

Polygonaceae, 54, 151, 152

Polygonum, 152

"aviculare, 152

Pomnulerris, 54, 235, 236, 238

, apetala, 236, 238

" phylicafolia, 238, 323

Poporo-kaiwhiri, 174

Poro-poro, 202, 366

Portulaceae, 53,158

Potts, Mit., 140, 141
Pratia, 403

Prickles, purpose of, 276

Primrose, Fatnily, 333

J'rimrose, New Zealund, 385

Primulaceae, 333

Pronunciation of Maori Hower names, 202

Proteaceae, 55, 56, 145

Pteris aquilina, 6

Pterostulis, $11 \mathrm{H}$

. Bamkisi, 110,111, 126

, oraminea, 110, 126

P'seudomena.s, 256, 257, 396, 325

." crussifolium, 306, 308, 310

". ferox, 306

Pua-o-te-reinga, 151

P'ua-tawhiwlyi, 260

Plua-wananka, 164

Pukatea, 174

Puna-weta, 188

Punui, 300

Puriri, 202, 282, 349, 350

Puta-puta-weta, 186

Pyomare, 369

Quintinia, 186

"Serrata, 186

Rama-rawa, 288

Rangiora, 435

Ranunculacene, 50, 55, 160, 166, 168, 296

Ranunculus, 166

1) acaulis, 171

, Baurit, 168

,. Buchanami, 168

,. crithmifolius, $168,170,171$

.. Godleyanus, 168

.. Heastii, 168, 171

.. hirtus, 171

. insignis, 168

1. lappaceus, 171

, Lyallii, 23, 166, 347

". macropus, 171

". nivicola, 168

"rivularis, 171

, Traversii, 168

Raoul, referred to, $190,380,438$

Ruoutia, 208, 423, 425,428, 430,432

, australis, 496

, bryoutes, 373

.1 eximia, 426

" Haastii, 426

"1 mammillaris, 373,426

, Monroi, 216

Rapanea, 331

" $\quad$ Salicina, 332

Rata, $8,9,21,278,280,281,282,284$

Rata-vine, 19,280

Rauhuia, 218 
Reukawa, 305

Raurekau, 394

Recapitulation, la w of, 256

Red Fowhai, 210

Reeves, the Hon. W. P., culuted, 13

Relict endewisw, 302

Rentrves, clinnatic secured, 12

Revirsion shoots, 374

Reversed spixal, in tendrils, 401

Rewa-rewa, 146

Ribhonword, 250-254

Rinu, 15, 60, 74

Rholdothamnus, 51, 388

$$
\text { , Solnmiri } 368
$$

Rhamnaceae, 50, 235

Rhipogonum scentens, 90

Rhizowhord, 356

Rhopalostylis, 50, 84

$$
\text { i. sapulte, 80, 84 }
$$

Robimia, 141

Rock-li] 102

Rohuhu, 288

Roots, adaptation of to enviromuent, 358

$$
\begin{aligned}
& \text {. nuewbranous, } 120 \\
& \text { " harasitic, } 149 \\
& \text {.. stilt, } 360 \\
& \text {, structure of, } 39,356
\end{aligned}
$$

Rostceae, 50, 195, 270

Rose Family, 195

Rosette plants, $178,179,180$

Ruljiaceae, 52,389

Teubus, 19, 149, 196, 198, 200, :344

, custralus, 200

.. rissoide $, 198,200$

" praves, 201

,Schmideliodides, 200

Rue Family, 18

Rumex, 152

$$
\text { " Hexuasus, } 154
$$

Ruskin, yuoted, 23

Rutacene, 52, 218

Rutland, MIr. .J, veferred to, $376^{\circ}$

Saliarnia, 55, 156

$$
\text { " imition, } 156
$$

Sitlutula, 155

$$
\text { ". tustoulis, } 155
$$

Somolus, 52, 57, 333

$$
\text { , littoralis, } 57,333,405
$$

Sanclalwoor Fannily, 148

Santalaceae, 54,148

Soutrolum, 148

$$
\text { "Cumminalurmii } 148
$$

Sajindacere, 22

Sapota, 5.3

Saluotacene, 331

Salroplytes, 16, 111

Surhochilus whersus, 21

Sarsitparilla Bush, so

Saxifrasaceace 51,185
Scandinavian element in New Zealand tlora, 31

Schethera. 313

$$
\text { " divitato, 151, 233, 312 }
$$

Schimper, referred to, 430

Scleranthus, 55

Screw Pine Family, 80

\begin{tabular}{|c|c|}
\hline " & antipenlus, 438 \\
\hline " & bellinlioides, 438 \\
\hline , & alumerophyllus, 436 \\
\hline , & Hectori, 347 \\
\hline " & Huntii, 4:36 \\
\hline , & lagop)us, 438 \\
\hline , & lututus, 436,13 is \\
\hline ," & Muelleri, 438 \\
\hline , & perdicioides, $46,170,436$ \\
\hline , & Pottsii, 436 \\
\hline ", & motumifolmes, 438 \\
\hline " & screfinugoinles, 382,438 \\
\hline & sciatophilus, 19,438 \\
\hline
\end{tabular}

Scrophularieceae, $53,54,366$

Serub, the, 21

Scrub plants, typical leaves of, 22

Sea-bind weed, 344

Seed Dismersal, 45; in C'ompositae, $405-6$

Seedling Forms, 254, 257, 308

Self-pollination, explained, 44 ; in compositae, 107 ; in Thelumito. 115

Sellieru milicuns, 401

Senecio, 35, 436

Sennation in llants, 38

Sense organs in plants, 217

Shepherd's Lily, $16 t^{\circ}$

Stellurue Roushit, 170

Shingle-slip blants, $157,170,178,180,317$.

Sicwos, 54, 400 428 , colour of, 158

$$
\text { " austrilis, 244, } 400
$$

Skey, Mr., reterred wo, $4336^{\circ}$

Sleep of plants, 217

Snap-drason Fausily, 3titi

Soda, olstained frou plants 154

Solanaceae, $53,36.5$

Solander, Dr., referred to,

Solitnum, 366

1. aviculare, $34 \mathrm{~h}, 366$

" migrum, 343, 3ьь

Somnus plunterum, 217

Sophom, 9, 203, 210, 214

" tetrapterc, 36, 212

". totrastera, var. ammithor. 36. 212

" tetraptere, var. muerophulla, a12

tetrantere, var, prostrata, 212

South American eloment in New Zealand HOPE, $25,36,2 \% 2$

Southern Alys, 157, 258

Spaniard, Wi]d, 321, 322

Spermernmia, 241 
Spinach, New Zealand, 160

suines, use of, 319,321

Spinous plants, 276

Spongy tissue, 40

Snontaneous motion in plants, 38

Sipurge Family, 224

Stack, Canon, referved to, 12

Stellaria, 156

$$
\text { "Roughii, 156, } 157
$$

Stem, processes of, 39

. structure of, 82,356

. structure of, in Conifers, 60, in I'aluraceae, 82, in Combline, 89,92

Stiswatic wovements, 367

Stilbocrorpa, 300, 304

, Lyallii, 300, 302, 304, 347

1. polaris, $300,302,304,347$

stitchworts, 156

Stomata described, 40

Structure of wh ter plants, 295-6

Stylidiaceae, 52

Stuphelia, 328

$$
\begin{array}{ll}
, & \text { acerosa, } 330 \\
, \quad \text { empetrifolia, } 330 \\
, \quad \text { robusta, } 330
\end{array}
$$

Suly-antarctic element in New Zealand flora, 36

Sundew Fanily, 180, 182

Supple-jack, $19,48,90$

Suppression of spines, due to alteration of climate, 241

Suttonia, 331

, dimaricate, 331

Tainui, 236, 238; in Maori lore, 236

Tanekaha, 60, 76, 78

Taraiti, 175

Taramea, 321,322

Tataramon, 196

Tarata, 194

Taraxacum, 408

Tauhinu, 238, 433

Taupata, 392, 395

Tawa, 16, 175; in Maori lnoverb, 176

Tawari, 188

Tawhera, 80, 189

Tawhiri, 321, 322

Tawhiwhi, 189

Taylor, Rev. R., referred to, 150,151

Tea-tree, 272

Tendril-bearing plants, 400

Tetranonia, 160

$$
\text { expansa, } 160
$$

Tencriatium, 350

. parviforum, 351

Tettorium, 350

Thelymitra, 115, 126

" inberbis, 127

longifolia, 115, 127

julchella, 127
Theory, Dr. Cockayne's, on leaf varia. bility, 257

"Dr. Wallace's, on the origin of the New Zealand Hora, 34

Thistle Family, 405

Thomson, Mr. G. M., referred to, 31,112 , $115,116,190,194,216,220,264$ 276,293

Thousand-jacket, 252

Thyme Fanily, 364

Thymelacear, 55, 269

Tiliaceae, 50, 242

Tilleen, 51

" moschate, 37

Timber, of Kauri, 63-4; hahikatea, 72; Matai, 70; Miro, 6R; Pruriri, 350: Rimu, 74; Tanekalıa, 76; Titoki. 2.25; Totara, 69

Titoki, 225, 268

Toa-toa, 78

Toi-toi, 4,5

Tomentum, purpose of, 420

Toot, 228, 230

Toro, 332

Toru, or Toro, 148

Totara, 15, 60, 69, 233

$$
\text { , Mountain, } 68
$$

Transpiration, 40, 41, 120, 236

Trimorphism, 292

Tumatakuru, 239

Tupakihi, 226

Tupeia, 144

$$
\text { "antarctica, } 145
$$

Tussock Country, 12

"description of , 4,5

$\because$ grass, 3, 4

Tutin, 229, 230

Tutu, 226, 230

Tutu Poisoning, 228, 2229

Tutu Wine, 229

Twining Plsnts, 19

Twining of leaf stems, in Clematis, 166

Types of Forest, 15

Typha, 49

$$
\text { , anmustifolin, } 6
$$

Umbelliferae, 50, 312

Uncinia, 45

Uniformity, lack of, in bush, 8

Unique flower forms in New Zealand, 29

Unisexukl flowers. 164

Irtica, 136

$$
\text { ,. ferox, } 136
$$

Urticaceae, $54,136^{\circ}$

Ttricularia, 54, 388

" monanthos, 389

novae-Zelandiare, 389

, protrusa, 389

Variation leaf, in Veronica, 369

" in Panax, 307 
Tariation in Parsonsia, 340

" in Rubus, 196-200

Veretable sheen, $424,426,428$

Venation of leaves, 48

Verbenaceae, $53,54,349$

Verbena Faunily, 349

Veronicas, sub-alpine, 22

$$
\text { * colour of, } 162
$$

Veronicas, 239

J'omica, 246, 257, 263, 270, 276, 348, 366, $367,369,371,374,379$

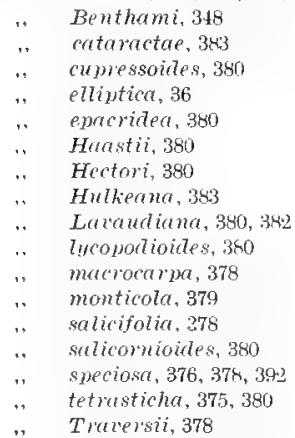

Finla, 29, 261, 263, insect pollination in. 262

Violaceae, 51, 261

Vinlet Faunily, 261

Violets, 262,264 , colour of, 152

Jisla C'umminahamii, 220, 262, 264

, filicallis, 261, 264

, tricolor, 262

risenm, 144

, Limlsatri, 144

.. sulicornioinles, 144

Jite.r. 210,350

.. littorulis, 349

. lucens, 350
I'ttadinia austrolis, 411

Vogel, Sir Julius, referred to, 13

Vries, Prof Hugo de, referred to, 370

Wahlenbergia, 342, 348, 401, 402, 403

. cortilugineu, 402

. gracilis, 402

Wallace, Dr. A. R, lefered to, 25, 30. 34, 196

Wallelower Family, 177

Water Plants, structure of, 295 . 296

Wattle Famils, 203

Wawa-raku, 305

Waxy Gentian, 337

Weismann, referred to, 371

Weinmannia, 188

" racemosa, 184, 18 !

, silvicola, 189

Wharangi, 220

Whau, 9,242, 244, 246

Whanwhi, 250

Whipcord Veronicas, 372, 37t

White flowers, mevalence of in Nem Zealand, 162

White Pine, 16, 70

Wild Spaniard, 321

. Irisumian, 239,240

Willow-herls, 295

Wind-pollinated plants, 126, 392

Wind-still sluces, 171, 172, 238

W'ines, nade from Tutu, szas

Winelserry, 246

Wright, David MeKee, quotations from, 3

Frochlone, 43\%

Xeroplytes, $41,42,159,200,239,258,296,318$

Terowhylla lomentolio, 306

Yellow-button, 434

Yellow liowhai, 3b, 212

Zostera, 



